Envases activos portadores de microorganismos para la bioconservación de alimentos

Laura Settier Ramírez

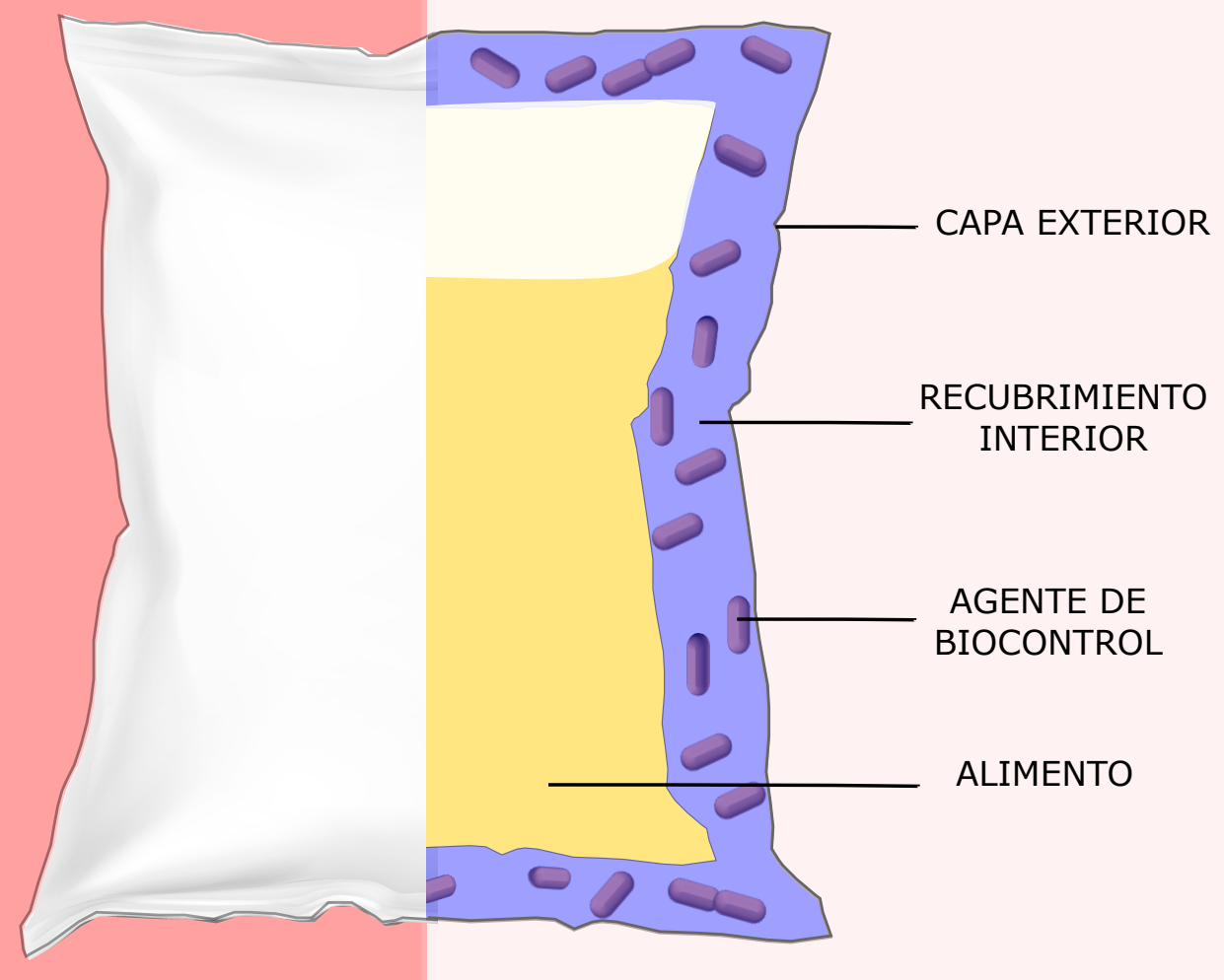

Directores:

Pilar Hernández Muñoz Gracia López Carballo Rafael Gavara Clemente 


Envases activos portadores de microorganismos para la bioconservación de alimentos 



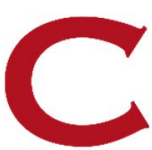

TESIS DOCTORAL

\title{
Envases activos portadores de microorganismos para la bioconservación de alimentos
}

\author{
Laura Settier Ramírez
}

Directores:

Dra. Pilar Hernández Muñoz

Dra. Gracia López Carballo

Dr. Rafael Gavara Clemente

Tutor:

Dr. Rafael Gavara Clemente

Valencia, septiembre de 2021 

Dra. Pilar Hernández Muñoz, Científica Titular del Instituto de Agroquímica y Tecnología de los Alimentos del Consejo Superior de Investigaciones Científicas,

Dra. Gracia López Carballo, Colaboradora I+D+I del Instituto de Agroquímica y Tecnología de los Alimentos del Consejo Superior de Investigaciones Científicas,

Dr. Rafael Gavara Clemente, Profesor de Investigación del Instituto de Agroquímica y Tecnología de los Alimentos del Consejo Superior de Investigaciones Científicas,

Hacen constar que:

La memoria titulada "Envases activos portadores de microorganismos para la bioconservación de alimentos" que presenta Da Laura Settier Ramírez para optar al grado de Doctor por la Universidad Politécnica de Valencia, ha sido realizada en el Instituto de Agroquímica y Tecnología de Alimentos (IATA-CSIC) bajo su dirección y que reúne las condiciones para ser defendida por su autora.

Paterna-Valencia, el de de 2021 

A mis padres, Rosa y Antonio 



\section{Agradecimientos}

La tesis doctoral es una aventura larga llena de retos que tenemos que ir superando cada día. También es una gran oportunidad de aprender y de enriquecerte. De hecho, no solo la ciencia y los experimentos contribuyen a este efecto...las personas que nos encontramos en el camino son igual o incluso más importantes y hoy quiero agradecerlo.

En primer lugar, gracias a mis directores de tesis que han contribuido activamente a que esta tesis haya sido posible. Rafa, gracias por darme esta oportunidad, por confiar en mi para este proyecto y dejarme pertenecer durante todos estos años a este maravilloso grupo de investigación (al que ya echo de menos). Gracias a ti se me abrieron las puertas de la ciencia, camino por el que quiero seguir. Gracias por compartir conmigo tu conocimiento y tu experiencia siempre que lo he necesitado.

Pilar, gracias por todas las cosas que me has enseñado a lo largo de este camino, por darme la oportunidad de descubrir ciencia internacional viajando y por confiar en mí dándome autonomía plena.

Y, como no, gracias a Gracia, por haber sido mucho más que una directora. Has sido una hermana mayor, un ejemplo de fuerza, compañera de cabina, de chivitos (aunque menos de los que nos hubiera gustado), de risas y de ideas científicas locas (que casi siempre funcionaban!). Has sido mi ángel de la Gracia en esta aventura y ha sido un placer compartir el día a día contigo. Gracias por tu tiempo y por escucharme siempre. Solo espero que la vida nos vuelva a dejar trabajar juntas en algún momento.

Gracias también a Ramón, por ser, además de pionero en el mundo del packaging, un ejemplo de dedicación y de pasión por la ciencia. Me alegro de haber podido coincidir unos años contigo.

He tenido la gran suerte de compartir los días con compañeras y compañero (gracias por todo $J P$ ) de laboratorio geniales, que no solo me han ayudado a desarrollar ciencia poniendo en común sus conocimientos si no a hacer de la tesis una experiencia única.

Gracias Rachel, compañera y amiga de fatigas y alegrías. Has sido un apoyo indispensable para mí durante todos estos años. Estoy deseando que podamos celebrar juntas por tierras lejanas que por fin lo hemos logrado...bebiendo del cáliz de PVOH.

Gracias Lauris, por ser un apoyo constante durante todos estos años. Por estar siempre dispuesta a sacar tus libretas, a ayudar, a compartir tu conocimiento y 
tus experiencias. Gracias también por prestarte a hacerle una última lectura de la tesis con esa "exactitud" que te caracteriza. Y por ser siempre tan participativa con la vida del labo, almuerzos, comidas, cumples, divulgación...sólo nos ha quedado pendiente publicar algo juntas.

Gracias Aida por ser un hombro químico sobre el que apoyarme, por compartir mil momentos en el labo y fuera de él y por apuntarte a cualquier bombardeo compartiendo el mismo entusiasmo que yo, ya sea divulgación, preparación de videos, pósters, haciendo un podcast, buceando....visca Albacete!

Tampoco se me olvidan las integrantes del labo con las que coincidí en mi última etapa de la tesis:

Gracias Raquel (alias Rachel 202 primahermana de Zoey 101), por compartir conmigo todo tu potencial redox! Porque me encanta tu forma de ver la vida y de enfrentarte a ella...eres todo un ejemplo. Pero, sobre todo, gracias por las risas, por los buenos momentos, por el concierto de Gisela y porque ambas sabemos que la vida es un musical.

Gracias también a Patricia, encargada de seguir escribiendo historias en este grupo, por los almuercitos compartidos al sol.

No puedo dejar de mencionar a los estudiantes que han sido partícipes de una manera u otra de mi vida en el labo y de esta tesis doctoral. Gracias a Aurora, Saúl, Borja, Vicky, Helena, Esther, Laura three y Laura Su. Pero, sobre todo, quiero AGRADECER (en mayúsculas) a Cristina (peliRosa!), por haber sido una TFM fabulosa que me acompañó en los inicios de la tesis y que todavía seguimos teniendo presente en el labo tras más de 4 años y, a Luca, por ser un aprendiz sensei de TFM fantástico y mejor persona. Gracias por involucrarte tanto, no solo en el trabajo sino en nuestras vidas ( $L$. sakei, concurso de tiramisú, la perla de la costa blanca, Bérgamo....solo de pensarlo me da un apechusque!)

Igualmente, gracias a la gente del IATA, amig@s y compañer@s que han estado presentes a lo largo de la realización de la tesis. Gracias a todo el grupo de las vecinas, Vicen, Deni, Adrián, Elena, Gabi y Carlos por el buen humor matutino, por las xarraetas y por el intercambio de material. Gracias Vicen por introducirme en el mundo gatuno, transmitirme tu amor por ellos (Petri y Baguira no lo olvidarán!) y por los consejos de la vida científica por los pasillos. Gracias Deni por tu apoyo científico-moral y por tus sabios consejos de maquetación. Gracias en general a la gente de la segunda planta, Patri, Mónica, Laura, Amparo, Ana, Teresa, María, Loles... con los que he compartido pasillos, carrito, equipos, catas y alguna que otra comida navideña. No muy lejos, a un piso de distancia, en la tercera planta del IATA, he tenido el placer de compartir bancada (gracias a todos los que me ayudasteis con la 
biología molecular) y momentazos fuera del IATA con gente encantadora. Gracias a mis forasteros favoritos Seba y Dolo (y Fer) por los momentos vividos y los que nos quedan por vivir. Gracias Albita por las risas interpasillos, en almuerzos y comidas. Gracias también a Flor por transmitirme toda la serenidad del mundo (Sat Nam), a LauPeTra por todos tus tips de experta en biomol, a Sonia y a toda la secta, Javi, Alba, Sara, Ric, Ying, Peris, Lucía, Miguel, Laura, Anto y Adri. Por supuesto, gracias a Amparo, Roberto y Eladio por hacerme sentir una más del grupo de levaduras tanto en el IATA, como en Montpellier o Argentina! Sin cambiar de piso y a unas puertas de distancia, gracias Walter por los momentos compartidos (y los que llegarán) de debate de vida científica y de, sobre todo, aficiones deportivas. En la misma línea, quiero agradecer a Ángela, haberme descubierto el mundo de la divulgación llamándome en cada ocasión, haberme ayudado con el video para el "yo soy CSIC" pero sobre todo por haberse convertido en mi amiga. Además, quiero hacer una mención especial a su disposición para sumarse a cualquier tipo de plan pensat i fet como irnos de camping, patinar, apuntarse a voleiplaya o grabar un podcast...entre otros. Por último, quiero agradecer a los que hacen posible el buen funcionamiento del IATA, al servicio de limpieza (en especial a Alba y a Vicky), a los servicios científicos, a recepción (en especial a los Fernandos) y a toda la gente de administración y almacén.

Merci à Sabine de m'avoir donné l'opportunité de faire un stage dans son groupe de recherche à l'Université de Montpellier et au CIRAD et de travailler sur le projet PATRISK. Merci à Angélique et Caroline d'avoir fait confiance à mes idées de travail, de m'avoir fourni tout le matériel nécessaire pendant mon séjour et de m'avoir intégré à Qualisud. Merci également aux collègues avec lesquels j'ai pu travailler pendant quatre mois et qui m'ont accueilli comme membre de l'équipe 2, Asma (اجمل اللغات الجزائرية), Lucille, Benjamin, Cheik, Ixchell et Sarah. Quiero agradecer especialmente haber coincidido con Mario que, además de ser una persona encantadora, me ha prometido llevarme a Argentina. Enfin, merci Reem, d'être une personne merveilleuse et d'être devenue ma sœur libanaise. Merci pour tout ton soutien durant mon stage, pour les happy box, pour la réunion PATRISKé, pour les bières à la Place des beaux-arts...(j'éspère te revoir bientôt). Tu mérites le meilleur (et d'avoir une super thèse de doctorat).

Aunque suene a cliché, gracias a todos mis amigos de fuera del IATA que en algún momento $u$ otro han tenido que escuchar mis historias científicas del IATA.

Gracias a mi familia, a mis hermanos Vero y Hugo pero sobre todo, gracias a mis padres...sin los que jamás hubiera llegado hasta aquí. Gracias a mi madre, por 
enseñarme a tener siempre ganas de aprender, a trabajar con entusiasmo y a tener el buen humor por bandera y a mi padre por enseñarme que el aprendizaje no tiene edad y demostrarme que todo es posible con esfuerzo y dedicación. Merci aussi à toute ma belle-famille que j'adore.

Por último, gracias Romain, por el apoyo que nos damos, gracias por alegrarme la vida, por habernos embarcarnos juntos en esta aventura tan lejos de tu hogar de origen y por seguir creciendo juntos día a día (TQMMQTYLS).

Gracias a todos por estar a mi lado, por apoyarme y por formar ya parte de mi vida. 
La presente tesis doctoral plantea distintas estrategias para el desarrollo y aplicación de envases activos portadores de agentes de biocontrol, con el fin de inhibir la proliferación de microorganismos como bacterias y hongos patógenos y alterantes y así, conseguir aumentar la seguridad y prolongar la vida útil de los alimentos.

El desarrollo de envases activos antibacterianos se llevó a cabo incorporando bacterias ácido lácticas productoras de bacteriocinas, Lactococcus lactis y Lactobacillus sakei en diferentes matrices formadoras de películas. Previa a la preparación de las películas activas, se estudió la actividad antimicrobiana de los agentes naturales seleccionados frente a Listeria monocytogenes. Los resultados sugirieron que, a partir de una determinada concentración inicial de bacterias viables, estos microorganismos son buenos candidatos para ser utilizados como aditivos naturales en materiales de envasado de alimentos, siendo una alternativa al uso de aditivos de origen sintético. En este trabajo se observó que la viabilidad inicial de las bacterias ácido lácticas (LAB) es esencial para obtener una buena capacidad antibacteriana por lo que la optimización de la composición de las películas o recubrimientos fue crucial para su aplicación con éxito.

El polímero escogido como base para hacer las películas y recubrimientos mediante la técnica de casting, fue el alcohol polivinílico, (PVOH) mezclado con diferentes proteínas, gelatina y caseinato sódico y sus versiones hidrolizadas añadidas en diferentes proporciones. En este estudio L. lactis demostró tener una mayor resistencia a la deshidratación durante la preparación y almacenamiento de las películas que $L$. sakei. Las películas de $\mathrm{PVOH}$ mezcladas con gelatina hidrolizada y caseína hidrolizada dotaron de protección a las bacterias ácido lácticas durante el secado y demostraron tener una mayor efectividad antilisteria. Por último, se varió la proporción de caseína hidrolizada obteniendo una mayor viabilidad de las bacterias en las películas prolongada en el tiempo a mayor proporción de HCas.

Para desarrollar un envase activo antilisteria, se adaptaron las matrices para ser aplicadas como recubrimiento sobre ácido poliláctico 
(PLA) con el objetivo de desarrollar bolsas activas antilisteria para crema de setas y como separadores de lonchas de jamón cocido. Los recubrimientos demostraron tener una efectividad similar a la obtenida con las películas in vitro. Sin embargo, su eficacia disminuyó ligeramente al ser aplicadas en la crema de champiñones y el jamón cocido debido a la complejidad de las matrices alimentarias utilizadas, pero siendo una buena herramienta para, junto a otras estrategias de conservación, asegurar la salubridad de los alimentos. Se llevaron a cabo ensayos sensoriales con consumidores y se obtuvo una buena aceptación de ambos productos. Sin embargo, los consumidores percibieron una alteración del sabor debido a la generación de ácido láctico en la crema de champiñones, acidez que puede ser controlada mediante correctores de acidez sin modificar la efectividad antimicrobiana.

Para desarrollar envases que aumentaran la vida útil, se trabajó para ampliar el espectro de acción de L. lactis frente a las bacterias Gram-negativas, normalmente responsables de la descomposición de los alimentos. Combinar el agente de biocontrol productor de nisina, $L$. lactis, con una baja concentración de ácido fítico, sustancia quelante y desestabilizadora de la membrana bacteriana, amplió el espectro antimicrobiano de $L$. lactis frente a las bacterias Gram-negativas obteniendo una nueva herramienta para garantizar la seguridad alimentaria y prolongar la vida útil de los alimentos. Las películas desarrolladas presentaron muy buena actividad antimicrobiana frente Salmonella enterica, Escherichia coli, Pseudomonas fluorescens y Listeria monocytogenes en medio de cultivo a temperaturas de refrigeración y simulando roturas en la cadena del frío. Por último, se desarrollaron recubrimientos de L. lactis y ácido fítico sobre polietileno y se formaron bolsas que consiguieron alargar la vida útil 10 días de una crema pastelera casera.

Finalmente, se estudiaron los impactos ambientales del envase convencional y del envase activo para la crema pastelera. En cualquier caso, a pesar de las limitaciones relativas a la estimación del producto desperdiciado, la prolongación de la vida útil mediante la innovación de 
los envases pudo reducir significativamente los impactos ambientales de todo el sistema de envasado de alimentos.

En la presente tesis, también se exploró el potencial uso de levaduras autóctonas con capacidad antifúngica para el control de Penicillium expansum y el control de la micotoxina que generan denominada patulina. En la presente investigación se seleccionaron tres nuevas cepas de levadura aisladas de la superficie de manzanas por su eficacia contra $P$. expansum. Las levaduras fueron identificadas como Metschnikowia pulcherrima siendo 3 cepas diferentes. También se demostró la capacidad de estas levaduras para la biodegradación de la patulina. A continuación, se realizaron diferentes estudios sobre la viabilidad de la levadura y su efectividad antifúngica en diferentes películas hechas con biopolímeros que se encuentran de forma natural en la manzana (pectina, éteres de celulosa y orujo de manzana). Los datos de los ensayos antifúngicos realizados in vitro mostraron que las películas bioactivas hechas a base de orujo de manzana mantuvieron la viabilidad de $M$. pulcherrima e inhibieron significativamente el crecimiento de $P$. expansum o modificaron su crecimiento morfológico. Finalmente, los recubrimientos realizados con residuo de manzana que contuvieron levaduras aisladas de manzana, fueron aplicados sobre manzanas contaminadas con $P$. expansum demostrando una muy buena eficacia antifúngica con respecto al resto de tratamientos aplicados por separado. 



\section{Resum}

La present tesi doctoral planteja diferents estratègies per al desenvolupament i aplicació d'envasos actius portadors d'agents de biocontrol, amb la finalitat d'inhibir la proliferació de microorganismes com a bacteris $\mathrm{i}$ fongs patògens $\mathrm{i}$ alteradors $\mathrm{i}$ així, aconseguir augmentar la seguretat i prolongar la vida útil dels aliments.

El desenvolupament d'envasos actius antibacterians, es va dur a terme incorporant bacteris àcid làctics productores de bacteriocines, Lactococcus lactis i Lactobacillus sakei en diferents matrius formadores de pel-lícules. Prèvia a la preparació de les pel-lícules actives, es va estudiar l'activitat antimicrobiana dels agents naturals seleccionats enfront de Listeria monocytogenes. Els resultats van suggerir que, a partir d'una determinada concentració inicial de bacteris viables, aquests microorganismes són bons candidats per a ser utilitzats com a additius naturals en materials d'envasament d'aliments, sent una alternativa a l'ús d'additius d'origen sintètic. En aquest treball es va observar que la viabilitat inicial dels bacteris àcid làctics (LAB) és essencial per a obtindre una bona capacitat antibacteriana pel que l'optimització de la composició de les pel.lícules o recobriments va ser crucial per a la seua aplicació amb èxit.

El polímer triat com a base per a fer les pel-lícules i recobriments mitjançant la tècnica de càsting, va ser l'alcohol polivinílic, (PVOH) mesclat amb diferents proteïnes, gelatina i caseinat sòdic i les seues versions hidrolitzades afegides en diferents proporcions.

En aquest estudi $L$. lactis va demostrar tindre una major resistència a la deshidratació durant la preparació i emmagatzematge de les pel-lícules que $L$. sakei. Les pel-lícules de PVOH mesclades amb gelatina hidrolitzada i caseina hidrolitzada van dotar de protecció als bacteris àcid làctics durant l'assecat i van demostrar tindre una major efectivitat antilistèria. Finalment, es va variar la proporció de caseïna hidrolitzada obtenint una millor resposta de les pel.lícules no sols des d'un punt de vista antimicrobià, sinó també de les propietats fisicoquímiques de les pel-lícules, a major proporció de caseïna hidrolitzada.Per a desenvolupar un envàs actiu antilistèria, es van 
adaptar les matrius per a ser aplicades com a recobriment sobre àcid polilàctic (PLA) amb l'objectiu de desenvolupar bosses actives antilistèria per a crema de bolets i com a separadors de rodanxes de pernil cuit. Els recobriments van demostrar tindre una efectivitat similar a l'obtinguda amb les pel.lícules in vitro. No obstant això, la seua eficàcia va disminuir lleugerament en ser aplicades en la crema de xampinyons i el pernil cuit a causa de la complexitat de les matrius alimentàries utilitzades, però sent una bona eina per $a$, al costat d'altres estratègies de conservació, assegurar la salubritat dels aliments. Es van dur a terme assajos sensorials amb consumidors i es va obtindre una bona acceptació de tots dos productes, però una alteració del sabor degut a la generació d'àcid làctic en la crema de xampinyons corregible mitjançant correctors d'acidesa sense modificació de l'efectivitat antimicrobiana.

Per a desenvolupar envasos que augmentaren la vida útil, es va treballar per a ampliar l'espectre d'acció de L. lactis enfront dels bacteris Gram-negatives, normalment responsables de la descomposició dels aliments. Combinar l'agent de biocontrol productor de nisina, L. lactis, amb una baixa concentració d'àcid fític, substància quelant i desestabilitzadora de la membrana bacteriana, va ampliar l'espectre antimicrobià de L. lactis enfront dels bacteris Gram-negatives obtenint una nova eina per a garantir la seguretat alimentària i prolongar la vida útil dels aliments. Les pel-lícules desenvolupades van presentar molt bona activitat antimicrobiana front Salmonella enterica, Escherichia coli, Pseudomonas fluorescens i Listeria monocytogenes enmig de cultiu a temperatures de refrigeració i simulant trencaments en la cadena del fred. Finalment, es van desenvolupar recobriments de L. lactis i àcid fític sobre polietilé i es van formar bosses que van aconseguir allargar la vida útil 10 dies d'una crema pastissera casolana.

Finalment, es van estudiar els impactes ambientals de l'envàs convencional i de l'envàs actiu per a la crema pastissera. En qualsevol cas, malgrat les limitacions relatives a l'estimació del producte malgastat, la prolongació de la vida útil mitjançant la innovació dels envasos va poder reduir significativament els impactes ambientals de tot el sistema d'envasament d'aliments. 
En la present tesi, també es va explorar el potencial ús de llevats autòctons amb capacitat antifúngica per al control de Penicillium expansum i el control de la micotoxina que generen denominada patulina. En la present investigació es van seleccionar tres nous ceps de llevat aïllades de la superfície de pomes per la seua eficàcia contra $P$. expansum. Els llevats van ser identificats com Metschnikowia pulcherrima sent 3 ceps diferents. També es va demostrar la capacitat d'aquests llevats per a la biodegradació de la patulina. A continuació, es van realitzar diferents estudis sobre la viabilitat del llevat i la seua efectivitat antifúngica en diferents pel-lícules fetes amb biopolímers que es troben de manera natural en la poma (pectina, èters de cellulusa $\mathrm{i}$ orujo de poma). Les dades dels assajos antifúngics realitzats in vitro van mostrar que les pel.lícules bioactives fetes a base d'orujo de poma van mantindre la viabilitat de M. pulcherrima i van inhibir significativament el creixement de $P$. expansum o van modificar el seu creixement morfològic. Finalment, els recobriments realitzats amb residu de poma que van contindre llevats aillats de poma, van ser aplicats sobre pomes contaminades amb $P$. expansum demostrant una molt bona eficàcia antifúngica respecte a la resta de tractaments aplicats per separat. 



\section{Abstract}

This doctoral thesis proposes different strategies for the development and application of active packaging containing biocontrol agents, to inhibit the proliferation of microorganisms such as pathogenic and spoilage bacteria and fungi, thus increasing the safety and increasing the shelf life of foodstuffs.

The development of antibacterial active packaging was carried out by incorporating bacteriocin-producing lactic acid bacteria, Lactococcus lactis and Lactobacillus sakei in different film-forming matrices. Prior to the preparation of the active films, the antimicrobial activity of the selected natural agents against Listeria monocytogenes was studied. The results suggested that, from a certain initial concentration of viable bacteria, these microorganisms are good candidates to be used as natural additives in food packaging materials, being an alternative to the use of additives of synthetic origin. In this work it was observed that the initial viability of lactic acid bacteria (LAB) is essential to obtain a good antibacterial capacity, so the optimization of the composition of the films or coatings was crucial for their successful application.

The polymer chosen as a base to make the films and coatings by casting technique was polyvinyl alcohol (PVOH) mixed with different proteins, gelatin and sodium caseinate and their hydrolysed versions added in different proportions. In this study L. lactis showed higher resistance to dehydration during film preparation and storage than $L$. sakei. PVOH films mixed with hydrolysed gelatin and hydrolysed casein provided protection to lactic acid bacteria during drying and were shown to have a greater antilisteria effectiveness. Finally, the proportion of hydrolysed casein was varied, obtaining a better response of the films not only from an antimicrobial point of view, but also from the physicochemical properties of the films, the higher the proportion of HCas.

To develop an antilisteria active packaging, the matrices were adapted to be applied as a coating on polylactic acid (PLA) with the 
objective of developing antilisteria active bags for cream of mushroom soup and as separator liner for cooked ham slices. The coatings showed similar effectiveness to that obtained with in vitro films. However, their effectiveness decreased slightly when applied to mushroom soup and cooked ham due to the complexity of the food matrices used, but being a good tool to, together with other preservation strategies, ensure food wholesomeness. Sensory tests were carried out with consumers and a good acceptance of both products was obtained. However, an alteration of taste due to the generation of lactic acid was detected in the mushroom soup that could be corrected by means of acidity correctors without modifying the antimicrobial effectiveness.

Finally, life cycle analysis of conventional and active packaging for pastry cream was studied. In any case, despite the limitations regarding the waste product estimation, shelf-life extension through packaging innovation could significantly reduce the environmental impacts of the entire food packaging system.

In the present thesis, the potential use of indigenous yeasts with antifungal capacity for the control of Penicillium expansum and the control of the mycotoxin they generate, called patulin, was also explored. In the present investigation, three new yeast strains isolated from the surface of apples were selected for their efficacy against $P$. expansum. The yeasts were identified as Metschnikowia pulcherrima being 3 different strains. The ability of these yeasts for patulin biodegradation was also demonstrated. Then, different studies on the viability of the yeast and its antifungal effectiveness on different films made with biopolymers naturally present in apples (pectin, cellulose ethers, and apple pomace) were carried out. Data from in vitro antifungal assays showed that bioactive films made from apple pomace maintained the viability of $M$. pulcherrima and significantly inhibited the growth of $P$. expansum or modified its morphological growth. Finally, coatings made with apple residue containing isolated apple yeasts were applied on apples contaminated with $P$. expansum showing a very good antifungal efficacy with respect to the other treatments applied separately. 


\section{Esquema de la tesis}

Esta Tesis Doctoral está estructurada en cinco apartados: Introducción, Objetivos, Capítulos, Discusión General y Conclusiones. El apartado de INTRODUCCIÓN se centra en el uso de agentes de biocontrol como alternativa a los conservantes de origen sintético, así como los beneficios potenciales de su incorporación en recubrimientos. También se discuten las diferentes aplicaciones de recubrimientos bioactivos y las características de los polímeros utilizados. Tanto los objetivos generales como los objetivos específicos de la Tesis se recogen en el apartado OBJETIVOS. Los resultados obtenidos se dividen en tres CAPÍTULOS, que se presentan como una recopilación de ocho publicaciones científicas, incluyendo las partes habituales: introducción, materiales y métodos, resultados y discusión y conclusión. En el apartado de DISCUSIÓN GENERAL se realiza un análisis global de los principales resultados obtenidos. Finalmente, las CONCLUSIONES más importantes de la Tesis se presentan en el apartado correspondiente. 



\section{Índice de contenidos}

1.1 Agentes antimicrobianos

1.1.1 Tipos de agentes de biocontrol

1.1.1.1 Bacterias ácido lácticas productoras de bacteriocinas

Lactococcus lactis

Lactobacillus sakei

Lactococcus lactis amplio espectro

1.1.1.2 Levaduras con capacidad antifúngica

Levaduras autóctonas

Metschnikowia pulcherrima

1.1.2 Principales limitaciones de los agentes de biocontrol

\subsection{Envases bioactivos antimicrobianos}

1.2.1 Fabricación de películas bioactivas

1.2.2 Técnicas de aplicación de recubrimientos bioactivos

a) Recubrimientos que incluyen bacterias acido lácticas sobre otras películas (película sustrato)

b) Recubrimientos que incluyen levaduras elaborados directamente sobre alimentos

1.2.3 Impacto ambiental de los envases bioactivos

1.2.4 Legislación

1.3 Polímeros utilizados en los envases bioactivos antimicrobianos

a) Recubrimientos que incluyen bacterias acido lácticas sobre otras películas

Polímero de base para hacer recubrimientos

Coadyuvantes

Polímeros usados como película sustrato

b) Recubrimientos que incluyen levaduras elaborados directamente sobre alimentos

Recubrimientos de polisacáridos extraídos de manzana

Recubrimientos de orujo de la manzana 
3.1. Capítulo I: Desarrollo de películas que incorporan bacterias ácido lácticas con capacidad antimicrobiana

Artículo 1: Antilisterial properties of PVOH-based films embedded with Lactococcus lactis subsp. lactis

Artículo 2: PVOH/protein blend films embedded with lactic acid bacteria and their antilisterial activity in pasteurized milk

Artículo 3: Effect of casein hydrolysates on physico-chemical properties and the survival of protective cultures of $L$. lactis and L. sakei in PVOH films

\subsection{Capítulo II: Aplicación tecnológica de películas portadoras de bacterias ácido lácticas para el desarrollo de envases bioactivos antimicrobianos}

Artículo 4: Evaluation of Lactococcus lactis subsp. lactis as protective culture for active packaging of nonfermented foods: Creamy mushroom soup and sliced cooked ham

Artículo 5: Broadening the antimicrobial spectrum of nisinproducing Lactococcus lactis subsp. Lactis to Gram-negative bacteria by means of active packaging

Artículo 6: Comparative LCA on conventional and active packaging systems for pastry cream

3.3. Capítulo III: Desarrollo de películas que incorporan levaduras con capacidad antifúngica y aplicación tecnológica como recubrimiento de alimentos

Artículo 7: New isolated Metschnikowia pulcherrima strains from apples for postharvest biocontrol of Penicillium expansum and patulin accumulation

Artículo 8: Apple-based coatings incorporating wild apple isolated yeast to reduce Penicillium expansum postharvest decay of apples 
5. CONCLUSIONES 



\section{Abreviaturas y símbolos}
A Apple pomace/orujo de manzana
AA Aminoácidos
AF Ácido fítico
BCA Biocontrol agent/Agente de biocontrol
Cas Caseinato sódico
Da Dalton
DSC Calorimetría diferencial de barrido
FAO United Nations Food and Agriculture Organization
FDA US Food and Drug Administration
Gel Gelatina
GRAS Generally Recognized As Safe
HCas Caseína hidrolizada
$\mathrm{HGel}$ Gelatina hidrolizada
HPMC Hidroxipropilmetilcelulosa
LAB Lactic acid bacteria/Bacterias ácido lácticas
LCA Life cycle análisis/Ciclo de vida útil
MC Metilcelulosa
MRS Man Rogosa and Shape
OMS Organización Mundial de la Salud/World Health Organization (WHO)
P Pectina
PE Polietileno
PLA Poliácido láctico
PVOH Polialcohol vinílico
$\mathrm{RH} \quad$ Relative humidity/humedad relativa
SEM Microscopía electrónica de barrido
TSB Triptone Soy Broth/Caldo de triptona y soja
$\mathrm{TSB}+\mathrm{YE}$ Triptone Soy Broth with yeast extract/Caldo de triptona y soja con extracto de levadura
TSA Triptone Soy Agar/Agar de triptona y soja
UE Unión Europea/European Union
UFC Unidad formadora de colonia
YE Yeast extract/Extracto de levadura
YEG Yeast extract glucosa/Extracto de levadura glucosa 



\section{INTRODUCCIÓN}



La historia de la conservación de los alimentos está estrechamente relacionada con la evolución humana. Desde que tenemos conocimiento, la conservación de los alimentos ha sido fundamental para la supervivencia. En la actualidad, las prácticas de producción de alimentos, su distribución o las pautas de consumo siguen en continua evolución. La automatización de los procesos productivos, el auge de las nuevas formas de distribución como la venta por internet, o la compra y transporte en un contexto de globalización, son algunas de las nuevas tendencias. El ritmo de vida actual ha incrementado la demanda de productos listos para el consumo de IV y $\checkmark$ gama, pero al mismo tiempo existe una tendencia por gran parte de los consumidores de priorizar alimentos saludables, y más duraderos y sostenibles [1].

La conservación de productos frescos constituye un reto adicional ya que presentan una vida útil muy limitada lo que implica la necesidad de una mayor protección contra el deterioro durante su preparación, almacenamiento y distribución. Los alimentos pueden sufrir una degradación más rápida como resultado de procesos físicos, químicos y biológicos, incluida la contaminación microbiana causada sobre todo por bacterias, levaduras y hongos. La carga microbiana intrínseca de los alimentos también está estrechamente relacionada con la producción de efectos indeseables como cambios de olor, color, sabor, textura, etc. Este tipo de cambios conducen a una reducción de la vida útil. Ésta puede definirse como el tiempo durante el cual el alimento mantiene su seguridad y propiedades organolépticas y sensoriales cumpliendo con los datos nutricionales indicados en su etiqueta siempre y cuando sea almacenado en condiciones adecuadas [2]. Por lo tanto, una reducción de la vida útil disminuye la seguridad de los alimentos, amenaza la seguridad de la salud pública y supone pérdidas económicas muy elevadas.

Además de los cambios en las prácticas de producción de alimentos y en el medio ambiente, el aumento del comercio mundial de alimentos y los cambios en las características genéticas de los microorganismos patógenos relevantes están generando nuevos riesgos relacionados con los brotes alimentarios [3]. 
Dentro del grupo de patógenos bacterianos responsables de la mayoría de las infecciones y/o toxiinfecciones de origen alimentario, cabe destacar Salmonella spp., Listeria monocytogenes y Escherichia coli, entre otros.

Según un informe científico de la Autoridad Europea de Seguridad Alimentaria [4], la infección por Salmonella es la segunda enfermedad transmitida por los alimentos con mayor incidencia en la UE. Aunque los criterios de seguridad alimentaria son estrictos (ausencia en 25 g) (Commission Regulation (EC) No 2160/2003) y se aplican a los productos comercializados durante su vida útil, todos los años se detectan casos de salmonelosis en la UE, principalmente por consumo de carne y productos cárnicos.

L. monocytogenes puede contaminar una gran variedad de alimentos. Su principal particularidad es que esta bacteria se multiplica a temperaturas de refrigeración o incluso inferiores [6] y puede sobrevivir a la pasteurización [7,8]. En consecuencia, L. monocytogenes puede encontrarse en alimentos listos para el consumo con una vida útil relativamente larga. El número de casos de listeriosis humana ha disminuido en comparación con los últimos 10 años. Lamentablemente, a pesar de contar con una legislación muy estricta sobre los criterios microbiológicos de L. monocytogenes en los alimentos listos para su consumo (Commission Regulation (EC) No 2073/2005) y de los controles rutinarios, se siguen produciendo casos de listeriosis. En 2019, España notificó un brote de listeriosis a la Organización Mundial de la Salud [10], que infectó a más de 220 personas y dejó siete abortos y tres muertes relacionadas con el consumo de un producto cárnico listo para su consumo.

En cambio, han aumentado las enfermedades de origen alimentario producidas por $\boldsymbol{E}$. coli. Aunque esta bacteria forma parte de la microbiota humana, cuando se ingiere en una concentración suficiente a través del consumo de alimentos o agua contaminados por contaminación cruzada, puede resultar patógena. En concreto, la cepa de E. coli $\mathrm{O} 157: \mathrm{H} 7$ se ha convertido en uno de los patógenos alimentarios más letales al tratarse de una bacteria enterohemorrágica capaz de producir un síndrome urémico hemolítico [11]. 
Dentro del grupo de hongos, Penicillium expansum es una de las especies más conocidas del género Penicillium debido a su gran relevancia, ya que es una especie muy extendida que se encuentra en el medio natural $[12,13]$. Además, puede infectar una amplia gama de alimentos, siendo las frutas de pepita y de hueso, los principales objetivos de este hongo aunque también se ha aislado en verduras [14], cereales e incluso en productos lácteos [15] y marisco [16,17]. Además de que la infección por $P$. expansum disminuye la calidad de los frutos, también tiene un potencial riesgo químico con graves consecuencias, ya que este hongo produce micotoxinas que aumentan el riesgo de enfermedades graves en los consumidores [18]. Entre las toxinas, la patulina es la principal micotoxina producida por $P$. expansum, producto de su metabolismo secundario y tóxica para los seres humanos y los animales a dosis muy bajas [19]. En la Unión Europea, la patulina está limitada a $50 \mu \mathrm{g} \cdot \mathrm{kg}^{-1}$ en los zumos de fruta, a $25 \mu \mathrm{g} \cdot \mathrm{kg}^{-1}$ en los productos de fruta sólida y a $10 \mu \mathrm{g} \cdot \mathrm{kg}^{-1}$ en los productos para lactantes y niños pequeños [20].

Para controlar la proliferación de estos microorganismos, la industria alimentaria ha empleado comúnmente durante años conservantes de síntesis química como los nitratos, los nitritos, los sulfitos, el benzoato de sodio o el sorbato de potasio. En la actualidad, se considera que el uso excesivo y continuado de este tipo de conservantes puede llegar a resultar nocivo para la salud. Además, los consumidores demandan cada vez más productos elaborados con ingredientes naturales, por lo que el uso de conservantes sintéticos está perdiendo apoyo [21,22]. Del mismo modo, existe una tendencia creciente hacia los alimentos menos procesados, que garanticen las propiedades sensoriales y nutricionales y por tanto la sustitución del tratamiento térmico clásico por tecnologías innovadoras de conservación no térmicas en combinación con otras barreras, como el uso de antimicrobianos naturales [23,24]. 


\subsection{Agentes antimicrobianos}

Como alternativa a los conservantes artificiales, se ha estudiado y comprobado el potencial antimicrobiano de una gran variedad de agentes naturales contra bacterias y hongos patógenos y alterantes causantes del deterioro de diversos alimentos [25], como son los aceites esenciales derivados de las plantas, las enzimas de origen animal (como la lisozima o la lactoferrina), las bacteriocinas de origen microbiano (como la nisina, la sakacina y la pediocina) y los biopolímeros (como el quitosano).

De entre los agentes antimicrobianos, los de origen microbiológico, se han propuesto como conservantes naturales para inhibir o prevenir el crecimiento de microorganismos de deterioro y patógenos en los alimentos $y$, por consiguiente, para mejorar su seguridad y prolongar su vida útil. Las bacteriocinas producidas por bacterias, principalmente por bacterias ácido lácticas, han sido las más estudiadas. Se trata de pequeños péptidos o proteínas sintetizadas en los ribosomas de las células, que actúan contra bacterias estrechamente relacionadas, sin afectar a las células productoras [26]. Las bacteriocinas se consideran seguras para el consumo, ya que pueden degradarse en el tracto gastrointestinal. Estas sustancias son especialmente activas contra las bacterias Gram-positivas, como los patógenos de origen alimentario L. monocytogenes, Staphylococcus aureus y Clostridium spp.

Sin embargo, las bacteriocinas presentan algunas desventajas como su descomposición durante el almacenamiento cuando se aplican como aditivo, su elevado coste, ya que necesita ser aislada y purificada y algunos aspectos legales ya que actualmente, el uso de las bacteriocinas está restringido y sólo están permitidas y disponibles comercialmente la nisina y la pediocina.

El uso directamente de las bacterias ácido lácticas (LAB) productoras de bacteriocinas para la conservación de los alimentos en lugar de las bacteriocinas es una estrategia innovadora para evitar los problemas citados anteriormente. Al inocular las bacterias acido lácticas directamente en el alimento, en condiciones que favorecen la producción de bacteriocinas, su producción es constante, superando así el problema de la descomposición cuando se utilizan como aditivos 
[27]. Además, su potencial antimicrobiano es mayor ya que las LAB generan metabolitos con actividad antimicrobiana, incluyendo varios ácidos orgánicos y peróxido de hidrógeno; durante el almacenamiento compiten con otras bacterias por los nutrientes y el oxígeno, y dominan la carga microbiana de muchos alimentos. Cuando se utilizan agentes activos vivos, como por ejemplo las bacterias ácido lácticas, para reducir las poblaciones de microorganismos patógenos, alterantes de los alimentos o productores de sustancias tóxicas, se definen como "agentes de control biológico" o "agentes de biocontrol".

\subsubsection{Tipos de agentes de biocontrol}

Los agentes de biocontrol utilizados en esta tesis se detallan a continuación.

1.1.1.1 Bacterias acido lácticas productoras de bacteriocinas

\section{Lactococcus lactis}

Entre las LAB, Lactococcus lactis subsp. lactis se utiliza especialmente para la conservación de alimentos. Fenotípicamente, se clasifica como una bacteria Gram-positiva, esférica, homolactada, no esporulada y anaerobia facultativa. La temperatura óptima de crecimiento es de $30{ }^{\circ} \mathrm{C}$, aunque es capaz de crecer a temperaturas de refrigeración [28].

Lactococcus lactis se ha utilizado durante siglos en la fermentación de alimentos, especialmente queso, yogur, chucrut y similares, lo que le ha valido el estatus de generalmente reconocido como seguro (GRAS) por la FDA. L. lactis es una bacteria ácido láctica que también produce ácido que conserva los alimentos. La cepa $L$. lactis subsp. lactis mejora aún más esta propiedad de conservación ya que produce nisina, reforzando así su papel en la industria alimentaria.

La nisina es una bacteriocina producto del metabolismo de $L$. lactis que ha sido ampliamente explotada como conservante de alimentos durante más de 60 años. La FDA clasifica la nisina como GRAS y su uso como aditivo para la conservación de alimentos está permitido 
en muchos países. La nisina es un péptido de $3.5 \mathrm{KDa}$ que pertenece a las bacteriocinas de clase I.A, también conocidas como lantibióticos ya que contienen lantionina. Es inofensiva para el ser humano, es termorresistente y se encuentra disponible comercialmente para su uso en diversos alimentos. Además, tiene una actividad antimicrobiana contra una amplia gama de bacterias Gram-positivas, incluyendo patógenos transmitidos por los alimentos como Listeria monocytogenes [29]. Los estudios han demostrado que el principal mecanismo de acción de esta bacteriocina frente a otras bacterias es la formación de poros en la membrana citoplasmática y la inhibición de la síntesis de peptidoglicano como se observa en la figura 1. Además, puede inducir la autolisis celular e inhibir el crecimiento de las esporas bacterianas [30-32].

\section{Lactobacillus sakei}

Lactobacillus sakei es un bacilo Gram-positivo y no esporulado que puede vivir en condiciones aeróbicas y anaeróbicas. La temperatura óptima de crecimiento es de $30^{\circ} \mathrm{C}$, pero también se sabe que es una de las bacterias más psicrófilas dentro del género Lactobacillus, ya que algunas cepas pueden crecer a temperaturas entre 2 y $4{ }^{\circ} \mathrm{C}$ [33]. Está reconocida como GRAS por la FDA.

A menudo se ha aislado de alimentos de origen vegetal como diversas harinas, masas madre o coles fermentadas, pero se asocia sistemáticamente con productos cárnicos y, a menudo, con el marisco $[34,35]$. De hecho, interviene en la fermentación de productos cárnicos, como los embutidos, donde normalmente actúa como agente de maduración. En algunos casos, también se utiliza como bacteria conservante ya que es capaz de producir sakacina $A$, una bacteriocina con capacidad antimicrobiana.

La sakacina $\mathrm{A}$ es un péptido de $4.3 \mathrm{KDa}$ y $41 \mathrm{AA}$, estable al calor, que forma parte de la clase II.A de las bacteriocinas, una familia compuesta por un elevado número de moléculas que muestra, en general, un modo de acción similar. Tal y como se recoge en múltiples referencias bibliográficas, estas bacteriocinas son eficaces contra las 
bacterias Gram-positivas. Su principal mecanismo de acción contra bacterias es la desestabilización de su membrana plasmática permeabilizándola. De hecho, tras su unión a los fosfolípidos, se produce una penetración a través de la membrana citoplasmática formando un canal abierto provocando un aumento de la permeabilidad de la membrana, la pérdida de compuestos celulares y la disipación de la fuerza motriz de los protones y el agotamiento del ATP intracelular $[36,37]$ como se puede observar en la figura 1.

NISINA

(Clase I)

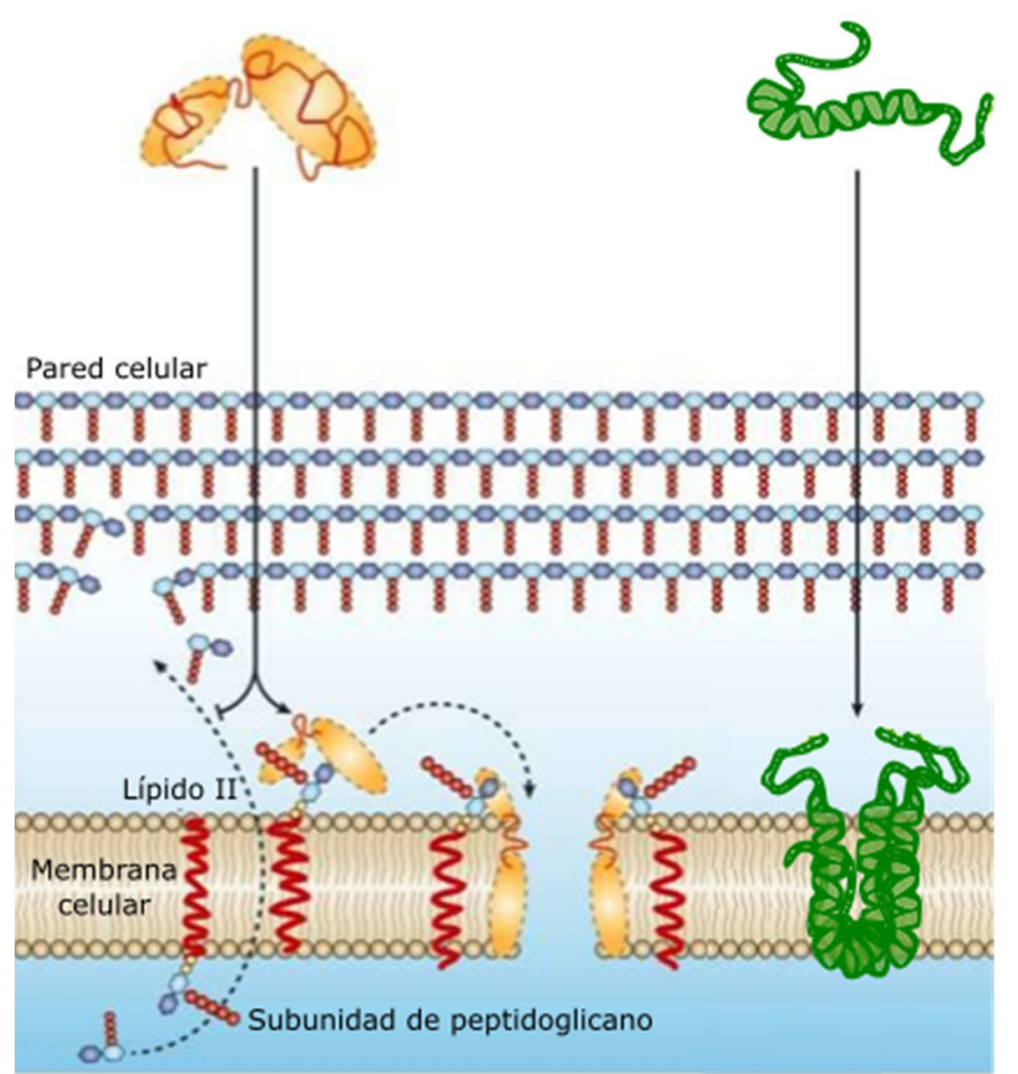

SAKACINA A (Clase II)

Figura 1. Modo de acción de nisina y sakacina contra bacterias Gram-positivas (adaptado de Cotter et al., (2005))

Cabe destacar que, a diferencia de la nisina, el uso directo de la sakacina como antimicrobiano en alimentos no está permitido ni por la 
FDA ni por la EFSA. A pesar de ello, es posible un uso no directo de la sakacina A mediante la aplicación de Lactobacillus sakei.

\section{L. lactis con amplio espectro: Ácido fítico}

Las bacteriocinas no suelen ser efectivas contra las bacterias Gram-negativas debido a que no pueden penetrar a través de su pared celular. No obstante, el efecto antimicrobiano de la nisina y por tanto de $L$. lactis puede mejorarse mediante el uso de agentes desestabilizadores de la membrana, como los compuestos quelantes, ácidos policatiónicos y los ácidos orgánicos débiles y sus sales $[39,40]$. De entre los agentes con capacidad quelante, el ácido fítico es una alternativa natural a la utilización clásica del ácido etilendiaminotetraacético (EDTA). El ácido fítico está presente en muchos cereales y legumbres. El nivel máximo de ácido fítico permitido por la FDA es del $0.2 \%(p / p)$ [41].

Estudios previos han demostrado que el ácido fítico en combinación con la nisina es capaz de ampliar el espectro de esta última contra bacterias Gram-negativas [42]. En efecto, el ácido fítico, por su estructura química mostrada en la figura 2, provoca la disfunción de la membrana celular de las bacterias Gram-negativas cambiando su morfología y disminuyendo las concentraciones de ATP intracelular [43].

Combinar el agente de biocontrol productor de nisina, L. lactis, con una baja concentración de ácido fítico, podría ampliar el espectro antimicrobiano de $L$. lactis a las bacterias Gram-negativas obteniendo una nueva herramienta para garantizar la seguridad alimentaria y prolongar la vida útil de los alimentos. 


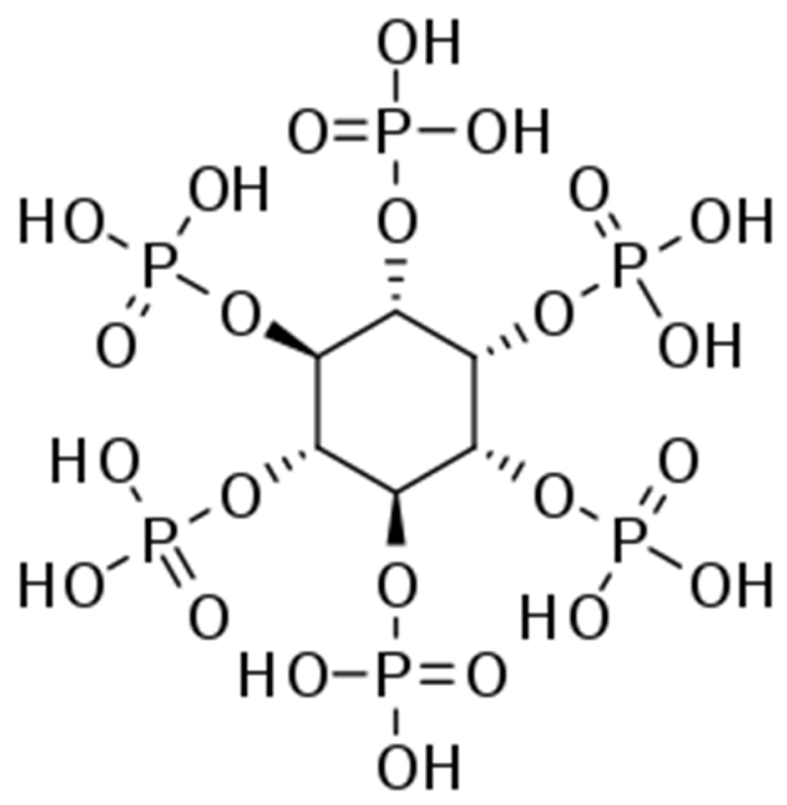

Figura 2. Estructura química del ácido fítico

\subsubsection{Levaduras con capacidad antifúngica}

Aunque la mayoría de los estudios y aplicaciones de agentes de biocontrol se han centrado en la utilización de $L A B$, las levaduras también han sido objeto de investigación debido a su capacidad para inhibir el crecimiento de bacterias y hongos transmitidos por los alimentos [44].

Las levaduras son microorganismos eucariotas, normalmente definidos como hongos unicelulares capaces de colonizar tejidos animales y vegetales, suelos, entornos acuáticos y alimentos.

La colonización de vastos ecosistemas está relacionada con su capacidad para proliferar y sobrevivir en condiciones exigentes ya que tienen requisitos nutricionales relativamente bajos, son eficaces a bajas concentraciones y son capaces de sobrevivir en condiciones adversas de temperatura y estrés oxidativo [45]. Las levaduras tienen un amplio espectro antimicrobiano, son genéticamente estables y son respetuosas con el medio ambiente. 
Históricamente, las levaduras han participado en una de las tecnologías de bioconservación más antiguas, el proceso de fermentación utilizado para la producción de productos básicos como el vino, la cerveza, la sidra, el pan, los quesos y los embutidos, entre otros. Más recientemente, las levaduras han sido consideradas como potenciales agentes de biocontrol, en particular para el control de enfermedades postcosecha de frutas y verduras producidas por hongos [46].

\section{Levaduras autóctonas}

El uso de levaduras autóctonas en el control de enfermedades postcosecha es especialmente ventajoso, ya que las levaduras se encuentran de forma natural en la superficie de las frutas y verduras, pueden colonizar las heridas durante largos periodos de tiempo y se ven mínimamente afectadas por los pesticidas [45]. Además, el uso de levaduras activas autóctonas es aún más interesante porque compiten de forma natural con los hongos patógenos en su entorno de origen, por lo que están fenotípicamente más adaptadas para sobrevivir y atacar a los patógenos [47].

Los mecanismo de acción de las levaduras dependen de la cepa en cuestión aunque los más habituales son la competencia de nutrientes, la competencia por el espacio disponible o el parasitismo $[44,48]$.

\section{Metschnikowia pulcherrima}

De entre las bacterias autóctonas, Metschnikowia pulcherrima ha sido aislada de manzanas, uno de los alimentos más susceptibles de ser contaminado por $P$. expansum. Las levaduras pertenecientes a este género son terrestres, a menudo asociadas a las flores y transmitidas a nuevos nichos por los insectos [49].

M. pulcherrima es una de las 13 especies habituales residentes en los manzanos de sidra [50]. Según otros estudios, se ha aislado en 
cultivares de manzanas a partir de partes florales, de yemas e incluso en tejido de manzana herido [51,52].

El principal mecanismo antifúngico de M. pulcherrima es la producción de un pigmento rojo, la pulcherrimina, que se acumula en las células y también se secreta alrededor de las colonias [53]. Este pigmento forma un complejo de quelatos e inmoviliza los iones de hierro en el medio de crecimiento que son esenciales para el crecimiento del hongo y la patogénesis [54]. Además de la actividad de competencia nutricional, otros autores han demostrado que $M$. pulcherrima también puede ejercer competencia por parasitismo debido a la producción de enzimas líticas como la quitinasa y compuestos volátiles antifúngicos [55,56]. Otra ventaja de utilizar levaduras como agentes de biocontrol es su capacidad para degradar micotoxinas [57-59]. Algunos estudios han demostrado que cepas del género Metschnikowia tienen la capacidad de degradar la patulina en condiciones anaeróbicas o aeróbicas $[60,61]$.

La utilización de M. pulcherrima aislada de manzanas podría constituir una estrategia para combatir a $P$. expansum si se aplica en una concentración suficiente en manzanas.

\subsubsection{Principales limitaciones de los agentes de biocontrol}

Para que los agentes de biocontrol desempeñen el papel antimicrobiano previsto en los alimentos, es esencial que tanto la viabilidad como la actividad metabólica se mantengan a lo largo de la cadena de procesamiento, almacenamiento y suministro de alimentos. Sin embargo, las condiciones a las que se suele enfrentar un alimento a lo largo de esta cadena conlleva etapas como la exposición al calor o al frío, el estrés osmótico, un bajo $\mathrm{pH}$ o la reducción del potencial redox que disminuyen drásticamente la viabilidad de los agentes de biocontrol y por tanto su actividad antimicrobiana puede verse afectada $[62,63]$.

Por lo tanto, es necesario explorar nuevas estrategias para aumentar su funcionalidad. El uso de recubrimientos o películas comestibles es una posible solución para superar estas limitaciones, ya que pueden mantener una concentración adecuada en la superficie del 
producto alimentario y también garantizan una mayor estabilidad de los microorganismos que quedan atrapados en la película matriz [64].

\subsection{Envases bioactivos antimicrobianos}

Tradicionalmente, las funciones principales de un envase alimentario han sido contener el producto, protegerlo contra los daños físicos y ambientales y proporcionar información a través del etiquetado. Sin embargo, en las últimas décadas el concepto de envase activo ha avanzado en la ciencia para satisfacer la demanda de alimentos seguros y de alta calidad. El envase activo se define como un sistema en el que el sistema producto/envase/entorno interactúa para mantener la seguridad y la calidad del producto y prolongar su vida útil [65]. En la actualidad se están desarrollado diferentes tecnologías de envasado activo, como son los envases para el control de la humedad, los secuestradores de oxígeno y dióxido de carbono, las películas poliméricas con permeabilidad selectiva a los gases, los susceptores de microondas o los envases antimicrobianos.

El uso de materiales de envasado como portadores de diversas sustancias activas, incluidos los compuestos antimicrobianos, es una opción prometedora para evitar la contaminación microbiana de los alimentos y preservarlos de los procesos de deterioro. En este sentido, las películas activas pueden garantizar una liberación sostenida del antimicrobiano en la superficie del alimento o en el espacio de cabeza del envase durante el almacenamiento del producto.

Los sistemas de envasado bioactivo antimicrobiano de alimentos son aquellos que incorporan agentes de biocontrol viables, como los mencionados en el apartado anterior, capaces de generar compuestos antimicrobianos in situ en el alimento ampliando su vida útil y su seguridad.

En la figura 3 se muestra un esquema que ilustra las principales características de las películas y recubrimientos comestibles que incorporan microorganismos vivos. 


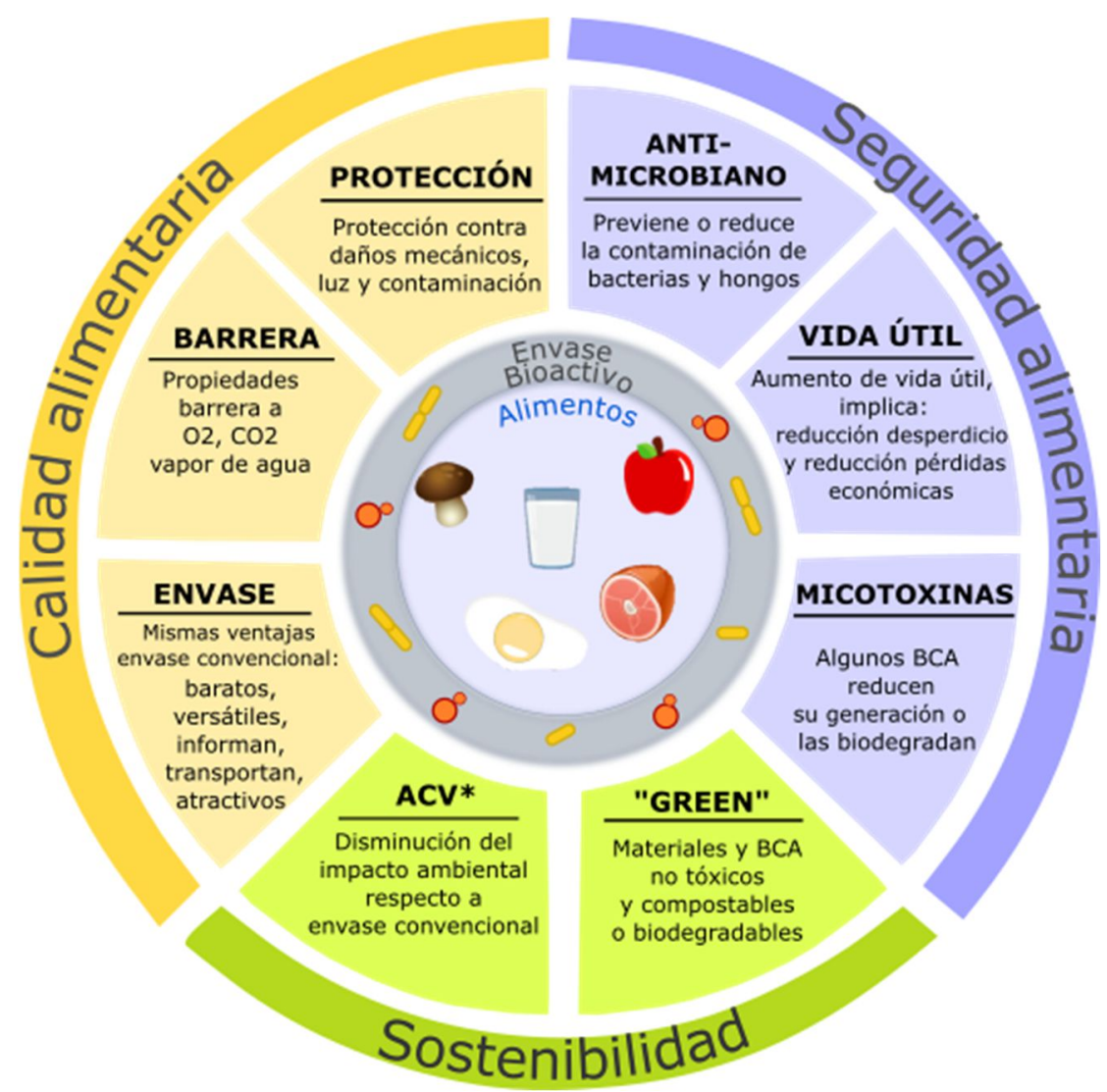

*ACV: Análisis del ciclo de vida

Figura 3. Resumen de los beneficios y ventajas de las películas y recubrimientos bioactivos que incorporan microorganismos vivos

En esta Tesis Doctoral se han desarrollado películas activas antimicrobianas portadoras de agentes de biocontrol y se han caracterizado sus propiedades funcionales $y$, especialmente, su actividad antimicrobiana in vitro, y sobre alimentos reales, mediante recubrimientos en sistemas alimentarios líquidos y sólidos, contra diferentes microorganismos como bacterias alternantes de los alimentos, bacterias patógenas $\mathrm{u}$ hongos.

1.2.1 Fabricación de películas bioactivas 
Existen básicamente dos metodologías para producir sistemas de envasado antimicrobiano que incorporen microorganismos vivos: a) el uso de agentes de biocontrol incorporados durante la fabricación del envase, es decir, el agente antimicrobiano se incorpora en una capa de una estructura multilaminada $\circ$ b) directamente recubriendo el producto a conservar.

El agente bioactivo ejerce por tanto su acción por contacto de la pared del envase con el alimento, por liberación en éste o por contacto directo con el propio alimento recubierto.

Existen varias técnicas de fabricación para incorporar agentes antimicrobianos en las paredes de un sistema de envasado. La selección debe basarse en el tipo de polímero, las características del agente antimicrobiano y, especialmente, el mecanismo de acción del agente y el tipo de alimento $[25,66]$.

La incorporación de microorganismos vivos en películas y recubrimientos comestibles supone un reto adicional: deben permanecer viables en concentraciones suficientes para ejercer actividad antimicrobiana, aunque sin alterar las propiedades mecánicas y de barrera de la película o el recubrimiento, y sin modificar las propiedades sensoriales del alimento. La adición de microorganismos vivos en películas y recubrimientos comestibles ha sido analizada recientemente por varios autores y se revisa en la tabla 1 y en la tabla 2. 
Tabla 1. Incorporación de bacterias vivas en películas y recubrimientos.

\begin{tabular}{|c|c|c|c|c|c|}
\hline Matriz & Otros aditivos & Agente de biocontrol & Alimento & Microorganismo(s) inhibido(s) & Referencia \\
\hline Caseinato sódico & - & Lactobacillus sakei & Ternera & Listeria monocytogenes & {$[67]$} \\
\hline Alginato sódico & - & Carnobacterium maltaromaticum & $\begin{array}{l}\text { Salmón } \\
\text { ahumado }\end{array}$ & Listeria monocytogenes & {$[68]$} \\
\hline $\begin{array}{l}\text { Alcohol polivinílico } \\
\text { (entrecruzado) }\end{array}$ & $\begin{array}{c}\text { N,N-dimetilformamida } \\
\text { Dietiléter }\end{array}$ & Enterococcus casseliflavus & $\begin{array}{l}\text { Würstel } \\
\text { Queso }\end{array}$ & Listeria monocytogenes & {$[69]$} \\
\hline Gelatina & $\begin{array}{l}\text { Glucosa } \\
\text { Cisteína } \\
\text { Sorbitol } \\
\text { Glicerol }\end{array}$ & $\begin{array}{l}\text { Lactobacillus acidophilus } \\
\text { Bifidobacterium bifidum }\end{array}$ & Merluza & Aerobios totales & {$[70]$} \\
\hline $\begin{array}{l}\text { Hidroxipropilmetilcelulosa } \\
\text { Proteína de guisante } \\
\text { Metilcelulosa } \\
\text { Caseinato sódico }\end{array}$ & Glicerol & Lactobacillus plantarum & Medio cultivo & Listeria innocua & {$[71]$} \\
\hline Agar & $\begin{array}{l}\text { Glucosa } \\
\text { Té verde }\end{array}$ & $\begin{array}{l}\text { Lactobacillus paracasei } \\
\text { Bifidobacterium animalis }\end{array}$ & $\begin{array}{c}\text { Merluza } \\
\text { descongelada }\end{array}$ & $\begin{array}{l}\text { Photobacterium phosphoreum } \\
\text { Shewanella putrefaciens }\end{array}$ & {$[72]$} \\
\hline $\begin{array}{c}\text { Metilcelulosa } \\
\text { Caseinato sódico }\end{array}$ & Glicerol & $\begin{array}{c}\text { Lactobacillus reuteri } \\
\text { Lactobacillus acidophilus }\end{array}$ & Medio cultivo & Listeria innocua & {$[73]$} \\
\hline $\begin{array}{l}\text { Hidroxipropilmetilcelulosa } \\
\text { Almidón de maíz }\end{array}$ & Glicerol & Lactococcus lactis & Medio cultivo & Listeria monocytogenes & {$[74]$} \\
\hline $\begin{array}{c}\text { Alginato sódico } \\
\text { Carboxilmetilcelulosa }\end{array}$ & Glicerol & Lactococcus lactis & Medio cultivo & Staphylococcus aureus & {$[75]$} \\
\hline Caseinato sódico & Glicerol & $\begin{array}{l}\text { Lactobacillus acidophilus } \\
\text { Lactobacillus casei }\end{array}$ & Medio cultivo & Listeria monocytogenes & {$[76]$} \\
\hline
\end{tabular}




\section{Alcohol polivinílico}

(entrecruzado)

Hidroxipropilcelulosa

Harina de konjac

Proteína de suero aislada

Glicerol

Glicerol

Glicerol

arboximetilcelulosa,

Colágeno

Caseinato sódico

Almidón de patata

Almidón de yuca

Carboximetilcelulosa

Carboximetilcelulosa

Caseinato sódico

Proteína del suero aislada

$$
\text { Gelatina }
$$

Inulina

Glicerol
$\mathrm{N}, \mathrm{N}$-dimetilformamida

Dietiléter

Enterococcus casseliflavus

Glicerol

Lactobacillus paracasei

$$
\text { Pollo }
$$

precocido

Fresas

Bifidobacterium animalis Lactobacillus casei

Lactococcus lactis

Lactococcus lactis

Lactobacillus plantarum

Lactobacillus plantarum

Pediococcus pentosaceus

Lactobacillus acidophilus

Lactobacillus reuteri

Lactobacillus casei

Lactobacillus rhamnosus

Bifidobacterium bifidum
Jamón cocido

Medio cultivo

Medio cultivo

Uvas de mesa

Banana

Filetes de

trucha

Lactobacillus curvatus

Medio cultivo
Listeria monocytogenes

Listeria monocytogenes,

Staphylococcus aureus

Escherichia coli

Salmonella typhimurium

Aerobios totales,

Staphylococcus spp.,

Pseudomonas spp.,

Enterobacteriaceae,

levaduras y hongos

Staphylococcus aureus

Staphylococcus aureus

Botrytis cinerea

Aeromonas

Photobacterium

Listeria innocua 


\section{Proteína del suero concentrada}

Glicerol

Goma Guar

Tween 20

Glicerol

Glucosa
Lactobacillus buchneri

Lactobacillus casei

Queso

'Flamengo'

Penicillium nordicum

[86]

Photobacterium phosphoreum

Shewanella putrefaciens

Aerobios totales

Pescado

Lactobacillus acidophilus

Bacterias productoras de $\mathrm{H}_{2} \mathrm{~S}$

Photobacterium phosphoreum

Pseudomonas spp. 
Tabla 2. Incorporación de levaduras vivas en películas y recubrimientos comestibles.

\begin{tabular}{|c|c|c|c|c|c|}
\hline Matriz & Otros aditivos & Agente de biocontrol & Alimento & $\begin{array}{c}\text { Microorganismo(s) } \\
\text { inhibido(s) }\end{array}$ & Referencia \\
\hline $\begin{array}{c}\text { Metilcelulosa } \\
\text { Hidroxipropilcelulosa }\end{array}$ & Sorbato potásico & Candida oleophila & Pomelo & Hongos y levaduras & {$[88]$} \\
\hline $\begin{array}{l}\text { Metilcelulosa, } \\
\text { Carboximetilcelulosa } \\
\text { Hidroxipropilcelulosa }\end{array}$ & $\begin{array}{c}\text { Glucosa } \\
\mathrm{CaCl}_{2}\end{array}$ & $\begin{array}{c}\text { C. guillermondii } \\
\text { Devaryomyces spp. }\end{array}$ & Naranja & Hongos y levaduras & [89] \\
\hline $\begin{array}{l}\text { Goma laca, } \\
\text { Látex de goma laca, } \\
\text { Éster de goma laca }\end{array}$ & $\begin{array}{c}\text { Etanol } \\
\text { Morfolina } \\
\text { Amonio, } \mathrm{KOH} \\
\text { Ácido oleico } \\
\text { Propilenglicol }\end{array}$ & Candida oleophila & Pomelo & Hongos y levaduras & {$[90]$} \\
\hline $\begin{array}{c}\text { Goma laca } \\
\text { Éster de sacarosa }\end{array}$ & $\begin{array}{l}\text { Propilenglico } \\
\text { Ácido oleico } \\
\text { Polisorbato } 80\end{array}$ & Candida oleophila & Pomelo & Hongos y levaduras & [91] \\
\hline Quitosano & Tween 80 & Candida utilis & Tomate & Goetrichum candidum & {$[92]$} \\
\hline Alginato & $\begin{array}{c}\text { Glicerol } \\
\text { Ácido palmítico } \\
\text { Glicerol } \\
\beta \text {-Ciclodextrinas }\end{array}$ & Cryptococcus laurentii & Fresa & Hongos y levaduras & [93] \\
\hline
\end{tabular}




\begin{tabular}{|c|c|c|c|c|c|}
\hline $\begin{array}{l}\text { Alginato de sodio } \\
\text { Goma de garrofín }\end{array}$ & Glicerol & $\begin{array}{c}\text { Wickerhamomyces } \\
\text { anomalus }\end{array}$ & Naranja & Penicillium digitatum & [94] \\
\hline Goma de garrofín & - & $\begin{array}{l}\text { Wickerhamomyce anomalus } \\
\text { Metschnikowia pulcherrima } \\
\text { Aureobasidium pullulans }\end{array}$ & Mandarina & $\begin{array}{l}\text { Penicillium digitatum } \\
\text { Penicillium italicum }\end{array}$ & [95] \\
\hline $\begin{array}{l}\text { Hidroxipropilmetilcelulosa } \\
\text { Almidón de maíz } \\
\text { Caseinato sódico } \\
\text { Proteína de guisante }\end{array}$ & $\begin{array}{l}\text { Ácido oleico } \\
\text { Span } 80 \\
\text { Tween } 85 \\
\text { Glicerol }\end{array}$ & Candida sake & Uva & Botrytis cinerea & [96] \\
\hline $\begin{array}{l}\text { Concentrado de proteína de } \\
\text { suero }\end{array}$ & Glicerol & Williopsis saturnus & Medio cultivo & $\begin{array}{l}\text { Penicilium expansum } \\
\text { Aspergillus niger }\end{array}$ & [97] \\
\hline $\begin{array}{c}\text { Concentrado de proteína de } \\
\text { suero (WPC) }\end{array}$ & Glicerol & Williopsis saturnus & Queso & Hongos y levaduras & [98] \\
\hline
\end{tabular}




\subsubsection{Técnicas de aplicación de recubrimientos bioactivos}

En la presente tesis se han empleado polímeros hidrosolubles evitando así el empleo de disolventes que afectarían a la viabilidad de los agentes de biocontrol. Las películas se han obtenido mediante la técnica de casting (extensión y evaporación del disolvente) que se puede llevar a cabo a temperatura ambiente sin dañar a los microorganismos que actúan como agentes de biocontrol.

En el presente trabajo, además de estudiar la actividad antimicrobiana de las películas también se plantea la utilización de éstas para desarrollar envases activos y aplicarlos en alimentos. Para ello, las películas se aplican como recubrimiento de dos formas diferentes tal y como se indica a continuación:

a) Recubrimientos que incluyen bacterias acido lácticas sobre otras películas (película sustrato)

En la figura 4 se muestra un esquema que resume la fabricación de recubrimientos sobre una película sustrato para posteriormente desarrollar envases.

b) Recubrimientos que incluyen levaduras elaborados directamente sobre alimentos

En la figura 5 se muestra un esquema que resume la fabricación de recubrimientos directamente sobre el alimento. 


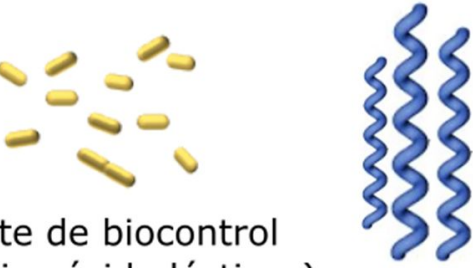

Agente de biocontrol

(Bacterias ácido lácticas) Polímeros

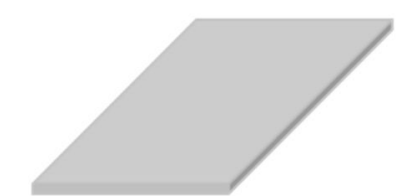

Película sustrato
$\| \longrightarrow$

Recubrimiento por "casting" con varilla

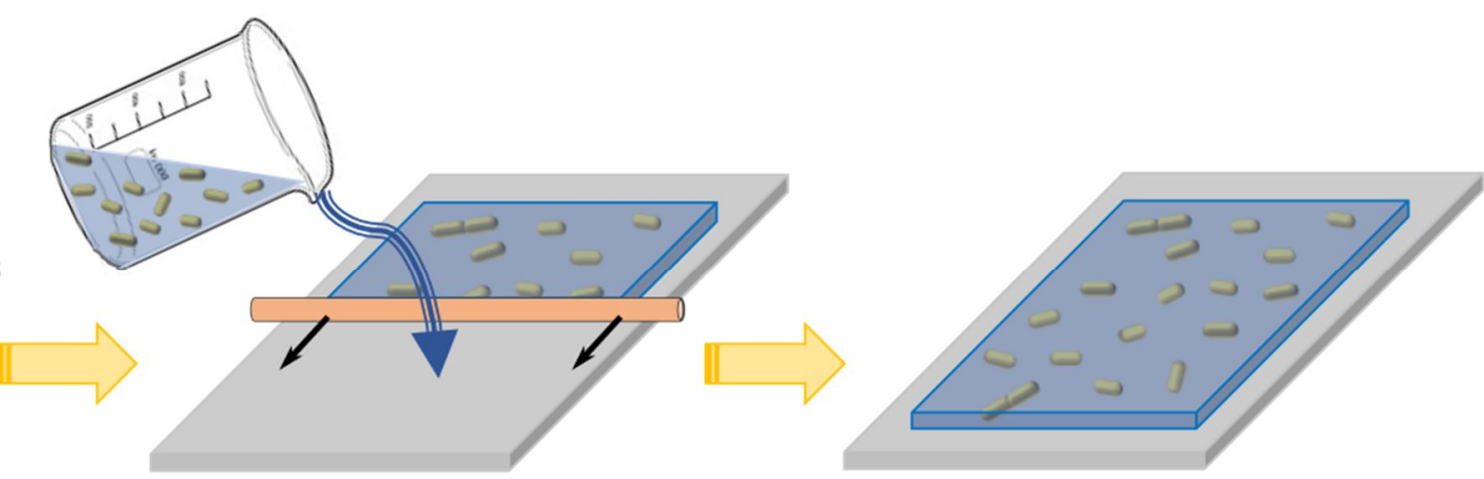

Recubrimiento con bacterias ácido lácticas con capacidad antimicrobiana

Figura 4. Etapas en la preparación de recubrimientos antimicrobianos que incorporan bacterias ácido lácticas sobre una película sustrato 


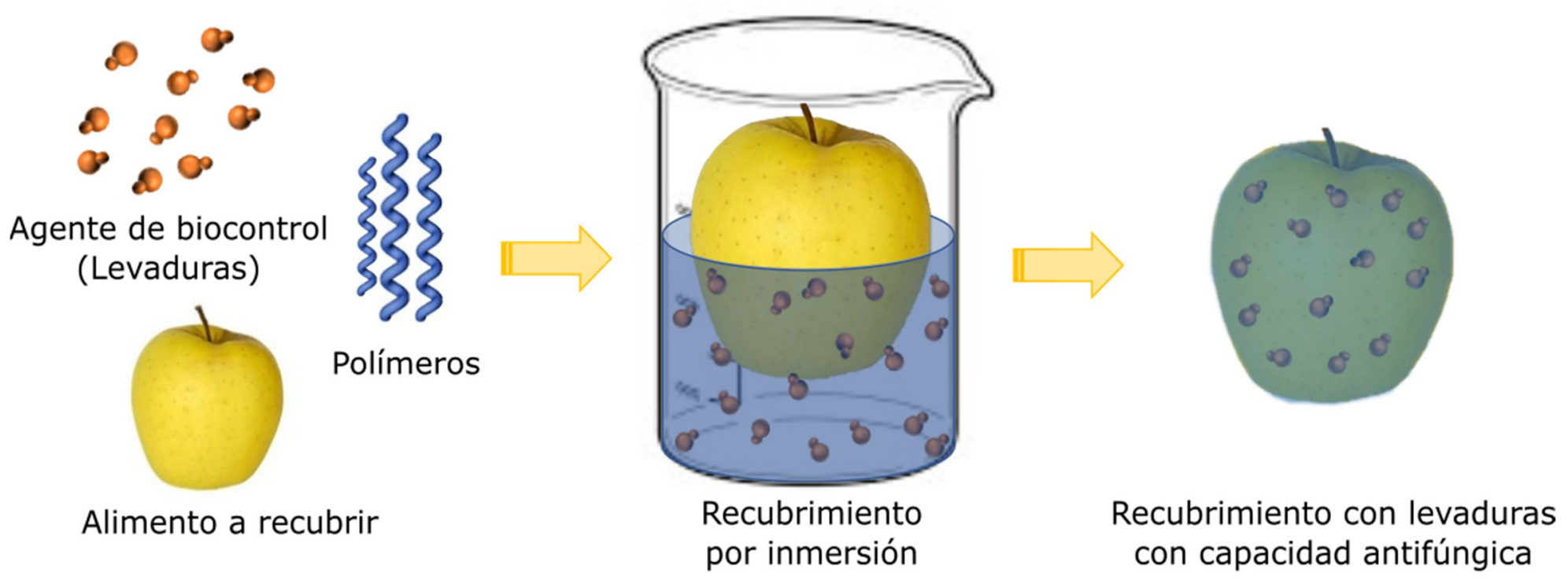

Figura 5. Etapas en la preparación de recubrimientos antifúngicos que incorporan levaduras directamente sobre un alimento 


\subsubsection{Impacto ambiental de los envases bioactivos}

Los envases realizados con polímeros se suelen asociar a un mayor impacto medioambiental; incluso se podría pensar que los cambios necesarios para obtener un envase antimicrobiano bioactivo generan un mayor impacto medioambiental. Sin embargo, estos nuevos envases tienen la función de aumentar la vida útil de los alimentos con respecto a los envases convencionales y por tanto reducir el desperdicio de éstos.

El desperdicio alimentario, también tiene consecuencias para el medio ambiente, ya que la fabricación de productos que posteriormente se desechan requiere recursos y provoca emisiones en el aire, el agua y el suelo en las fases de producción y la cadena de suministro. Así lo confirma la huella de carbono mundial generada por los residuos alimentarios, que se ha estimado en el equivalente a 3,3 Gt de $\mathrm{CO}_{2}$ [99]. Por lo tanto, la conexión entre el diseño de los envases y el desperdicio de alimentos debe reconocerse e incluirse en el impacto ambiental, ya que un envase diseñado como respetuoso con el medio ambiente, pero ineficaz para proteger los alimentos, puede parecer una mejor alternativa medioambiental que un envase que ayuda a reducir las pérdidas de alimentos, aunque no sea cierto [100].

Una herramienta muy útil para estimar el impacto ambiental es el análisis del ciclo de vida (ACV). Se trata de un método estandarizado (ISO, 2006) que evalúa los posibles impactos ambientales asociados a un producto, proceso o servicio a lo largo de su ciclo de vida, y está reconocido internacionalmente como la mejor herramienta para evaluar el comportamiento ambiental de los productos o sistemas (European commission, 2013, 2003).

En los últimos años, este método se ha utilizado ampliamente para investigar la sostenibilidad de la fabricación y el envasado de alimentos $[103,104]$.

Diversos estudios han demostrado que la inclusión de la función [105] "evitar el desperdicio de alimentos" en un estudio de ACV es necesaria para evaluar la sostenibilidad real de un sistema de envasado. Además, otros autores evaluaron los impactos ambientales resultantes de los residuos de alimentos generados por los consumidores en función de las propiedades del envase, revelando que las soluciones de envasado que minimizan la 
generación de residuos de alimentos conducen a los impactos ambientales más bajos de toda la cadena producto-envase $[106,107]$.

\subsubsection{Legislación}

La seguridad de los materiales en contacto con los alimentos, en especial los activos, requiere una evaluación puesto que los componentes activos se añaden deliberadamente para que migren de estos materiales a los alimentos. Los materiales deben fabricarse de acuerdo con la normativa de la UE, incluidas las Buenas Prácticas de Fabricación (BPF), para que cualquier posible transferencia a los alimentos no suponga un peligro para la salud, ni cambie la composición de los alimentos de forma inaceptable, ni provoque el deterioro de sus características organolépticas. Los requisitos generales para todos los materiales en contacto con los alimentos se establecen en el Reglamento Marco de la UE CE 1935/2004 y se apoyan en el Reglamento UE 2023/2006 sobre Buenas Prácticas de Fabricación.

El Reglamento UE 450/2009 establece requisitos específicos para el uso y la autorización de materiales y objetos activos e inteligentes destinados a entrar en contacto con alimentos. El reglamento también establece una lista comunitaria de sustancias que pueden utilizarse en la fabricación de estos materiales. Sólo las sustancias reguladas como aditivos o aromas alimentarios pueden ser liberadas en los alimentos. Según este Reglamento, los envases activos e inteligentes sólo pueden comercializarse si son adecuados y eficaces para su uso previsto, y tienen que ir acompañados de una declaración de conformidad e incluir información al consumidor en la fase de venta al por menor, como establece el artículo 3 del Reglamento UE 1935/2004.

Se están realizando esfuerzos para la armonización y la sustitución de la legislación nacional restante por reglamentos de ámbito comunitario, ya que algunos materiales en contacto con alimentos pueden estar cubiertos específicamente en la legislación nacional de los Estados miembros y sólo parcialmente por los reglamentos de la UE [108].

Por último, este 2021 entra en aplicación el Reglamento UE 1381/2019 sobre la transparencia y la sostenibilidad de la determinación o evaluación del riesgo de la UE en la cadena alimentaria.

Los agentes antimicrobianos utilizados en este trabajo son productos GRAS. 


\subsection{Polímeros utilizados en los envases bioactivos antimicrobianos}

La optimización de la composición de las películas o recubrimientos es crucial para su aplicación con éxito, ya que deben formularse en función de su finalidad, del agente antimicrobiano que van a transportar y de las propiedades del alimento en el que se van a aplicar. Los polímeros utilizados en esta tesis se eligieron en función del recubrimiento a desarrollar y se indican a continuación:

a) Recubrimientos que incluyen bacterias acido lácticas sobre otras películas

\section{Polímero de base para hacer recubrimientos}

El polímero escogido como base para hacer los recubrimientos ha sido el poli (alcohol vinílico) o alcohol polivinílico, PVOH, cuya estructura se muestra en la figura 6 .

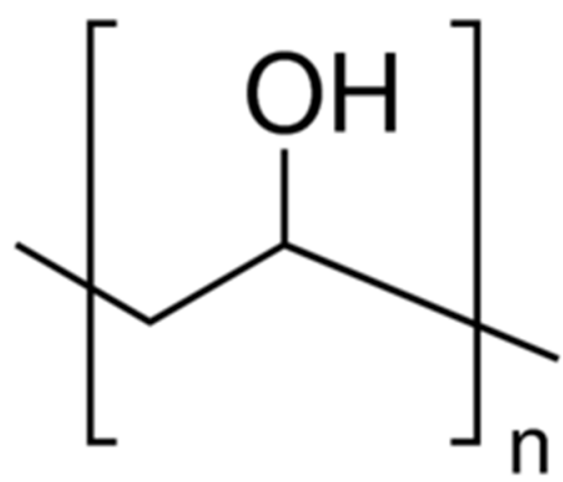

Figura 6. Estructura química del PVOH

Es un polímero biodegradable e hidrófilo, con múltiples usos en la preparación de materiales plásticos, en la industria textil y en la industria farmacéutica. Aunque su principal fuente de obtención es el petróleo, también puede obtenerse a partir de materias primas que no sean derivados del petróleo, como el gas natural $[109,110]$. Se obtiene a partir de la hidrólisis total o parcial del poliacetato de vinilo (PVA). Las propiedades químicas y físicas del 
polímero final dependerán de dicho grado de hidrólisis. El polímero presenta una estructura semicristalina ortorrómbica similar a la del polietileno, debido a que el tamaño del grupo hidroxilo es suficientemente pequeño como para sustituir al $\mathrm{H}$. Presenta fuertes fuerzas intermoleculares por puentes de hidrógeno entre los grupos - $\mathrm{OH}$ de diferentes cadenas lo que confiere un elevado grado de cohesión y una reducción del volumen libre. Además, tiene excelentes características para formar películas que presentan una buena resistencia a la tracción, flexibilidad sin necesidad de adición de moléculas plastificantes y excelente barrera a oxígeno y otros gases permeantes, debido a las mencionadas cristalinidad y cohesión interna. Tanto su solubilidad como otras propiedades son influenciadas por su grado de hidrólisis y su peso molecular. A menor grado de hidrólisis, es decir mayor número de grupos acetato, menor es la cristalinidad, la solubilidad al agua, así como sus propiedades barrera [111]. Cabe destacar que las películas desarrolladas en esta tesis se realizaron con $\mathrm{PVOH}$ con un alto grado de hidrólisis. Las películas obtenidas son solubles en agua, inodoras, incoloras y no tóxicas $[112,113]$. Además, el PVOH está aprobado por la FDA para su uso en contacto con alimentos y como aditivo alimentario con el INS n 1203 (Codex Alimentarius) [114]. En la UE está aprobado por la EFSA como aditivo alimentario en complementos alimenticios de acuerdo con el anexo II del Reglamento (CE) $n^{\circ} 1333 / 2008$.

\section{Coadyuvantes}

Con el objetivo de aumentar la viabilidad de las $L A B$ en las matrices de $\mathrm{PVOH}$, se han incorporado a las películas diferentes proteínas que pueden actuar como coadyuvante. Las proteínas son fuente de carbono y nitrógeno y en función de su tamaño y los diferentes aminoácidos presentes, podría actuar como protector frente a los daños que sufren las bacterias durante el procesado y el almacenamiento de las películas.

En este sentido, el uso de matrices de $\mathrm{PVOH}$ mezclado con estas proteínas o sus hidrolizados, podría mejorar la viabilidad de las bacterias acido lácticas incluidas. Con el mismo propósito, el extracto de levadura (una mezcla de aminoácidos y vitaminas) también podría utilizarse para promover el crecimiento bacteriano y la producción de nisina cuando se añade al PVOH 
como agente coadyuvante. Los coadyuvantes utilizados en combinación con el PVOH para desarrollar películas bioactivas se detallan en la tabla 3.

Tabla 3. Coadyuvantes empleados para la realización de películas bioactivas

\begin{tabular}{|c|c|c|c|}
\hline Coadyuvante & Tamaño & Origen & Principales ventajas \\
\hline Gelatina & $>250 \mathrm{KDa}$ & $\begin{array}{l}\text { Proteína extraída } \\
\text { de porcino }\end{array}$ & \multirow{5}{*}{$\begin{array}{l}\text { - Fuente de } \mathrm{C} \text { y } \mathrm{N} \text { y diferente } \\
\text { biodisponibilidad en función } \\
\text { de peso molecular. } \\
\text { - Ejerce protección durante } \\
\text { conservación LAB en función } \\
\text { de su peso molecular y tipos } \\
\text { de AA. } \\
\text { - En función de peso molecular } \\
\text { y cantidad añadida, modifica } \\
\text { la funcionalidad, estructura y } \\
\text { morfología de las películas } \\
\text { de PVOH obtenidas. }\end{array}$} \\
\hline $\begin{array}{l}\text { Caseinato } \\
\text { sódico }\end{array}$ & $25 \mathrm{KDa}$ & $\begin{array}{l}\text { Proteína extraída } \\
\text { de leche de vaca }\end{array}$ & \\
\hline $\begin{array}{l}\text { Gelatina } \\
\text { hidrolizada }\end{array}$ & $\begin{array}{c}<5 \mathrm{KDa} \\
\text { Diferentes } \\
\text { fragmentos } \\
17 \mathrm{KDa} \text { y }<5 \mathrm{KDa}\end{array}$ & $\begin{array}{l}\text { Hidrolizada con } \\
\text { enzimas } \\
\text { digestivos }\end{array}$ & \\
\hline $\begin{array}{l}\text { Caseína } \\
\text { hidrolizada }\end{array}$ & $\begin{array}{l}\text { Diferentes } \\
\text { fragmentos } \\
\quad<5 \mathrm{KDa}\end{array}$ & $\begin{array}{l}\text { Hidrolizada con } \\
\text { enzimas } \\
\text { digestivos }\end{array}$ & \\
\hline $\begin{array}{l}\text { Extracto de } \\
\text { levadura }\end{array}$ & $\begin{array}{c}\text { Aminoácidos } \\
\text { sueltos y } \\
\text { vitaminas < 5KDa }\end{array}$ & $\begin{array}{l}\text { Levaduras } \\
\text { inactivadas, } \\
\text { deshidratadas e } \\
\text { hidrolizadas }\end{array}$ & \\
\hline
\end{tabular}

\section{Polímeros usados como película sustrato}

Con el objetivo de desarrollar envases activos se han utilizado dos polímeros sustrato sobre los cuales se aplicaron los recubrimientos activos de $\mathrm{PVOH}$.

\section{Ácido poliláctico (PLA)}

El ácido poliláctico (PLA) es un biopolímero obtenido por síntesis a partir de monómeros procedentes de recursos renovables como el maíz, la caña de azúcar y los residuos de madera [115]. La estructura molecular se 
muestra en la figura 7. Su popularidad ha crecido por su uso comercial como sustituto de los polímeros derivados del petróleo, como el polietileno de baja densidad (LDPE), el polietileno de alta densidad (HDPE), el poliestireno (PS) y el tereftalato de polietileno (PET) [116]. El PLA puede desarrollarse como una película delgada transparente, adecuada para productos de corta duración en aplicaciones comunes como envases, vasos para beber, vasos para ensalada, películas que recubren y laminación, y envases blíster [117,118]. Sin embargo, la característica más interesante del PLA es su biodegradabilidad y presenta los requisitos de compostabilidad de la norma EN13432 para envases (EN $13.432,2005)$ [119].

\section{Polietileno (PE)}

Los PE son polímeros pertenecientes a la familia de las poliolefinas formado por múltiples unidades de etileno. Son estructuralmente simples, únicamente con enlaces de carbono e hidrógeno, con resistencias notablemente altas que han promovido su uso generalizado en los envases. Su estructura se muestra en la figura 7. El polietileno de baja densidad (LDPE, por sus siglas en inglés) es menos cristalino y por lo tanto es más transparente y elástico que el polietileno de alta densidad, por lo que se utiliza ampliamente para la producción de películas [120].
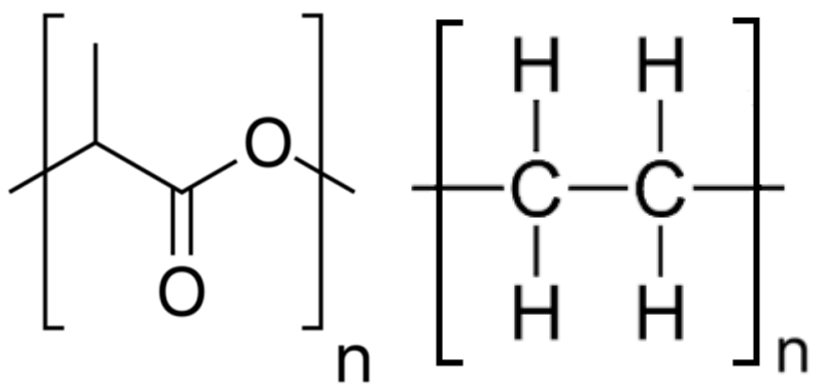

Figura 7. Estructura química del PLA (izquierda) y PE (derecha)

El LDPE tiene una estructura muy ramificada, que impide el empaquetamiento y reduce la densidad. Es un polímero sellable y muy flexible. A ello se unen otras cualidades como una buena resistencia tanto al impacto como a altas temperaturas y a sustancias químicas. Se trata de un material 
barato, muy fácil de procesar mediante métodos como inyección o extrusión y dependiendo de su espesor, puede llegar a ser casi transparente. Aunque este material proviene de fuentes no renovables como es el petróleo, es un material reciclable al que se le asigna el código de identificación plástico $n^{\circ} 4$ [121].

b) Recubrimientos que incluyen levaduras elaborados directamente sobre alimentos

Los recubrimientos también pueden formarse directamente sobre la superficie del producto que pretenden proteger [122]. Por el hecho de ser consumidos junto con el alimento, las películas y recubrimientos comestibles son simultáneamente un envase y un componente alimentario, por lo que deben cumplir algunas especificaciones [64]. Por ejemplo, deben tener buenas propiedades mecánicas y de barrera, una excelente estabilidad físico-química y microbiológica, ser compatibles con los alimentos desde el punto de vista organoléptico y funcional, no ser tóxicos y ser seguros para la salud además de tener un bajo coste de producción [123].

Por otro lado, al incorporan microorganismos vivos (en este caso levaduras), se necesita que los polímeros que se utilicen sean hidrosolubles y puedan proteger al microorganismo para que mantenga su viabilidad durante el almacenamiento del alimento.

También responden a la preocupación por el medio ambiente, ya que suelen producirse con subproductos de origen agrícola y marino, sustituyendo los envases alimentarios fabricados con fuentes no renovables y reduciendo, por tanto, los residuos [124].

En esta tesis se han desarrollado biopolímeros extraídos de manzanas para aplicarse posteriormente como recubrimiento de manzanas fomentando así la economía circular.

\section{Recubrimientos de polisacáridos extraídos de manzana}

Los subproductos de las industrias de zumo de manzana, sidra o vino representan entre el $25-30 \%$ del peso original de la manzana y se generan cada año en todo el mundo [125]. Esto se denomina orujo de manzana. Su 
alta composición en ácidos y azúcares y su baja composición en proteínas no permite su utilización para la alimentación animal o el vertido por lo que se considera un residuo alimentario. Este subproducto está compuesto principalmente por celulosa, pectina, almidón y lignina [126,127]. En consecuencia, es una buena fuente para extraer biopolímeros. Los biopolímeros utilizados en este trabajo han sido la pectina y los ésteres de celulosa, hidroxilpropilmetilcelulosa y metilcelulosa [66].

\section{Recubrimientos de orujo de la manzana}

La utilización directa de residuos de manzana puede actuar como una matriz en sí misma $[128,129]$. En este caso, se evitaría la extracción y purificación de los biopolímeros. La utilización del orujo de manzana, sería, no solo una manera más sostenible de revalorizar un subproducto de la industria, sino que, además, tendría más compatibilidad con las levaduras antifúngicas aisladas de las propias manzanas ya que están fenotípicamente más adaptadas para sobrevivir en este tipo de sustrato. El orujo de manzana se compone principalmente de celulosa (7 -44\%), almidón (14 -17\%), pectina (4 $-14 \%)$ y lignina insoluble (15 -20 \%) [126].

\subsection{Referencias bibliográficas}

1. Grunert, K.G. Consumer trends and new product opportunities in the food sector; Wageningen Academic Publishers, 2017; ISBN 978-908686-307-5.

2. Kilcast, D.; Subramaniam, P. The stability and shelf-life of food; Woodhead Publishing Cambridge, 2000; ISBN 9781855735002.

3. Franz, C.M.A.P.; Den Besten, H.M.W.; Böhnlein, C.; Gareis, M.; Zwietering, M.H.; Fusco, V. Reprint of: Microbial food safety in the 21st century: Emerging challenges and foodborne pathogenic bacteria is. 2019, doi:10.1016/j.tifs.2019.01.009.

4. EFSA Salmonella the most common cause of foodborne outbreaks in the Available online: https://www.efsa.europa.eu/en/news/salmonellamost-common-cause-foodborne-outbreaks-european-union (accessed on Mar 10, 2021).

5. Commission regulation EC No 2160/2003 of 17 November 2003 on the control of Salmonella and other specified food-borne zoonotic agents. 
Regulation 2003, 2003, 1-15.

6. Walker, S.J.; Archer, P.; Banks, J.G. Growth of Listeria monocytogenes at refrigeration temperatures. J. Appl. Bacteriol. 1990, 68, 157-162, doi:10.1111/j.1365-2672.1990.tb02561.x.

7. Doyle, M.P.; Glass, K.A.; Beery, J.T.; Garcia, G.A.; Pollard, D.J.; Schultz2, R.D. Survival of Listeria monocytogenes in Milk during HighTemperature, Short-Time Pasteurization. Appl. Environ. Microbiol. 1987, 53, 1433-1438.

8. Muriel-Galet, V.; López-Carballo, G.; Gavara, R.; Hernández-Muñoz, P. Antimicrobial food packaging film based on the release of LAE from EVOH. Int. J. Food Microbiol. 2012, 157, 239-244, doi:10.1016/j.ijfoodmicro.2012.05.009.

9. Commission Regulation (EC) No 2073/2005 Commission Regulation (EC) No 2073/2005 of 15 November 2005 on microbiological criteria for foodstuffs. OJ L 338, 22.12.2005, p. 1-26.;

10. WHO (World Health Organization) Listeriosis- Spain, World Health Organization Disease outbreak news Available online: https://www.who.int/csr/don/16-september-2019-listeriosis-spain/en/ Accessed 16 Sept. 2019 (accessed on Nov 19, 2019).

11. Malvano, F.; Pilloton, R.; Albanese, D. Sensitive detection of Escherichia coli $\mathrm{O} 157: \mathrm{H7}$ in food products by impedimetric immunosensors. Sensors (Switzerland) 2018, 18, 2168, doi:10.3390/s18072168.

12. Demirel, R.; Sariozlu, N.Y.; Ilhan, S. Polymerase chain reaction (PCR) identification of terverticillate penicillium species isolated from agricultural soils in Eskisehir Province. Brazilian Arch. Biol. Technol. 2013, 56, 980-984, doi:10.1590/S1516-89132013005000004.

13. Gutarowska, B.; Skora, J.; Zduniak, K.; Rembisz, D. Analysis of the sensitivity of microorganisms contaminating museums and archives to silver nanoparticles. Int. Biodeterior. Biodegrad. 2012, 68, 7-17, doi:10.1016/j.ibiod.2011.12.002.

14. Van De Perre, E.; Jacxsens, L.; Van Der Hauwaert, W.; Haesaert, I.; De Meulenaer, B. Screening for the presence of patulin in molded fresh produce and evaluation of its stability in the production of tomato products. J. Agric. Food Chem. 2014, 62, 304-309, doi:10.1021/jf404192n.

15. Pattono, D.; Grosso, A.; Stocco, P.P.; Pazzi, M.; Zeppa, G. Survey of the presence of patulin and ochratoxin $A$ in traditional semi-hard cheeses. Food Control 2013, 33, 54-57, doi:10.1016/j.foodcont.2013.02.019.

16. Vansteelandt, M.; Kerzaon, I.; Blanchet, E.; Fossi Tankoua, O.; Robiou Du Pont, T.; Joubert, Y.; Monteau, F.; Le Bizec, B.; Frisvad, J.C.; Pouchus, Y.F.; 
et al. Patulin and secondary metabolite production by marine-derived Penicillium strains. Fungal Biol. 2012, 116, 954-961, doi:10.1016/j.funbio.2012.06.005.

17. Geiger, M.; Guitton, Y.; Vansteelandt, M.; Kerzaon, I.; Blanchet, E.; Robiou du Pont, T.; Frisvad, J.C.; Hess, P.; Pouchus, Y.F.; Grovel, O. Cytotoxicity and mycotoxin production of shellfish-derived Penicillium spp., a risk for shellfish consumers. Lett. Appl. Microbiol. 2013, 57, 385392, doi:10.1111/lam.12143.

18. Yu, L.; Qiao, N.; Zhao, J.; Zhang, H.; Tian, F.; Zhai, Q.; Chen, W. Postharvest control of Penicillium expansum in fruits: A review. Food Biosci. 2020, 36, 100633.

19. Reddy, K.R.N.; Spadaro, D.; Lore, A.; Gullino, M.L.; Garibaldi, A. Potential of patulin production by Penicillium expansum strains on various fruits. Mycotoxin Res. 2010, 26, 257-265, doi:10.1007/s12550-010-0064-5.

20. European Commission Regulation EC 1881/2006, setting maximum levels for certain contaminants in foodstuffs. Off. J. Eur. Union 2006, No $1881,26$.

21. Dwivedi, S.; Prajapati, P.; Vyas, N.; Malviya, S.; Kharia, A. A Review on Food Preservation: Methods, harmful effects and better alternatives. Asian J. Pharm. Pharmacol. 2017, 3, 193-199.

22. Erickson, M.C.; Doyle, M.P. The Challenges of Eliminating or Substituting Antimicrobial Preservatives in Foods. Annu. Rev. Food Sci. Technol. 2017, 8, 371-390, doi:10.1146/annurev-food-030216-025952.

23. Haghighi-Manesh, S.; Azizi, M.H. Active packaging systems with emphasis on its applications in dairy products. J. Food Process Eng. 2017, 40, e12542, doi:10.1111/jfpe.12542.

24. Odueke, O.B.; Farag, K.W.; Baines, R.N.; Chadd, S.A. Irradiation Applications in Dairy Products: a Review. Food Bioprocess Technol. 2016, 9, 751-767, doi:10.1007/s11947-016-1709-y.

25. Aloui, H.; Khwaldia, K. Natural Antimicrobial Edible Coatings for Microbial Safety and Food Quality Enhancement. Compr. Rev. Food Sci. Food Saf. 2016, 15, 1080-1103, doi:10.1111/1541-4337.12226.

26. Camargo Peralta, I.; Gómez Bertel, S.; Salazar Montoya, V. Impact of bacteriocins and their relevance as preservatives in the food industry. Teoría y Prax. Investig. 2009, 4, 27-32.

27. Rodgers, S. Preserving non-fermented refrigerated foods with microbial cultures - A review. Trends Food Sci. Technol. 2001, 12, 276284.

28. Song, A.A.L.; In, L.L.A.; Lim, S.H.E.; Rahim, R.A. A review on Lactococcus lactis: From food to factory. Microb. Cell Fact. 2017, 16, 55. 
29. Deegan, L.H.; Cotter, P.D.; Ross, P. Bacteriocins: Biological tools for biopreservation and shelf-life extension. Int. Dairy J. 2006, 16, 1058-1071, doi:10.1016/J.IDAIRYJ.2005.10.026.

30. Montville, T.J.; Winkowski, K.; Ludescher, R.D. Models and mechanisms for bacteriocin action and application. Int. Dairy J. 1995, 5, 797-814, doi:10.1016/0958-6946(95)00034-8.

31. Ibarra-Sánchez, L.A.; El-Haddad, N.; Mahmoud, D.; Miller, M.J.; Karam, L. Invited review: Advances in nisin use for preservation of dairy products. J. Dairy Sci. 2020, 103, 2041-2052, doi:10.3168/jds.201917498.

32. Santos, J.C.P.; Sousa, R.C.S.; Otoni, C.G.; Moraes, A.R.F.; Souza, V.G.L.; Medeiros, E.A.A.; Espitia, P.J.P.; Pires, A.C.S.; Coimbra, J.S.R.; Soares, N.F.F. Nisin and other antimicrobial peptides: Production, mechanisms of action, and application in active food packaging. Innov. Food Sci. Emerg. Technol. 2018, 48, 179-194.

33. Champomier-Vergès, M.C.; Chaillou, S.; Cornet, M.; Zagorec, M. Lactobacillus sakei: Recent developments and future prospects. Res. Microbiol. 2001, 152, 839-848.

34. Zagorec, M.; Champomier-Vergès, M.-C. Lactobacillus sakei: A Starter for Sausage Fermentation, a Protective Culture for Meat Products. Microorganisms 2017, 5, 56, doi:10.3390/microorganisms5030056.

35. Chaillou, S.; Christieans, S.; Rivollier, M.; Lucquin, I.; ChampomierVergès, M.C.; Zagorec, M. Quantification and efficiency of Lactobacillus sakei strain mixtures used as protective cultures in ground beef. Meat Sci. 2014, 97, 332-338, doi:10.1016/J.MEATSCI.2013.08.009.

36. Parada, J.L.; Caron, C.R.; Medeiros, A.B.P.; Soccol, C.R. Bacteriocins from lactic acid bacteria: Purification, properties and use as biopreservatives. Brazilian Arch. Biol. Technol. 2007, 50, 521-542, doi:10.1590/s151689132007000300018.

37. Drider, D.; Fimland, G.; Héchard, Y.; McMullen, L.M.; Prévost, H. The Continuing Story of Class Ila Bacteriocins. Microbiol. Mol. Biol. Rev. 2006, 70, 564-582, doi:10.1128/mmbr.00016-05.

38. Cotter, P.D.; Hill, C.; Ross, R.P. Food microbiology: Bacteriocins: Developing innate immunity for food. Nat. Rev. Microbiol. 2005, 3, 777788.

39. Facon, M.J.; Skura, B.J. Antibacterial activity of lactoferricin, lysozyme and EDTA against Salmonella enteritidis. Int. Dairy J. 1996, 6, 303-313, doi:10.1016/0958-6946(95)00004-6.

40. Helander, I.M.; Mattila-Sandholm, T. Permeability barrier of the Gramnegative bacterial outer membrane with special reference to nisin. In 
Proceedings of the International Journal of Food Microbiology; 2000; Vol. 60, pp. 153-161.

41. FDA (Food and Drug Administration) Agency Response Letter GRAS Notice (GRN) n742. Office and Food Additive Safety, Centre for Food Safety and Applied Nutrition, US Food and Drug Administration Available online: https://www.fda.gov/dowloads/Food/Ingredientes Packaging Labeling/GRAS/Noticelnventoryy/UCM608746.pdf.Accessed 6 Nov. 2017 (accessed on Nov 19, 2019).

42. Bari, M.L.; Ukuku, D.O.; Kawasaki, T.; Inatsu, Y.; Isshiki, K.; Kawamoto, A.S. Combined Efficacy of Nisin and Pediocin with Sodium Lactate, Citric Acid, Phytic Acid, and Potassium Sorbate and EDTA in Reducing the Listeria monocytogenes Population of Inoculated Fresh-Cut Produce; 2005; Vol. 68;.

43. Zhou, Q.; Zhao, Y.; Dang, H.; Tang, Y.; Zhang, B. Antibacterial effects of phytic acid against foodborne pathogens and investigation of its mode of action. J. Food Prot. 2019, 82, 826-833, doi:10.4315/0362-028X.JFP18-418.

44. Liu, J.; Sui, Y.; Wisniewski, M.; Droby, S.; Liu, Y. Review: Utilization of antagonistic yeasts to manage postharvest fungal diseases of fruit. Int. J. Food Microbiol. 2013, 167, 153-160.

45. Sharma, R.R.; Singh, D.; Singh, R. Biological control of postharvest diseases of fruits and vegetables by microbial antagonists: A review. Biol. Control 2009, 50, 205-221.

46. Freimoser, F.M.; Rueda-Mejia, M.P.; Tilocca, B.; Migheli, Q. Biocontrol yeasts: mechanisms and applications. World J. Microbiol. Biotechnol. 2019, 35, 154.

47. da Rocha Neto, A.C.; Luiz, C.; Maraschin, M.; Di Piero, R.M. Efficacy of salicylic acid to reduce Penicillium expansum inoculum and preserve apple fruits. Int. J. Food Microbiol. 2016, 221, 54-60, doi:10.1016/j.ijfoodmicro.2016.01.007.

48. Droby, S.; Chalutz, E.; Wilson, C.L.; Wisniewski, M. Characterization of the biocontrol activity of Debaryomyces hansenii in the control of Penicillium digitatum on grapefruit . Can. J. Microbiol. 1989, 35, 794800, doi:10.1139/m89-132.

49. Molnár, O.; Prillinger, H. Analysis of yeast isolates related to Metschnikowia pulcherrima using the partial sequences of the large subunit rDNA and the actin gene; Description of Metschnikowia andauensis sp. nov. Syst. Appl. Microbiol. 2005, 28, 717-726, doi:10.1016/j.syapm.2005.05.009. 
50. Davenport, R.R. Distribution of yeasts and yeast-like organisms from aerial surfaces of developing apples and grapes. Microbiol. Aer. plant surfaces 1976, 325-359.

51. Janisiewicz, W.J.; Tworkoski, T.J.; Kurtzman, C.P. Biocontrol potential of Metchnikowia pulcherrima strains against blue mold of apple. Phytopathology 2001, 91, 1098-1108, doi:10.1094/PHYTO.2001.91.11.1098.

52. Spadaro, D.; Sabetta, W.; Acquadro, A.; Portis, E.; Garibaldi, A.; Gullino, M.L. Use of AFLP for differentiation of Metschnikowia pulcherrima strains for postharvest disease biological control. Microbiol. Res. 2008, 163, 523-530, doi:10.1016/j.micres.2007.01.004.

53. Miller, M.W.; Phaff, H.J. Metschnikowia Kamienski. In The Yeasts; Elsevier, 1998; pp. 256-267.

54. Pawlikowska, E.; James, S.A.; Breierova, E.; Antolak, H.; Kregiel, D. Biocontrol capability of local Metschnikowia sp. isolates. Antonie van Leeuwenhoek, Int. J. Gen. Mol. Microbiol. 2019, 112, 1425-1445, doi:10.1007/s10482-019-01272-w.

55. Yang, H.; Wang, L.; Li, S.; Gao, X.; Wu, N.; Zhao, Y.; Sun, W. Control of postharvest grey spot rot of loquat fruit with Metschnikowia pulcherrima $\mathrm{E} 1$ and potential mechanisms of action. Biol. Control 2021, 152, 104406, doi:10.1016/j.biocontrol.2020.104406.

56. Pawlikowska, E dan Kręgiel, D. Enzymatic Profiles and Antimicrobial Activity of the Yeast Metschnikowia Pulcherrima. Acta Innov. 2017, 6, $1-7$.

57. Cunha, S.C.; Faria, M.A.; Pereira, V.L.; Oliveira, T.M.; Lima, A.C.; Pinto, E. Patulin assessment and fungi identification in organic and conventional fruits and derived products. Food Control 2014, 44, 185190, doi:10.1016/j.foodcont.2014.03.043.

58. Cao, J.; Zhang, H.; Yang, Q.; Ren, R. Efficacy of Pichia caribbica in controlling blue mold rot and patulin degradation in apples. Int. J. Food Microbiol. 2013, 162, 167-173, doi:10.1016/j.ijfoodmicro.2013.01.007.

59. Castoria, R.; Mannina, L.; R., D.-P.; Maffei, F.; Sobolev, A.P.; De Felice, D. $V_{. ;} ; . ;$; Wright, S.A. Conversion of the mycotoxin patulin to the less toxic desoxypatulinic acid by the biocontrol yeast Rhodosporidium kratochvilovae strain LS11. J. Agric. Food Chem. 2011, 59(21), 1157111578.

60. Reddy, K.R.N.; Spadaro, D.; Gullino, M.L.; Garibaldi, A. Potential of two Metschnikowia pulcherrima (yeast) strains for in vitro biodegradation of patulin. J. Food Prot. 2011, 74, 154-156, doi:10.4315/0362-028X.JFP10-331. 
61. Spadaro, D.; Lorè, A.; Garibaldi, A.; Gullino, M.L. A new strain of Metschnikowia fructicola for postharvest control of Penicillium expansum and patulin accumulation on four cultivars of apple. Postharvest Biol. Technol. 2013, 75, 1-8, doi:10.1016/j.postharvbio.2012.08.001.

62. Tripathi, M.K.; Giri, S.K. Probiotic functional foods: Survival of probiotics during processing and storage. J. Funct. Foods 2014, 9, 225-241.

63. Fu, N.; Chen, X.D. Towards a maximal cell survival in convective thermal drying processes. Food Res. Int. 2011, 44, 1127-1149.

64. Guimarães, A.; Abrunhosa, L.; Pastrana, L.M.; Cerqueira, M.A. Edible Films and Coatings as Carriers of Living Microorganisms: A New Strategy Towards Biopreservation and Healthier Foods. Compr. Rev. Food Sci. Food Saf. 2018, 17, 594-614.

65. Catalá, R.; Gavara, R. Nuevos envases. De la protección pasiva a la defensa activa de los alimentos envasados. Arbor 2001, 168, 109-127.

66. Zoghi, A.; Khosravi-Darani, K.; Mohammadi, R. Application of edible films containing probiotics in food products. J. Consum. Prot. Food Saf. 2020, 15, 307-320, doi:10.1007/s00003-020-01286-x.

67. Gialamas, H.; Zinoviadou, K.G.; Biliaderis, C.G.; Koutsoumanis, K.P. Development of a novel bioactive packaging based on the incorporation of Lactobacillus sakei into sodium-caseinate films for controlling Listeria monocytogenes in foods. Food Res. Int. 2010, 43, 2402-2408, doi:10.1016/j.foodres.2010.09.020.

68. Concha-Meyer, A.; Schöbitz, R.; Brito, C.; Fuentes, R. Lactic acid bacteria in an alginate film inhibit Listeria monocytogenes growth on smoked salmon. Food Control 2011, 22, 485-489, doi:10.1016/j.foodcont.2010.09.032.

69. Iseppi, R.; de Niederhäusern, S.; Anacarso, I.; Messi, P.; Sabia, C.; Pilati, F.; Toselli, M.; Esposti, M.D.; Bondi, M. Anti-listerial activity of coatings entrapping living bacteria. Soft Matter 2011, 7, 8542, doi:10.1039/c1sm05650f.

70. López De Lacey, A.M.; López-Caballero, M.E.; Gómez-Estaca, J.; GómezGuillén, M.C.; Montero, P. Functionality of Lactobacillus acidophilus and Bifidobacterium bifidum incorporated to edible coatings and films. Innov. Food Sci. Emerg. Technol. 2012, 16, 277-282, doi:10.1016/j.ifset.2012.07.001.

71. Sánchez-González, L.; Quintero Saavedra, J.I.; Chiralt, A. Physical properties and antilisterial activity of bioactive edible films containing Lactobacillus plantarum. Food Hydrocoll. 2013, 33, 92-98, doi:10.1016/j.foodhyd.2013.02.011. 
72. López de Lacey, A.M.; López-Caballero, M.E.; Montero, P. Agar films containing green tea extract and probiotic bacteria for extending fish shelf-life. LWT - Food Sci. Technol. 2014, 55, 559-564, doi:10.1016/j.Iwt.2013.09.028.

73. Sánchez-González, L.; Quintero Saavedra, J.I.; Chiralt, A. Antilisterial and physical properties of biopolymer films containing lactic acid bacteria. Food Control 2014, 35, 200-206, doi:10.1016/j.foodcont.2013.07.001.

74. Bekhit, M.; Arab-Tehrany, E.; Kahn, C.J.F.; Cleymand, F.; Fleutot, S.; Desobry, S.; Sánchez-González, L. Bioactive films containing alginatepectin composite microbeads with Lactococcus lactis subsp. lactis: Physicochemical characterization and antilisterial activity. Int. J. Mol. Sci. 2018, 19, 1-12, doi:10.3390/ijms19020574.

75. Ye, J.; Ma, D.; Qin, W.; Liu, Y. Physical and antibacterial properties of sodium alginate-sodium carboxymethylcellulose films containing Lactococcus lactis. Molecules 2018, 23, 2645, doi:10.3390/molecules23102645.

76. Abdollahzadeh, E.; Ojagh, S.M.; Fooladi, A.A.I.; Shabanpour, B.; Gharahei, M. Effects of probiotic cells on the mechanical and antibacterial properties of sodium-caseinate films. Appl. Food Biotechnol. 2018, 5, 155-162, doi:10.22037/afb.v\%vi\%i.20360.

77. Degli Esposti, M.; Toselli, M.; Sabia, C.; Messi, P.; de Niederhäusern, S.; Bondi, M.; Iseppi, R. Effectiveness of polymeric coated films containing bacteriocin-producer living bacteria for Listeria monocytogenes control under simulated cold chain break. Food Microbiol. 2018, 76, 173-179, doi:10.1016/j.fm.2018.05.005.

78. Dai, L.; Yuan, Y.; Song, Z.; Qiu, Y.; Yue, T. Preparation and Characterization of Lactobacilli-Loaded Composite Films with Sustaining Antipathogenic Activity and Preservation Effect. J. Food Sci. 2018, 83, 2511-2519, doi:10.1111/1750-3841.14348.

79. Odila Pereira, J.; Soares, J.; J.P. Monteiro, M.; Gomes, A.; Pintado, M. Impact of whey protein coating incorporated with Bifidobacterium and Lactobacillus on sliced ham properties. Meat Sci. 2018, 139, 125-133, doi:10.1016/j.meatsci.2018.01.016.

80. Ye, J.; Ma, D.; Qin, W.; Liu, Y. Physical and antibacterial properties of sodium alginate-sodium carboxymethylcellulose films containing Lactococcus lactis. Molecules 2018, 23, 2645, doi:10.3390/molecules23102645.

81. Ma, D.; Jiang, Y.; Ahmed, S.; Qin, W.; Liu, Y. Physical and antimicrobial properties of edible films containing Lactococcus lactis. Int. J. Biol. Macromol. 2019, 141, 378-386, doi:10.1016/j.jbiomac.2019.09.006. 
82. Marín, A.; Plotto, A.; Atarés, L.; Chiralt, A. Lactic Acid Bacteria Incorporated into Edible Coatings to Control Fungal Growth and Maintain Postharvest Quality of Grapes. HortScience 2019, 54, 337-343, doi:10.21273/HORTSCI13661-18.

83. Li, S.; Ma, Y.; Ji, T.; Sameen, D.E.; Ahmed, S.; Qin, W.; Dai, J.; Li, S.; Liu, Y. Cassava starch/carboxymethylcellulose edible films embedded with lactic acid bacteria to extend the shelf life of banana. Carbohydr. Polym. 2020, 248, 116805, doi:10.1016/j.carbpol.2020.116805.

84. Mozaffarzogh, M.; Misaghi, A.; Shahbazi, Y.; Kamkar, A. Evaluation of probiotic carboxymethyl cellulose-sodium caseinate films and their application in extending shelf life quality of fresh trout fillets. LWT 2020, 126, 109305, doi:10.1016/j.lwt.2020.109305.

85. La Storia, A.; Di Giuseppe, F.A.; Volpe, S.; Oliviero, V.; Villani, F.; Torrieri, E. Physical properties and antimicrobial activity of bioactive film based on whey protein and Lactobacillus curvatus 54M16 producer of bacteriocins. Food Hydrocoll. 2020, 108, 105959, doi:10.1016/j.foodhyd.2020.105959.

86. Guimarães, A.; Ramos, Ó.; Cerqueira, M.; Venâncio, A.; Abrunhosa, L. Active Whey Protein Edible Films and Coatings Incorporating Lactobacillus buchneri for Penicillium nordicum Control in Cheese. Food Bioprocess Technol. 2020, 13, 1074-1086, doi:10.1007/s11947-02002465-2.

87. Yasin, R.; Samiullah, K.; Fazal, R.M.; Hussain, S.; Mahboob, S.; Al-Ghanim, K.A.; Al-Misned, F.A.; Ahmed, Z. Combined effect of probiotics on prolonging the shelf life of GIFT tilapia fillets. Aquac. Res. 2020, 51, 5151-5162, doi:10.1111/are.14853.

88. McGuire, R.G.; Baldwin, E.A. Compositions of cellulose coatings affect populations of yeasts in the liquid formulation and on coated grapefruits. In Proceedings of the Florida State Horticultural Society. Meeting (USA); 1995; pp. 107, 293-293.

89. Potjewijd, R.; Nisperos, M.O.; Burns, J.K.; Parish, M.; Baldwin, E.A. Cellulose-based coatings as carriers for Candida guillermondii and Debaryomyces sp. in reducing decay of oranges. HortScience 1995, 30, 1417-1421, doi:10.21273/hortsci.30.7.1417.

90. McGuire, R.G.; Hagenmaier, R.D. Shellac coatings for grapefruits that favor biological control of Penicillium digitatum by Candida oleophila. Biol. Control 1996, 7, 100-106, doi:10.1006/bcon.1996.0071.

91. McGuire, R.G.; Dimitroglou, D.A. Evaluation of shellac and sucrose ester fruit coating formulations that support biological control of postharvest grapefruit decay. Biocontrol Sci. Technol. 1999, 9, 53-65, 
doi:10.1080/09583159929901.

92. Sharma, N.; Verma, U.; Awasthi, P. A combination of the yeast Candida utilis and chitosan controls fruit rot in tomato caused by Alternaria alternata (Fr.) Keissler and Geotrichum candidum Link ex Pers. J. Hortic. Sci. Biotechnol. 2006, 81, 1052-1056, doi:10.1080/14620316.2006.11512170.

93. Fan, Y.; Xu, Y.; Wang, D.; Zhang, L.; Sun, J.; Sun, L.; Zhang, B. Effect of alginate coating combined with yeast antagonist on strawberry (Fragaria $\times$ ananassa) preservation quality. Postharvest Biol. Technol. 2009, 53, 84-90, doi:10.1016/j.postharvbio.2009.03.002.

94. Aloui, H.; Licciardello, F.; Khwaldia, K.; Hamdi, M.; Restuccia, C. Physical properties and antifungal activity of bioactive films containing Wickerhamomyces anomalus killer yeast and their application for preservation of oranges and control of postharvest green mold caused by Penicillium digitatum. Int. J. Food Microbiol. 2015, 200, 22-30, doi:10.1016/J.IJFOODMICRO.2015.01.015.

95. Parafati, L.; Vitale, A.; Restuccia, C.; Cirvilleri, G. The effect of locust bean gum (LBG)-based edible coatings carrying biocontrol yeasts against Penicillium digitatum and Penicillium italicum causal agents of postharvest decay of mandarin fruit. Food Microbiol. 2016, 58, 87-94, doi:10.1016/J.FM.2016.03.014.

96. Marín, A.; Cháfer, M.; Atarés, L.; Chiralt, A.; Torres, R.; Usall, J.; Teixidó, $N$. Effect of different coating-forming agents on the efficacy of the biocontrol agent Candida sake CPA- 1 for control of Botrytis cinerea on grapes. Biol. Control 2016, 96, 108-119, doi:10.1016/j.biocontrol.2016.02.012.

97. Karabulut, G.; Cagri-Mehmetoglu, A. Antifungal, Mechanical, and Physical Properties of Edible Film Containing Williopsis saturnus var. saturnus Antagonistic Yeast. J. Food Sci. 2018, 83, 763-769, doi:10.1111/1750-3841.14062.

98. Civelek, l.; Cagri-Mehmetoglu, A. Determination of Antifungal Effect of Edible Coatings Containing Williopsis saturnus var. saturnus Against Yeast and Mold Growth on Kashar Cheese. J. Food Sci. 2019, 84, $311-$ 318, doi:10.1111/1750-3841.14431.

99. FAO Food wastage footprint: Impacts on natural resources.(Technical report. 2013.

100. Williams, H.; Wikström, F.; Otterbring, T.; Löfgren, M.; Gustafsson, A. Reasons for household food waste with special attention to packaging. J. Clean. Prod. 2012, 24, 141-148, doi:10.1016/j.jclepro.2011.11.044.

101. Commission, E. Communication from the Commission to the Council 
and the European Parliament—Integrated product policy—Building on environmental life-cycle thinking. 2003.

102. Commission, E. Commission recommendation of 9 April 2013 on the use of common methods to measure and communicate the life cycle environmental performance of products and organisations (2013/179/EU). 2013.

103. Meneses, M.; Pasqualino, J.; Castells, F. Environmental assessment of the milk life cycle: The effect of packaging selection and the variability of milk production data. J. Environ. Manage. 2012, 107, 76-83, doi:10.1016/j.jenvman.2012.04.019.

104. Manfredi, M.; Vignali, G. Comparative Life Cycle Assessment of hot filling and aseptic packaging systems used for beverages. J. Food Eng. 2015, 147, 39-48, doi:10.1016/j.jfoodeng.2014.09.018.

105. Wikström, F.; Williams, H.; Verghese, K.; Clune, S. The influence of packaging attributes on consumer behaviour in food-packaging life cycle assessment studies - A neglected topic. J. Clean. Prod. 2014, 73, 100-108, doi:10.1016/j.jclepro.2013.10.042.

106. Silvenius, F.; Grönman, K.; Katajajuuri, J.M.; Soukka, R.; Koivupuro, H.K.; Virtanen, $Y$. The role of household food waste in comparing environmental impacts of packaging alternatives. Packag. Technol. Sci. 2014, 27, 277-292, doi:10.1002/pts.2032.

107. Manfredi, M.; Fantin, V.; Vignali, G.; Gavara, R. Environmental assessment of antimicrobial coatings for packaged fresh milk. J. Clean. Prod. 2015, 95, 291-300, doi:10.1016/j.jclepro.2015.02.048.

108. Rijk, R.; Veraart, R. Global legislation for food packaging materials; John Wiley \& Sons, 2010;

109. De Prisco, N.; Immirzi, B.; Malinconico, M.; Mormile, P.; Petti, L.; Gatta, G. Preparation, physico-chemical characterization, and optical analysis of polyvinyl alcohol-based films suitable for protected cultivation. J. Appl. Polym. Sci. 2002, 86, 622-632, doi:10.1002/app.10912.

110. Dorigato, A.; Pegoretti, A. Biodegradable single-polymer composites from polyvinyl alcohol. Colloid Polym. Sci. 2012, 290, 359-370, doi:10.1007/s00396-011-2556-z.

111. López-De-Dicastillo, C.; Jordá, M.; Catalá, R.; Gavara, R.; HernándezMuñoz, P. Development of active polyvinyl alcohol/ $\beta$-cyclodextrin composites to scavenge undesirable food components. J. Agric. Food Chem. 2011, 59, 11026-11033, doi:10.1021/jf200749f.

112. DeMerlis, C. C., \& Schoneker, D.R. Review of the oral toxicity of polyvinyl alcohol (PVA). Food Chem. Toxicol. 2003, 41(3), 319-326.

113. Goodship, V., \& Jacobs, D.K. Polyvinyl alcohol: materials, processing and 
applications; Smithers Rapra Technology, 2009;

114. FAO/WHO Expert Committee Organization, W.H. Evaluation of certain food additives and contaminants: sixty-first report of the Joint FAO/WHO Expert Committee on Food Additives; World Health Organization, 2004; Vol. 61;.

115. Gao, H.; Fang, X.; Chen, H.; Qin, Y.; Xu, F.; Jin, T.Z. Physiochemical properties and food application of antimicrobial PLA film. Food Control 2017, 73, 1522-1531, doi:10.1016/j.foodcont.2016.11.017.

116. Peelman, N.; Ragaert, P.; De Meulenaer, B.; Adons, D.; Peeters, R.; Cardon, L.; Van Impe, F.; Devlieghere, F. Application of bioplastics for food packaging. Trends Food Sci. Technol. 2013, 32, 128-141.

117. Auras, R.; Singh, S.; Singh, J. Performance Evaluation of PLA against Existing PET and PS Containers. J. Test. Eval. 2006, 34, 100041, doi:10.1520/jte100041.

118. Briassoulis, D.; Mistriotis, A.; Giannoulis, A.; Giannopoulos, D. Optimized PLA-based EMAP systems for horticultural produce designed to regulate the targeted in-package atmosphere. Ind. Crops Prod. 2013, 48, 68-80, doi:10.1016/j.indcrop.2013.03.017.

119. Mistriotis, A.; Briassoulis, D.; Giannoulis, A.; D'Aquino, S. Design of biodegradable bio-based equilibrium modified atmosphere packaging (EMAP) for fresh fruits and vegetables by using micro-perforated polylactic acid (PLA) films. Postharvest Biol. Technol. 2016, 111, 380-389, doi:10.1016/j.postharvbio.2015.09.022.

120. Gupta, A.K.; Rana, S.K.; Deopura, B.L. Crystallization behavior of highdensity polyethylene/linear low-density polyethylene blend. J. Appl. Polym. Sci. 1992, 44, 719-726, doi:10.1002/app.1992.070440418.

121. Schyns, Z.O.G.; Shaver, M.P. Mechanical Recycling of Packaging Plastics: A Review. Macromol. Rapid Commun. 2021, 42, 2000415, doi:10.1002/marc.202000415.

122. Gennadios, A. Protein-based films and coatings; CRC press, 2002;

123. Debeaufort, F.; Quezada-Gallo, J.A.; Voilley, A. Edible films and coatings: Tomorrow's packagings: A review. Crit. Rev. Food Sci. Nutr. 1998, 38, 299-313.

124. Tharanathan, R.N. Biodegradable films and composite coatings: Past, present and future. Trends Food Sci. Technol. 2003, 14, 71-78.

125. Plaza, M.; Abrahamsson, V.; Turner, C. Extraction and Neoformation of Antioxidant Compounds by Pressurized Hot Water Extraction from Apple Byproducts. J. Agric. Food Chem. 2013, 61, 5500-5510, doi:10.1021/jf400584f.

126. Bhushan, S.; Kalia, K.; Sharma, M.; Singh, B.; Ahuja, P.S. Processing of 
apple pomace for bioactive molecules. Crit. Rev. Biotechnol. 2008, 28, 285-296.

127. Skinner, R.C.; Gigliotti, J.C.; Ku, K.-M.; Tou, J.C. A comprehensive analysis of the composition, health benefits, and safety of apple pomace. Nutr. Rev. 2018, doi:10.1093/nutrit/nuy033.

128. Gustafsson, J.; Landberg, M.; Bátori, V.; Åkesson, D.; Taherzadeh, M.J.; Zamani, A. Development of Bio-Based Films and 3D Objects from Apple Pomace. Polymers (Basel). 2019, 11, 289, doi:10.3390/polym11020289.

129. Min, B.; Lim, J.; Ko, S.; Lee, K.G.; Lee, S.H.; Lee, S. Environmentally friendly preparation of pectins from agricultural byproducts and their structural/rheological characterization. Bioresour. Technol. 2011, 102, 3855-3860, doi:10.1016/j.biortech.2010.12.019. 


\section{OBJETIVOS}



El objetivo principal de esta Tesis doctoral fue desarrollar $y$ caracterizar películas activas portadoras de agentes de biocontrol, (bacterias ácido lácticas y levaduras), y optimizar su aplicación como envase activo a alimentos con el fin de aumentar su seguridad y vida útil.

Para lograr este objetivo principal se plantearon los siguientes objetivos parciales:

1. Selección de los agentes antimicrobianos, Lactococcus lactis y Lactobacillus sakei y estudio de su actividad antimicrobiana frente a $L$. monocytogenes in vitro.

2. Desarrollo de películas de alcohol polivinílico (PVOH) mezclado con diferentes coadyuvantes: gelatina, caseinato sódico, gelatina hidrolizada, caseína hidrolizada y extracto de levadura.

3. Evaluación de la viabilidad de las bacterias ácido lácticas durante el secado y almacenamiento de las películas y estudio in vitro de sus propiedades antimicrobianas.

4. Aplicación de las películas desarrolladas como recubrimientos sobre ácido poliláctico para desarrollar envases activos que aumenten la seguridad de alimentos (crema de setas y jamón cocido) y estudio del impacto sensorial.

5. Desarrollo de películas activas con capacidad antimicrobiana frente a bacterias Gram-positivas y Gram-negativas mediante la incorporación de L. lactis y ácido fítico en matrices de PVOH y caseína hidrolizada.

6. Aplicación de las matrices desarrolladas en el punto anterior como recubrimientos sobre polietileno para envasar crema pastelera fresca y aumentar su vida útil.

7. Determinación del impacto ambiental del envase activo para crema pastelera en comparación con un envase convencional.

8. Selección de levaduras aisladas de manzanas con actividad antifúngica contra P. expansum. Identificación y caracterización de las levaduras 
seleccionadas y cuantificación de su capacidad antifúngica y de su capacidad de reducir la patulina acumulada.

9. Desarrollo de películas hechas con biopolímeros derivados de manzana que incorporan levaduras antifúngicas capaces de mantener la viabilidad y efectividad antimicrobiana.

10. Aplicación de la mejor película desarrollada como recubrimiento directamente sobre manzanas con el fin de evidenciar su potencial antifúngico para la protección de esta fruta en postcosecha. 
3. CAPÍTULOS 

El objetivo principal de esta Tesis Doctoral ha sido desarrollar y caracterizar películas antimicrobianas que incluyen agentes de biocontrol con la finalidad de aplicarlas como envase o recubrimiento bioactivo. Para ello, se utilizaron dos tipos de agentes de biocontrol: I) bacterias ácido lácticas productoras de bacteriocinas con capacidad antibacteriana que se inmovilizaron en películas a base de alcohol polivinílico y diferentes concentraciones de proteínas y sus versiones hidrolizadas; II) levaduras aisladas de superficie de manzanas con capacidad antifúngica incorporadas en películas con biopolímeros extraídos de manzana. En ambos casos, las películas se aplicaron como envases activos o recubrimientos para aumentar la seguridad alimentaria y/o la vida útil de alimentos sólidos y semisólidos.

El trabajo realizado para lograr este objetivo se presenta en tres capítulos separados.

\section{Capítulo I. Desarrollo de películas que incorporan bacterias ácido lácticas con capacidad antimicrobiana}

En este primer capítulo se ha trabajado en la optimización del desarrollo de películas de PVOH que incorporen bacterias ácido lácticas con actividad antimicrobiana frente a $L$. monocytogenes. Para ello, se obtuvieron películas compuestas por matrices de $\mathrm{PVOH}$ simple o mezcladas con gelatina, caseinato sódico, hidrolizados de gelatina o caseína, y extracto de levadura, y se estudió la viabilidad de las bacterias en las películas a lo largo del tiempo, así como su actividad frente a $L$. monocytogenes a diferentes temperaturas. Las películas con la formulación que presentó la mejor actividad antilisteria en los estudios in vitro se probaron después en leche pasteurizada inoculada con Listeria monocytogenes. Por último, se compararon dos cepas productoras de bacteriocinas Lactococcus lactis y Lactobacillus sakei frente a L. monocytogenes. Estas fueron añadidas a películas de $\mathrm{PVOH}$ e hidrolizado de caseína en diferentes proporciones. A continuación, se caracterizaron las películas desarrolladas y se determinó la supervivencia de las $L A B$ en las películas y su actividad antilisteria. 


\section{Capítulo II. Aplicación tecnológica de películas portadoras de bacterias ácido lácticas para el desarrollo de envases bioactivos antimicrobianos}

La propuesta de este capítulo se centra en la aplicación tecnológica en alimentos de las películas desarrolladas en el capítulo anterior. En la primera parte se desarrollaron recubrimientos de $\mathrm{PVOH}$ con una pequeña cantidad de hidrolizado de gelatina sobre ácido poliláctico (PLA) que incorporó Lactococcus lactis para controlar el crecimiento de Listeria monocytogenes en alimentos. Para ello, se estudió la viabilidad de L. lactis y su capacidad antilisteria in vitro, en medio de cultivo líquido y sólido. Para aplicar los recubrimientos en alimentos reales, se realizaron bolsas termoselladas de PLA bioactivas para envasar crema de champiñones y separadores de lonchas de PLA bioactivo para aplicar en lonchas de jamón cocido. Se estudió la viabilidad de L. lactis así como su actividad antilisteria. Por último, se realizó una prueba sensorial con consumidores para estudiar la aceptación de los estos alimentos almacenados en refrigeración en los envases bioactivos.

En la segunda parte se desarrollaron recubrimientos de una mezcla a partes iguales de $\mathrm{PVOH}$ e hidrolizado de caseína que incorporaron L. lactis con el objetivo de desarrollar un envase activo que aumentara la vida útil. Para ampliar el espectro de acción de L. lactis frente a bacterias Gramnegativas, se incorporó ácido fítico en la formulación de las películas y se estudió la viabilidad de $L$. lactis y la actividad antimicrobiana frente a $L$. monocytogenes, Salmonella enterica, Escherichia coli y Pseudomonas fluorescens en medio de cultivo a temperatura de refrigeración y simulando roturas en la cadena del frío. A continuación, las películas activas se aplicaron como recubrimiento sobre polietileno para envasar crema pastelera casera y así aumentar su vida útil. Por último, se estudiaron los impactos ambientales del envase convencional y del envase activo para la crema pastelera fresca, considerando también la reducción de los residuos del producto obtenido gracias a las propiedades del envase activo. 


\section{Capítulo III. Desarrollo de películas que incorporan levaduras con capacidad antifúngica y aplicación tecnológica como recubrimiento de alimentos}

En este capítulo, se han desarrollado recubrimientos bioactivos que incorporan levaduras para el control de Penicillium expansum y su micotoxina, la patulina, con el objetivo de prolongar la vida útil y la seguridad de frutas en postcosecha. En la primera parte del capítulo, se aislaron cepas de levadura de las manzanas y se seleccionaron aquellas que presentaban actividad antifúngica contra $P$. expansum. También se realizó una identificación y caracterización de las levaduras seleccionadas. Finalmente, se cuantificó la capacidad antifúngica de las levaduras y también se estudió su capacidad de biodegradación de la patulina. En la segunda parte del capítulo, se incorporó la cepa de levadura que presentó el mejor rendimiento, Metschnikowia pulcherrima, en películas hechas con biopolímeros derivados de manzana para aumentar su viabilidad y su actividad antifúngica. Por último, la película con mayor actividad se aplicó como recubrimiento directamente sobre manzanas con el fin de evidenciar su potencial antifúngico para la protección de esta fruta en postcosecha. 



\section{CAPÍTULO I}

Desarrollo de películas que incorporan bacterias ácido lácticas con capacidad antimicrobiana

Artículo 1.

Antilisterial properties of PVOH-based films embedded with Lactococcus lactis subsp. lactis

\section{Artículo 2.}

PVOH/protein blend films embedded with lactic acid bacteria and their antilisterial activity in pasteurized milk

\section{Artículo 3.}

Effect of casein hydrolysates on physico-chemical properties and the survival of protective cultures of L. lactis and $L$. sakei in PVOH films 



\section{Artículo 1}

\section{Antilisterial properties of PVOH- based films embedded with Lactococcus lactis subsp. lactis}

Laura Settier-Ramírez; Gracia López-Carballo; Rafael Gavara; Pilar Hernández-Muñoz

Food Hydrocolloids, 2019, vol. 87, p. 214-220

Packaging Lab, Instituto de Agroquímica y Tecnología de Alimentos, IATA-CSIC, Av. Agustín Escardino 7, 46980 Paterna, Spain. 



\section{ABSTRACT}

The incorporation of lactic acid bacteria (LAB) in edible films and coatings has recently emerged as an innovative strategy to provide packaging films with new functionalities in order to ensure food quality and safety. In this work, bioactive films were made by incorporating Lactococcus lactis subsp. lactis in cast polyvinyl alcohol $(\mathrm{PVOH})$ matrices, alone or blended with a small percentage of proteins, protein hydrolysates, or yeast extract, and the effect of incorporating them on the morphology and optical properties of the PVOH films was studied. Moreover, the viability of L. lactis in the films developed stored at $20{ }^{\circ} \mathrm{C}$ and $43.2 \%$ relative humidity for four weeks, and the antimicrobial activity against $L$. monocytogenes were determined. The thickness, color properties, and morphology of the films incorporating $L A B$ and nutrients did not show significant differences compared with plain PVOH films, but moisture content increased slightly with nutrient incorporation. L. lactis remained viable for 4 weeks of storage, but viability depended on the matrix composition, being lower in plain $\mathrm{PVOH}$ films and higher in films supplemented with proteins, hydrolysates, or yeast extract. The highest antimicrobial activity was observed in PVOH matrices with hydrolyzed gelatin or casein, and the lowest in plain PVOH films. The growth of $L$. lactis was similar in all the films after incubation in contact with L. monocytogenes at $37^{\circ} \mathrm{C}$ in liquid medium, regardless of the initial concentration. The films developed could be applied in the design of food packages with the purpose of inhibiting growth of $L$. monocytogenes.

Keywords: Lactococcus lactis, PVOH films, gelatin, sodium caseinate, protein hydrolysates, Listeria monocytogenes. 


\section{Introduction}

Nowadays, there is an increasing tendency for food consumption to be linked intrinsically with a healthy lifestyle. Consumers now demand less processed foods made with natural ingredients, which means a preference for products free of synthetic additives and preservatives. In order to satisfy the wishes of consumers while maintaining food safety, the use of naturally occurring antimicrobials has been presented as an alternative to synthetic ones, causing great interest in the food industry [1]. Many studies have shown that incorporating antimicrobials in polymer films or coatings is more effective than adding them directly to the food product. In fact, films and coatings not only immobilize the antimicrobial compound and provide a protective environment for it, but also modulate its release to the packaged food $[2,3]$.

Bacteriocins are antimicrobial peptides and products of the metabolism of certain bacteria. The use of bacteriocins from lactic acid bacteria (LAB) in the food industry has been an advance for improving the shelf-life of foods while guaranteeing the safety and health of consumers [4]. The incorporation of bacteriocins from LAB into packaging films and coatings has been studied, with results that only show good effectiveness of the antimicrobial at the beginning of the food storage period [5-7]. This is due to the gradual depletion of the bacteriocin from the matrix reservoir. In order to solve this problem, some studies propose the incorporation of LAB directly into the film as a natural tool to extend film antimicrobial activity over time by means of the ability of bacteria to produce bacteriocins [8]. In this regard, other mechanisms such as competition between bacteria and pathogens for nutrients and the production of organic acids can help bioactivity. Lactococcus lactis subsp. lactis is used in food preservation because of its ability to produce nisin [9]. This bacteriocin is a polycyclic peptide with antibacterial properties that has been well characterized and that is classified as GRAS (Generally Recognized as Safe) by the FDA (Food and Drug Administration). L. lactis inhibits the growth of certain Gram + bacteria, such as Listeria monocytogenes, a pathogen that causes listeriosis, a serious foodborne disease [10]. 
Currently, there are few studies regarding the development of antimicrobial films incorporating bacteria, and all of them have been done with naturally occurring protein and polysaccharide polymers derived from plants and animals [11-15], because they create a favorable environment for $L A B$ survival. However, studies regarding the use of synthetic polymers as carriers of $L A B$ intended for antimicrobial packaging applications are scarce [16].

Polyvinyl alcohol (PVOH) is a synthetic polymer that is completely biodegradable and biocompatible. It can be obtained from raw materials that are not oil derivatives, such as natural gas $[17,18]$. PVOH is soluble in water and has excellent film-forming, emulsifying, and adhesive properties. PVOH films and coatings are easily obtained by casting [17,19], they have great flexibility and mechanical resistance, and are water soluble, odorless, colorless, and non-toxic [20,21]. Furthermore, $\mathrm{PVOH}$ is approved by the FDA for use in food contact and as a food additive with INS No 1203 (Codex Alimentarius) (FAO/WHO (Food and Agriculture Organization/World Health Organization), 2004). In the EU it is approved by the EFSA as a food additive in food supplements in accordance with Annex II to Regulation (EC) No 1333/2008.

The viability of Lactobacillus plantarum has been shown to be greater in protein films than in polysaccharide films [15]. Soukoulis, Singh, Macnaughtan, Parmenter, and Fisk (2016) have recently found that protein films are better matrices than starch films to sustain Lactobacillus rhamnosus viability, but a synergistic effect on viability has been observed when blending starch with proteins. [22] found higher viability values and higher antilisterial activity of $L$. lactis entrapped in matrices of gelled alginate blended with sodium caseinate than in plain gelled alginate, and greater survival of LAB in the caseinate-rich phase. Gelatin and sodium caseinate are edible proteins of animal origin that are commonly used in the food industry. In this regard, using PVOH matrices, blended with these proteins or their hydrolysates, as carriers of Lactococcus lactis could improve bacteria viability. For the same purpose, yeast extract (a cocktail of amino acids and vitamins) could also be used to promote bacterial 
growth and nisin production when added to $\mathrm{PVOH}$ as a coadjuvant agent.

Therefore, the main purpose of this work was to develop antilisterial PVOH-based films incorporating L. lactis. For this purpose, a series of films consisting of plain $\mathrm{PVOH}$ matrices or matrices blended with gelatin, sodium caseinate, gelatin or casein hydrolysates, and yeast extract was obtained and the bacteria viability in the films over time was studied. Moreover, the antimicrobial activity of the films against $L$. monocytogenes, and the survival of LAB after the films had been in contact with the pathogen in liquid medium during the antimicrobial assay were also evaluated. Furthermore, the effect of incorporating $L A B$ and proteins on the optical and morphological properties of the PVOH films was determined.

\section{Materials and methods}

\subsection{Bacterial strains}

Bacterial strains were supplied by the Spanish Type Culture Collection (CECT).

The L. lactis strain (CECT 539, ATCC 11454) was selected for the development of nisin-producing films. The strain was maintained at $-80^{\circ} \mathrm{C}$ in Man, Rogosa, and Sharpe broth (MRS) with $20 \%$ glycerol. The microbial culture was regenerated and maintained by regular subculture at $4{ }^{\circ} \mathrm{C}$ on MRS broth. Prior to beginning work, a subculture was made by transferring a loopful of the strain to $10 \mathrm{~mL}$ of MRS broth and incubating it at $30^{\circ} \mathrm{C}$ for $24 \mathrm{~h}$.

The Listeria monocytogenes strain (CECT 934, ATCC 19114) was chosen because of its importance in foodborne illness. The strain was kept frozen at $-80{ }^{\circ} \mathrm{C}$ in Tryptone Soy Broth (TSB) supplemented with $20 \%$ glycerol. For experimental use, the stock culture was maintained by regular subculture at $4{ }^{\circ} \mathrm{C}$ on Tryptone Soy Agar (TSA) and transferred monthly. Prior to the experiments, a loopful of the strain was transferred to $10 \mathrm{~mL}$ of TSB and incubated overnight at $37^{\circ} \mathrm{C}$. All microbiological products were provided by Scharlau, Barcelona, Spain. 
2.2. Determination of minimum inoculum of $L$. lactis active against $L$. monocytogenes

The minimum initial inoculum of $L$. lactis able to reduce microbial growth of $L$. monocytogenes was determined in liquid medium. L. lactis cells were harvested by centrifugation at 2500 RCF for 15 min at $4{ }^{\circ} \mathrm{C}$ and washed twice with peptone water; then they were resuspended in TSB with $0.3 \%$ of yeast extract (TSB+YE). Appropriate dilutions were made in order to inoculate tubes with 10 $\mathrm{mL}$ of $\mathrm{TSB}+\mathrm{YE}$ with concentrations ranging from $7 \mathrm{log} / \mathrm{mL}$ to 0.01 $\log / \mathrm{mL}$; then all the tubes were inoculated with $3 \log C F U / m L$ of $L$. monocytogenes. One tube without $L$. lactis and another one without $L$. monocytogenes were used as controls. The tubes were incubated at 37 ${ }^{\circ} \mathrm{C}$ for $24 \mathrm{~h}$. After incubation, serial dilutions with peptone water were made and plated in Petri dishes with $15 \mathrm{~mL}$ of Polymyxin Acriflavine Lithium Chloride Ceftazidime Aesculin Mannitol agar (PALCAM agar) to study logarithmic reduction of $L$. monocytogenes, and also in MRS to study growth of L. lactis in contact with L. monocytogenes. MRS agar plates and PALCAM plates were incubated at $30{ }^{\circ} \mathrm{C}$ and $37{ }^{\circ} \mathrm{C}$ for 4 days and $48 \mathrm{~h}$, respectively. Thus, L. lactis colonies were counted in MRS agar and L. monocytogenes colonies were counted in PALCAM agar. Tests were carried out in triplicate.

\subsection{Film formation}

Five different film-forming solutions (FFS) were prepared by dissolving $2 \%$ of polyvinyl alcohol (PVOH, Gohsenol GH17, Nippon Synthetic Chemical Company, Osaka, Japan) in distilled water as the main polymer matrix, and gelatin (gelatin from porcine skin, type A, Sigma-Aldrich, USA), sodium caseinate (casein sodium salt from bovine milk, Sigma-Aldrich, New Zealand), casein and gelatin hydrolysates (peptone from casein and gelatin, enzymatic digest, Sigma-Aldrich, France), and yeast extract (yeast autolysate, SigmaAldrich, France) as nutritional supplements for L. lactis. They were prepared in a mass ratio of 1:0.125. L. lactis cells were harvested by centrifugation at $2500 \mathrm{RCF}$ for $15 \mathrm{~min}$ at $4{ }^{\circ} \mathrm{C}$ and washed twice with peptone water. Then they were incorporated into the film-forming 
solution in order to obtain $7 \log \mathrm{CFU} / \mathrm{mL}$ of FFS, and $15 \mathrm{~g}$ of it was cast in Petri dishes $(90 \mathrm{~mm})$ and dried at $37{ }^{\circ} \mathrm{C}$ for $24 \mathrm{~h}$. PVOH films without nutritional supplement were used as control films.

\subsection{Film characterization}

\subsubsection{Film thickness}

Film thickness was measured with a digital micrometer (Mitutoyo Manufacturing Co., Ltd., Tokyo, Japan) with a sensitivity of 1 $\mu \mathrm{m}$. Five readings were taken randomly for each film sample.

\subsubsection{Moisture content}

Film samples of approximately $0.5 \mathrm{~g}$ were placed on aluminum plates and stored in a desiccator containing a saturated solution of potassium carbonate anhydrous (Acros Organics, France) in order to obtain $43.2 \% \mathrm{RH}$ at $20{ }^{\circ} \mathrm{C}$. After reaching weight equilibrium, in approximately two weeks, they were weighed and placed in desiccators with phosphorus pentoxide (Fluka, Sigma-Aldrich, France) for dehydration until constant weight, in approximately two weeks. The tests were carried out in triplicate.

\subsubsection{Optical properties}

The color of the films developed was measured using a Konica Minolta CM-3500d spectrophotometer (Konica Minolta Sensing, Inc., Osaka, Japan) set to D65 illuminant $/ 10^{\circ}$ observer. The samples were measured against the surface of a standard white plate to acquire the color data and to display them in the CIELAB color space. The parameters $L^{*}$ [black (0) to white (100)], $a^{*}$ [green $(-)$ to red $(+)$ ], and $b^{*}$ [blue $(-)$ to yellow $\left.(+)\right]$ were obtained and the polar coordinates, the chroma $C^{*}$, and the hue angle $h^{\circ}$ were calculated. Eight measurements of each sample were taken, and three samples of each film were measured.

The apparent opacity of the films was calculated as the area under the absorption curve $(\mathrm{Au} \times \mathrm{nm})$ in the UV and visible wavelengths. For this purpose, films were cut in strips and put in a glass cuvette. The absorption spectrum was recorded by a Perkin 
Elmer Lambda 16 UV-Visible spectrometer scanning in the wavelength range of $190-800 \mathrm{~nm}$.

\subsubsection{Fluorescence microscopy}

The distribution of bacteria on the surface of the films was observed with a Nikon Eclipse 90i fluorescence microscope. For this purpose, a dry film sample was placed onto a glass slide and colored with a drop of SYBR ${ }^{\circledR}$ Green I nucleic-acid gel 10000X (Lonza, Spain) diluted 1:10. The films were observed under a green filter (excitation at $497 \mathrm{~nm}$, emission at $520 \mathrm{~nm}$ ).

\subsubsection{Scanning Electron Microscopy (SEM)}

The morphology of the film surface was studied by scanning electron microscopy with a HITACHI S-4100 unit equipped with a BSE AUTRATA detector and an EMIP 3.0 image capture system (HITACHI, Madrid, Spain). Samples were previously coated under vacuum with gold-palladium in a sputter coating unit. Images were captured at 5 $\mathrm{kV}$. The film surfaces in contact with polystyrene Petri dishes during casting were named "PS", and those exposed to "air" during drying were labeled as "AS"

\subsection{Viability of $L$. lactis in the films}

The viability of $L$. lactis was periodically evaluated in film stored at $20^{\circ} \mathrm{C}$ and $43.2 \%$ relative humidity (RH) for one month. Once a week, film samples of $90 \mathrm{~mm}$ in diameter were placed in tubes with $10 \mathrm{~mL}$ of sterile peptone water and vigorously stirred, being readily dissolved in water. Then serial dilutions were made and plated onto MRS agar. Colonies were counted after incubation for 4 days at $30^{\circ} \mathrm{C}$.

\subsection{Antimicrobial activity}

The antimicrobial activity of films with L. lactis was tested against $L$. monocytogenes. Moreover, the survival of LAB bacteria after being in contact with the pathogen during the antimicrobial test was also studied. For this purpose, films stored at $20{ }^{\circ} \mathrm{C}$ and $43.2 \% \mathrm{RH}$ for different times were added to TSB $+Y E$ tubes previously inoculated 
with $10^{3} \mathrm{CFU} / \mathrm{mL}$ of $L$. monocytogenes, and incubated at the optimal growth temperature for Listeria, $37^{\circ} \mathrm{C}$, for $24 \mathrm{~h}$. As described in section 2.1, serial dilutions were made and plated in MRS agar and PALCAM agar to count $L$. lactis and $L$. monocytogenes colonies after incubation. Tests were done in triplicate.

\subsection{Statistical analysis}

One-way analyses of variance were carried out. The SPSS computer program (SPSS Inc., Chicago, IL) was used. Differences in pairs of mean values were evaluated by the Tukey $b$ test for $a$ confidence interval of $95 \%$. Data were represented as the average \pm standard deviation.

\section{Results and discussion}

3.1. Determination of minimum inoculum of $L$. lactis active against $L$. monocytogenes

Prior to the formation of films, the minimum initial inoculum of $L$. lactis necessary to inhibit $L$. monocytogenes was studied in liquid medium (TSB+YE) at $37{ }^{\circ} \mathrm{C}$ for $24 \mathrm{~h}$. It was considered that this value corresponds to the initial concentration of inoculated L. lactis able to reduce the population of $L$. monocytogenes by at least 2 logs. The antilisterial activity of the inoculum and the growth of the LAB are shown in Figure 1. Four times more $L$. lactis $(7 \log \mathrm{CFU} / \mathrm{ml})$ than $L$. monocytogenes was needed to reduce the pathogen (3.48 log $\mathrm{CFU} / \mathrm{mL}$ ). When a smaller amount of $L$. lactis was added $(<3 \mathrm{log}$ $\mathrm{CFU} / \mathrm{mL}$ ), the reduction was lower than $1 \log \mathrm{CFU} / \mathrm{ml}$, which was not considered inhibition. It should be pointed out that whatever initial amount of inoculum was added to the medium the growth of L. lactis in the presence of $L$. monocytogenes was similar, without observing competition between strains, and reaching a maximum around 8-9 log $\mathrm{CFU} / \mathrm{mL}$ in the stationary phase.

Moisture content of the films evaluated at $43.2 \% \mathrm{RH}$ and $20^{\circ} \mathrm{C}$ was $4.05 \pm 0.24 \mathrm{~g} / \mathrm{g}$ dry film; incorporation of lactic acid bacteria slightly decreased the moisture content of the film, with a value of $3.66 \pm 0.17 \mathrm{~g} / \mathrm{g}$ dry film. Gelatin and sodium caseinate are more 
hygroscopic than PVOH, so when PVOH was blended with them, their hydrolysates, or yeast extract, mainly consisting of a cocktail of amino acids and vitamins, the moisture content of the films increased by $25 \%$.

\subsection{Thickness and moisture content}

Incorporation of L. lactis did not modify the thickness of the PVOH films, which was around $0.040 \pm 0.01 \mathrm{~mm}$. Several authors have shown similar results for protein films embedded with bacteria $[11,23,24]$. The incorporation of proteins, protein hydrolysates, or yeast extract also did not modify the thickness of the films.

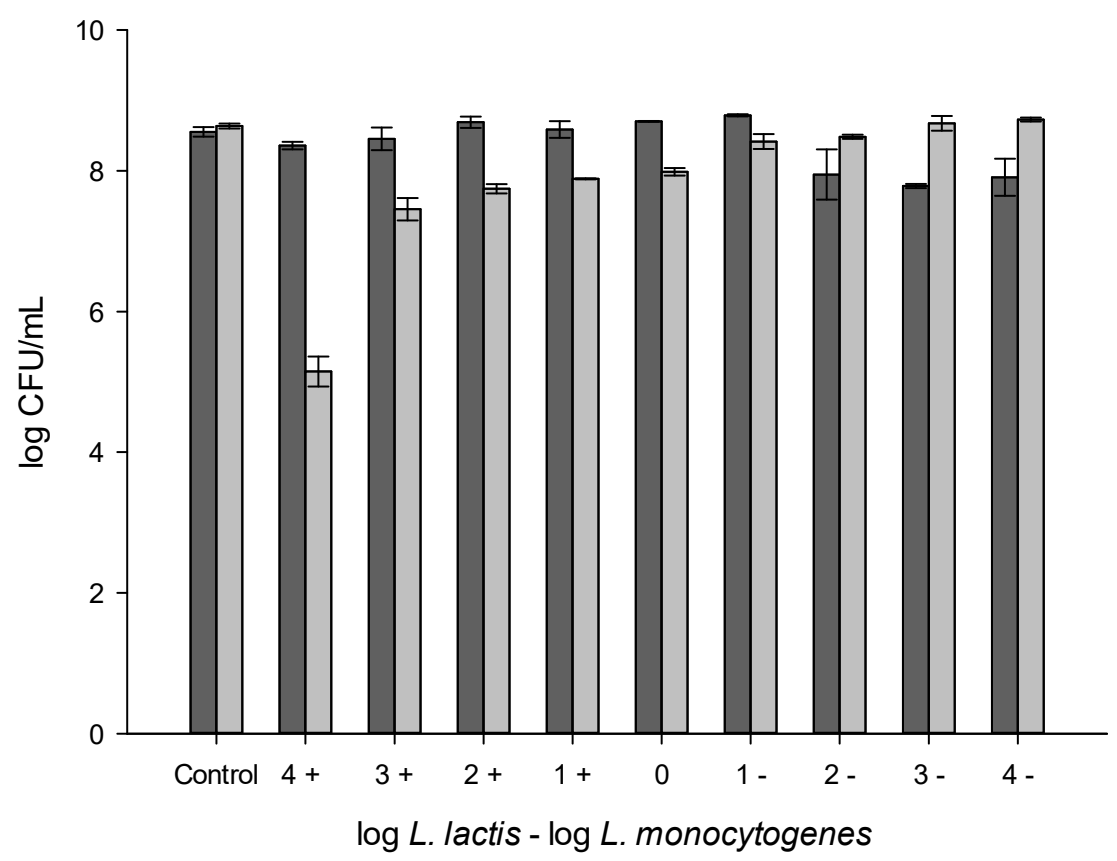

Figure 1. Growth of $L$. lactis and antilisterial activity of different concentrations of $L$. lactis against a concentration $3 \log \mathrm{CFU} / \mathrm{mL}$ of $L$. monocytogenes after incubation in TSB+YE at $37^{\circ} \mathrm{C}$ during $24 \mathrm{~h}$. Dark gray column represents the amount of $L$. lactis and light gray column represents the amount of $L$. monocytogenes. Mean values and 95\% LSD intervals

\subsection{Optical properties}


Film color and transparency have a direct impact on the appearance of the packaged or coated product which can determinate its acceptance by consumers. Color parameters of the formulated films are shown in Table 1. There were no statistical differences between films embedded with bacteria and the same films without bacteria (data not shown). All the films had high values of $L^{*}$, close to 100 (white plate coordinates $L^{*}=96.79, a^{*}:-0.12, b^{*}:-0.12, C^{*}: 0.17$, h: 226.53), which is an indirect measure of film transparency. The films also had similar chroma, except films incorporating yeast extract, which exhibited slightly higher chromaticity. With regard to tone, all the films incorporating proteins or their hydrolysates had similar hue values and were in quadrant II, whereas the hue of plain PVOH films was close to the white plate, both in quadrant III. Films incorporating yeast extract had the lowest hue. However, these differences were not appreciable to the naked eye.

Table 1. Effect of the incorporation of proteins, protein hydrolysates or yeast extract on the optical properties of films embedded with Lactococcus lactis.

\begin{tabular}{lccccc}
\hline \multicolumn{1}{c}{ Films } & L $^{*}$ & $\mathrm{a}^{*}$ & $\mathbf{b}^{*}$ & $\mathrm{C}^{*}$ & $\mathbf{h}^{\circ}$ \\
\hline PVOH & $89.24 \pm 0.06^{\mathrm{a}}$ & $-0.15 \pm 0.01^{\mathrm{ab}}$ & $-0.1 \pm 0.01^{\mathrm{a}}$ & $0.18 \pm 0.01^{\mathrm{a}}$ & $214.73 \pm 1.31^{\mathrm{a}}$ \\
PVOH Gel & $88.80 \pm 0.04^{\mathrm{b}}$ & $-0.17 \pm 0.01^{\mathrm{ab}}$ & $0.15 \pm 0.03^{\mathrm{b}}$ & $0.22 \pm 0.02^{\mathrm{a}}$ & $139.85 \pm 3.52^{\mathrm{b}}$ \\
PVOH Cas & $89.34 \pm 0.35^{\mathrm{a}}$ & $-0.14 \pm 0.01^{\mathrm{a}}$ & $0.12 \pm 0.03^{\mathrm{b}}$ & $0.19 \pm 0.03^{\mathrm{a}}$ & $140.47 \pm 7.01^{\mathrm{b}}$ \\
PVOH HGel & $89.25 \pm 0.15^{\mathrm{a}}$ & $-0.18 \pm 0.02^{\mathrm{bc}}$ & $0.17 \pm 0.06^{\mathrm{b}}$ & $0.25 \pm 0.06^{\mathrm{a}}$ & $138.98 \pm 8.10^{\mathrm{b}}$ \\
$\begin{array}{l}\text { PVOH } \\
\text { HCas }\end{array}$ & $88.92 \pm 0.2^{\mathrm{ab}}$ & $-0.21 \pm 0.01^{\mathrm{c}}$ & $0.15 \pm 0.02^{\mathrm{b}}$ & $0.26 \pm 0.01^{\mathrm{a}}$ & $143.87 \pm 3.86^{\mathrm{b}}$ \\
PVOH YE & $88.79 \pm 0.16^{\mathrm{b}}$ & $-0.43 \pm 0.03^{\mathrm{d}}$ & $1.47 \pm 0.14^{\mathrm{c}}$ & $1.53 \pm 0.14^{\mathrm{b}}$ & $106.36 \pm 0.59^{\mathrm{c}}$ \\
\hline
\end{tabular}

$a, b, c, d$, e Different letters in the same column indicate significant differences among formulations $(p<0.05)$.

Apparent opacity of the films was measured as the area under the absorbance curve in the visible region $(400-800 \mathrm{~nm})$ and in the middle and near UV region (190-400 $\mathrm{nm}$ ). The results are shown in 
Figure 2. Incorporation of bacteria did not modify the opacity of the films in either the UV or the visible region (results not shown). The $\mathrm{PVOH}$ films were very transparent, as indicated by the low opacity values in the visible region $(8(A \times n m))$. When gelatin hydrolysates or yeast extract were incorporated, opacity increased slightly (11 (A $\times$ $\mathrm{nm})$ ). Sodium caseinate or casein hydrolysates did not modify the apparent opacity of the PVOH film. Incorporation of gelatin increased the apparent opacity of the PVOH films to $31(\mathrm{~A} \times \mathrm{nm})$. The average molecular weight of gelatin is $95 \mathrm{kDa}$, much higher than that of sodium caseinate, which is around $25 \mathrm{kDa}$, whereas the average molecular weight of $\mathrm{PVOH}$ is close to $30 \mathrm{kDa}$. Miscibility of proteins with $\mathrm{PVOH}$ could be affected by the molecular weight, causing small changes in some properties such as apparent opacity. In fact, gelatin hydrolysates did not modify the apparent opacity of the films. A film $90 \%$ opaque to visible light corresponds to an area under the curve of $400(\mathrm{~A} \times \mathrm{nm})$. This value is $210(\mathrm{~A} \times \mathrm{nm})$ in the UV region from 190 to $400 \mathrm{~nm}$. Apparent opacity of PVOH films in the UV region was very low. When proteins, protein hydrolysates, or yeast extract were added to a PVOH matrix, the films blocked at least $90 \%$ of UV light. It is well known that aromatic amino acids, tryptophan, tyrosine, and phenylalanine are responsible for UV light absorbance by proteins.

\subsection{Fluorescence microscopy and SEM}

A fluorescence microscopy image of PVOH film loaded with bacteria is shown in Figure 3. It reveals the presence of bacteria grouped together in clusters ranging from five to twenty micrometers, approximately, and homogeneously distributed in the polymer matrix. Similar images were obtained when proteins, protein hydrolysates, or yeast extract were added to PVOH films. 


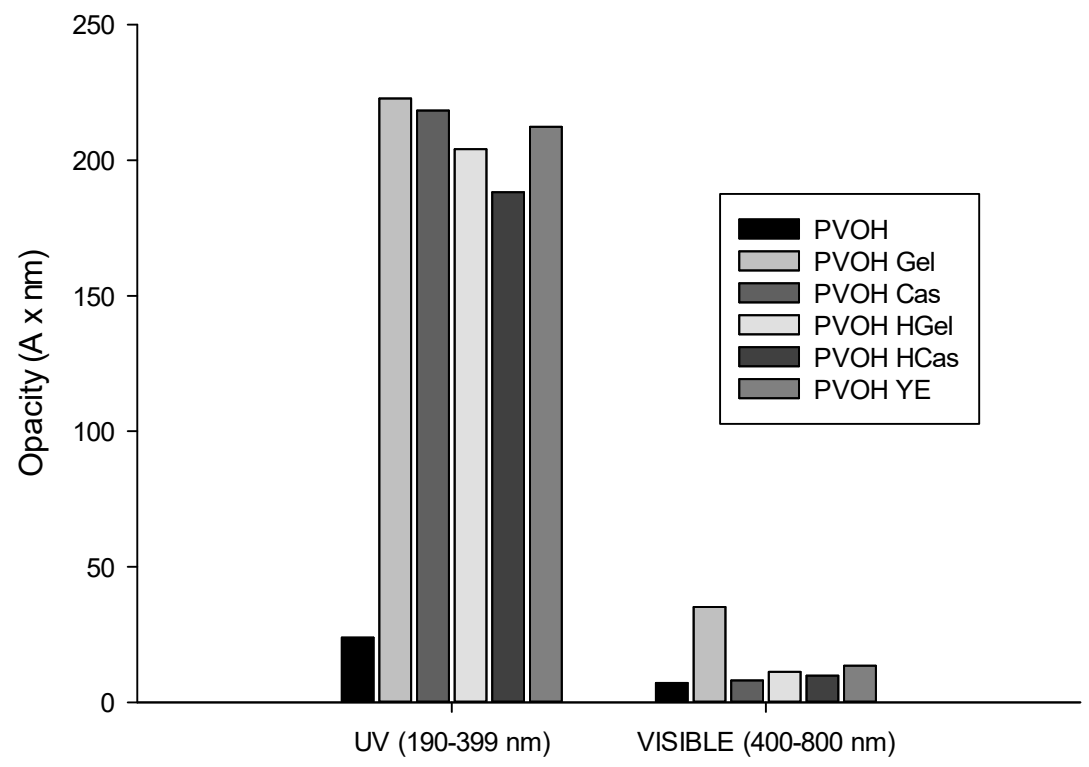

Figure 2. Effect of the incorporation of proteins, protein hydrolysates or yeast extract on the opacity of films embedded with L. lactis

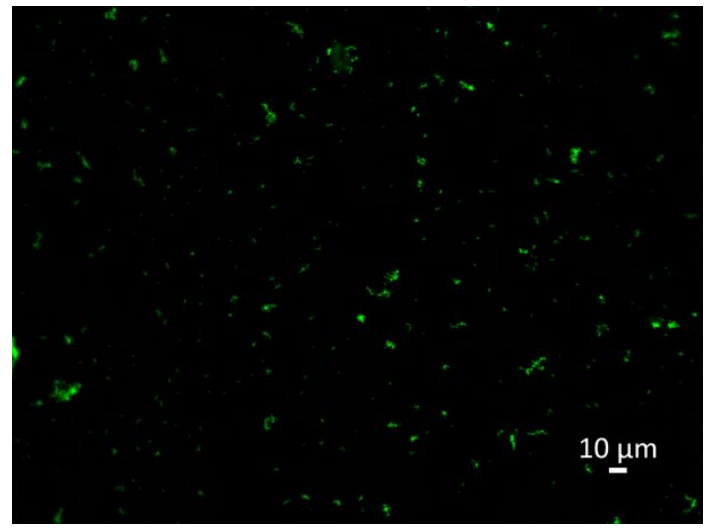

Figure 3. Fluorescence microscopy image of PVOH film embedded with bacteria 
The surface of the films was also examined by SEM. The incorporation of protein, protein hydrolysates, and yeast extract did not change the morphology of the cross-section surface of the PVOH films, presenting a smooth surface without apparent phase separation, indicative of good compatibility. When bacteria were incorporated into the films, the cross-section surface was covered with small bumps corresponding to bacterial aggregates (images not shown). Figures 4a and $4 \mathrm{~b}$ show the topography of the "AS" (surface exposed to "air" during drying) and "PS" (surface in contact with polystyrene Petri dish during drying) of a $\mathrm{PVOH}$ film embedded with bacteria. In both images, bacterial aggregates breaking the smooth surface of the $\mathrm{PVOH}$ films can be seen. Similar results were obtained for whey protein films embedded with bacteria [23]. Aggregates were between five and twenty micrometers, whereas the size of the bacteria was approximately $0.6-1.5$ micrometers, which corresponds to the expected size for L. lactis subsp. lactis. It can also be seen that the film surface exposed to air during drying (Figure 4a) was more irregular than the surface in contact with the Petri dish during drying (Figure $4 b)$.

\subsection{Bacterial viability}

The viability of $L$. lactis embedded in $\mathrm{PVOH}$-based films was studied to determine how many cells survived after film drying and during a storage period of four weeks at $20{ }^{\circ} \mathrm{C}$ and $43.2 \% \mathrm{RH}$, and to evaluate if the addition of protein, protein hydrolysates, or yeast extract had any effect on it. Viability results are in Table 2.

Regardless of the matrix, the results indicate the great resistance of this strain to the decrease in water content and to the lack of nutrients when it is embedded in a synthetic, hydrophilic polymer matrix. L. lactis remained viable in all the prepared films and was able to grow in culture media during the whole storage period of four weeks. Slight differences in viability were found when the bacteria were embedded in films with different compositions. 


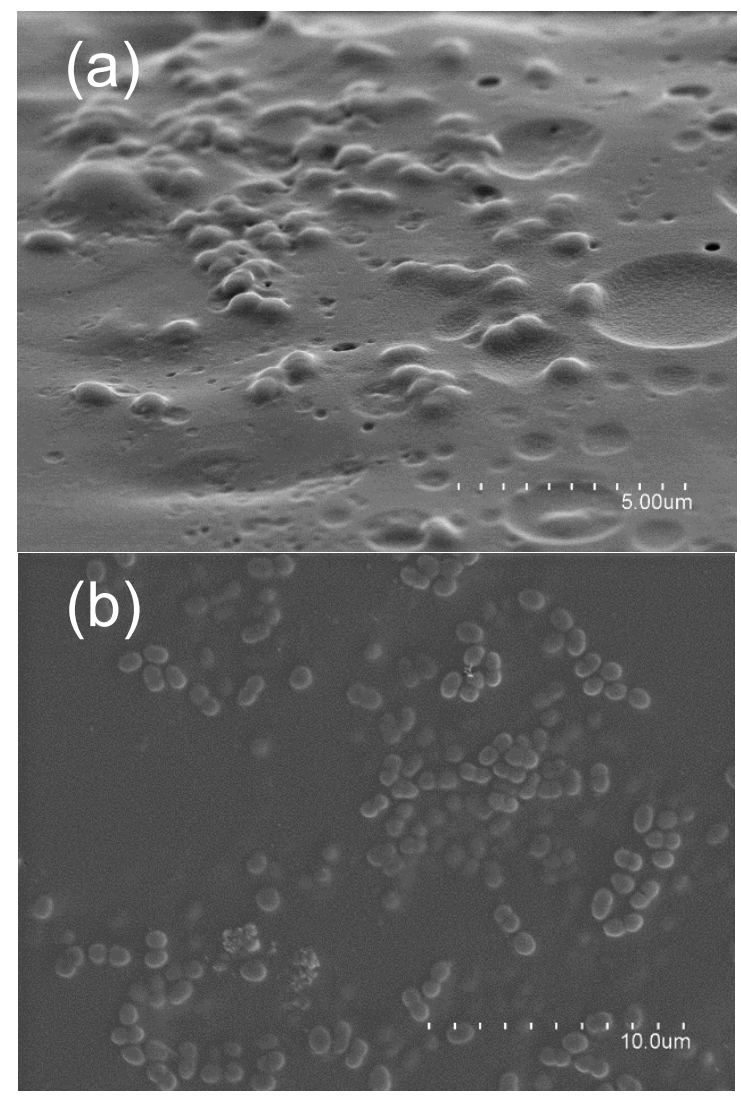

Figure 4. Scanning electron microscopy visualization of "AS" (a) and "PS" (b) surfaces of PVOH films with bacteria.

After film drying, cell viability in $\mathrm{PVOH}$ blended with gelatin and casein hydrolysates was greater than in the other films, and around 1 log higher compared to that of plain PVOH films. The cell viability of PVOH with sodium caseinate and yeast extract was lower than that of films with protein hydrolysates. Plain $\mathrm{PVOH}$ films and those incorporating gelatin presented the lowest viability. 
Table 2. Viability of L. lactis in films throughout storage time at $20^{\circ} \mathrm{C}$ and $43.3 \% \mathrm{RH}$.

\begin{tabular}{ccccccc}
\hline \multirow{2}{*}{ Days } & \multicolumn{5}{c}{ CELL VIABILITY } \\
\cline { 2 - 6 } & PVOH & PVOH Gel & PVOH Cas & PVOH HGel & PVOH HCas & PVOH YE \\
\hline 0 & $6.89 \pm 0.12^{\mathrm{aAB}}$ & $6.38 \pm 0.68^{\mathrm{aA}}$ & $7.52 \pm 0.13^{\mathrm{aB}}$ & $7.95 \pm 0.14^{\mathrm{aC}}$ & $7.80 \pm 0.03^{\mathrm{aC}}$ & $7.62 \pm 0.12^{\mathrm{aBC}}$ \\
7 & $6.25 \pm 0.23^{\mathrm{bcA}}$ & $6.67 \pm 0.58^{\mathrm{aAB}}$ & $7.23 \pm 0.25^{\mathrm{abBC}}$ & $7.56 \pm 0.07^{\mathrm{bC}}$ & $7.91 \pm 0.02^{\mathrm{aC}}$ & $7.39 \pm 0.23^{\mathrm{aBC}}$ \\
14 & $6.67 \pm 0.05^{\mathrm{abA}}$ & $6.84 \pm 0.25^{\mathrm{aA}}$ & $6.98 \pm 0.06^{\mathrm{bcA}}$ & $7.63 \pm 0.07^{\mathrm{abB}}$ & $7.75 \pm 0.10^{\mathrm{aB}}$ & $7.84 \pm 0.05^{\mathrm{aB}}$ \\
21 & $5.83 \pm 0.06^{\mathrm{cdA}}$ & $6.22 \pm 0.13^{\mathrm{aA}}$ & $7.21 \pm 0.09^{\mathrm{bcB}}$ & $7.74 \pm 0.14^{\mathrm{abBC}}$ & $7.86 \pm 0.06^{\mathrm{aC}}$ & $7.42 \pm 0.06^{\mathrm{aBC}}$ \\
28 & $5.49 \pm 0.46^{\mathrm{dA}}$ & $6.00 \pm 0.05^{\mathrm{aA}}$ & $6.85 \pm 0.07^{\mathrm{cB}}$ & $7.59 \pm 0.15^{\mathrm{bC}}$ & $7.73 \pm 0.13^{\mathrm{aC}}$ & $7.56 \pm 0.46^{\mathrm{aC}}$
\end{tabular}

$A, B, C$ : different letters in the same file indicate significant differences among formulation $(p<0.05)$.

$a, b, c, d$ : different letters in the same column indicates significant differences among time for a same formulation $(p<0.05)$. 
Since all the film-forming solutions were inoculated with the same concentration of $L$. lactis, the differences found in cell viability after film drying could be explained because the bacteria incorporated in the filmforming solutions having proteins, their hydrolysates or yeast extract are able to maintain in a greater extent their initial population until the film is dried. According to the results obtained after film drying, hydrolyzed proteins could act as a source of nutrients that is more accessible to bacteria than proteins with a long chain and high molecular weight, whereas yeast extract consisting of amino acids and vitamins could be very accessible to bacteria. That would explain differences in cell viability found among films just after drying. Previous studies have shown that the use of animal proteins as film matrices allows other lactic acid bacteria such as Lactobacillus plantarum, Lactobacillus sakei, Bifidobacterium animalis, and Lactobacillus casei to maintain cell viability $[11,14,15,23]$.

The viability of $L$. lactis in dried films was also studied during a storage period of 4 weeks at $20{ }^{\circ} \mathrm{C}$ and $43.2 \% \mathrm{RH}$. The results are presented in Table 2, and they show that cell viability for PVOH films decreased by approximately $1.5 \mathrm{log}$ after four weeks. When proteins, protein hydrolysates, or yeast extract were added to the $\mathrm{PVOH}$ matrix the viability decreased slightly during storage time, but by no more than 0.5 log for any film composition. The presence of proteins or protein hydrolysates in the $\mathrm{PVOH}$ matrix could create a more favorable environment for the survival of bacteria during storage.

\subsection{Antilisterial activity}

The antimicrobial capacity of the films stored for one month at $20^{\circ} \mathrm{C}$ and $43.2 \% \mathrm{RH}$ was evaluated against $L$. monocytogenes. Moreover, the survival of $L A B$ bacteria after being in contact with the pathogen during the antimicrobial test was also studied.

Figure 5 a shows the survival of $L A B$ throughout the storage time for different film compositions. This remained around 8 log independently of film composition and storage time. This shows that although the bacteria had different viabilities, depending on film composition, when the film was immersed in an enriched liquid medium and incubated at $37^{\circ} \mathrm{C}$ for $24 \mathrm{~h}$ the 
cell growth was similar in all the films. These results are in accordance with the results obtained in the determination of the minimum inoculum of $L$. lactis active against $L$. monocytogenes, where, regardless of the initial amount of $L$. lactis inoculum placed in the medium, lactic acid bacteria reached the stationary phase.

Figure $5 b$ shows the antilisterial activity of films with different compositions during the storage time of four weeks. All the films with embedded bacteria possessed antilisterial activity, but not all the films presented the same antilisterial activity.

(a)

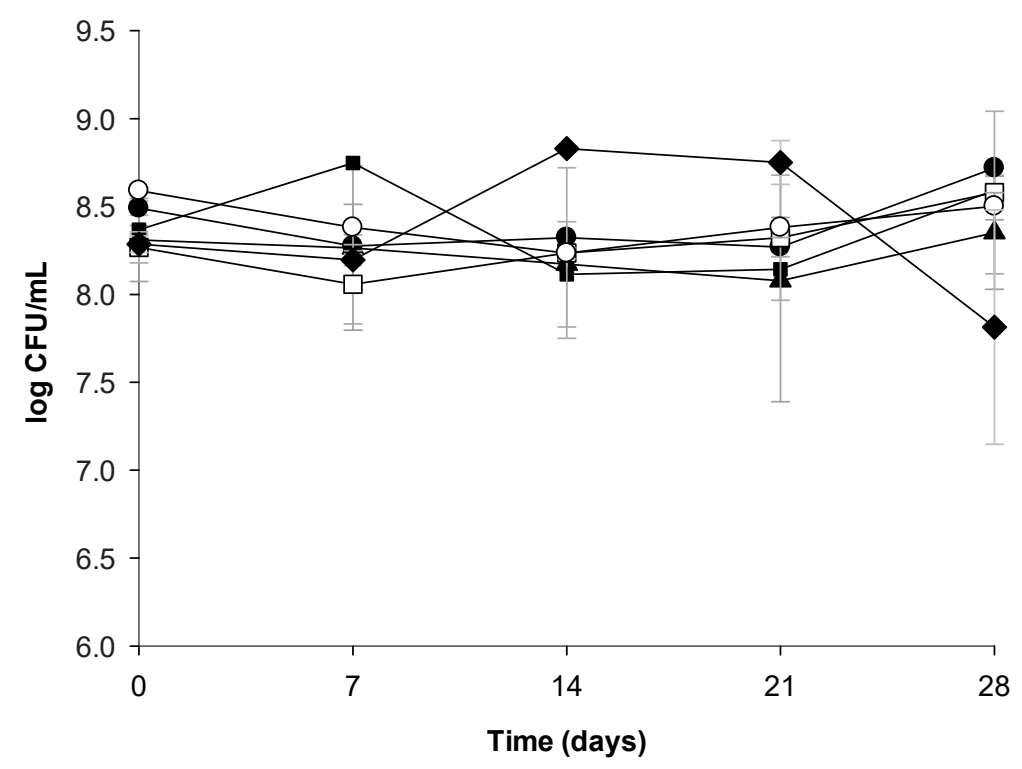


(b)

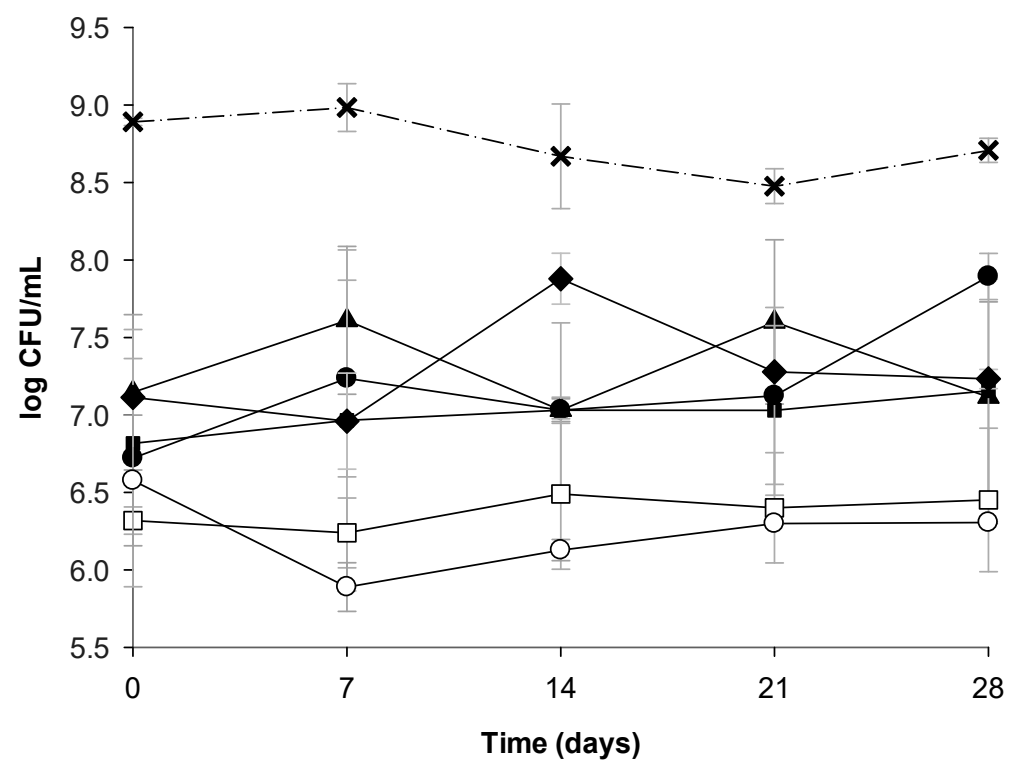

Figure 5. Survival of lactic acid bacteria (a) and antimicrobial activity (b) of films stored at $16{ }^{\circ} \mathrm{C}$ and $43.3 \% \mathrm{RH}$ after incubation in liquid medium (TSB+yeast) in contact with L. monocytogenes at $37{ }^{\circ} \mathrm{C}$ during $24 \mathrm{~h}$. Mean values and $95 \%$ LSD intervals. ( $\Delta$ PVOH, • PVOH Cas, $\square$ PVOH Gel, O PVOH HCas, $\square$ PVOH HGel, $\bullet \mathrm{PVOH}$ $\mathrm{YE}, \times$ Control)

The greatest antimicrobial activity was observed for matrices of $\mathrm{PVOH}$ incorporating gelatin or casein hydrolysates, with a microbial reduction of up to $3 \log \mathrm{CFU} / \mathrm{ml}$, which was maintained through the whole storage period. Whereas films blended with sodium caseinate, gelatin or yeast extract showed a growth inhibition around $2 \log \mathrm{CFU} / \mathrm{ml}$, which decreased for films with yeast extract at the $14^{\text {th }}$ day of storage, and that happen for films with sodium caseinate after 21 days of storage. In general, plain $\mathrm{PVOH}$ matrices presented the lower growth inhibition results.

It is interested to note that the initial amount of viable L. lactis in the film affects its antilisterial activity. In this context, [25] studied the antilisterial capacity of alginate and a blend of alginate with sodium caseinate matrices loaded with two different concentrations of L. lactis, $10^{8} \mathrm{CFU} / \mathrm{mL}$ and $10^{4}$ $\mathrm{CFU} / \mathrm{mL}$. The authors reported film activity against Listeria monocytogenes 
when the matrix was loaded with $10^{8} \mathrm{CFU} / \mathrm{mL}$, whereas the matrix loaded with $10^{4} \mathrm{CFU} / \mathrm{mL}$ did not present antilisterial activity.

In view of the results obtained in the present work, it could be stated that films with a greater amount of viable bacteria attain greater antilisterial activity, which is in agreement with the results obtained in the above section, where the antimicrobial activity depended on the initial inoculum of L. lactis in the medium and not on the quantity reached after incubation.

Thus, $\mathrm{PVOH}$ films create an environment where bacteria can survive after casting. When the films entered in contact with the infected media, they lost their integrity and readily dissolved, thus releasing the carrying bacteria which produced nisin together with other antimicrobials such as lactic acid capable of inhibiting the growth of $L$. monocytogenes. According to the growth inhibition results obtained through film storage, the bacteria supposedly are inactive in the film; otherwise, if bacteria would have produced nisin and lactic acid during storage, growth inhibition should have increased through storage time.

The antimicrobial activity of the films is affected by the film composition. The presence of carbon and nitrogen provided by proteins, protein hydrolysates, and yeast extract favors the metabolism of L. lactis, presumably increasing the production of antimicrobial metabolites, mainly nisin and lactic acid. However, PVOH blended with casein and gelatin hydrolysates produced the best results because hydrolyzed proteins could be more available for bacteria. Other authors have studied the influence of other nutrients on bacterial growth and nisin production, observing similar results [26].

\section{Conclusions}

Antilisterial films were successfully obtained from PVOH-based films enriched with proteins, protein hydrolysates, or yeast extract and incorporating nisin-producing $L$. lactis.

The results of this study demonstrated that the addition of $L$. lactis and different proteins did not significantly modify thickness, or optical and morphological properties of the films. Cell viability was affected by film composition. However, all the formulated films acted as carriers of living bacteria during one month of storage without losing cell viability. L. lactis 
embedded in the films was able to reach a maximum of 8-9 log CFU/ml in the stationary phase after films being in contact with $L$. monocytogenes. All the films presented antimicrobial activity, but the incorporation of proteins, protein hydrolysates, or yeast extract had a significant effect on their antimicrobial activity, having the best results when hydrolysates were used.

Studies comprising the incorporation of the active films developed in the design of a food package and testing the shelf-life of various packaged food matrices are being carried out.

\section{Acknowledgments}

The authors acknowledge the financial support of the Spanish Ministry of Economy and Competitiveness (AGL2015-64595-R).

\section{References}

1. $\mathrm{Xu}, \mathrm{W}_{\text {; }} \mathrm{Qu}, \mathrm{W} . ;$ Antibacterial effect of Grapefruit Seed Extract on food-borne pathogens and its application in the preservation of minimally processed vegetables. Postharvest Biol. Technol. 2007, 45, 126-133, doi:10.1016/j.postharvbio.2006.11.019.

2. Realini, C.E.; Marcos, B. Active and intelligent packaging systems for a modern society. Meat Sci. 2014, 98, 404-419, doi:10.1016/j.meatsci.2014.06.031.

3. Aloui, H.; Khwaldia, K. Natural Antimicrobial Edible Coatings for Microbial Safety and Food Quality Enhancement. Compr. Rev. Food Sci. Food Saf. 2016, 15, 1080-1103, doi:10.1111/1541-4337.12226.

4. Reis, J.A.; Paula, A.T.; Casarotti, S.N.; Penna, A.L.B. Lactic Acid Bacteria Antimicrobial Compounds: Characteristics and Applications. Food Eng. Rev. 2012, 4, 124-140, doi:10.1007/s12393-012-9051-2.

5. Ercolini, D.; Ferrocino, I.; Storia, A. La; Mauriello, G.; Gigli, S.; Masi, P.; Villani, F. Development of spoilage microbiota in beef stored in nisin activated packaging. 2009, doi:10.1016/j.fm.2009.09.006.

6. Coma, V.; Sebti, I.; Pardon, P.; Deschamps, A.; Pichavant, F.H. Antimicrobial Edible Packaging Based on Cellulosic Ethers, Fatty 
Acids, and Nisin Incorporation To Inhibit Listeria innocua and Staphylococcus aureus. J. Food Prot. 2001, 64, 470-475.

7. Marcos, B.; Aymerich, T.; Monfort, J.M.; Garriga, M. High-pressure processing and antimicrobial biodegradable packaging to control Listeria monocytogenes during storage of cooked ham. Food Microbiol. 2008, 25, 177-182, doi:10.1016/J.FM.2007.05.002.

8. Espitia, P.J.P.; Batista, R.A.; Azeredo, H.M.C.; Otoni, C.G. Probiotics and their potential applications in active edible films and coatings. Food Res. Int. 2016, 90, 42-52, doi:10.1016/j.foodres.2016.10.026.

9. Deegan, L.H.; Cotter, P.D.; Ross, P. Bacteriocins: Biological tools for bio-preservation and shelf-life extension. Int. Dairy J. 2006, 16, 10581071, doi:10.1016/J.IDAIRYJ.2005.10.026.

10. Benkerroum, N.; Sandine, W.E. Inhibitory Action of Nisin Against Listeria monocytogenes. J. Dairy Sci. 1988, 71, 3237-3245, doi:10.3168/jds.S0022-0302(88)79929-4.

11. Gialamas, H.; Zinoviadou, K.G.; Biliaderis, C.G.; Koutsoumanis, K.P. Development of a novel bioactive packaging based on the incorporation of Lactobacillus sakei into sodium-caseinate films for controlling Listeria monocytogenes in foods. Food Res. Int. 2010, 43, 2402-2408, doi:10.1016/j.foodres.2010.09.020.

12. López De Lacey, A.M.; López-Caballero, M.E.; Gómez-Estaca, J.; Gómez-Guillén, M.C.; Montero, P. Functionality of Lactobacillus acidophilus and Bifidobacterium bifidum incorporated to edible coatings and films. Innov. Food Sci. Emerg. Technol. 2012, 16, 277282, doi:10.1016/j.ifset.2012.07.001.

13. Concha-Meyer, A.; Schöbitz, R.; Brito, C.; Fuentes, R. Lactic acid bacteria in an alginate film inhibit Listeria monocytogenes growth on smoked salmon. Food Control 2011, 22, 485-489, doi:10.1016/j.foodcont.2010.09.032.

14. Sánchez-González, L.; Quintero Saavedra, J.l.; Chiralt, A. Physical properties and antilisterial activity of bioactive edible films containing Lactobacillus plantarum. Food Hydrocoll. 2013, 33, 92-98, doi:10.1016/j.foodhyd.2013.02.011.

15. Sánchez-González, L.; Quintero Saavedra, J.l.; Chiralt, A. Antilisterial and physical properties of biopolymer films containing lactic acid 
bacteria. Food Control 2014, 35, 200-206, doi:10.1016/j.foodcont.2013.07.001.

16. Iseppi, R.; de Niederhäusern, S.; Anacarso, I.; Messi, P.; Sabia, C.; Pilati, F.; Toselli, M.; Esposti, M.D.; Bondi, M. Anti-listerial activity of coatings entrapping living bacteria. Soft Matter 2011, 7, 8542, doi:10.1039/c1sm05650f.

17. Dorigato, A.; Pegoretti, A. Biodegradable single-polymer composites from polyvinyl alcohol. Colloid Polym. Sci. 2012, 290, 359-370, doi:10.1007/s00396-011-2556-z.

18. De Prisco, N.; Immirzi, B.; Malinconico, M.; Mormile, P.; Petti, L.; Gatta, G. Preparation, physico-chemical characterization, and optical analysis of polyvinyl alcohol-based films suitable for protected cultivation. $J$. Appl. Polym. Sci. 2002, 86, 622-632, doi:10.1002/app.10912.

19. López-De-Dicastillo, C.; Jordá, M.; Catalá, R.; Gavara, R.; HernándezMuñoz, P. Development of active polyvinyl alcohol/ $\beta$-cyclodextrin composites to scavenge undesirable food components. J. Agric. Food Chem. 2011, 59, 11026-11033, doi:10.1021/jf200749f.

20. DeMerlis, C. C.; Schoneker, D. R. Review of the oral toxicity of polyvinyl alcohol (PVA). Food and chemical Toxicology, 2003, 41, 3, 319-326.

21. Goodship, V., \& Jacobs, D.K. Polyvinyl alcohol: materials, processing and applications; Smithers Rapra Technology, 2009;

22. Léonard, L.; Gharsallaoui, A.; Ouaali, F.; Degraeve, P.; Waché, Y.; Saurel, R.; Oulahal, N. Preferential localization of Lactococcus lactis cells entrapped in a caseinate/alginate phase separated system. Colloids Surfaces B Biointerfaces 2013, 109, 266-272, doi:10.1016/j.colsurfb.2013.03.005.

23. Odila Pereira, J.; Soares, J.; Sousa, S.; Madureira, A.R.; Gomes, A.; Pintado, M. Edible films as carrier for lactic acid bacteria. LWT - Food Sci. Technol. 2016, 73, 543-550, doi:10.1016/j.Iwt.2016.06.060.

24. Piermaria, J.; Diosma, G.; Aquino, C.; Garrote, G.; Abraham, A. Edible kefiran films as vehicle for probiotic microorganisms. Innov. Food Sci. Emerg. Technol. 2015, 32, 193-199, doi:10.1016/j.ifset.2015.09.009.

25. Léonard, L.; Degraeve, P.; Gharsallaoui, A.; Saurel, R.; Oulahal, N. 
Design of biopolymeric matrices entrapping bioprotective lactic acid bacteria to control Listeria monocytogenes growth: Comparison of alginate and alginate-caseinate matrices entrapping Lactococcus lactis subsp. lactis cells. Food Control 2014, 37, 200-209, doi:10.1016/j.foodcont.2013.09.041.

26. Farinha, L.R.L.; Sabo, S.S.; Porto, M.C.; Souza, E.C.; Oliveira, M.N.; Oliveira, R.P.S. Influence of Prebiotic Ingredients on the Growth Kinetics and Bacteriocin Production of Lactococcus lactis. Chem. Eng. Trans. 2015, 43, 313-318, doi:10.3303/CET1543053. 

Artículo 2

\section{PVOH/protein blend films embedded with lactic acid bacteria and their antilisterial activity in pasteurized milk}

Laura Settier-Ramírez; Gracia López-Carballo; Rafael Gavara; Pilar Hernández-Muñoz

International journal of food microbiology, 2020, vol. 322, p. 108545.

Packaging Lab, Instituto de Agroquímica y Tecnología de Alimentos, IATA-CSIC, Av. Agustín Escardino 7, 46980 Paterna, Spain. 



\section{ABSTRACT}

PVOH-based polymer matrices in the form of films were evaluated as carriers of living Lactococcus lactis subsp. lactis. These lactic acid bacteria are capable of producing nisin, which is an effective antilisterial peptide. A low percentage $(1: 0.125 \mathrm{w} / \mathrm{w})$ of yeast extract, gelatin, sodium caseinate, gelatin, or casein hydrolysates was incorporated in PVOH matrices with the aim of increasing the viability of bacteria in the film. The films were obtained by casting after incorporating $L$. lactis. Then they were evaluated for antilisterial activity in liquid medium at $37{ }^{\circ} \mathrm{C}$ for $24 \mathrm{~h}$, and also at $4{ }^{\circ} \mathrm{C}$ for 21 days in order to simulate the storage of liquid foods in refrigeration conditions. The survival of the lactic acid bacteria was also evaluated at both temperatures during the experiment. L. lactis remained viable in all the films tested at 37 and $4{ }^{\circ} \mathrm{C}$. The antimicrobial activity of the films was greater at $4{ }^{\circ} \mathrm{C}$ than at $37^{\circ} \mathrm{C}$. With regard to the effect of the film composition, the activity of the films was higher when protein hydrolysates and sodium caseinate were incorporated in the formulation. Films supplemented with protein hydrolysates or sodium caseinate inhibited growth of the pathogen during the 21 days of storage at $4{ }^{\circ} \mathrm{C}$. At $37^{\circ} \mathrm{C}$, after $24 \mathrm{~h}$ the films had slowed the growth of the inoculated pathogen by between 2 and $4 \log C F U / m L$.

Finally, as the films developed are intended to be used in the design of active packaging of foods, they were tested in pasteurized milk inoculated with $4 \mathrm{log} \mathrm{CFU} / \mathrm{mL}$ of Listeria monocytogenes and stored at $4{ }^{\circ} \mathrm{C}$ for 21 days. The pathogen began to grow after the second day of storage with or without film, but when the films were added to the medium the growth of the pathogen was slowed down, without reaching more than 6 log CFU, whereas the control reached a maximum growth of $8.5 \mathrm{log}$ CFU. The $\mathrm{pH}$ of the milk was monitored throughout the experiment, and it decreased with time. This was due to the generation of organic acids by the lactic bacteria. Buffering the food stabilized the $\mathrm{pH}$ without modifying the activity of the films. Thus, the current study shows that PVOH films supplemented with 
nutrients can act as carriers of L. lactis, and they can help to increase the safety of refrigerated dairy beverages and sauces.

Keywords: Lactococcus lactis, PVOH films, protein, protein hydrolysates, Listeria monocytogenes, pasteurized milk. 


\section{Introduction}

Since ancient times, refrigeration has been a conservation method for perishable food that we continue to use daily in our home. Unfortunately, sometimes this method is not enough to ensure the safety of fresh foods. Various pathogenic bacteria can be sources of food toxin infections.

Among them, Listeria monocytogenes continues to be a major concern for food safety [1]. This Gram-positive foodborne pathogenic bacterium is responsible for listeriosis. The manifestations of this disease produce septicemia, meningitis or meningoencephalitis, and encephalitis, usually producing symptoms similar to flu [2]. Listeriosis is a rare but severe disease, especially for pregnant women, newborns, children, the elderly, and immunosuppressed people. The morbidity of listeriosis is relatively low, although the rate of mortality from systemic disease can be very high $[2,3]$. Food products can be contaminated with $L$. monocytogenes by cross contamination in the various steps of the production chain, such as cutting, peeling, or even packaging. Furthermore, L. monocytogenes is able to form biofilm and survive by adhering to the surfaces of processing equipment, becoming a potential route of contamination [4].This pathogen has the capacity to grow at refrigeration temperatures, and even at temperatures below $0.5^{\circ} \mathrm{C}[5]$, and to survive at low $\mathrm{pH}$ values that are normally inhibitory for other food pathogens [6]. Furthermore, studies have shown that Listeria monocytogenes could survive pasteurization [7]. For these reasons, L. monocytogenes is a bacterium that is difficult to control, especially in foods that do not require previous heating, such as ready-to-eat and dairy products $[8,9]$.

Pasteurized milk is frequently used in the industry as the basis of many other products, such as yogurts, fermented beverages, juices, or sauces. The characteristics of milk, with a $\mathrm{pH}$ close to neutral and a large presence of nutrients, could enhance the viability of $L$. monocytogenes [10], so refrigeration is sometimes not enough to prevent its growth in food products. It has recently been reported that L. monocytogenes frequently occurs in packaged raw milk and is able to grow at refrigeration temperatures [11]. 
Chemical antimicrobials have been widely employed for years to prevent spoilage of foods by $L$. monocytogenes. Consumers now demand products made with natural ingredients, so the use of synthetic preservatives is losing support. Similarly, there is an increasing tendency toward less processed food, ensuring sensory and nutritional properties, and therefore replacement of classical heat treatment by non-thermal preservation technologies in combination with other barriers, such as the use of natural antimicrobials [12,13].

Bacteriocins are antimicrobial peptides, mostly produced by lactic acid bacteria (LAB). These bacteria are present in many fermented foods and have a long history of safe use $[14,15]$. Bacteriocins do not raise health risk concerns because they are degraded by proteolytic enzymes in the mammalian gastrointestinal tract, and they are an alternative to the use of chemical preservatives [16].

The use of bacteriocin-producing $L A B$ for food preservation instead of bacteriocins has several advantages, including legal aspects and costs. In fact, the use of bacteriocins is restricted and currently only nisin and pediocin are commercially available; they also have a high isolation and purification cost, which limits their use as preservatives in several countries. In addition to in situ production of bacteriocins in a food product, LAB generate metabolites with antimicrobial activity, including various organic acids and hydrogen peroxide; during storage they outcompete other bacteria for nutrients and oxygen, and they dominate the microflora of many foods $[17,18]$.

Among LAB, Lactococcus lactis subsp. lactis is particularly used for food preservation because of its ability to produce nisin, the bestcharacterized bacteriocin, classified as GRAS (Generally Recognized as Safe) by the FDA (Food and Drug Administration). Nisin is applied worldwide in dairy products [18]. However, the possible interactions between food components and $L A B$ reduce their effectiveness. The immobilization of $L A B$ in edible films provides a protective environment for them, and therefore appears to be a suitable approach to increase their survival and make them more effective than when they are added directly to the product. Some studies have been done using edible films based on proteins and polysaccharides embedded with various $L A B$ and applied in several fresh food products such as fish, fruit, and meat $[19,20]$. 
The use of PVOH films as carriers of LAB has not yet been explored. In comparison with proteins and polysaccharides, synthetic polymers have better processing performance and properties when applied in a food package. Polyvinyl alcohol (PVOH) is a synthetic polymer that is completely biodegradable and biocompatible, with excellent film-forming properties [21,22]. Moreover, PVOH is approved by the FDA for use in food contact and as a food additive with INS No. 1203 (Codex Alimentarius) (FAO/WHO (Food and Agriculture Organization/World Health Organization), 2004). In the EU it is approved by EFSA (European Food Safety Authority) as a food additive in food supplements in accordance with Annex II to Regulation (EC) No. $1333 / 2008$.

In a recent article it was demonstrated that $\mathrm{PVOH}$ films are excellent matrices for immobilizing Lactococcus lactis [24]. Furthermore, blending this polymer with a small amount of proteins increases the viability of the bacteria in the film. These findings make $\mathrm{PVOH}$-based films attractive carriers of LAB intended for antimicrobial food packaging applications, and therefore they are worthy of further exploration.

The aim of the current work was to study the antilisterial properties of $\mathrm{PVOH}$-based films incorporating Lactococcus lactis blended with a small amount $(<15 \%)$ of gelatin, sodium caseinate, gelatin or casein hydrolysates, or yeast extract. The antimicrobial activity of the films against Listeria monocytogenes and the survival of $\angle A B$ after the films were placed in contact with the pathogen in liquid medium was evaluated at $37^{\circ} \mathrm{C}$ for $24 \mathrm{~h}$, and at $4{ }^{\circ} \mathrm{C}$ for three weeks, in the latter case simulating the storage conditions of a fresh product. Films with the formulation that presented the best antilisterial performance in the in vitro studies were then tested in pasteurized milk inoculated with Listeria monocytogenes. In addition, changes in the $\mathrm{pH}$ of the milk due to fermentation of $L A B$ were monitored throughout the period of time studied.

\section{Materials and methods}

\subsection{Bacterial strains}

Bacterial strains were supplied by the Spanish Type Culture Collection CECT). Lactococcus lactis strain (CECT 539, ATCC 11454) was 
stored at $-80{ }^{\circ} \mathrm{C}$ in De Man, Rogosa, and Sharpe (MRS) broth supplemented with $20 \%$ glycerol. The microbial culture was regenerated and maintained by regular subculture at $4{ }^{\circ} \mathrm{C}$ on MRS broth. Before use, an aliquot from the culture was subcultured by overnight incubation in $10 \mathrm{~mL}$ of MRS.

The Listeria monocytogenes strain (CECT 934, ATCC 19114) was kept frozen in Tryptone Soy Broth (TSB) supplemented with $20 \%$ glycerol. The stock culture was maintained by regular subculture at 4 ${ }^{\circ} \mathrm{C}$ on Tryptone Soy Agar (TSA) and transferred monthly. Prior to the start of the experiments, a loopful of the strain was transferred to 10 $\mathrm{mL}$ of TSB and incubated overnight at $37^{\circ} \mathrm{C}$.

All microbiological products were provided by Scharlau, Barcelona, Spain.

\subsection{Molecular weight of protein hydrolysates}

Gelatin, sodium caseinate, and their hydrolysates were analyzed by Trycine-SDS-PAGE according to the Laemmli system (1970), using a $4 \%$ stacking gel and a $10 \%$ or $15 \%$ resolving gel. The dry hydrolysates were dissolved $(10 \mathrm{mg} / \mathrm{mL})$ in the loading buffer $(0.5$ $\mathrm{M}$ Tris- $\mathrm{HCl} \mathrm{pH} 6.8,10 \%$ SDS, 25\% glycerol, 5\% mercaptoethanol, and $0.5 \%$ bromophenol blue), heat-denatured at $95{ }^{\circ} \mathrm{C}$ for $5 \mathrm{~min}$, centrifuged at $4000 \mathrm{~g}$ for $4 \mathrm{~min}$, and run in a Mini Protean Tetra cell (Bio-Rad Laboratories, Hercules, CA, USA) at $160 \mathrm{~V}$. The loading volume was $20 \mu \mathrm{l}$ in all lines. Protein bands were stained with Coomassie Brilliant Blue R250. The protein standard consisted of a low and high molecular weight SDS marker kit (Amersham Pharmacia Biotech, Uppsala, Sweden).

\subsection{Film formation}

Polyvinyl alcohol (PVOH, Gohsenol AH17, Nippon Synthetic Chemical Company, Osaka, Japan) was used as the base matrix for the development of the films. It was dissolved at $2 \%$ in distilled water, and five different film-forming solutions (FFD) were prepared by adding gelatin (Gelatin from porcine skin, type A, Sigma-Aldrich USA) (Gel), sodium caseinate (Casein sodium salt from bovine milk, Sigma-Aldrich, 
New Zealand) (Cas), casein and gelatin hydrolysates (Peptone from casein and gelatin, enzymatic digest, Sigma-Aldrich, France) (Hcas and Hgel), and yeast extract (Yeast autolysate, Sigma-Aldrich, France) (YE). All proteins were chosen as nutritional supplements for Lactococcus lactis and were added to the PVOH solution in a 1:0.125 mass ratio. $\mathrm{PVOH}$ films without nutritional supplement were used as control films. L. lactis cells were collected by centrifugation ( $2500 \mathrm{RCF}$ for $15 \mathrm{~min}$ ) at $4{ }^{\circ} \mathrm{C}$. The supernatant was removed and washed twice with peptone water; then the cells were incorporated into the film-forming solution in order to obtain $8 \log \mathrm{CFU} / \mathrm{mL}$, and $15 \mathrm{~g}$ of the resulting mixture was cast in Petri dishes and dried at room temperature for $24 \mathrm{~h}$. Plain $\mathrm{PVOH}$ films were used as a control.

\subsection{Film thickness}

The thickness of the films was measured with a digital micrometer (Mitutoyo Manufacturing Co., Ltd., Tokyo, Japan) with a sensitivity of $1 \mu \mathrm{m}$. Five readings were taken randomly for each film sample.

2.5. In vitro activity of the films against $L$. monocytogenes, and survival of $L$. lactis in liquid medium

2.5.1. Survival of L. lactis and antilisterial activity of the films in liquid medium at $37^{\circ} \mathrm{C}$

The antimicrobial activity of films incorporating L. lactis was evaluated against $L$. monocytogenes in liquid medium for $24 \mathrm{~h}$ at $37^{\circ} \mathrm{C}$, the optimal growth temperature of the pathogen. For this purpose, films were removed from Petri dishes and each one was immersed in $10 \mathrm{~mL}$ of Tryptone Soy Broth supplemented with $0.6 \%$ of yeast extract (TSB+YE). The tubes were previously inoculated with $4 \log \mathrm{CFU} / \mathrm{mL}$ of L. monocytogenes. Then the tubes were stored at $37{ }^{\circ} \mathrm{C}$ for $24 \mathrm{~h}$. Samples were taken immediately after film dissolution (time zero), and at $1,3,6$, and $24 \mathrm{~h}$. Serial dilutions with peptone water were made and plated in Petri dishes with $15 \mathrm{~mL}$ of Polymyxin Acriflavine Lithium Chloride Ceftazidime Aesculin Mannitol (PALCAM) agar and in MRS 
agar. Plates with PALCAM agar were incubated at $37^{\circ} \mathrm{C}$ for $24 \mathrm{~h}$, and then $L$. monocytogenes colonies were counted. In order to evaluate the survival of $L$. lactis, periodical samples were also diluted with peptone water and plated in MRS agar, incubated at $30{ }^{\circ} \mathrm{C}$ for 4 days, and then colonies were counted. The tests were done in triplicate.

2.5.2. Survival of $L$. lactis and antilisterial activity of the films in liquid medium at $4{ }^{\circ} \mathrm{C}$

The antimicrobial activity of the films was evaluated in liquid medium at $4{ }^{\circ} \mathrm{C}$ for 21 days. For this purpose, $50 \mathrm{~mL}$ glass tubes with $10 \mathrm{~mL}$ of $\mathrm{TSB}+\mathrm{YE}$ were inoculated with $4 \mathrm{log} \mathrm{CFU} / \mathrm{mL}$ of $L$. monocytogenes and the films were immersed following the previously described methodology. Aliquots were taken immediately after film dissolution, and after 1, 2, 6, 9, 12, and 21 days. Serial dilutions with peptone water were made and plated in Petri dishes previously filled with $15 \mathrm{~mL}$ of MRS agar, and they were incubated at $30{ }^{\circ} \mathrm{C}$ for 4 days to evaluate survival of L. lactis. L. monocytogenes colonies were counted after incubation of PALCAM plates at $37^{\circ} \mathrm{C}$ for $48 \mathrm{~h}$. The tests were done in triplicate.

2.6. Antilisterial activity of the films in pasteurized milk inoculated with L. monocytogenes.

Pasteurized milk was chosen as a food matrix to test the activity of the films in liquid food because it is a natural reservoir for Listeria monocytogenes. Pasteurized whole milk was purchased from a local supermarket. The film that exhibited the greatest antilisterial activity was selected for this experiment. PVOH films incorporating gelatin hydrolysates were removed from Petri dishes and added to tubes with pasteurized milk previously inoculated with $4 \log \mathrm{CFU} / \mathrm{mL}$ of Listeria monocytogenes; the tubes were stored at $4{ }^{\circ} \mathrm{C}$ to simulate refrigeration conditions. Films without $L$. lactis were used as a control. The microbial counts on the samples were obtained immediately after inoculation, and after 2, 4, 6, 8, 12, and 21 days of storage. Serial dilutions with peptone water were made and plated in Petri dishes with $15 \mathrm{~mL}$ of MRS agar and PALCAM agar. L. lactis and $L$. 
monocytogenes colonies were counted after incubation. The tests were done in triplicate.

\subsection{Evolution of $\mathrm{pH}$ of fresh milk during storage time}

LAB generally produce organic compounds as a product of their metabolism. An increase in the acidity of a food product can produce rejection by consumers. The generation of organic acid compounds by Lactococcus lactis in the culture medium and in pasteurized milk was measured by monitoring the $\mathrm{pH}$ during the storage time. For this purpose, a Consort $\mathrm{C} 830 \mathrm{pH}$ meter combined with a Consort SP10T pH electrode (Cleaver Scientific Ltd, United Kingdom) was used. PVOH with gelatin hydrolysates with or without $\mathrm{LAB}$ was immersed in TSB+YE, and in fresh milk, both media previously inoculated with Listeria monocytogenes. In addition, the $\mathrm{pH}$ of fresh milk without the film and the pathogen was also monitored.

Finally, prior to inoculation with $L$. monocytogenes and immersion of $\mathrm{PVOH}$ films incorporating $\mathrm{LAB}$, fresh milk was buffered with sodium hydrogen phosphate and potassium dihydrogen phosphate (Sigma, Spain), with the aim of controlling the $\mathrm{pH}$ during the storage time.

Samples were stored at $4{ }^{\circ} \mathrm{C}$ and the $\mathrm{pH}$ was measured after $2,4,6,8$, 12 , and 21 days of storage. The experiments were performed at least in triplicate.

\section{Results and discussion}

Incorporation of $L$. lactis did not modify the thickness of the $\mathrm{PVOH}$ films, which was $0.040 \pm 0.05 \mathrm{~mm}$. The incorporation of proteins, protein hydrolysates, or yeast extract at the studied ratio also did not change the thickness. The films were homogeneous and transparent to the naked eye, and they dissolved rapidly when they were immersed in water or milk. The antilisterial properties of $\mathrm{PVOH}$ based films carrying $L A B$ and their survival were studied in TSB+YE culture medium and in pasteurized milk, both of which were inoculated with L. monocytogenes. 


\subsection{Molecular weight of protein hydrolysates}

The hydrolysates employed were commercial compounds without information about molecular weight; moreover, there was no information about the hydrolysis process (time, enzymes, etc.). Consequently, the molecular weights of the gelatin and casein hydrolysates employed as nutrients in the formulations of the PVOHbased films were analyzed by SDS-PAGE. The electrophoretic profile of sodium caseinate and gelatin used in the present study is shown in figure 1a, and that for casein hydrolysates and gelatin hydrolysates is shown in figure $1 \mathrm{~b}$. Lanes 1 and 2 of the gel in figure $1 \mathrm{a}$ show electrophoretic bands around $25 \mathrm{kDa}$ corresponding to sodium caseinate; the gelatin used in this work has a very high molecular weight, as shown by lanes 3 and 4 of the gel. No peptide bands were observed for the casein hydrolysates (lanes 1 and 2) of the gel in figure $1 \mathrm{~b}$. This could be because this hydrolysate consists of peptides of very low molecular weight that could have passed through the electrophoretic gel. The electrophoretic profile of the gelatin hydrolysates was dominated by peptides of around $17 \mathrm{kDa}$. As in the case of the casein hydrolysates, no information was provided by the supplier about the gelatin used to make the hydrolysates, or about the method employed.

3.2. Survival of L. lactis and antilisterial activity of the films in liquid medium at $37^{\circ} \mathrm{C}$

The survival of $L$. lactis in liquid medium after film dissolution and the antimicrobial effectiveness of the films developed against $L$. monocytogenes was evaluated at $37{ }^{\circ} \mathrm{C}$, the optimal growth temperature of the pathogen. The cell growth of $L$. lactis and $L$. monocytogenes was monitored for $24 \mathrm{~h}$ and is represented in figure 2 .

It can be observed in figure $2 \mathrm{a}$ that at time 0 L. lactis was viable in all the films developed, but several differences among the films were found; the PVOH control films and those incorporating gelatin presented lower cell viability, while those incorporating protein hydrolysates and sodium caseinate showed greater cell viability. 


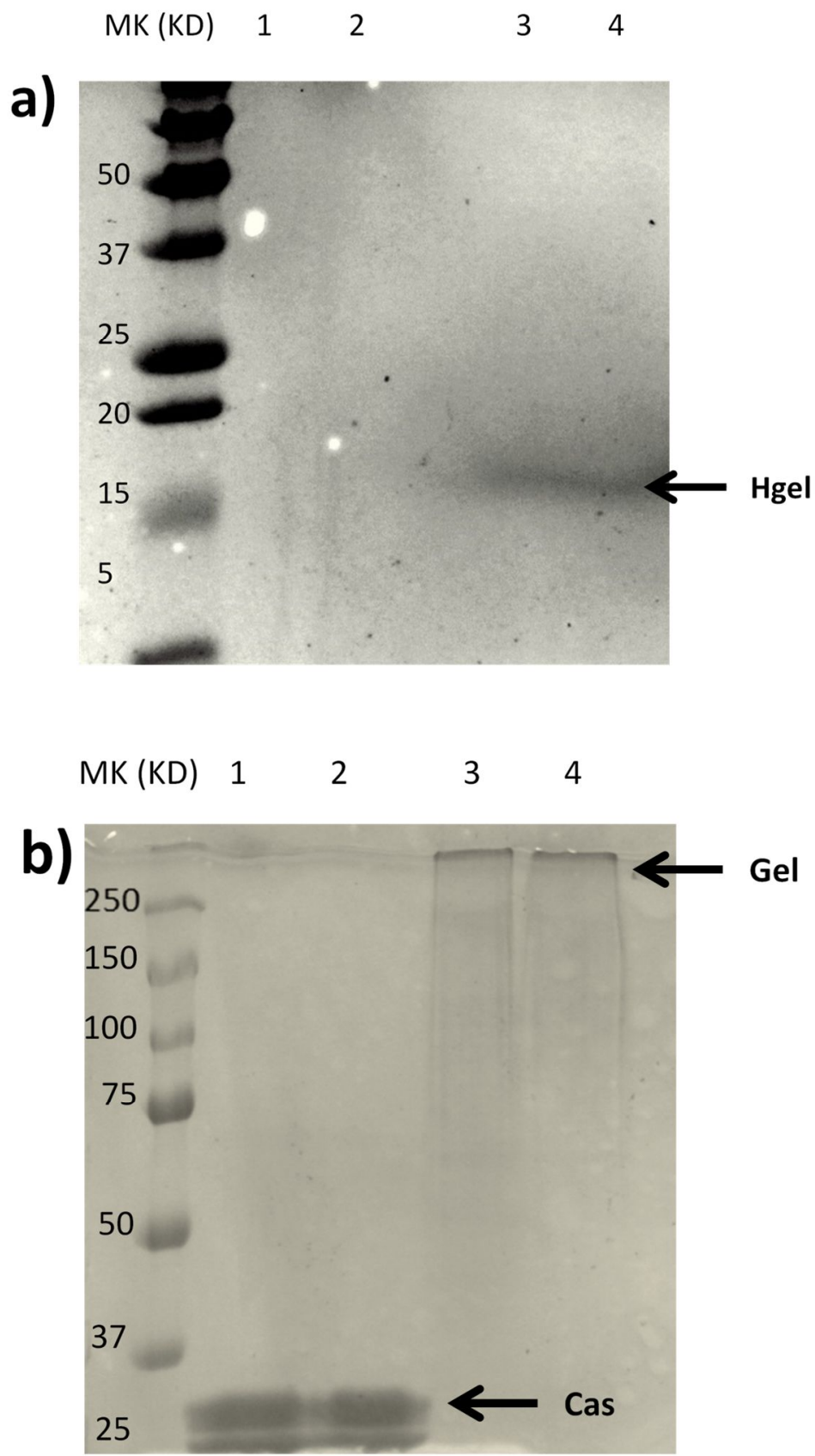

Figure 1. a) Electrophoretic profile of sodium caseinate (lines 1-2) and gelatin (lines 3-4). b) Electrophoretic profile of casein hydrolysates (lines 1-2) and gelatin hydrolysates (lines 3-4). MK: molecular weight marker 
The explanation for these differences could be that the bacteria were able to maintain the original population in the filmforming solution after film drying thanks to the presence of low molecular weight proteins available as nutrients during the drying of the films.

L. lactis is used in starter cultures to make fermented dairy products, and therefore it is well adapted to milk as a source of nutrients for cell growth. This bacterium has a complex proteolytic system adapted to the consumption of caseins which has been intensely studied. The proteinase system is involved in the first step of casein degradation into peptides. Subsequently, the oligopeptides are taken up by the oligopeptide transport system of each strain, having substrate specificity; hydrophobic basic peptides of low molecular mass are preferentially taken up [26]. In the present study, the survival of $L$. lactis was similar when sodium caseinate or casein hydrolysates were employed, indicating that, besides hydrolysates, L. lactis also uses sodium caseinate proteins as a nutritional source.

\section{(a)}

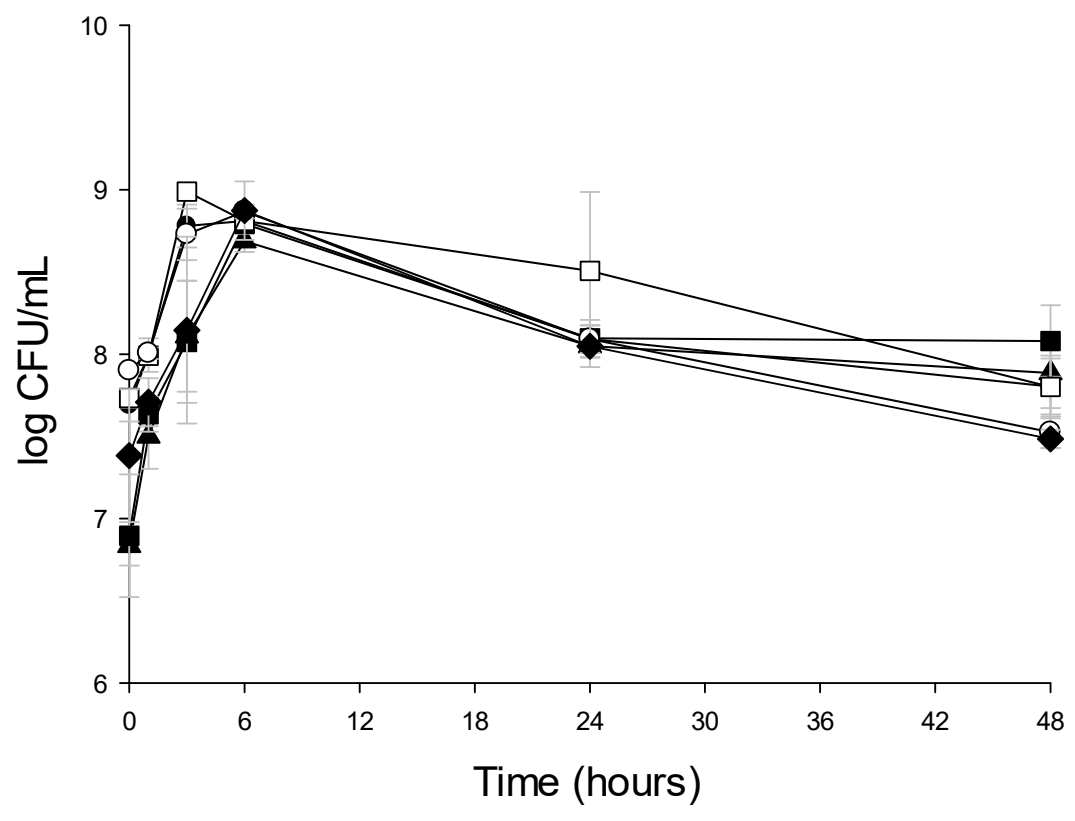




\section{(b)}

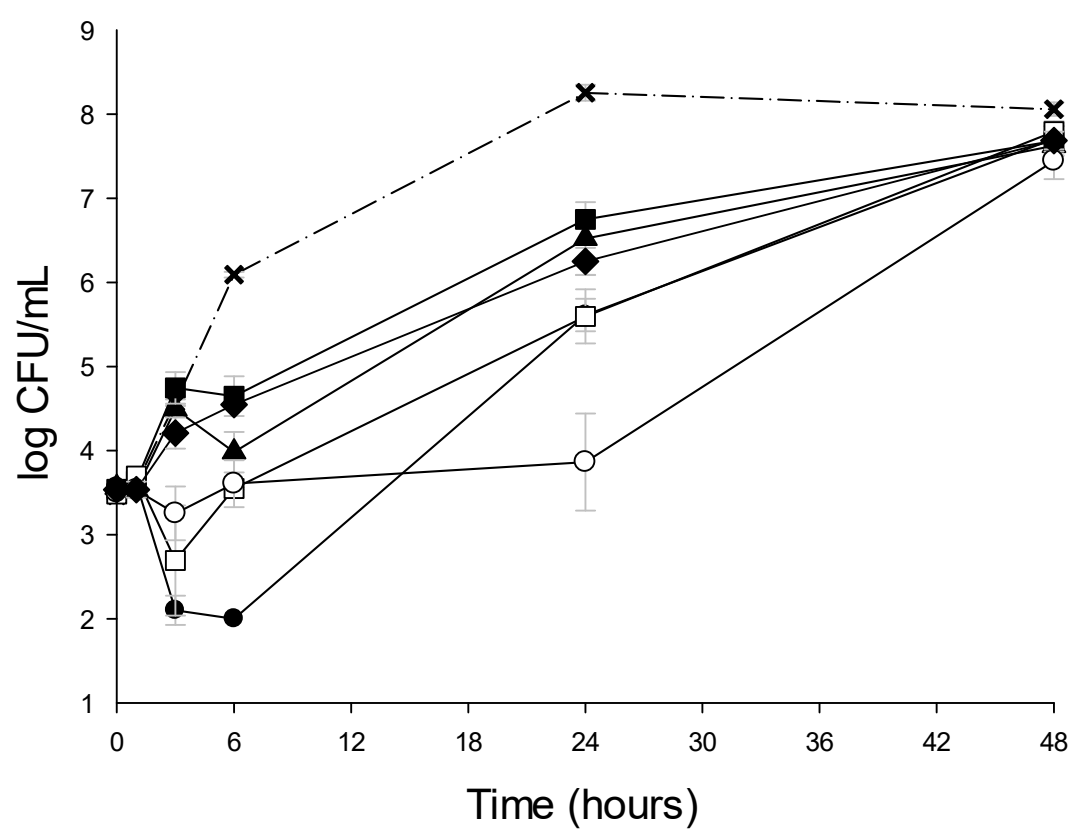

Figure 2. Survival of lactic acid bacteria (a) and antimicrobial activity (b) of films immersed in liquid medium (TSB + yeast) inoculated with $L$. monocytogenes and stored at $37{ }^{\circ} \mathrm{C}$ for $48 \mathrm{~h}$. Mean values and $95 \%$ LSD intervals. (ム PVOH, • PVOH Cas, $\square$ PVOH Gel, O PVOH HCas, $\square$ PVOH HGel, $\mathrm{PVOH}$ YE, $\times$ Control).

However, the viability of the bacteria in the films (figure $2 a$, at time zero) was different when gelatin was incorporated in the filmforming solution instead of sodium caseinate. L. lactis is auxotrophic for Glutamine, Methionine, Leucine, Isoleucine, Valine, Arginine, and Histidine. These amino acids are present in casein and gelatin, although Leucine and Ile to a lesser extend in gelatin. In addition, there are also amino acids that are non-essential but stimulate growth of bacteria, such as proline [27]. Moreover, the form in which amino acids are taken up by the cell (free or in the form of peptides) is also a growth-limiting factor for bacteria. The gelatin used in this study has a 
high molecular weight compared with caseins (19-25 kDa). It could be more than the amino acid composition, the molecular weight of the protein that gives rise to differences in cell viability. The availability of gelatin as a protein source for $L$. lactis could be limited owing to its high molecular weight. In this regard, [28] found much greater L. lactis protease activity in M17 medium supplemented with casein than in medium enriched with gelatin. The results obtained in the present study show that gelatin proteins in the form of hydrolysates are more available as nutrients for cell growth, and no differences were found in the survival of $L$. lactis carried in $\mathrm{PVOH}$ films enriched with casein and gelatin hydrolysates. Apart from the nutrient effect of supplementing the PVOH matrix with yeast extract, proteins, or their hydrolysates, these supplements could also act as protectants against cell dehydration stress during film drying. In this regard, it has been demonstrated that control of osmotic pressure variation during dehydration should preserve the membrane from damage and therefore enhance cell viability [29]. Moreover, the bacteria level interacts with the polymer matrix in which it is embedded, and the adhesion properties between the cell envelope and the surrounding polymer could be crucial in overcoming drying stress.

More research should be done in this regard as there is a lack of studies considering the way in which bacteria interact with polymer protectants that do not penetrate the cell wall during the drying step when various technologies that include a drying step are applied for cell preservation [30]. In the present study, sodium caseinate and casein hydrolysates could act as protectants during PVOH film drying. In addition, gelatin hydrolysates could be a better osmoprotectant during film drying than high molecular weight gelatin. Incorporation of polymer protectants such as glucose-oligosaccharides and polydextrose to encapsulate living bacteria in gelatin films increased the viability of Lactobacillus rhamnosus GG, but inulin or wheat dextrin did not have the same effect [31]; it has also been reported that fructo-oligosaccharides increase the viability of LAB in methylcellulose films [32]. 
It is noteworthy that L. lactis from the films with hydrolysates and sodium caseinate, which had a greater amount of viable cells, reached the stationary phase after three hours. The microorganisms from the other formulations reached the stationary phase after six hours. It was from that moment on and until the end of the experiment that the survival of L. lactis decreased slightly for all the films studied. This could be due to various factors, such as an incubation temperature that is not optimal for L. lactis, depletion of nutrients in the medium, especially the amino acids needed for the synthesis of antilisterial nisin [33], or microbial growth competing with L. monocytogenes. In fact, this pathogen reached the stationary phase after $24 \mathrm{~h}$.

Figure $2 \mathrm{~b}$ shows the evolution of the cell population of $L$. monocytogenes inoculated in TSB+YE without film or with films of various compositions. During the first hour, the population of $L$. monocytogenes remained at $4 \mathrm{log}$, being in the lag phase. After three hours, films with sodium caseinate reduced the pathogen population by $2 \log$ CFU, whereas films with protein hydrolysates inhibited growth of the inoculated $L$. monocytogenes. After six hours, the control $L$. monocytogenes reached $6 \log C F U$, and L. monocytogenes growth was inhibited in films incorporating $T S B+Y E$, their population being around 4 log or less, depending on the film composition. It is noteworthy that, as commented above, after three hours $L$. lactis reached the stationary phase for films with protein hydrolysates and sodium caseinate, whereas for PVOH films with gelatin and plain films it took three more hours. In this regard, the relationship between cell growth and bacteriocin production has been deeply studied. The maximum bacteriocin production occurs when the cell mass concentration is maximal, which happens at the stationary phase [34]. After $24 \mathrm{~h}$, the control L. monocytogenes reached the stationary phase, 8 log CFU. The L. monocytogenes population in the media in contact with films also grew, but in no case did it reach this value. In this regard, films with casein hydrolysates presented the highest activity, with 4 log reduction, followed by films incorporating gelatin hydrolysates and sodium caseinate, with a $2 \log$ reduction with respect to the $L$. 
monocytogenes control. The evolution of $L$. monocytogenes in contact with films supplemented with yeast extract was similar to when it was in contact with $\mathrm{PVOH}$ and gelatin-enriched PVOH films.

It is worth noting that, although the inoculum incorporated in the film solution of each film formulation had the same concentration of $L$. lactis, it decreased after the drying of the film, depending on the film composition (figure $2 \mathrm{a}$, time zero). After six hours at $37{ }^{\circ} \mathrm{C}$, the inoculum population of $L$. lactis was recovered for all the film formulations. However, differences in the antilisterial activity of the films were evident. Therefore, it is apparent that the amount of viable L. lactis in the film after drying affects its antilisterial activity during time [24].

3.3. Survival of L. lactis and antilisterial activity of the films in liquid medium at $4{ }^{\circ} \mathrm{C}$

The survival of $L$. lactis subsp. lactis and the antimicrobial effectiveness of the films developed against $L$. monocytogenes were also evaluated in TSB for three weeks at $4{ }^{\circ} \mathrm{C}$ to simulate the storage of a refrigerated liquid food. The results obtained are shown in figure 3.

In this case, unlike the previous experiment, the temperature was a limiting factor that affected the growth rate of both microorganisms studied, L. monocytogenes is psychrophilic, and therefore this bacterium is capable of growing in refrigerated foods, whereas $L$. lactis is a mesophilic bacterium with an optimum growth temperature of $30^{\circ} \mathrm{C}$ which also grows in refrigerated foods.

According to the results shown in figure $3 a, L$. lactis maintained its initial population for the various film formulations for three weeks at $4{ }^{\circ} \mathrm{C}$, although a slightly higher survival was observed in films with gelatin and casein hydrolysates and those with sodium caseinate. Therefore, even if this bacterium is not at its optimum growth temperature, it is able to survive and remain viable during refrigerated storage.

In this case, unlike the previous experiment, the temperature was a limiting factor that affected the growth rate of both 
microorganisms studied, L. monocytogenes is psychrophilic, and therefore this bacterium is capable of growing in refrigerated foods, whereas $L$. lactis is a mesophilic bacterium with an optimum growth temperature of $30^{\circ} \mathrm{C}$ which also grows in refrigerated foods.

According to the results shown in figure $3 \mathrm{a}, \mathrm{L}$. lactis maintained its initial population for the various film formulations for three weeks at $4{ }^{\circ} \mathrm{C}$, although a slightly higher survival was observed in films with gelatin and casein hydrolysates and those with sodium caseinate. Therefore, even if this bacterium is not at its optimum growth temperature, it is able to survive and remain viable during refrigerated storage.

The results of the $L$. monocytogenes count in TSB with or without the various film formulations are shown in figure $3 \mathrm{~b}$. The $L$. monocytogenes control reached the stationary phase after 9 days of cold storage, and the counts were maintained after the end of the experiment. Films supplemented with protein hydrolysates and sodium caseinate were capable of keeping the initial population of 4 log inoculated pathogenic bacteria, inhibiting their proliferation during cold storage, and then exerting a bacteriostatic effect. When compared with the L. monocytogenes control, these films achieved reductions ranging from $4 \log$ at the $6^{\text {th }}$ day to 6 logs after 9 and 12 days of storage at $4{ }^{\circ} \mathrm{C}$. Pathogen counts increased with the other films after the third day of cold storage, but, compared with the control, the reduction of $L$. monocytogenes by the films was $\geq 2 \log$ CFU. The results obtained showed that, in general, L. lactis has a greater antilisterial activity at refrigeration temperature than at $37^{\circ} \mathrm{C}$. In this regard, previous studies reported that the bacteriocinproducing lactic acid bacterium Carnobacterium piscicola LK5 suppressed growth of L. monocytogenes in milk stored at $5{ }^{\circ} \mathrm{C}$ but it was not active against the pathogen at $19{ }^{\circ} \mathrm{C}$ [35]. L. monocytogenes was inhibited in beef meat by bacteriocin-producer Lactobacillus bavaricus MN. The antilisterial activity was reported to be due to bacteriocin production, which was enhanced when the refrigeration temperature decreased from 10 to $7{ }^{\circ} \mathrm{C}$ [36]. It has been reported that the application of bacteriocins as preservatives in refrigerated foods 
without combination with other antimicrobial hurdles does not work properly $[37,38]$.

The present study shows that applying bacteriocin-producing bacteria in a water-soluble polymer matrix could control growth of $L$. monocytogenes in refrigerated foods. The potential of using bacteriocin-producing bacteria embedded in a film to inhibit microbial growth in refrigerated foods has also been studied with other LAB strains. Carnobacterium maltaromaticum incorporated in alginate matrices inhibited growth of $L$. monocytogenes in smoked salmon stored at $4{ }^{\circ} \mathrm{C}$ for 28 days (Concha-Meyer, Schöbitz, Brito, \& Fuentes, 2011); whereas Lactobacillus sakei that was incorporated in sodium caseinate films showed antilisterial activity when the film was in contact with fresh beef stored at $4{ }^{\circ} \mathrm{C}$ for 30 days [39].

\section{(a)}

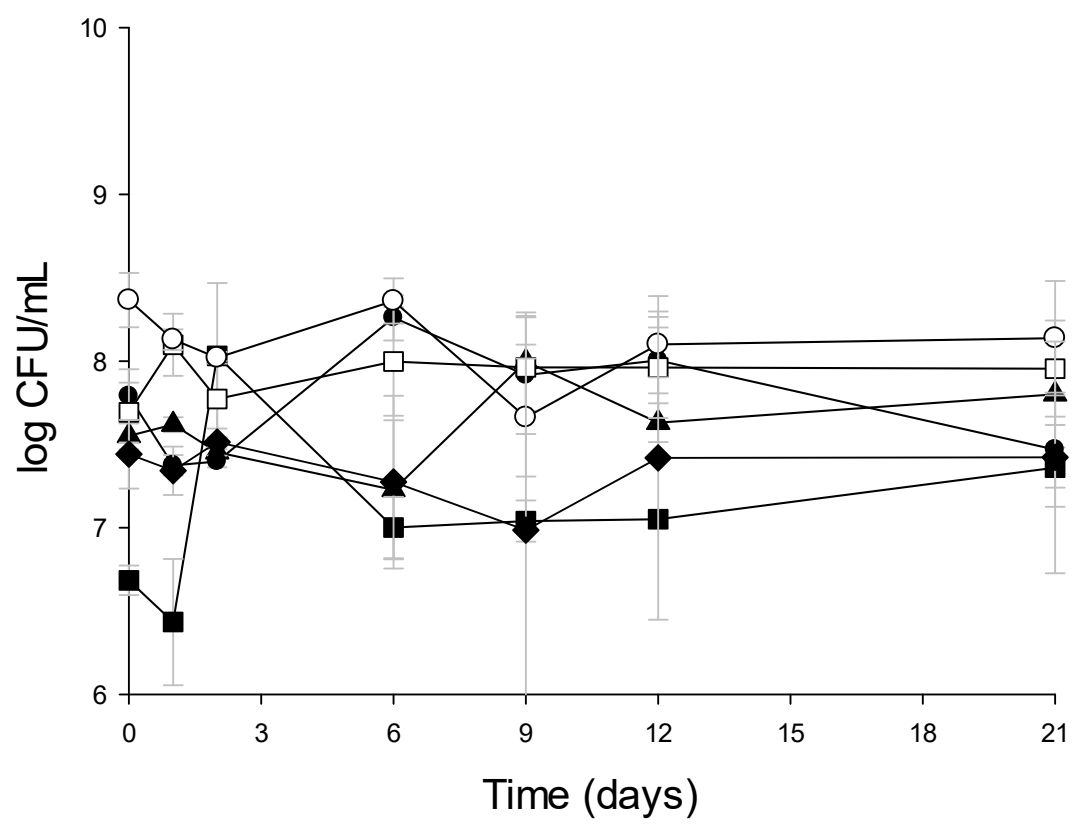




\section{(b)}

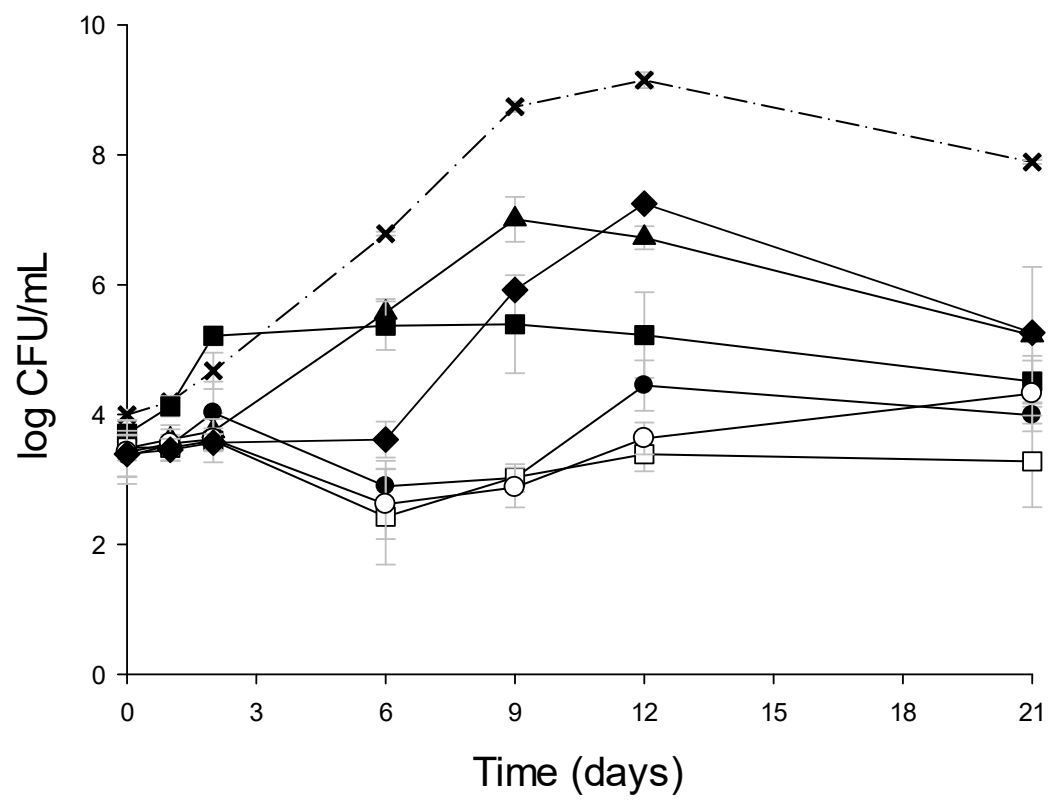

Figure. 3. Survival of lactic acid bacteria (a) and antimicrobial activity (b) of films immersed in liquid medium (TSB + yeast) inoculated with $L$. monocytogenes and stored at $4{ }^{\circ} \mathrm{C}$ for 21 days. Mean values and 95\% LSD intervals. ( $\triangle \mathrm{PVOH}, \bullet \mathrm{PVOH}$ Cas, $\square$ PVOH Gel, O PVOH HCas, $\square$ PVOH HGel, PVOH YE, $\times$ Control).

3.4. Survival of $L$. lactis and antilisterial activity against $L$. monocytogenes in pasteurized milk

The films developed could be applied in a food product with the purpose of inhibiting growth of psychrophilic pathogenic Grampositive microorganisms such as L. monocytogenes. Therefore, once the effectiveness of the films had been demonstrated in refrigerated liquid culture media, the next step was their application in a food product. The experiment was carried out using one of the film formulations with the highest antimicrobial activity, namely, the film enriched with gelatin hydrolysates, and it was applied in fresh milk 
previously inoculated with $L$. monocytogenes. Fresh milk was chosen because it is used as an ingredient for making many other food products susceptible to being contaminated with L. monocytogenes.

Figure 4 shows the survival of $L$. lactis, the antilisterial activity of the films, and the evolution of the L. monocytogenes population after being inoculated at 4 log in fresh milk without film.

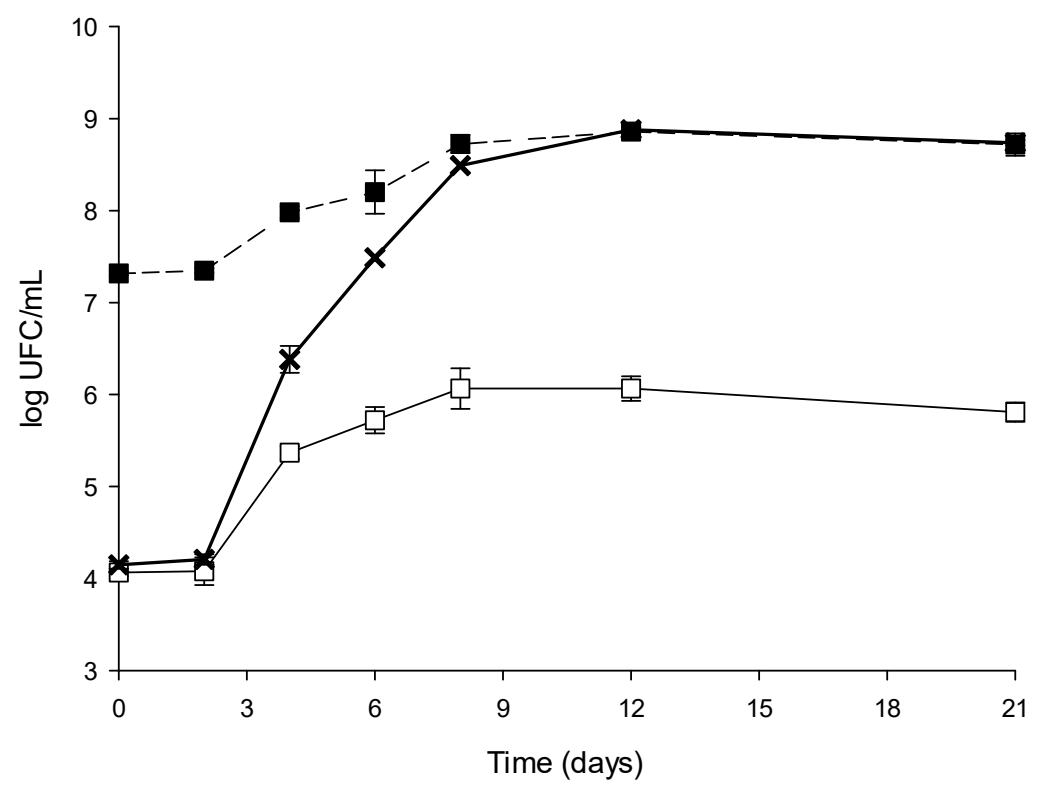

Figure 4. Survival of lactic acid bacteria and antimicrobial activity of $\mathrm{PVOH}$ films incorporating gelatin hydrolysates immersed in pasteurized milk previously inoculated with $L$. monocytogenes for 21 days at $4{ }^{\circ} \mathrm{C}$. Mean values and $95 \%$ LSD intervals. ( $\mathbf{L}$. lactis in milk in contact with active film. $\square L$. monocytogenes in milk in contact with active film. $\times$ Control L. monocytogenes without active film)

Survival of L. lactis in milk was similar to that in TSB+YE, and it was around 8 log CFU during the storage time. Other authors have also observed that this bacterium is capable of remaining viable for 30 days at refrigerated conditions in fermented milks [40]. With regard to the antilisterial activity of the film, during the first two days of storage it was observed that L. monocytogenes in milk with or without film did 
not show growth or death, remaining in latency. At the fourth day, differences between the L. monocytogenes control in milk with or without added film began to be observed. Growth of the pathogen in milk without film was similar to its growth in TSB+YE, reaching the stationary phase at the $9^{\text {th }}$ day.

L. monocytogenes counts were maintained at 5.5-6 log from the fourth day until the end of the study. Although the evolution of the populations of Lactococcus lactis and Listeria monocytogenes were similar in TSB+YE and milk, the antilisterial activity of LAB was lower in milk, which could be due to the influence of the food itself. It is well known that, in general, owing to the complexity of food matrices, the activity of antimicrobials is lower when tested in foods. In fact, the antilisterial activity of nisin has been found to be greater in culture medium than in soy milk [41] and cottage cheese [42].

\subsection{Evolution of $\mathrm{pH}$ of milk during storage time}

The application of lactic acid bacteria as an antimicrobial instead of using only the bacteriocin provides, in addition to in situ production of the bacteriocin, other compounds with antimicrobial activity such as organic acids, lactic acid being the one that is produced in the largest amounts. These acids are the main products of the fermentative metabolism of lactic acid bacteria and they can cause a decrease in the $\mathrm{pH}$ of food and, as a consequence, sensory rejection of the product by consumers. Therefore, the $\mathrm{pH}$ of milk was monitored during three weeks of storage at $4{ }^{\circ} \mathrm{C}$. Moreover, although the TSB+YE culture medium was buffered, measurements were also made in it to ensure that there were no changes in $\mathrm{pH}$. The results are shown in table 1.

L. lactis had no effect on the $\mathrm{pH}$ of the culture medium. With regard to the evolution of $\mathrm{pH}$ in the milk, it started with an optimum value within the range required at the quality level of a milk suitable for consumption, that is, between 6.6 and 6.8. PVOH did not affect the $\mathrm{pH}$ of milk previously inoculated with $L$. monocytogenes. However, when PVOH film carrying L. lactis was dissolved in milk, the $\mathrm{pH}$ started to decrease very slowly after the $4^{\text {th }}$ day. Between the $4^{\text {th }}$ and $6^{\text {th }}$ days it experienced a sharp decrease of one unit (from 6.5 to 5.5). Lactic 
acid bacteria ferment the lactose present in milk, producing lactic acid and other acids, causing this drop in $\mathrm{pH}[43,44]$. From day 12 , the $\mathrm{pH}$ was close to 4.6, and milk syneresis occurred. This phenomenon consists in the separation of the aqueous phase from the continuous phase $[45,46]$. Buffering of milk maintained the $\mathrm{pH}$ around 7.5 during 21 days of storage, and the buffer had no effect on the antilisterial activity of the films (results not shown). In a previous study, [47] reported that incorporating potassium dihydrogen phosphate in a liquid and gelled medium has no effect on growth of Listeria innocua in co-culture with L. lactis.

Therefore, buffering of milk should be considered when using $\mathrm{PVOH}$ films incorporating $L$. lactis for packaging products containing milk as an ingredient to avoid acidification of the medium, or syneresis. Phosphates are one of the most widely used functional food ingredients. Applications of the various salt forms of phosphates include uses such as leavening agents in baked goods, moisture loss inhibitors in frozen and processed meats, emulsifiers in dairy products, and buffering agents for many different food formulations [48]. Indeed, it is usual to employ acidity regulators or $\mathrm{pH}$ control agents to maintain $\mathrm{pH}$ (acidity or basicity) and avoid to modify the sensorial properties of the food. It is worthy to point out that acidity regulators differ from acidulants, which are often acidic but are added to confer sour flavors. They are not intended to stabilize the food [49]. 
Table 1. $\mathrm{pH}$ of different liquid mediums inoculated with L. monocytogenes containing films with and without Lactococcus lactis stored for $2,4,6,8,12$ and 21 days at $4^{\circ} \mathrm{C}$.

\begin{tabular}{|c|c|c|c|c|c|c|c|c|}
\hline \multirow{2}{*}{$\begin{array}{l}\text { Liquid medium } \\
\text { inoculated with } \\
\text { L. monocytogenes }\end{array}$} & \multirow{2}{*}{ Film } & \multicolumn{7}{|c|}{ pH } \\
\hline & & $t_{0}$ & $t_{2}$ & $t_{4}$ & $t_{6}$ & $t_{8}$ & $t_{12}$ & $t_{21}$ \\
\hline $\begin{array}{c}\text { Milk } \\
\text { (without } \\
\text { L. monocytogenes) }\end{array}$ & - & $6.68 \pm 0.07^{b c A}$ & $6.65 \pm 0.04^{\mathrm{bc} A B}$ & $6.74 \pm 0.05^{\mathrm{bcB}}$ & $6.77 \pm 0.01^{\mathrm{cBC}}$ & $6.73 \pm 0.03^{\mathrm{bcBC}}$ & $6.59 \pm 0.03^{b B}$ & $6.02 \pm 0.13^{a B}$ \\
\hline Milk & $\begin{array}{l}\text { PVOH Hgel } \\
+ \text { L. lactis }\end{array}$ & $6.74 \pm 0.01^{d A B}$ & $6.46 \pm 0.05^{\mathrm{dA}}$ & $6.47 \pm 0.15^{\mathrm{dA}}$ & $5.55 \pm 0.34^{\mathrm{cA}}$ & $5.19 \pm 0.09^{b A}$ & $4.68 \pm 0.04^{\mathrm{aA}}$ & $4.54 \pm 0.06^{\mathrm{aA}}$ \\
\hline Milk & PVOH Hgel & $6.81 \pm 0.02^{\mathrm{cdB}}$ & $6.71 \pm 0.02^{\mathrm{cB}}$ & $6.87 \pm 0.02^{\mathrm{dB}}$ & $6.71 \pm 0.02^{\mathrm{cBC}}$ & $6.72 \pm 0.03^{\mathrm{cBC}}$ & $6.43 \pm 0.07^{\mathrm{bB}}$ & $6.25 \pm 0.1^{\mathrm{aB}}$ \\
\hline Buffered milk & $\begin{array}{l}\text { PVOH Hgel } \\
+ \text { L. lactis }\end{array}$ & $7.68 \pm 0.13^{\mathrm{dD}}$ & $7.49 \pm 0.25^{\mathrm{cdc}}$ & $7.52 \pm 0.02^{\mathrm{cdDE}}$ & $7.45 \pm 0.03 c d D$ & $7.22 \pm 0.1^{b c D E}$ & $6.98 \pm 0.09^{b D}$ & $6.06 \pm 0.25^{a B}$ \\
\hline Buffered milk & PVOH Hgel & $7.71 \pm 0.01^{C D}$ & $7.76 \pm 0.06^{\mathrm{CD}}$ & $7.61 \pm 0.01^{\mathrm{bE}}$ & $7.6 \pm 0.01 b D$ & $7.55 \pm 0.01^{\mathrm{abE}}$ & $7.51 \pm 0.01^{\mathrm{aE}}$ & $7.55 \pm 0.05^{\mathrm{abD}}$ \\
\hline
\end{tabular}

$A, B, C, D, E$ : different letters in the same column indicate significant differences among formulation $(p<0.05)$.

$a, b, c$, d: different letters in the same file indicates significant differences among time for a same formulation $(p<0.05)$. 


\section{Conclusions}

In the present study, PVOH-based films supplemented with proteins, protein hydrolysates, or yeast extract and incorporating nisin-producing Lactococcus lactis subsp. lactis. were successfully developed. It was demonstrated that PVOH-based films can act as effective carriers of living bacterial cells with the aim of being used as a competitive culture against $L$. monocytogenes. L. lactis previously embedded in the films was able to grow until the stationary phase when the films were in contact with $L$. monocytogenes after incubation in liquid medium at $37{ }^{\circ} \mathrm{C}$ for $24 \mathrm{~h}$, and at 4 ${ }^{\circ} \mathrm{C}$ for 21 days. All the films presented antimicrobial activity, but the incorporation of proteins, protein hydrolysates, or yeast extract had a significant effect on their antimicrobial activity, obtaining the best results when hydrolysates were used. However, films applied at refrigeration conditions achieved a greater inhibition of the pathogen compared to the samples stored at $37{ }^{\circ} \mathrm{C}$. The use of $\mathrm{PVOH}$ films with gelatin hydrolysate against $L$. monocytogenes inoculated in refrigerated pasteurized milk resulted in a significant reduction of the pathogen compared to control milk inoculated with the pathogen. The drop in $\mathrm{pH}$ due to the organic acids generated during the fermentation by $L A B$ can be neutralized by buffering the food product without losing antilisterial activity. In conclusion, the results showed a considerable antimicrobial capacity of PVOH films supplemented with gelatin hydrolysates. The films developed could be applied in the design of packages for refrigerated food, with the purpose of inhibiting growth of psychrophilic pathogenic microorganisms such as bacteria of the genus Listeria.

\section{Acknowledgments}

The authors acknowledge the financial support of the Spanish Ministry of Economy and Competitiveness (AGL2015-64595-R).

\section{References}

1. Batz, M.B.; Hoffmann, S.; Morris, J.G. Ranking the Disease Burden of 
14 Pathogens in Food Sources in the United States Using Attribution Data from Outbreak Investigations and Expert Elicitation. J. Food Prot. 2012, 75, 1278-1291, doi:10.4315/0362-028X.JFP-11-418.

2. Muriel-Galet, V.; López-Carballo, G.; Gavara, R.; Hernández-Muñoz, P. Antimicrobial Effectiveness of Lauroyl Arginate Incorporated into Ethylene Vinyl Alcohol Copolymers to Extend the Shelf-Life of Chicken Stock and Surimi Sticks. Food Bioprocess Technol. 2015, 8, 208-217, doi:10.1007/s11947-014-1391-x.

3. Ramaswamy, V.; Cresence, V.M.; Rejitha, J.S.; Lekshmi, M.U.; Dharsana, K.S.; Prasad, S.P.; Vijila, H.M. Listeria-review of epidemiology and pathogenesis. J. Microbiol. Immunol. Infect. 2007, 40, 4-13.

4. Møretrø, T.; Langsrud, S. Listeria monocytogenes: biofilm formation and persistence in food-processing environments. Biofilms 2004, 1, 107-121, doi:10.1017/S1479050504001322.

5. Walker, S.J.; Archer, P.; Banks, J.G. Growth of Listeria monocytogenes at refrigeration temperatures. J. Appl. Bacteriol. 1990, 68, 157-162, doi:10.1111/j.1365-2672.1990.tb02561.x.

6. Cole, M.B.; Jones, M. V.; Holyoak, C. The effect of $\mathrm{pH}$, salt concentration and temperature on the survival and growth of Listeria monocytogenes. J. Appl. Bacteriol. 1990, 69, 63-72, doi:10.1111/j.13652672.1990.tb02912.x.

7. Doyle, M.P.; Glass, K.A.; Beery, J.T.; Garcia, G.A.; Pollard, D.J.; Schultz2, R.D. Survival of Listeria monocytogenes in Milk during HighTemperature, Short-Time Pasteurization. Appl. Environ. Microbiol. 1987, 53, 1433-1438.

8. Lianou, A.; Sofos, J.N. A Review of the Incidence and Transmission of Listeria monocytogenes in Ready-to-Eat Products in Retail and Food Service Environments. J. Food Prot. 2007, 70, 2172-2198, doi:10.4315/0362-028X-70.9.2172.

9. Dalzini, E.; Bernini, V.; Bertasi, B.; Daminelli, P.; Losio, M.N.; Varisco, G. Survey of prevalence and seasonal variability of Listeria monocytogenes in raw cow milk from Northern Italy. Food Control 2016, 60, 466-470, doi:10.1016/j.foodcont.2015.08.019. 
10. Muriel-Galet, V.; López-Carballo, G.; Gavara, R.; Hernández-Muñoz, P. Antimicrobial food packaging film based on the release of LAE from EVOH. Int. J. Food Microbiol. 2012, 157, 239-244, doi:10.1016/j.ijfoodmicro.2012.05.009.

11. Castro, H.; Ruusunen, M.; Lindström, M. Occurrence and growth of Listeria monocytogenes in packaged raw milk. Int. J. Food Microbiol. 2017, 261, 1-10, doi:10.1016/j.ijfoodmicro.2017.08.017.

12. Odueke, O.B.; Farag, K.W.; Baines, R.N.; Chadd, S.A. Irradiation Applications in Dairy Products: a Review. Food Bioprocess Technol. 2016, 9, 751-767, doi:10.1007/s11947-016-1709-y.

13. Haghighi-Manesh, S.; Azizi, M.H. Active packaging systems with emphasis on its applications in dairy products. J. Food Process Eng. 2017, 40, e12542, doi:10.1111/jfpe.12542.

14. Donohue, D.C.; Salminen, S. Safety of probiotic bacteria. Asia Pacific J. Clin. Nutr. 1996, 5, 25-28.

15. Maragkoudakis, P.A.; Mountzouris, K.C.; Psyrras, D.; Cremonese, S.; Fischer, J.; Cantor, M.D.; Tsakalidou, E. Functional properties of novel protective lactic acid bacteria and application in raw chicken meat against Listeria monocytogenes and Salmonella enteritidis. Int. J. Food Microbiol. 2009, 130, 219-226, doi:10.1016/j.ijfoodmicro.2009.01.027.

16. Gálvez, A.; Abriouel, H.; López, R.L.; Omar, N. Ben Bacteriocin-based strategies for food biopreservation. Int. J. Food Microbiol. 2007, 120, 51-70, doi:10.1016/j.ijfoodmicro.2007.06.001.

17. Comi, G.; Andyanto, D.; Manzano, M.; lacumin, L. Lactococcus lactis and Lactobacillus sakei as bio-protective culture to eliminate Leuconostoc mesenteroides spoilage and improve the shelf life and sensorial characteristics of commercial cooked bacon. Food Microbiol. 2016, 58, 16-22, doi:10.1016/J.FM.2016.03.001.

18. Silva, C.C.G.; Silva, S.P.M.; Ribeiro, S.C. Application of bacteriocins and protective cultures in dairy food preservation. Front. Microbiol. 2018, 9, doi:10.3389/fmicb.2018.00594.

19. Realini, C.E.; Marcos, B. Active and intelligent packaging systems for a modern society. Meat Sci. 2014, 98, 404-419, 
doi:10.1016/j.meatsci.2014.06.031.

20. Aloui, H.; Khwaldia, K. Natural Antimicrobial Edible Coatings for Microbial Safety and Food Quality Enhancement. Compr. Rev. Food Sci. Food Saf. 2016, 15, 1080-1103, doi:10.1111/1541-4337.12226.

21. Dorigato, A.; Pegoretti, A. Biodegradable single-polymer composites from polyvinyl alcohol. Colloid Polym. Sci. 2012, 290, 359-370, doi:10.1007/s00396-011-2556-z.

22. López-De-Dicastillo, C.; Jordá, M.; Catalá, R.; Gavara, R.; HernándezMuñoz, P. Development of active polyvinyl alcohol/ $\beta$-cyclodextrin composites to scavenge undesirable food components. J. Agric. Food Chem. 2011, 59, 11026-11033, doi:10.1021/jf200749f.

23. FAO Preventing post-harvest losses in the apple supply chain in Lebanon. Food Agric. Organ. United Nations Minist. Lebanon, Beirut 2018, 5 .

24. Settier-Ramírez, L.; López-Carballo, G.; Gavara, R.; Hernández-Muñoz, P. Antilisterial properties of $\mathrm{PVOH}$-based films embedded with Lactococcus lactis subsp. lactis. Food Hydrocoll. 2019, 87, 214-220, doi:10.1016/j.foodhyd.2018.08.007.

25. Laemmli, U. Most commonly used discontinuous buffer system for SDS electrophoresis. Nature 1970, 227, 680-686.

26. Juillard, V.; Guillot, A.; Le Bars, D.; Gripon, J.C. Specificity of milk peptide utilization by Lactococcus lactis. Appl. Environ. Microbiol. 1998, 64, 1230-1236.

27. Ummadi, M. (Soni); Curic-Bawden, M. Chapter 6. Use of Protein Hydrolysates in Industrial Starter Culture Fermentations. In Protein Hydrolysates in Biotechnology; Pasupuleti, V.K., Demain, A.L., Eds.; Springer Netherlands: Dordrecht, 2010; pp. 91-114 ISBN 978-1-40206673-3.

28. Addi, N.; Guessas, B. Research Article Characterization of Protease Activity of Lactococcus lactis Species Isolated from Raw Camel 's Milk. J. Biol. Sci. 2016, 16, 215-220, doi:10.3923/jbs.2016.215.220.

29. Mille, Y.; Obert, J.P.; Beney, L.; Gervais, P. New drying process for lactic 
bacteria based on their dehydration behavior in liquid medium. Biotechnol. Bioeng. 2004, 88, 71-76, doi:10.1002/bit.20211.

30. Burgain, J.; Gaiani, C.; Francius, G.; Revol-Junelles, A.M.; Cailliez-Grimal, C.; Lebeer, S.; Tytgat, H.L.P.; Vanderleyden, J.; Scher, J. In vitro interactions between probiotic bacteria and milk proteins probed by atomic force microscopy. Colloids Surfaces B Biointerfaces 2013, 104, 153-162, doi:10.1016/j.colsurfb.2012.11.032.

31. Soukoulis, C.; Behboudi-Jobbehdar, S.; Yonekura, L.; Parmenter, C.; Fisk, I.D. Stability of Lactobacillus rhamnosus GG in prebiotic edible films. Food Chem. 2014, 159, 302-308, doi:10.1016/j.foodchem.2014.03.008.

32. Romano, N.; Tavera-Quiroz, M.J.; Bertola, N.; Mobili, P.; Pinotti, A.; Gómez-Zavaglia, A. Edible methylcellulose-based films containing fructo-oligosaccharides as vehicles for lactic acid bacteria. Food Res. Int. 2014, 64, 560-566, doi:10.1016/j.foodres.2014.07.018.

33. Farinha, L.R.L.; Sabo, S.S.; Porto, M.C.; Souza, E.C.; Oliveira, M.N.; Oliveira, R.P.S. Influence of Prebiotic Ingredients on the Growth Kinetics and Bacteriocin Production of Lactococcus lactis. Chem. Eng. Trans. 2015, 43, 313-318, doi:10.3303/CET1543053.

34. Matsusaki, H.; Endo, N.; Sonomoto, K.; Ishizaki, A. Lantibiotic nisin Z fermentative production by Lactococcus lactis IO-1: relationship between production of the lantibiotic and lactate and cell growth. Appl. Microbiol. Biotechnol. 1996, 45, 36-40, doi:10.1007/s002530050645.

35. Buchanan, R.L.; Klawitter, L.A. Effectiveness of Carnobacterium piscicola Lk5 for controlling the growth of Listeria monocytogenes scott a in refrigerated foods. J. Food Saf. 1991, 12, 219-236, doi:10.1111/j.1745-4565.1991.tb00080.x.

36. Winkowski, K.; Montville, T.J. Use of meat isolate, Lactobacillus bavaricus $\mathrm{MN}$, to inhibit Listeria monocytogenes growth in a model meat gravy system. 1992, 13, 19-31.

37. Montville, T.J.; Winkowski, K.; Ludescher, R.D. Models and mechanisms for bacteriocin action and application. Int. Dairy J. 1995, 5, 797-814, doi:10.1016/0958-6946(95)00034-8. 
38. Concha-Meyer, A.; Schöbitz, R.; Brito, C.; Fuentes, R. Lactic acid bacteria in an alginate film inhibit Listeria monocytogenes growth on smoked salmon. Food Control 2011, 22, 485-489, doi:10.1016/j.foodcont.2010.09.032.

39. Gialamas, H.; Zinoviadou, K.G.; Biliaderis, C.G.; Koutsoumanis, K.P. Development of a novel bioactive packaging based on the incorporation of Lactobacillus sakei into sodium-caseinate films for controlling Listeria monocytogenes in foods. Food Res. Int. 2010, 43, 2402-2408, doi:10.1016/j.foodres.2010.09.020.

40. Gueimonde, M.; Delgado, S.; Mayo, B.; Ruas-Madiedo, P.; Margolles, A.; de los Reyes-Gavilán, C.G. Viability and diversity of probiotic Lactobacillus and Bifidobacterium populations included in commercial fermented milks. Food Res. Int. 2004, 37, 839-850, doi:10.1016/J.FOODRES.2004.04.006.

41. Schillinger, U.; Becker, B.; Vignolo, G.; Holzapfel, W.H. Efficacy of nisin in combination with protective cultures against Listeria monocytogenes Scott A in tofu. Int. J. Food Microbiol. 2001, 71, 159168, doi:10.1016/S0168-1605(01)00612-2.

42. Ferreira, M.A.S.S.; Lund, B.M. The effect of nisin on Listeria monocytogenes in culture medium and long-life cottage cheese. Lett. Appl. Microbiol. 1996, 22, 433-438, doi:10.1111/j.1472765X.1996.tb01197.x.

43. Leroy, F.; De Vuyst, L. Lactic acid bacteria as functional starter cultures for the food fermentation industry. Trends Food Sci. Technol. 2004, 15, 67-78, doi:10.1016/J.TIFS.2003.09.004.

44. Sahadeva, R.P.K.; Leong, S.F.; Chua, K.H.; Tan, C.H.; Chan, H.Y.; Tong, E. V.; Wong, S.Y.W.; Chan, H.K. Survival of commercial probiotic strains to $\mathrm{pH}$ and bile. Int. Food Res. J. 2011, 18, 1515-1522.

45. Gauche, C.; Tomazi, T.; Barreto, P.L.M.; Ogliari, P.J.; Bordignon-Luiz, M.T. Physical properties of yoghurt manufactured with milk whey and transglutaminase. LWT - Food Sci. Technol. 2009, 42, 239-243, doi:10.1016/J.LWT.2008.05.023.

46. Ozcan, T.; Yilmaz-Ersan, L.; Akpinar-Bayizit, A.; Delikanli, B. Antioxidant properties of probiotic fermented milk supplemented with chestnut 
flour (Castanea sativa Mill). J. Food Process. Preserv. 2017, 41, doi:10.1111/jfpp.13156.

47. Antwi, M.; Theys, T.E.; Bernaerts, K.; Van Impe, J.F.; Geeraerd, A.H. Validation of a model for growth of Lactococcus lactis and Listeria innocua in a structured gel system: Effect of monopotassium phosphate. Int. J. Food Microbiol. 2008, 125, 320-329, doi:10.1016/j.jifoodmicro.2008.04.014.

48. Elbert, A.G. Phosphorus: the Forgotten, Essential Ingredient. Retrieved April 14, 2007 Available online: https://www.preparedfoods.com/articles/104026-ingredientchallenges- br-phosphorus-the-forgotten-essential-ingredient.

49. Lück, E.; von Rymon Lipinski, G.-W. Foods, 3. Food Additives. In Ullmann's Encyclopedia of Industrial Chemistry; Wiley-VCH Verlag $\mathrm{GmbH} \&$ Co. KGaA: Weinheim, Germany, 2000. 


\section{Artículo 3}

\section{Effect of casein hydrolysates on the survival of protective cultures of Lactococcus lactis and Lactobacillus sakei in PVOH films}

Laura Settier-Ramírez; Gracia López-Carballo; Rafael Gavara; Pilar Hernández-Muñoz

Food Hydrocolloids, 2021, vol. 121, p. 107012

Packaging Lab, Instituto de Agroquímica y Tecnología de Alimentos, IATA-CSIC, Av. Agustín Escardino 7, 46980 Paterna, Spain. 



\section{ABSTRACT}

The aim of this work has been to explore the potential of blending polyvinyl alcohol (PVOH) with casein hydrolysates (HCas) to obtain self-standing films capable to act as carriers of lactic acid bacteria $(L A B)$ as biocontrol agents against food pathogens. For this purpose, PVOH was blended with $\mathrm{HCas}$ at different weight ratios and the blends were incorporated with Lactococcus lactis and Lactobacillus sakei. Blending HCas with $\mathrm{PVOH}$ resulted in the modification of some functional properties of the films whereas bacteria did not change them. Moreover, incorporation of HCas resulted in an increase in cell viability after film casting and in long-term film storage, and also in film antilisterial properties. These results could be related to the capacity of bacterial autoaggregation in the films during the drying process when HCas was added, as observed by fluorescence light microscopy. Blends could be used in the active packaging of foods.

Keywords: lactic acid bacteria, biocontrol agents, anti-Listeria films, casein hydrolysates, polymer matrices, bacterial auto-aggregation 


\section{Introduction}

The use of bacteriocins to design active packages to control the growth of foodborne pathogens has been greatly explored in the last years. However, antimicrobial packaging based on the use of bacteriocin producing bacteria as biocontrol agents has not been deeply explored. The use of bacteria instead of their bacteriocins presents several advantages. In this regard, commercial bacteriocins preparations have a high price due to the low fermentation yields and high production costs [1], and some bacteriocins are not classified as GRAS.

It is known that foodborne pathogens and spoilage organisms can lose viability during growth in associative cultures with lactic acid bacteria $(\mathrm{LAB})$, which in most of the cases is attributed to the production of bacteriocins and also other antimicrobial compounds such as organic acids and hydrogen peroxide that help to increment the antimicrobial effect; in addition, bacteria also compete with other bacteria that can cause spoilage in foods or being pathogens [2].

The incorporation of $L A B$ as protective cultures into films and coatings is recent and a deeper understanding of the dependency between $L A B$ viability and antimicrobial activity, and the film composition, processing and storage is required [3]. Until now, most of the studies are based on the use of water soluble biopolymers which are incorporated with low molecular compounds with the aim of acting as nutrients or protective agents for bacteria $[3,4]$. However, the use of water soluble Polyvinyl alcohol (PVOH) has been little explored.

$\mathrm{PVOH}$ is a water soluble biodegradable and synthetic polymer with excellent film forming properties. $\mathrm{PVOH}$ is widely used in the industry due to its emulsifying and adhesive properties, having an excellent mechanical strength and flexibility. Contrary to water soluble films made from biopolymers, $\mathrm{PVOH}$ films are stable during storage without altering their physico-chemical properties; that can be a great advantage for its industrial application as carrier of protective cultures for active food packaging purposes. PVOH is approved by the FDA for use in food contact and as a food additive with INS $n^{\circ} .1203$ (Codex alimentarius) [5]. In the EU, PVOH is approved by the EFSA as a food 
additive in food supplements in accordance with Annex II to Regulation (EC) No 1333/2008. The studies focused on the use of $\mathrm{PVOH}$ as carrier of protective cultures for active packaging are scarce. Only a couple of works related to the use of PVOH coatings as carriers of antilisterial producing bacteriocin are documented in the bibliography [6].

In previous studies, the authors of the current work have reported that PVOH is capable of maintaining the viability of L. lactis and its antilisterial properties. They also found that these properties are improved when a low percentage of proteins or protein hydrolysates are incorporated in the film formulation (Settier-Ramírez et al., 2019). Thus, it is worthy to optimize the formulation of PVOH incorporated with protein hydrolysates to improve the antimicrobial effectivity of the films without altering some $\mathrm{PVOH}$ functional properties that are of great importance when used in the design of food packages.

Therefore, the aim of this work has been to study the effect of incorporating different amounts of casein hydrolysates in PVOH matrices on the viability and antilisterial properties of two LAB strains producers of bacteriocins, nisin-producer Lactococcus lactis and sakacin-producer Lactobacillus sakei in different testing conditions. The structural and morphological properties of the blend films have been correlated with the microbiological results obtained. Moreover, some important functional properties of the resulting films for its use in the design of antimicrobial food packages (moisture absorption, optical, and mechanical properties) were assayed.

\section{Materials and methods}

\subsection{Bacterial strains}

Lactococcus lactis subsp. lactis (CECT 539, ATCC 11454) supplied by the Spanish Type Culture Collection (CECT) and Lactobacillus sakei subsp. sakei (ATCC 15521) kindly supplied by M. Rollini from Università degli Sudi from Milan, were stored in Man, Rogosa, and Sharpe (MRS) broth supplemented with $20 \%$ glycerol at $-80{ }^{\circ} \mathrm{C}$. The microbial cultures were re-generated and maintained by regular subcultures at $4{ }^{\circ} \mathrm{C}$ on MRS broth. An aliquot from the cultures 
was subcultured by overnight incubation in $10 \mathrm{~mL}$ of MRS prior to the experiments.

Listeria monocytogenes strain (CECT 934, ATCC 19114) supplied by CECT was kept frozen at $-80{ }^{\circ} \mathrm{C}$ in Tryptone Soy Broth (TSB) supplemented with $20 \%$ glycerol. The stock culture was maintained by regular subculture at $4{ }^{\circ} \mathrm{C}$ on Tryptone Soy Agar (TSA) and transferred monthly. Before use, a loopful of the strain was transferred to $10 \mathrm{~mL}$ of TSB and incubated overnight at $37^{\circ} \mathrm{C}$. All microbiological products were provided by Scharlau, Barcelona, Spain.

2.2. Determination of the minimum inoculum of L. lactis and L. sakei active against $L$. monocytogenes

The minimum initial inoculum of $L$. lactis and $L$. sakei able to reduce the microbial growth of $L$. monocytogenes under refrigerated storage in liquid culture medium was adapted from previous work [7]. L. lactis cells were harvested by centrifugation at 2,500 RCF for 15 min at $4{ }^{\circ} \mathrm{C}$ and washed twice with peptone water. Then, they were suspended in TSB with $0.3 \%$ of yeast extract (TSB + YE). Appropriate dilutions were made in order to inoculate tubes with $10 \mathrm{~mL}$ of TSB + $\mathrm{YE}$ with concentrations ranging from 9 to $6 \log \mathrm{CFU} / \mathrm{mL}$. After that, all the tubes were inoculated with $4 \log \mathrm{CFU} / \mathrm{mL}$ of $L$. monocytogenes. The same procedure was repeated with $L$. sakei. Three control tubes for each bacterium were prepared to evaluate their growth without any influence.

The tubes were stored at $4{ }^{\circ} \mathrm{C}$ during 13 days. Aliquots were taken immediately after bacteria inoculation, and after 1, 2, 3, 6, 8, 10 and 13 days of storage. Serial dilutions with peptone water were made and plated in Petri dishes with Polymyxin Acriflavine Lithium Chloride Ceftazidime Aesculin Mannitol agar (PALCAM agar) to study logarithmic reduction of $L$. monocytogenes, and also in MRS to study growth of L. lactis and L. sakei in contact with L. monocytogenes. MRS agar plates were incubated at $30^{\circ} \mathrm{C}$ during 4 days and PALCAM plates were incubated at $37^{\circ} \mathrm{C}$ for $48 \mathrm{~h}$, respectively. After the incubation time, L. lactis and $L$. sakei colonies were counted in MRS agar and $L$. 
monocytogenes colonies were counted in PALCAM agar. Tests were carried out in triplicate.

\subsection{Film formation}

Polyvinyl alcohol (PVOH, Gohsenol GH17, Nippon Synthetic Chemical Company, Osaka, Japan) was used as the polymer matrix for the preparation of the films. Film forming solutions (FFS) were prepared in distilled water dissolving $\mathrm{PVOH}$ and incorporating casein hydrolysates (HCas, Peptone from casein, enzymatic digest, SigmaAldrich, France) in a mass ratio of 1:0, 1:0.125 and 1:1 (w:w) obtaining a final concentration of dry solids of $2 \%(w / w)$ in all the cases. L. lactis and $L$. sakei cells were harvested by centrifugation at 2,500 RCF for 15 $\min$ at $4{ }^{\circ} \mathrm{C}$ and washed twice with peptone water. Then they were incorporated into the different FFS in order to obtain 7 log CFU/mL (selected for the results observed in the above section). Next, $15 \mathrm{~g}$ of each FFS were cast in Petri dishes (90 mm of diameter) and dried at 20 ${ }^{\circ} \mathrm{C}$ under the air flow of a biological safety cabinet (Biostar Plus, Telstar) for $24 \mathrm{~h}$. Films were stored at $43.2 \% \mathrm{RH}$ and $20{ }^{\circ} \mathrm{C}$ for two weeks prior to be characterized. PVOH films and their blends with $H C$ as without $L A B$ were used as controls.

\subsection{Functional properties of the films}

\subsubsection{Thickness}

A digital micrometer (Mitutoyo Manufacturing Co., Ltd., Tokyo, Japan) with a sensitivity of $1 \mu \mathrm{m}$ was used to measure film thickness. Five measurements were taken randomly for each film sample and three samples of each film were measured.

\subsubsection{Moisture content}

Films of approximately $0.5 \mathrm{~g}$ were placed on aluminum plates and stored at $20{ }^{\circ} \mathrm{C}$ in glass desiccators containing a saturated solution of potassium carbonate anhydrous and potassium acetate (Acros Organics, France) in order to obtain $43.2 \%$ and $23.1 \% \mathrm{RH}$ respectively. After two weeks, the weight equilibrium was reached and samples were weighed and placed in desiccators with phosphorus pentoxide (Fluka, Sigma-Aldrich, France) for dehydration until reaching 
constant weight. Moisture content was calculated based in weight changes [8]. Tests were carried out in triplicate.

\subsubsection{Optical properties}

Color of the films was measured with a Konica Minolta CM3500d spectrophotometer (Konica Minolta Sensing, Inc., Osaka, Japan) set to D65 illuminant $/ 10^{\circ}$ observer was used to determine the color of all the prepared films. The samples were measured against the surface of a standard white plate to acquire the color data and to display them in the CIELAB color space. The parameters L* [black (0) to white (100)], $a^{*}$ [green $(-)$ to red $(+)$ ], and $b^{*}$ [blue $(-)$ to yellow $(+)$ ] were obtained and the polar coordinates, the chroma $C^{*}$, and the hue angle $h^{\circ}$ were calculated. Eight measurements of each sample were taken, and three samples of each film were measured.

A Perkin Elmer Lambda 16 UV-Visible spectrometer was used to obtain the absorption spectrum of the films in the wavelength range of 190-800 $\mathrm{nm}$. The apparent opacity of the films was calculated as the area under the absorption curve $(\mathrm{Au} \times \mathrm{nm})$ in the UV and visible wavelengths.

\subsubsection{Mechanical properties}

A Mecmesin MultiTest 1-í universal test machine (Landes Poli Ibérica, S.L., Barcelona, Spain) equipped with a $100-\mathrm{N}$ static load cell was used to evaluate the maximum tensile strength $\left(\sigma_{\mathrm{m}}\right)$, percentage of elongation at break $\left(\varepsilon_{b}\right)$ and Young's modulus (E) of the films. Films were cut into $25.4 \mathrm{~mm} \times 130 \mathrm{~mm}$ strips and conditioned at $43.2 \% \mathrm{RH}$ and $20{ }^{\circ} \mathrm{C}$ for one week before testing. Sample Grip separation was set at $100 \mathrm{~mm}$ and cross-head speed at $25 \mathrm{~mm} / \mathrm{min}$. 12 replicates from each sample were tested.

\subsection{Structural and morphological properties of the films}

\subsubsection{Modulated differential scanning calorimetry (MDSC)}

Differential scanning calorimetry was performed using a DSC Q2000 (TA Instruments Inc., New Castle, DE, USA) equipped with Universal Analysis 2000 software. $\mathrm{N}_{2}$ was used as the purge gas at a 
flow rate of $50 \mathrm{~mL} / \mathrm{min}$, and at a heating rate of $10{ }^{\circ} \mathrm{C} / \mathrm{min}$ from - 50 ${ }^{\circ} \mathrm{C}$ up to $220^{\circ} \mathrm{C}$ the modulation period was $60 \mathrm{~s}$, and the amplitude of modulation was $0.32{ }^{\circ} \mathrm{C}$. Temperature calibration of the instrument was performed with indium. Dry samples of approximately $5 \mathrm{mg}$ were weighted in an Tzero aluminum pan and hermetically closed with a TZero lid (TA instruments), punctured three times, and kept over $\mathrm{P}_{2} \mathrm{O}_{5}$ for two weeks prior to scanning. Experiments were carried out in three cycles to eliminate the thermal history of the samples. Thus, samples were cooled down to $-50^{\circ} \mathrm{C}$ and after 2 min of equilibrium, they were heated at a constant $10^{\circ} \mathrm{C} / \mathrm{min}$ rate up to $115^{\circ} \mathrm{C}$, and equilibrated for 2 , then cooled to $-50^{\circ} \mathrm{C}, 2$ min of equilibrium and a second heating up to $220^{\circ} \mathrm{C}$. Glass transitions temperature $\left(T_{g}\right)$ was taken at the inflexion point of the transition the case of samples $\mathrm{PVOH}: \mathrm{HCas} 1: 1, \mathrm{~T}_{\mathrm{gs}}$ were recorded during the first heating since in this cycle the presence of the transitions of both polymers were observed. Melting temperatures $\left(T_{m}\right)$ were taken at the minimum point of the endotherm at the third heating. Melting enthalpy $(\Delta H)$ was calculated using the TA Universal Analysis software. From melting enthalpy values, the crystalline fraction $(\chi(\%))$ of $\mathrm{PVOH}$ blend films was calculated using the following equation:

$$
\chi(\%)=\frac{1}{\left(\mathrm{~m}_{\mathrm{p}}\right)}\left[\frac{\Delta H}{\Delta H_{0}}\right] \times 100
$$

where $\Delta H$ is the enthalpy for melting; $\Delta H_{0}$ is melting for a $100 \%$ crystalline $\mathrm{PVOH}$ sample and $\mathrm{m}_{\mathrm{p}}$ the weight fraction of $\mathrm{PVOH}$ in the sample. The melting enthalpy of $100 \% \mathrm{PVOH}$ was taken as $161.1 \mathrm{~J} / \mathrm{g}$ [9].

\subsubsection{Scanning electron microscopy}

Cross-sectional images of polyvinyl alcohol films and their blends with casein hydrolysates without and with $L A B$ were observed by scanning electron microscopy (SEM) using a HITACHI S-4100 unit equipped with a BSE AUTRATA detector and an EMIP 3.0 image capture system (HITACHI, Madrid, Spain). Prior to cross-sectional cut of the films, they were immersed in liquid nitrogen to obtain a perfect cut without mechanical damage of the area. Then, samples were 
mounted on a stub of metal with adhesive, and film surface and cross sectional area coated under vacuum with gold-palladium in a sputter coating unit. Images were captured at $5 \mathrm{kV}$.

\subsubsection{Fluorescence light microscopy}

The distribution of bacteria and casein hydrolysates in polyvinyl alcohol matrix was observed using a Nikon Eclipse 90i fluorescence microscope.

Prior to the formation of the film, $L A B$ were stained with DNAintercalating agent DAPI (4',6-diamidino-2-phenylindole, dihydrochloride, Sigma-Aldrich). 1 microliter of a solution of $1 \mathrm{mg} / \mathrm{mL}$ DAPI was added to $1 \mathrm{~mL}$ of bacterial suspension and incubated for 10 min at $20^{\circ} \mathrm{C}$ in the dark. Then, stained LAB cells were resuspended in $10 \mathrm{~mL}$ sterile distilled water. Cells were harvested by centrifugation at $2,500 \mathrm{RCF}$ for $15 \mathrm{~min}$ at $4{ }^{\circ} \mathrm{C}$ and washed twice with distilled water. Then, they were incorporated into the different FFS and films were cast following the same methodology than in section 2.3. The films were observed under a blue filter (DAPI was excited at the wavelength of $405 \mathrm{~nm}$ and the emission filter was set at $420-460 \mathrm{~nm}$ ).

\subsection{Antioxidant properties of the films}

Antioxidant activities of just made films and films stored for one month at $43.2 \% \mathrm{RH}$ and $20^{\circ} \mathrm{C}$ were measured by the ABTS assay following the methodology described by López De Dicastillo et al. (2013), this assay is based on the inhibition of the radical cation 2,2'azinobis(3-ethylbenzothiazoline-6-sulphonate), ABTS ${ }^{\circ}$, which has a characteristic wavelength absorption spectrum at $715 \mathrm{~nm}$. When this indicator radical is neutralized by an antioxidant substance, its absorption decreases. The percentage inhibition values were calculated using this equation:

$$
I(\%)=[(\text { Abs control-Abs sample }) / \text { Abs control }] \times 100
$$


For the determination, films were dissolved in $10 \mathrm{~mL}$ distilled water and were incubated during $1 \mathrm{~h}$ with $\mathrm{ABTS}^{\circ}+$. Results were expressed as ABTS inhibition activity after $1 \mathrm{~h}$ reaction.

\subsection{Microbiological studies of the films}

2.7.1. $L A B$ survival after film processing and in vitro antilisterial activity

The survival of $L$. lactis and $L$. sakei after the film was formed, was evaluated according to the equation:

$$
\% \text { viability after film processing }=100 \times \frac{\mathrm{N}}{\mathrm{N}_{0}}
$$

where " $\mathrm{N}_{0}$ " represents the number of viable bacteria in the film forming solution (FFS) prior the drying process of the FFS and " $\mathrm{N}$ " is the number of viable bacteria in just made films.

The bacterial viability in the FFS was evaluated placing $1 \mathrm{~mL}$ of each solution in tubes with $10 \mathrm{~mL}$ of sterile peptone water. After homogenization, appropriate dilutions were made. Counts of L. lactis and $L$. sakei were performed in MRS agar after incubation for 4 days at $30{ }^{\circ} \mathrm{C}$. To determine bacteria viability after film drying, circular films of $90 \mathrm{~mm}$ of diameter ( $0.3 \mathrm{~g}$ approx.) corresponding to different blend ratios were peeled off from Petri dish after drying and placed in tubes with $10 \mathrm{~mL}$ of sterile peptone water. Then, tubes were vigorously stirred at $20{ }^{\circ} \mathrm{C}$ until the film was dissolved and the microorganisms released. Later, appropriate dilutions were made and it was proceeded as described above. Tests were carried out in triplicate.

Antilisterial activity of just made films incorporating $L A B$ was evaluated against $L$. monocytogenes, the survival of $L A B$ after being in contact with the pathogen during the antimicrobial test was also studied. To this end, films of $90 \mathrm{~mm}$ of diameter were removed from Petri dishes and immersed in tubes containing $10 \mathrm{~mL}$ of Tryptone Soy Broth supplemented with $0.6 \%$ of yeast extract (TSB+YE) which were previously inoculated with $4 \log \mathrm{CFU} / \mathrm{mL}$ of $L$. monocytogenes. Then, tubes were stored at $37^{\circ} \mathrm{C}$ for $24 \mathrm{~h}$, after that time, serial dilutions with peptone water were made and plated in Petri dishes with PALCAM 
agar and MRS agar. Culture conditions for both $L A B$ and $L$. monocytogenes were the same as previously described in section 2.2.

2.7.2. In vitro evolution of antilisterial activity and growth of $L A B$ after immersion of the films in liquid culture medium at $4{ }^{\circ} \mathrm{C}$

The activity of the films against $L$. monocytogenes was evaluated in refrigerated liquid culture medium through the time to simulate the active packaging of a liquid food using the developed films; the survival of $L A B$ in the refrigerated culture medium during that time was evaluated at the same time. To carry out the experiments, films were immersed in tubes with $10 \mathrm{~mL}$ of TSB+YE previously inoculated with $4 \mathrm{log} \mathrm{CFU} / \mathrm{mL}$ of $L$. monocytogenes and stored at $4{ }^{\circ} \mathrm{C}$ for 15 days. Aliquots were taken immediately after film dissolution, and after 1, 3, 6, 9 and 15 days. Serial dilutions with peptone water were made and plated in Petri dishes with PALCAM agar and MRS agar. Culture conditions for both $L A B$ and $L$. monocytogenes were the same as previously described in section 2.2. The tests were done in triplicate.

\subsubsection{Survival of $L A B$ in long-term stored films}

To know the survival of bacteria in the films through storage, just made films were stored at $20{ }^{\circ} \mathrm{C}$ for four weeks in desiccators conditioned with saturated salt solutions of potassium acetate, and potassium carbonate for reaching relative humidities of $23.1 \pm 0.3 \%$ and $43.2 \pm 0.3 \%$, respectively. The viability of $L$. lactis and $L$. sakei was evaluated each week as mentioned above. Analyses were performed in triplicate.

\subsection{Statistical analysis}

One-way analyses of variance were carried out. The SPSS computer program (SPSS Inc., Chicago, IL) was used. Differences in pairs of mean values were evaluated by the Tukey $b$ test for $a$ confidence interval of $95 \%$. Data were represented as the average \pm standard deviation. 


\section{Results and discussion}

3.1 Determination of the minimum inoculum of L. lactis and L. sakei active against L. monocytogenes

When using $L A B$ as protective cultures to develop antilisterial films for active packaging it is essential to choose an adequate size of the inoculum to be incorporated in the film and also to keep cell viability and antimicrobial properties after film processing.

Before the formation of the film, the minimum initial inoculum of $L$. lactis and $L$. sakei necessary to inhibit $L$. monocytogenes was studied in liquid $\mathrm{TSB}+\mathrm{YE}$ for 13 days at $4{ }^{\circ} \mathrm{C}$ simulating refrigerated storage of perishable foods. Inoculum sizes of 6, 7, 8 and $9 \mathrm{log} C F U / \mathrm{mL}$ of $L$. lactis or $L$. sakei were assayed against $4 \log C F U / m L$ of $L$. monocytogenes. Figure 1a shows the evolution of the initial inoculum size of L. lactis or L. sakei when is confronted with $4 \mathrm{log} C F U / \mathrm{mL}$ of $L$. monocytogenes in liquid TSB+YE for 13 days at $4{ }^{\circ} \mathrm{C}$.

Independently of the size of the inoculum added to the liquid medium, the population of $L$. lactis was slightly lower than that of $L$. sakei, that is attributable to small differences in the amount of bacteria in the preculture, in any case, these differences were not relevant. When inoculum sizes of 9 and $8 \log C F U / m L$ of both $L A B$ were assayed (differences of +5 and +4 respect to 4 log CFU/mL of $L$. monocytogenes), both $\mathrm{LAB}$ had the same growth, reaching values around $9 \log$ for differences of +5 , and $8 \log$ CFU/mL for differences of +4 . When the size of the inoculum was lower, 7 and $6 \log C F U / m L$ (differences of +3 and +2 respect to $4 \log C F U / m L$ of $L$. monocytogenes), the growth of $L$. sakei in the liquid medium was faster than for $L$. lactis. In fact, the former reached a stationary phase of around $8 \log$ CFU/mL after six days. However, when the inoculum size was +3 , L. lactis reached values of $7 \mathrm{log} C F U / \mathrm{mL}$ after eight days of storage, it took ten days to reach this stationary phase for an inoculum size of +2 . Figure $1 \mathrm{~b}$ shows the antilisterial activity of different inoculum sizes of $L$. sakei and $L$. lactis evaluated at $4{ }^{\circ} \mathrm{C}$ for 13 days. All the inoculum sizes tested for both LAB exerted antilisterial activity although was greater for $L$. lactis. 
a)

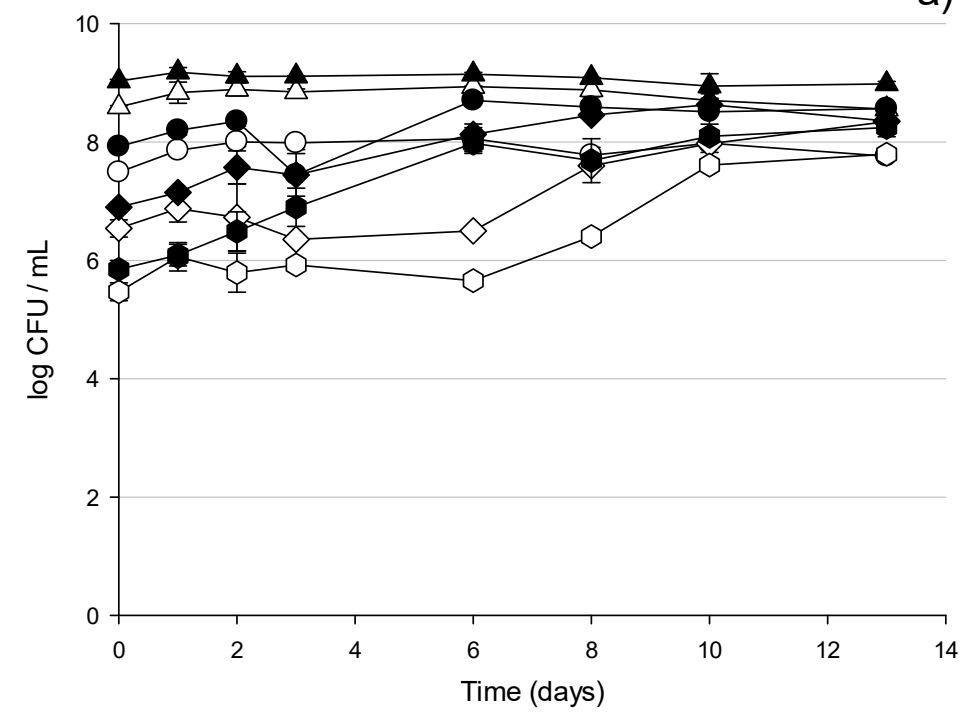

b)

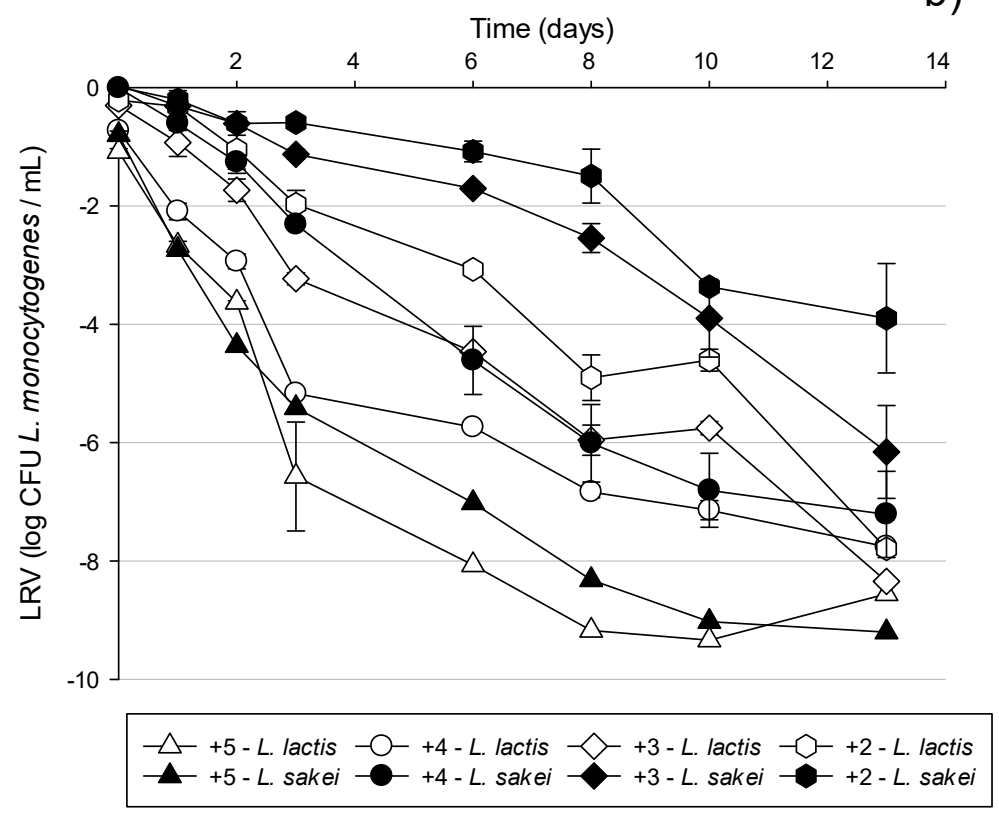

Figure 1. Evolution of the initial inoculum size of $L$. lactis or $L$. sakei (a) and $L$. monocytogenes logarithmic reduction rate (b) when is confronted with 4 log $\mathrm{CFU} / \mathrm{mL}$ of $L$. monocytogenes in liquid TSB $+\mathrm{YE}$ for 13 days at $4{ }^{\circ} \mathrm{C}$. Mean values and $95 \%$ LSD intervals. 
The two bacteria strains assayed are effective against Grampositive bacteria mainly due to the generation of organic acids and bacteriocins, which are products of their metabolism and also due to direct competition for nutrients [2]. In this study, TSB+YE is a liquid culture buffered medium so $\mathrm{pH}$ was maintained around 7 during all the storage. Thus, the antilisterial activity of $L$. sakei and L. lactis could be attributable to the bacteriocins produced. Indeed, $L$. lactis generates nisin, a bacteriocin classified as class I and L. sakei generates sakacin classified as class II [11]. The greater antilisterial activity of $L$. lactis can be attributable to the different effectiveness of each of the two bacteriocins. Both bacteriocins have a similar mode of action by destabilization of the plasmatic membrane of $L$. monocytogenes but they are not the same molecule. In the same way, the biosynthesis of L. lactis and L. sakei is not exactly the same [12]. The rate of production of the bacteriocin considering the temperature and time of storage can also affect to the antimicrobial properties of the tested LAB.

The inoculum size of $L$. lactis and $L$. sakei is essential to obtain an effective antilisterial activity through the whole storage time as shown in Figure 1b. Regarding L. lactis, depending on the size of the inoculum used the antimicrobial properties changed considerably during the first 10 days of storage, the greater antimicrobial activity through this time was exerted by an inoculum size of $9 \log \mathrm{CFU} / \mathrm{mL}$, however, the antimicrobial activity was independent of the inoculum size after 13 days. Related to $L$. sakei, the antilisterial activity was greater for all the storage time when using inoculum sizes of 8 and 9 $\log \mathrm{CFU} / \mathrm{mL}$. Therefore, a concentration of $8 \log \mathrm{CFU} / \mathrm{mL}$ was chosen as inoculum size to incorporate in the film forming solution.

\subsection{Functional properties of the films}

Previous studies carried out by the authors showed that 1:1 was the ratio with the greater concentration of casein hydrolysates (HCas) that being incorporated in polyvinyl alcohol (PVOH) matrix give homogeneous films with good visual appearance and handling. The addition of $L A B$ did not modify the appearance of the films at the naked eye compared to that of PVOH films without bacteria. 
Table 1 recompiles moisture content and optical properties of $\mathrm{PVOH}$ films and its blends with casein hydrolysate (HCas). As other authors pointed out in several studies with different film formulations, LAB incorporation did not change film properties such as thickness [13], color [14], opacity [15] or mechanical properties [16]. The results are given for films without carrying bacteria since the tested properties did not alter after $L A B$ incorporation. The thickness of PVOH films was not modified after addition of HCas, being the concentration of dried solids in the film forming solution the same for all the films prepared.

It is important to determine the moisture content (MC) of the hydrophilic films because it can affect the rate of viability of LAB after drying during long storage periods [17]. MC of the films stored at 43.2 $\%$ and $23.1 \% \mathrm{RH}$, and $20{ }^{\circ} \mathrm{C}$ are shown in Table 1. As expected, moisture absorbed by all the films was lower when they were stored at $23.1 \% \mathrm{RH}$, and similar values were obtained for all the blending ratios, ranging from 3.8 for plain $\mathrm{PVOH}$ to 4.1 (g water/ $100 \mathrm{~g}$ of dry film) for 1:1 blends. When films were stored at a higher relative humidity, they absorbed more water and differences among compositions were more evident.

It is well known that optical properties of food packaging materials are important properties to be considered in packaging design since it has a great impact on the appearance of the package and their commercialization. Color parameters and opacity of the films are represented in Table 1. All the films presented high values of $L^{*}$, close to the white plate, which indicates a high transparency. Indeed, $\mathrm{PVOH}$ is well known for its transparency. The addition of HCas did not modify $L^{*}$ parameter, even at 1:1 ratio which indicated the great compatibility of hydrolysates with $\mathrm{PVOH}$.

Regarding film color, incorporation of HCas resulted in an increase in yellow color which provoked a decrease in the hue angle of the blends, whereas chromaticity of the films increased with the content of HCas. The tendency to yellowness when several proteins such as whey protein isolate or gelatin hydrolysate protein were added in different film formulation was also reported by other authors [18-21]. However, these differences were not appreciable to the naked eye. 
Apparent opacity of the films was measured as the area under the absorbance curve in the visible region $(400-800 \mathrm{~nm})$ and in the middle and near UV region (190-400 nm). Low opacity values in the visible region were observed in all the films indicating the high transparency of films to the visible light. Nevertheless, some differences were found in the UV region from 190 to $400 \mathrm{~nm}$. It can be noted that the more HCas was added, the more opacity was reported. It is known that proteins are a good barrier in the UV spectrum region. This is due to certain aromatic amino acids such as tryptophan, tyrosine, and phenylalanine present in $\mathrm{HCas}$, which exerts a great light absorbance in the UV region. Absorbance of UV light by films could be considered as an advantage for packaged foods because they can decrease the undesirable chemical reaction like lipid oxidation that are of importance for maintaining bacterial viability [22].

Mechanical properties of the films are displayed in Table 2. It can be appreciated that casein hydrolysates act as plasticizers on PVOH films, decreasing tensile strength and Young's modulus and increasing elongation of the films. Nevertheless, films still had good mechanical properties with higher strength when comparing with edible films made from proteins [23]. Those results are in line with other authors that found the same behaviour in the mechanical properties of agar films when incorporating protein hydrolysates [20].

In fact, other authors also reported that peptides with short chain can act as plasticizers reducing interactions between polymer chains, thus increasing the free volume between them and leading to a reduction of the tensile strength and Young's modulus [19]. The incorporation of LAB did not have a significant effect on the mechanical properties of the films probably due to the relatively insignificant mass of cells added. 
Table 1. Effect of the incorporation of different amount of HCas and L. sakei on the thickness, moisture content of films stored at $43.2 \%$ and 23.1 $\%$ RH at $12{ }^{\circ} \mathrm{C}$ and optical properties

\begin{tabular}{|c|c|c|c|c|c|c|c|c|}
\hline \multirow{2}{*}{ FILMS } & \multirow{2}{*}{$\begin{array}{c}\text { Thickness } \\
(\mu \mathrm{m})\end{array}$} & \multicolumn{2}{|c|}{$\begin{array}{l}\text { Moisture content } \\
\text { (g/100 g dry film) }\end{array}$} & \multicolumn{3}{|c|}{ Color Properties } & \multicolumn{2}{|c|}{ Opacity (A x nm) } \\
\hline & & $43.2 \%$ & $23.1 \%$ & $L^{*}$ & $h^{\circ}$ & $C^{*}$ & UV & VISIBLE \\
\hline $1: 0$ & $32 \pm 3^{a}$ & $5.8 \pm 0.06^{a}$ & $3.8 \pm 0.04^{a}$ & $89.23 \pm 0.16^{\mathrm{a}}$ & $211.04 \pm 23.2^{\mathrm{d}}$ & $0.02 \pm 0.00^{\mathrm{a}}$ & 31.82 & 22.88 \\
\hline $1: 0,125$ & $32 \pm 3^{a}$ & $6.4 \pm 0.09^{c}$ & $4.0 \pm 0.06^{\mathrm{ab}}$ & $89.25 \pm 0.31^{a}$ & $152.29 \pm 17.13^{b}$ & $0.05 \pm 0.05^{\mathrm{a}}$ & 174.29 & 27.12 \\
\hline $1: 1$ & $31 \pm 4^{a}$ & $8.4 \pm 0.01^{d}$ & $4.1 \pm 0.06^{b c}$ & $90.18 \pm 0.74^{b}$ & $122.61 \pm 8.79^{a}$ & $0.24 \pm 0.02^{b}$ & 255.26 & 49.84 \\
\hline
\end{tabular}

${ }^{a-d}$ Different letters in the same column indicate significant differences among formulations $(p<0.05)$. 
Table 2. Mechanical properties of PVOH films with different proportions casein hydrolysates with and without bacteria.

\begin{tabular}{ccccc}
\hline \multicolumn{2}{c}{ Film (PVOH:HCas) } & $\begin{array}{c}\text { Tensile strength } \\
(\mathrm{MPa})\end{array}$ & $\begin{array}{c}\text { Young's } \\
\text { modulus (MPa) }\end{array}$ & $\begin{array}{c}\text { Elongation at } \\
\text { break (\%) }\end{array}$ \\
\hline without & $1: 0$ & $60 \pm 12^{\mathrm{b}}$ & $2275 \pm 115^{\mathrm{c}}$ & $10 \pm 4^{\mathrm{a}}$ \\
bacteria & $1: 0.125$ & $17 \pm 1^{\mathrm{a}}$ & $1139 \pm 41^{\mathrm{b}}$ & $79 \pm 11^{\mathrm{b}}$ \\
& $1: 1$ & $12 \pm 5^{\mathrm{a}}$ & $445 \pm 273^{\mathrm{a}}$ & $124 \pm 44^{\mathrm{c}}$ \\
\hline L. sakei & $1: 0.125$ & $23 \pm 2^{\mathrm{a}}$ & $1103 \pm 157^{\mathrm{b}}$ & $78 \pm 2^{\mathrm{b}}$ \\
& $1: 1$ & $11 \pm 1^{\mathrm{a}}$ & $453 \pm 102^{\mathrm{a}}$ & $104 \pm 23^{\mathrm{b}, \mathrm{c}}$ \\
\hline \multirow{2}{*}{ lactis } & $1: 0.125$ & $27 \pm 5^{\mathrm{a}}$ & $1078 \pm 154^{\mathrm{b}}$ & $106 \pm 24^{\mathrm{b}, \mathrm{c}}$ \\
& $1: 1$ & $11 \pm 1^{\mathrm{a}}$ & $464 \pm 95^{\mathrm{a}}$ & $123 \pm 49^{\mathrm{c}}$ \\
\hline
\end{tabular}

$a, b, c$ Different letters in the same column indicate significant differences among formulations $(p<0.05)$.

\subsection{Structural and morphological properties of the films}

\subsubsection{Thermal properties of the films}

Thermal properties of polyvinyl alcohol (PVOH) powder, casein hydrolysates (HCas), and their blends in the form of cast films without incorporating or incorporating L. lactis and L. sakei are shown in Table 3. PVOH powder experienced a glass transition temperature $\left(T_{g}\right)$ at $54.1^{\circ} \mathrm{C}$, and the melting temperature $\left(\mathrm{T}_{\mathrm{m}}\right)$ at $184.7{ }^{\circ} \mathrm{C}$ which is in line with the results given in the literature [24]. Casein hydrolysates are amorphous and only present a glass transition temperature at $73.1{ }^{\circ} \mathrm{C}$. Cast PVOH films and those blended with $\mathrm{HCas}$ at the ratio $1: 0.125$ displayed a unique $\mathrm{T}_{\mathrm{g}}$ around $68.2^{\circ} \mathrm{C}$ and $69.2{ }^{\circ} \mathrm{C}$, respectively. However, two separate $T_{\text {gs }}$ were observed at $62.4^{\circ} \mathrm{C}$ and $74.3^{\circ} \mathrm{C}$ in films blended with $\mathrm{HCas}$ at $1: 1$ weight ratio which suggested the occurrence of phase separation between $\mathrm{PVOH}$ and $\mathrm{HCas}$. The $\mathrm{T}_{\mathrm{g}}$ related to $\mathrm{PVOH}$ phase at $62.4{ }^{\circ} \mathrm{C}$ was slightly lower respect to plain PVOH films which can be due to the plasticizing effect of HCas. 
Table 3. Thermal properties of films and its blends with HCas measured by MDSC.

\begin{tabular}{|c|c|c|c|c|}
\hline Sample & & $\mathbf{T}_{\mathbf{g}}\left({ }^{\circ} \mathrm{C}\right)$ & $\mathbf{T}_{\mathrm{m}}\left({ }^{\circ} \mathrm{C}\right)$ & $\Delta \mathbf{H}(\mathrm{J} / \mathrm{g})$ \\
\hline \multicolumn{5}{|c|}{ POWDER } \\
\hline \multicolumn{2}{|l|}{ PVOH } & 67.6 & 185.5 & 43.3 \\
\hline \multicolumn{2}{|l|}{ HCas } & 73.3 & - & - \\
\hline \multicolumn{5}{|c|}{ FILMS } \\
\hline \multirow{3}{*}{$\begin{array}{l}\text { without } \\
\text { bacteria }\end{array}$} & $1: 0$ & 68.3 & 185.5 & 32.6 \\
\hline & 1:0.125 & 69.3 & 182.6 & 16.1 \\
\hline & $1: 1$ & $\begin{array}{l}74.3 \\
62.5\end{array}$ & 168.9 & 5.5 \\
\hline \multirow{3}{*}{ L. sakei } & $1: 0$ & 64.8 & 185.2 & 30.6 \\
\hline & 1:0.125 & 67.7 & 180.3 & 15.4 \\
\hline & $1: 1$ & $\begin{array}{l}74.2 \\
63.8\end{array}$ & 168.9 & 6.5 \\
\hline \multirow{3}{*}{ L. lactis } & $1: 0$ & 67.6 & 183.1 & 28.4 \\
\hline & $1: 0.125$ & 69.3 & 184.9 & 25.6 \\
\hline & $1: 1$ & $\begin{array}{l}74.9 \\
64.6\end{array}$ & 171.8 & 4.9 \\
\hline
\end{tabular}

$T_{\mathrm{g}}\left({ }^{\circ} \mathrm{C}\right)$, temperature of glass transition; $T_{\mathrm{m}}\left({ }^{\circ} \mathrm{C}\right)$, temperature of melt; $\Delta H(\mathrm{~J} / \mathrm{g})$, melting enthalpy.

The melting temperature of plain $\mathrm{PVOH}$ films was similar than that for $\mathrm{PVOH}$ powder, although the percentage of crystallinity of the films $(\chi \%)$ suffered a slight decrease with respect to the powder. The melting temperature of $\mathrm{PVOH}$ blended with $\mathrm{HCas}$ moved to lower values, and the melting enthalpy and crystallinity of $\mathrm{PVOH}$ films incorporating $\mathrm{HCas}$ decreased considerably as the content of protein hydrolysates in the matrix increased. Therefore, inclusion of a great amount of low molecular weight hydrolysates of casein disrupted crystallization of PVOH and also decreased the melting point of the polymer which elucidates an increase in smaller less organised crystallites. When L. lactis or L. sakei were added to the films, no relevant changes were found in the thermodynamic properties of them. 


\subsubsection{SEM}

The morphology of the cross-section surface of polyvinyl alcohol (PVOH) films and their blends with casein hydrolysates (HCas) was examined by SEM and showed in Figure 2.

The fracture surface of plain PVOH films and of those blended with a small amount of HCas (1:0.125 weight ratio) was uniform and smooth as shown in Figure 2 a) and Figure 2 b) respectively. However, a less smooth cross-section surface with pores and cracks was observed in films with a greater amount of HCas (1:1 weight ratio) as Figure 2 c) shows. This topography is due to separation of the blend components in two phases. Meanwhile, the observed cracks are due to the mechanical damage caused when the cross-sectional cut was made using freeze-fracture method in liquid nitrogen since 1:1 films did not have a brittle nature as reported when measuring mechanical properties.

The differences observed between 1:0.125 and 1:1 films indicate that when the content of HCas in the blends is beyond a certain threshold, the blends are not miscible. SEM observations support the conclusions obtained by means of thermal characterization of the films, where two separate $\mathrm{Tg}$ were observed in 1:1 film and was attributed to a phase separation between $\mathrm{PVOH}$ and $\mathrm{HCas}$. The cross-section surfaces of films carrying LAB were similar to films without incorporating bacteria (results not shown).

These findings along with the MSDC results found for films carrying bacteria support that their incorporation into the films did not modify their mechanical properties. 3.3.3. Fluorescence Light microscopy

Fluorescence light microscopy images of polyvinyl alcohol (PVOH) films and their blends with casein hydrolysates (HCas) loaded with bacteria stained with DAPI are shown in Figure 3. Pictures revealed that the arrangement of the entrapped bacteria in the film matrix was different depending on the strain immobilized and the matrix formulation. 

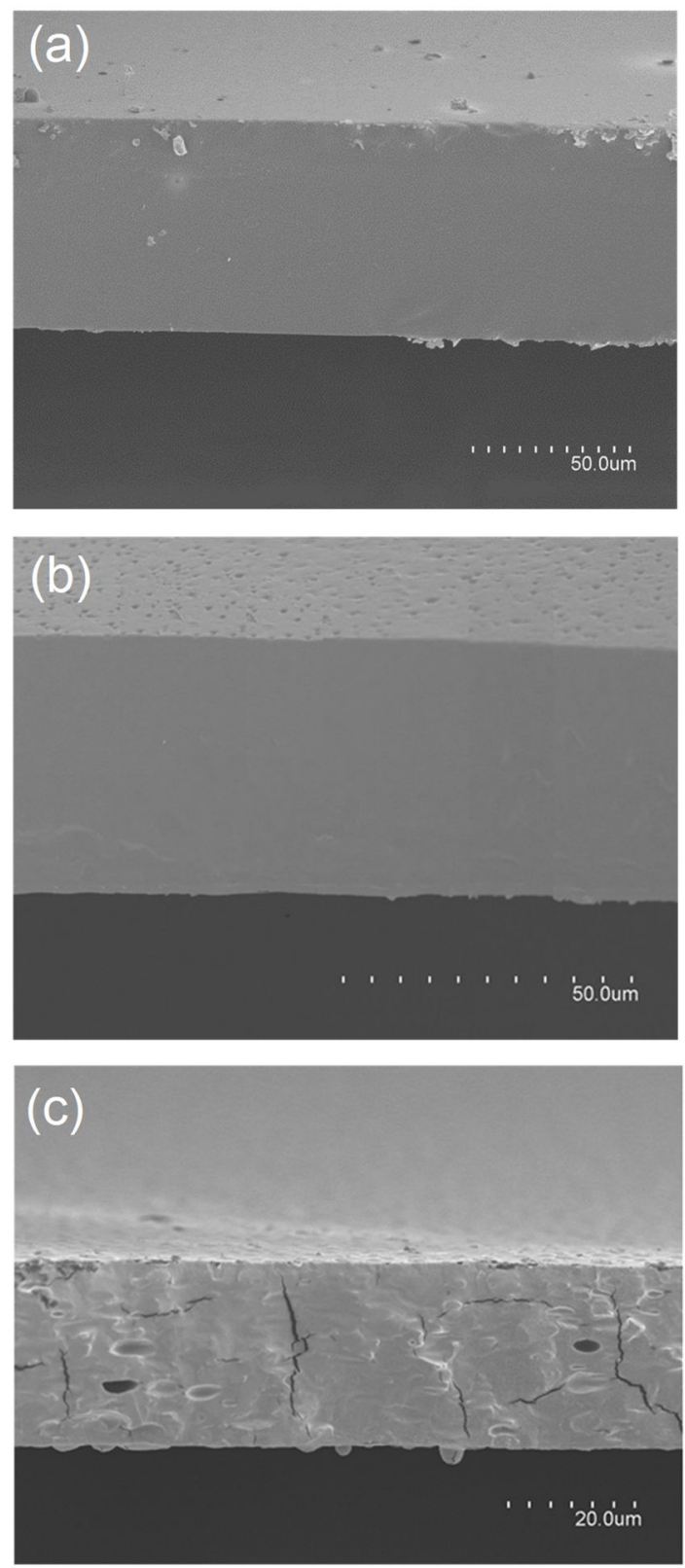

Figure 2. Scanning electron microscopy pictures of cross-section surface of $\mathrm{PVOH}$ films blended with HCas, PVOH:HCas, at different weight ratios: a) 1:0, b) 1:0.125 and c) $1: 1$. 
Regarding the distribution of $L$. lactis in plain PVOH films, dispersed bacterial clusters of different sizes were observed (Figure 3 a). Bacteria clusters tend to agglomerate in large aggregates of undefined shape with a high cell density when a small amount of casein hydrolysates was added to $\mathrm{PVOH}$ films (Figure $3 \mathrm{~b}$ ); when PVOH was blended with HCas at the ratio 1:1, it was found bacterial aggregates of irregular shape and very different sizes (Figure $3 \mathrm{c}$ ). In contrast, when L. sakei was added to PVOH films, the cells distributed uniformly, and no clusters were observed (Figure $3 \mathrm{~d}$ ). Small clusters of L. sakei were formed in 1:0.125 films (Fig 3 e); increasing the amount of HCas in the ratio 1:1 gave rise to larger clusters (Figure $3 \mathrm{f}$ ). Doherty et al., (2010) studied cell immobilization of Lactobacillus rhamnosus GG in native, denatured, and hydrolysed whey protein isolate (WPI), reporting the formation of cell aggregates in hydrolysed proteins together with higher values of cell survival. Many bacteria present the property of auto-aggregate which has been related with a greater survival rate against environmental stresses [26].

In the current study, it was observed that after centrifugation of both bacteria, the auto-aggregation of L. lactis was much greater than the autoaggregation of $L$. sakei. Indeed, studies carried out with LAB have shown that bacteria auto-aggregation is strain dependent [27]. This may explain why in plain PVOH films small clusters of bacteria were observed when L. lactis was added while they were not observed with $L$. sakei.

Several authors have found that bacteria strains with autoaggregation ability present a greater hydrophobic surface compared with autoaggregation-deficient bacteria [28]. Since casein hydrolysates have hydrophobic groups along the unfolded peptidic chains, they are able to stablish hydrophobic interactions with apolar binding sites present in the surface of LAB cells [29]. This "preference" for the hydrophobic groups of the $\mathrm{HCas}$ instead of polar groups of hydrophilic $\mathrm{PVOH}$ may explain clustering or/and aggregation by current bacteria when casein hydrolysates are added to $\mathrm{PVOH}$ matrix. 

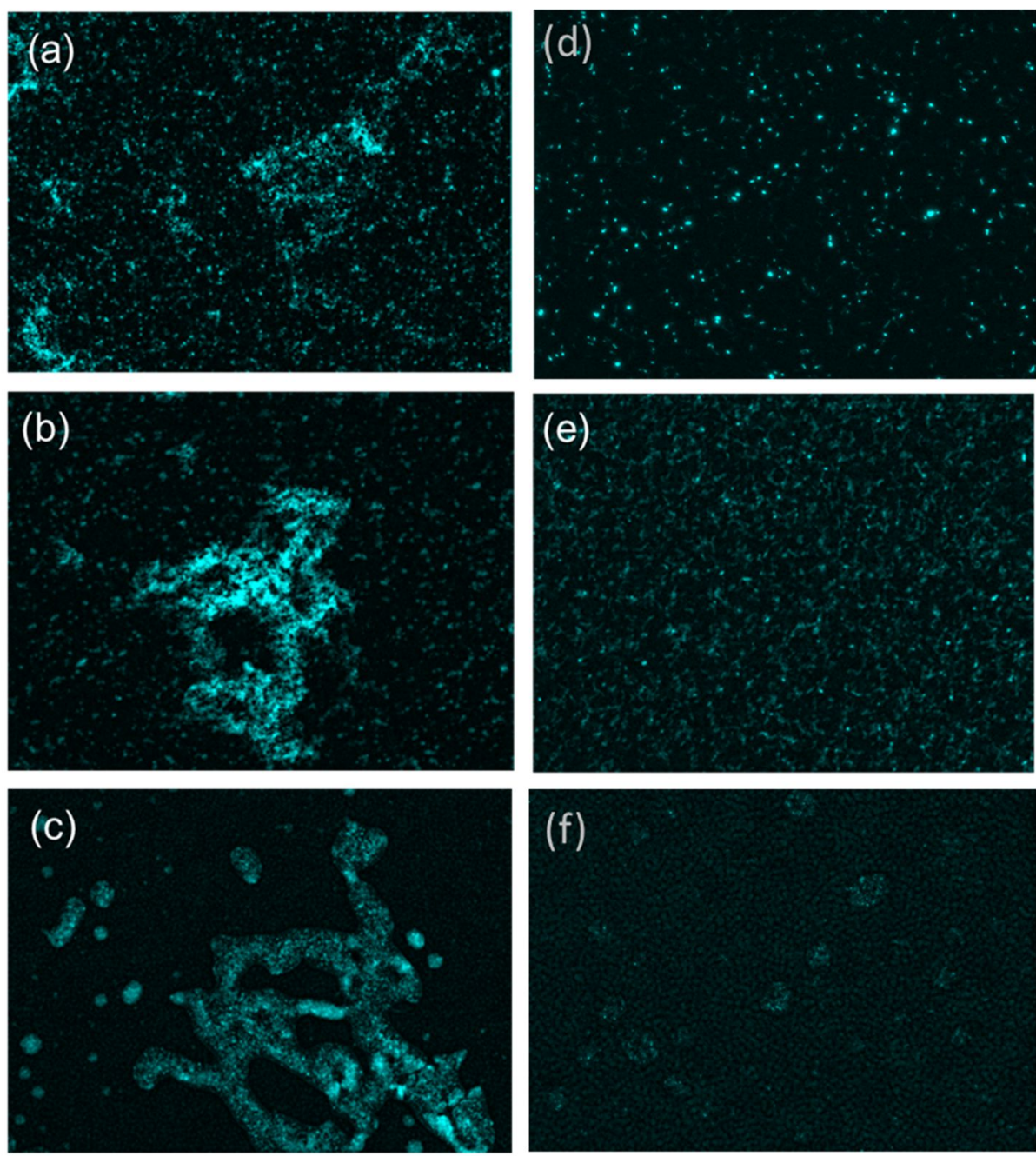

Figure 3. Fluorescence light microscopy images of L. lactis (a-c) and L. sakei (d-f) entrapped in $\mathrm{PVOH}$ films blended with $\mathrm{HCas}, \mathrm{PVOH}: \mathrm{HCas}$, at different weight ratios: a \& d) 1:0, b \& e) 1:0.125 and c \& f) 1:1. Blue color corresponds to cells dyed with DAPI. Magnification 20x.

Together with the ability of cells to auto-aggregate, the disruption of polymer-polymer interactions in the structure of $\mathrm{PVOH}$ by $\mathrm{HCas}$, and the decrease of film crystallinity could also contribute to the auto-aggregation of cells during the processing of the films. 
The drying time was also a key factor in the formation of these clusters, in the current study when thinner films were prepared and dried in $30 \mathrm{~min}$ compared to 18 hours for regular films, clusters were only observed for $L$. lactis immobilized in 1:1 films and were much smaller in size than those observed above (supplementaryInformation, Figure S6). In fact, autoaggregation is a time-dependent process characterized by the creation of a network between the cells and further sedimentation [30]. The same authors demonstrated that auto-aggregation follows a constant increase through the time for all the strains studied (including $L A B$ ), reaching the maximum autoaggregation values after $4 \mathrm{~h}$ of incubation at $23{ }^{\circ} \mathrm{C}$. This fact is consistent with the current results where no aggregates were found in the films dried in 30 minutes.

\subsection{Antioxidant properties of the films}

ABTS assay was selected to test the antioxidant properties of the films since the radical and the films solubilize completely in water. ABTS radical scavenging results are shown in Table 4.

Plain polyvinyl alcohol (PVOH) films did not show ABTS radical scavenging activity regardless the addition of $L A B$. However, when casein hydrolysates (HCas) were added, the ABTS radical scavenging reaction increased considerably after $1 \mathrm{~h}$ reaching almost a $100 \%$ of scavenging for 1:1 blend films. Previous studies conducted by ABTS + assay of different amino acids determined that cysteine followed by tryptophan, tyrosine and histidine were the most active scavengers [31]. All of those amino acids are present in HCas [32]. These results are in line with different works reporting the accessibility to the oxidant-antioxidant test systems is greater for small peptides and amino acids than for large peptides and proteins [31,33]. In this case, casein hydrolysates also had the ability to scavenge the ABTS radical cation by hydrogen or electron donation [34]. 
Table 4. Antioxidant activity of just made PVOH films with different proportions of casein hydrolysates with and without bacteria, and after one month of storage at $12{ }^{\circ} \mathrm{C}$ at $43.2 \%$.

\begin{tabular}{cccc}
\hline Film (PVOH:HCas) & $\begin{array}{c}\text { Newly dried films } \\
\text { I (\%) }\end{array}$ & $\begin{array}{c}\text { One month } \\
\text { stored films } \\
\text { I (\%) }\end{array}$ \\
\hline without & $1: 0$ & $0 \pm 0^{\mathrm{a}}$ & $0 \pm 0^{\mathrm{a}}$ \\
bacteria & $1: 0.125$ & $63.9 \pm 3^{\mathrm{b}}$ & $64.0 \pm 1^{\mathrm{b}}$ \\
& $1: 1$ & $97.3 \pm 0.4^{\mathrm{c}}$ & $97.1 \pm 0.3^{\mathrm{c}}$ \\
& $1: 0$ & $0 \pm 0^{\mathrm{a}}$ & $0 \pm 0^{\mathrm{a}}$ \\
L. sakei & $1: 0.125$ & $64.1 \pm 2^{\mathrm{b}}$ & $65.3 \pm 0.1^{\mathrm{b}}$ \\
& $1: 1$ & $96.9 \pm 0.4^{\mathrm{c}}$ & $91.2 \pm 0.1^{\mathrm{c}}$ \\
& $1: 0$ & $0 \pm 0^{\mathrm{a}}$ & $0 \pm 0^{\mathrm{a}}$ \\
L. lactis & $1: 0.125$ & $64.8 \pm 2.3^{\mathrm{b}}$ & $65.1 \pm 1.1^{\mathrm{b}}$ \\
& $1: 1$ & $96.9 \pm 0.2^{\mathrm{c}}$ & $92.7 \pm 1^{\mathrm{c}}$ \\
\hline
\end{tabular}

As it can be seen in Table 4, no differences in ABTS radical scavenging were found between newly dried films and one-month stored films at $43.2 \%$. These results seem logical since no film degradation was produced at such low humidity and storage time.

Finally, no differences in ABTS radical scavenging were found when $L A B$ were added to the films. Other authors have reported that some LAB strains such as $L$. lactis or $L$. sakei are able to produce antioxidant exopolysaccharides [35,36]. Nevertheless, those molecules are products of their metabolism and when LAB were entrapped in films at such low $\mathrm{RH}$, they remain in a latency state [37].

\subsection{Microbiological studies of the films}

3.5. 1. $L A B$ survival after film drying and in vitro antilisterial activity at $37^{\circ} \mathrm{C}$ The viability of $L$. lactis and $L$. sakei in polyvinyl alcohol $(\mathrm{PVOH})$ and their blends with casein hydrolysates (HCas) after film processing is displayed in Figure 4. 


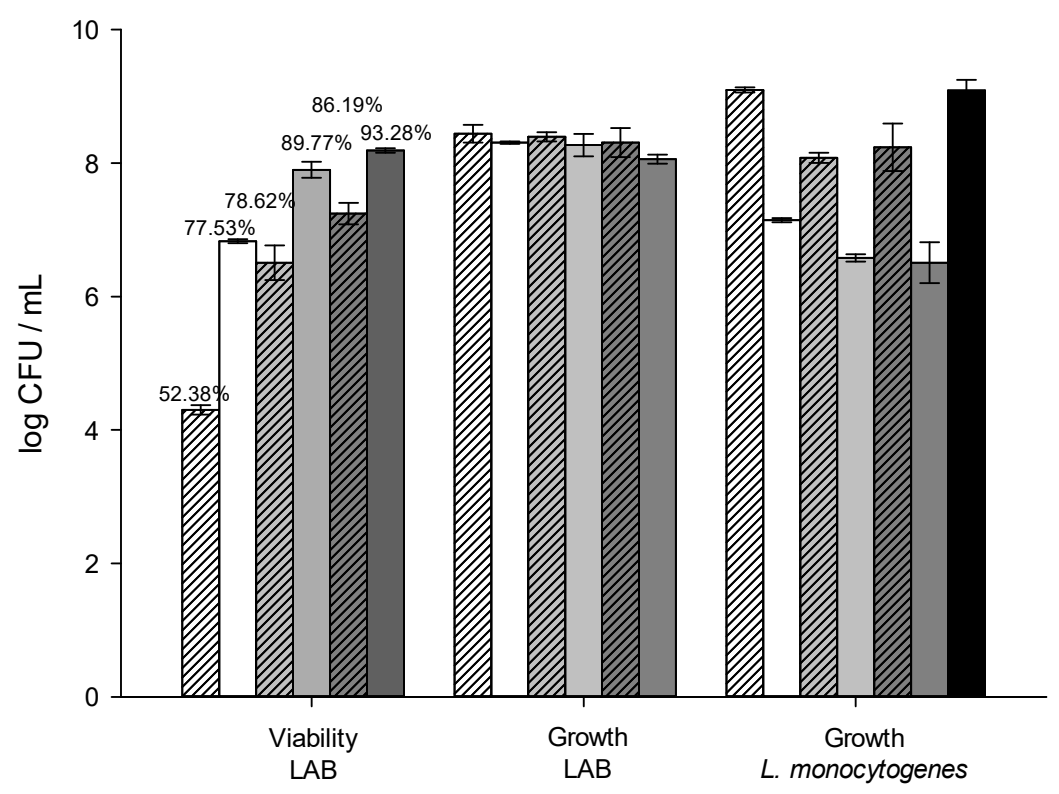

WIIA Film (1:0) - L. sakei खIIA Film (1:0.125) - L. sakei WIIA Film (1:1) - L. sakei Film (1:0) - L. lactis $\square$ Film (1:0.125) - L. lactis Film $(1: 1)-$ L. lactis

Figure 4. Viability of $L$. lactis and $L$. sakei in just made PVOH films blended with HCas, PVOH:HCas, at different weight ratios (1:0, 1:0.125, 1:1); survival of LAB after being in contact with the pathogen during the antimicrobial assay; and antimicrobial activity of the different blend films against L. listeria monocytogenes. Mean values and $95 \%$ LSD intervals.

The survival of $L A B$ after being in contact with the pathogen during the antimicrobial assay and the antimicrobial activity of the films against $L$. monocytogenes after $24 \mathrm{~h}$ of incubation at $37^{\circ} \mathrm{C}$ also are shown in the figure. In the present study, for the same film formulation and processing parameters, $L$. lactis presented greater viability values than $L$. sakei, being differences more accentuated in plain $\mathrm{PVOH}$ films where L. lactis had a viability of $77.53 \%$ while that for L. sakei was $52.38 \%$.

The viability of lactic acid bacteria depends on factors that are intrinsic or inherent to the $L A B$ strain and on extrinsic factors such as film processing parameters and composition. 
Related to extrinsic factors affecting cell viability, it has to be considered that many parameters can injure bacterial cells during film processing by casting. In this regard, the drying step is a critical factor for bacteria survival during film casting since surface proteins, cell wall and membrane can be damaged when bound water is removed during the evaporation of the solvent. As a consequence, desiccation can destabilize the structural integrity of cellular components which entails in loss or damage of cell function [38]. However, the parameters used in this work to cast the films, low temperature for a prolonged time allows low rates of dehydratation and great percentage of bacteria survival after their encapsulation in a film. Therefore, film casting can be considered a lowaggressive technique for bacteria encapsulation in contrast to other more aggressive techniques such as spray drying where greater temperatures and short times are required (Carvalho et al., 2004, Meng et al., 2008).

Besides the drying process, the composition of the film plays a considerable role in the viability of encapsulated bacteria. In the current work, the incorporation of casein hydrolysates to the $\mathrm{PVOH}$ matrix increased the viability of both $L A B$. When $H C$ as were added at the weight ratio 1:0.125 with respect to $\mathrm{PVOH}$, the viability of L. lactis increased from $77.5 \%$ to 89.8 $\%$, and from $52.4 \%$ to $78.6 \%$ for L. sakei.

In the present study, it has been observed by fluorescence light microscopy that the incorporation of $\mathrm{HCas}$ in $\mathrm{PVOH}$ films promoted that $L$. lactis clusters observed in $\mathrm{PVOH}$ films tended to agglomerate in large aggregates, and L. sakei tended to form clusters when HCas were incorporated. Several authors have related high percentages of autoaggregation with greater resistance to stresses such as acid, salts or dehydration. In the present study, the films with greater bacterial viability were those having a greater content of HCas and consequently, autoaggregation.

Apart from HCas providing protection to the cells against dehydration by promoting cell auto-aggregation during the step of evaporation of the solvent in the processing of the film, HCas could also supply micronutrients and provide protection to the cells against the dehydratation step by additional ways. In that sense, it has been reported that amino acids and low molecular weight polymers can penetrate the cell 
wall providing protection to the cell during dehydratation (Carvalho et al., 2004, Meng et al., 2008). The molecular weight of commercial HCas used in this work is around $5 \mathrm{kDa}$ [40], therefore they could act in that way although this kind of study has not been the aim of this work.

The antimicrobial capacity of the resulting films was tested against $L$. monocytogenes in liquid medium (TSB+YE) after $24 \mathrm{~h}$ of incubation at $37^{\circ} \mathrm{C}$ which is the optimal growth temperature of the pathogen. TSB+YE tubes inoculated with $L$. monocytogenes without film were used as control since it was previously proved that nor $\mathrm{PVOH}$ nor $\mathrm{HCas}$ had influence on the growth of the pathogen. The survival of $L A B$ in the culture medium was also determined, and the results are displayed in Figure 4. When films entered in contact with the liquid culture medium, they lost their integrity and readily dissolved, thus releasing the carrying bacteria. The availability of nutrients and the amount of water provided by TSB+YE promoted LAB growth reaching counts up to 8 log independently of the film composition and the type of LAB. This fact proves that although both bacteria had different viabilities, when films were immersed in enriched culture medium, they were able to reach the stationary phase in $24 \mathrm{~h}$. Those results are in accordance with previous works where $L$. lactis population was recovered achieving the stationary phase in contact with $L$. monocytogenes regardless of the initial inoculum using the same incubation time and culture medium conditions [7].

In general, the antilisterial activity of films carrying L. lactis was greater compared with those carrying $L$. sakei, independently of the film composition. Regarding the effect of the film composition on the antimicrobial activity, this increased when films were supplemented with HCas, obtaining the best results when incorporating HCas at 1:1 weight ratio. However, only a slight increase in the antimicrobial capacity of the films was observed for 1:1 blend films. Thus. only a small amount of HCas is enough to increase the effectiveness of PVOH films when tested in liquid medium at 37 ${ }^{\circ} \mathrm{C}$.

3.5.2. Evolution of the antilisterial activity of the films immersed in liquid medium for 15 days at $4{ }^{\circ} \mathrm{C}$.

The antilisterial activity of $\mathrm{PVOH}$ film and its blends with $\mathrm{HCas}$ carrying $\mathrm{LAB}$ was studied in TSB+YE for 15 days at $4{ }^{\circ} \mathrm{C}$ in order to simulate the storage of 
a refrigerated liquid food. The survival of $L A B$ liberated from the films into the medium previously inoculated with $L$. monocytogenes was also monitored during this time and the results are displayed in Figures $5 a$ and $5 b$.

Figure $5 a$ shows that in spite of $L$. lactis and $L$. sakei being mesophiles they can growth at refrigeration temperatures since they have psychrotrophic behavior as well as the mesophile $L$ monocytogenes. However, the growth rate was different depending on the bacteria. L. lactis incorporated in plain PVOH films or films blended with HCas maintained their initial population through the whole storage time. However, independently of the initial population of the bacteria and film formulation, L. sakei only reached $8 \log (\mathrm{CFU} / \mathrm{mL})$ counts after 15 days of storage.

The antilisterial activity of the films is represented in Figure $5 \mathrm{~b}$. It can be observed that this property increased for the two LAB assayed and for all the film combinations during the first 9 days of storage. Films of PVOH blended with HCas and incorporating $L$. lactis exhibited the greater antilisterial activity. After 9 days of refrigerated storage, reductions of 7 logs were obtained for 1:1 PVOH:HCas films and around 6 log for 1:0.125 $\mathrm{PVOH}: \mathrm{HCas}$ films, whereas plain PVOH films achieved reductions of $3 \mathrm{log}$ after this time. Regarding the antilisterial activity exerted by films carrying $L$. sakei after nine days of storage at $4{ }^{\circ} \mathrm{C}$, it was found that film composition had little effect on the antimicrobial properties of the films, and plain PVOH and 1:0.125 blend films achieved reductions of $3 \log$, whereas reductions were of $3.5 \log$ for 1:1 blend films. In the next days of storage reductions began to decrease independently of the bacteria strain and film composition except for PVOH film carrying L. lactis. One explanation for this behaviour could be that, after nine days of storage nutrients in the medium are scarce and $L A B$ could decrease their active metabolism and production of bacteriocins. Moreover, L. monocytogenes could tolerate better the refrigeration temperature used when there is a lack of nutrients in the medium. 
a)

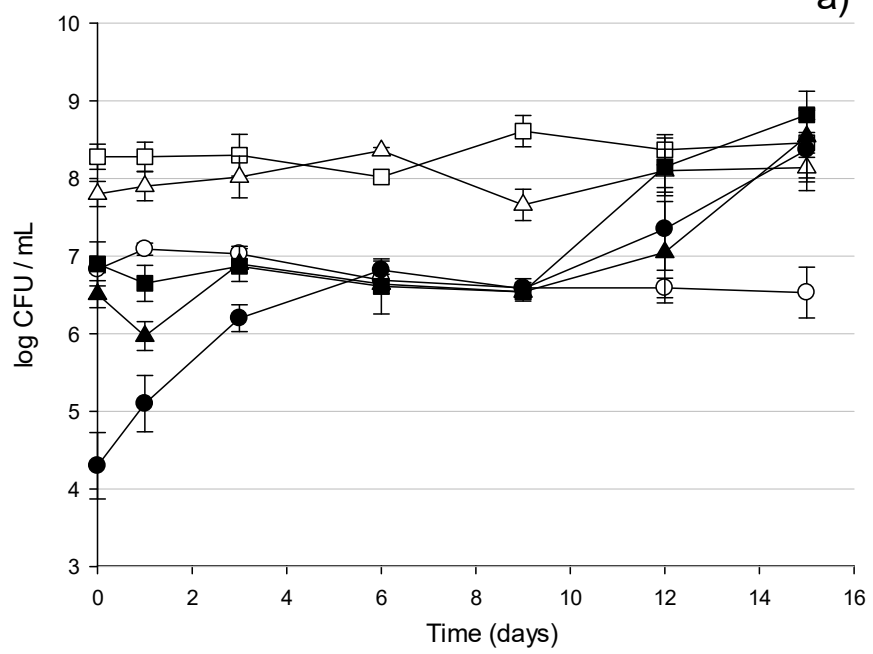

b)

Time (days)

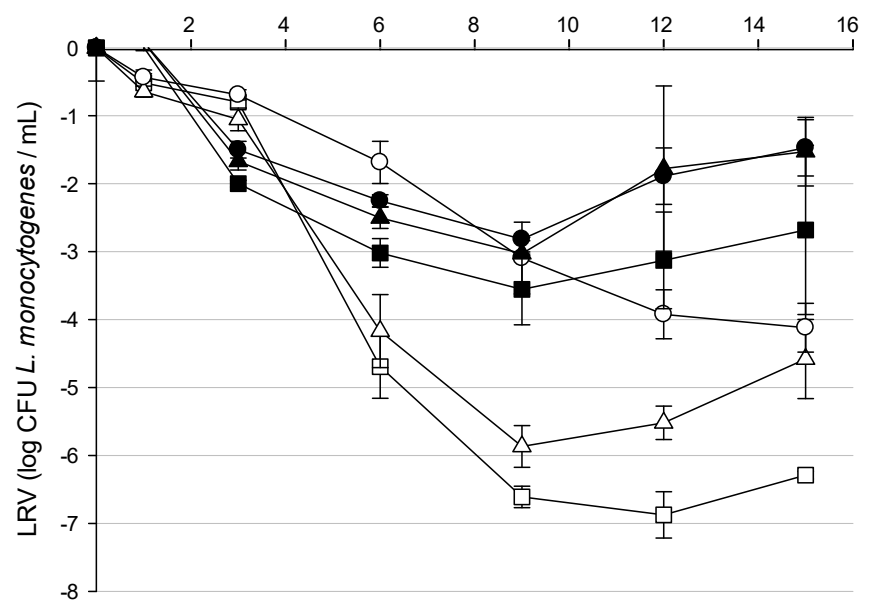

$\square-$ Film (1:1) - L. lactis $\longrightarrow$ - Film (1:0.125) - L. lactis $-0-$ Film (1:0) - L. lactis
$\square$ Film (1:1) - L. sakei $\simeq$ Film (1:0.125) - L. sakei - Film (1:0) - L. sakei

Figure 5. Growth of lactic acid bacteria (a) and L. monocytogenes logarithmic reduction value (b) corresponding to $\mathrm{PVOH}$ films blended with $\mathrm{HCas}, \mathrm{PVOH}: \mathrm{HCas}$, at different weight ratios (1:0, 1:0.125, 1:1) and immersed in liquid medium (TSB+yeast) stored at $4{ }^{\circ} \mathrm{C}$ for 15 days. Mean values and 95\% LSD intervals. 
Correlating Figure $5 a$ with Figure $5 b$, it can be appreciated that during the first 9 days of storage there is a slower growth of L.sakei coming from PVOH films, whereas the population of $L$. sakei corresponding to films incorporating HCas remained constant and around 7 log through the first 9 days of storage. Regarding L. lactis, its population was of 7 log for bacteria coming from plain $\mathrm{PVOH}$ films and 8 log for bacteria coming from films incorporating HCas through the whole storage time (Figure 5a). At day 9 the antilisterial activity exerted by plain $\mathrm{PVOH}$ films carrying $L$. lactis was the same than that for plain PVOH carrying L. sakei and their blends with HCas. However, the antimicrobial activity of $\mathrm{PVOH}$ blends incorporated with $L$. lactis was higher (Figure 5b). Thus, it is observed that the greater survival of the cells in the films is accompanied by a superior and rapid recovery of the cells in the refrigerated medium inoculated with L. monocytogenes and also better antimicrobial activity.

These results correlate well with the results obtained when studying the distribution of bacteria in the films by light fluorescence microscopy and concluding that cell auto-aggregation promoted by HCas during the processing of the film, implies higher cell viability and a slight increase of the antimicrobial activity evaluated at $37^{\circ} \mathrm{C}$ after $24 \mathrm{~h}$ (section 3.5.1). However, when the test is carried out at $4{ }^{\circ} \mathrm{C}$ for 15 days immersing the films in the liquid medium at day zero, and monitoring bacterial population and antilisterial capacity of the two LAB strains, it can be clearly appreciated that the evolution of the population of each strain through the time is different and related to the film composition. Moreover, the incorporation of HCas in $\mathrm{PVOH}$ films slightly affects the antilisterial properties of films with $L$. sakei compared with films with L. lactis.

\subsubsection{Survival of $L A B$ in long-term stored films}

When encapsulating bacteria in a polymer matrix, the knowledge of their survival throughout the time of storage is essential in order to ensure its effectivity when are used.

The inactivation of LAB during storage is influenced by several factors such as species/strain dependency, storage environmental conditions, water content in the polymer matrix, presence of protective agents, and oxidative 
damage of the cells due to oxygen permeation through the encapsulating polymer wall [41].

Therefore, the effect of storage time on cell viability of L. lactis and L. sakei encapsulated in polyvinyl alcohol $(\mathrm{PVOH})$, plain or blended with casein hydrolysates (HCas) and stored at $23.1 \%$ and $43.2 \% \mathrm{RH}$ and $20{ }^{\circ} \mathrm{C}$ for one month is depicted in Figure 6.

Cell viability in plain PVOH films, was reduced from $6.8 \mathrm{log}$ to $5.3 \mathrm{log}$ for L. lactis and from $4.5 \log$ to $3.5 \log$ for $L$. sakei after one more of storage at $23.1 \% \mathrm{RH}$, whereas at $43.2 \% \mathrm{RH}$ the viability decreased in the same range but with more abrupt changes.

Residual moisture content in the film can allow in some degree biochemical and enzymatic reactions and metabolic activity. Since the storage environment does not allow reproduction, cells presenting a minor degree of metabolic activity would suffer natural death [42]. In the present study, the water content in the films exposed to the two relative humidities studied is below to the water needed for LAB to start metabolic processes [43]. Thus, $\mathrm{PVOH}$ films were able to sustain viable $L A B$ more than 1 month with high levels of bacterial counts at the humidities studied.

Compared with other polymers used to entrap $L A B, P V O H$ is a polymer that achieves considerable maintenance of viability. Different authors have observed reductions from 4 to 5 logs in the viability of LAB immobilized in biopolymer films for a long-term storage (Ma et al., 2019; Ye et al., 2018; Sánchez-González et al., 2018). When PVOH was blended with $\mathrm{HCas}$, the long-term viability of $L$. lactis and $L$. sakei improved considerably. $\mathrm{PVOH}$ films blended with $\mathrm{HCas}$ at the 1:1 ratio maintained the viability of $L$. lactis in $8 \log \mathrm{CFU} / \mathrm{ml}$ without suffering any variation through the storage time independently of the environmental moisture used to store the films. This result also was observed for 1:0.125 blend films incorporating L. lactis although the viability values were slightly lower. Cell viability of $L$. sakei in 1:1 blend stored at $23.1 \% \mathrm{RH}$ also was maintained stable in $7 \mathrm{log}$, and the viability varied between 6.5 and 6 log for the blend 1:0.125 when films were stored at $23.1 \% \mathrm{RH}$. Storing the films at $43.2 \% \mathrm{RH}$ gave rise to some viability variations but always ranging 6-7 log. 

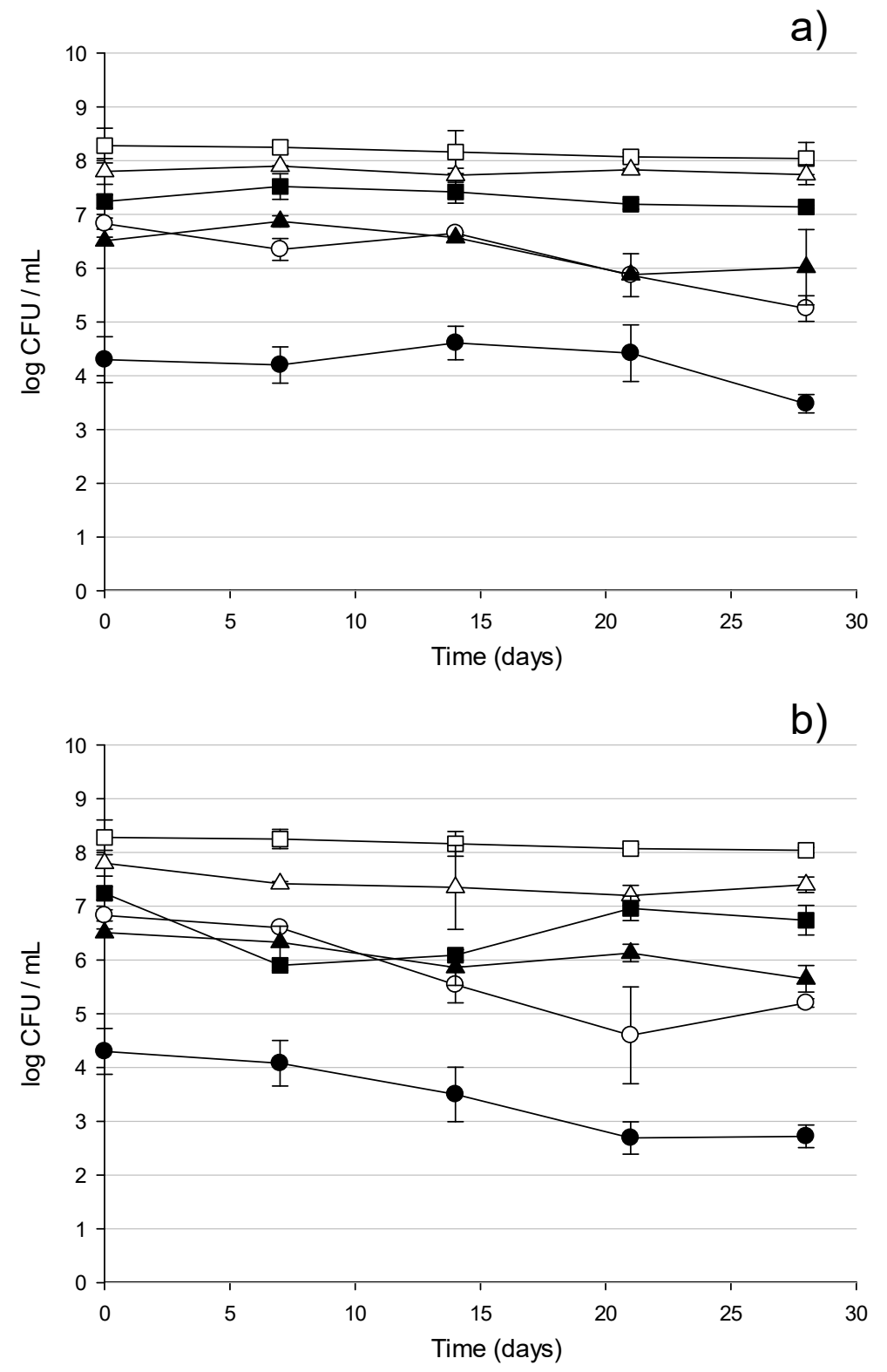

$\square-$ Film (1:1) - L. lactis $\triangle$ - Film (1:0.125) - L. lactis - - Film (1:0) - L. lactis
- Film (1:1) - L. sakei $\triangle$ Film (1:0.125) - L. sakei - Film (1:0) - L. sakei

Figure 6. Viability of $L$. lactis and $L$. sakei in PVOH films blended with HCas at different weight ratios and stored at $20^{\circ} \mathrm{C}$ and $23.1 \% \mathrm{RH}$ (a) and $43.2 \% \mathrm{RH}$ (b). Mean values and $95 \%$ LSD intervals. 
It can be stated from these results that long-term viability of L. lactis and L.sakei in the blends increased compared with that in plain PVOH films, and was higher and less affected by environmental moisture content for $L$. lactis. These findings can probably be attributed to the formation of aggregates in blends carrying L. lactis and clusters in blends incorporated with $L$. sakei as observed by fluorescence light microscopy. Cells can better support time and some degree of humidity when auto-aggregation is greater as it has been observed.

Oxidative stress is another factor that bacteria have to face to avoid cell damage and death during storage. PVOH presents high oxygen barrier properties at low humidities, and still exhibits great oxygen barrier properties at the humidities assayed in the current work [45], thus, PVOH can exert a protective role against oxygen and oxidative processes in LAB such as lipid oxidation of membrane fatty acid that is responsible for cell death during storage [46]. Moreover, it is also deeply studied that proteins can inhibit the peroxidation o membrane cells via free radical scavenging and can maintain the biological activity of LAB. In the current study, it has been demonstrated that the incorporation of HCas into the polymer matrix, increases the antioxidant activity of films reaching values of almost $100 \%$ antioxidant inhibition in 1:1 films maintaining the antioxidant activity after one month of storage.

\section{Conclusions}

PVOH has been successfully blended with casein hydrolysates (HCas) for carrying nisin-producing $L$. lactis and sakacin-producing $L$. sakei acting as biocontrol agents against $L$. monocytogenes. Cell viability after film drying was strain-dependent and was enhanced with the addition of HCas. Films supplemented with HCas also maintained L. lactis and L. sakei viability throughout one-month storage. HCas promoted auto-aggregation of cells which was more accused for $L$. lactis strain. Bacterial auto-aggregation in the films could be related with a greater cell viability. The higher antilisterial activity was obtained for $\mathrm{PVOH}$ blended with $\mathrm{HCas}$ at 1:1 weight ratio, and 
entrapping L. lactis. HCas act as plasticizers for PVOH polymer, and when a great amount of HCas was added to the films, their mechanical strength dramatically decreases improving film elongation; HCas also confers films with UV barrier and antioxidant properties. In spite of the loss of mechanical strength, films incorporating a great proportion of $\mathrm{HCas}$ can be formed by casting and used as self-standing films or coatings to be applied in the antilisterial preservation of refrigerated foods or as carriers of LAB.

\section{Acknowledgments}

The authors acknowledge the financial support of the Spanish Ministry of Spanish Ministry of Science, Innovation and universities (AGL2015-64595-R, RTI2018-093452-B-I00).

\section{References}

1. Musatti, A.; Cavicchioli, D.; Mapelli, C.; Bertoni, D.; Hogenboom, J.A.; Pellegrino, L.; Rollini, M. From Cheese Whey Permeate to Sakacin A: A Circular Economy Approach for the Food-Grade Biotechnological Production of an Anti-Listeria Bacteriocin. Biomolecules 2020, 10, 597, doi:10.3390/biom10040597.

2. De Vuyst, L.; Leroy, F. Bacteriocins from lactic acid bacteria: Production, purification, and food applications. J. Mol. Microbiol. Biotechnol. 2007, 13, 194-199, doi:10.1159/000104752.

3. Guimarães, A.; Abrunhosa, L.; Pastrana, L.M.; Cerqueira, M.A. Edible Films and Coatings as Carriers of Living Microorganisms: A New Strategy Towards Biopreservation and Healthier Foods. Compr. Rev. Food Sci. Food Saf. 2018, 17, 594-614.

4. Bekhit, M.; Arab-Tehrany, E.; Kahn, C.J.F.; Cleymand, F.; Fleutot, S.; Desobry, S.; Sánchez-González, L. Bioactive films containing alginatepectin composite microbeads with Lactococcus lactis subsp. lactis: Physicochemical characterization and antilisterial activity. Int. J. Mol. Sci. 2018, 19, doi:10.3390/ijms19020574.

5. FAO Preventing post-harvest losses in the apple supply chain in Lebanon. Food Agric. Organ. United Nations Minist. Lebanon, Beirut 2018, 5 . 
6. Iseppi, R.; de Niederhäusern, S.; Anacarso, I.; Messi, P.; Sabia, C.; Pilati, F.; Toselli, M.; Esposti, M.D.; Bondi, M. Anti-listerial activity of coatings entrapping living bacteria. Soft Matter 2011, 7, 8542, doi:10.1039/c1sm05650f.

7. Settier-Ramírez, L.; López-Carballo, G.; Gavara, R.; Hernández-Muñoz, P. Antilisterial properties of $\mathrm{PVOH}$-based films embedded with Lactococcus lactis subsp. lactis. Food Hydrocoll. 2019, 87, 214-220, doi:10.1016/j.foodhyd.2018.08.007.

8. Bittante, A.M.Q.B.; Lacerda, R.S.; Oliveira, T.G.; Makishi, G.L.A.; Costa, P.A.; Chambi, H.N.M.; Gomide, C.A.; Sobral, P.J.A. Properties of biodegradable films made with proteins extracted from castor bean (ricinus communis) cake: Effect of protein extraction pH. Chem. Eng. Trans. 2014, 37, 751-756, doi:10.3303/CET1437126.

9. Faisant, J.B.; Aït-Kadi, A.; Bousmina, M.; Deschênes, L. Morphology, thermomechanical and barrier properties of polypropylene-ethylene vinyl alcohol blends. Polymer (Guildf). 1998, 39, 533-545, doi:10.1016/S0032-3861(97)00313-3.

10. López De Dicastillo, C.; Castro-López, M.D.M.; Lasagabaster, A.; LópezVilariño, J.M.; González-Rodríguez, M.V. Interaction and release of catechin from anhydride maleic-grafted polypropylene films. ACS Appl. Mater. Interfaces 2013, 5, 3281-3289, doi:10.1021/am4003364.

11. Carvalho, K.G.; Bambirra, F.H.S.; Nicoli, J.R.; Oliveira, J.S.; Santos, A.M.C.; Bemquerer, M.P.; Miranda, A.; Franco, B.D.G.M. Characterization of multiple antilisterial peptides produced by sakacin P-producing Lactobacillus sakei subsp. sakei 2a. Arch. Microbiol. 2018, 200, 635-644, doi:10.1007/s00203-018-1477-3.

12. Ibarra-Sánchez, L.A.; El-Haddad, N.; Mahmoud, D.; Miller, M.J.; Karam, L. Invited review: Advances in nisin use for preservation of dairy products. J. Dairy Sci. 2020, 103, 2041-2052, doi:10.3168/jds.201917498.

13. Gialamas, H.; Zinoviadou, K.G.; Biliaderis, C.G.; Koutsoumanis, K.P. Development of a novel bioactive packaging based on the incorporation of Lactobacillus sakei into sodium-caseinate films for controlling Listeria monocytogenes in foods. Food Res. Int. 2010, 43, 2402-2408, doi:10.1016/j.foodres.2010.09.020. 
14. Ye, J.; Ma, D.; Qin, W.; Liu, Y. Physical and antibacterial properties of sodium alginate-sodium carboxymethylcellulose films containing Lactococcus lactis. Molecules 2018, 23, 2645, doi:10.3390/molecules23102645.

15. Settier-Ramírez, L.; López-Carballo, G.; Gavara, R.; Hernández-Muñoz, P. Antilisterial properties of PVOH-based films embedded with Lactococcus lactis subsp. lactis. Food Hydrocoll. 2019, 87, doi:10.1016/j.foodhyd.2018.08.007.

16. Sánchez-González, L.; Quintero Saavedra, J.I.; Chiralt, A. Antilisterial and physical properties of biopolymer films containing lactic acid bacteria. Food Control 2014, 35, 200-206, doi:10.1016/j.foodcont.2013.07.001.

17. Kanmani, P.; Lim, S.T. Development and characterization of novel probiotic-residing pullulan/starch edible films. Food Chem. 2013, 141, 1041-1049, doi:10.1016/j.foodchem.2013.03.103.

18. Soukoulis, C.; Singh, P.; Macnaughtan, W.; Parmenter, C.; Fisk, I.D. Compositional and physicochemical factors governing the viability of Lactobacillus rhamnosus GG embedded in starch-protein based edible films. Food Hydrocoll. 2016, 52, 876-887, doi:10.1016/j.foodhyd.2015.08.025.

19. Nuanmano, S.; Prodpran, T.; Benjakul, S. Potential use of gelatin hydrolysate as plasticizer in fish myofibrillar protein film. Food Hydrocoll. 2015, 47, 61-68, doi:10.1016/j.foodhyd.2015.01.005.

20. da Rocha, M.; Alemán, A.; Romani, V.P.; López-Caballero, M.E.; Gómez-Guillén, M.C.; Montero, P.; Prentice, C. Effects of agar films incorporated with fish protein hydrolysate or clove essential oil on flounder (Paralichthys orbignyanus) fillets shelf-life. Food Hydrocoll. 2018, 81, 351-363, doi:10.1016/j.foodhyd.2018.03.017.

21. Gonzalez-Cuello, R.E.; Ortega-Toro, R.; Zapateiro, L.G. Effect of Lactobacillus acidophilus addition on mechanical and barrier properties of binary films during storage. Contemp. Eng. Sci. 2018, 11, 269-282, doi:10.12988/ces.2018.8117.

22. Ebrahimi, B.; Mohammadi, R.; Rouhi, M.; Mortazavian, A.M.; ShojaeeAliabadi, S.; Koushki, M.R. Survival of probiotic bacteria in 
carboxymethyl cellulose-based edible film and assessment of quality parameters. LWT - Food Sci. Technol. 2018, 87, 54-60, doi:10.1016/j.lwt.2017.08.066.

23. Sánchez-González, L.; Quintero Saavedra, J.I.; Chiralt, A. Physical properties and antilisterial activity of bioactive edible films containing Lactobacillus plantarum. Food Hydrocoll. 2013, 33, 92-98, doi:10.1016/j.foodhyd.2013.02.011.

24. Tang, X.; Alavi, S. Recent advances in starch, polyvinyl alcohol based polymer blends, nanocomposites and their biodegradability. Carbohydr. Polym. 2011, 85, 7-16.

25. Doherty, S.B.; Gee, V.L.; Ross, R.P.; Stanton, C.; Fitzgerald, G.F.; Brodkorb, A. Efficacy of whey protein gel networks as potential viability-enhancing scaffolds for cell immobilization of Lactobacillus rhamnosus GG. J. Microbiol. Methods 2010, 80, 231-241, doi:10.1016/j.mimet.2009.12.009.

26. Trunk, T.; S. Khalil, H.; C. Leo, J. Bacterial autoaggregation. AIMS Microbiol. 2018, 4, 140-164, doi:10.3934/microbiol.2018.1.140.

27. Gómez, N.C.; Ramiro, J.M.P.; Quecan, B.X.V.; de Melo Franco, B.D.G. Use of potential probiotic lactic acid bacteria (LAB) biofilms for the control of Listeria monocytogenes, Salmonella Typhimurium, and Escherichia coli O157: H7 biofilms formation. Front. Microbiol. 2016, 7, 863, doi:10.3389/fmicb.2016.00863.

28. Nikolic, M.; Jovcic, B.; Kojic, M.; Topisirovic, L. Surface properties of Lactobacillus and Leuconostoc isolates from homemade cheeses showing auto-aggregation ability. Eur. Food Res. Technol. 2010, 231, 925-931, doi:10.1007/s00217-010-1344-1.

29. Léonard, L.; Gharsallaoui, A.; Ouaali, F.; Degraeve, P.; Waché, Y.; Saurel, R.; Oulahal, N. Preferential localization of Lactococcus lactis cells entrapped in a caseinate/alginate phase separated system. Colloids Surfaces B Biointerfaces 2013, 109, 266-272, doi:10.1016/j.colsurfb.2013.03.005.

30. Arellano-Ayala, K.; Ascencio-Valle, F.J.; Gutiérrez-González, P.; EstradaGirón, Y.; Torres-Vitela, M.R.; Macías-Rodríguez, M.E. Hydrophobic and adhesive patterns of lactic acid bacteria and their antagonism 
against foodborne pathogens on tomato surface (Solanum lycopersicum L.). J. Appl. Microbiol. 2020, 129, 876-891, doi:10.1111/jam.14672.

31. Gómez-Ruiz, J.Á.; López-Expósito, l.; Pihlanto, A.; Ramos, M.; Recio, I. Antioxidant activity of ovine casein hydrolysates: Identification of active peptides by HPLC-MS/MS. Eur. Food Res. Technol. 2008, 227, 1061-1067, doi:10.1007/s00217-008-0820-3.

32. Wang, J.; Su, Y.; Jia, F.; Jin, H. Characterization of casein hydrolysates derived from enzymatic hydrolysis. Chem. Cent. J. 2013, 7, 62, doi:10.1186/1752-153X-7-62.

33. Re, R.; Pellegrini, N.; Proteggente, A.; Pannala, A.; Yang, M.; Rice-Evans, C. Antioxidant activity applying an improved ABTS radical cation decolorization assay. Free Radic. Biol. Med. 1999, 26, 1231-1237, doi:10.1016/S0891-5849(98)00315-3.

34. Díaz, M.; Decker, E.A. Antioxidant mechanisms of caseinophosphopeptides and casein hydrolysates and their application in ground beef. J. Agric. Food Chem. 2004, 52, 8208-8213, doi:10.1021/jf048869e.

35. Guo, Y.; Pan, D.; Sun, Y.; Xin, L.; Li, H.; Zeng, X. Antioxidant activity of phosphorylated exopolysaccharide produced by Lactococcus lactis subsp. lactis. Carbohydr. Polym. 2013, 97, 849-854, doi:10.1016/j.carbpol.2013.06.024.

36. Bajpai, V.K.; Rather, I.A.; Park, Y.H. Partially Purified Exo-Polysaccharide from Lactobacillus Sakei Probio 65 with Antioxidant, $\alpha$-Glucosidase and Tyrosinase Inhibitory Potential. J. Food Biochem. 2016, 40, 264274, doi:10.1111/jfbc.12230.

37. Settier-Ramírez, L.; López-Carballo, G.; Gavara, R.; Hernández-Muñoz, P. Evaluation of Lactococcus lactis subsp. lactis as protective culture for active packaging of non-fermented foods: Creamy mushroom soup and sliced cooked ham. Food Control 2021, 122, 107802, doi:10.1016/j.foodcont.2020.107802.

38. Brennan, M.; Wanismail, B.; Johnson, M.C.; Ray, B. Cellular Damage in Dried Lactobacillus acidophilus. J. Food Prot. 1986, 49, 47-53, doi:10.4315/0362-028x-49.1.47. 
39. Meng, X.C.; Stanton, C.; Fitzgerald, G.F.; Daly, C.; Ross, R.P. Anhydrobiotics: The challenges of drying probiotic cultures. Food Chem. 2008, 106, 1406-1416, doi:10.1016/j.foodchem.2007.04.076.

40. Settier-Ramírez, L.; López-Carballo, G.; Gavara, R.; Hernández-Muñoz, $\mathrm{P}$. PVOH/protein blend films embedded with lactic acid bacteria and their antilisterial activity in pasteurized milk. Int. J. Food Microbiol. 2020, 322, 108545, doi:10.1016/j.jijoodmicro.2020.108545.

41. Tripathi, M.K.; Giri, S.K. Probiotic functional foods: Survival of probiotics during processing and storage. J. Funct. Foods 2014, 9, 225-241.

42. Fu, N.; Chen, X.D. Towards a maximal cell survival in convective thermal drying processes. Food Res. Int. 2011, 44, 1127-1149.

43. Romano, N.; Tavera-Quiroz, M.J.; Bertola, N.; Mobili, P.; Pinotti, A.; Gómez-Zavaglia, A. Edible methylcellulose-based films containing fructo-oligosaccharides as vehicles for lactic acid bacteria. Food Res. Int. 2014, 64, 560-566, doi:10.1016/j.foodres.2014.07.018.

44. Ma, D.; Jiang, Y.; Ahmed, S.; Qin, W.; Liu, Y. Physical and antimicrobial properties of edible films containing Lactococcus lactis. Int. J. Biol. Macromol. 2019, 141, 378-386, doi:10.1016/j.ijbiomac.2019.09.006.

45. Labuschagne, P.W.; Germishuizen, W.A.; Sabine, S.M.; Moolman, F.S. Improved oxygen barrier performance of poly(vinyl alcohol) films through hydrogen bond complex with poly(methyl vinyl ether-comaleic acid). Eur. Polym. J. 2008, 44, 2146-2152, doi:10.1016/j.eurpolymj.2008.04.015.

46. Teixeira, P.; Castro, H.; Kirby, R. Evidence of membrane lipid oxidation of spray-dried Lactobacillus bulgaricus during storage. Lett. Appl. Microbiol. 1996, 22, 34-38, doi:10.1111/j.1472-765X.1996.tb01103.x. 



\section{CAPÍTULO II}

\section{Aplicación tecnológica de películas portadoras de bacterias ácido lácticas para el desarrollo de envases bioactivos antimicrobianos}

Artículo 4.

Evaluation of Lactococcus lactis subsp. lactis as protective culture for active packaging of nonfermented foods: Creamy mushroom soup and sliced cooked ham

\section{Artículo 5.}

Broadening the antimicrobial spectrum of nisin-producing Lactococcus lactis subsp. lactis to Gram-negative bacteria by means of active packaging

\section{Artículo 6.}

Assessing the environmental consequences of shelf life extension: conventional versus active packaging of pastry cream 

Artículo 4

\section{Evaluation of Lactococcus lactis}

subsp. lactis as protective culture for active packaging of non-fermented foods: creamy mushroom soup and sliced cooked ham

Laura Settier-Ramírez; Gracia López-Carballo; Rafael Gavara; Pilar Hernández-Muñoz

Food Control, 2021, vol. 122, p. 107802

Packaging Lab, Instituto de Agroquímica y Tecnología de Alimentos, IATA-CSIC, Av. Agustín Escardino 7, 46980 Paterna, Spain. 



\section{ABSTRACT}

An innovative edible coating, made from food grade polyvinyl alcohol (PVOH) and gelatin hydrolysates ( $\mathrm{HGel})$, was evaluated as a carrier of Lactococcus lactis acting as anti-listeria protective culture for refrigerated foods. The coating was applied on a compostable polylactic acid film surface and its anti-listeria activity was evaluated at $4{ }^{\circ} \mathrm{C}$ in a liquid culture medium and in solid agar, inoculated with Listeria monocytogenes. The best results were obtained in agar, exerting a bactericide effect, whereas in the liquid medium the coating had bacteriostatic behaviour. Furthermore, the active coating was applied to the surface of bags or separator liners made from polylactic acid. Its effectivity was evaluated with creamy mushroom soup (bags) and sliced cooked ham (separator liners) previously inoculated with $L$. monocytogenes and stored at $4{ }^{\circ} \mathrm{C}$. Results showed that the coating was effective at inhibiting pathogen growth; however, it did not display a bactericide effect in the foods. In addition, L. lactis remained viable in all experiments conducted in this study. The acidification produced by $L$. lactis, because of the generation of organic acids, did not compromise the sensory properties of the sliced cooked ham after 16 days of refrigerated storage. In contrast, consumers perceived a mushroom soup acidification because of a greater decrease in $\mathrm{pH}$ than the sliced cooked ham.

This study demonstrates that a food grade polyvinyl alcohol polymer blended with gelatin hydrolysates can be used as a carrier of protective cultures of $L$. lactis to increase the microbiological safety of refrigerated foods.

Keywords: polyvinyl alcohol, gelatin hydrolysates, Lactococcus lactis, Listeria monocytogenes, protective culture. sliced cooked ham, creamy mushroom soup. 


\section{Introduction}

Changes in consumer demands and lifestyles have increased the consumption of ready-to-eat (RTE) products. RTE food products require no further treatment before consumption, in such a way that may significantly reduce the microbial load [1], thus, it is essential to control pathogenic bacteria that can cause food-borne infectious diseases.

Among these diseases, listeriosis is a key for its profound consequences. Listeriosis is caused by a Gram + pathogenic bacterium, Listeria monocytogenes. This bacterium can affect the bloodstream, the central nervous system, and the placenta, with immunosuppressed people, new-borns, elderly, and pregnant women the high-risk groups (Centers for Disease Control and Preservation, 2019; Donovan, 2015).

Authors have shown, for years, that although other modes of transmission exist, food is the main source [4]. L. monocytogenes is a psychrophilic bacterium capable of growing at low temperatures and adapting to different types of food [5]. Its high prevalence in food, together with a high mortality rate from listeriosis, make this bacterium a health hazard. Therefore, L. monocytogenes in food and food environments must be controlled.

Key RTE food categories related with human listeriosis include meat, fish, and milk products in Canada, the European Union, and United States [6]. Moreover, according to the EFSA (EFSA Panel on Biological Hazards (BIOHAZ), 2018), "Between 2008 and 2015 in the EU/EEU, the 'dairy' food category was responsible for four outbreaks causing 44 cases, while 'fish and seafood' and 'meat and meat products' food categories were responsible for 7 and 11 outbreaks causing 40 and 126 cases, respectively. These three categories caused 22 (59\%) strong-evidence food-borne outbreaks, 210 (40\%) human cases, 125 (69\%) hospitalisations and 26 (70\%) deaths".

Unfortunately, despite having a very strict legislation on microbiological criteria for $L$. monocytogenes in RTE foods (Commission Regulation (EC) No 2073/2005) and routine controls, cases of listeriosis are still occurring. In 2019, Spain reported an outbreak of listeriosis to the World Health Organisation (WHO, 2019), 
that infected over 220 persons and left seven abortions and three deaths related to the consumption of an RTE meat product.

The food industry's strategy for preventing pathogen growth is the addition of artificial preservatives, even if some are harmful to the human body [10]. However, an alternative is using active packaging, incorporating natural antimicrobial agents with the aim to reduce the microbial growth and extend shelf life in food products.

Plastic is the main packaging material used by the food industry because of its versatility and low cost, but often becomes a pollutant; hence, it is one of the major global threats. Because plastics can transport adhered pollutants and have been detected worldwide, especially in the marine environment because of its low degradation rates in situ [11,12], alternatives are critical.

Another approach could be the use of antimicrobial active packaging using natural antimicrobial agents, made with biodegradable polymers. Therefore, studies have reported that incorporating a living bacteriocin producer lactic acid bacteria (LAB) in films, instead of just using bacteriocins, is a good tool to control $L$. monocytogenes $[13,14]$. Among $L A B$, Lactococcus lactis is considered as GRAS (Generally Recognised as Safe) and produces nisin, a bacteriocin also considered as GRAS, that is effective against Gram + bacteria such as L. monocytogenes [15].

Using biodegradable polymers in food packaging is a key to modern designs. Therefore, in this study, polyvinyl alcohol (PVOH) was chosen as the active coating material because of its biodegradability and excellent film properties. Besides, although this polymer is synthetic, it is completely biodegradable and biocompatible [16]. Previous studies have demonstrated the good capacity of PVOH films to carry living Lactococcus lactis. Our group demonstrated that a small amount addition of gelatin hydrolysates $(\mathrm{HGel})$ in a $\mathrm{PVOH}$ matrix resulted in a greater $L$. lactis viability and a more powerful anti-listeria activity $[17,18]$. Furthermore, polylactic acid (PLA) has been used as the packaging material for applying an active $\mathrm{PVOH}$ coating. PLA is a biopolymer obtained from renewable resources like corn, sugarcane, and wood residues [19]. Its popularity has grown for its commercial 
use as a substitute for petroleum-based polymers, such as low-density polyethylene (LDPE), high-density polyethylene (HDPE), polystyrene (PS), and polyethylene terephthalate (PET) [20]. PLA can be developed as a transparent thin film, suitable for short shelf life products in common applications such as containers, drinking cups, salad cups, overwrap and lamination films, and blister packages [21,22]. However, the most interesting characteristic of PLA is its biodegradability and presents the compostability requirements of EN13432 for packaging (EN 13.432, 2005) [24].

Few studies have shown LAB incorporating in biopolymer films to control L. monocytogenes growth in food products. Gialamas, Zinoviadou, Biliaderis, \& Koutsoumanis, (2010) applied sodium caseinate films on fresh beef, whereas Concha-Meyer, Schöbitz, Brito, \& Fuentes, (2011) developed alginate and starch films for application on smoke salmon [26]. In addition López de Lacey, López-Caballero, \& Montero, (2014) applied agar films, containing green tea extract, Lactobacillus paracasei L26, and Bifidobacterium lactis B94 on hake fillets [27]. The novelty of this study is the application of commercial $\mathrm{PVOH}$ as an active coating incorporated in the design of packages for viscous and solid foods.

In this study, PLA thermo-sealed bags and separator liners were coated with $\mathrm{PVOH}$ carrying $L$. lactis. The $L$. lactis viability and $L$. monocytogenes loads were studied in liquid and solid culture media, stored under refrigeration conditions. Furthermore, commercial RTE food, previously related with human listeriosis; a dairy based product: creamy mushroom soup; and a meat product: cooked ham slices, were packaged with the developed bioactive packages to study their effectivity against $L$. monocytogenes inoculated in the named foods. Finally, a sensory test was conducted with consumers to study the acceptance of the food products stored under refrigeration in the bioactive packages.

\section{Materials and methods}

\subsection{Bacterial strains}


In this study, the Lactococcus lactis strain (CECT 539, ATCC 11454), supplied by the Spanish Type Culture collection (CECT), was selected for its ability to produce nisin. The bacterial strain was kept frozen at $80{ }^{\circ} \mathrm{C}$ in Man, Rogosa, and Shape broth (MRS) with $20 \%$ glycerol. Microbial culture was regenerated and maintained by regular subculture at $4{ }^{\circ} \mathrm{C}$ on the MRS broth. Before use, an aliquot was transferred to $10 \mathrm{~mL}$ of MRS broth and incubated at $30^{\circ} \mathrm{C}$ for $24 \mathrm{~h}$.

The pathogen strain Listeria monocytogenes (CECT 934, ATCC 19114) was chosen for its impact in food-borne illness. The strain was maintained at $-80{ }^{\circ} \mathrm{C}$ in a Tryptone Soy Broth (TSB) supplemented with $20 \%$ glycerol. For experimental use, the stock culture was maintained by regular subculture at $4{ }^{\circ} \mathrm{C}$ on Tryptone Soy Agar (TSA) and transferred monthly. Before use, a loopful of the strain was transferred to $10 \mathrm{~mL}$ of TSB and incubated at $37{ }^{\circ} \mathrm{C}$ for $24 \mathrm{~h}$. All microbiological products were provided by Sharlau, Barcelona, Spain.

\subsection{Coating formation on PLA film}

A coating forming solution (CFS) was prepared by dissolving $10 \%$ of polyvinyl alcohol (PVOH, Gohsenol GH17, Nippon Synthetic Chemical Company, Osaka, Japan) in distilled water, as the polymer matrix, in a mass ratio of 1:0.125, with gelatin hydrolysate (HGel) (enzymatic digest, Sigma-Aldrich, France) as a nutritional supplement for $L$. lactis. L. lactis cells were harvested by centrifugation at 2,500 RFC for $15 \mathrm{~min}$ at $4{ }^{\circ} \mathrm{C}$ and washed twice with peptone water. This was incorporated in the CFS with a target inoculum of $2.5 \times 10^{6} \mathrm{UFC} / \mathrm{cm}^{2}$ film. CFS without $L$. lactis was used for preparing control films.

Coatings were obtained by casting on poly-( $D, L$-lactide) (PLA) film surface; for that, PLA films of a $28 \times 40 \mathrm{~cm}$ surface and $30 \mu \mathrm{m}$ thickness was fixed on a glass plate. After, $7 \mathrm{~mL}$ of the CFS were spread over the PLA using an extension bar with a $200 \mu \mathrm{m}$ deep thread (Lin-Lab Rioja, Logroño, Spain). The CFS was dried in a laminar flow hood at $23^{\circ} \mathrm{C}$ and the thickness of the coating was determined with a digital micrometre (Mitutoyo, Osaka, Japan). PLA/(PVOH+HGel) films were cut for manufacturing two-sided thermo-sealed bags with a $4 \times 8$ $\mathrm{cm}$ surface $\left(64 \mathrm{~cm}^{2}\right)$; for the packaging of mushroom soup. PLA coated 
films were also cut in discs of $9 \mathrm{~cm}$ diameter (also with a total area of $64 \mathrm{~cm}^{2}$ ) to act as separators in the packaging of the sliced cooked ham.

2.3 Survival of $L$. lactis and activity of $P L A /(P V O H+H G e l)$ films against $L$. monocytogenes

$\mathrm{PLA} /(\mathrm{PVOH}+\mathrm{HGel}$ ) films (two squares of $8 \times 4 \mathrm{~cm}$ ) were added in small pieces to glass tubes containing $10 \mathrm{~mL}$ of TSB+yeast extract $(\mathrm{YE})$, which was previously inoculated with $4 \log \mathrm{CFU} / \mathrm{mL}$ of $L$. monocytogenes. The tubes were stored at $4{ }^{\circ} \mathrm{C}$ for 21 days, simulating a refrigerated food. Aliquots were taken at different times and serial dilutions with peptone water were made. The diluted aliquot was plated in Petri dishes with $15 \mathrm{~mL}$ of MRS agar and Polymyxin Acriflavine Lithium Chloride Ceftazidime Mannitol agar (Palcam agar). MRS agar plates and Palcam plates were incubated at 30 and $37^{\circ} \mathrm{C}$ for 4 days and $48 \mathrm{~h}$, respectively. After incubation time, L. lactis colonies were counted in the MRS agar and L. monocytogenes colonies were counted in the Palcam agar. Tests were done in triplicate.

\subsubsection{In vivo studies in creamy mushroom soup}

An ultra-high temperature (UHT) creamy mushroom soup (containing milk) obtained from a local supermarket was chosen because dairy based products are high prevalence reservoirs for $L$. monocytogenes. Thermo-seal PLA/(PVOH+HGel) bags coated with the same surface than in previous section $(8 \times 4 \mathrm{~cm}$ surface) were filled with $10 \mathrm{~mL}$ of creamy mushroom soup previously inoculated with 4 $\log$ CFU L. monocytogenes $/ \mathrm{mL}$. The bags were thermo-sealed and stored at $4{ }^{\circ} \mathrm{C}$. Filled bags coated with $\mathrm{PVOH}+\mathrm{HGel}$ film without $L$. lactis were used as controls.

Samples were analysed immediately after packaging (day 0 ) and days $2,7,10$, and 15 of storage. Thecreamy mushroom soup and its commercial packaging, washed with alcohol to sterilise the container's outside surface, were placed in a sterile BagPage (Interscience, France) with $100 \mathrm{~mL}$ of peptone water. They were analysed for the total amount of bacteria. Each sample was homogenised for 2 min 
(Stomacher Interscience, France). After serial dilutions with peptone water were made, the samples were plated in Petri dishes with $15 \mathrm{ml}$ of MRS agar and Palcam agar. L. lactis and L. monocytogenes colonies were counted after incubation. Tests were completed in triplicate.

2.4 Survival of $L$. lactis and antimicrobial activity of coatings against $L$. monocytogenes

2.4.1 In vitro studies using solid culture medium

In vitro assays simulating a solid food model were completed using a TSA supplemented with $0.6 \%$ yeast extract (TSA+YE) (because this is a culture medium rich in nutrients) with $\mathrm{pH} 7.3$ and high water activity. Petri dishes (9 $\mathrm{cm}$ diameter) were filled with $10 \mathrm{~g}$ of TSA+YE and dilutions of $L$. monocytogenes were completed to inoculate the surface of TSA+YE for a concentration of $4 \log \mathrm{CFU} / \mathrm{g}$ of the pathogen. $\mathrm{PLA} /(\mathrm{PVOH}+\mathrm{HGel})$ films, previously cut to $9 \mathrm{~cm}$ diameter discs, were placed on the inoculated surface. Film samples that did not carry $L$. lactis were used as controls.

Petri dishes were protected from the environment with Parafilm (Merck) to avoid dehydration and stored at ${ }^{\circ} \mathrm{C}$ for 16 days. The samples were analysed immediately after being prepared (day 0 ) and days $1,5,7$, and 16 of storage.

For analysis, TSA+YE and PLA/(PVOH+HGel) films were aseptically removed from the Petri dishes and placed in a sterile BagPage with $100 \mathrm{~mL}$ of peptone water. Each bag was homogenised for $2 \mathrm{~min}$ and serial dilutions with peptone water were made and plated in Petri dishes with $15 \mathrm{ml}$ of MRS agar and Palcam agar. L. lactis and $L$. monocytogenes colonies were counted after incubation. Tests were completed in triplicate.

\subsubsection{In vivo studies in sliced cooked ham}

Sliced cooked ham was chosen as a solid food to evaluate the effectiveness of active PLA/PVOH films, used as separator liners, to control the growth of $L$. monocytogenes. Sliced cooked ham, packaged in modified atmosphere conditions, was purchased from a local supermarket; the slices were cut to $9 \mathrm{~cm}$ diameter disc, like the PLA/ 
(PVOH+HGel) films, with a final weight of $10 \mathrm{~g}$ per slice. Dilutions were made to cover the slices with a total amount of $4 \log C F U / g$ of $L$. monocytogenes. The active surface of the separator liner was placed in contact with the contaminated surface of the ham slice. $\mathrm{PLA} /(\mathrm{PVOH}+\mathrm{HGel})$ films without $L$. lactis were used as control. Antimicrobial analysis was conducted according to the method in section 2.4.1.

\section{$2.5 \mathrm{pH}$ evolution of assayed foods in contact with active films}

The ability of lactic acid bacteria (LAB) to produce organic acids, especially lactic acid, as a product of their metabolism is well known. Therefore, the $\mathrm{pH}$ of the foods was monitored through the storage time with a $\mathrm{pH}$ metre (consort C830, Belgium) and a combined $\mathrm{pH}$ electrode (Consort SP10T, Belgium) used in viscous foods, with a penetration pH electrode (PHEL-GB5-001, Belgium) for solid foods. Measurements were completed in triplicate.

\subsection{Flow cytometry}

Flow cytometry can explain dynamics and physiological heterogeneity of cell populations; thus, this technique can provide more accurate information about the bacterial population than the traditional plate count method. Therefore, the physiological state of $L$. lactis migrated from the film to the tested culture media ( $T S B+Y E$, $\mathrm{TSA}+\mathrm{YE}$ ) and foods (creamy mushroom soup and sliced cooked ham), both of them without being inoculated with L. monocytogenes, was evaluated. To compare the matrices, the experiment was conducted after 12 days of refrigerated storage.

After 12 days, the samples were placed separately in sterile bags with $100 \mathrm{~mL}$ of a filtered saline solution $(0.8 \% \mathrm{NaCl})$ and each bag was homogenised for $2 \mathrm{~min}$. Aliquots were taken and filtered through a 0.50 micrometre filter to remove debris. Dilutions were made and the bacteria population was stained with a mixture of the cell-permeant double-stranded DNA fluorochrome SYTO-13 (Molecular Probes Europe BV, Netherlands) and Propidium lodide solution (PI, Calbiochem). SYTO-13 is cell-permeable thus stains the nucleic acids 
in all bacteria. PI is not membrane-permeable thus stains the nucleic acids in the bacteria, whose membrane integrity has been damaged. The combination SYTO-13/PI is useful to differentiate dead cells from viable cells based on membrane integrity. The study was performed with a BD FACSVerse ${ }^{\mathrm{TM}}$ (Becton Dickinson, USA) flow cytometer in the Central Service for Experimental Research at the University of Valencia (Spain). The optical parameters forward scatter (FSC), side scatter (SSC), green fluorescence for SYTO-13 (497 and $520 \mathrm{~nm}$ excitation and emission light, respectively), and red fluorescence for PI (493 and 630 $\mathrm{nm}$ excitation and emission light, respectively) were analysed for each sample. The data were collected with the software BD Food Bioprocess Technol FACS Suite v. 1.0.3.2924 (Becton Dickinson, USA).

\subsection{Sensory evaluation of active packaged food products}

$L A B$ can ferment foods imparting a certain flavours and can even modify the texture. Therefore, a sensory evaluation is required to assess the acceptability of food, packaged using L. lactis as a protective culture.

\subsubsection{Sensory evaluation of the creamy mushroom soup}

Untrained judges received four samples of $15 \mathrm{~g}$ of hotcreamy mushroom soup placed in plastic cups coded with three random digits. One sample corresponded to just opened UHT creamy mushroom soup. Three more samples corresponded to the product packaged in active bags and with different storage times: newly packaged and after 6 and 12 days of storage. The sensory test was conducted until day 12 , as consumption of this product after longer storage can be unsafe for humans. The order of sample presentation was randomised for each judge. The judges were requested to rank the basic general aspect with four intensities, from low to high (rank 1 for the least intense and rank 4 for the most intense). This technique allows an initial evaluation of samples difference and when it happens, the technique also allows measurement of the difference's magnitude from the rating scores. 
Table 1. Sex-and age-related features, and consumption habit of panelists

\begin{tabular}{|c|c|c|c|c|c|}
\hline \multicolumn{2}{|c|}{ SEX } & \multicolumn{2}{|c|}{ AGE } & \multicolumn{2}{|c|}{$\begin{array}{c}\text { CONSUMPTION } \\
\text { HABIT }\end{array}$} \\
\hline \multicolumn{6}{|c|}{ Creamy Mushroom Soup } \\
\hline \multirow[t]{2}{*}{ Female } & \multirow[t]{2}{*}{50} & $\leq 30$ years & 38 & \multirow{3}{*}{$\begin{array}{l}\text { Frequently } \\
\text { Once a week } \\
\text { Once a month } \\
\text { Rarely }\end{array}$} & \multirow{2}{*}{$\begin{array}{l}13 \\
27 \\
11\end{array}$} \\
\hline & & $31-45$ years & 18 & & \\
\hline Male & 21 & $\geq 46$ years & 15 & & \\
\hline \multicolumn{6}{|c|}{ Sliced Cooked Ham } \\
\hline \multirow[t]{2}{*}{ Female } & \multirow[t]{2}{*}{48} & $\leq 30$ years & 47 & \multirow{3}{*}{$\begin{array}{l}\text { Frequently } \\
\text { Once a week } \\
\text { Once a month } \\
\text { Rarely }\end{array}$} & 35 \\
\hline & & $31-45$ years & 16 & & $\begin{array}{l}21 \\
12\end{array}$ \\
\hline Male & 25 & $\geq 46$ years & 10 & & 5 \\
\hline
\end{tabular}

The selected character attributes were "colour intensity", "aroma intensity", "thickness", and "lumpiness", which were scored as: 'aroma' - from the least to the most aromatic, 'colour' - from lightest to darkest, 'thickness' - resistance to flow checked with a teaspoon, and 'lumpiness' - presence and amount of soft lumps or graininess. To evaluate the taste of creamy mushroom soup, the judges were asked to use a hedonic scale $(1=$ dislike extremely, $5=$ neither like nor dislike, 9 = like extremely). Judges were also asked to mark the attributes detected in samples from a closed list which contained: milk taste, mushroom taste, sour taste, lemon taste, bland taste, salty taste, and strange taste. In this test, panel members were also asked for their purchase intention before and after learning the information concerning bioactive packaging on a 1-5 scale ( $1=$ I would never buy it, $5=$ I would certainly buy it).

The data interpretation of the ordering tests was completed according to Friedman's test [28], which indicates significant differences between the samples at a $5 \%$ significance level. If the difference between the sums of the ranks is greater than or equal to the tabulated value, according to the number of testers who took part 
in the analysis, it is concluded that there is a significant difference between the samples.

\subsubsection{Sensory evaluation of sliced cooked ham}

To assess the aroma and taste acceptability, together with the general aspect of sliced cooked ham slices stored in contact with the active separator liners, a hedonic sensory test was conducted in a standardised test room (UNE-ISO 8589, 2007).

The test was conducted presenting three ham slices on disposable dishes identified by three-digit codes. One dish represented the package obtained from the supermarket and opened at day 0 , while the others related to the slices in contact with the active separator liners after 8 and 16 days of storage. The sensory test was conducted until day 16 , as longer storage can be unsafe for human consumption.

To evaluate the sensory properties of the three cooked ham slices samples, the judges were asked to use a hedonic scale $(1=$ dislike extremely, $5=$ neither like nor dislike, $9=$ like extremely). The panel comprised 73 untrained members with the features showed in Table 1. Panel members were also asked for their purchase intention before and after learning the information concerning bioactive packaging on a 1-5 scale ( 1 = I would never buy it, $5=$ I would certainly buy it).

\subsection{Statistical analysis}

Statistical analysis was performed using the SPSS computer program (SPSS Inc., Chicago, IL) by one-way analysis of variance (ANOVA). Means were separated using the Tukey test $p \leq 0.05$ were considered significant.

Compusense Five software (release 5.0, Ontario, Canada) was used to design the sensory evaluation and the data analysis.

\section{Results and discussion}

Polylactic acid (PLA) films coated with the polyvinyl alcohol $(\mathrm{PVOH})$ based solution were homogeneous, and transparent to the naked eye, without discontinuities or visible particles. The coating has 
an average thickness of $15 \pm 3 \mu \mathrm{m}$ while PLA uncoated had an average thickness of $25 \pm 1 \mu \mathrm{m}$.

3.1. Survival of Lactococcus lactis and antimicrobial activity of coatings against Listeria monocytogenes

\subsubsection{In vitro studies using a liquid culture medium}

The survival of $L$. lactis and the antimicrobial effectiveness of active $\mathrm{PLA} /(\mathrm{PVOH}+\mathrm{HGel})$ system immersed in TSB+YE inoculated with L. monocytogenes was monitored for 21 days at $4{ }^{\circ} \mathrm{C}$ simulating the storage of refrigerated liquid food; the results are shown in figure 1.

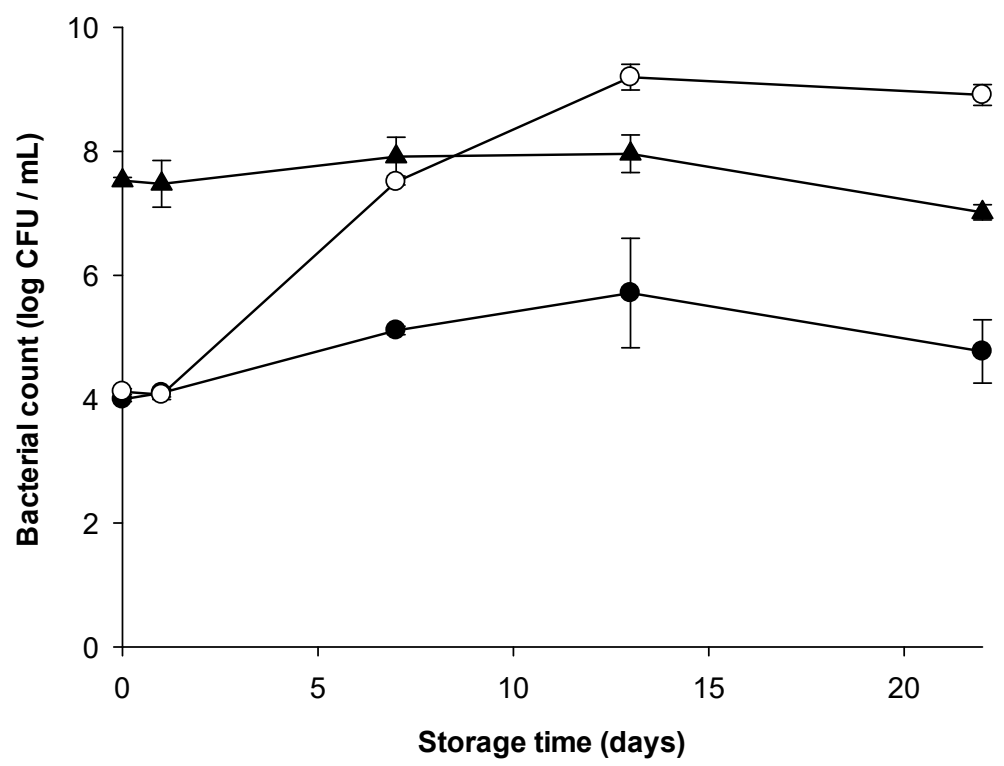

Figure 1. Growth of Lactococcus lactis $(\boldsymbol{\Delta})$ and anti-listeria activity of active (•) and control films $(\mathrm{O})$ immersed in a TSB+YE medium and stored at $4{ }^{\circ} \mathrm{C}$ for 21 days.

L. lactis maintained its initial population for three weeks, whereas $L$. monocytogenes maintained the initial inoculated population, because of the bacteriostatic effect of $L$. lactis. When control films were evaluated, L. monocytogenes reached the stationary phase after 13 days of storage, and the counts were maintained to the end of the experiment. Comparing films carrying the protective culture 
and the control films, the former achieved reductions of $L$. monocytogenes from $3 \log \mathrm{CFU} / \mathrm{mL}$ after 6 days to $4 \log \mathrm{CFU} / \mathrm{mL}$ after 13 and 21 days of storage at $4{ }^{\circ} \mathrm{C}$.

Notably, when coated PLA films were immersed in the culture medium, the coating began losing its integrity and finally dissolved releasing lactic acid bacteria (LAB). Thus, $L$. lactis needed a time delay to produce the anti-listeria metabolites, since no activity was found on the first storage days. Furthermore, nisin was the main anti-listeria metabolite produced in TSB+YE since the liquid medium was buffered at $\mathrm{pH}$ 7. Therefore, the organic acids produced by L. lactis were neutralised and their antimicrobial action was excluded, as the most common LAB produced acids have a pka below 5.0 [29].

This study's results agree with those of a previous study carried out by the authors Settier-Ramírez, López-Carballo, Gavara, \& Hernández-Muñoz, (2020) where L. lactis was incorporated into (PVOH+HGel) films [17]. The main difference between (PVOH+HGel) films studied previously and ( $\mathrm{PVOH}+\mathrm{HGel}$ ) coatings here, is that the concentration of L. lactis/g of the polymer was greater in the coating because the thickness of the coating $(15 \mu \mathrm{m})$ was lower than the thickness of the self-standing film $(45 \mu \mathrm{m})$; moreover, the polymer forming solution concentration was greater (from 2 to 10\%). Therefore, the drying time was reduced from $20 \mathrm{~h}$ for films to 30 minutes for coatings. However, L. lactis viability was similar in the films and coatings, and also exhibited similar bacteriostatic effects against $L$. monocytogenes in TSB+YE, despite differences in the studies.

\subsubsection{In vivo studies in the creamy mushroom soup}

$\mathrm{PLA} /(\mathrm{PVOH}+\mathrm{HGel})$ with and without $L$. lactis were used to make active thermo-sealed bags and control thermo-sealed bags, respectively. Pasteurisedcreamy mushroom soup was packaged with these bags and stored for 12 days at $4{ }^{\circ} \mathrm{C}$. The survival of $L$. lactis and the anti-listeria effectiveness of $\mathrm{PLA} /(\mathrm{PVOH}+\mathrm{HGel}+L$. lactis $)$ bags through refrigerated storage are shown in figure 2 . 


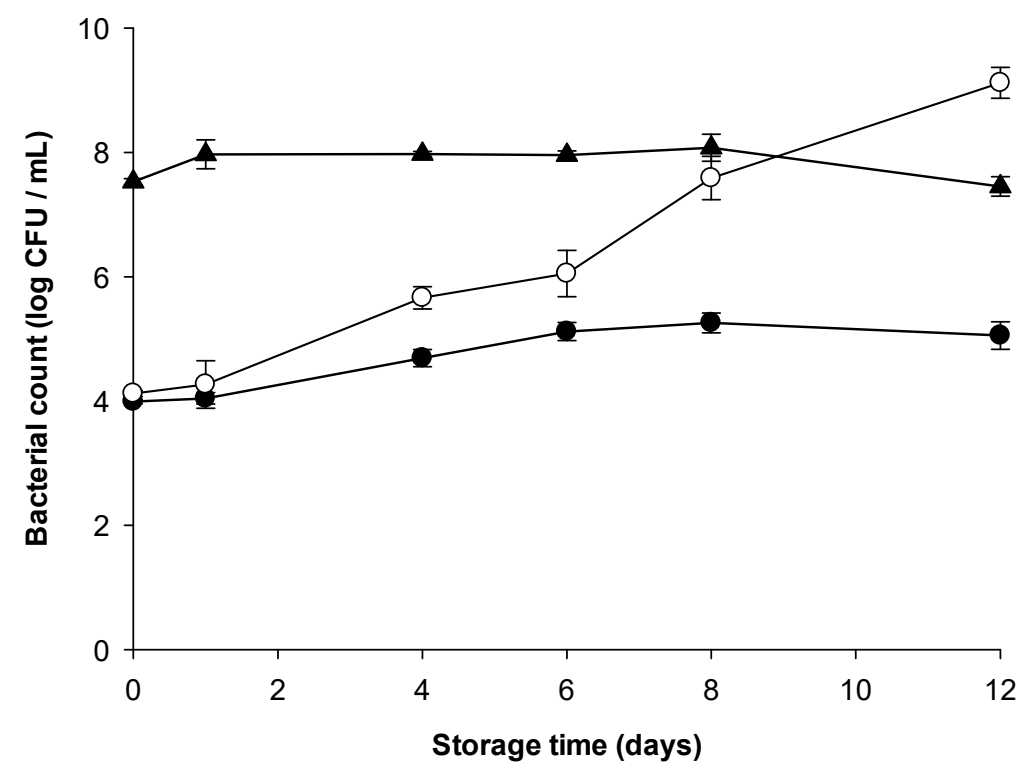

Figure 2. Growth of Lactococcus lactis $(\mathbf{\Delta})$ and anti-listeria activity in creamy mushroom soup of active $(\bullet)$ and control bags $(O)$ stored at $4{ }^{\circ} \mathrm{C}$ for 12 days.

Like the results obtained in the liquid medium (section 3.1.1.), L. lactis counts were also around $7.5-8 \log \mathrm{CFU} / \mathrm{mL}$ and the viability was maintained throughout storage. Regardingcreamy mushroom soup packaged with bags without $L A B, L$. monocytogenes could reach its maximum growth on the last day of storage (day 12), and the growth rate was slower than the results obtained in liquid medium. This slower growth of the pathogen can be attributable to the food matrix complexity because it has a different nutritional composition and could be less rich in specific nutrients and they can also be less available than in the culture medium due to interactions among them. Anti-listeria activity of $L$. lactis shows the results were like the liquid culture medium; the bioactive package exerted a bacteriostatic effect on the pathogen inoculated in creamy mushroom soup.

Several studies have reported that a higher nisin concentration is required in real food than in broth media [17,30,31]. Furthermore, a reduction in the antimicrobial activity of the active compound because 
of the food matrix has been well documented [32-34]. Thus, higher concentrations of antimicrobial agents are generally required when applied to food [35].

However, active bags carrying bacteria instead of nisin could inhibit the growth of inoculated $L$. monocytogenes. Results here can be explained by arguing that $L$. lactis can produce organic acids besides nisin, and as thecreamy mushroom soup was not buffered as the liquid culture medium, the acids can dissociate and contribute to the antimicrobial effect on the pathogen. Moreover, there are several studies about the antimicrobial action of bacteriocins produced by $\mathrm{LAB}$ in combination with a $\mathrm{pH}$ below 5.5 [19].

Notably, the optimal pH for L. monocytogenes growth is neutral, and although this pathogen appears to be relatively tolerant to acidic conditions, especially at low temperatures [37], the acidification of food could also affect its growth.

\subsection{Evolution of $\mathrm{pH}$ in creamy mushroom soup}

The anti-listeria activity of L. lactis is provided by nisin, but the production of organic acids also contributes to their antimicrobial capacity. These acids can modify the $\mathrm{pH}$ of the food; therefore, it was monitored through the creamy mushroom soup storage. Table 2 shows the $\mathrm{pH}$ storage evolution in creamy mushroom soup packaged in PLA bags and in creamy mushroom soup, inoculated with $L$. monocytogenes, packaged in PLA/(PVOH+HGel) with and without $L$. lactis. 
Table 2. Evolution of $\mathrm{pH}$ in creamy mushroom soup

\begin{tabular}{|c|c|c|c|c|}
\hline \multirow{2}{*}{ Packaging } & \multirow{2}{*}{ Food matrix } & \multicolumn{3}{|c|}{$\mathrm{pH}$} \\
\hline & & Day 0 & Day 6 & Day 12 \\
\hline PLA & MS & $5.87 \pm 0.01^{\mathrm{aB}}$ & $5.78 \pm 0.03^{\mathrm{bB}}$ & $5.75 \pm 0.02^{\mathrm{bA}}$ \\
\hline $\mathrm{PLA} /(\mathrm{PVOH}+\mathrm{HGel})$ & MS + L. monocytogenes & $5.95 \pm 0.02^{\mathrm{aA}}$ & $5.86 \pm 0.03^{\mathrm{aA}}$ & $5.68 \pm 0.10^{\mathrm{bA}}$ \\
\hline $\mathrm{PLA} /(\mathrm{PVOH}+\mathrm{HGel}+$ L. lactis) & $\mathrm{MS}+$ L. monocytogenes & $5.84 \pm 0.03^{\mathrm{aB}}$ & $4.52 \pm 0.03^{b c}$ & $4.33 \pm 0.01^{\mathrm{CB}}$ \\
\hline
\end{tabular}

$a, b, c$ : different letters in the same line indicate significant differences among time for the same formulation $(p<0.05)$.

$A, B, C$ : different letters in the same column indicate significant differences among formulation $(p<0.05)$.

MS: Mushroom Soup 
The starting $\mathrm{pH}$ of the creamy mushroom soup was 5.87 and did not suffer considerable changes over 12 days for samples packaged in PLA bags and those inoculated with $L$. monocytogenes and packaged without $L$. lactis. Thus, neither the coating nor the inoculation of the pathogen altered the $\mathrm{pH}$. However, when a $\mathrm{PLA} /(\mathrm{PVOH}+\mathrm{HGel}+L$. lactis) bag was used, a drop in the $\mathrm{pH}$ was observed during storage. The starting $\mathrm{pH}$ value was the same as the other bags, meaning the initial addition of $L$. lactis did not modify the $\mathrm{pH}$. From the day 0 to 6 , thecreamy mushroom soup experienced a sharp decrease in the $\mathrm{pH}$, reaching 4.52. This $\mathrm{pH}$ is because of organic acids generation, such as lactic or acetic, resulted from sugar fermentation by $L A B$ during cell growth $[38,39]$. Therefore, $L$. lactis was metabolically active at day 6 and accumulated enough acids to produce the $\mathrm{pH}$ decrease. At storage day 12 the $\mathrm{pH}$ was 4.33 without suffering further considerable decrease.

3.3. Survival of $L$. lactis and antimicrobial activity against $L$. monocytogenes in solid food

3.3.1. In vitro studies using a solid culture medium

In this study, separator liners of PLA coated with PVOH+HGel with or without carrying $L$. lactis were placed on the surface of a $\mathrm{TSA}+\mathrm{YE}$ inoculated with $L$. monocytogenes and maintained at $4{ }^{\circ} \mathrm{C}$ for 16 days. Figure 3 shows the anti-listeria activity of the films and the viable cell numbers of $L$. lactis, periodically measured on the agar plates.

L. lactis maintained its viability after the film contacted the surface of the TSA medium, having approximately 8 log CFU/g, which was maintained throughout storage. Regarding the anti-listeria effect of the films, a bacteriostatic effect was observed during the first 5 days of storage, whereas reductions over 8 log CFU/g were found after 16 days storage for $L$. monocytogenes. 


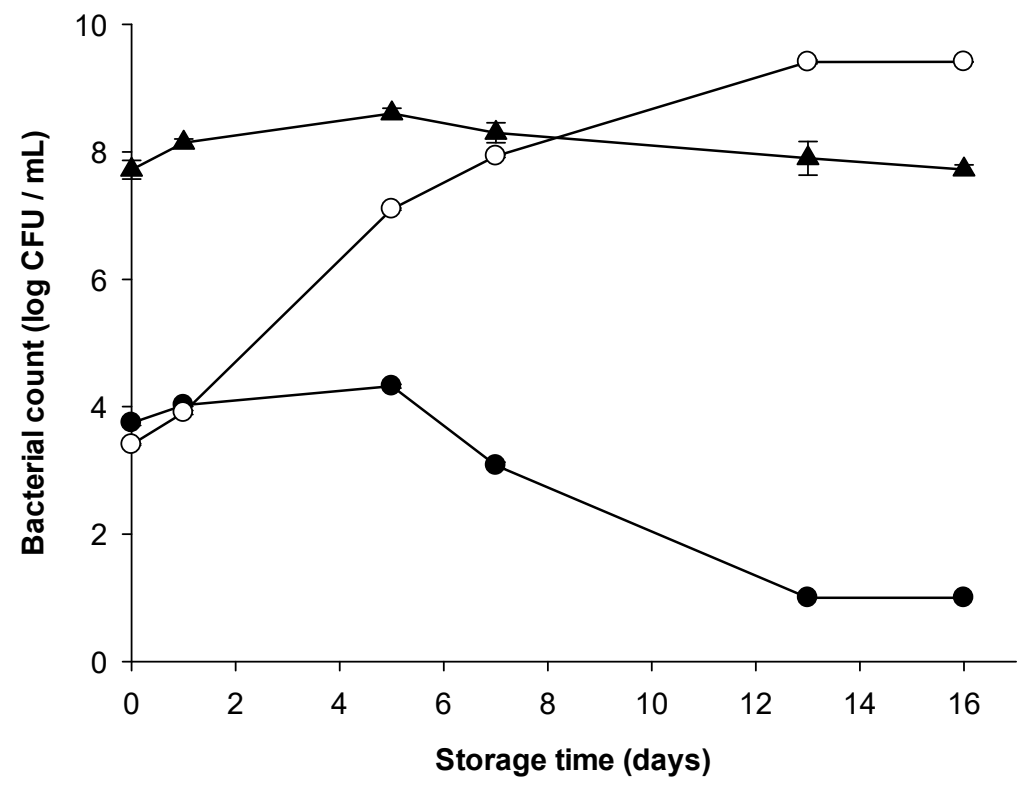

Figure 3. Growth of Lactococcus lactis $(\mathbf{\Delta})$ and anti-listeria activity of active ( $\bullet$ ) and control films $(O)$ placed on the surface of the agar culture medium and stored at $4{ }^{\circ} \mathrm{C}$ for 16 days.

Despite having the same population of $L$. lactis and $L$. monocytogenes in the tested media; the bacteriostatic effect was seen in both, but the effect was only observed in the solid medium and after 5 days. Usually, growth and metabolism of food bacteria are tested in broth media; however, to predict the growth of bacteria in food, the study must be done in conditions that closely reflect the real conditions, i.e., in solid model foods [40]. It has been reported that the predictive models of growth built in broth media are not accurate in describing immobilised growth, especially under stressful conditions that exist in a food medium $[41,42]$. Thus, although the population of L. monocytogenes inoculated was the same in this study, the environments where they must grow and interact is different. In a solid medium L. monocytogenes is spread on the surface of the agar gel and 
the film with L. lactis is in contact with the surface, thus their interaction could produce a competition for the same nutrients, and a strong inhibition because of the metabolites production, such as a bacteriocin like nisin [43] or lactic acid [44]. Therefore, bacteria cannot migrate inward in solid agar and colonies appear immobilised on the agar surface (providing the depth is not shown) [40].

Consequently, the space in which the bacteria can grow is smaller than the space they have in $10 \mathrm{~mL}$ of liquid culture medium. If it is assumed that the volume where the LAB grow is $64 \mathrm{~cm}^{2}$ (area of the Petri dish) and $1 \mathrm{~mm}$ deep, we obtain a volume of $6.4 \mathrm{~cm}^{3}$, as opposed to the $10 \mathrm{~cm}^{3}$ in which they grow in the liquid medium. Calculating the ratio between these volumes, the space bacteria have to grow in the liquid media, is 1.5 times greater than in solid media. Therefore, L. lactis and L. monocytogenes are 1.5 times more concentrated on the agar. This means that although the ratio between L. lactis and L. monocytogenes is the same, their concentration is higher; therefore, there will be more competition for food and space to grow. In addition, the by-products of L. lactis metabolism, such as nisin or organic acids, will be 1.5 times more concentrated than in the liquid medium; thus, explaining the results in this study.

Moreover, L. monocytogenes strains are highly flagellated and motile at low temperatures $\left(\leq 30^{\circ} \mathrm{C}\right)$ [45], whereas L. lactis is nonmotile [46]. In several cases where competition between several bacterial species exists, motility with flagella is shown to provide a specific advantage for a bacterium in a liquid culture medium [47].

\subsubsection{In vivo studies in sliced cooked ham}

Ready-to-eat (RTE) meats such as sliced cooked ham is greatly consumed in Europe and USA. However, these products have a substantial risk of recontamination by the pathogen $L$. monocytogenes when handling after cooking and slicing prior to packaging.

Studies related to using protective cultures in the design of active packages for sliced cooked meats are scarce. Pavli et al., (2017) have 
shown that Lactobacillus plantarum and Lactobacillus pentosus migrated from calcium-treated alginate films to sliced cooked ham, and still grew in the food matrix after high hydrostatic pressure (HHP) treatment, but they did not test the anti-listeria activity of the coating [48]. L. lactis is frequently found on vegetable substrates and in the dairy environment, can also grow in a variety of niches; Vermeiren, Devlieghere, \& Debevere, (2004) found that 24\% LAB, isolated from cooked meats, corresponded to the specie Lactococcus lactis subsp. lactis [49]. In this study, L. lactis has been incorporated in sliced cooked ham through separator liners, which are highly used for Deli meats.

Initial testing accounted for the total aerobe counts of sliced cooked ham at time 0 , to determine the endogenous microbial load in this product. The results were low (data not shown), probably because sliced cooked ham is pasteurised and packed in modified atmospheric packaging (MAP). Likewise, LAB from sliced cooked ham on day 16 storage was measured on MRS agar yielding less than $10^{2} \mathrm{CFU} / \mathrm{g}$. Thus, the endogenous microbial load in sliced cooked ham was low, enabling $L$. lactis and $L$. monocytogenes strains to be the dominant population in ham.

Figure 4 shows the population of $L$. lactis viable cells in cooked ham slices, which were previously inoculated with L. monocytogenes and stored, using separators, at $4{ }^{\circ} \mathrm{C}$ for 16 days. Viable cell numbers of L. lactis maintained high and constant levels, approximately 8 log $\mathrm{CFU} / \mathrm{g}$ through storage, like results obtained with a solid culture medium. Figure 4 also shows the growth of $L$. monocytogenes in slices stored with separators without incorporating the protective culture. $L$. monocytogenes grew like in agar when the L. lactis culture was not added, reaching 8 log $\mathrm{CFU} / \mathrm{g}$. 


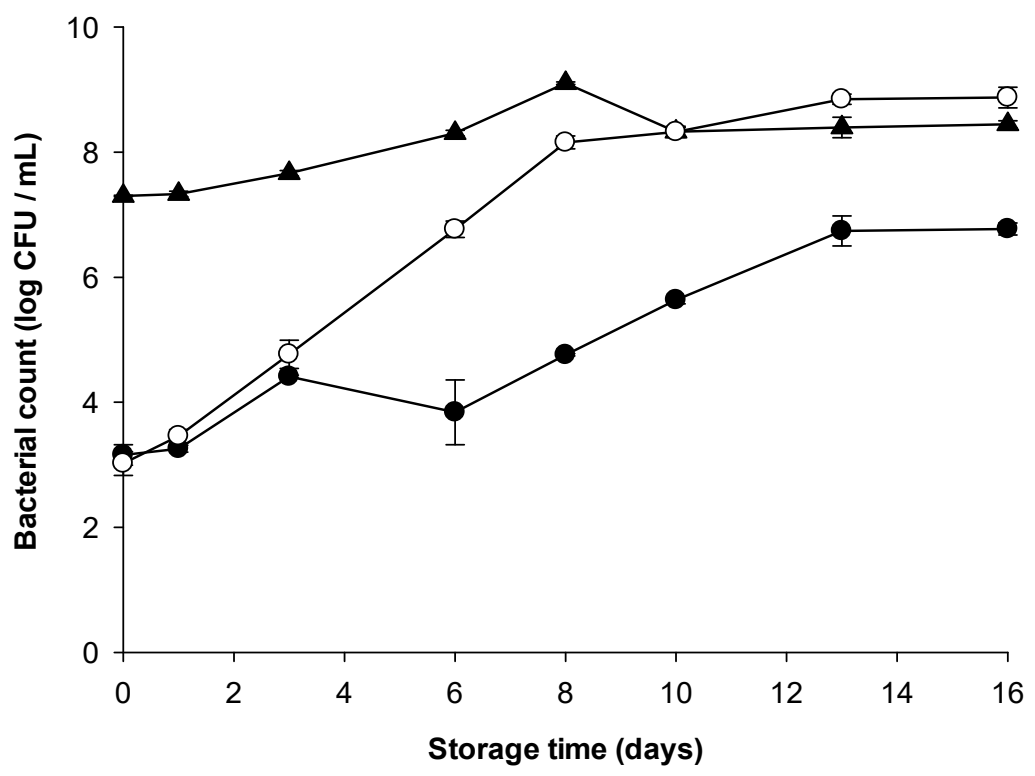

Figure 4. Growth of Lactococcus lactis $(\mathbf{\Lambda})$ and anti-listeria activity of active ( $\bullet)$ and control $(O)$ separator liners placed on the surface of cooked ham slices stored at $4{ }^{\circ} \mathrm{C}$ for 16 days.

When active separator liners were applied, no antimicrobial activity was detected during the first 3 days. However, from day 4 to 16 , a reduced growth of $L$. monocytogenes was observed (approximately $3.5 \log \mathrm{CFU} / \mathrm{g}$ ), different to growth found in agar. Wang et al., (2016) also found a lower thermal inactivation of $L$. monocytogenes on the surface of vacuum packaged RTE sliced cooked ham and sausage than vacuum-package solid agar. Sliced cooked ham has a more complex matrix, whereas agar is designed exclusively for microbial growth and the environment in food products rarely provides optimal conditions for the microorganism growth. The main factors affecting the bacterial growth in food are $\mathrm{pH}$, temperature, nutrients concentration, $\mathrm{NaCl}$ concentration, and water activity $\left(\mathrm{a}_{\mathrm{w}}\right)$ [40]. Nutrients and bioavailability are not the same for both matrices; sliced cooked ham contains proteins, fat, and complex sugars, like 
starch, whereas TSA+YE contains proteins hydrolysates and free glucose components that are more available for bacteria. Moreover, the sliced cooked ham structure differs from agar's because cooked ham is a piece of pig muscle with fibrous tissue and agar has a smooth surface. Besides, the sliced cooked ham structure can limit the contact between surfaces and thus, proper delivery of L. lactis to the slice. In addition, the lower $\mathrm{a}_{\mathrm{w}}$ of the sliced cooked ham, compared with agar, can slow down the erosion of PVOH hydro-soluble film and thus, the delivery of the culture, affecting their anti-listeria capacity. Therefore, despite the similar LAB amounts in sliced cooked ham and in agar medium, their metabolic activity can be different. The null antimicrobial activity observed during the first 3 days could be because of the $\angle A B$, although they are alive in a concentration of $8 \mathrm{log}$ $\mathrm{CFU} / \mathrm{mL}$, they could still be latent. During the following days, the more complex composition and structure of the ham, regarding the liquid and solid culture media, may make them less metabolically active and thus generate fewer metabolism by-products, such as nisin or organic acids, therefore have less antimicrobial activity.

A reduction in antimicrobial activity of active metabolites segregated by $L$. lactis can also contribute to the results found. Explained by bacteriocins being able to reduce their activity in a food matrix because of the proteolytic action of endogenous food enzymes, or binding to food ingredients.

\subsection{Evolution of $\mathrm{pH}$ in sliced cooked ham}

Table 3 show the $\mathrm{pH}$ of sliced cooked ham in contact with PLA separator liners, and also of sliced cooked ham inoculated with $L$. monocytogenes in contact with separator liners was measured at days 0,8 , and 16 . 
Table 3. Evolution of $\mathrm{pH}$ in sliced cooked ham.

\begin{tabular}{ccccc}
\hline \multirow{2}{*}{ Packaging } & Food matrix & Day 0 & Day 6 & Day 12 \\
\cline { 3 - 4 } PLA & $\mathrm{CH}$ & $6.07 \pm 0.02^{\mathrm{aA}}$ & $6.04 \pm 0.02^{\mathrm{aA}}$ & $6.08 \pm 0.04^{\mathrm{aA}}$ \\
$\mathrm{PLA} /(\mathrm{PVOH}+\mathrm{HGel})$ & $\mathrm{CH}+$ L. monocytogenes & $6.08 \pm 0.01^{\mathrm{aA}}$ & $6.07 \pm 0.02^{\mathrm{aA}}$ & $6.01 \pm 0.03^{\mathrm{bA}}$ \\
$\mathrm{PLA} /(\mathrm{PVOH}+\mathrm{HGel}+$ L. lactis $)$ & $\mathrm{CH}+$ L. monocytogenes & $6.07 \pm 0.03^{\mathrm{aA}}$ & $5.56 \pm 0.03^{\mathrm{bB}}$ & $5.35 \pm 0.05^{\mathrm{cB}}$ \\
\hline
\end{tabular}

$a, b, c$ : different letters in the same line indicate significant differences among time for the same formulation $(p<0.05)$.

$A, B$ : different letters in the same column indicate significant differences among formulation $(p<0.05)$.

$\mathrm{CH}$ : Cooked Ham 
The organic acids production is related to the growth of LAB. No significant changes were observed in the $\mathrm{pH}$ of sliced cooked ham using uncoated separator liners or those coated with $\mathrm{PVOH}+\mathrm{HGel}$ without incorporating L. lactis; inoculation with L. monocytogenes neither affected to the $\mathrm{pH}$. The initial $\mathrm{pH}$ of the samples was 6.1, normal for cooked ham, and was maintained through storage. When $L$. lactis was incorporated in the separator liners the $\mathrm{pH}$ decreased to 5.35 after 16 days of storage at $4{ }^{\circ} \mathrm{C}$. A greater drop in $\mathrm{pH}$ was reported by Pavli et al. (2017) when alginate-based edible films loaded with a population of $10^{9} \mathrm{CFU} / \mathrm{mL} \mathrm{LAB}$ were applied on vacuum packed sliced cooked ham and stored for 66 days at $4{ }^{\circ} \mathrm{C}$; dropping from 6.49 to 4.4 on day 18 [13]. Y. Gao et al. (2015) also found a decreased pH, from 6.6 to 5.4, in vacuum packed sliced cooked ham inoculated with $6 \log$ CFU/g of Lactobacillus sakei C2 after 20 days of storage at $4{ }^{\circ} \mathrm{C}$ [19]. Danielski et al. (2020) did not find significant changes in $\mathrm{pH}$ of sliced cooked ham inoculated with different strains of Carnobacterium maltaromaticum after 7 days of being packaged in sterile expanded polystyrene trays covered with polyvinyl chloride film and stored at 4 ${ }^{\circ} \mathrm{C}$ [51]. Likewise, Vermeiren et al. (2004) studied the acidification capacity of different LAB strains in vacuum packaged sliced cooked ham stored for 34 days at $4{ }^{\circ} \mathrm{C}$ [19]. They found acidification depended on the strain with values of $\mathrm{pH}$ ranging from 6.10 to 5.75 . This low $\mathrm{pH}$ change is explained by cooked ham having a small glucose level, thus a low lactic acid production and acidification of the medium. Notably, the drop in $\mathrm{pH}$ in sliced cooked ham was lower than in creamy mushroom soup, which can be correlated with a lower metabolic activity of L. lactis in sliced cooked ham; this agrees with the lower antimicrobial activity found in sliced cooked ham. It can be expected that if bacteria are metabolically less active, there will be fewer byproducts of their metabolism, such as organic acids, but also less production of nisin since it is a primary metabolite $[52,53]$.

\subsection{Flow cytometry analysis.}


Flow cytometry analyses the viability of cells with suitable fluorochromes. It was used to distinguish viable cell from non-viable cell populations of $L$. lactis. After 12 days of storage, the liquid medium presented the highest number of dead cells (33.54\%), followed by the solid culture medium with $23.17 \%$, the creamy mushroom soup with $20.68 \%$, and sliced cooked ham with $16.64 \%$. Thus, the percentage of cell death in all matrices was different, although the population of L. lactis, measured on day 12 , was similar. These differences are probably related to the number of cells reaching the different phases of cell cycle, meaning cells that died on day 12 passed through the entire phase of the cell cycle with the corresponding generation of bacterial growth metabolites (primary metabolites such as nisin or organic acids).

Therefore, it is expected that the liquid culture medium, rich in available and fermentable carbohydrates, had a higher percentage of dead cells; thus, cells are metabolically more active, with a faster growth, and increased secretion of antimicrobial metabolites. In addition, a previous study reported microbial growth is faster in liquid culture medium than in solid medium [40]. The lower percentage of dead cells in the creamy mushroom soup implies a lower cell growth because of the complexity of the matrix. This explains the lower antilisteria activity than in liquid media. Moreover, the percentage of cells dead in agar was lower than in liquid medium because the higher percentage of live bacteria in agar can be related to the culture medium itself. TSA is used for maintaining bacterial strains because it has a balanced and high nutrient value and a lack of fermentable carbohydrates. For of liquid TSB, the medium is not suitable for maintenance as carbohydrate fermentation liberates many acids which may threaten the organism's viability [54].

The sliced cooked ham had the lowest percentage of dead bacteria because $L$. lactis did not grow at the same rate (less metabolic activity) as in the other matrices. The lower bacteria release from the film to the sliced cooked ham, together with a less favourable growth 
matrix, made L. lactis remain longer in latency, and with less growth. Therefore, a lower production of antimicrobial metabolites resulted in a lower anti-listeria activity.

\subsection{Sensory evaluation of active packaged food products}

\subsubsection{Sensory evaluation of creamy mushroom soup}

Using lactic bacteria as a bio-preservative to inhibit pathogen and spoilage Gram + bacteria can alter the organoleptic properties of the food product, such as changes in aroma, texture, colour, and taste because of the products of their metabolism [55]. These changes may be expected in foods where LAB is used as a starter, like in fermented foods, but is unexpected in non-fermented food. Creamy mushroom soup is an RTE food whose organoleptic properties could be altered when using $L A B$ for biocontrol and could be rejected by consumers. Therefore, a sensory analysis was conducted using non-expert judges with the aim to evaluate if the amount of L. lactis and its metabolites were perceptible in the aroma, colour, thickness, lumpiness, and taste of creamy mushroom soup, and overall the acceptance or rejection of the product. The tests were conducted on the 0 (newly packaged), 6 , and 12 days storedcreamy mushroom soup at $4{ }^{\circ} \mathrm{C}$. Results were compared with the controlcreamy mushroom soup at day 0 , packaged without incorporating $L A B$; results are shown in Table 4.

Friedman analysis indicated that no significant differences in the intensity of aroma and colour were perceived in any sample, except for the colour in creamy mushroom soup active packaged stored for 12 days. Thickness and lumpiness of active packaged creamy mushroom soup increased at days 6 and 12. This was expected because LAB can coagulate proteins in milk or cream because of the production of organic acids, increasing the thickness and lumpiness [56].

Regarding the taste of creamy mushroom soup, samples were submitted to a hedonic test to check for consumer acceptance (1 to 9 scale). No differences were found between active and conventional 
newly packaged creamy mushroom soup with values above 6.9. However, when active packaging was applied, acceptability in taste decreased with storage. Judges were asked to choose taste attributes from a proposed list. All the judges selected the sour taste for creamy mushroom soup stored for 6 and 12 days, which corresponds to the drop in the $\mathrm{pH}$. Almost all the judges also selected lemon taste. Thus, they related the sour taste with "addition of lemon".

Regarding purchase intention ( 1 to 5 scale), the test showed the judges might buy the creamy mushroom soup newly packaged with both conventional and active packaging, they would buy or not buy a creamy mushroom soup with 6 days of storage, and probably they would not buy a creamy mushroom soup with 12 days of storage. After providing the information about the active packaging, values slightly increased but without major changes in the purchase intention. These results were mostly because of the sour taste provided by $L A B$. In the food industry, using acidity regulators or buffering agents are common for food formulations, as they are safe and a good strategy to avoid excessive acidification from LAB. Likewise, in previous studies it was demonstrated that the neutralisation of the $\mathrm{pH}$ had no effect on the anti-listeria activity of films incorporating L. lactis in milk [17].

\subsubsection{Sensory evaluation of sliced cooked ham}

Sensory evaluation of sliced cooked ham stored using active separator liners was also conducted to evaluate the effect of metabolites produced by L. lactis during storage on its organoleptic perception. For that, the aroma, general aspect, and taste of the sliced cooked ham, in contact with active separator liners, was judged at day 0,8 , and 16 days of refrigerated storage $\left(4{ }^{\circ} \mathrm{C}\right)$. Samples were compared with sliced cooked ham in contact with conventional separator liners at day 0; results are shown in Table 5. 
Table 4. Sensory attributes, taste acceptability and purchase intention of packaged mushroom cream stored at $4{ }^{\circ} \mathrm{C}$ for 12 days.

\begin{tabular}{|c|c|c|c|c|c|c|c|c|}
\hline \multirow[b]{2}{*}{ Bag } & \multirow{2}{*}{$\begin{array}{l}\text { Storage } \\
\text { time } \\
\text { (days) }\end{array}$} & \multicolumn{4}{|c|}{ Rank intensity attributes } & \multirow{2}{*}{$\begin{array}{c}\text { Acceptability } \\
\text { Taste } \\
(1-9)\end{array}$} & \multicolumn{2}{|c|}{ Purchase intention } \\
\hline & & $\begin{array}{c}\text { Aroma } \\
(1-4)\end{array}$ & $\begin{array}{l}\text { Color } \\
(1-4)\end{array}$ & $\begin{array}{c}\text { Thickness } \\
(1-4)\end{array}$ & $\begin{array}{l}\text { Lumpiness } \\
\qquad(1-4)\end{array}$ & & $\begin{array}{c}\text { Before } \\
\text { information } \\
(1-5)\end{array}$ & $\begin{array}{c}\text { After } \\
\text { information } \\
(1-5)\end{array}$ \\
\hline Active & 0 & $2.57^{a}$ & $2.92^{\mathrm{a}}$ & $1.44^{\mathrm{d}}$ & $1.51^{c}$ & $6.89^{a}$ & $3.52^{\mathrm{a}}$ & $3.52^{\mathrm{a}}$ \\
\hline Active & 6 & $2.40^{a}$ & $2.77^{\mathrm{a}}$ & $2.83^{b}$ & $2.65^{b}$ & $5.14^{b}$ & $2.56^{b}$ & $2.80^{b}$ \\
\hline Active & 12 & $2.33^{a}$ & $1.79^{b}$ & $3.69^{a}$ & $3.62^{\mathrm{a}}$ & $4.35^{c}$ & $2.08^{c}$ & $2.42^{b}$ \\
\hline Conventional & 0 & $2.70^{a}$ & $2.52^{\mathrm{a}}$ & $2.04^{c}$ & $2.22^{b}$ & $6.92^{\mathrm{a}}$ & $3.52^{\mathrm{a}}$ & $3.75^{a}$ \\
\hline
\end{tabular}

Different letters in the same column regarding intensity attributes indicates bags differ statistically by Friedman test.

Different letters in the same column indicate significant $(p<0.05)$ differences in taste acceptability and purchase intention of packaged MS.

Table 5. Sensory attributes and purchase intention of cooked ham in contact with separator liners stored at $4^{\circ} \mathrm{C}$ for 16 days.

\begin{tabular}{|c|c|c|c|c|c|c|}
\hline \multirow[b]{2}{*}{$\begin{array}{c}\text { Separator } \\
\text { liner }\end{array}$} & \multirow[b]{2}{*}{$\begin{array}{l}\text { Storage } \\
\text { time } \\
\text { (days) }\end{array}$} & \multicolumn{3}{|c|}{ Acceptability } & \multicolumn{2}{|c|}{ Purchase intention } \\
\hline & & $\begin{array}{l}\text { Aroma } \\
\text { (1-9) }\end{array}$ & $\begin{array}{l}\text { General } \\
\text { aspect } \\
(1-9)\end{array}$ & $\begin{array}{l}\text { Taste } \\
(1-9)\end{array}$ & $\begin{array}{l}\text { Before information } \\
\qquad(1-5)\end{array}$ & $\begin{array}{l}\text { After information } \\
\qquad(1-5)\end{array}$ \\
\hline Active & 0 & $6.29^{a}$ & $6.26^{a}$ & $6.51^{a}$ & $3.37^{a}$ & $3.59^{a}$ \\
\hline Active & 8 & $6.64^{a}$ & $6.70^{\mathrm{a}}$ & $6.48^{a}$ & $3.34^{a}$ & $3.59^{a}$ \\
\hline Active & 16 & $5.83^{a}$ & $5.70^{a}$ & $6.40^{\mathrm{a}}$ & $3.33^{a}$ & $3.55^{a}$ \\
\hline Conventional & 0 & $6.26^{a}$ & $6.29^{a}$ & $6.50^{\mathrm{a}}$ & $3.37^{a}$ & $3.59^{a}$ \\
\hline
\end{tabular}

Different letters in the same acceptability column indicate separator liners differ statistically by Friedman test.

Different letters in the same column indicate significant differences $(p<0.05)$ in taste acceptability and purchase intention of cooked ham slices in contact with different separator liners. 
Friedman analysis indicated no significant differences were found in any of the studied parameters for all the samples. This means that neither a $(\mathrm{PVOH}+\mathrm{HGel})$ coating nor $\mathrm{LAB}$ modified the organoleptic properties perceived by consumers. These results agree with the studies carried out by Odila Pereira, Soares, J.P. Monteiro, Gomes, \& Pintado (2018) [57]. They evaluated the consumer's acceptability of sliced cooked ham previously immersed in a whey coating solution incorporating B. animalis $B b-12^{\circledR}$ and $L$. casei-01. Vermeiren et al., (2004) studied the viability of different LAB strains in cooked ham for their use as a protective culture, reporting that, for some inoculated strains, vacuum packaged cooked ham was not rejected by a trained sensory panel after 34 days of storage at $4{ }^{\circ} \mathrm{C}$ [19].

Regarding the purchase intention ( 1 to 5 scale), the test showed that the judges would probably buy the samples regardless of the type and time of packaging. These results were expected as no differences were found in the acceptability test. When judges were informed samples were in contact with active separator liners, the values of purchase intention increased from 3.3 to 3.5 , thus consumers appreciated active packaging.

\section{Conclusions}

This study demonstrates that PVOH coatings can deliver Lactococcus lactis in liquid and solid culture media; whereas coatings have anti-listeria bactericide effect in a solid culture medium, they exert a bacteriostatic effect in a liquid medium.

The active coatings applied on the surface of separator liners for sliced cooked ham or in PLA bags for refrigerated creamy mushroom soup, maintained $L$. lactis viability and exerted reductions on the growth of Listeria monocytogenes compared with food in contact with control films. However, the coating lacking anti-listeria effects on sliced cooked ham could be improved by facilitating the delivery of $L$. lactis to the food surface by modifying the coating formulation so the erosion of the coating was faster. 
Sensory studies showed that acidification of the media, because of organic acids generated by L. lactis, was perceived by panellists in creamy mushroom soup but not perceived in sliced cooked ham.

Therefore, this study demonstrated that the protective culture $L$. lactis can be incorporated in $\mathrm{PVOH}$ coatings for the design of biodegradable active packages, for both refrigerated viscous and solid non-fermented foods. This will aid inhibiting the growth of psychrophilic pathogenic Gram+ bacteria such as L. monocytogenes during storage. However, more studies must be conducted to improve the effectivity of the films depending on physico-chemical properties of the food and the application of the protective culture.

\section{Acknowledgements}

The authors acknowledge the financial support of the Ministerio de Ciencia e Innovación Español (AGL 2015-64595-R).

\section{References}

1. Cabedo, L.; Picart I Barrot, L.; Teixidó I Canelles, A. Prevalence of Listeria monocytogenes and Salmonella in ready-to-eat food in Catalonia, Spain. J. Food Prot. 2008, 71, 855-859, doi:10.4315/0362-028X-71.4.855.

2. Donovan, S. Listeriosis: A Rare but Deadly Disease. Clin. Microbiol. Newsl. 2015, 37, 135-140, doi:10.1016/j.clinmicnews.2015.08.001.

3. "Centers for Disease Control and Preservation" Listeria (listeriosis) Available online: www.cdc.gov/listeria/ (accessed on Dec 13, 2019).

4. Schlech, W.F.; Lavigne, P.M.; Bortolussi, R.A.; Allen, A.C.; Haldane, E.V.; Wort, A.J.; Hightower, A.W.; Johnson, S.E.; King, S.H.; Nicholls, E.S.; et al. Epidemic Listeriosis - Evidence for Transmission by Food. N. Engl. J. Med. 1983, 308, 203-206, doi:10.1056/NEJM198301273080407.

5. Walker, S.J.; Archer, P.; Banks, J.G. Growth of Listeria monocytogenes at refrigeration temperatures. J. Appl. Bacteriol. 1990, 68, 157-162, doi:10.1111/j.1365-2672.1990.tb02561.x.

6. Rodrigues, C.S.; de Sá, C.V.G.C.; de Melo, C.B. An overview of Listeria monocytogenes contamination in ready to eat meat, 
dairy and fishery foods. Cienc. Rural 2017, 47, doi:10.1590/0103-8478cr20160721.

7. EFSA Panel on Biological Hazards (BIOHAZ); Ricci, A.; Allende, A.; Bolton, D.; Chemaly, M.; Davies, R.; Fernández Escámez, P.S.; Girones, R.; Herman, L.; Koutsoumanis, K.; et al. Listeria monocytogenes contamination of ready-to-eat foods and the risk for human health in the EU. EFSA J. 2018, 16, doi:10.2903/j.efsa.2018.5134.

8. Commission Regulation (EC) No 2073/2005 Commission Regulation (EC) No 2073/2005 of 15 November 2005 on microbiological criteria for foodstuffs. OJ L 338, 22.12.2005, p. 126.;

9. WHO (World Health Organization) Listeriosis- Spain, World Health Organization Disease outbreak news Available online: https://www.who.int/csr/don/16-september-2019-listeriosisspain/en/ Accessed 16 Sept. 2019 (accessed on Nov 19, 2019).

10. Khanum Mirza, S.; Asema, U.; Sultan Kasim, S. International peer reviewed Journal Special Issue Analytical Chemistry Teacher and Researchers Association National Convention/Seminar Issue 02. 2017, 02, 610-616.

11. Bessa, F.; Barría, P.; Neto, J.M.; Frias, J.P.G.L.; Otero, V.; Sobral, P.; Marques, J.C. Occurrence of microplastics in commercial fish from a natural estuarine environment. Mar. Pollut. Bull. 2018, 128, 575-584, doi:10.1016/j.marpolbul.2018.01.044.

12. Lavender, K. Plastics in the marine environment. Ann. Rev. Mar. Sci. 2017, 9, 205-229, doi:10.1146/annurev-marine-010816060409.

13. Pavli, F.; Tassou, C.; Nychas, G.J.E.; Chorianopoulos, N. Probiotic incorporation in edible films and coatings: Bioactive solution for functional foods. Int. J. Mol. Sci. 2018, 19, 150.

14. Espitia, P.J.P.; Batista, R.A.; Azeredo, H.M.C.; Otoni, C.G. Probiotics and their potential applications in active edible films and coatings. Food Res. Int. 2016, 90, 42-52, doi:10.1016/j.foodres.2016.10.026.

15. Benkerroum, N.; Sandine, W.E. Inhibitory Action of Nisin Against Listeria monocytogenes. J. Dairy Sci. 1988, 71, 32373245, doi:10.3168/jds.S0022-0302(88)79929-4.

16. López-De-Dicastillo, C.; Jordá, M.; Catalá, R.; Gavara, R.; Hernández-Muñoz, P. Development of active polyvinyl 
alcohol/ $\beta$-cyclodextrin composites to scavenge undesirable food components. J. Agric. Food Chem. 2011, 59, 11026-11033, doi:10.1021/jf200749f.

17. Settier-Ramírez, L.; López-Carballo, G.; Gavara, R.; HernándezMuñoz, P. PVOH/protein blend films embedded with lactic acid bacteria and their antilisterial activity in pasteurized milk. Int. J. Food Microbiol. 2020, 322, 108545, doi:10.1016/j.ijfoodmicro.2020.108545.

18. Settier-Ramírez, L.; López-Carballo, G.; Gavara, R.; HernándezMuñoz, P. Antilisterial properties of $\mathrm{PVOH}$-based films embedded with Lactococcus lactis subsp. lactis. Food Hydrocoll. 2019, 87, 214-220, doi:10.1016/j.foodhyd.2018.08.007.

19. Gao, $H_{. ;}$Fang, $X_{. ;}$Chen, $H_{. ;}$Qin, $Y_{\text {.; }} X_{\text {u, }} F_{. ;}$Jin, T.Z. Physiochemical properties and food application of antimicrobial PLA film. Food Control 2017, 73, 1522-1531, doi:10.1016/j.foodcont.2016.11.017.

20. Peelman, N.; Ragaert, P.; De Meulenaer, B.; Adons, D.; Peeters, R.; Cardon, L.; Van Impe, F.; Devlieghere, F. Application of bioplastics for food packaging. Trends Food Sci. Technol. 2013, 32, 128-141.

21. Briassoulis, D.; Mistriotis, A.; Giannoulis, A.; Giannopoulos, D. Optimized PLA-based EMAP systems for horticultural produce designed to regulate the targeted in-package atmosphere. Ind. Crops Prod. 2013, 48, 68-80, doi:10.1016/j.indcrop.2013.03.017.

22. Auras, R.; Singh, S.; Singh, J. Performance Evaluation of PLA against Existing PET and PS Containers. J. Test. Eval. 2006, 34, 100041, doi:10.1520/jte100041.

23. 13.432, E. EN 13.432. Packaging -Requirements for Packaging Recoverable Through Composting And Biodegradation-Test Scheme and Evaluation Criteria for the Final Acceptance of Packaging, European Standard. European Committee for Standardization, Brussels, Belgium; 2005;

24. Mistriotis, A.; Briassoulis, D.; Giannoulis, A.; D'Aquino, S. Design of biodegradable bio-based equilibrium modified atmosphere packaging (EMAP) for fresh fruits and vegetables by using micro-perforated poly-lactic acid (PLA) films. Postharvest Biol. Technol. 2016, 111, 380-389, doi:10.1016/j.postharvbio.2015.09.022.

25. Gialamas, H.; Zinoviadou, K.G.; Biliaderis, C.G.; Koutsoumanis, K.P. Development of a novel bioactive packaging based on the 
incorporation of Lactobacillus sakei into sodium-caseinate films for controlling Listeria monocytogenes in foods. Food Res. Int. 2010, 43, 2402-2408, doi:10.1016/j.foodres.2010.09.020.

26. Concha-Meyer, A.; Schöbitz, R.; Brito, C.; Fuentes, R. Lactic acid bacteria in an alginate film inhibit Listeria monocytogenes growth on smoked salmon. Food Control 2011, 22, 485-489, doi:10.1016/j.foodcont.2010.09.032.

27. López de Lacey, A.M.; López-Caballero, M.E.; Montero, P. Agar films containing green tea extract and probiotic bacteria for extending fish shelf-life. LWT - Food Sci. Technol. 2014, 55, 559-564, doi:10.1016/j.lwt.2013.09.028.

28. Newel, G.J.; MacFarlane, J.D. Expanded Tables for Multiple Comparison Procedures in the Analysis of Ranked Data. J. Food Sci. 1987, 52, 1721-1725, doi:10.1111/j.13652621.1987.tb05913.x.

29. De Muynck, C.; Leroy, A.I.J; De Maeseneire, S.; Arnaut, F.; Soetaert, W.; Vandamme, E.J. Potential of selected lactic acid bacteria to produce food compatible antifungal metabolites. Microbiol. Res. 2004, 159, 339-346, doi:10.1016/j.micres.2004.07.002.

30. Schillinger, U.; Becker, B.; Vignolo, G.; Holzapfel, W.H. Efficacy of nisin in combination with protective cultures against Listeria monocytogenes Scott A in tofu. Int. J. Food Microbiol. 2001, 71, 159-168, doi:10.1016/S0168-1605(01)00612-2.

31. Ferreira, M.A.S.S.; Lund, B.M. The effect of nisin on Listeria monocytogenes in culture medium and long-life cottage cheese. Lett. Appl. Microbiol. 1996, 22, 433-438, doi:10.1111/j.1472-765X.1996.tb01197.x.

32. Belletti, N.; Lanciotti, R.; Patrignani, F.; Gardini, F. Antimicrobial efficacy of citron essential oil on spoilage and pathogenic microorganisms in fruit-based salads. J. Food Sci. 2008, 73, M331-M338, doi:10.1111/j.1750-3841.2008.00866.x.

33. Burt, S. Essential oils: Their antibacterial properties and potential applications in foods - A review. Int. J. Food Microbiol. 2004, 94, 223-253.

34. Muriel-Galet, V.; López-Carballo, G.; Gavara, R.; HernándezMuñoz, P. Antimicrobial Effectiveness of Lauroyl Arginate Incorporated into Ethylene Vinyl Alcohol Copolymers to Extend the Shelf-Life of Chicken Stock and Surimi Sticks. Food Bioprocess Technol. 2015, 8, 208-217, doi:10.1007/s11947-014- 
1391-x.

35. Gutierrez, J.; Barry-Ryan, C.; Bourke, P. The antimicrobial efficacy of plant essential oil combinations and interactions with food ingredients. Int. J. Food Microbiol. 2008, 124, 91-97, doi:10.1016/j.jijoodmicro.2008.02.028.

36. Gao, Y.; Li, D.; Liu, X. Effects of Lactobacillus sakei C2 and sakacin C2 individually or in combination on the growth of Listeria monocytogenes, chemical and odor changes of vacuumpacked sliced cooked ham. Food Control 2015, 47, 27-31, doi:10.1016/j.foodcont.2014.06.031.

37. Lado, B.H.; Yousef, A.E. Characteristics of Listeria monocytogenes Important to Food Processors. In Listeria, Listeriosis, and Food Safety; 2007.

38. Leroy, F.; De Vuyst, L. Lactic acid bacteria as functional starter cultures for the food fermentation industry. Trends Food Sci. Technol. 2004, 15, 67-78, doi:10.1016/J.TIFS.2003.09.004.

39. Sahadeva, R.P.K.; Leong, S.F.; Chua, K.H.; Tan, C.H.; Chan, H.Y.; Tong, E. V.; Wong, S.Y.W.; Chan, H.K. Survival of commercial probiotic strains to $\mathrm{pH}$ and bile. Int. Food Res. J. 2011, 18, 1515-1522.

40. Jeanson, S.; Floury, J.; Gagnaire, V.; Lortal, S.; Thierry, A. Bacterial Colonies in Solid Media and Foods: A Review on Their Growth and Interactions with the Micro-Environment. Front. Microbiol. 2015, 6, 1284, doi:10.3389/fmicb.2015.01284.

41. Pipe, L.Z.; Grimson, M.J. Spatial-temporal modelling of bacterial colony growth on solid media. Mol. Biosyst. 2008, 4, 190-198, doi:10.1039/b708241j.

42. Skandamis, P.N.; Jeanson, S. Colonial vs. planktonic type of growth: Mathematical modeling of microbial dynamics on surfaces and in liquid, semi-liquid and solid foods. Front. Microbiol. 2015, 6, 1178.

43. Thomas, L. V.; Wimpenny, J.W.T. Investigation of the effect of combined variations in temperature, $\mathrm{pH}$, and $\mathrm{NaCl}$ concentration on nisin inhibition of Listeria monocytogenes and Staphylococcus aureus. Appl. Environ. Microbiol. 1996, 62, 20062012, doi:10.1128/aem.62.6.2006-2012.1996.

44. Antwi, M.; Theys, T.E.; Bernaerts, K.; Van Impe, J.F.; Geeraerd, A.H. Validation of a model for growth of Lactococcus lactis and Listeria innocua in a structured gel system: Effect of monopotassium phosphate. Int. J. Food Microbiol. 2008, 125, 
320-329, doi:10.1016/j.jijfoodmicro.2008.04.014.

45. Gründling, A.; Burrack, L.S.; Bouwer, H.G.A.; Higgins, D.E. Listeria monocytogenes regulates flagellar motility gene expression through MogR, a transcriptional repressor required for virulence. Proc. Natl. Acad. Sci. U. S. A. 2004, 101, 12318-12323, doi:10.1073/pnas.0404924101.

46. Siroli, L.; Patrignani, F.; Serrazanetti, D.I.; Tabanelli, G.; Montanari, C.; Gardini, F.; Lanciotti, R. Lactic acid bacteria and natural antimicrobials to improve the safety and shelf-life of minimally processed sliced apples and lamb's lettuce. Food Microbiol. 2015, 47, 74-84, doi:10.1016/j.fm.2014.11.008.

47. Moens, S.; Vanderleyden, J. Functions of bacterial flagella. Crit. Rev. Microbiol. 1996, 22, 67-100.

48. Pavli, F.; Kovaiou, I.; Apostolakopoulou, G.; Kapetanakou, A.; Skandamis, P.; Nychas, G.J.E.; Tassou, C.; Chorianopoulos, N. Alginate-based edible films delivering probiotic bacteria to sliced ham pretreated with high pressure processing. Int. J. Mol. Sci. 2017, 18, 1867, doi:10.3390/ijms18091867.

49. Vermeiren, L.; Devlieghere, F.; Debevere, J. Evaluation of meat born lactic acid bacteria as protective cultures for the biopreservation of cooked meat products. Int. J. Food Microbiol. 2004, 96, 149-164, doi:10.1016/j.ijfoodmicro.2004.03.016.

50. Wang, X.; Uyttendaele, M.; Geeraerd, A.; Steen, L.; Fraeye, I.; Devlieghere, F. Thermal inactivation kinetics of surface contaminating Listeria monocytogenes on vacuum-packaged agar surface and ready-to-eat sliced ham and sausage. Food Res. Int. 2016, 89, 843-849, doi:10.1016/j.foodres.2016.10.019.

51. Danielski, G.M.; Imazaki, P.H.; de Andrade Cavalari, C.M.; Daube, G.; Clinquart, A.; de Macedo, R.E.F. Carnobacterium maltaromaticum as bioprotective culture in vitro and in cooked ham. Meat Sci. 2020, 162, 108035, doi:10.1016/j.meatsci.2019.108035.

52. Matsusaki, H.; Endo, N.; Sonomoto, K.; Ishizaki, A. Lantibiotic nisin Z fermentative production by Lactococcus lactis 10-1: relationship between production of the lantibiotic and lactate and cell growth. Appl. Microbiol. Biotechnol. 1996, 45, 36-40, doi:10.1007/s002530050645.

53. De Vuyst, L.; Vandamme, E.J. Influence of the carbon source on nisin production in Lactococcus lactis subsp. lactis batch fermentations. J. Gen. Microbiol. 1992, 138, 571-8, 
doi:10.1099/00221287-138-3-571.

54. Atlas, R.M.; Parks, L.C. Handbook of microbiological media; CRC Press, 1993; ISBN 0849329442.

55. Juvonen, R.; Honkapää, K.; Maina, N.H.; Shi, Q.; Viljanen, K.; Maaheimo, H.; Virkki, L.; Tenkanen, M.; Lantto, R. The impact of fermentation with exopolysaccharide producing lactic acid bacteria on rheological, chemical and sensory properties of pureed carrots (Daucus carota L.). Int. J. Food Microbiol. 2015, 207, 109-118, doi:10.1016/j.ijfoodmicro.2015.04.031.

56. Lucey, J.A. Acid coagulation of milk. In Advanced Dairy Chemistry: Volume 1B: Proteins: Applied Aspects: Fourth Edition; Springer New York, 2016; pp. 309-328 ISBN 9781493928002.

57. Odila Pereira, J.; Soares, J.; J.P. Monteiro, M.; Gomes, A.; Pintado, M. Impact of whey protein coating incorporated with Bifidobacterium and Lactobacillus on sliced ham properties. Meat Sci. 2018, 139, 125-133, doi:10.1016/j.meatsci.2018.01.016. 


\section{Artículo 5}

\section{Broadening the antimicrobial}

spectrum of nisin-producing Lactococcus lactis subsp. Lactis to Gram-negative bacteria by means of active packaging

Laura Settier-Ramírez; Gracia López-Carballo; Rafael Gavara; Pilar Hernández-Muñoz

International Journal of Food Microbiology, 2021, vol. 339, p. 109007

Packaging Lab, Instituto de Agroquímica y Tecnología de Alimentos, IATA-CSIC, Av. Agustín Escardino 7, 46980 Paterna, Spain. 



\section{ABSTRACT}

Cast films obtained from polyvinyl alcohol (PVOH) blended with casein hydrolysates (HCas) in a weight ratio of 1:1 were employed to carry nisin-producing $L$. lactis and phytic acid in order to broaden the antimicrobial spectrum of L. lactis to Gram-positive and Gramnegative spoilage and pathogen bacteria. For this purpose, the effect of the antimicrobial activity of various film formulations and combinations of films on the growth of E. coli at $37^{\circ} \mathrm{C}$ for $24 \mathrm{~h}$ was studied. The film system that showed antimicrobial activity against Gram-negative bacteria consisted of phytic acid and $L$. lactis incorporated in separate films. When the active agents were in the same film the viability of $L$. lactis decreased considerably and it did not exert antimicrobial activity against the bacterium. Therefore, the combination of $L$. lactis and phytic acid in separate films was chosen as the reliable system, and the effect of its activity on the growth of Gram-negative bacteria (E. coli, Salmonella enterica, and Pseudomonas fluorescens) and Gram-positive bacteria (Listeria monocytogenes) in liquid culture medium was tested at refrigeration temperature $\left(4^{\circ} \mathrm{C}\right)$, and with simulated breaks in the cold chain $\left(14{ }^{\circ} \mathrm{C}\right.$ and $\left.24^{\circ} \mathrm{C}\right)$. The survival of $L$. lactis in coexistence with these bacteria was also studied. The film system exerted an antimicrobial effect against the Gramnegative bacteria tested, and the activity depended on the bacteria and the temperature assayed. With regard to the antimicrobial activity against $L$. monocytogenes, phytic acid improved the antimicrobial capacity of $L$. lactis. The survival of $L$. lactis was maintained at 7-8 log $(\mathrm{CFU} / \mathrm{mL})$ culture in liquid medium throughout the storage period.

The films developed were intended to be used as coatings in the design of a double-sided active bag for a non-fermented dairy product. The bags were filled with homemade preservative-free pastry cream, and the microbiological shelf life and evolution of $\mathrm{pH}$ of the packaged ready-to-eat food stored at $4{ }^{\circ} \mathrm{C}$ was studied for 20 days. The results showed a reduction in the growth of spoilage bacteria and therefore an increase in the shelf life of the packaged product. The films developed could be applied in the design of packages for 
perishable dairy foods in order to increase their microbiological shelf life.

Keywords: Lactococcus lactis, PVOH; bioactive packaging; phytic acid; broad-spectrum; pastry cream. 


\section{Introduction}

Choosing environmentally friendly polymers is just as important as selecting natural antimicrobial agents. The main disadvantage of synthetic polymers is that they are usually not biodegradable. However, polyvinyl alcohol (PVOH) is a synthetic polymer that is completely biodegradable and biocompatible, and it has excellent film-forming properties [1]. PVOH has been approved by the FDA for use in food contact and as a food additive with INS N 1203 (Codex Alimentarius) (FAO/WHO (Food and Agriculture Organization/World Health Organization), 2004). In the EU it is permitted by the EFSA as a food additive in food supplements in accordance with Annex II to Regulation (EC) No 1333/2008.

Previous studies carried out in our laboratory showed that PVOHbased films supplemented with protein hydrolysates and incorporating nisin-producing Lactococcus lactis subsp. lactis have antimicrobial activity against $L$. monocytogenes inoculated previously in pasteurized milk [2].

Lactic acid bacteria have an advantage as they are considered as GRAS (Generally Recognized As Safe). However, bacteriocins produced by lactic acid bacteria are generally effective against Gram-positive bacteria but not against Gram-negative bacteria [3,4]. The outer membrane of Gram-negative bacteria acts as a good protective barrier to nisin [5]. Moreover, the insensitivity of Gram-negative bacteria to nisin could be due to the large size $(1.8-4.6 \mathrm{kDa})$ of nisin, which hinders its passage across the membrane of these bacteria. With the exception of listeriosis, almost all foodborne bacterial infections can be attributed to the ingestion of Gram-negative bacteria. Escherichia coli can cause gastroenteritis; it is a coliform bacterium that is ubiquitous in the environment. Coliform bacteria are considered as a global indicator of low hygiene in food processing environments. It is essential to control the presence of coliform bacteria to obtain safe food.

The genus Pseudomonas comprises a large group of ubiquitous bacteria that are present in a great variety of sources. Most of them act as specific spoilage microorganisms in foods. They can adapt and 
grow at low temperatures, reaching high loads in chilled foods such as fish, meat, and refrigerated dairy products, causing spoilage due to the production of volatile compounds and amino acid metabolites. Pseudomonads produce heat-stable proteolytic and lipolytic enzymes that can remain active in heat-treated products, and thus they can reduce the quality and shelf life of foods, especially proteinaceous foods. The spoiled food often appears discolored, owing to the biosynthesis of pigments by these bacteria. Moreover, some Pseudomonas spp. produce pectolytic enzymes, causing browning of ready-to-eat fruits and vegetables [6]. Microbial spoilage is the main cause of food spoilage and it places a considerable economic burden on the food industry [7]. Pseudomonas is the predominant milkassociated psychrotrophic bacterium, and it is one of the most important bacterial groups in the dairy industry [8]; $70 \%$ of the spoilage microorganisms isolated from cold-stored dairy products belong to Pseudomonas species, causing a large part of food losses at the consumption stage [6]. P. fluorescens, $P$. gessardii, $P$. fragi, and $P$. lundensis are the most common Pseudomonas species found in milk and milk products [9]. In particular, P. fluorescens is associated with numerous defects in dairy products [10].

Salmonellosis is another dangerous food disease produced by Gram-negative bacteria that affects a high percentage of the world's population. Centers for disease control and prevention estimate that Salmonella causes about 1.2 million illnesses, 23,000 hospitalizations, and 450 deaths in the United States every year.

These bacteria are important in food microbiology because most foodborne pathogens are Gram-negative, and for that reason they have been included in the present study.

It would be very interesting to develop antimicrobial systems with a broad spectrum of activity against Gram-positive and Gram-negative bacteria. Some authors have modified model lantibiotic nisin with antimicrobial peptides that have known antibacterial activity against Gram-negative bacteria [5]. Other strategies have also been developed to increase the antimicrobial effect of bacteriocins against Gramnegative bacteria, such as the use of chelating agents, sanitization 
treatments with other antimicrobial agents such as sodium hypochlorite, temperature treatments, high pressure processing, or pulsed electric fields [11].

The antimicrobial effect of nisin can be improved by the use of membrane destabilizing agents, such as chelating compounds, polycationic acid, and waek organic acids and their salts $[12,13]$. Researchers have shown that exposure of Gram-negative bacteria to chelating agents increases the antimicrobial effect of nisin against them $[14,15]$. Nisin in combination with phytic acid reduced the population of L. monocytogenes on cabbage and broccoli [16]. Other authors have studied the antibacterial effect and mode of action of phytic acid [17]. Phytic acid causes cell membrane dysfunction, and it is able to change cell morphology, disrupt intercellular adhesion, and decrease intracellular ATP concentrations [17]. It has been reported that phytic acid combined with other compounds such as sodium chloride or ethanol has a synergistic antimicrobial effect against Gramnegative bacteria $[17,18]$. Phytic acid is a food additive that is present in many grains and legumes. The maximum level of phytic acid permitted by the FDA is $0.2 \%(\mathrm{w} / \mathrm{w})[19]$.

Several studies have shown that phytic acid has some health properties, such as antioxidant activity achieved by reducing lipid peroxidation and free radical generation $[20,21]$, a neuroprotective effect in Parkinson's disease [22], and anticarcinogenic activity. Phytic acid could reduce the calcification process and prevent renal stone formation [23], and it could lower blood glucose in diabetes [24-26].

Therefore, it is worth exploring whether the use of phytic acid combined with nisin-producing lactic acid bacteria broadens the antimicrobial spectrum to Gram-negative bacteria. To date, there are no studies on the development of films carrying nisin-producing lactic bacteria capable of reducing the growth of Gram-negative bacteria, and on their application to the design of an active package for food. This approach could be a great tool to ensure food safety and extend the shelf life of packaged food products.

Accordingly, the aim of this work was to broaden the spectrum of activity of polyvinyl alcohol (PVOH)-based films 
incorporating L. lactis to Gram-negative bacteria. To achieve this goal, phytic acid was incorporated in the film formulation or in the active film system. Then the active film system was used as the inner wall of an active polyethylene bag for the packaging of pastry cream, and its microbiological shelf life was studied.

\section{Materials and methods}

\subsection{Bacterial strains}

The Lactococcus lactis strain obtained from the Spanish Type Culture Collection (CECT 539, ATCC 11454) was chosen for its antimicrobial activity, and it was stored at $-80{ }^{\circ} \mathrm{C}$ in De Man-Rogosa-Sharpe (MRS) broth supplemented with $20 \%$ of glycerol. The microbial culture was regenerated and maintained by regular subculture at $4{ }^{\circ} \mathrm{C}$ on MRS broth. Before use, an aliquot from the culture was subcultured by overnight incubation in $10 \mathrm{~mL}$ of MRS.

The Listeria monocytogenes strain (CECT 934, ATCC 19114) was chosen as a Gram-positive model because of its importance in foodborne illness. Pseudomonas fluorescens (CECT 378, ATCC 13525), Escherichia coli (CECT 434, ATCC 25922), and Salmonella enterica (CECT 4300, ATCC 13076) were chosen as Gram- negative bacteria because of their importance in food spoilage and foodborne illness. These strains were kept frozen in Tryptone Soy Broth (TSB) supplemented with $20 \%$ of glycerol. The stock culture was maintained by regular subculture at $4{ }^{\circ} \mathrm{C}$ on Tryptone Soy Agar (TSA) and transferred monthly. Before use, a loopful of each strain was transferred to $10 \mathrm{~mL}$ of Tryptone Soy Agar supplemented with $0.6 \%$ of yeast extract $(\mathrm{TSB}+\mathrm{YE})$ and incubated overnight at $30^{\circ} \mathrm{C}$ or $37^{\circ} \mathrm{C}$.

Culture media were provided by Scharlab (Barcelona, Spain).

\subsection{Film formation}

Polyvinyl alcohol (PVOH, Gohsenol AH17, Nippon Synthetic Chemical Company, Osaka, Japan) was dissolved in distilled water at $1 \%(\mathrm{w} / \mathrm{w})$ as the polymer matrix used to make the films. Casein hydrolysate (Sigma-Aldrich, Barcelona, Spain) was chosen as a 
nutritional supplement for Lactococcus lactis and was added to the PVOH solution in a mass ratio of 1:1.

L. lactis cells were collected by centrifugation $(2,500$ RCF for 15 min) at $4{ }^{\circ} \mathrm{C}$. The supernatant was removed and washed twice with peptone water; then L. lactis was added to the film-forming solution (FFS) in accordance with the amount shown in Table 1.

Phytic acid (50\% phytic acid solution (w/w) in $\mathrm{H}_{2} \mathrm{O}$, Aldrich Chemistry) was added to the FFS together with L. lactis, or alone without the presence of bacteria. It was also added directly to the culture medium, as indicated in Table 1. Control films were prepared without bacteria and without phytic acid.

All the films were cast in $90 \mathrm{~mm}$ Petri dishes and dried at room temperature for $24 \mathrm{~h}$.

The average thickness of the films obtained (FCON, FLAC, FPA, $\mathrm{F}[\mathrm{LAC}+\mathrm{PA}]$, and $\mathrm{FLAC}+\mathrm{PA})$ was $43 \pm 5 \mu \mathrm{m}$ and $21 \pm 5 \mu \mathrm{m}$ for films when studied the combination (FLAC+FPA). Thickness was measured at 3 points randomly in order to verify uniformity.

2.3. Preliminary tests of viability and antimicrobial properties of several film formulations and combinations of them

\subsubsection{Viability of L. lactis}

Films incorporating L. lactis (FLAC), or films combining L. lactis and phytic acid (F[LAC+PA]), or two separate films, one with L. lactis and another one carrying phytic acid (FLAC+FPA), were transferred to glass tubes containing $10 \mathrm{~mL}$ of sterile Tryptone Soy Agar supplemented with $0.6 \%$ of yeast extract (TSB+YE). In the case of the combination (FLAC+PA), FLAC was placed in a glass tube containing $10 \mathrm{~mL}$ of TSB+YE and PA. The films were left to hydrate under vigorous agitation until complete dissolution. The resulting solutions were diluted in peptone water and plated in MRS agar. Colonies were counted after incubation at $30^{\circ} \mathrm{C}$ for 4 days. 
Table 1. Film formation and combination of them.

\begin{tabular}{|c|c|c|c|}
\hline Films & $\begin{array}{c}\text { L. lactis } \\
\text { (CFU/mL FFS) }\end{array}$ & $\begin{array}{l}\text { Phytic acid* } \\
\text { ( } \mu \text { L/mL FSS) }\end{array}$ & $\begin{array}{c}\text { Casting } \\
\text { (mL/Petri dish) }\end{array}$ \\
\hline $\begin{array}{l}\text { Control films } \\
\text { (FCON) }\end{array}$ & - & - & 15 \\
\hline $\begin{array}{l}\text { L. lactis films } \\
\text { (FLAC) }\end{array}$ & $1 \times 10^{8}$ & - & 15 \\
\hline $\begin{array}{l}\text { Phytic acid films } \\
\text { (FPA) }\end{array}$ & - & 2.66 & 15 \\
\hline $\begin{array}{l}\text { L lactis and Phytic acid film } \\
\text { (F[LAC+PA]) }\end{array}$ & $1 \times 10^{8}$ & 2.66 & 15 \\
\hline \multirow{2}{*}{$\begin{array}{l}L \text { lactis film (FLAC)+ Phytic acid film (FPA) } \\
\text { (FLAC+FPA) }\end{array}$} & $2 \times 10^{8}$ & - & 7.5 \\
\hline & - & 5.32 & 7.5 \\
\hline $\begin{array}{l}\text { L. lactis films + free phytic acid } \\
\text { (FLAC+PA) }\end{array}$ & $1 \times 10^{8}$ & $\begin{array}{c}3.99 \text { per } 10 \mathrm{~mL} \\
\text { sample } \\
\text { (directly added } \\
\text { to the medium) }\end{array}$ & 15 \\
\hline
\end{tabular}

*Quantities referred to phytic acid at 50\% 
Phytic acid (50\% phytic acid solution (w/w) in $\mathrm{H}_{2} \mathrm{O}$, Aldrich Chemistry) was added to the FFS together with L. lactis, or alone without the presence of bacteria. It was also added directly to the culture medium, as indicated in Table 1. Control films were prepared without bacteria and without phytic acid.

All the films were cast in $90 \mathrm{~mm}$ Petri dishes and dried at room temperature for $24 \mathrm{~h}$.

The average thickness of the films obtained (FCON, FLAC, FPA, $F[L A C+P A]$, and $F L A C+P A)$ was $43 \pm 5 \mu \mathrm{m}$ and $21 \pm 5 \mu \mathrm{m}$ for films when studied the combination (FLAC+FPA). Thickness was measured at 3 points randomly in order to verify uniformity.

2.3. Preliminary tests of viability and antimicrobial properties of several film formulations and combinations of them

\subsubsection{Viability of L. lactis}

Films incorporating L. lactis (FLAC), or films combining L. lactis and phytic acid (F[LAC+PA]), or two separate films, one with L. lactis and another one carrying phytic acid (FLAC+FPA), were transferred to glass tubes containing $10 \mathrm{~mL}$ of sterile Tryptone Soy Agar supplemented with $0.6 \%$ of yeast extract $(T S B+Y E)$. In the case of the combination (FLAC+PA), FLAC was placed in a glass tube containing $10 \mathrm{~mL}$ of TSB+YE and PA. The films were left to hydrate under vigorous agitation until complete dissolution. The resulting solutions were diluted in peptone water and plated in MRS agar. Colonies were counted after incubation at $30^{\circ} \mathrm{C}$ for 4 days.

\subsubsection{In vitro antimicrobial activity against $E$. coli}

The antimicrobial activity of the various combinations shown in Table 1 was tested against E. coli, a Gram-negative bacterium. Furthermore, for all the combinations except the films that only carried phytic acid (FPA), L. lactis survival after being in contact with E. coli during the test was also studied. For this purpose, the formulations described in Table 1 were added to TSB+YE tubes previously inoculated with $10^{3} \mathrm{CFU} / \mathrm{mL}$ of $E$. coli and incubated at its optimal growth temperature, $37^{\circ} \mathrm{C}$, for $24 \mathrm{~h}$. Then serial dilutions were made 
in peptone water and plated in Violet Red Bile Dextrose (VRBD) agar and in MRS agar for the films containing L. lactis. The agar plates were incubated at $37{ }^{\circ} \mathrm{C}$ and $30{ }^{\circ} \mathrm{C}$ for 2 days and 4 days, respectively. Colonies were counted after incubation. The tests were performed in triplicate.

2.4. In vitro antimicrobial activity of films against several bacteria and survival of $L$. lactis at different storage time and temperature combinations

The film combination that exhibited the best results in the above section, FLAC+FPA, was chosen for the next experiments. In order to compare its activity with control films, FCON, FLAC, and FPA were also studied separately.

The antimicrobial effectiveness of the films was tested against L. monocytogenes, P. fluorescens, E. coli, and S. enterica in liquid medium at $4{ }^{\circ} \mathrm{C}$ and $14{ }^{\circ} \mathrm{C}$ for 20 days, and at $24{ }^{\circ} \mathrm{C}$ for 5 days. The growth of $L$. lactis was also studied in FLAC and FLAC+FPA films. Films were removed from dishes and placed in glass tubes containing $10 \mathrm{~mL}$ of TSB+YE previously inoculated with $10^{3} \mathrm{CFU} / \mathrm{mL}$ of the spoilage or pathogen bacteria. The tubes were stored in the conditions mentioned above. Samples were taken immediately after inoculation and at various times. Serial dilutions with peptone water were made and plated in Petri dishes with $15 \mathrm{~mL}$ of agar medium. L. lactis bacteria were incubated in MRS agar plates at $30{ }^{\circ} \mathrm{C}$ for 4 days, $L$. monocytogenes bacteria were incubated in PALCAM agar with selective supplement at $37^{\circ} \mathrm{C}$ for $48 \mathrm{~h}, P$. fluorescens bacteria were incubated in Pseudomonas agar with CFC selective supplement at $30{ }^{\circ} \mathrm{C}$ for $48 \mathrm{~h}$, and S. enterica and E. coli were incubated in VRBD agar at $37^{\circ} \mathrm{C}$ for 24 h. After the incubation time, the colony forming units (CFU) were counted and the results were expressed as $\log \mathrm{CFU} / \mathrm{mL}$. The tests were done in triplicate.

\subsection{Active bags}

Active bags $(8 \mathrm{~cm} \times 4 \mathrm{~cm})$ were made from polyethylene (PE) film previously coated on one side with PVOH containing L. lactis (LAC) 
and with PVOH containing PA on the other side. The corresponding coating-forming solutions (CFS) containing phytic acid or L. lactis were prepared dissolving $10 \%$ of $\mathrm{PVOH}$ and $\mathrm{HCas}$ in mass ratio of $1: 1$. The amount of PA and the target inoculum of L. lactis were adapted to CFS in order to obtain the same $\mathrm{pH}$ and the same $L$. lactis concentration found in TSB+YE when films prepared in section 2.2. were applied. Both CFS, with LAC and with PA, were applied on the PE surface using an extension bar with a $100 \mu \mathrm{m}$ deep thread (Lin-Lab Rioja, Logroño, Spain). PE/FLAC and PE/FPA were heat-welded to obtain the bags. Control passive bags were made following the same protocol but without $L A B$ and phytic acid. The average thickness of all the coatings obtained was $12 \pm 3 \mu \mathrm{m}$, and it was measured at 3 points randomly in order to verify uniformity.

2.6. Study of the shelf life of homemade pastry cream packaged in active bags

The food matrix chosen to study the antimicrobial effectiveness of the films was pastry cream because this dairy product is a ready-to-eat product that is highly perishable. An antimicrobial study was carried out to test spoilage bacteria such as Pseudomonas spp., Enterobacteria and mesophilic, psychrotrophic, and coliform bacteria that limit the shelf life of the product, and also the pathogenic bacterium $L$. monocytogenes. The lactic acid bacteria load was also monitored. Homemade pastry cream was prepared with the following ingredients: $100 \mathrm{~g}$ of sugar, $600 \mathrm{~mL}$ of UHT-treated semi-skimmed milk, $50 \mathrm{~g}$ of cornmeal, 3 eggs, and five drops of vanilla flavor. The ingredients were stirred and heated at $100{ }^{\circ} \mathrm{C}$ in a Thermomix TM31 (Vorwerk, Germany). Control and active bags were filled with $10 \mathrm{~g}$ of pastry cream and stored at $4{ }^{\circ} \mathrm{C}$, simulating refrigeration conditions. The microbial counts were done on the samples immediately after packaging and after 1, 3, 7, 10, 13, and 20 days of storage. Serial dilutions with peptone water were made and plated in Petri dishes with $15 \mathrm{~mL}$ of selective agar medium. The enumeration of particular microbial groups was performed by using the following media (Scharlab, Barcelona, Spain) and culture conditions: 1) PCA (Plate 
Count Agar) for total aerobic at $30{ }^{\circ} \mathrm{C}$ for $48 \mathrm{~h}$, and also for total aerobic psychrotrophic count at $6.5{ }^{\circ} \mathrm{C}$ for 10 days; 2) VRBD (Violet Red Bile Dextrose Agar) for total enterobacteria at $37{ }^{\circ} \mathrm{C}$ for $24 \mathrm{~h}, 3$ ) Pseudomonas agar with CFC (Cetrimide Fucidin Cephalosporin) selective supplement for Pseudomonas spp. at $30{ }^{\circ} \mathrm{C}$ for $24 \mathrm{~h}$, 4) BGA (Brilliant Green Agar) at $37{ }^{\circ} \mathrm{C}$ for $24 \mathrm{~h}$ for coliform bacteria, 5) PALCAM (Polymyxin Acriflavin Lithium-chloride Ceftazidime Esculin Mannitol) agar with selective supplement at $37{ }^{\circ} \mathrm{C}$ for $24 \mathrm{~h}$ for Listeria, and 6) MRS (Man, Rogosa, Sharpe) agar at $30{ }^{\circ} \mathrm{C}$ for 4 days for lactic acid bacteria. The counts were performed in triplicate. A scheme showing microbiological assays carried out is shown in Figure S1.

\subsection{Evolution of $\mathrm{pH}$ of homemade pastry cream during storage time}

Organic acids are compounds usually produced by lactic acid bacteria as a product of their metabolism. An increase in the acidity of a food product can produce rejection by consumers. Moreover, phytic acid could also affect the $\mathrm{pH}$ of the cream. Therefore, the $\mathrm{pH}$ of the packaged pastry cream was monitored during storage at $0,1,3,7,10$, 13 , and 20 days of storage. The $\mathrm{pH}$ was measured in $5 \mathrm{~g}$ of pastry cream (Figure S1) using a Consort $\mathrm{C} 830 \mathrm{pH}$ meter and a $\mathrm{pH}$ ) electrode combined with a Consort SP10T electrode (United Kingdom).

\subsection{Statistical analysis}

One-way analyses of variance were carried out with the SPSS computer program (SPSS Inc., Chicago, IL). Tukey b test for a confidence interval of $95 \%$ was used to evaluate differences in pairs of mean values. Data were represented as the average \pm standard deviation.

\section{Results and Discussion}

3.1. Preliminary tests of viability of L. lactis and antimicrobial activity against $E$. coli of several formulated films and combinations of them

\subsubsection{Viability of L. lactis}

The viability of $L$. lactis for the various film formulations with active agents and combinations of them is shown in Figure 1. 


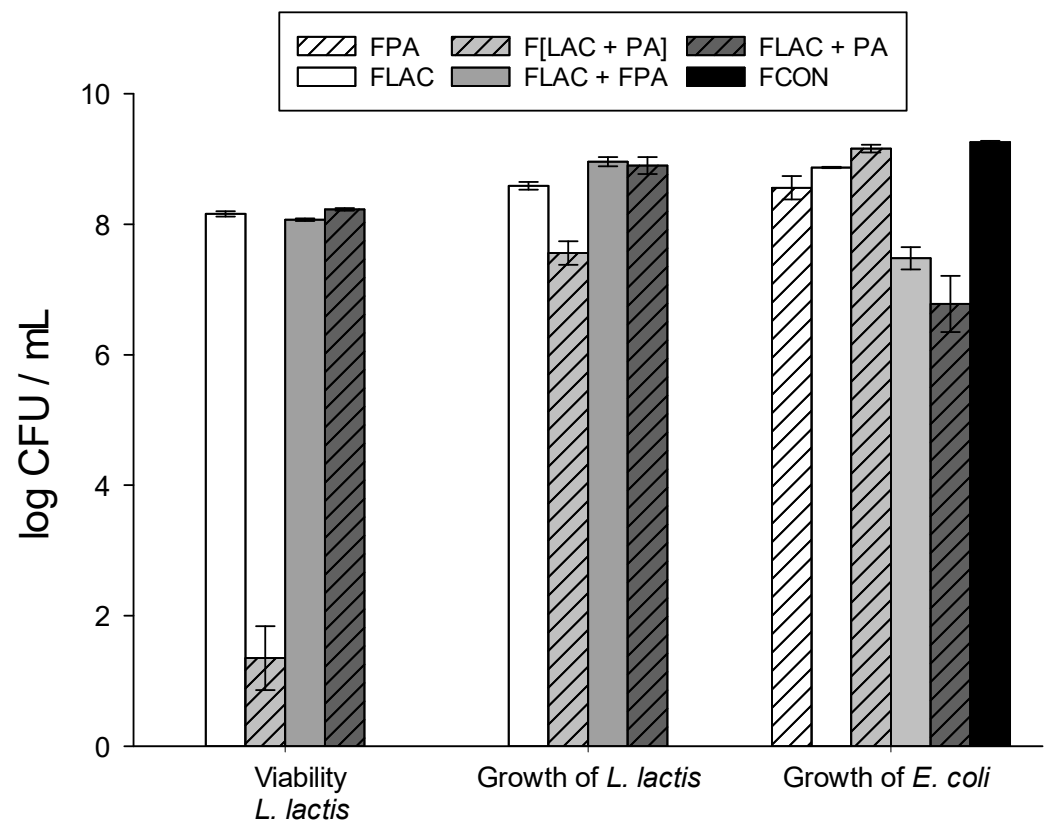

Figure 1. Viability of L. lactis in films directly after drying, and growth of L. lactis and antimicrobial activity of films after incubation in liquid medium in contact with $E$. coli at $37{ }^{\circ} \mathrm{C}$ for $24 \mathrm{~h}$. Mean values and 95\% LSD intervals.

Previous studies have shown that PVOH films are good carriers for the delivery of L. lactis into packaged foods [2,27]. However, the way in which the film is processed and the nature of the film composition can drastically affect cell viability [28], and therefore viability was studied when phytic acid was incorporated.

In this study, phytic acid was incorporated in the test growth medium in various ways - in the same film as $L$. lactis ( $F[L A C+P A])$; in separate films (FLAC+FPA); and directly added (without film) (FLAC+PA) - in order to study its effect on the viability of L. lactis. Figure 1 shows the viability of $L$. lactis for the various combinations with phytic acid.

No differences in $L$. lactis viability were found between films without PA (FLAC), used as a control, and the combinations FLAC+FPA 
and FLAC+PA. However, a reduction of more than 6.2 log was observed when film was cast from the film-forming solution containing both $\mathrm{LAC}$ and $\mathrm{PA}, \mathrm{F}[\mathrm{LAC}+\mathrm{PA}]$. The drying process involves a concentration of all the film components, including PA. The drop in $\mathrm{pH}$ during this step could explain the losses observed. Similarly, Soukoulis et al. (2017) concluded that the low pH of pectin films (3.9-4.2) was the reason for losses of Lactobacillus rhamnosus during drying. Thus, the survival ability of the microorganisms in films is closely related to the $\mathrm{pH}$ reached in the drying process.

\subsubsection{In vitro antimicrobial activity against E. coli}

The antimicrobial activity of the film formulations or combinations of them against E. coli at $37^{\circ} \mathrm{C}$ after $24 \mathrm{~h}$ is shown in Figure 1. No reductions were observed for films carrying PA or LAC compared with the control films. This result was expected because the nisin produced by $L$. lactis is not effective against Gram-negativebacteria (De Vuyst \& Vandamme, 1992; Helander \& Mattila-Sandholm, 2000). On the other hand, the decision concerning the amount of PA in the films was based on previous studies (data not shown) in which it was not expected to have antimicrobial activity against $E$. coli per se, but to have a synergistic effect with L. lactis. Thus, in the (FLAC+FPA) and (FLAC+PA) films, reductions of $1.79 \log$ and $2.49 \log$, respectively, were observed. It is well known that various food-grade chelators, such as EDTA, EGTA, citrate, or phosphate, have extended the antimicrobial activity of nisin, the bacteriocin produced by L. lactis, to Gram-negative bacteria (Castellano, Belfiore, \& Vignolo, 2011; Cutter \& Siragusa, 1995). As phytic acid is also a chelator, this synergy was observed between PA and L. lactis. The differences in the reductions could be due to the fact that not all the PA that was incorporated in the films was available, probably owing to non-covalent interactions between hydroxyl groups of PVOH and phytic acid.

The growth of L. lactis in contact with the pathogen was also studied and is shown in Figure 1. L. lactis reached the stationary phase after incubation at $37{ }^{\circ} \mathrm{C}$ for $24 \mathrm{~h}$, and its concentration was maintained around $9 \log \mathrm{CFU} / \mathrm{mL}$ in all the cases except for the 
combination $F[L A C+P A]$. Microbial growth of $L$. lactis was not affected by neither the presence of $E$. coli nor PA as long as PA and L. lactis are not in the same film. Other authors have shown that lactic acid bacteria maintained their viability even in the presence of pathogenic bacteria such as Listeria monocytogenes [27,34,35]. In films containing LAC and PA (F[LAC+PA]), L. lactis grew from $1.35 \mathrm{log}$ to $7.56 \mathrm{log}$. This increase in the number of cells indicates that, despite damage to cells during drying of FFS containing PA, most of them were able to multiply, growing to $7.56 \log \mathrm{CFU} / \mathrm{mL}$, very close to the maximum cell growth experienced in the other combinations, as shown in Figure 1.

3.2. In vitro antimicrobial activity of films against various bacteria and survival of $L$. lactis at various storage time and temperature combinations

Figure 2 shows the growth of $E$. coli when the various films were immersed in liquid medium at $4{ }^{\circ} \mathrm{C}$ or $14{ }^{\circ} \mathrm{C}$ for 20 days, and at $24^{\circ} \mathrm{C}$ for 5 days.

As can be seen in Figure 2a, refrigeration temperatures had a bacteriostatic effect on the growth of $E$. coli, and the inoculated amount of the pathogen was maintained around 4 log regardless of the film employed. When the storage temperature increased to $14{ }^{\circ} \mathrm{C}$ (Figure 2b), E. coli took five days to reach the stationary phase for control films or films containing PA or L. lactis; when the experiment was carried out at $24{ }^{\circ} \mathrm{C}$ with the same films, the stationary phase was reached in one day. 
a)

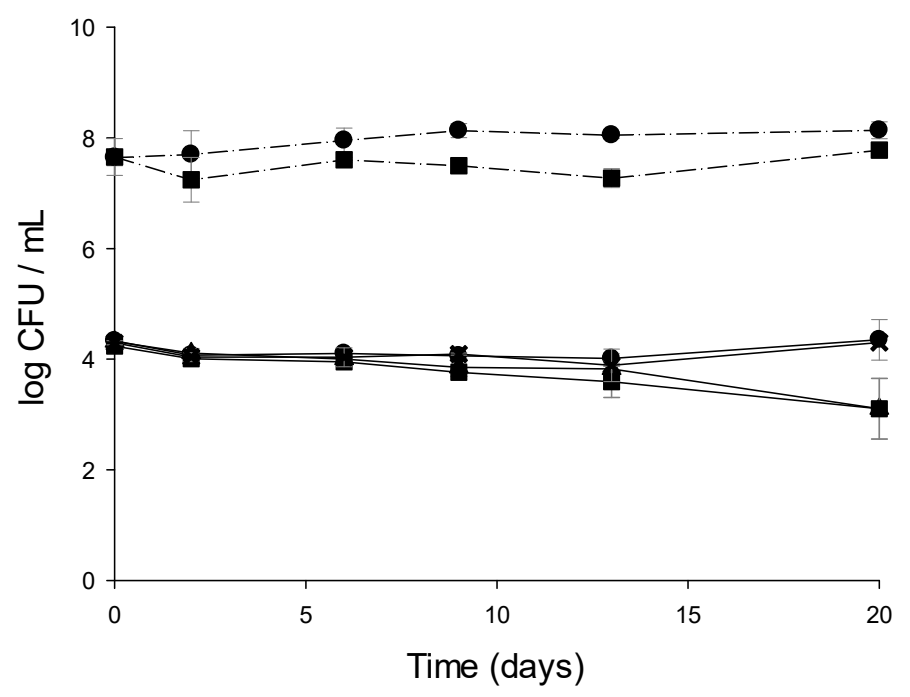

b)

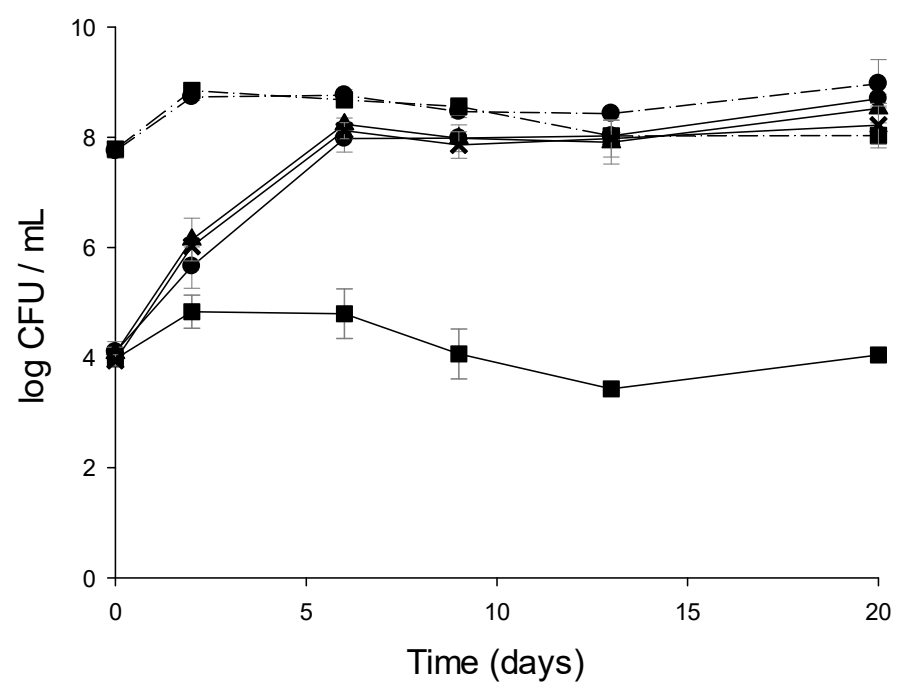


c)

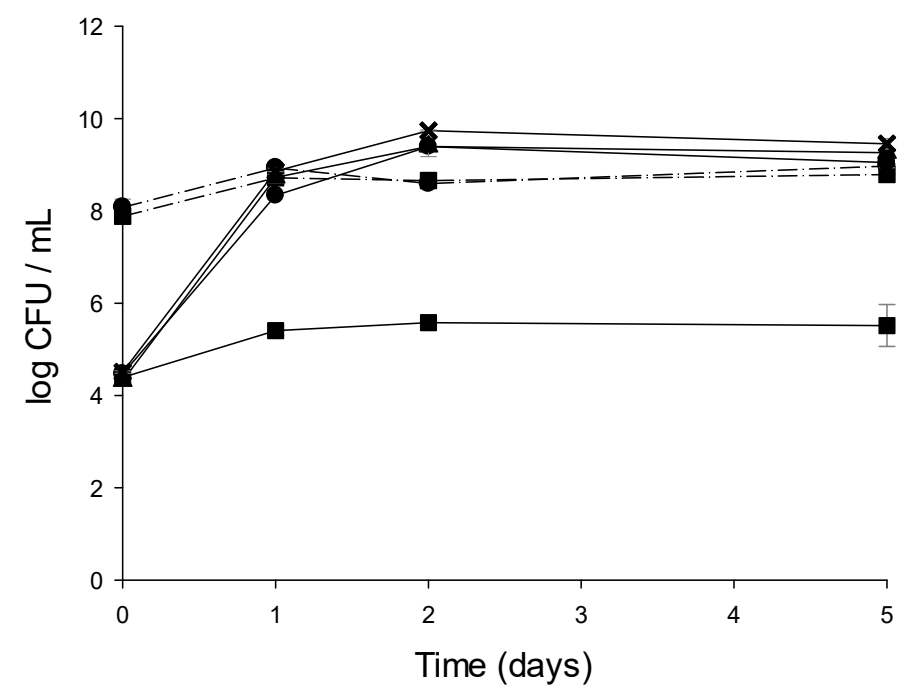

- - - FLAC - L. lactis FLAC+FPA - L. lactis

- FLAC - E. coli FPA - E. coli

FLAC+FPA - E. coli FCON - E. coli

Figure 2. Growth of $L$. lactis and antimicrobial activity of films immersed in liquid medium (TSB + yeast) previously inoculated with $E$. coli and monitored for a) 20 days at $4{ }^{\circ} \mathrm{C}$ and b) 20 days at $14{ }^{\circ} \mathrm{C}$ and c) 5 days at $24{ }^{\circ} \mathrm{C}$. Mean values and $95 \%$ LSD intervals.

The incorporation of phytic acid in the film (FPA) did not affect the growth of pathogens in any case at any temperature, so the same growth was observed as that obtained with the control film. In fact, the amount of PA was chosen in previous studies for not having antimicrobial activity per se against bacteria. Zhou et al. (2019) determined the MIC of PA against E. coli, Salmonella Typhimurium, and two Gram-positive bacteria [17]. They found that the MIC was between 0.20 and $0.28 \%(\mathrm{w} / \mathrm{w})$, depending on the bacterium, and this value is much higher than the amount released by FPA (which was around $1.33 \times 10^{-4} \mathrm{~mL} \mathrm{PA} / \mathrm{mL}$ ). With regard to the films carrying $L$. lactis (FLAC), when they were tested against $E$. coli the results were similar to those obtained with the PVOH control film (FCON) for all the 
temperatures tested. As stated earlier, the nisin produced by L. lactis is not effective against Gram-negative bacteria, and, although L. lactis started with a much higher amount (around $8 \mathrm{log}$ ) than the other pathogens, there was not enough competition to affect growth of the pathogens. Léonard et al. (2014) proved that, even if lactic acid bacteria have various antimicrobial mechanisms, the proteinaceous compounds released, such as nisin for L. lactis, are the most effective.

When the active agents, L. lactis and phytic acid, were incorporated in separate films (FLAC+FPA), the results were similar to those obtained with the other films at $4{ }^{\circ} \mathrm{C}$, but after 20 days 1 log reduction was observed. That is because $E$. coli is mesophilic and low temperatures do not allow it to grow. However, when the growth of E. coli was studied at $14{ }^{\circ} \mathrm{C}$ and $24^{\circ} \mathrm{C}$, the combination of FPA and FLAC exerted a synergistic effect that hindered growth of the pathogen, maintaining the population at the same level as the amount previously inoculated (4 log).

The growth behavior of $S$. enterica at different temperatures and against different film formulations and combinations of them is shown in Figure 3.

This pathogen is a mesophilic bacterium, so its growth was very slow at $4{ }^{\circ} \mathrm{C}$ and its population increased by only 1.5 log after 20 days of storage with FCON and FPA films. However, with the same films at higher temperatures the growth rate increased, reaching the stationary phase with a population of $8 \log$ in 2 days at $14{ }^{\circ} \mathrm{C}$ and in 1 day at $24^{\circ} \mathrm{C}$. As observed for $E$. coli, neither phytic acid nor L. lactis exerted any effect separately on this Gram-negative pathogen. When PA and LAC were incorporated in separate films and tested together at $14{ }^{\circ} \mathrm{C}$, they inhibited the microbial growth by $4.5 \log$. At $24{ }^{\circ} \mathrm{C}$ the growth of $S$. enterica was retarded, achieving a maximum reduction of $2.5 \log$ after 5 days.

The effect of the various film formulations or combinations of them on the growth of $P$. fluorescens was evaluated at various temperatures and is displayed in Figure 4. 
(a)

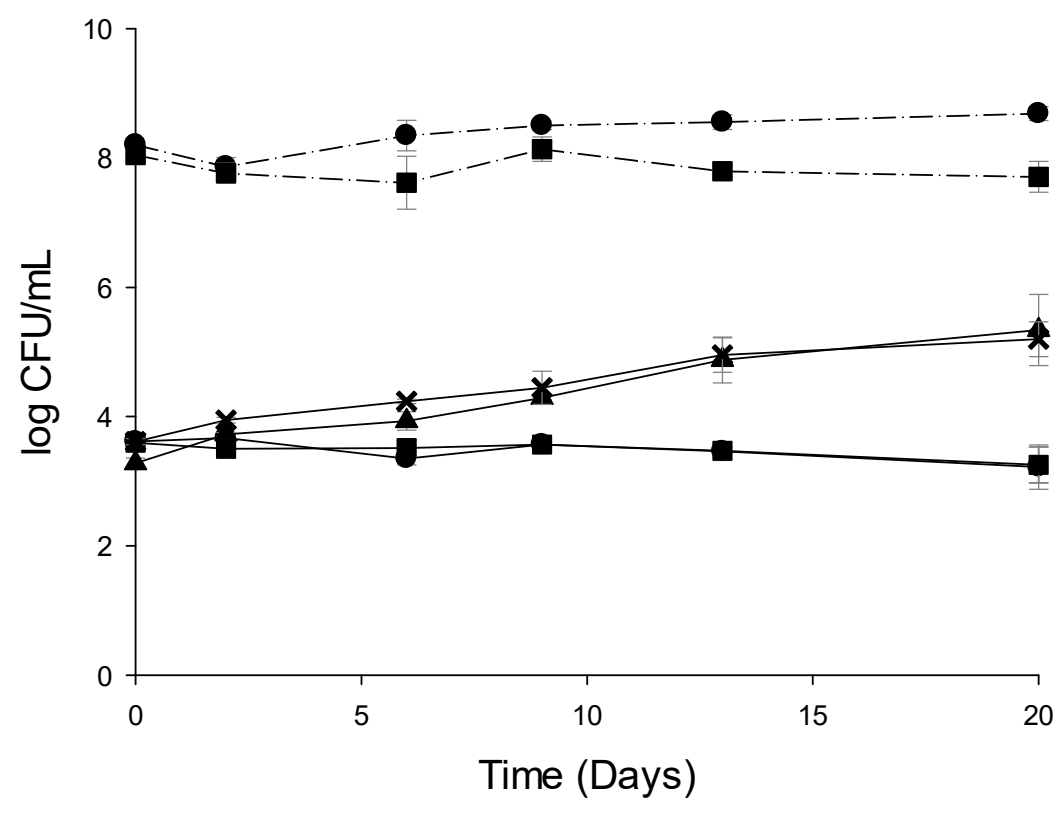

(b)

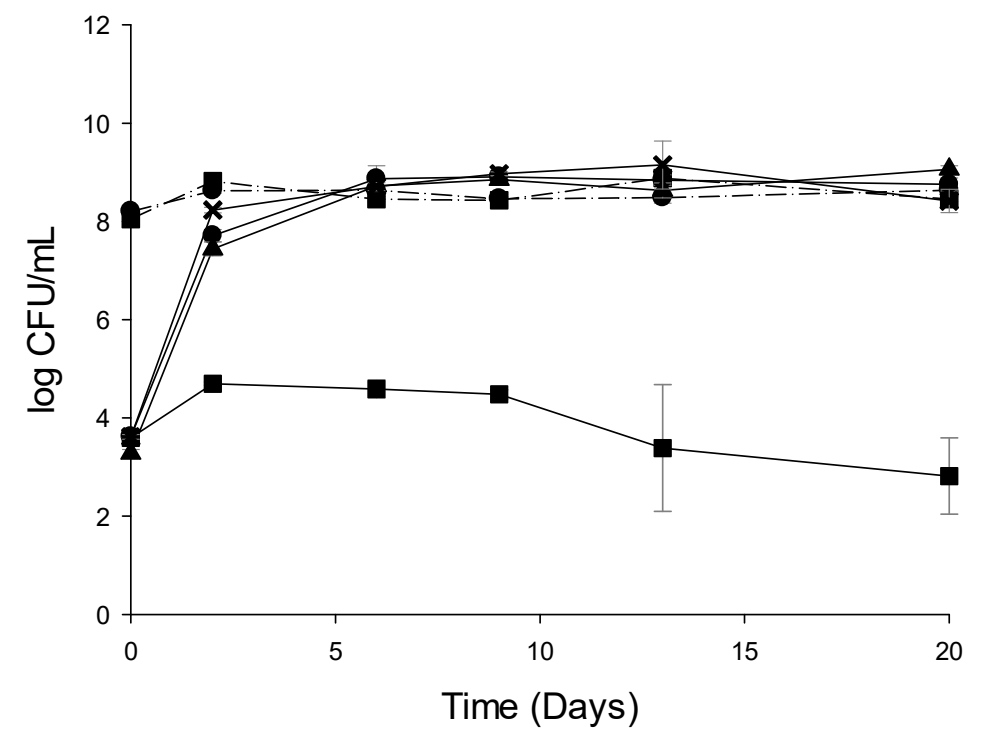


(c)

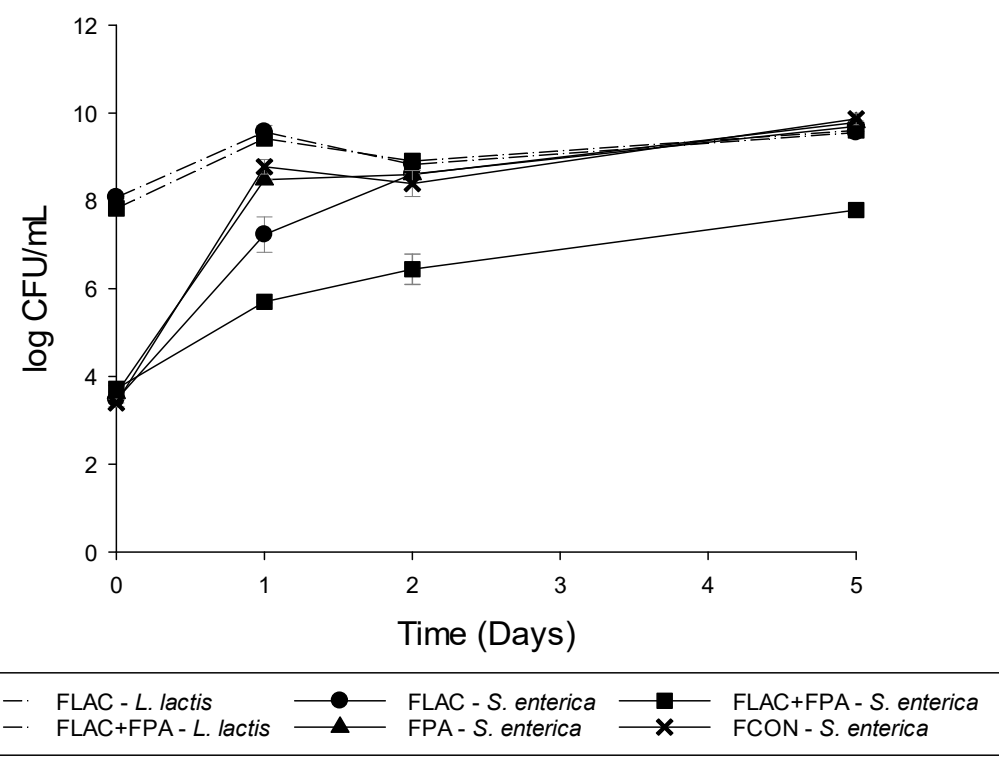

Figure 3. Growth of L. lactis and antimicrobial activity of films immersed in liquid medium (TSB + yeast) inoculated with $\mathrm{S}$. enterica and monitored for a) 20 days at $4{ }^{\circ} \mathrm{C}$ and b) 20 days at $14{ }^{\circ} \mathrm{C}$ and during c) 5 days at $24^{\circ} \mathrm{C}$. Mean values and $95 \%$ LSD intervals

With the control films, or those containing PA or LAC, this bacterium had exponential growth at $4{ }^{\circ} \mathrm{C}$ because it is psychrotrophic [37], and it reached the stationary phase with a population of 8 log in 2 days at $4{ }^{\circ} \mathrm{C}$, and in $24 \mathrm{~h}$ at $14{ }^{\circ} \mathrm{C}$ and $24{ }^{\circ} \mathrm{C}$. When the FLAC+FPA combination was tested, the bacteriostatic effect of the film combination on this pathogen was again observed at $4{ }^{\circ} \mathrm{C}$, whereas at higher temperatures FLAC+FPA had a bactericidal effect, reducing $P$. fluorescens completely from day 8 at $14{ }^{\circ} \mathrm{C}$, and almost completely from day 5 at $24{ }^{\circ} \mathrm{C}$. Finally, the growth of $L$. monocytogenes was monitored at various temperatures after being in contact with control films, films carrying LAC, or films incorporating PA. The results are shown in Figure 5. 
(a)

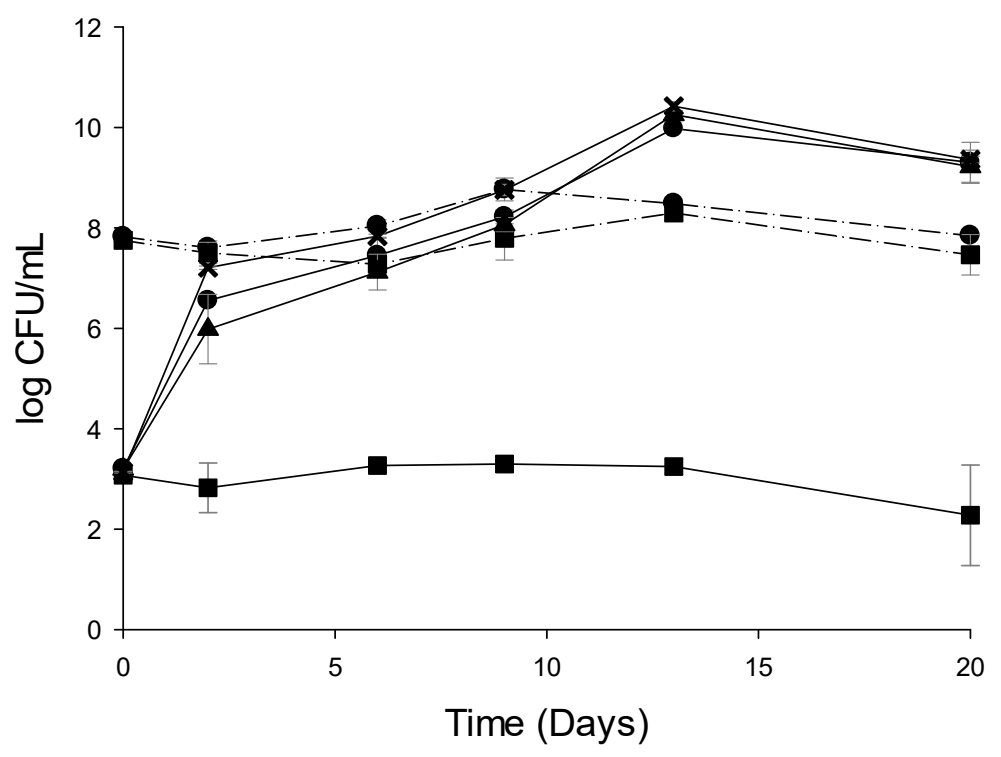

(b)

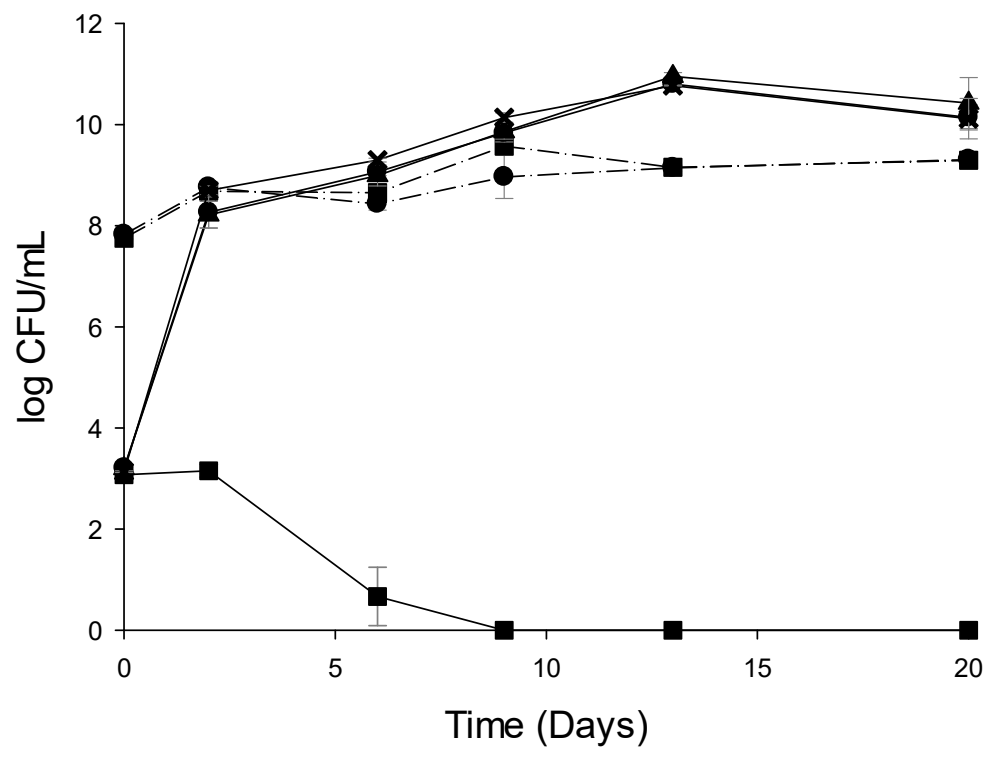


(c)

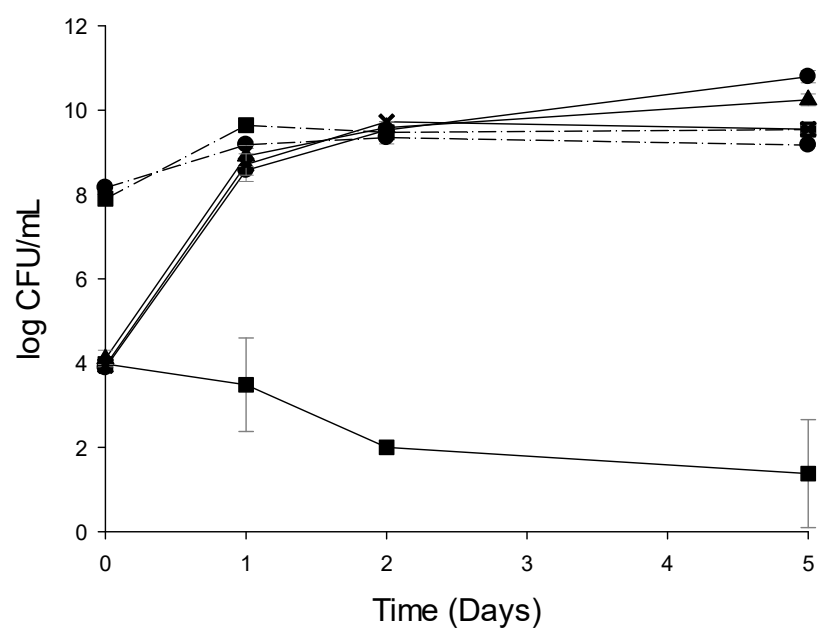

$\begin{array}{ll}-1 & \text { FLAC }- \text { L. lactis } \\ - & \text { FLAC }+ \text { FPA - L. lactis }\end{array}$

(Days)

Figure 4. Growth of L. lactis and antimicrobial activity of films immersed in liquid medium (TSB + yeast) inoculated with $P$. fluorescens and monitored for a) 20 days at $4{ }^{\circ} \mathrm{C}$ and b) 20 days at $14{ }^{\circ} \mathrm{C}$ and during c) 5 days at $24{ }^{\circ} \mathrm{C}$. Mean values and $95 \%$ LSD intervals

This pathogen is psychrotrophic, and therefore it had exponential growth at $4{ }^{\circ} \mathrm{C}$ and reached the stationary phase with an amount of $8 \log$ in 8 days. The stationary phase was attained in 6 days at $14{ }^{\circ} \mathrm{C}$, and in $24 \mathrm{~h}$ when the temperature was increased to $24^{\circ} \mathrm{C}$. In contrast to the behavior of the Gram-negative bacteria, a reduction was observed when FLAC was applied against $L$. monocytogenes. At 4 ${ }^{\circ} \mathrm{C}$ a bactericidal effect was observed, with reductions of up to 8 log after 20 days. At $14{ }^{\circ} \mathrm{C}$ the effect was bacteriostatic until day 9 , when $L$. monocytogenes started to grow, reaching a 6 log population after 20 days. Similarly, at $24^{\circ} \mathrm{C}$ a 5 log reduction was achieved by day 2 , and a $3.5 \log$ reduction by day 5 , compared with the control film. This was because $L$. monocytogenes is a Gram-positive bacterium that is sensitive to nisin [38]. 
(a)

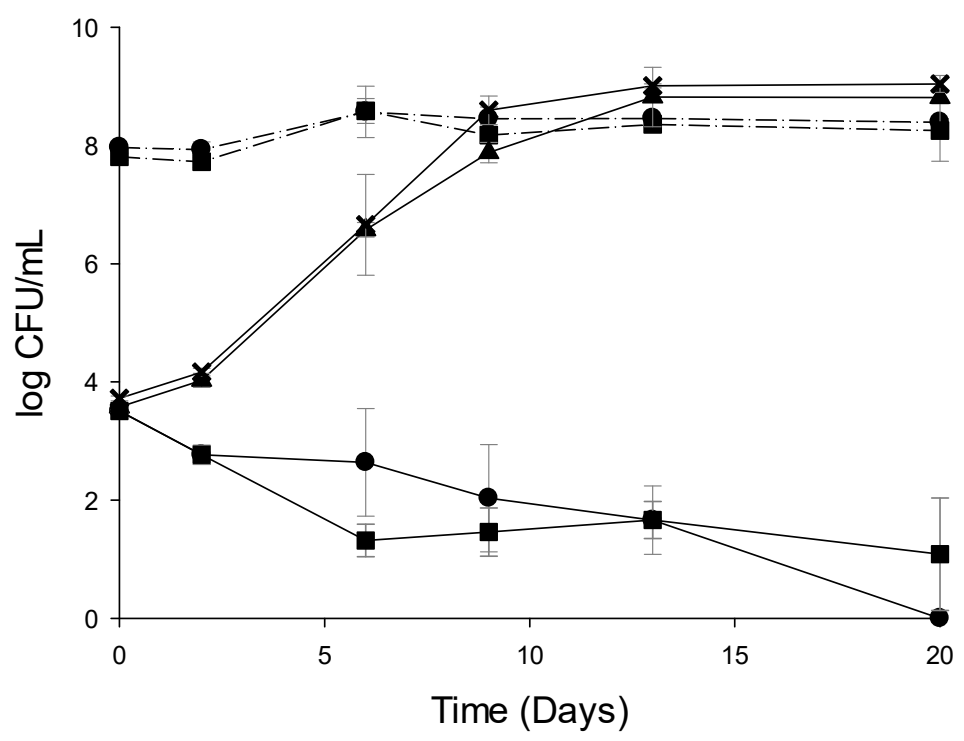

(b)

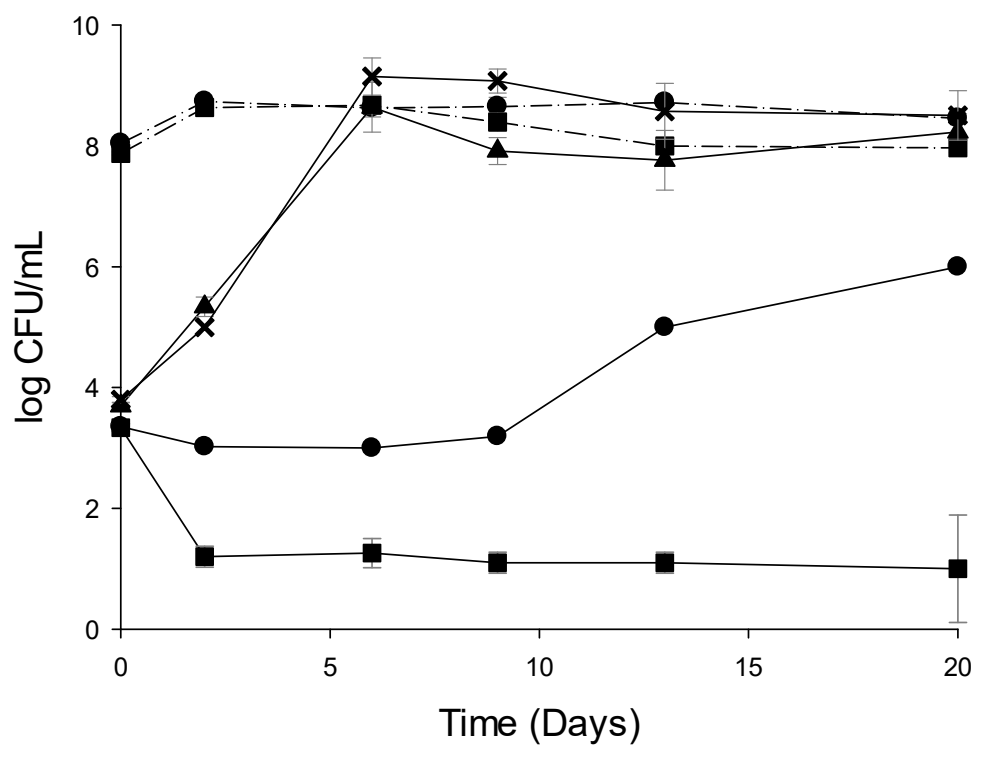


(c)

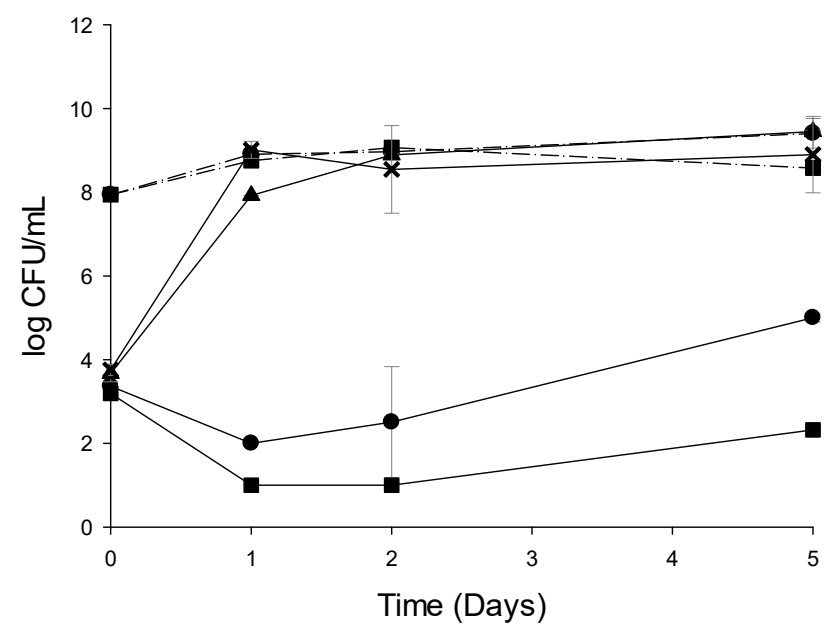

- FLAC - L. lactis FLAC+FPA - L. lactis

Figure 5. Growth of L. lactis and antimicrobial activity of films immersed in liquid medium (TSB + yeast) inoculated with $L$. monocytogenes and monitored for a) 20 days at $4{ }^{\circ} \mathrm{C}$ and b) 20 days at $14{ }^{\circ} \mathrm{C}$ and during c) 5 days at $24^{\circ} \mathrm{C}$. Mean values and 95\% LSD intervals

Other authors have shown the efficacy of entrapping lactic acid bacteria in films to kill Gram-positive bacteria such as $L$. monocytogenes and S. aureus [39-41].

When FLAC+FPA was applied at $4{ }^{\circ} \mathrm{C}$, the antilisterial activity exerted by the system was very similar to that of FLAC alone and a bactericidal effect was observed after 20 days (Figure $5 a$ ).

The film combination FLAC+FPA had a greater effect at $14{ }^{\circ} \mathrm{C}$ compared with the FLAC film alone and reduced the inoculated population of the pathogen from $4 \log$ to $1 \log C F U / m L$ after $24 \mathrm{~h}$. Moreover, after 20 days of storage the system FLAC+FPA maintained L. monocytogenes population in $1 \mathrm{log} C F U / \mathrm{mL}$ (Figure $5 \mathrm{~b}$ ). When the storage temperature was $24^{\circ} \mathrm{C}$, the growth of $L$. monocytogenes also was lower when the combination FLAC+FPA was applied compared with the results obtained for the film FLAC alone (Figure $5 \mathrm{c}$ ), and after 
5 days of storage the population of the pathogen was 5 and $2 \log$ $\mathrm{CFU} / \mathrm{mL}$ for the systems FLAC and FLAC+FPA, respectively.

Thus, the combination of FLAC+FPA was more effective than FLAC alone against Gram-positive bacteria. Bari et al. (2005) studied a combination of nisin with $0.02 \%$ of phytic acid against $L$. monocytogenes and found greater antimicrobial activity than when only nisin was added. It must be emphasized that the L. lactis survival rate was the same when the films were applied alone (FLAC) or in combination with phytic acid (FLAC+FPA). As with pathogenic bacteria, the small amount of PA used had no antimicrobial effect against $L$. lactis, provided that it was applied in a separate film.

With regard to the growth of lactic acid bacteria released from FLAC alone, or together with PA but in separate films (FLAC+FPA), the initial population, around $8 \log$, was able to remain viable at all the temperatures and times assayed, regardless of the pathogen coinoculated, as shown in Figures 2 to 5.

\subsection{Study of the shelf life of homemade pastry cream packaged in active} bags

Pastry cream (PC) packaged in control and active PE bags was stored at $4{ }^{\circ} \mathrm{C}$ for 20 days. The microbial load and the evolution of the $\mathrm{pH}$ of the cream during the storage time were studied, and the results are shown in Table 2.

Directly after packaging, the mesophilic and psychrotrophic bacteria count in the active packaged PC showed a significant increase, around 5 log, compared with the control sample. This was due to the load of L. lactis transferred from the active coating, which was prepared by loading about $3.2 \times 10^{6} \mathrm{CFU}$ L. lactis $/ \mathrm{cm}^{2}$ with the aim of releasing viable cells into the staple food to control the growth of other microorganisms. In fact, at time zero there was a difference of 5.20 log between lactic acid bacteria in the PC packaged in active bags and the PC packaged in control bags. No differences in the other microbial loads were found in the PC packaged in active or control bags at the beginning of storage. 
The total mesophilic and psychrotrophic counts were maintained in the active packaged PC during the storage time, which corresponded with the survival of L. lactis in the stationary phase. In the control PC, both mesophilic and psychrotrophic bacteria increased during storage, from $2.5 \log$ to $8 \mathrm{log}$. According to the Spanish national standard for "Ready meals group A" (R.D. 3484/2000, B.O.E. 12/01/01), the microbiological shelf life of pastry cream should finish on the fourth day. However, it should be noted that the high levels of aerobic counts found in the PC packaged in active bags were expected because of the presence of $L$. lactis in the coatings. With regard to this national standard, mesophilic bacteria and enterobacteria counts cannot be used to indicate the microbiological quality of products in "Ready meals group A" that are ripened or fermented, as occurred in our case. Indeed, active pastry cream could be fit for human consumption until the last day of storage.

No contamination by bacteria of the Listeria genus was found in the samples tested, which was expected, because healthy ingredients were used to prepare the PC and it was processed and packaged under good hygienic conditions, avoiding secondary contamination. 
Table 2. Mean microbial counts (log $\mathrm{CFU} / \mathrm{g}$ ) of microbial groups and evolution of $\mathrm{pH}$ during storage of packaged fresh pastry $\mathrm{cream}$ at $5{ }^{\circ} \mathrm{C}$ during 20 days

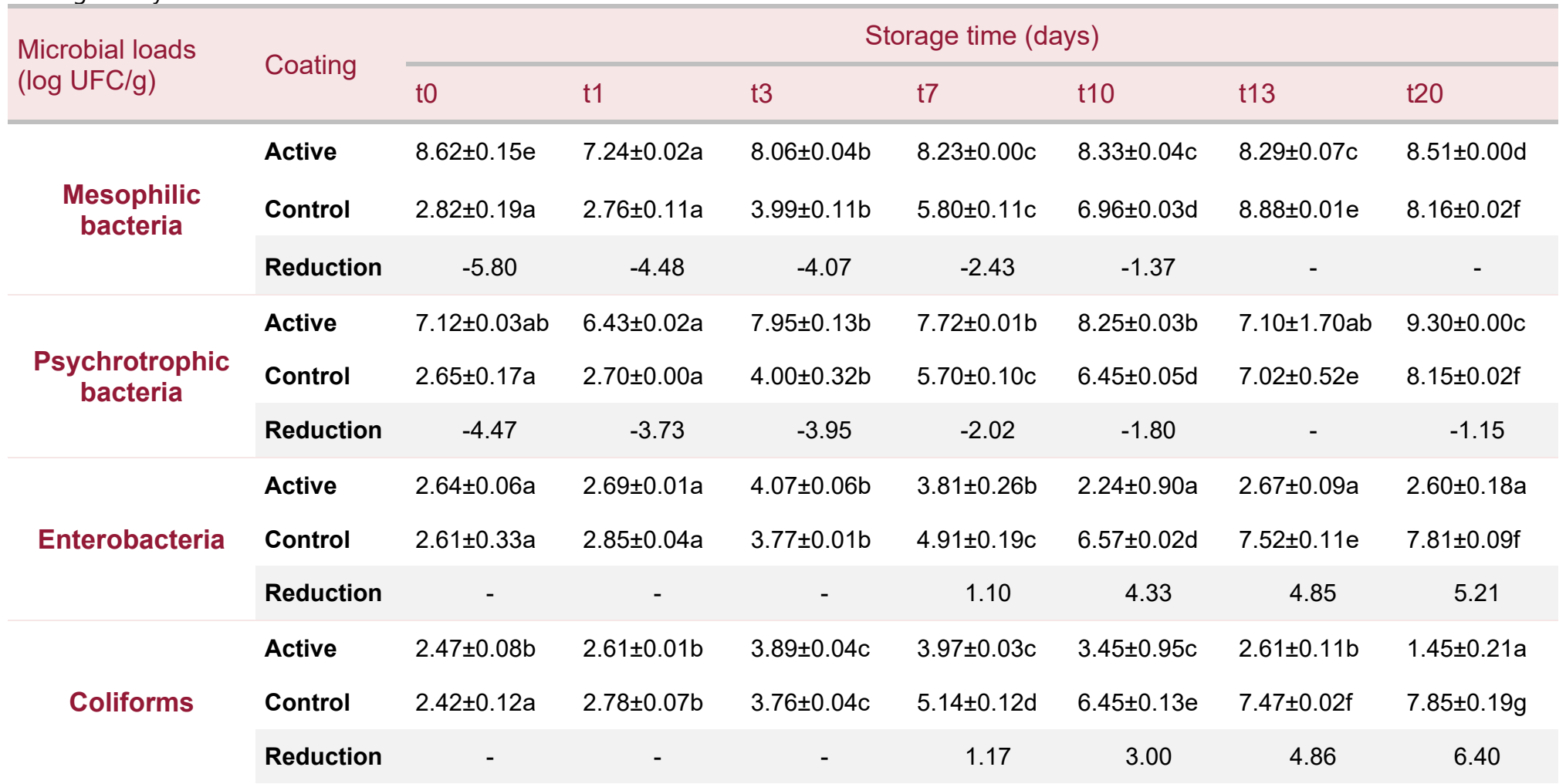




\begin{tabular}{|c|c|c|c|c|c|c|c|c|}
\hline & Active & $0.00 \pm 0.00 a$ & $0.00 \pm 0.00 a$ & $0.00 \pm 0.00 a$ & $0.00 \pm 0.00 a$ & $0.00 \pm 0.00 a$ & $0.00 \pm 0.00 a$ & $0.00 \pm 0.00 a$ \\
\hline \multirow[t]{3}{*}{ Listeria spp } & Control & $0.00 \pm 0.00 a$ & $0.00 \pm 0.00 a$ & $0.00 \pm 0.00 a$ & $0.00 \pm 0.00 a$ & $0.00 \pm 0.00 a$ & $0.00 \pm 0.00 a$ & $0.00 \pm 0.00 a$ \\
\hline & Reduction & - & - & - & - & - & - & - \\
\hline & Active & $1.64 \pm 0.34 a$ & $1.78 \pm 0.00 a$ & $3.01 \pm 0.06 b c$ & $3.12 \pm 0.20 c$ & $2.64 \pm 0.42 b$ & $1.99 \pm 0.30 a$ & $1.69 \pm 0.12 a$ \\
\hline \multirow[t]{2}{*}{ Pseudomonas } & Control & $1.72 \pm 0.03 a$ & $2.04 \pm 0.06 a$ & $2.84 \pm 0.04 b$ & $4.76 \pm 0.14 \mathrm{c}$ & $6.43 \pm 0.07 d$ & $7.20 \pm 0.12 \mathrm{e}$ & $8.05 \pm 0.13 f$ \\
\hline & Active & $6.95 \pm 0.07 a$ & $7.25 \pm 0.00 \mathrm{ab}$ & $7.94 \pm 0.14 b$ & $8.36 \pm 0.08 b$ & $8.32 \pm 0.11 \mathrm{c}$ & $8.55 \pm 0.14 \mathrm{c}$ & $8.37 \pm 0.07 d$ \\
\hline \multirow{2}{*}{$\begin{array}{l}\text { Lactic acid } \\
\text { bacteria }\end{array}$} & Control & $1.75 \pm 0.21 a$ & $2.04 \pm 0.06 b$ & $2.61 \pm 0.28 \mathrm{c}$ & $2.56 \pm 1.11 \mathrm{~d}$ & $3.55 \pm 0.14 d$ & $4.02 \pm 0.05 \mathrm{e}$ & $5.03 \pm 0.07 d$ \\
\hline & Reduction & -5.20 & -5.21 & -5.33 & -5.80 & -4.77 & -4.53 & -3.34 \\
\hline $\mathrm{pH}$ & Reduction & 1.09 & 0.97 & 1.05 & 1.46 & 1.84 & 1.55 & 1.21 \\
\hline
\end{tabular}

$a, b, c$, d: different letters in the same file indicates significant differences among time for a same formulation $(p<0.05)$.

Reduction is considered when a minimum difference of 1 log respect to the control was observed. 
The counts of enterobacteria, coliforms, Pseudomonas, and lactic acid bacteria found in newly packaged PC were $2.6 \mathrm{log}, 2.5 \mathrm{log}, 1.6 \mathrm{log}$, and 1.8 log (lactic acid bacteria in control PC), respectively. These levels were attributable to the PC production process, in which the cooking temperature was not high enough to sterilize the product completely. The microbial load in PC grew quickly after the second day of storage (except for Listeria), because pastry cream is a product with high water activity, a pH close to neutral, and is rich in proteins and sugars that feed microorganisms, enhancing their growth $[42,43]$. Consequently, PC is a perishable product that may rapidly become an unsafe product.

During the first three days of storage, no measurable reduction of coliforms, enterobacteria, or Pseudomonas was produced by the active packaging. This may have been due to the latency time needed by $L$. lactis to adapt to a new environment after being dehydrated during film-forming. Nisin is the bacteriocin responsible for the antimicrobial power of L. lactis, and it is only produced when bacteria are at mid to end logarithmic growth phase, reaching a maximum in the stationary phase, because certain peptides called "peptide pheromones" have to accumulate in the environment until a threshold concentration is reached in order to start producing bacteriocins [44].

However, when measurements were taken on day 7 , the active packaging had reduced the enterobacteria count by $1.10 \mathrm{log}$, the coliform count by $1.17 \mathrm{log}$, and the Pseudomonas count by $1.64 \mathrm{log}$. By the end of the storage time, reductions of $5.21 \mathrm{log}, 6.40 \mathrm{log}$, and 6.36 log, respectively, had been achieved.

These results are promising because they show that active packaging is able to extend the microbiological shelf life of pastry cream from 3 days to 20 days.

Pastry cream is commonly used as an ingredient in many other readyto-eat food products, such as filled pastries, cakes, and strudels. Active bags could be used for the preservation of homemade style pastry cream during transport to confectionery manufacturers. These bags could also be employed for the distribution and storage of ready-to eat packaged pastry cream at the retail site. Moreover, these bags 
could be used in the home for the preservation of products prepared at home, such as pastry cream.

It is worth pointing out the potential for temperature abuse in bakery products $[45,46]$. In this regard, most pastry products that are sold in confectionery stores are normally placed in cooled confectionery display cabinets, and they are usually kept on sale for a period ranging from $12 \mathrm{~h}$ to $48 \mathrm{~h}$ [47]. Unfortunately, sometimes those devices do not operate at a temperature below $4{ }^{\circ} \mathrm{C}$ because they are constantly being opened and shut, and they also contain other products that are damaged at such a low temperature. Moreover, at home, consumers often handle purchased bakery products that contain pastry cream and store them at room temperature for hours or even days. As active bags are effective in a temperature range from $4{ }^{\circ} \mathrm{C}$ to $24{ }^{\circ} \mathrm{C}$, if products made with pastry cream are packaged in active bags the antimicrobial capacity of the packaging should have an effect even after unpacking because $L$. lactis will produce bacteriocins in situ in the PC.

\subsection{Evolution of $\mathrm{pH}$ of homemade pastry cream during storage time}

As lactic acid bacteria produce organic acids, the $\mathrm{pH}$ of the pastry cream was monitored during storage, and the results are displayed in Table 2. The $\mathrm{pH}$ of PC just after being packaged in active bags was 6.05 , while the $\mathrm{pH}$ for $\mathrm{PC}$ packaged in the control bags was 7.14 . This difference was only due to the presence of phytic acid in the active bag. Previous studies concluded that neither PVOH and HCas nor $L$. lactis affect the $\mathrm{pH}$ of pasteurized milk during the first days of storage [2]. Indeed, the $\mathrm{pH}$ of the active packaged PC started to decrease slowly from 5.93 on the 3rd day to 4.58 on the 20th day of storage. This drop in $\mathrm{pH}$ was mainly due to the fermentative metabolism of lactic acid bacteria. From the results, it was noticed that the beginning of the $\mathrm{pH}$ decrease coincided with the beginning of the antimicrobial activity. This coincidence was probably due to the activation of metabolism after the latency time needed by L. lactis [36] and the resulting production of antimicrobial metabolites such as nisin and organic acids. In fact, the use of viable lactic acid bacteria instead of 
just their bacteriocins provides not only production of the bacteriocins in situ but also production of other compounds with antimicrobial activity, such as lactic acid.

Organic acids generated by $L$. lactis combined with the acidity caused by phytic acid can also act as antimicrobial agents, causing a decrease or inhibition of bacterial growth or even cell death. The lowest $\mathrm{pH}$ at which bacteria are able to grow and spoil food products is different for each bacterium. Although almost all food spoiling bacteria have an optimal $\mathrm{pH}$ close to neutral, the minimum $\mathrm{pH}$ at which they are able to survive is different, e.g. $\mathrm{pH}=3.7$ for Salmonella spp, $\mathrm{pH}=4.0$ for $E$. coli, $\mathrm{pH}=4.3$ for $L$. monocytogenes, $\mathrm{pH}=4.5$ for Pseudomonas among other spoilage bacteria [49]. Although the $\mathrm{pH}$ of homemade pastry cream moves from 6 to 5 in two weeks and thus, did not reach the above mentioned $\mathrm{pH}$ values. However, it has to point out that moving away from the $\mathrm{pH}$ optimum for each microorganism slows microbial growth [50]. Therefore, it can be concluded that no single factor is responsible for making homemade pastry cream microbiologically stable, but rather the stability results from the synergism among the followed combined factors: nisin, PA chelating properties and the drop in $\mathrm{pH}$.

With regard to the PC packaged in control bags, the drop in the $\mathrm{pH}$ values from 7.14 to 5.79 correlated well with the growth of lactic acid bacteria, which started with $1.75 \mathrm{log}$ and finished with 5.03 log on the last day of storage. The other bacterial loads could reduce $\mathrm{pH}$, but much less than lactic acid bacteria [51].

The decrease in $\mathrm{pH}$ could result in sensory rejection of the product by consumers. Lactic acid bacteria can modify flavor, making it more acidic; they can also alter aroma, owing to the volatile compounds generated; and they can alter color and even texture. Syneresis, which consists in the separation of aqueous and continuous phases, can occur in dairy products when the $\mathrm{pH}$ is close to 4.6 [52]. To determine the shelf life of a food product precisely, both microbiological and organoleptic analysis are decisive. The point in time at which a food product becomes either unsafe or unacceptable to consumers marks the end of its shelf life [53]. Therefore, a 
qualitative sensory test was carried out with 10 members of the laboratory. The color, aroma, texture, and general appearance of the active packaged PC was evaluated on each day of storage by comparing the samples. To simulate the active PC flavor, the $\mathrm{pH}$ was reduced artificially with food-grade lactic acid (Sigma, Spain) in order to obtain the same $\mathrm{pH}$ as that obtained on each day of storage. No differences were found in color and aroma during storage time. Indeed, vanilla extract aroma masked the possible volatile compounds generated by $L$. lactis. From day 13 , when the consistency became more liquid, few changes in texture were observed. With regard to taste, on the 13th day of storage acidity was perceived by $75 \%$ of the judges. The perception was described as a light lemon taste that was not unpleasant, but it was an unexpected flavor for pastry cream. On day 20, all the judges detected a pungent acid flavor that was not acceptable for pastry cream. It is pointed out that no strange taste was found in the samples due to the addition of phytic acid. Future sensory tests with consumers are necessary to confirm these results.

In conclusion, with the results obtained from the microbiological analysis and sensory test, the shelf life of the pastry cream increased by 10 days, from day 3 to day 13 .

\section{Conclusions}

Lactococcus lactis is characterized by producing the bacteriocin nisin, which has proved to have antimicrobial activity against Listeria and other Gram-positive bacteria. Therefore, it could be used as a biopreservative incorporated in a polymer film. In the past, Lactococcus lactis has been encapsulated successfully in a PVOHbased matrix supplemented with protein hydrolysates. The current study demonstrates that it is possible to broaden the antimicrobial spectrum of $\mathrm{PVOH}$ carrying nisin-producing lactic bacteria films. For this purpose, together with the PVOH film carrying lactic acid bacteria, phytic acid was added to growth medium that had previously been inoculated with Gram-negative E. coli. The phytic acid was incorporated in various ways: directly, in the same film as the lactic acid bacteria, or in a separate film. The best results were obtained 
when L. lactis and phytic acid were incorporated in different films. Then this antimicrobial system was successfully assayed against other Gram-negative bacteria. Finally, the two-film system was incorporated in the design of a bag to package a real refrigerated semisolid food: pastry cream. The shelf life of the product was extended when packaged in the active bag.

\section{Acknowledgments}

The authors acknowledge the financial support of the Spanish Ministry of Economy and Competitiveness (AGL2015-64595-R).

\section{References}

1. López-De-Dicastillo, C.; Jordá, M.; Catalá, R.; Gavara, R.; Hernández-Muñoz, P. Development of active polyvinyl alcohol/ $\beta$-cyclodextrin composites to scavenge undesirable food components. J. Agric. Food Chem. 2011, 59, 11026-11033, doi:10.1021/jf200749f.

2. Settier-Ramírez, L.; López-Carballo, G.; Gavara, R.; HernándezMuñoz, P. PVOH/protein blend films embedded with lactic acid bacteria and their antilisterial activity in pasteurized milk. Int. J. Food Microbiol. 2020, 322, 108545, doi:10.1016/j.jijfoodmicro.2020.108545.

3. Kuwano, K.; Tanaka, N.; Shimizu, T.; Nagatoshi, K.; Nou, S.; Sonomoto, K. Dual antibacterial mechanisms of nisin $\mathrm{Z}$ against Gram-positive and Gram-negative bacteria. Int. J. Antimicrob. Agents 2005, 26, 396-402, doi:10.1016/j.ijantimicag.2005.08.010.

4. Holcapkova, P.; Hurajova, A.; Kucharczyk, P.; Bazant, P.; Plachy, T.; Miskolczi, N.; Sedlarik, V. Effect of polyethylene glycol plasticizer on long-term antibacterial activity and the release profile of bacteriocin nisin from polylactide blends. Polym. Adv. Technol. 2018, 29, 2253-2263, doi:10.1002/pat.4336.

5. Li, Q.; Montalban-Lopez, M.; Kuipers, O.P. Increasing the antimicrobial activity of nisinbased lantibiotics against Gramnegative pathogens. Appl. Environ. Microbiol. 2018, 84, doi:10.1128/AEM.00052-18.

6. Quintieri, L.; Fanelli, F.; Caputo, L. Antibiotic resistant Pseudomonas spp. spoilers in fresh dairy products: An 
underestimated risk and the control strategies. Foods 2019, 8 , 1-32, doi:10.3390/foods8090372.

7. Singh, O. V. Foodborne pathogens and antibiotic resistance; 2017; ISBN 9781119139188.

8. Meng, L.; Zhang, Y.; Liu, H.; Zhao, S.; Wang, J.; Zheng, N. Characterization of Pseudomonas spp. and associated proteolytic properties in raw milk stored at low temperatures. Front. Microbiol. 2017, 8, 1-7, doi:10.3389/fmicb.2017.02158.

9. Mallet, A.; Guéguen, M.; Kauffmann, F.; Chesneau, C.; Sesboué, A.; Desmasures, N. Quantitative and qualitative microbial analysis of raw milk reveals substantial diversity influenced by herd management practices. Int. Dairy J. 2012, 27, 13-21, doi:10.1016/j.idairyj.2012.07.009.

10. de Oliveira, G.B.; Favarin, L.; Luchese, R.H.; Mclntosh, D. Psychrotrophic bacteria in milk: How much do we really know? Brazilian J. Microbiol. 2015, 46, 313-321, doi:10.1590/S1517838246220130963.

11. Prudêncio, C.V.; dos Santos, M.T.; Vanetti, M.C.D. Strategies for the use of bacteriocins in Gram-negative bacteria: relevance in food microbiology. J. Food Sci. Technol. 2015, 52, 5408-5417.

12. Facon, M.J.; Skura, B.J. Antibacterial activity of lactoferricin, lysozyme and EDTA against Salmonella enteritidis. Int. Dairy J. 1996, 6, 303-313, doi:10.1016/0958-6946(95)00004-6.

13. Helander, I.M.; Mattila-Sandholm, T. Permeability barrier of the Gram-negative bacterial outer membrane with special reference to nisin. In Proceedings of the International Journal of Food Microbiology; 2000; Vol. 60, pp. 153-161.

14. Boziaris, I.S.; Adams, M.R. Effect of chelators and nisin produced in situ on inhibition and inactivation of Gram negatives. Int. J. Food Microbiol. 1999, 53, 105-113, doi:10.1016/S0168-1605(99)00139-7.

15. Delves-Broughton, J. The use of EDTA to enhance the efficacy of nisin towards Gram-negative bacteria. Int. Biodeterior. Biodegradation 1993, 32, 87-97, doi:10.1016/09648305(93)90042-Z.

16. Bari, M.L.; Ukuku, D.O.; Kawasaki, T.; Inatsu, Y.; Isshiki, K.; Kawamoto, A.S. Combined Efficacy of Nisin and Pediocin with Sodium Lactate, Citric Acid, Phytic Acid, and Potassium Sorbate and EDTA in Reducing the Listeria monocytogenes. Population of Inoculated Fresh-Cut Produce ; 2005; Vol. 68;. 
17. Zhou, Q.; Zhao, Y.; Dang, H.; Tang, Y.; Zhang, B. Antibacterial effects of phytic acid against foodborne pathogens and investigation of its mode of action. J. Food Prot. 2019, 82, 826833, doi:10.4315/0362-028X.JFP-18-418.

18. Kim, N.H.; Rhee, M.S. Phytic acid and sodium chloride show marked synergistic bactericidal effects against nonadapted and acid-adapted Escherichia coli O157:H7 strains. Appl. Environ. Microbiol. 2016, 82, 1040-1049, doi:10.1128/AEM.03307-15.

19. FDA (Food and Drug Administration) Agency Response Letter GRAS Notice (GRN) n ${ }^{\circ} 742$. Office and Food Additive Safety, Centre for Food Safety and Applied Nutrition, US Food and Drug Administration Available online: https://www.fda.gov/dowloads/Food/Ingredientes Packaging Labeling/GRAS/Noticelnventoryy/UCM608746.pdf.Accessed 6 Nov. 2017 (accessed on Nov 19, 2019).

20. Bohn, L.; Meyer, A.S.; Rasmussen, S.K. Phytate: Impact on environment and human nutrition. A challenge for molecular breeding. J. Zhejiang Univ. Sci. B 2008, 9, 165-191.

21. Canan, C.; Delaroza, F.; Casagrande, R.; Baracat, M.M.; Shimokomaki, M.; Ida, E.l. Capacidade antioxidante do ácido fítico purificado de farelo de arroz. Acta Sci. - Technol. 2012, 34, 457-463, doi:10.4025/actascitechnol.v34i4.16358.

22. Xu, Q.; Kanthasamy, A.G.; Reddy, M.B. Neuroprotective effect of the natural iron chelator, phytic acid in a cell culture model of Parkinson's disease. Toxicology 2008, 245, 101-108, doi:10.1016/j.tox.2007.12.017.

23. Grases, F.; Costa-Bauza, A.; Prieto, R.M. Renal lithiasis and nutrition. Nutr. J. 2006, 5.

24. Lee, H.H.; Loh, S.P.; Bong, C.F.J.; Sarbini, S.R.; Yiu, P.H. Impact of phytic acid on nutrient bioaccessibility and antioxidant properties of dehusked rice. J. Food Sci. Technol. 2015, 52, 7806-7816, doi:10.1007/s13197-015-1918-9.

25. Lee, S.H.; Park, H.J.; Chun, H.K.; Cho, S.Y.; Cho, S.M.; Lillehoj, H.S. Dietary phytic acid lowers the blood glucose level in diabetic KK mice. Nutr. Res. 2006, 26, 474-479, doi:10.1016/j.nutres.2006.06.017.

26. Yoon, J.H.; Thompson, L.U.; Jenkins, D.J.A. The effect of phytic acid on in vitro rate of starch digestibility and blood glucose response. Am. J. Clin. Nutr. 1983, 38, 835-842, doi:10.1093/ajcn/38.6.835. 
27. Settier-Ramírez, L.; López-Carballo, G.; Gavara, R.; HernándezMuñoz, P. Antilisterial properties of PVOH-based films embedded with Lactococcus lactis subsp. lactis. Food Hydrocoll. 2019, 87, 214-220, doi:10.1016/j.foodhyd.2018.08.007.

28. Espitia, P.J.P.; Batista, R.A.; Azeredo, H.M.C.; Otoni, C.G. Probiotics and their potential applications in active edible films and coatings. Food Res. Int. 2016, 90, 42-52, doi:10.1016/j.foodres.2016.10.026.

29. Soukoulis, C.; Behboudi-Jobbehdar, S.; Macnaughtan, W.; Parmenter, C.; Fisk, I.D. Stability of Lactobacillus rhamnosus GG incorporated in edible films: Impact of anionic biopolymers and whey protein concentrate. Food Hydrocoll. 2017, 70, 345-355, doi:10.1016/j.foodhyd.2017.04.014.

30. De Vuyst, L.; Vandamme, E.J. Influence of the carbon source on nisin production in Lactococcus lactis subsp. lactis batch fermentations. J. Gen. Microbiol. 1992, 138, 571-8, doi:10.1099/00221287-138-3-571.

31. Castellano, P.; Belfiore, C.; Vignolo, G. Combination of bioprotective cultures with EDTA to reduce Escherichia coli 0157:H7 in frozen ground-beef patties. Food Control 2011, 22, 1461-1465, doi:10.1016/J.FOODCONT.2011.02.018.

32. Stevens,', K.A.; Sheldon,', B.W.; Klapes,' And, N.A.; Klaenhammer', T.R. Nisin Treatment for Inactivation of Salmonella Species and Other Gram-Negative Bacteriat; 1991; Vol. 57;

33. Cutter, C.N.; Siragusa, G.R. Population reductions of gramnegative pathogens following treatments with nisin and chelators under various conditions. J. Food Prot. 1995, 58, 977983, doi:10.4315/0362-028X-58.9.977.

34. Gialamas, H.; Zinoviadou, K.G.; Biliaderis, C.G.; Koutsoumanis, K.P. Development of a novel bioactive packaging based on the incorporation of Lactobacillus sakei into sodium-caseinate films for controlling Listeria monocytogenes in foods. Food Res. Int. 2010, 43, 2402-2408, doi:10.1016/j.foodres.2010.09.020.

35. Sánchez-González, L.; Quintero Saavedra, J.l.; Chiralt, A. Antilisterial and physical properties of biopolymer films containing lactic acid bacteria. Food Control 2014, 35, 200-206, doi:10.1016/j.foodcont.2013.07.001.

36. Léonard, L.; Degraeve, P.; Gharsallaoui, A.; Saurel, R.; Oulahal, N. Design of biopolymeric matrices entrapping bioprotective 
lactic acid bacteria to control Listeria monocytogenes growth: Comparison of alginate and alginate-caseinate matrices entrapping Lactococcus lactis subsp. lactis cells. Food Control 2014, 37, 200-209, doi:10.1016/j.foodcont.2013.09.041.

37. Gounot, A.M. Psychrophilic and psychrotrophic microorganisms. Experientia 1986, 42, 1192-1197, doi:10.1007/BF01946390.

38. Wu, S.; Yu, P.L.; Flint, S. Persister cell formation of Listeria monocytogenes in response to natural antimicrobial agent nisin. Food Control 2017, 77, 243-250, doi:10.1016/j.foodcont.2017.02.011.

39. Ye, J.; Ma, D.; Qin, W.; Liu, Y. Physical and antibacterial properties of sodium alginate-sodium carboxymethylcellulose films containing Lactococcus lactis. Molecules 2018, 23, 2645, doi:10.3390/molecules23102645.

40. Ma, D.; Jiang, Y.; Ahmed, S.; Qin, W.; Liu, Y. Physical and antimicrobial properties of edible films containing Lactococcus lactis. Int. J. Biol. Macromol. 2019, 141, 378-386, doi:10.1016/j.jijbiomac.2019.09.006.

41. Guimarães, A.; Abrunhosa, L.; Pastrana, L.M.; Cerqueira, M.A. Edible Films and Coatings as Carriers of Living Microorganisms: A New Strategy Towards Biopreservation and Healthier Foods. Compr. Rev. Food Sci. Food Saf. 2018, 17, 594-614.

42. Asadi, S.; Maram, Z.R.; Kooshk, F. Evaluation of microbial contamination of pastry cream in Arak city of Iran. J. Food Saf. Hyg. 2015, 1, 26-29.

43. Huis In't Veld, J.H.J.H.I. Microbial and biochemical spoilage of foods: An overview. Int. J. Food Microbiol. 1996, 33, 1-18, doi:10.1016/0168-1605(96)01139-7.

44. Kleerebezem, M. Quorum sensing control of lantibiotic production; nisin and subtilin autoregulate their own biosynthesis. Peptides 2004, 25, 1405-1414, doi:10.1016/j.peptides.2003.10.021.

45. Nawawi, N.S.M.; Abdullah, N.; Noor, Z.M.; Bujang, A. A Review on Food Safety Risk in Bakery Outlet: Halalan-Toyyiban Perspective. In Proceedings of the 3rd International Halal Conference (INHAC 2016); Springer Singapore: Singapore, 2018; pp. 533-543.

46. Kotzekidou, P. Microbiological examination of ready-to-eat foods and ready-to-bake frozen pastries from university 
canteens. Food Microbiol. 2013, 34, 337-343, doi:10.1016/J.FM.2013.01.005.

47. Morelli, E.; Noel, V.; Rosset, P.; Poumeyrol, G. Performance and conditions of use of refrigerated display cabinets among producer/vendors of foodstuffs. Food Control 2012, 26, 363368, doi:10.1016/J.FOODCONT.2012.02.002.

48. De Vuyst, L.; Vandamme, E.J. Antimicrobial Potential of Lactic Acid Bacteria. In Bacteriocins of Lactic Acid Bacteria; Springer US, 1994; pp. 91-142.

49. FDA (Food and Drug Administration) Hazard Analysis and RiskBased Preventive Controls for Human Food: Guidance for Industry. 2016, Appendix 3, 1-185.

50. Forsythe, S.J. The microbiology of safe food; Blackwell Science Ltd, Ed.; Oxford, England, 2000;

51. Gram, L.; Ravn, L.; Rasch, M.; Bruhn, J.B.; Christensen, A.B.; Givskov, M. Food spoilage - Interactions between food spoilage bacteria. Int. J. Food Microbiol. 2002, 78, 79-97, doi:10.1016/S0168-1605(02)00233-7.

52. Gauche, C.; Tomazi, T.; Barreto, P.L.M.; Ogliari, P.J.; BordignonLuiz, M.T. Physical properties of yoghurt manufactured with milk whey and transglutaminase. LWT - Food Sci. Technol. 2009, 42, 239-243, doi:10.1016/J.LWT.2008.05.023.

53. Subramaniam, P.; Wareing, P. The Stability and Shelf Life of Food; 2016; ISBN 9780081004357. 


\section{Artículo 6}

\section{Assessing the environmental}

consequences of shelf life

\section{extension: conventional versus}

\section{active packaging of pastry cream}

Laura Settier-Ramirez', Gracia López-Carballo', Pilar Hernandez-Muñoz ${ }^{1}$, Raisa Tinitana², Rafael Gavara ${ }^{1}$, Neus Sanjuán ${ }^{2}$

Journal of Cleaner Production, (Submitted 2021)

1Packaging Lab, Instituto de Agroquímica y Tecnología de Alimentos, IATA-CSIC, Av. Agustín Escardino 7, 46980 Paterna, Spain

${ }^{2}$ Grupo ASPA, Departamento Tecnología de Alimentos, Universitat Politècnica de València, Camí de Vera s/n, 46022 Valencia, Spain 



\section{ABSTRACT}

Shelf life extension can reduce food losses throughout the entire food chain and packaging can be an effective way to attain this goal. In this study, conventional and bioactive bags carrying viable Lactococcus lactis subsp. lactis and phytic acid with antimicrobial activity were used to pack pastry cream and the environmental implications of the packaging choice have been assessed considering both the direct and indirect effects in terms of shelf life and food waste. Specifically, life cycle focus has been applied, including the impacts of the waste treatment according to EU statistics. To assess the empty packages, a bag of $200 \mathrm{~mL}$ capacity was the functional unit. In that case, the active packaging implies an increase in all the impact categories, due to the application on the conventional bag film of the bacterial coating. When assessing the food-packaging systems, considering $218 \mathrm{~g}$ of pastry cream packed as functional unit, this effect is compensated by shelf life extension from 3 to 13 days, with the subsequent reduction in the waste generated along the food chain. In this way, a reduction in all the impact categories corresponding to the pastry cream in active packaging has been observed, with ranging from 45 for ionizing radiation to $75 \%$ for climate change. It can be concluded that, despite the limitations regarding waste estimation, extending the shelf life of foods is a key issue when assessing the environmental impacts of novel packages. Future research should focus on developing better models, based on empirical data, which relate product shelf life and the potential waste. In addition, a holistic sustainability assessment should also consider economic issues under a life cycle approach.

Keywords: antimicrobial active packaging; food waste; LCA; shelf life 


\section{Introduction}

Halving the rate of food loss and waste is an strategy that would contribute to achieve the UN Sustainable Development Goals, meeting the goals of the Paris Agreement on climate change, and sustainably feeding the planet [1]. Product expiration is a key cause of waste for retailers and consumers, especially in perishable food categories such as fresh dairy, meats, fruits and vegetables. Taking into account that most of the food losses in western countries take place at retail and consumption stages, shelf life extension can play a key role for reducing food waste. In this context, packaging is an effective way to prevent food spoilage and increase the shelf life of food. Therefore, extending food shelf life using innovative packaging technologies could be a reliable approach for increasing the global sustainability of a food product, reducing its production, loss and waste.

In addition, we must not forget that consumers demand less processed foods, made with natural ingredients, which implies the inclination towards products free of synthetic preservatives. Along these lines, the development of active packaging (AP) using natural antimicrobial compounds that inhibit the growth of microorganisms that cause food spoilage, arises as an interesting way to extend product's shelf life. Numerous studies have demonstrated that incorporating antimicrobials in polymer films or coatings is more effective than adding them directly to the food product. Indeed, films and coatings immobilize antimicrobial agents providing a protective environment for them, and can also modulate their release from the packaging to the food [2]. Bacteriocins are antimicrobial peptides resulting from the metabolism of certain bacteria.

Particularly, bacteriocins from lactic acid bacteria (LAB) have been a breakthrough in the food industry because, in addition to increase food safety and food shelf-life, they ensure the health and safety of consumers [3]. However, the use of bacteriocins has limitations due to the gradual depletion of the compound during storage time. In this sense, the incorporation of viable LAB directly into the films instead of just using their bacteriocins is a good tool to solve this problem [4]. $L A B$ not only produce bacteriocins in situ in the food but they also 
have other mechanisms, such as the production of organic acids or the competition against spoiling microorganisms for nutrients, that can increase the antimicrobial activity.

Despite the key role of packaging in food preservation, it also represents an environmental issue, mainly related to its production and specially as corcerns packaging waste treatment. Specifically, the development of AP implies an additional environmental impact due to the use of resources needed for the production and stabilization of the $L A B$ and the coating forming solutions. Therefore, to evaluate the sustainability of AP, we need to assess whether the environmental burdens resulting from the packaging production offset the potential beneficial effects in terms of food waste reduction.

Life cycle assessment (LCA) is a useful and standarized tool to address the environmental sustainability of products and processes considering all the stages in their life cycle. Many LCA studies have analysed the environmental impacts of food packaging, without taking into account the packed product [5]. However, assessing the packaging in that way neglects its influence on the environmental impact of the product's life cycle [6,7]. This perspective has been reflected in recent LCAs on active packaging [8-10] in which the food life cycle is considered in the system boundaries, although these studies considered other packaging systems, such as coextruded films and coatings that release organic volatile substances, or nanocomposites obtained by melt blending.

A key point to elucidate when applying LCA to compare packaging systems is the relationship between product's shelf life and the amount of wasted food generated. This relation is not direct and, as pointed out in WRAP (Waste \& Resources Action Programme, 2013), empirical determination is hard. In fact, studies on waste reduction initiatives should take into account how each stakeholder would respond to the implemented changes, this requiring behavioural knowledge which implies often expensive field research [12]. In addition, differences in local infrastructure and practices for packaging and food waste treatment increase the uncertainty when quantifying the impact of such initiatives and makes it difficult to 
propose global (or regional) strategies. Different approaches have been applied in the literature, which are reviewed in section 1.1.

Thus, the aim of this study is to compare the environmental impacts of conventional packaging (CP) and AP for a specific food, namely fresh pastry cream, also considering the reduction in the product's waste. Specifically, we addressed (i) the environmental impact of the two packaging alternatives, $C P$ and $A P$, and (ii) the environmental impact of the complete system food- packaging considering the food wasted according to the shelf life of each alternative.

\subsection{Review on shelf life of foods and related food waste}

There is an increasing body of studies which claim that shelf life extension would reduce avoidable food waste along the supply chain. However, there is limited data available on the relation between shelf life and food waste and the perspectives used in the literature to calculate this relation are very different.

Food generation at household level has been modeled by WRAP (2013) by using discret event simulation applied to milk waste. The model takes into account different factors affecting food waste (FW) production at home. Among them, the effect of an increase of shelf life and the effect of an increase of the milk durability once the packaging was open. This model has been further used by Manfredi et al. (2015) and by Valsasina et al. (2017), in prospective LCA studies to evaluate the effect of shelf life extention of milk due to alternative packaging and new processing technologies, respectively $[8,13]$.

The influence of consumer behaviour on food waste resulting from food shelf life extension due to the use of nano-packaging for different kinds of food was assessed by Zhang et al. (2019) [14]. The authors conducted a stated-preference survey to indirectly quantify the food waste. In addition, a sensitivity analysis revealed that the uncertainty of the estimation on shelf life extension had a limited influence on the beneficial effect of the use of nano-packaging. Notwithstading, the authors emphasize that the results obtained with 
those approaches remain to be confirmed with laboratory tests and observational studies [15].

In a study on cheese packaging, Conte et al. (2015) considered three models to relate the probability of the food waste and shelf life, namely a first order kinetics, a sigmoid and a straight line [16]. The authors do not properly specify the links of the food chain to which this food waste corresponds, although it can be inferred that both retailer and consumer stages are affected. The proposed models span between 0 (shelf life reaches infinity) and 1 (shelf life is zero). In addition, based on Lebersorger and Schneider (2011), they assign an 8 $\%$ by mass of avoidable food waste to the package causing the greatest shelf life extension. These data allowed the parameters of the three models to be obtained, although the results were not validated with real data. This model was later adopted by Vigil et al. (2020) in a case study on fresh cut salad [10].

An economic perspective was adopted by Gutierrez et al. (2017) to determine the waste at retailer level in a case study on two packaging alternatives for cheesecake [17]. Due to the short shelf life of the product, the authors apply an economic model that considers the minimum amount of delivered product to consingnement that must be sold to select the most advantageous packaging solution for the firm. In addition, they assume that the distribution of sales follow an exponential function and calculate the food losses as the difference between the consigned product to the market place in a week and the quantity sold during that time period.

Westergaard-Kabelmann and Olsen, (2016) used cost benefit analysis to quantify the potential impacts of the application of new bacteria strains to extend yoghurt shelf life [18]. The authors estimated the yoghurt wasted and the potential waste reduction accruing from shelf life extension not only at retailing and household consumption, but also at the production stage. As to the production stage, the underlying assumption was that shelf life extension of the product would allow larger production batches. The authors considered data on the reduction of the number of batches from a dairy manufacturer together with data on the relationship between batch size and frequency and waste reduction from Berlin and Sonesson, (2008). The 
waste at retailer was estimated based on case studies in supermarkets, where the percentages of yoghurt left on the shelves were monitored for an increasing number of shelf days. These discrete observation sets were approximated by a continuous exponential function. On the other hand, waste reduction at household level was estimated by adapting the milk model developed by WRAP, (2013).

Spada et al., (2018) identified a relationship between the shelf life and an important food waste component, i.e. the product returned from the market. To this aim, they used a statistical approach, to model real market data. An inverse function between shelf life and product returned was found for those products with a shelf life between 30 and 50 days.

Summarizing, different perspectives have been applied to estimate the waste generated by shelf life expiration. It must be noted that the models proposed in the literature are not always validated with real data, which are difficult to obtain when the product system studied is a new one, and this generates uncertainty in the results when using this models in LCA.

\section{Materials and methods}

\subsection{Packaging description}

In this study, Lactococcus lactis subsp. lactis was chosen as the microorganism producer of antimicrobial agents for developing the active packaging. Indeed, among lactic acid bacteria (LAB), L. lactis is considered as GRAS (Generally Recognizes As Safe) by the FDA (Food and Drug Administration) and produces nisin, a well-studied bacteriocin classified as GRAS with antimicrobial activity against Grampositive bacteria such as Listeria monocytogenes [21]. In addition, nisin is currently applied worldwide in milk-based products [22].

However, nisin is only effective against Gram-positive bacteria $[23,24]$. Researchers have shown that the addition of chelating agents to nisin increases the antimicrobial effectiveness against Gramnegative bacteria [25,26]. Phytic acid (PA) is a food additive which is present in nuts, grains and legumes with high chelating capacity. It was used in combination with $L$. lactis to broaden the antimicrobial 
spectrum to Gram-negative bacteria in order to extend the shelf life of food products.

The main polymer chosen to develop active packaging was polyvinyl alcohol (PVOH). Despite PVOH is a synthetic polymer, it is completely biodegradable and biocompatible. $\mathrm{PVOH}$ is soluble in water and has excellent film-forming, emulsifying, and adhesive properties. PVOH films and coatings are easily obtained by casting; they have great flexibility and mechanical resistance, and are water soluble, odorless, colorless, and non-toxic. Furthermore, $\mathrm{PVOH}$ is approved by the FDA for use in food contact and as a food additive with INS No. 1203 (Codex Alimentarius) (FAO/WHO (Food and Agriculture Organization/World Health Organization), 2004). In the EU, it is approved by the EFSA as a food additive in food supplements in accordance with Annex II to Regulation (EC) No. 1333/2008. Previous studies have shown the high potential of $\mathrm{PVOH}$ films to delivery living Lactococcus lactis. The combination of $\mathrm{PVOH}$ matrix with a small amount of casein hydrolysates (HCas) has led to a further L. lactis viability and also a more powerful antimicrobial activity $[27,28]$

To develop active packaging, two coating forming solutions (CFS), one with $L$. lactis and the other one with phytic acid (PA) were prepared by dissolving $10 \%$ of Polyvinyl alcohol (PVOH, Gohsenol GH17, Nippon Synthetic Chemical Company, Osaka, Japan) and casein hydrolysate (Sigma-Aldrich, Barcelona, Spain) in a mass ratio of 1:1 $(w / w)$. On the one hand, viable $L$. lactis cells were collected by centrifugation $(2,500 \mathrm{RCF}$ for $15 \mathrm{~min})$ at $4{ }^{\circ} \mathrm{C}$. The supernatant was removed and washed twice with peptone water and then L. lactis was added to the CFS in order to obtain a final target inoculum of $10^{7}$ CFU $/ \mathrm{cm}^{2}$ of coating. On the other hand, phytic acid (50\% phytic acid solution (w/w) in $\mathrm{H}_{2} \mathrm{O}$, Aldrich Chemistry) was added to the CFS in order to obtain a final concentration of $1.92 \mu \mathrm{L} / \mathrm{cm}^{2}$ of coating.

Active bags were made from polyethylene film (PE) previously coated on one side with the CFS containing L. lactis and with the CFS containing PA on the other side. Both CFS were applied on the PE surface using an extension bar with a $100 \mu \mathrm{m}$ deep thread (Lin-Lab Rioja, Logroño, Spain) and left to dry at $60^{\circ} \mathrm{C}$ during $3 \mathrm{sec}$. The total coated surface was $(20 \mathrm{~cm} \times 10 \mathrm{~cm})$ on both sides and a $0.8 \mathrm{~cm}$ margin 
of PE was left around the coating to make bags by heat-welded at 180 ${ }^{\circ} \mathrm{C}$ during 1.5 seconds. The average thickness was $72 \mu \mathrm{m}$ for PE and 12 $\pm 3 \mu \mathrm{m}$ for both coatings. Therefore, the final polymer concentrations of coatings were $10^{-3} \mathrm{~g} \mathrm{PVOH} / \mathrm{cm}^{2}$ and $10^{-3} \mathrm{~g} \mathrm{HCas} / \mathrm{cm}^{2}$. Uncoated PE was used to make conventional bags.

The product under consideration is a handmade pastry cream (PC), prepared at lab scale as follows: semi-skimmed milk (59\%), cornmeal (6\%), eggs (23\%), sugar (11.5\%) and vanilla extract (0.5\%) were stirred and heated at $100{ }^{\circ} \mathrm{C}$ for 10 minutes. After cooling, $218 \mathrm{~g}$ of pastry cream were properly packaged and stored under refrigerated conditions.

2.2. Quantification of pastry cream shelf life and associated food waste with the two packaging alternatives

The shelf life of a food is defined as the time after its production under controlled storage conditions, in which it suffers a loss or unacceptable changes in its sensorial or physicochemical properties, or when a change in its microbiological profile occurs. The study of the shelf life of homemade pastry cream packaged in both active and conventional packaging was carried out during storage at $0,1,3,7,10$, 13 , and 20 days.

First, a microbiological study was conducted to test spoilage bacteria such as Pseudomonas spp., Enterobacteria, mesophilic, psychrotrophic, lactic acid and coliform bacteria that limit the shelf life of the product as well as L. monocytogenes, a pathogenic bacterium that could be found in milk and egg-based products. $\mathrm{pH}$ was also monitored. Finally, a qualitative sensory test was carried out where taste, color, aroma, texture, and general appearance of the active packaged PC was evaluated on each day of storage by comparing the samples. According to the Spanish national standard for "Ready meals group A" (R.D. 3484/2000, B.O.E. 12/01/01) and with the results obtained from the sensory test, the shelf life of the pastry cream increased by 10 days, from day 3 with conventional packaging to day 13 with active packaging [29]. 
As commented above, product shelf life is related with the amount of food waste. Thus, the pastry cream wasted at manufacturing, retailing and household storage was quantified according to the previously estimated shelf life following Westergaard-Kabelmann and Olsen (2016).

At the manufacturing stage, waste production is closely related with the number of batches, as each production batch requires cleaning. Berlin and Sonesson (2008), estimated between 5.3\% and $6.7 \%$ waste in yogurt production with 2-3 production batches. In the present study, we assumed that the waste generated when processing the pastry cream is the same than that of yogurt, since both are viscous products. Hence, for the pastry cream in the conventional PE bags, 3 batches per week (every other day), with $6 \%$ waste, have been considered. In addition, Westergaard-Kabelmann and Olsen (2016) estimated that reducing batch frequency by one batch per week can reduce production waste by $33-50 \%$, which would require an extra four to five shelf life days. Hence, for the active packaging, which increases the shelf life to 13 days, and assuming $33 \%$ waste reduction to be conservative, $2 \%$ waste in the production stage was considered [17].

As concerns the pastry cream wasted before consumption because shelf life expiration, both at retailing and household, the model proposed by Westergaard-Kabelmann and Olsen (2016) for yogurt was applied. Based on discrete data on the percentages of yogurt left on retailer shelves and the number of shelf days, these authors adopted a continuous linear function assuming that the product had a constant probability $(p)$ of being sold each day it is on the shelf. The ex-ante probability of the product being sold within day $t$ (day $t$ included), called $P(t)$, is given by:

Ex ante probability for yogurt being sold within day

$$
t=P(t)=1-(1-p)^{t}
$$

Assuming that the waste rate is given by a percentage $w$ and that the total shelf life is $n$, the daily probability of the yoghurt being sold can be calculated as: 


$$
\begin{gathered}
(1-w)=1-(1-p)^{n} \\
p=1-\sqrt[n]{1-(1-w)}
\end{gathered}
$$

Westergaard-Kabelmann and Olsen, (2016) reported values for $w$ varying from $1.4 \%$ for UK and $2.5 \%$ for French supermarkets [17]. Therefore, by using equation (3), $w=1.95 \%$, the average of UK and FR data, and $n=13, p$ was calculated; then the ex-ante probability of the pastry cream not being sold before shelf life for $n=3$ (conventional package) and 13 days (active packaging) was calculated using equation (1), which corresponds to $40 \%$ and $2 \%$ of wasted product, respectively.

Finally, based on Lebersorger and Schneider, (2011) a $7.5 \%$ of uneaten food in the original sales packaging for dairy products was assumed as the wasted cream after consumption [12].

\subsection{Life cycle assessment}

Life Cycle Assessment (LCA) was applied to assess the environmental impact of the developed product systems. Following the ISO (2006) guidelines, the LCA phases were developed.

\subsubsection{Goal and scope definition}

The main purpose of this study was to carry out a comparative assessment of the environmental profiles of two packaging systems, namely a conventional PE packaging (CPE) and a bioactive PE packaging (BPE) that includes an antimicrobial coating. From an environmental perspective, bioactive packaging can be a viable alternative to conventional one when the environmental impacts of the system packaging-product decrease, even if the life cycle impacts of the packaging increase. Thus, a twofold goal was pursued:

- To make a comparison between the environmental impacts of CPE and BPE packaging. This allows to know the environmental profiles from the different packaging materials, independently from the 
product class they will contain, thus making it possible to use the results for other case studies.

- To make a comparison of the complete product-packaging system taking into account the influence of the two packaging alternatives on the shelf life of the packaged pastry cream and the subsequent food waste. In this case, PC-CPE corresponds to the pastry cream with conventional PE packaging, whereas the pastry cream packaged in the bioactive PE packaging is named PC-BPE.

In order to reach the first goal, the functional unit chosen is one packaging with $200 \mathrm{~mL}$ capacity and the systems boundaries comprise all the life cycle stages of the packaging including the waste treatment (Figure 1a).

The functional unit for the second goal of the study corresponds to $218 \mathrm{~g}$ of packaged pastry cream consumed in EU28 (which corresponds to $200 \mathrm{~mL}$ of pastry cream, since product density is $1.09 \mathrm{~kg} / \mathrm{L}$ ). According to this, the system boundaries (Figure 1b) include the whole life cycle of the pastry cream-package system. The pastry cream is included to understand the impact of each kind of package on food waste and assess whether its inclusion changes the environmental profile of the product. The life cycle begins with the production of both the packaging and the raw materials for the pastry cream manufacturing, packages are then filled with pastry cream and transported to the supermarket, where they are stored at the market rag, and ends with the waste treatment. It must be noted that the production and application of the coating corresponds only to the active packaging, whereas all the other stages are common to the two product systems analyzed, although the reference flows change depending on the shelf life of the product, as calculated in section 2.2. 
a

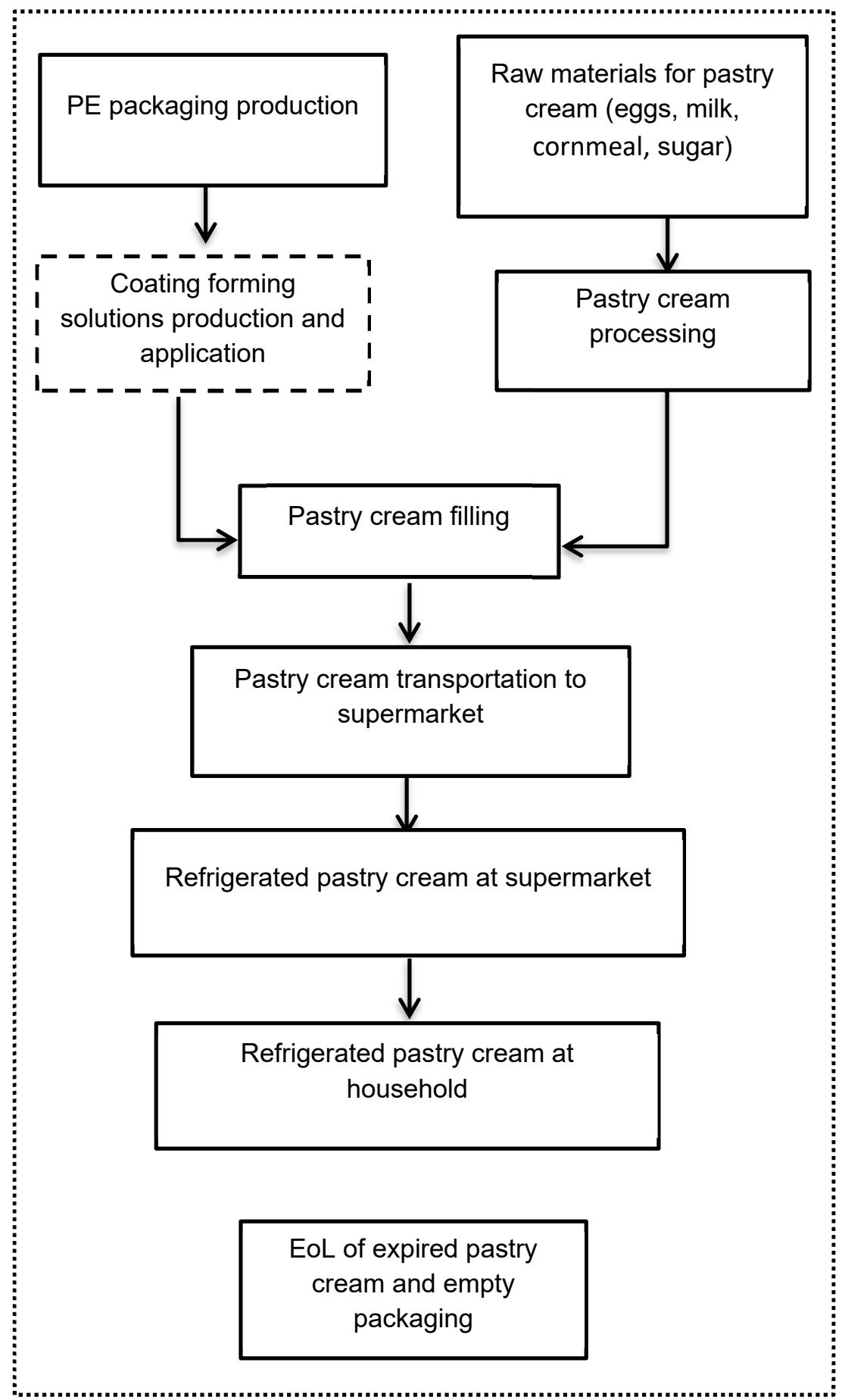




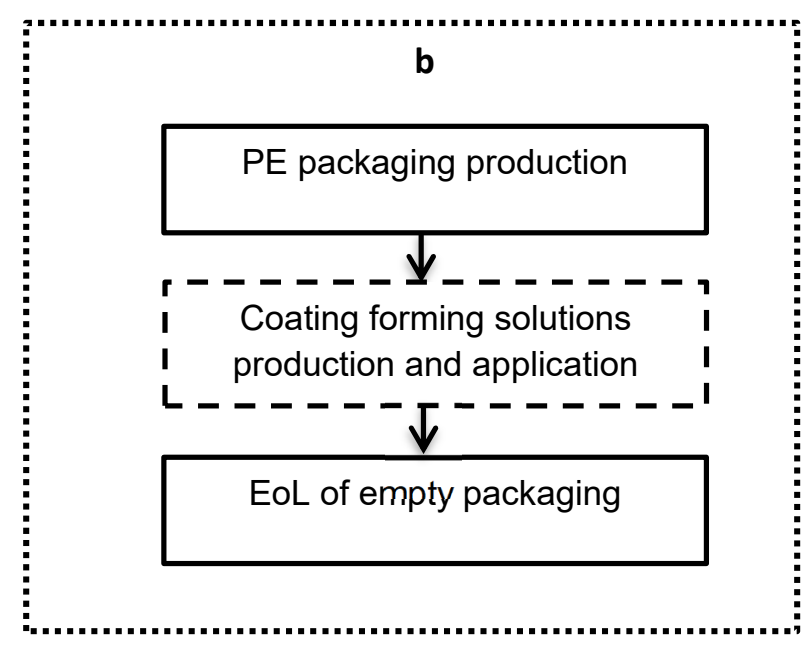

Figure 1. System boundaries of the packaging alone (a) and the foodpackaging system (b). The stage in dashed line occurs only in the active packaging

\subsubsection{Reference flows}

When considering the pastry cream-package system to reach the second goal of the study, it must be taken into account that the food waste generated imply that in the beginning of the food production chain, more food must be produced to fulfil the product demand at consumption. Therefore, the reference flows have been calculated by using the percentages of wasted pastry cream from section 2.2. From the same reference unit, that is, $218 \mathrm{~g}$ of pastry cream to be consumed, the amount of pastry cream to be processed, delivered to the supermarket, and purchased have been estimated (Table 1). Thus, per each $218 \mathrm{~g}$ of PC-CPE consumed, around $187 \mathrm{~g}$ are wasted, whereas in the case of PC-BPE the calculated amount of pastry cream waste in the same stages is $25.2 \mathrm{~g}$. 
Table 1. Pastry cream flow in the life cycle stages

\begin{tabular}{|c|c|c|c|c|}
\hline Cream flow in the life cycle stages & $\begin{array}{c}\text { Average } \\
\text { waste } \\
\text { PC-CPE }\end{array}$ & $\begin{array}{l}\text { Pastry cream } \\
\text { in PC-CPE (g) }\end{array}$ & $\begin{array}{l}\text { Average waste } \\
\text { PC-BPE }\end{array}$ & $\begin{array}{l}\text { Pastry cream } \\
\text { in PC-BPE (g) }\end{array}$ \\
\hline Cream waste after consumption & $7.5 \%$ & 16.4 & $7.5 \%$ & 16.4 \\
\hline Consumed pastry cream & & 218.0 & & 218.0 \\
\hline Cream waste due to expiration* & $40 \%$ & 147.2 & $2 \%$ & 4.3 \\
\hline $\begin{array}{l}\text { Pastry cream stored* to consume } 218 \mathrm{~g} \\
\text { at home }\end{array}$ & & 365.2 & & 222.3 \\
\hline Cream waste at manufacturing & $6 \%$ & 23.3 & $2 \%$ & 4.5 \\
\hline $\begin{array}{l}\text { Pastry cream manufactured to consume } \\
218 \mathrm{~g} \text { cream at home including wasted } \\
\text { cream }\end{array}$ & & 388.5 & & 226.9 \\
\hline
\end{tabular}

*at retailing/home 


\subsubsection{Life cycle inventory}

The amount of each component for a $200 \mathrm{~mL}$ bag of CPE and BPE is shown in Table 2, this data is used both when assessing the empty packages and the cream-packaging system.

Table 2. Components of conventional and bioactive PE-packaging of $200 \mathrm{~mL}$

\begin{tabular}{llll}
\hline & PC-BPE & PC-CPE & Units \\
\hline Polyethylene (PE) & $3.82 \mathrm{E}-03$ & $3.82 \mathrm{E}-03$ & $\mathrm{~kg}$ \\
Polyvinyl alcohol (PVOH) & $4.00 \mathrm{E}-04$ & - & $\mathrm{kg}$ \\
Casein hydrolysated & $4.00 \mathrm{E}-04$ & - & $\mathrm{kg}$ \\
Lactococcus lactis subsp. lactis & $3.96 \mathrm{E}-06$ & - & $\mathrm{kg}$ \\
Phytic acid (50\% in water) & $4.99 \mathrm{E}-04$ & - & $\mathrm{kg}$ \\
\hline
\end{tabular}

Primary data were used for the production of the active coating. Processes corresponding to the raw materials for the production of the two packaging alternatives were taken from GaBi database (Sphera Solutions $\mathrm{GmbH}$, Leinfelden-Echterdingen, Germany). Since inventory data on phytic acid was not available in GaBi database or in Ecoinvent 3.5, citric acid was used as an approximation in this study. As to the production of casein hydrolysate, the most energy intensive processes were considered, namely skim milk microfiltration and heat treatment, by using data from Depping, (2020), and the subsequent spray drying process from $\mathrm{GaBi}$ database. Inventory data for the production of the frozen $L A B$ were adapted from the study of Pénicaud et al. (2018), considering freezing for 3 months as the average preservation time for the $\operatorname{LAB}[30,31]$. For the coating preparation and application by using rotogravure technique, the data provided by Manfredi et al. (2015) for a case study on active packaging were adapted taking into account the bag surface area .

Inventory data for the production of raw materials for the pastry cream, namely milk, sugar and maize starch flour, have been taken from $\mathrm{GaBi}$ database, except eggs, which were taken from Abín et al. (2018), although, instead of including meat from exhausted hens as an avoided product, an economic allocation was carried out [32]. Food loss and waste at the agricultural, postharvest and processing stages 
of the raw materials for the pastry cream were considered. To this aim, the food loss percentages corresponding to those stages were taken from Garcia-Herrero et al. (2018) [33], which in turn are based on FAO data for Europe [34] and Spanish data [35]. The electricity consumption for preparing the cream was extrapolated based on industrial catalogue data for an equipment with $120 \mathrm{~L}$ capacity and 12 $\mathrm{kW}$ power. The cleaning of the equipment was not considered in the study due to lack of data, however it must be taken into account that the potential impact of cleaning would be lower when using the active packaging, given that the number of batches per week is reduced, as commented in section 2.2.

An average distance of $25 \mathrm{~km}$ was considered for the transportation of the pastry cream between the production center and the supermarket, with a refrigerated truck (Ecoinvent 3.5). Once the pastry cream is delivered to the retailer, 1.5 days of cold storage at the supermarket were considered, with an average energy consumption of $40 \mathrm{kWh} / \mathrm{m}^{3} /$ year [36]. Following Manfredi et al. (2015) assumptions, a class A refrigerator of $298 \mathrm{~L}$ with an average annual consumption of $292 \mathrm{kWh}$ was considered for household storage [8].

It was assumed that the pastry cream wasted before consumption, that is, because the shelf life date expired, was landfilled without separating the packaging. In this case, the GaBi process "Municipal solid waste on landfill" was used. In case the pastry cream was consumed, the packaging was disposed of according to the European end-of-life (EoL) scenario. The rates of each EoL treatment for plastic packaging in the EU28 in 2017 were taken from Eurostat (2020a, 2020b): $41.9 \%$ recycling, $33 \%$ incineration. The incineration rate was set by subtracting the recycling rate from the recovery rate $(74.9 \%)$, as recycling is a kind of recovery. The remaining $25.1 \%$ was supposed to go to landfill. Processes corresponding to PE incineration and PE landfill of GaBi database were used, considering the avoided loads due to electricity and thermal energy generation in the incineration process to give a better insight of the environmental consequences of these treatments. For the same reason, PE recycling was modelled 
by including the burdens of the recycling process and the credits from the material obtained.

As to background processes, electricity mix and thermal energy for EU28 were also taken from $\mathrm{GaBi}$ database.

\subsubsection{Impact assessment}

The impact Assessment method ReCiPe 2016 v1.1 [37] was used in this study. This method considers midpoint and endpoint indicators. The midpoint indicators include eighteen impact categories (abbreviated name and units in brackets): Climate change (CC, expressed as kg CO2 eq.), fine particulate matter formation (FPMF, kg PM2.5 eq), fossil depletion (FD, $\mathrm{kg}$ oil eq), freshwater consumption (m3), freshwater ecotoxicity (Fw-Etx, kg 1,4 DB eq.), freshwater eutrophication ( $\mathrm{Fw}-\mathrm{Eu}, \mathrm{kg} \mathrm{P}$ eq.), human toxicity carcinogenic and no carcinogenic ( $\mathrm{Htx}-\mathrm{CC}$ and $\mathrm{Htx}-\mathrm{NC}, \mathrm{kg}$ 1,4 DB eq.), ionizing radiation $(\mathrm{IR}, \mathrm{kBq} \mathrm{Co}-60$ eq. to air), land use (LU, annual crop eq.y), marine ecotoxicity (M-Etx, kg 1,4 DB eq.), marine eutrophication (M-Eu, $\mathrm{kg} \mathrm{N}$ eq.), metal depletion ( $M D, k g C U$ eq.), photochemical ozone formation in ecosystems and human health (POP-Etx, POF-HH, kg NOx eq.), stratospheric ozone depletion (SOD, $\mathrm{kg}$ CFC-11 eq.), terrestrial acidification (TA, kg SO2 eq.) and terrestrial ecotoxicity ( $\mathrm{T}$-Etx, kg 1,4DB eq.).

To better understand the relative significance of impact category results, normalization was applied. In this way, abstract impact scores for every impact category are translated into relative contributions of the product to a reference situation [38]. Specifically, the normalized factors of midpoint impact for ReCiPe at world level expressed as person equivalents available in $\mathrm{GaBi}$ software were applied.

\section{Results and discussion}

3.1. Environmental impacts of the PE packaging with and without bioactive coating

Firstly, the environmental impacts of the two PE packaging alternatives (without considering the food) were compared in table 3. As expected, CPE shows lower environmental impacts, since more elements are needed for the packaging production; in addition, eight of the impact categories have negative values due to the avoided loads caused by the EoL treatment stage, which compensates the environmental impacts of the packaging production. Those avoided 
Table 3. Environmental impacts of $200 \mathrm{~mL}$ PE bags without (CPE) and with bioactive coating (BPE)

\begin{tabular}{lll} 
& & CPE \\
\hline Climate change, default, excl biogenic carbon (kg CO2 eq.) & $9.57 \cdot 10^{-3}$ & $1.55 \cdot 10^{-2}$ \\
Fine Particulate Matter Formation (kg PM2.5 eq.) & $9.42 \cdot 10^{-6}$ & $2.31 \cdot 10^{-5}$ \\
Fossil depletion (kg oil eq.) & $4.24 \cdot 10^{-3}$ & $5.31 \cdot 10^{-3}$ \\
Freshwater consumption (m3) & $1.43 \cdot 10^{-4}$ & $3.45 \cdot 10^{-4}$ \\
Freshwater ecotoxicity (kg 1,4 DB eq.) & $-3.46 \cdot 10^{-7}$ & $1.80 \cdot 10^{-5}$ \\
Freshwater Eutrophication (kg P eq.) & $8.53 \cdot 10^{-9}$ & $1.04 \cdot 10^{-6}$ \\
Human toxicity, cancer (kg 1,4-DB eq.) & $-1.13 \cdot 10^{-6}$ & $5.98 \cdot 10^{-5}$ \\
Human toxicity, non-cancer (kg 1,4-DB eq.) & $-3.03 \cdot 10^{-4}$ & $1.03 \cdot 10^{-3}$ \\
lonizing Radiation (kBq Co-60 eq. to air) & $-5.93 \cdot 10^{-5}$ & $2.14 \cdot 10^{-4}$ \\
Lan use (Annual crop eq. y) & $-1.02 \cdot 10^{-4}$ & $2.19 \cdot 10^{-3}$ \\
Marine ecotoxicity (kg 1,4-DB eq.) & $-1.99 \cdot 10^{-6}$ & $2.15 \cdot 10^{-5}$ \\
Marine Eutrophication (kg N eq.) & $-4.70 \cdot 10^{-8}$ & $3.41 \cdot 10^{-6}$ \\
Metal depletion (kg Cu eq.) & $6.103 \cdot 10^{-6}$ & $2.77 \cdot 10^{-5}$ \\
Photochemical Ozone Formation, Ecosystems (kg NOx eq.) & $1.57 \cdot 10^{-5}$ & $2.44 \cdot 10^{-5}$ \\
Photochemical Ozone Formation, Human Health (kg NOx eq.) & $1.56 \cdot 10^{-5}$ & $2.37 \cdot 10^{-5}$ \\
Stratospheric Ozone Depletion (kg CFC-11 eq.) & $-1.01 \cdot 10^{-9}$ & $1.62 \cdot 10^{-8}$ \\
Terrestrial Acidification (kg SO2 eq.) & $3.25 \cdot 10^{-5}$ & $6.42 \cdot 10^{-5}$ \\
Terrestrial ecotoxicity (kg 1,4-DB eq.) & $-5.80 \cdot 10^{-4}$ & $3.53 \cdot 10^{-3}$ \\
\hline
\end{tabular}


loads, as explained in section 2.3.3, are implicit in incineration and recycling treatments, whereas landfill does not produce any useful energy o product and therefore has no negative values.

As can be observed in Figure $2 \mathrm{~A}$, for the CPE bag, the production of low density PE is the main contributor to all the impact categories, whereas the EoL shows negative values except for MD and Fw-Eu, which contribute to $82 \%$ and $43 \%$ of the total impact category respectively, mainly caused by landfill.
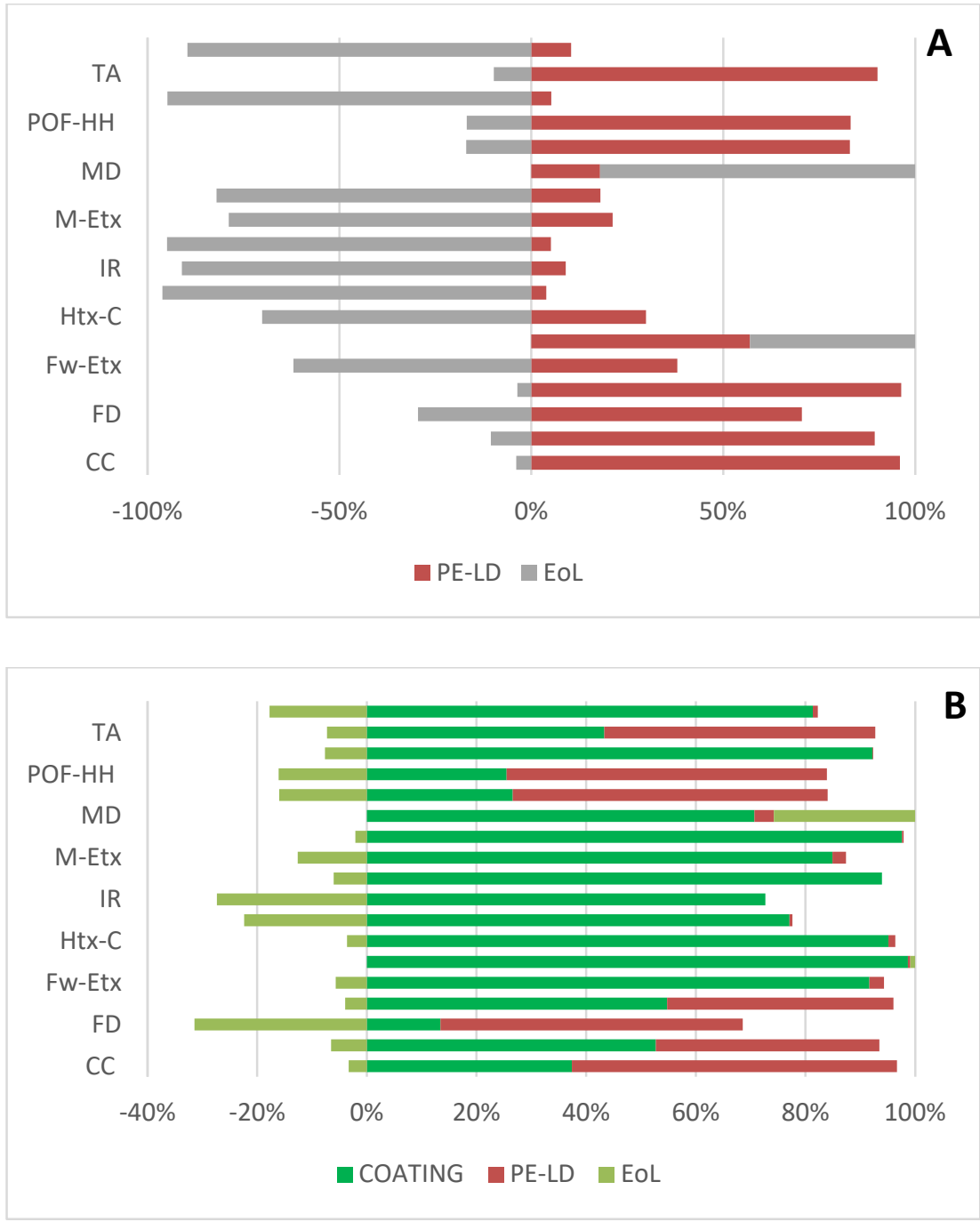

Figure 2. Contribution analysis of $200 \mathrm{~mL}$ PE bags without (A) and with bioactive coating (B) 
The contribution analysis for the active packaging (Figure 2B) shows that the coating production is responsible for most of the impact categories. It must be noted that the production of the LAB has a low contribution to this stage, whereas the production of casein hydrolysate and citric acid are the main causes of the high values of the coating in most of the impact categories. As commented in section 2.3.3, phytic acid was replaced by citric acid due to lack of inventory data for this compound, hence results may change if phytic acid production is considered. PE production means also a great share of CC (6 $4 \%$ of the total impact), FPMF (46\%), FD (136\%), FwC (43\%), POF ( $81 \%$ and $82 \%$ for ecosystems and human health, respectively) and TA (57\%). EoL stage has negative values for all the impact categories except for FwEu (less than $1 \%$ ) and MD (18\%), which are caused by landfilling the packaging waste.

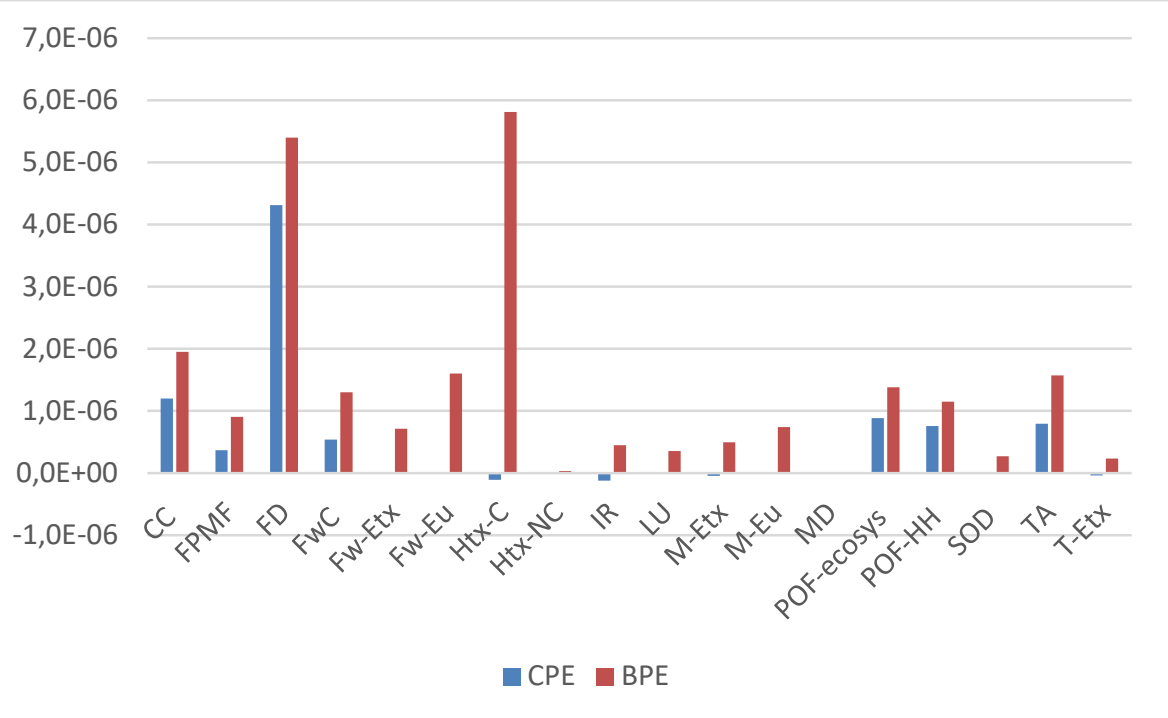

Figure 3. Comparison of normalized impact results of conventional PE packaging (CPE) and bioactive PE packaging (BPE).

The normalization of the midpoint impact categories (Figure 3) highlights the categories which appear to be the most critical ones for the two analysed packaging systems, and shows that for BPE human 
toxicity carcinogenic is the most critical impact, although this impact seems negligible for CPE. FD is also critical for both CPE and BPE, followed by CC and TA.

\subsection{Environmental impacts of the packed pastry cream}

In this section, the environmental impacts of the food-packaging systems (PC-PCE and PC-BPE) are analysed. As commented above, this allows to understand the impact of the two packages in the context of the food packaged within them, also considering the effect of the shelf life on the packaged food and its subsequent waste. As can be observed in Table 4, in this case, the active packaging shows lower environmental impacts, with differences ranging from $36 \%$ for SOD, TA and T-Ecotx, to $76 \%$ for CC. This is due to the lower amount of food waste generated when using the active packaging as a consequence of the elongation of the product shelf life. In other words, the food waste avoided by the use of bioactive packaging is more significant than the environmental burden generated by the bioactive coating.

In the contribution analysis, the life cycle stages have been grouped in four items as follows:

- Pastry cream: it includes the production of the consumed pastry cream, which in both cases is $218 \mathrm{~g}$ per FU.

- Wasted pastry cream, which includes the production of the pastry cream surplus that is wasted through manufacturing, retailing and consumption stages. The amount of wasted pastry cream depends on the kind of packaging, as shown in Table 1.

- Packaging, which includes the packaging production, which will depend on the amount of pastry cream purchased by the retailer taking into account the waste.

- Distribution \& use, which includes the transport, storage at retailer and household, and consumption of the packed pastry cream.

- End of life (EoL), which includes all the inputs and outputs related to the treatment of both packaging and pastry cream waste. As shown in Table 1, the amount of waste to be treated differs depending on the kind of packaging.

Figure 4 reports the relative contribution of each those five items to the product-packaging system for PC-CPE (A) and PC-BPE (B). Pastry cream manufacturing together with the wasted pastry cream are, as expected, the main cause of impacts in both systems. These 
two items represent jointly $84-100 \%$ of the total environmental burdens in PC-CPE, and 91-99 \% in CP-BPE. That is, once food and food waste are included in the system boundaries, the impact of the production of the packaging becomes a small part of the impact of the total system, as reported in previous studies (e.g. Conte et al., 2015; Dilkes-Hoffman et al., 2018; Dobon et al., 2011; Manfredi et al., 2015).

For PC-CPE, the production of $218 \mathrm{~g}(200 \mathrm{~mL})$ of pastry cream is the main cause of the impacts (48 to $57 \%$, depending on the category), followed by the production of the wasted cream (36 to $43 \%$ of the total impact, depending on the impact category). The high share of the wasted pastry cream is explained by the high percentages of waste, since per each $218 \mathrm{~g}$ consumed $202 \mathrm{~g}$ are wasted. The remaining life cycle stages have a very low contribution to all the impact categories. It must be noted that LDPE production is the main responsible of FD impact category (12\% of the total impact of the system), and $2 \%$ of CC, POF-ecosys and POF-HH. The distribution \& use stage means 3-6\% of toxicity related impacts (Fw-Etx Htx-NC, MEtx and T-Etx). As to EoL, it is responsible of $14 \%$ of CC (mainly because of $\mathrm{PE}$ incineration) and $11 \%$ of $\mathrm{MD}$.

The results for PC-BPE show that the production of the pastry cream is the main cause of the impacts (78 to $89 \%$ of the total impact, depending on the impact category). The wasted cream means 9-11\% of the total impact (depending on the category) since in this case it amounts $27.3 \mathrm{~g}$ (see Table 1). The packaging is, on average, the third source of impacts in almost all categories, meaning 7-0.5\% of the total impacts, except for FD (16\% total impact). Only for toxicity related impacts (Fw-Etx, Htx-C, Htx-NC and T-Etx), the product distribution \& use stage shows again higher values than the packaging production.

The normalization phase (Figure 5) highlights $\mathrm{Htx}-\mathrm{C}$ as the most critical impact category for the two food-packaging systems analyzed, followed by Fw-Eu and M-Eu. On the other hand, the normalized values of Htx-NC, IR and MD have a rather low significance. 


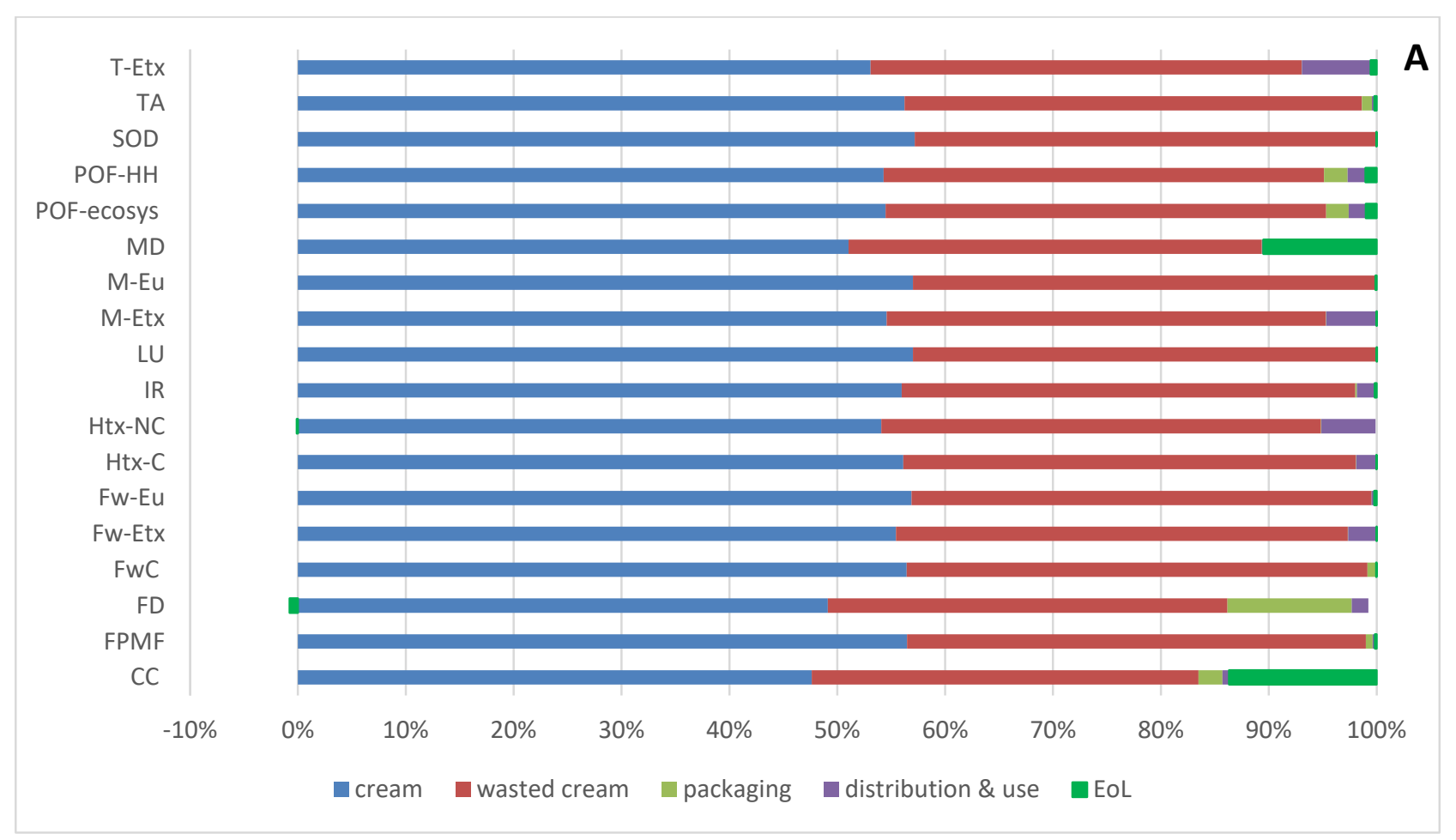




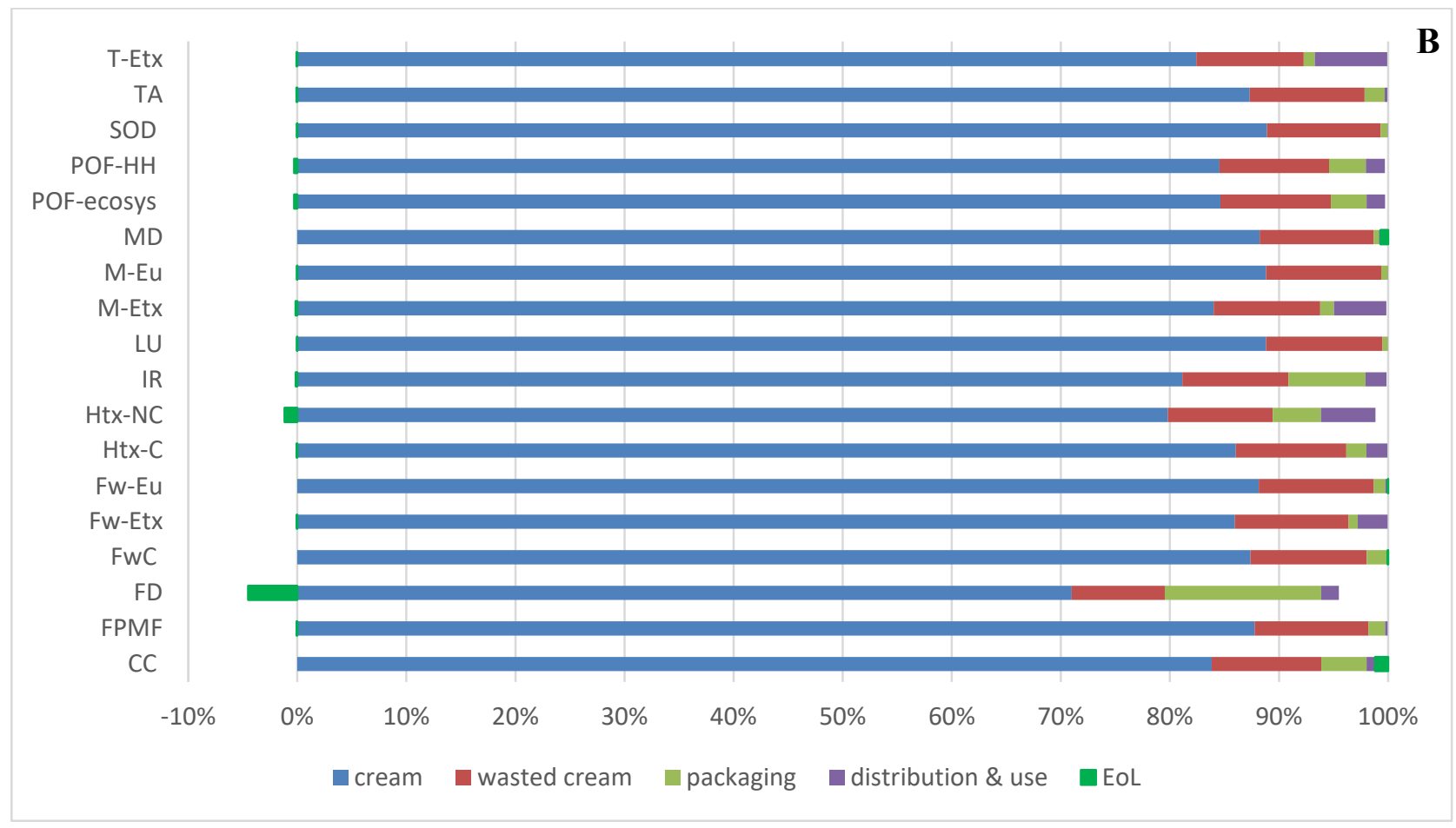

Figure 4. Contribution analysis of the pastry cream packed in conventional (A) and bioactive PE packaging (B). 


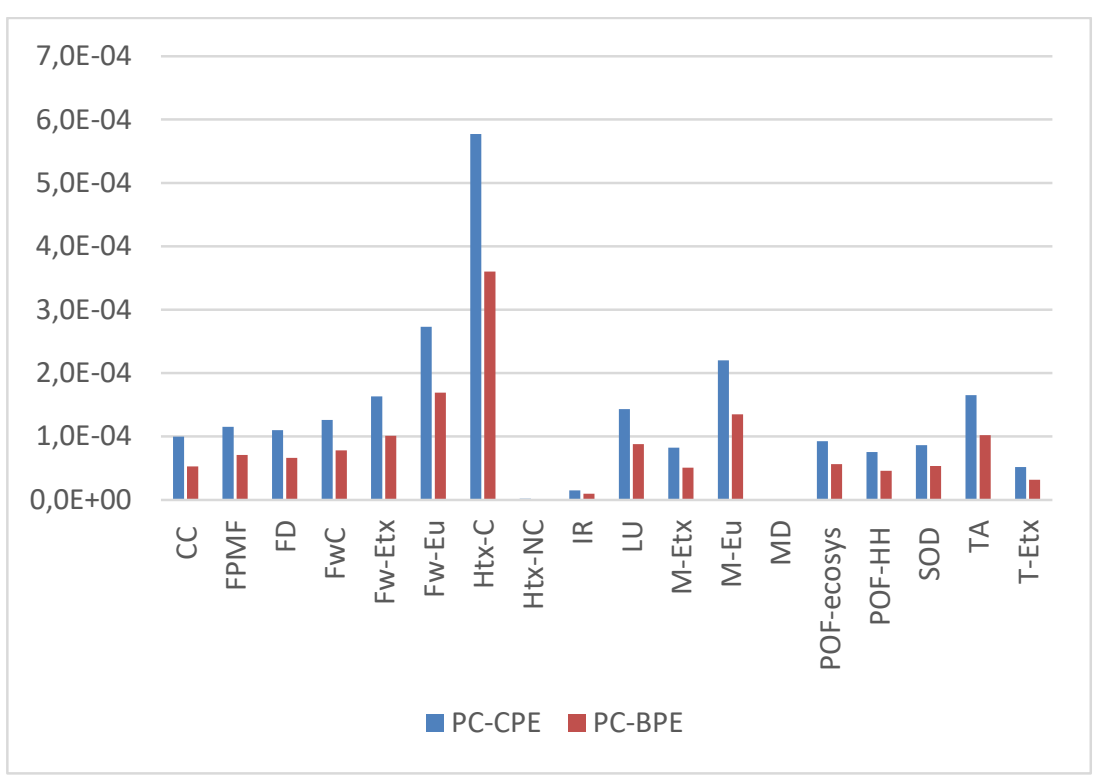

Figure 5. Comparison of normalized impact results of pastry cream in conventional PE packaging (PC-CPE) and in bioactive PE packaging (PC-BPE).

\subsection{Discussion}

The results of the environmental impacts of the two PE packaging alternatives shows that CPE presents lower environmental impacts, since more elements are needed for the packaging production. These results totally change when the systems boundaries comprise the food packaged within them, also considering the effect of the shelf life on the packaged food and its subsequent waste. In that case, PC-BPE has a lower impact because the wasted product decreases as a consequence of the product shelf-life extension.

Some data quality issues should be improved to obtain more reliable results. First, it must be bear in mind that although packaging disposal has been modelled according to data for EU28, all the product wasted because of expiration was supposed to be landfilled. However, this landfill process is not adjusted for the input of a specific food or packaging, that is, it does not reflect the specific composition of the emissions related to the disposal of the individual food product. In any case, this issue would affect both systems proportionally to the waste generated. In addition, the wastewater from cleaning in the pastry cream manufacturing stage has not been included due to lack of data. Taking that treatment into account would mean a greater difference between the impacts of the two systems, since, as 
commented in section 2.2, a reduction in the number of batches and in the subsequent cleaning is expected if the shelf life of the product increases due to the bioactive packaging.

However, those issues are less decisive on the results, because the estimation of the amount of wasted food due to shelf-life expiration is key when comparing the two product-packaging systems. As commented in section 1, the relationship between product's shelf life and the amount of wasted food is not direct and empirical determination is hard, specialy when studying a new food product or packaging. Thus, an alternative model from the literature has been used to identify this relationship, namely the exponential relationship proposed by Conte et al. (2015). In this case, $55.8 \%$ of the pastry cream is wasted when the shelf life is 3 days (scenario PC-CPE_alt) and $8 \%$ waste is generated when it is 3 days (scenario PC-BPE_alt), whereas according to the model proposed in section 2.2 the pastry cream wasted varies from $40 \%$ to $2 \%$ for PC-CPE and PC-BPE, respectively.

The results of the alternative scenarios (Figure 6) show 36-45\% increase on the impact values for the PC-CPE_alt vs. the conventional reference system, and 4-5\% increase for the PC-BPE_alt vs. the bioactive reference system. Therefore, differences between the conventional and bioactive food packaging system are even bigger using this alternative model. Although these results could be used to reinforce the results of the study, some criticisms can be made to the proposal of Conte et al. (2015). On the one hand, an $8 \%$ waste is associated to the product with the highest shelf life, without any empirical evidence of the real amount of waste. On the other hand, that value corresponds to the leftovers accounted for by Lebersorger and Schneider, (2011) for food consumption in general, without distinguishing food types such as dairy, meat products, etc.

In addition, the environmental break-even rate has been calculated by using the equation proposed by Yokokawa et al. (2018). According to those authors, the break-even rate represents the required reduction of food waste rate provided by the alternative packaging that can sufficiently decrease the overall environmental impacts. 


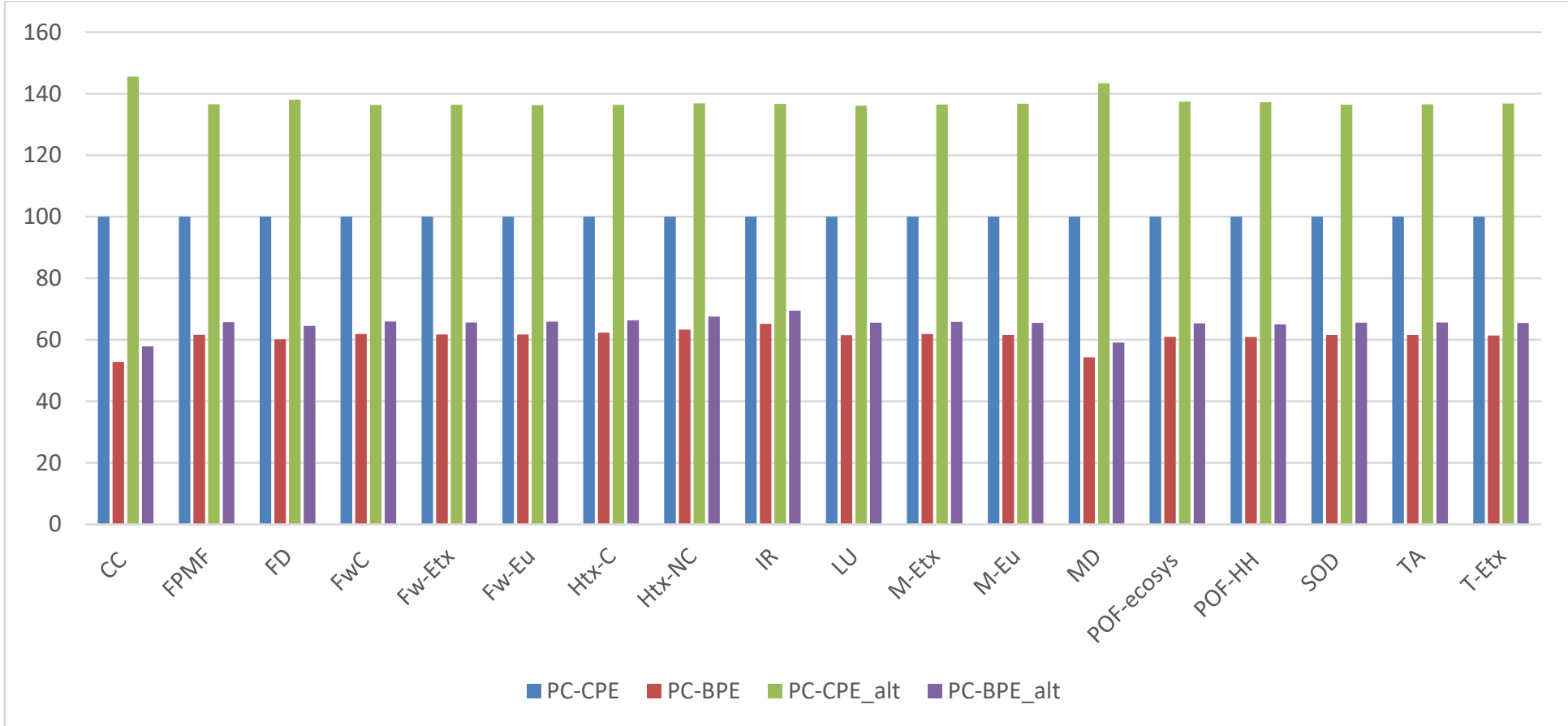

Figure 6. Percentage variation of the different impact categories for each scenario with respect to the pastry cream in conventional PE packaging. 
The break-even rate varies depending on the impact category from $0.4 \%$ for MD to $6.7 \%$ for IR. This means that the increased impacts from shifting to bioactive packaging for pastry cream can be easily compensated by a small reduction in the amount of waste due to shelf life expiration.

The break-even rate depends on the EoL treatment, thus it can be calculated for other EoL treatments. If the break-even rate is calculated taking into account incineration very similar values are obtained (from $0.5 \%$ for MD to $6.6 \%$ for IR). Other treatments could be assessed taking into account that the break-even rate will be higher when EoL technologies are less harmful for the environment [41]. In any case, as mentioned at the beginning of this section, the landfill process used in the calculations is not specific for the product, and the same for the incineration, thus different break-even rates could be obtained if specific processes were used and also if the other quality issues commented in this section were improved.

\section{Conclusions}

In this study, the environmental implications of packaging selection have been assessed considering both the direct and indirect effects, in terms of shelf-life and food waste. Specifically, a conventional PE packaging and a bioactive one, consisting on a PE bag coated with PVOH and casein hydrolysates containing L. lactis and phytic acid with shelf-life enhancing capacity, have been compared. The trade-off between the impact increase due to the addition of active coating and the environmental benefits related to the reduction of food loss was evaluated and the food shelf-life extension has proved to be a key issue when assessing the environmental impacts of novel packages. Along these lines, active packaging arises as a packaging technique which allows food loss and waste along the food chain to be reduced. These reductions concern not only refrigerated storage at retailing, but also at manufacturing, as the number of batches per week can be decreased, and at consumption, because once the packaging is open the antimicrobial effect is still active.

The results interpretation should be made with caution. The analysis and its results are based on a number of assumptions and generalizations that will generate uncertainty in the results, mainly because waste percentages and waste causes correspond to different 
countries and to a different product, yogurt, although it is also a viscous food. Thus, the calculation of the break-even rate of food waste can help to determine a threshold of food waste reduction provided by the alternative packaging that can decrease the overall environmental impacts. In any case, despite the limitations regarding the estimation of the wasted product, there is no doubt that shelf life life extension through packaging innovation can significantly reduce the environmental impacts of the whole food-packaging system.

To reduce the uncertainty of the LCA results, future research is needed to develop more accurate models to relate product shelf life and the potential waste. In addition, the economic sustainability should also be considered under a life cyle approach, taking into account potential changes in the manufacturing and retailing stages and internalizing the benefits to the environment of waste reduction.

\section{REFERENCES}

1. Hanson, C.; Flanagan, K.; Robertson, K.; Axmann, H.; BosBrouwers, H.; Broeze, J.; Kneller, C.; Maier, D.; McGee, C.; $\mathrm{O}^{\prime}$ Connor, $\mathrm{C}$.; et al. Reducing food loss: Ten interventions to scale impact; 2019;

2. Aloui, H.; Khwaldia, K. Natural Antimicrobial Edible Coatings for Microbial Safety and Food Quality Enhancement. Compr. Rev. Food Sci. Food Saf. 2016, 15, 1080-1103, doi:10.1111/15414337.12226.

3. Reis, J.A.; Paula, A.T.; Casarotti, S.N.; Penna, A.L.B. Lactic Acid Bacteria Antimicrobial Compounds: Characteristics and Applications. Food Eng. Rev. 2012, 4, 124-140, doi:10.1007/s12393-012-9051-2.

4. Espitia, P.J.P.; Batista, R.A.; Azeredo, H.M.C.; Otoni, C.G. Probiotics and their potential applications in active edible films and coatings. Food Res. Int. 2016, 90, 42-52, doi:10.1016/j.foodres.2016.10.026.

5. Williams, H.; Wikström, F. Environmental impact of packaging and food losses in a life cycle perspective: A comparative analysis of five food items. J. Clean. Prod. 2011, 19, 43-48, doi:10.1016/j.jclepro.2010.08.008.

6. Molina-Besch, K. Prioritization guidelines for green food packaging development. Br. Food J. 2016, 118, 2512-2533.

7. Grönman, K.; Soukka, R.; Järvi-Kääriäinen, T.; Katajajuuri, J.M.; 
Kuisma, M.; Koivupuro, H.K.; Ollila, M.; Pitkänen, M.; Miettinen, O.; Silvenius, F.; et al. Framework for sustainable food packaging design. Packag. Technol. Sci. 2013, 26, 187-200, doi:10.1002/pts.1971.

8. Manfredi, M.; Fantin, V.; Vignali, G.; Gavara, R. Environmental assessment of antimicrobial coatings for packaged fresh milk. J. Clean. 2015, Prod. 291-300, doi:10.1016/j.jclepro.2015.02.048.

9. Zhang, H.; Hortal, M.; Dobon, A.; Bermudez, J.M.; Lara-Lledo, M. The Effect of Active Packaging on Minimizing Food Losses: Life Cycle Assessment (LCA) of Essential Oil Component-enabled Packaging for Fresh Beef. Packag. Technol. Sci. 2015, 28, 761774, doi:10.1002/pts.2135.

10. Vigil, M.; Pedrosa-Laza, M.; Cabal, J.V.A.; Ortega-Fernández, F. Sustainability analysis of active packaging for the fresh cut vegetable industry by means of attributional \& consequential life cycle assessment. Sustain. 2020, 12, doi:10.3390/su12177207.

11. WRAP (Waste \& Resources Action Programme) The Milk Model: Simulating Food Waste in the Home; 2013; ISBN 9781844054633.

12. Lebersorger, S.; Schneider, F. Discussion on the methodology for determining food waste in household waste composition studies. Waste Manag. 2011, 31, 1924-1933, doi:10.1016/j.wasman.2011.05.023.

13. Valsasina, L.; Pizzol, M.; Smetana, S.; Georget, E.; Mathys, A.; Heinz, V. Life cycle assessment of emerging technologies: The case of milk ultra-high pressure homogenisation. J. Clean. Prod. 2017, 142, 2209-2217, doi:10.1016/j.jclepro.2016.11.059.

14. Zhang, B.Y.; Tong, Y.; Singh, S.; Cai, H.; Huang, J.Y. Assessment of carbon footprint of nano-packaging considering potential food waste reduction due to shelf life extension. Resour. Conserv. Recycl. 2019, 149, 322-331, doi:10.1016/j.resconrec.2019.05.030.

15. Zhang, Q.; Zhao, L.; Li, Z.; Li, C.; Li, B.; Gu, X.; Zhang, X.; Zhang, $\mathrm{H}$. Screening and identification of an antagonistic yeast controlling postharvest blue mold decay of pears and the possible mechanisms involved. Biol. Control 2019, 133, 26-33, doi:10.1016/J.BIOCONTROL.2019.03.002.

16. Conte, A.; Cappelletti, G.M.; Nicoletti, G.M.; Russo, C.; Del Nobile, M.A. Environmental implications of food loss 
probability in packaging design. Food Res. Int. 2015, 78, 11-17, doi:10.1016/j.foodres.2015.11.015.

17. Gutierrez, M.M.; Meleddu, M.; Piga, A. Food losses, shelf life extension and environmental impact of a packaged cheesecake: A life cycle assessment. Food Res. Int. 2017, 91, 124-132, doi:10.1016/j.foodres.2016.11.031.

18. Westergaard-Kabelmann, T.; Olsen, M.D. Reducing food waste and losses in the fresh dairy supply chain Chr. Hansen impact study. White Pap. Chr. Hansen 2016, 45.

19. Berlin, J.; Sonesson, U. Minimising environmental impact by sequencing cultured dairy products: two case studies. J. Clean. Prod. 2008, 16, 483-498, doi:10.1016/j.jclepro.2006.10.001.

20. Spada, A.; Conte, A.; Del Nobile, M.A. The influence of shelf life on food waste: A model-based approach by empirical market evidence. J. Clean. Prod. 2018, 172, 3410-3414, doi:10.1016/j.jclepro.2017.11.071.

21. Benkerroum, N.; Sandine, W.E. Inhibitory Action of Nisin Against Listeria monocytogenes. J. Dairy Sci. 1988, 71, 32373245, doi:10.3168/jds.S0022-0302(88)79929-4.

22. Silva, C.C.G.; Silva, S.P.M.; Ribeiro, S.C. Application of bacteriocins and protective cultures in dairy food preservation. Front. Microbiol. 2018, 9, doi:10.3389/fmicb.2018.00594.

23. Kuwano, K.; Tanaka, N.; Shimizu, T.; Nagatoshi, K.; Nou, S.; Sonomoto, K. Dual antibacterial mechanisms of nisin $\mathrm{Z}$ against Gram-positive and Gram-negative bacteria. Int. J. Antimicrob. Agents 2005, 26 , 396-402, doi:10.1016/j.ijantimicag.2005.08.010.

24. Holcapkova, P.; Hurajova, A.; Kucharczyk, P.; Bazant, P.; Plachy, T.; Miskolczi, N.; Sedlarik, V. Effect of polyethylene glycol plasticizer on long-term antibacterial activity and the release profile of bacteriocin nisin from polylactide blends. Polym. Adv. Technol. 2018, 29, 2253-2263, doi:10.1002/pat.4336.

25. Boziaris, I.S.; Adams, M.R. Effect of chelators and nisin produced in situ on inhibition and inactivation of Gram negatives. Int. J. Food Microbiol. 1999, 53, 105-113, doi:10.1016/S0168-1605(99)00139-7.

26. Delves-Broughton, J. The use of EDTA to enhance the efficacy of nisin towards Gram-negative bacteria. Int. Biodeterior. Biodegrad. 1993, 32, 87-97, doi:10.1016/0964-8305(93)90042Z.

27. Settier-Ramírez, L.; López-Carballo, G.; Gavara, R.; Hernández- 
Muñoz, P. Antilisterial properties of PVOH-based films embedded with Lactococcus lactis subsp. lactis. Food Hydrocoll. 2019, 87, doi:10.1016/j.foodhyd.2018.08.007.

28. Settier-Ramírez, L.; López-Carballo, G.; Gavara, R.; HernándezMuñoz, P. PVOH/protein blend films embedded with lactic acid bacteria and their antilisterial activity in pasteurized milk. Int. J. Food Microbiol. 2020, 322, 108545, doi:10.1016/j.jifoodmicro.2020.108545.

29. Settier-Ramírez, L.; López-Carballo, G.; Gavara, R.; HernándezMuñoz, P. Broadening the antimicrobial spectrum of nisinproducing Lactococcus lactis subsp. Lactis to Gram-negative bacteria by means of active packaging. Int. J. Food Microbiol. 2021, 339, 109007, doi:10.1016/j.ijfoodmicro.2020.109007.

30. Depping, V. Quantitative environmental and economic sustainability analyses of food supply chains: The case of novel dairy products, Technische Universität München, 2020.

31. Pénicaud, C.; Monclus, V.; Perret, B.; Passot, S.; Fonseca, F. Life cycle assessment of the production of stabilized lactic acid bacteria for the environmentally-friendly preservation of living cells. J. Clean. Prod. 2018, 184, 847-858, doi:10.1016/j.jclepro.2018.02.191.

32. Abín, R.; Laca, A.; Laca, A.; Díaz, M. Environmental assesment of intensive egg production: A Spanish case study. J. Clean. Prod. 2018, 179, 160-168, doi:10.1016/j.jclepro.2018.01.067.

33. Garcia-Herrero, I.; Hoehn, D.; Margallo, M.; Laso, J.; Bala, A.; Batlle-Bayer, L.; Fullana, P.; Vazquez-Rowe, I.; Gonzalez, M.J.; Durá, M.J.; et al. On the estimation of potential food waste reduction to support sustainable production and consumption policies. Food Policy 2018, 80, 24-38, doi:10.1016/j.foodpol.2018.08.007.

34. Gustavsson, J.; Cederberg, C.; Sonesson, U. Global Food losses and Food waste. Unep 2011, 1.

35. MAGRAMA Las pérdidas y el desperdicio alimentario en la industria agroalimentaria española: situación actual y retos de futuro. Cent. Publicaciónes 2013, 29.

36. Duiven, J.E.; Binard, P. Refrigerated storage: new developments. Bull. IIR 2002, 2, 2002.

37. Huijbregts, M.A.J.; Steinmann, Z.J.N.; Elshout, P.M.F.; Stam, G.; Verones, F.; Vieira, M.; Zijp, M.; Hollander, A.; van Zelm, R. ReCiPe2016: a harmonised life cycle impact assessment method at midpoint and endpoint level. Int. J. Life Cycle Assess. 
2017, 22, 138-147, doi:10.1007/s11367-016-1246-y.

38. Sleeswijk, A.W.; van Oers, L.F.C.M.; Guinée, J.B.; Struijs, J.; Huijbregts, M.A.J. Normalisation in product life cycle assessment: An LCA of the global and European economic systems in the year 2000. Sci. Total Environ. 2008, 390, 227240, doi:10.1016/j.scitotenv.2007.09.040.

39. Dilkes-Hoffman, L.S.; Lane, J.L.; Grant, T.; Pratt, S.; Lant, P.A.; Laycock, B. Environmental impact of biodegradable food packaging when considering food waste. J. Clean. Prod. 2018, 180, 325-334, doi:10.1016/j.jclepro.2018.01.169.

40. Dobon, A.; Cordero, P.; Kreft, F.; Østergaard, S.R.; Robertsson, M.; Smolander, M.; Hortal, M. The sustainability of communicative packaging concepts in the food supply chain. A case study: Part 1. Life cycle assessment. Int. J. Life Cycle Assess. 2011, 16, 168-177, doi:10.1007/s11367-011-0257-y.

41. Yokokawa, N.; Kikuchi-Uehara, E.; Sugiyama, H.; Hirao, M. Framework for analyzing the effects of packaging on food loss reduction by considering consumer behavior. J. Clean. Prod. 2018, 174, 26-34, doi:10.1016/j.jclepro.2017.10.242. 



\section{CAPÍTULO III}

Desarrollo de películas que incorporan levaduras con capacidad antifúngica y aplicación tecnológica como recubrimiento de alimentos

\section{Artículo 7.}

New isolated Metschnikowia pulcherrima strains from apples for postharvest biocontrol of Penicillium expansum and patulin accumulation

Artículo 8.

Apple-based coatings incorporating wild apple isolated yeast to reduce Penicillium expansum postharvest decay of apples 



\title{
Artículo 7
}

\section{New isolated Metschnikowia pulcherrima strains from apples for postharvest biocontrol of Penicillium expansum and patulin accumulation}

\author{
Laura Settier-Ramírez 1,2, Gracia López- \\ Carballo', Pilar Hernández-Muñoz ${ }^{1}$, Angélique \\ Fontana-Tachon ${ }^{2}$, Caroline Strub², Sabine \\ Schorr-Galindo ${ }^{2}$
}

Toxins, 2021, vol. $13, n^{\circ} 6$, p. 397

1 Packaging Lab, Instituto de Agroquímica y Tecnología de Alimentos, IATA-CSIC, Av. Agustín Escardino 7, 46980 Paterna, Spain.

${ }^{2}$ Qualisud, Univ Montpellier, Avignon Université, CIRAD, Institut Agro, IRD, Université de La Réunion, Montpellier, France. 



\section{ABSTRACT}

Wild yeasts isolated from the surface of apples, were screened for antagonistic activity against Penicillium expansum, the main producer of the mycotoxin patulin. Three antagonistic yeasts (Y33, Y29 and Y24) from a total of 90 were found to inhibit $P$. expansum growth. Identification by ITS region sequence and characterization showed that three selected isolates of yeast should be constitute different strains of Metschnikowia pulcherrima. Several concentrations of the selected yeasts were used to study their in vitro antifungal effectivity against $P$. expansum on Petri dishes (plates with $63.6 \mathrm{~cm}^{2}$ surface) whereas their potential activity on patulin reduction was studied in liquid medium. Finally, the BCA that had the best in vitro antifungal capacity against $P$. expansumthe BCA that shown the best in vitro antifungal capacity against $P$. expansum and the best patulin degradation capacity was selected to be assessed directly on apples. All the selected strains demonstrated antifungal activity in vitro but the most efficient was the strain Y29. with differences depending on the strain and concentration. The best antifungal activity was obtained for strain Y29 (8 log CFU/plate) when it was more concentrated than pathogen (3 log spores/plate). All of them Isolated strains were able to reduce patulin content in liquid medium, Y29 being the only strain that completely reduced patulin levels within $120 \mathrm{~h}$. Finally, the yeast Y29 which exhibited the best performance was applied The application of Y29 as biocontrol agent on the surface of apples inoculated with $P$. expansum, inhibited fungal. The results proved that Y29 applied on apple was able to reduce $P$. expansum growth and patulin production during storage. Therefore, the results shown that this yeast strain could be used for the reduction of $P$. expansum and its mycotoxincontamination in apples or apple-based products by adapting the procedure application.

Keywords: Biological control; Metschnikowia pulcherrima; Penicillium expansum; patulin; epiphytic isolated yeasts; apple 


\section{Introduction}

Currently, more than $30 \%$ of fruit and vegetables produced worldwide is discarded every year [1]. These losses occur throughout all the supply chain from cultivation to household consumption although most of them happen during the postharvest stage, processing, transportation or storage. The decomposition of fruits by fungal spoilage represents the main cause of those economic losses [2].

Penicillium expansum is one of the best-known species of the genus Penicillium due to its high relevance as it is a widespread species found in the natural environment both in soil, air and even indoor air $[3,4]$. Furthermore, $P$. expansum infect a wide range of food products including pome and stone fruits (such as apples, pears, cherries, or peaches) which are the primary targets for this toxigenic fungus. it can infect a wide range of food products being the primary targets for this toxigenic fungus, pome and stone fruits (such as apples, pears, cherries, or peaches). It has also been isolated worldwide from vegetables [5], grains and even in dairy products [6] and sea food $[7,8]$. This common fungus is responsible for the blue mold decay of fruits (blue mold rot disease also called soft rot), where damaged and bruised fruits soften and brown [9].

Besides the fact that $P$. expansum decreases the quality and increases the economic losses of infected fruits, it can also lead to sanitary consequences since it produces toxins that increase the risk of serious diseases in human consumers [2]. Patulin (4-hydroxy-4Hfuro[3,2c]pyran-2[6H]-one) is the main mycotoxin pose by $P$. expansum, but it could also be produced by a wide range of fungi. It is a polyketide-derived mycotoxin product of the secondary metabolism of fungi and it is toxic to humans and animals at very low doses [10]. It can produce acute and chronic toxicity such as genotoxicity, cytotoxicity, mutagenicity and immunotoxicity [11]. Thus, many countries and organizations have established regulatory limits for patulin content. In the European Union, patulin is limited to $50 \mu \mathrm{g} \cdot \mathrm{kg}^{-1}$ in fruit juices, to $25 \mu \mathrm{g} \cdot \mathrm{kg}^{-1}$ in solid fruit products, and to $10 \mu \mathrm{g} \cdot \mathrm{kg}^{-1}$ in products for infants and children [12]. Besides, it is hard to remove 
patulin from processed products since this mycotoxin is relatively stable to thermal treatments and resistant to acidic conditions.

In order to contain $P$. expansum contamination at the preharvest and postharvest stages and soft rot at postharvest stages, Synthetic chemical fungicides represent the most common used strategy to contain $P$. expansum at the preharvest and postharvest stages. However, the use of these products can involve potential health risks and fungicide accumulation in agricultural products affecting the safety of the entire food chain. The emergence of new fungal species resistant to fungicides as well as the impact of pesticides on the environment [2] has also to be considered. Moreover, different strategies have been developed for patulin detoxification, being both physical and chemical decontamination being the most used. Nevertheless, some problems exist in the use of available methods, like safety issues, probable losses in the nutritional quality, limited efficiency and high costs [13]. For that, consumers are demanding the use of more ecofriendly alternatives. Given the current legislation and public opinion, the use of biological control agents (BCA) such as yeast, filamentous fungi and bacteria, which have an antagonistic effect against $P$. expansum, as an alternative to the conventional methods, has managed to significant interest for its sustainability. Given the current legislation and public opinion, BCA such as yeast, filamentous fungi, and bacteria that have been shown to have antagonistic effects against $P$. expansum, have gained significant interest as alternatives to conventional methods currently in use. Withln contrast with the traditional methods discussed above, BCA are able to persist for long periods after treatment and are able to protect fruit from re-infection [14]. In this sense, BCA are often part of integrated pest management, which aims to combine a variety of control methods (such as crop rotation, use of mixed cropping, use of pest-resistant varieties or targeted use of pesticides), which minimize overall economic, health and environmental risks [15]. Among BCA, yeasts are good candidates because they have relevant characteristics in the selection of a BCA such as simple nutritional requirements. They also can grow rapidly on inexpensive substrates in bioreactors, they 
are able to colonize dry surfaces, survive for long periods of time and they have a low impact on the environment [16]. Moreover, yeasts do not produce allergenic spores or toxins and do not damage fruits as it could occur with fungi [17]. In addition, most of them have the ability to survive on the surface of fruits contrary to bacteria [2]. Antifungal yeasts can be applied at pre-harvest and post-harvest stages. Indeed, yeasts spraying or dipping are some of the best practical and useful methods developed to control postharvest disease of fruits and vegetables [18].

Among yeasts, strains isolated from the epiphytic microbial community of fruits and vegetables are the most promising BCA since they are phenotypically adapted to this niche. The benefit of belonging to the microbial community naturally established in the target food product can provide their colonization and survival on it when applied in the appropriate concentration [19]. Other authors have also demonstrated that a better disease suppression is observed when growth conditions for both antagonist and fungal pathogen are similar [20]. Therefore, the microbial antagonists isolated from the same environment are appropriate for disease control and are the best sources of antagonistic microorganisms [21,22]. Another advantage of using yeasts as BCA is that more of them exhibited the ability to detoxify patulin in anaerobic or aerobic conditions. This potential was first observed in cider fermented by strains of Saccharomyces genus, where patulin levels did not exceed $50 \mu \mathrm{g} \cdot \mathrm{kg}^{-1}$ [23]. Different authors have reported that yeast such as Pichia caribbica [24], Saccharomyces cerevisiae or Rhodosporidium kratochvilova [25] were able to degrade patulin to undetectable levels. In some cases, products of patulin biodegradation by yeasts have been identified as (E)- and (Z)-ascladiol and desoxypatulinic acid, products which are much less toxic than patulin for humans [25,26].

The aim of the current study was to search indigenous yeast strains of apple to act as a potential biocontrol agent against $P$. expansum with the ability to reduce patulin content of fruits and that could be applied directly on the surface of apples as an alternative to conventional pesticides. For this purpose, different yeast strains have 
been isolated from apples and screened for their antifungal activity against $P$. expansum. An identification and characterization of selected yeasts was also conducted. Finally, the antifungal capacity of the selected yeasts was quantified and their ability to biodegrade patulin was also studied. The yeast that presented the best performance in the in vitro studies was then applied on wounded "Golden delicious" apples inoculated with $P$. expansum to study its potential as a BCA.

\section{Materials and Methods}

\subsection{Isolation and qualitative confrontation test}

Yeasts used in this study, were isolated from the skin of apples of the variety "Bedan", in an orchard situated in Brittany, France [27]. A screening was done with 90 isolated yeasts to evaluate their antifungal potential against Penicillium expansum. To study the antifungal activity, a qualitative confrontation test was performed. Yeast strains were grown in $10 \mathrm{~mL}$ of Yeast Extract and Glucose liquid medium (YEG) (9\% yeast extract (Biokar diagnostics, France) and 20\% glucose $\left(\mathrm{D}(+)\right.$ Glucose monohydrate, Merk, Germany)) at $30{ }^{\circ} \mathrm{C}$ during $24 \mathrm{~h}$.

Patulin producing-Penicillium expansum (NRRL 35695) was grown on Potato Dextrose Agar (PDA) (Biokar diagnostics, France) in Petri dishes for 7 days at $28^{\circ} \mathrm{C}$. The inoculum was collected by flooding the surface of the plates with sterile peptone water with Tween 80 $(0.05 \% \mathrm{v} / \mathrm{v})$ (Sigma, France) and then scraping the surface with a spatula. A $5 \mathrm{~mL}$ sample of the mold culture suspension was filtered through sterile cotton in order to remove mycelium and transferred to a sterile tube and shaken to obtain a homogeneous suspension. Several dilutions were made to obtain the targeted spore concentration $\left(10^{5}\right.$ spores $\left./ \mathrm{mL}\right)$ determined using a Thoma cell counting chamber. Then, an amount of $100 \mu \mathrm{L}$ Penicillium expansum suspension $\left(10^{5}\right.$ spores $/ \mathrm{mL}$ ) were spread on surface of PDA plates. Then, wells were hollowed in the agar using a Durham and $30 \mu \mathrm{L}$ of each yeast isolates cultured overnight were deposited in the wells Is. A negative control was done using $30 \mu \mathrm{L}$ of YEG medium. Plates were incubated for 7 days at $25{ }^{\circ} \mathrm{C}$. Three parallel repetitions were 
performed evaluating two wells per Petri dish. Yeasts which exhibited an inhibition halo around wells were selected for the following studies. All microbiological products were provided by Sigma (France).

\subsection{Molecular analysis}

Yeast total genomic DNA was obtained according to standard procedures [28].

\subsubsection{Identification}

Amplification reactions: PCR amplification of the ITS1 - 5.8S ITS2 region of rDNA with the universal primers ITS1 (5'TCCTCCGCTTATTGATATGC-3') and ITS4 (5'TCCGTAGGTGAACCTGCGG-3') were carried out according to Kurtzman et al. (1998) and Esteve-Zarzoso et al. (1999) [29,30].

Sequence analysis of the ITS1 - 5.8S - ITS2 region: PCR amplification of the ITS1 - 5.8S - ITS2 region were sequenced. PCR products were purified using the NucleoFast Kit (Macherey-Nagel, Germany) following the manufacturer's instructions, and were subsequently sequenced through Eurofino Genomics Mix 2seg Sanger sequencing service according to Pérez-Través et al. (2014) [31]. The corresponding sequences, both 5'-3'and 3'-5'reads, were aligned and analyzed with the MEGA 5.0 software. The identification of the closest relatives was obtained from Gen Bank database using NCBI BLAST searching tool. The sequences were deposited in the GenBank database with assigned accession numbers.

\subsubsection{Characterization by PCR fingerprinting assay}

Mitochondrial DNA-restriction fragment length polymorphism (mtDNA-RFLP) analysis was performed by the method of Querol et al. (1992) [28]. Two microliters of DNA were digested with the restriction endonucleases that recognize 5 bp (Hinfl) (Thermo scientific, Lithuania) according to the instructions of the supplier. This enzyme recognizes a large number of sites in the yeast nuclear DNA but few sites in the mtDNA. Restriction fragments were separated in $0.8 \%$ agarose gel electrophoresis and visualized in a UV transilluminator after staining. 


\subsection{Antifungal activity of yeasts}

The minimum initial inoculum of selected yeasts (called Y33, Y29 and Y24) able to reduce microbial growth of Penicillium expansum was determined in PDA plates. Yeast strains were precultured in $10 \mathrm{~mL}$ of YEG liquid medium at $28^{\circ} \mathrm{C}$ overnight. Yeast cells were collected by centrifugation at $8,000 \times \mathrm{g}$ for $10 \mathrm{~min}$ at $4{ }^{\circ} \mathrm{C}$ and washed twice with physiological water. Then, the pellet was suspended on $1 \mathrm{~mL}$ physiological water (obtaining a final concentration of $10^{8} \mathrm{CFU} / \mathrm{mL}$ verified by plate count) and 5 serial decimal dilutions were made with each strain. $100 \mu \mathrm{L}$ of the preculture and of each dilution were spread on the surface of PDA plates. It must be pointed out that the experiment was carried out in petri dishes with a diameter of $9 \mathrm{~cm}$ (total area $63.6 \mathrm{~cm}^{2}$ ) and yeast concentration was expressed as $\mathrm{CFU} /$ plate. Prior to the experiment, $P$. expansum was precultured for 7 days at $25{ }^{\circ} \mathrm{C}$ in PDA. An amount of $20 \mu \mathrm{L}$ P. expansum conidial suspension $\left(10^{5}\right.$ spores $\left./ \mathrm{mL}\right)$ was spotted in the center of the plates previously inoculated with yeasts. Control plates without yeasts were prepared simultaneously. Plates were incubated at $25^{\circ} \mathrm{C}$ for 21 days. Mold diameters were measured periodically during the storage period. Three parallel repetitions were performed.

\subsection{Biodegradation of patulin by antagonistic yeasts}

2.4.1. Microorganisms and culture conditions

The patulin biodegradation ability of the previously selected yeasts was tested adapting the protocol of Reddy et al. (2011) [32]. 20 $\mathrm{mL}$ of peptone malt extract broth (PM) (1\% sucrose (Sigma, Switherland), $0.5 \%$ yeast extract, $0.5 \%$ peptone, and $0.2 \%$ malt extract (Biokar diagnostics, France) were poured into $100 \mathrm{~mL}$ flasks containing patulin standard from $100 \mu \mathrm{g} / \mathrm{mL}$ in acetonitrile (Libios, France) in order to achieve a final concentration of $1000 \mu \mathrm{g} / \mathrm{L}$ of patulin. A volume of $100 \mu \mathrm{L}$ of $10^{8} \mathrm{CFU} / \mathrm{mL}$ of each yeast strain were inoculated in different flasks and incubated at $25^{\circ} \mathrm{C}$ for $120 \mathrm{~h}$ at $200 \mathrm{rpm}$ shaking conditions in the light. Controls consisted of non-inoculated broth supplemented with patulin. Cells were collected by centrifugation at $5,000 \times \mathrm{g}$ for $10 \mathrm{~min}$ at $4{ }^{\circ} \mathrm{C}$ at different incubation times, $24,48,72 \mathrm{~h}$ 
and 120h. Cell free supernatant (CFS) was used for measuring patulin reduction. The patulin measured in the cell pellet was used to confirm if an adsorption in the cell wall or an absorption into the cell occurs. Four parallel repetitions were performed in triplicate.

\subsubsection{Influence of patulin on yeast cell viability}

The viability of yeast isolates Y24, Y29 and Y33 was determined after $24,48,72$ and $120 \mathrm{~h}$ of incubation at $25^{\circ} \mathrm{C}$ in PM medium with patulin (1000 $\left.\mu \mathrm{g} \cdot \mathrm{L}^{-1}\right)$ and without patulin (control). Serial dilutions with physiological water were made and plated in Petri dishes previously filled with $15 \mathrm{~mL}$ of PDA agar, and they were incubated at $25^{\circ} \mathrm{C}$ for 2 days to evaluate survival of yeast cells. The test was performed in four parallel repetitions.

\subsubsection{HPLC MS/MS analysis}

HPLC/MS (ACQUITY ${ }^{\circledR} T Q D$, Waters, US) was used to detect and quantify patulin in the samples. The chromatographic separation was achieved on an $\mathrm{C}_{18} \mathrm{BEH}(2.1 \times 100 \mathrm{~mm}, 1.7 \mu \mathrm{m})$ (Waters) column at $30{ }^{\circ} \mathrm{C}$ with a flow rate of $0.3 \mathrm{~mL} / \mathrm{min}$. The injection was made with a volume of $5 \mu \mathrm{L}$. Eluent A was HPLC-grade water and eluent B was acetonitrile (HPLC MS grade, Sigma).

Elution conditions were as follows: a 1-min isocratic passage of solvent B from 100 to $2 \%$, a 3-min gradient increase of solvent B from 2 to $90 \%$, 1-min isocratic passage of solvent B at $90 \%$, a 1-min gradient decrease of solvent $B$ from 90 to 2 and re-equilibration at $2 \%$ solvent B for 4 min.

Electrospray ionization was the ionization source. The parameters were as follows: Source temperature: $120{ }^{\circ} \mathrm{C}$, Desolvation temperature: $300{ }^{\circ} \mathrm{C}$, Cone gas: $60 \mathrm{~L} / \mathrm{h}$, Desolvatation gas flow: 800 $\mathrm{L} / \mathrm{h}$. Spectra were acquired in negative ionization selected reaction monitoring (SIR) mode with interchannel delay of $0.050 \mathrm{~s}$

\subsubsection{Patulin cell adsorption or absorption}

Freezing-Thawing in Methanol procedure, adapted from Canelas et al. (2009), was used to extract intracellular metabolites (IM) from yeasts cells [33]. Pellets obtained from experiment described in 
section 5.4.1. were resuspended in $2.5 \mathrm{~mL}$ of $100 \%$ methanol (Honeywell, Germany) precooled to $-80{ }^{\circ} \mathrm{C}$; then, the solution was frozen for 3-5 min in liquid nitrogen and thawed on ice for 3-5 min. Three freeze-thaw cycles were done before centrifuging at 5,000 x g during $5 \mathrm{~min}$ at $-9{ }^{\circ} \mathrm{C}$. The supernatants were then collected separately, and once more, $2.5 \mathrm{~mL}$ of methanol were added to the pellet to extract remaining patulin. Samples were vortexed for $30 \mathrm{~s}$ and centrifuged. The supernatants were pooled with the supernatants from the round of extraction. The combined extracts were evaporated using a nitrogen flux and dissolved in $2 \mathrm{~mL}$ of water with $0.1 \%$ of acetic acid and filtered. The patulin concentration of the methanolic extracts of the intracellular metabolites was determined by HPLC/MS as described as described in section 5.4.3. The remaining pellet consisting of cell walls was sonicated with physiological water for $20 \mathrm{~min}$. The cell wall suspension (CWS) was then filtered and patulin concentration was determined by HPLC/MS as described above.

\subsection{Antifungal activity of the strain Y29 applied on apples}

2.5.1. Strain Y29 application and antifungal activity

Golden delicious" apples were purchased from a local supermarket and used within $24 \mathrm{~h}$. Fruits without injuries and with similar maturity (in terms of color and firmness) and size (200 g \pm 20 ) were selected. Then apples were immersed in $2 \%$ sodium hypochlorite solution for $2 \mathrm{~min}$, then rinsed in distilled water and dried at room temperature to disinfect the surface. Finally, four wounds ( 3 $\mathrm{mm}$ diameter $\times 3 \mathrm{~mm}$ deep) were artificially made along the equator of each apple with a sterile needle. Then, a suspension of Y29 at a concentration of $10^{8} \mathrm{CFU} . \mathrm{mL}^{-1}$ in sterile water was prepared following the methodology described in section 5.3. Apples were dipped in Y29 suspension for 2 min and dried under laminar flow during $2 \mathrm{~h}$. Wounded apples dipped in water without BCA were used as control. Once dried, wounds were inoculated with $20 \mu \mathrm{L}$ of $P$. expansum at $10^{5}$ spores/mL. Apples dipped in Y29 suspension and in water were also prepared without $P$. expansum in order to observe if potential changes occur on wounds due to oxidative reactions or yeasts colonization. 
Apples were stored at $21{ }^{\circ} \mathrm{C}$ for 17 days. The disease incidence was then expressed as the measure of $P$. expansum invasion diameter. The test was performed in four parallel repetitions with four wounds per apple.

\subsubsection{Yeasts viability after drying}

Yeast survival in apple surface after drying was studied. A sterile knife was used to remove wounds from each apple and were placed with the whole apple in a sterile plastic bag with $100 \mathrm{~mL}$ of sterile distilled water. Apples were then rinsed inside the bag, rubbing them with the hands during $3 \mathrm{~min}$. Then, apples were aseptically removed from bags. The "apples washing water" with the wounds were stomached during $2 \mathrm{~min}$ in order to extract yeasts from the wounds. Serial dilutions were made and plated in Yeast extract, glucose and chloramphenicol agar (YEG-C). Colonies were counted after incubation during $48 \mathrm{~h}$ at $30^{\circ} \mathrm{C}$.

\subsection{Patulin quantification on apple}

After 17 days of storage, apples from the previous test were used to quantify patulin. Methodology was adapted from Tannous et al., 2015. Apples were placed individually in sterile plastic bag and were mashed to homogenize in a Stomacher. Five $\mathrm{g}$ of apple puree were weighed and were mixed with $5 \mathrm{~mL}$ of distilled water, and $75 \mu \mathrm{L}$ of pectinase (Pectinase from Aspergillus aculeatus, Sigma, Danemark) on a falcon tube. The mixture was homogenized and let overnight at room temperature. After that, samples were centrifuged at 4,500 $\mathrm{xg}$ during $5 \mathrm{~min}$ and $5 \mathrm{~mL}$ of the supernatant were recovered for make the extraction. The patulin was then extracted and prepared for highperformance liquid chromatography (HPLC) following the next steps.

\subsubsection{Patulin extraction}

About $5 \mathrm{~mL}$ of the previous supernatant were transferred separately into Falcon flask of $50 \mathrm{~mL}$ containing $2 \mathrm{~g}$ of sodium bicarbonate (Fluka, France) and $15 \mathrm{~g}$ sodium sulphate anhydrous (VWR Chemicals, France). $15 \mathrm{~mL}$ of a mixture of ethylacetate (VWR 
chemicals, France) and hexane (Fisher scientific, U.K.) in proportion (60/40) were added before shaking for 10 minutes. Then, samples were centrifuged at $3000 \mathrm{Xg}$ for 10 minutes. The organic layer was recovered and completely evaporated under nitrogen stream. The dry extract was suspended in $9 \mathrm{~mL}$ of $50 \%$ acetic acid solution and sonicated during $30 \mathrm{~min}$. Finally, $1 \mathrm{~mL}$ of an internal standard was added, and samples were filtered through a $0.45 \mathrm{~mm}$ syringe filter into a clean $2 \mathrm{~mL}$ vial.

\subsubsection{HPLC MS/MS analysis}

HPLC/MS-MS (LCMS 8040 Shimadzu) was used to detect and quantify patulin in the samples. The data were analyzed using Labsolution software (Shimadzu). The chromatographic separation was carried out on Kinetex $2.6 \mu \mathrm{m}$ C18 100A $50 \times 2.1 \mathrm{~mm}$ ID column (Phenomenex). Column temperature was maintained at $50^{\circ} \mathrm{C}$ and injection was made with a volume of $50 \mu \mathrm{L}$. The mobile phase $\mathrm{A}$ consisted of $90 \%$ water $10 \%$ Mobile phase B consisted acetonitrile (HPLC MS grade, Sigma).

Electrospray ionization was the ionization source. The parameters were as follows: positive and negative ionization ES+ and ES-, MRM (Multiple Reaction Monitoring) mode, Desolvation line: 250 ${ }^{\circ} \mathrm{C}$, Heater block: $400{ }^{\circ} \mathrm{C}$ NEB gas: 3 L/min, Drying gas: $15 \mathrm{~L} / \mathrm{min}$.

\subsection{Statistical analysis}

One-way analyses of variance were carried out. The SPSS computer program (SPSS Inc., Chicago, IL) was used. Differences in pairs of mean values were evaluated by the Tukey $b$ test for $a$ confidence interval of $95 \%$. In the case of figure 6 (a), the data were analyzed by F-test to test the equality of two variances, followed by Student's $t$-test to evaluate the differences of the mean between sample and control for a confidence interval of $95 \%$. Data were represented as the average \pm standard deviation. 


\section{Results}

\subsection{Screening for antagonistic yeasts}

90 yeast strains were isolated from the skin of apples as soon as they were harvested in the orchard. A screening of these isolates for biocontrol efficacy against $P$. expansum growth was carried out in PDA plates previously inoculated with $100 \mu \mathrm{L}$ of $10^{5}$ spores $/ \mathrm{mL}$ of $P$. expansum. As it can be seen in figure 1, only yeasts that exhibited an inhibition halo were chosen (here in figure $1(b)$, as an example, among yeasts $24,25,26$ and 27 tested, only yeast 24 exhibited an inhibition halo). The screening showed that only three strains were able to inhibit the growth of the mold. These antifungal yeasts were assigned as $Y 33$, Y29 and Y24.

Yeast strains Y33, Y29 and Y24 were found to be similar in colony characteristics and cell morphologies (results not showed) and the three presented a brown-red halo around wells and around colonies in PDA plates when they grew without $P$. expansum as it can be noticed in figure 1(a) for $\mathrm{Y} 24$.
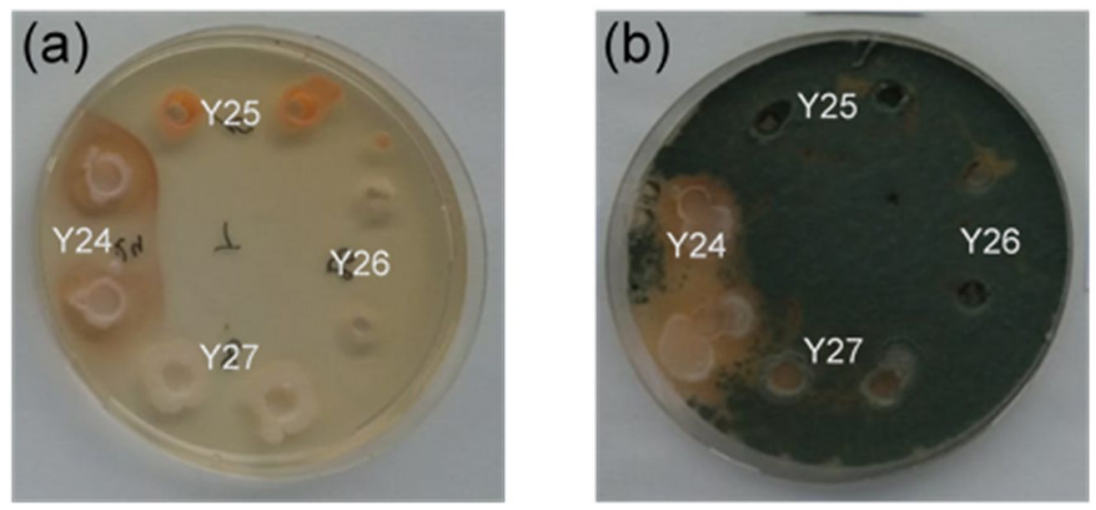

Figure 1. Growth of some isolated yeasts in PDA Petri dishes (a) and growth of those yeasts and antifungal activity (b) against $P$. expansum after 7 days at $25^{\circ} \mathrm{C}$. In the figure, a duplicate of yeasts number $24,25,26$ and 27 were tested in the same Petri dish.

\subsection{Identification and characterization of antagonistic yeast}

The identification and characterization of Y33, Y29 and Y24 were carried out. The $5.8 \mathrm{~S}$ genes were amplified by the PCR technique, 
which yielded in 390-400 bp for each DNA fragment as it is shown in figure S1.

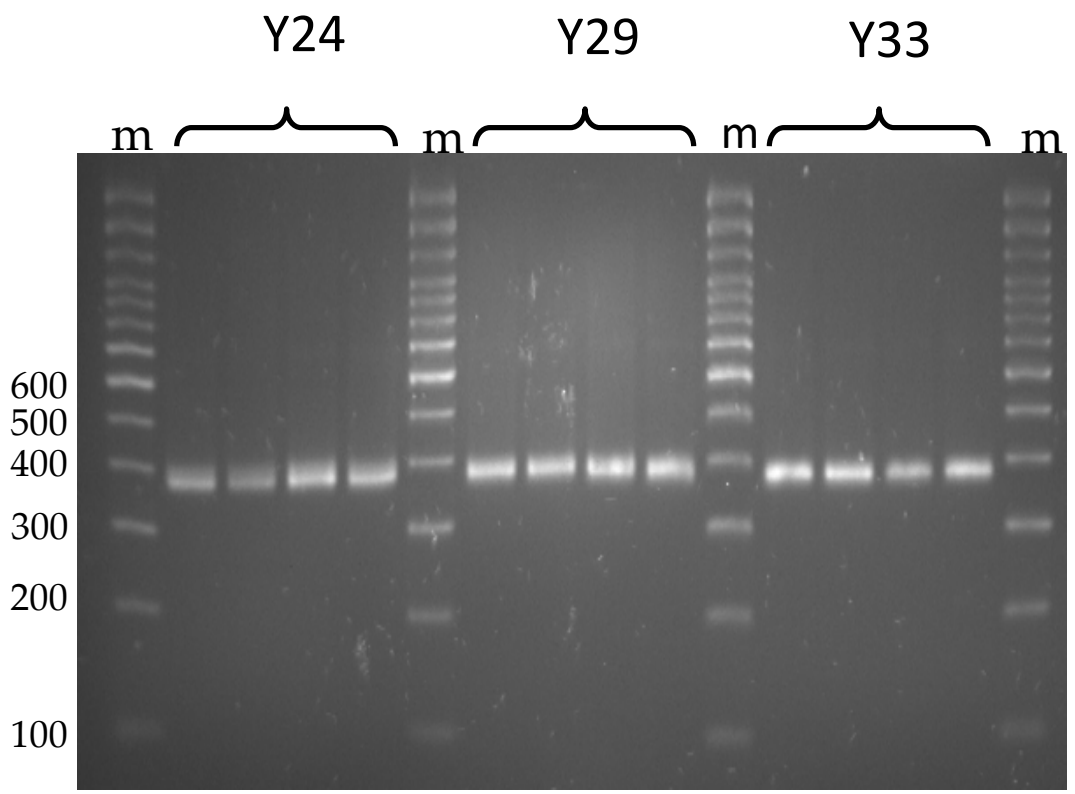

Figure S1. PCR fragment of $5.8 \mathrm{~S}$ genes (ITS region) of isolated yeasts. Lanes $\mathrm{m}$ correspond to $100 \mathrm{bp}$ DNA ladder.

Sequencing was carried out for the ITS region. The 5.8S rDNA sequences of the isolated yeasts were compared with the homologous sequences contained in the GenBank database by using the BLAST software. The 5.8S rDNA sequence of yeast strains Y33, Y29, and Y24 showed high identity with Metschnikowia pulcherrima at 100\%, $97.2 \%$, and $100 \%$, respectively. Partial sequences of the $5.8 \mathrm{~S}$ rRNA gene were deposited at GenBank under the following accession numbers: MW532819 for M. pulcherrima strain Y33; MW532956 for $M$. pulcherrima strain Y29 and MW532963 for M. pulcherrima strain Y24.

Additionally, as it is showed in figure 2, none of the isolated yeasts showed the same mtDNA-RFLP pattern. Therefore, Y33, Y29 and Y24 isolated from apples belong to the Metschnikowia pulcherrima species but they are different strains. 


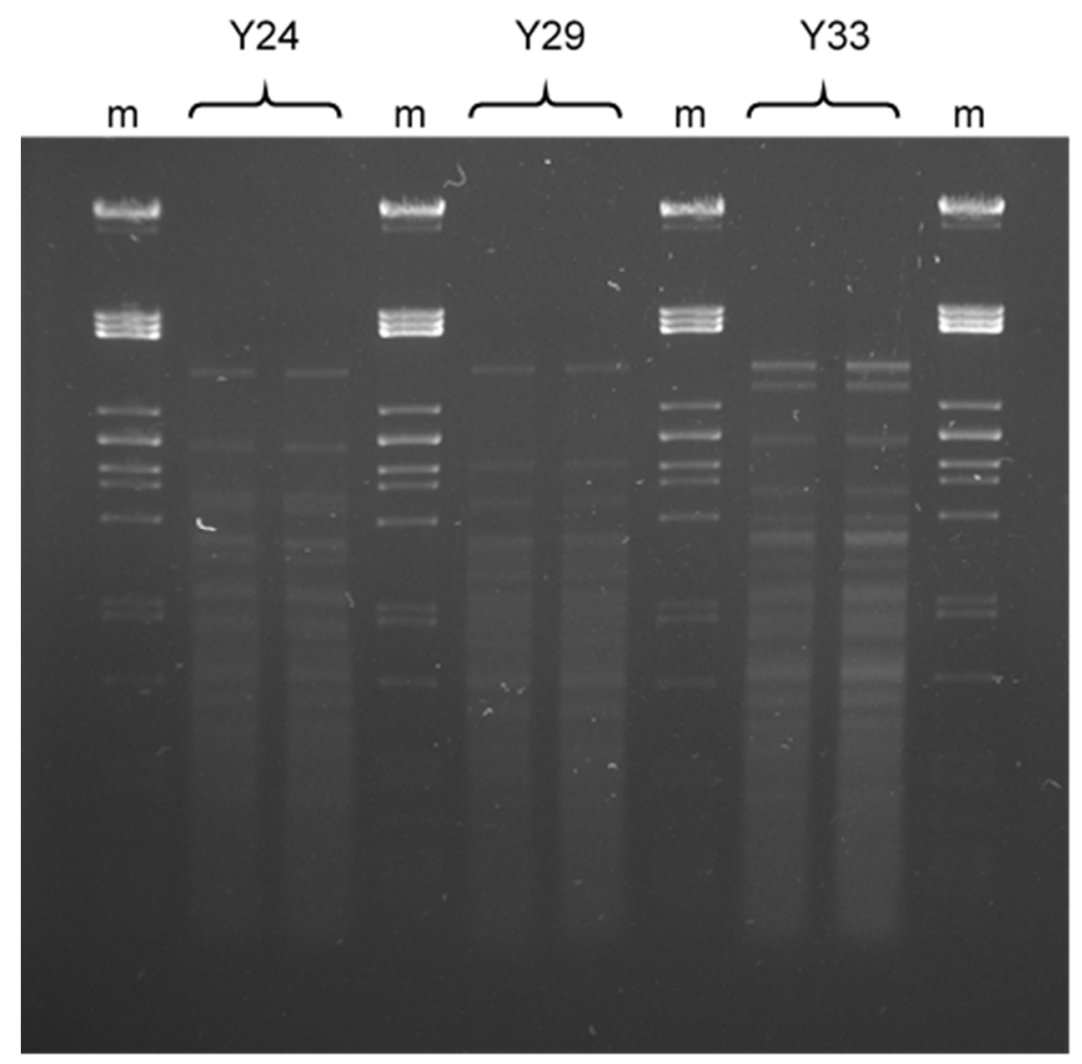

Figure 2. mt DNA patterns obtained after digestion with Hinf I of isolated yeasts. Lanes $\mathrm{m}$ correspond to Lambda DNA Pst I ladder.

\subsection{Comparison of in vitro biocontrol efficacy of different concentrations} of antagonistic yeasts

Once the strains were isolated and identified, their antifungal activity against $P$. expansum was studied using different yeast concentrations for 21 days at $28{ }^{\circ} \mathrm{C}$, the optimal temperature growth of the pathogen, as can be seen in figure 3 . In all the cases, pathogen incidence was reduced when the antagonistic concentration was increased. The best results were obtained when the concentration of antagonist yeast was greater, 8 log CFU/plate, than $P$. expansum concentration, 3 log spores/plate. The lower antagonist concentration tested, 3 log CFU/plate was not effective against the pathogen.

However, some differences in the antifungal activity were observed among isolated yeasts. The application of the antagonists at 
the higher concentration significantly inhibited pathogen development obtaining reductions of $91.4 \%, 85.3 \%$ and $52.6 \%$ for $\mathrm{Y} 33$, Y29 and Y24, respectively after 21 days of incubation at $28{ }^{\circ} \mathrm{C}$. In addition, no $P$. expansum growth was observed until day 13 , day 16 and day 10 when Y33, Y29 and Y24 were applied, respectively. Therefore, the results shown that yeast strain Y29 was more effective than the other two strains in reducing the growth of $P$. expansum.

\subsection{Biodegradation of patulin by antagonistic yeasts in liquid medium}

3.4.1. Check of patulin impact on yeast cell viability

Isolated yeast growth in pepton malt extract broth (PM) medium supplemented with $1000 \mu \mathrm{g} / \mathrm{L}$ patulin is presented in figure 4 . The maximum microbial count for all the yeasts in contact with patulin was observed around $24 \mathrm{~h}$. However, yeasts without patulin were able to increase their growth until the end of the experiment. The presence of patulin slightly restrained the yeast growth and after $120 \mathrm{~h}$, yeast growth in the presence of patulin was less than the control observing reductions between 1.5 and 0.5 log depending on the yeast.

\subsubsection{Patulin reduction by antagonistic yeasts}

The three isolated strains were evaluated for their potential for patulin degradation under in vitro conditions in PM liquid medium and the results are presented in figure 5 . For the three tested strains, the highest level of patulin degradation was observed for the isolate Y29. In fact, it reduced patulin concentration up to half after $24 \mathrm{~h}$ and it was able to completely reduce patulin in $120 \mathrm{~h}$. Y24 had also a great potential to reduce patulin exerting a progressive reduction over time until obtaining a value of $28 \mu \mathrm{g} / \mathrm{L}$ after $120 \mathrm{~h}$. 

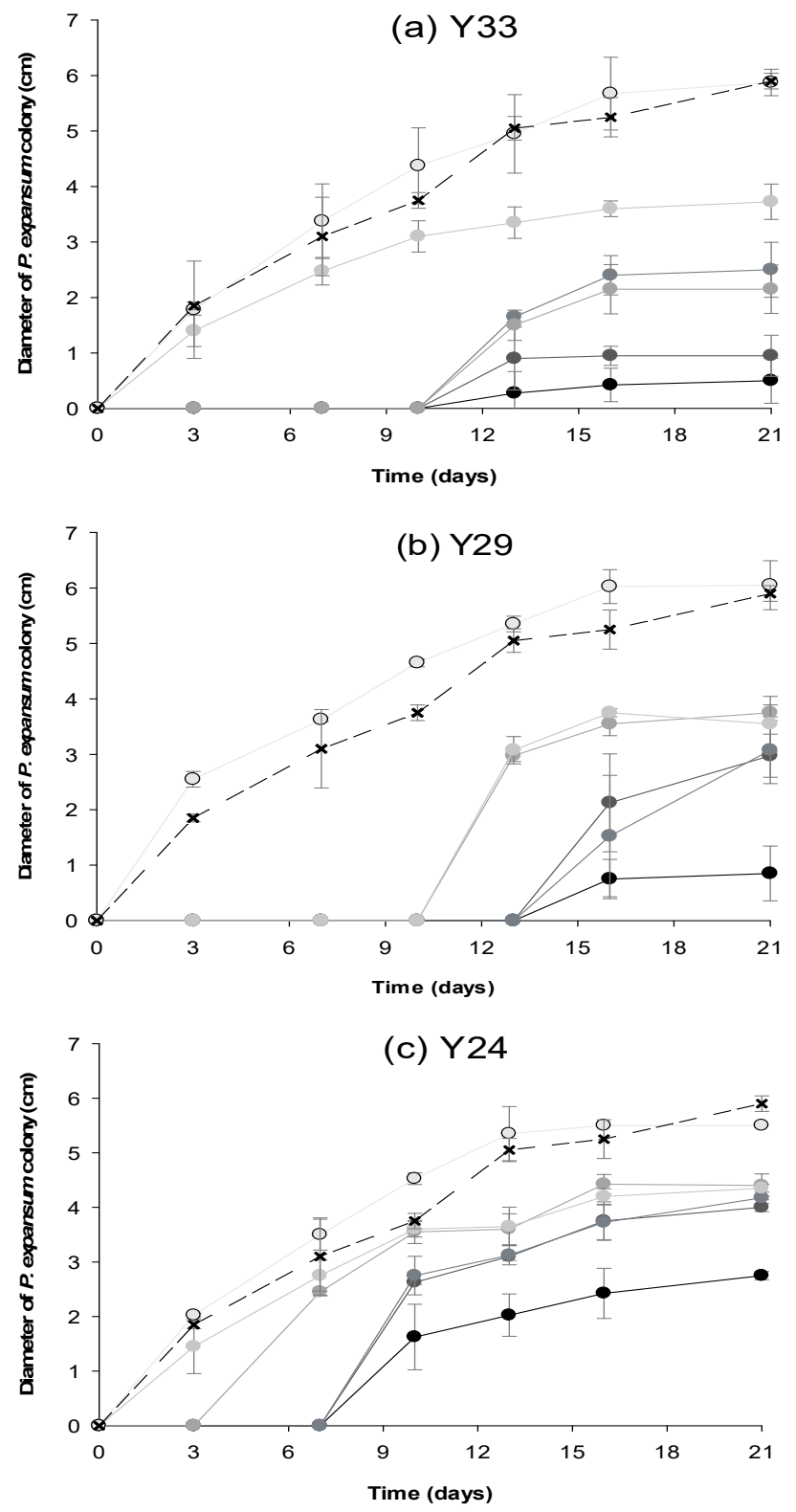

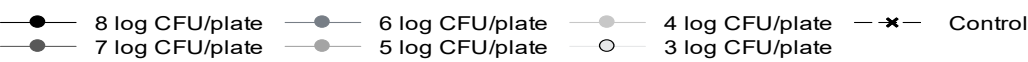
5 log CFU/plate O $3 \log$ CFU/plate

Figure 3. Antifungal activity of different concentrations of (a) Y33, (b) Y29 and (c) Y24 against Penicillium expansum (3 log spores/plate) in PDA incubated at $28^{\circ} \mathrm{C}$ during 21 days. 


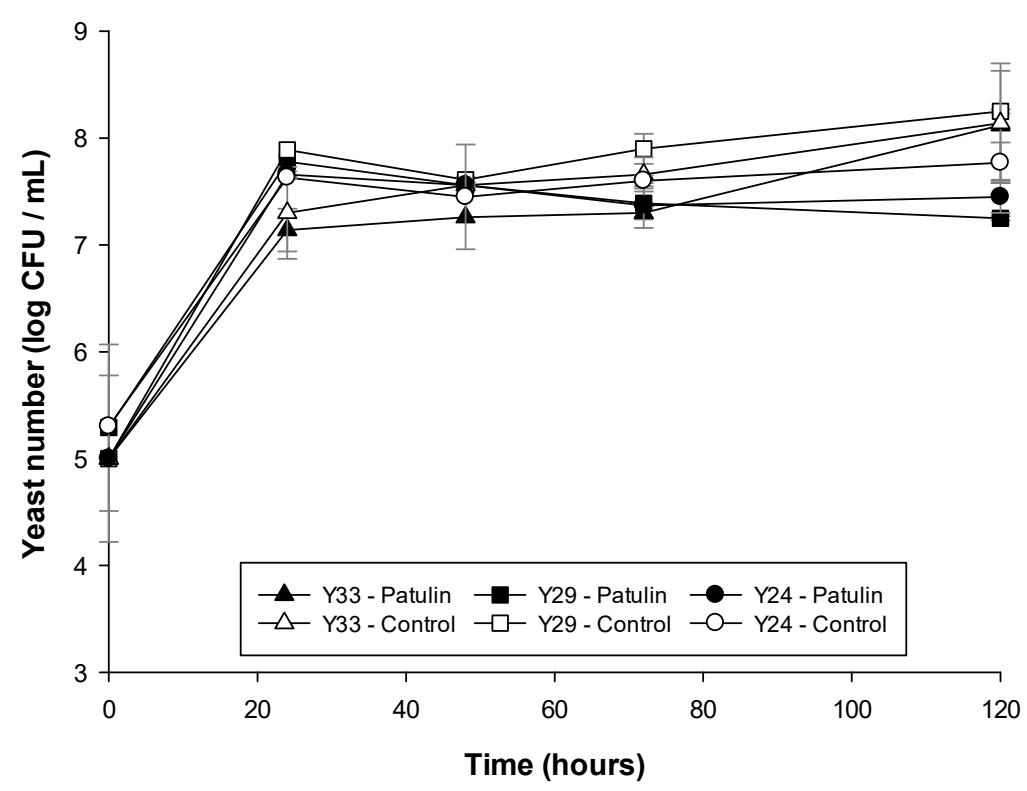

Figure 4. Viability of yeasts strains in contact with patulin in liquid medium at $25^{\circ} \mathrm{C}$ during $120 \mathrm{~h}$.

Finally, although Y33 was also able to considerably reduce the patulin, it was the slowest to degrade it. Contrary to the other two strains, after $120 \mathrm{~h}$ of incubation, patulin concentration was above the limits established by the EFSA $(50 \mu \mathrm{g} / \mathrm{mL})$. It must be pointed out that no detectable levels of patulin were observed neither in yeast cell walls nor in intracellular metabolites. This indicated that patulin was degraded to another substance and was not absorbed or adsorbed by yeast cells. 


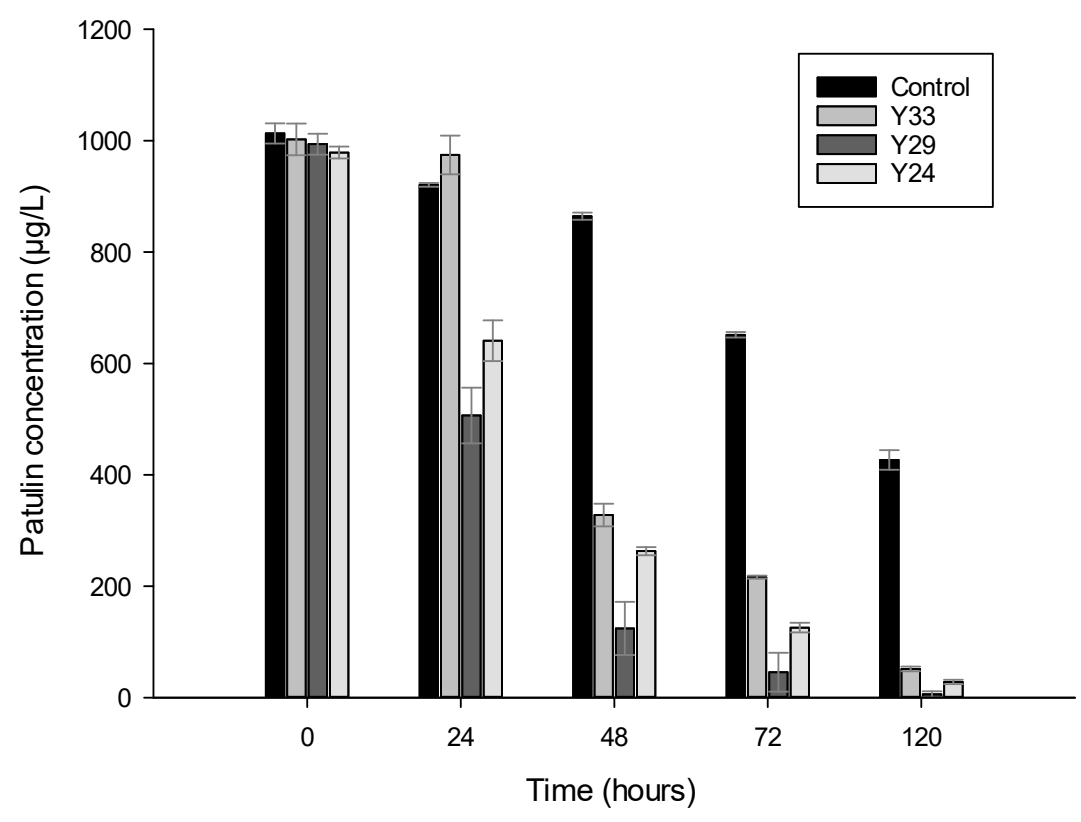

Figure 5. Efficacy of yeast strains on biodegradation of patulin in liquid medium at $25{ }^{\circ} \mathrm{C}$ during $120 \mathrm{~h}$. Different letters within a sampling day mean significant differences among samples $(p<0.05)$.

3.5. Biocontrol activity of Y29 applied on apples

Y29 has shown the best in vitro antifungal capacity against $P$. expansum (section 2.3) and the best patulin degradation capacity (section 2.4). Therefore, it was selected to be assessed directly on apples. The initial number of viable yeasts after dipping in 8 log $\mathrm{CFU} / \mathrm{mL}$ suspension and drying was $6.11 \mathrm{log}$ CFU/apple. The growth of $P$. expansum was monitored by measuring the halo of infection around the $3 \mathrm{~mm}$ wound made in the apples and the results are shown figure 6(a). 


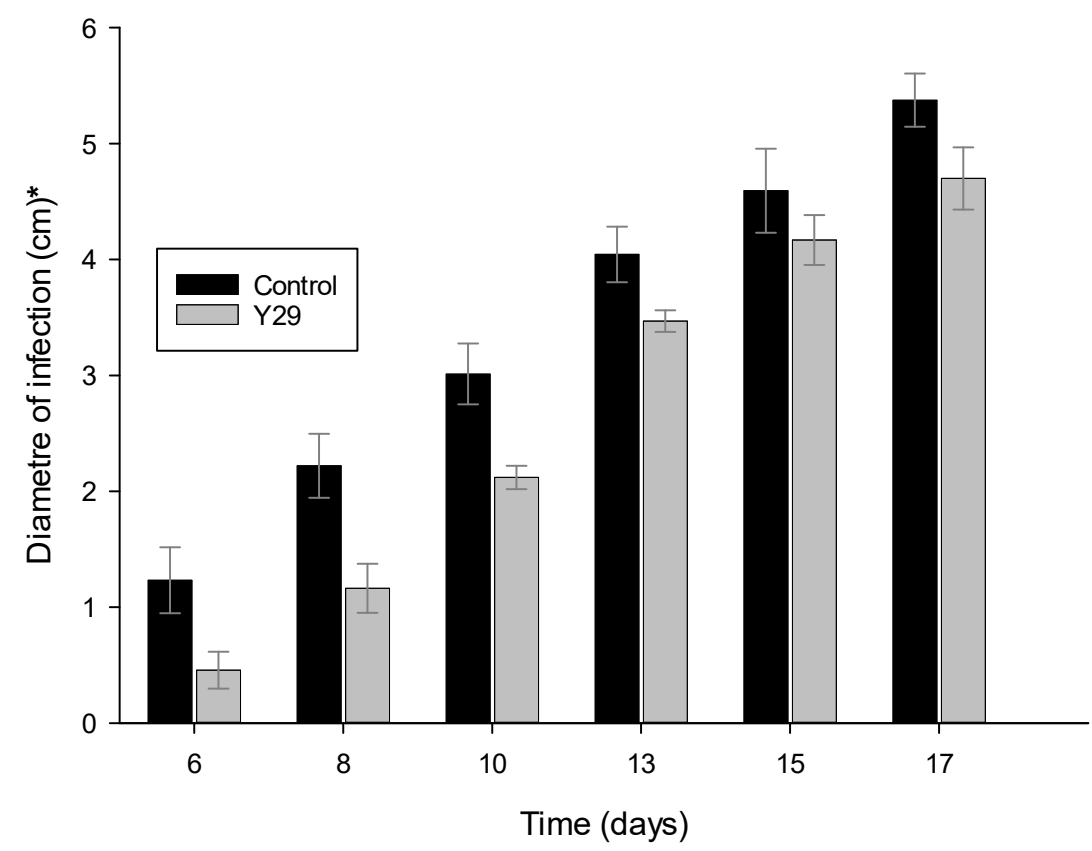

Figure 6. Biocontrol activity of Y29 applied on apples artificially inoculated with Penicillium expansum stored at $21^{\circ} \mathrm{C}$ for 17 days. Different letters within a sampling day mean significant differences among samples $(p<0.05)$. diameter of the infection has been subtracted from the diameter of artificially wound made before $P$. expansum inoculation ( $3 \mathrm{~mm}$ diameter)

Pictures of the appearance of control apples and apples treated with BCA and the progression of the infection in 17 days of storage are depicted in figure $6(\mathrm{~b})$. It should be mentioned that the halo size of apples dipped in water (results not shown) and dipped in yeast suspension without $P$. expansum (figure $6(\mathrm{~b})$ for Control Y29), did not exceed $2 \mathrm{~mm}$ throughout storage time. Thus, neither the oxidative reactions that naturally occur on apple wounds, nor $M$. pulcherrima colonization of the wounds had a significant impact on the development of the halo. When Y29 suspension was applied on apple surface, the disease was delayed during the first ten days of 
storage, showing a significant reduction in fungal growth; after ten days fungal growth increased rapidly.

\subsection{Patulin quantification on apples}

At the end of the storage (after 17 days at $21^{\circ} \mathrm{C}$ ), apples artificially inoculated with $P$. expansum and subjected to the different treatments were crushed and treated to extract patulin. Patulin was produced in all the samples inoculated with $P$. expansum with a low but significant decrease from $1995.73 \pm 103.62 \mu \mathrm{g} /$ fruit in control apples to $1793.55 \pm 86.21 \mu \mathrm{g} /$ fruit in apples treated with BCA. No patulin was detected in control Y29 (without $P$. expansum) apples. It must be pointed out that each apple was injured with four wounds and each wound was inoculated with a high concentration of $P$. expansum. Therefore, such high amounts of patulin per apple after 17 days of storage period at $21^{\circ} \mathrm{C}$ were expected. The amount of patulin is related with the diameter of wound infection in treated apples (as seen in previous section), highest patulin content corresponding to highest infection. 


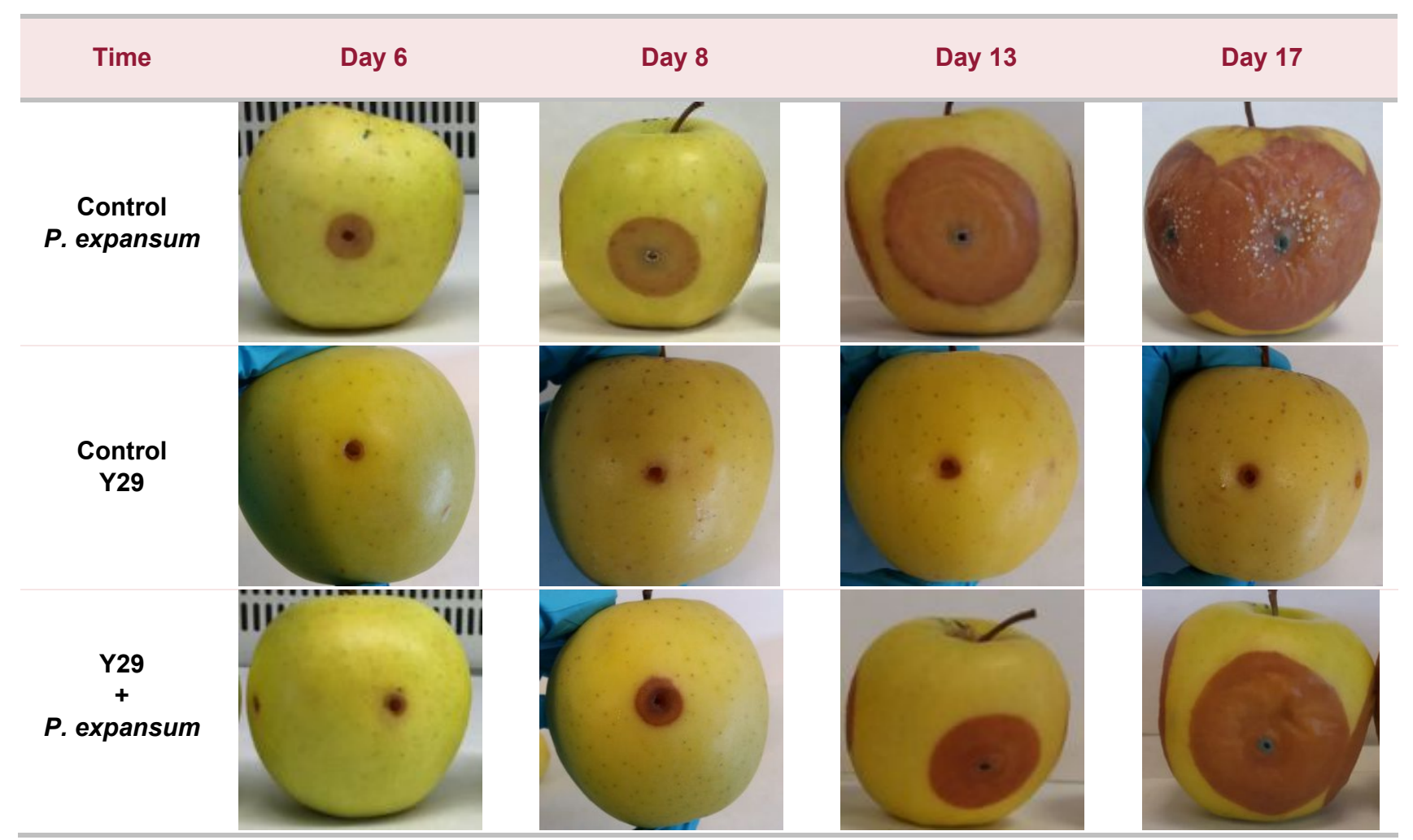

Figure 7. Visual effect of the application of Y29 on apples artificially inoculated with Penicillium expansum after incubation at $21^{\circ} \mathrm{C}$ for $6,8,13$ and 17 days (b). 


\section{Discussion}

Penicillium expansum is the agent of the blue mold decay considered as the most severe postharvest fungal disease since it causes heavy losses in the transportation and storage and it produces the harmful mycotoxin patulin especially in apple fruit [27]. The use of biocontrol agents could inhibit postharvest fruit pathogens by simple antagonistic interaction. Yeasts such as Pichia carribbica, Candida sake or Rhodosporidium paludigenum among others have been successfully used for controlling fruit diseases [2]. However, the most promising $\mathrm{BCA}$ are yeasts isolated from the epiphytic microbial community of fruits as they are phenotypically adapted to this niche. The benefit of belonging to the microbial community naturally established in the target fruit is that it can provide their colonization and survival on it when applied in the appropriate concentration [35]. Besides, until date, the resident microbial load of apples has been found to be considered as the most effective antagonists against pome fruit decay [36].

In the current research new yeast strains isolated from the surface of apples, named Y33, Y29 and Y24, were selected for their efficacy against $P$. expansum. Yeasts were identified as three strains of Metschnikowia pulcherrima through sequencing of the ITS region mtDNA could clearly distinguish that three different strains of $M$. pulcherrima were involved.

In fact, Metschnikowia spp. are terrestrial, free-living, often associated with flowers and transmitted to new niches by insects [37]. M. pulcherrima, in particular, is considered as one of the 13 resident species on cider apple trees [38]. According to other studies, it has been isolated from apples cultivars from floral parts, from buds and even in wounded apple tissue [36,39].

In vitro experiments revealed that the three strains were effective against $P$. expansum but despite belonged to the same species, they exhibited different antifungal activity. The best results were obtained with Y29. These results are in agreement with previous studies, where different strains of the same yeast species showed different biocontrol abilities because of their genetic background $[39,40]$ as it is often the 
case in biocontrol interaction. A wider brown-red pigmented inhibition zone of $P$. expansum was observed for $Y 33, Y 29$ and $Y 24$ (figure 1 (a)). In fact, the main antifungal mechanism of $M$. pulcherrima is the production of a red pigment, pulcherrimin, which accumulates in cells and it is also secreted around the colonies [41]. This pigment forms a chelate complex and immobilizes the iron ions in the growth medium which are essential for the fungal growth and pathogenesis [42]. In addition to the nutritional competition activity, other authors have reported that M. pulcherrima can also exert competition by parasitism due to the production of lytic enzymes such as chitinase and volatile antifungal compounds that contribute to the overall antagonistic effects $[43,44]$. Moreover, for all the isolated yeasts, the higher concentration of yeast produced the more antifungal activity. Other authors have also observed that biocontrol activity of the microbial antagonist was concentration dependent [45]. As it occurs in this experiment, the initial concentration of the antagonist remains essential to obtain high inhibition of pathogens either against fungi or bacteria $[40,46,47]$.

Patulin, the mycotoxin produced by $P$. expansum is very toxic to humans and has high prevalence in apple-based products. This mycotoxin is essential to the growth of the fungus in apple contributing to its pathogenicity [48]. It is thus important to control the presence of this mycotoxin when controlling the pathogen growth. Different studies have shown that some yeasts such as Rhodotorula mucilaginosa, Pichia caribbica, Rhodosporium paludigenum were able to reduce the content of this mycotoxin $[24,49,50]$. However, very few studies have been able to find strains capable to inhibit the growth of $P$. expansum and also reduce the mycotoxin content directly, not only by restricting the fungus specific production. For this purpose, tests were performed with the three selected strains in liquid culture medium having a high concentration of patulin $(1000 \mu \mathrm{g} / \mathrm{mL})$. Although yeasts could grow in the presence of a high concentration of patulin, it slowed down the growth rate of yeast and reduced the final concentration of viable yeasts between 0.5 and $1 \mathrm{log}$. This finding is expected since patulin is a secondary metabolite that $P$. expansum 
produces to improve its pathogenicity and virulence as a defense mechanism against other organisms [48,51]. Furthermore, these results are in agreement with those found by other authors where the growth of S. cerevisiae and Kodameae ohmeri was reduced in apple juice and YEPD liquid medium, both with patulin added [13,52]. All the selected yeasts in the present study were capable to reduce patulin content in liquid medium artificially contaminated, Y29 being the most effective with $97 \%$ of concentration reduction. In $120 \mathrm{~h}$ of incubation, for Y24 and Y29, patulin levels were below the limits established by the EFSA considering the apple juice content regulation of $50 \mu \mathrm{g} / \mathrm{Kg}$ Different studies have elucidated that antagonistic yeasts can reduce patulin from a contaminated medium by different mechanisms. These are: (i) patulin adsorption at the yeast cell wall, (ii) patulin uptake into yeast cells or (iii) patulin biotransformation into less toxic metabolites [53,54]. The mechanism used therefore depends on the BCA used [49]. In this case, patulin was not detected in the intracellular metabolites nor in the yeast cell wall on any analyze, indicating that the mycotoxin was not absorbed and that presumably was subjected to a biological degradation process. This is in accordance with the results of other authors that also studied the ability of different Metschnikowia spp. strains such as M. pulcherrima or M. fructicola in patulin detoxification $[32,40]$.Other studies with different yeasts have shown that the main products of patulin biodegradation are less toxic compounds than patulin itself. The metabolism of patulin to desoxypatulinic, Eascladiol or Z-ascladiol by yeasts has been previously reported [25,52]. Some of these compounds are to be expected from the biodegradation of the three strains selected in this work, although further studies are needed to confirm that hypothesis.

To sum up, isolated yeasts can be effective in reducing patulin accumulation in apples through their indirect effect on the reduction of $P$. expansum growth and their direct effect in the patulin biodegradation. Among yeasts, Y29 showed the best performance in both effects. Therefore, Y29 was selected to be applied as a BCA on apples inoculated with $P$. expansum and stored during 17 days at 21 ${ }^{\circ} \mathrm{C}$. Y29 was able to delay the disease occasioned by $P$. expansum in 
apples. There are a couple of aspects than can contribute to the success of Y29 as BCA on apples. The nutritional environment of the apple wound could be favorable to the development of M. pulcherrima and thus, it could colonize fruit tissues rapidly competing with pathogens. In this regard, Spadaro et al. (2013) [40] concluded that the antifungal action of M. pulcherrima strain on "Golden Delicious" apples was better than on other apple cultivars. They attributed this to the high soluble solid content of "Golden Delicious", which is related to a higher efficacy of BCA. These authors pointed out that one of the main mechanisms of action of these yeasts is competition for nutrients (not only for iron ions) and specially for carbon sources, such as sugars [40]. Moreover, the efficacy of the selected yeast reducing pathogen growth on apples could also be related to yeast were isolated from apple skin, the apple skin, an environment in which yeasts were already able to grow as other authors have previously reported [10].However, during the last few days of storage, pathogen reduction decreased (figure 7). This could be due to high storage temperatures resulted in a low efficacy of the BCA. In fact, fungi stored close to its optimal temperature can increase its growth rate resulting in higher aggressiveness [55,56]. Experiments at low temperatures closed to those applied in industrial warehouses will require longer storage period in order to demonstrate the BCA effectiveness. Future prospects involve to increase the antifungal effectiveness of $Y 29$ in apples contaminated with $P$. expansum by increasing the viability of yeasts or their adhesive properties on apple skin.

Other authors have studied the kinetic of the patulin production in Golden delicious apples artificially inoculated with $P$. expansum during storage [57]. Patulin was not detected for the first three days in apples and its content increased correlated with the developmental profiles of the blue mold observed on apples as occurs in the present work. Indeed, differences in biochemical characteristics of apples, such as sugar concentration, phenolic compounds and $\mathrm{pH}$ can affect the growth and production of secondary metabolites by this fungal species [58]. Different studies in Golden delicious apples pointed out that patulin is a virulence factor that helps $P$. expansum to 
grow [51,57].On the other hand, the ability of yeast strains to biodegrade patulin has been demonstrated in section 2.4. The Y29 strain is able to reduce patulin content when applied on apple inoculated with $P$. expansum. However, it is not possible to know which proportion of the lower amount of patulin observed in apples with BCA corresponds to a biodegradation or a non-production of this patulin by $P$. expansum. Further studies are needed to determine and quantify the biodegradation products of patulin in order to draw conclusive results on this reduction.

\section{Conclusions}

The development of naturally efficient control tools that reduce the incidence of $P$. expansum remains essential to avoid food loss of harvested fruits. The results of this study provide evidence of the high potential of M. pulcherrima isolated strains from apples as biocontrol agent that not only reduced $P$. expansum incidence but also have the ability to biodegrade patulin into less toxic metabolites. The biocontrol efficacy of the selected yeast in reducing the growth of $P$. expansum, and in reducing patulin content under in vitro conditions have been demonstrated. Y29 exhibited the bests results in both in vitro studies. Therefore, it was chosen for applying on stored apple and showed a low but significant inhibition of blue mold decay on wounded inoculated apples by comparison to control. These results are encouraging since the degree of fruit damage and pathogen inoculum level used in this work were far worse than those normally occurring in apples. The isolated strains could be applied as a hurdle with the purpose of inhibiting growth of $P$. expansum and its mycotoxin content on fruits. Studies comprising the incorporation of the BCA into edible coating formulations to improve and maintain the concentration of viable yeasts on the fruit surface are being carried out.

\section{Acknowledgments}

The authors acknowledge Amparo Querol and her research group sited in the Instituto de Agroquímica y Tecnología de Alimentos (IATA- 
CSIC) for their technical support on molecular analyses. Acknowledgments also go to predoctoral researcher Reem Al-Riachy for her sampling work in the cider orchard and for her support during the development of this work.

\section{References}

1. FAO Preventing post-harvest losses in the apple supply chain in Lebanon. Food Agric. Organ. United Nations Minist. Lebanon, Beirut 2018, 5 .

2. Yu, L.; Qiao, N.; Zhao, J.; Zhang, H.; Tian, F.; Zhai, Q.; Chen, W. Postharvest control of Penicillium expansum in fruits: A review. Food Biosci. 2020, 36, 100633.

3. Demirel, R.; Sariozlu, N.Y.; Ilhan, S. Polymerase chain reaction (PCR) identification of terverticillate Penicillium species isolated from agricultural soils in Eskisehir Province. Brazilian Arch. Biol. Technol. 2013, 56, 980-984, doi:10.1590/S151689132013005000004.

4. Gutarowska, B.; Skora, J.; Zduniak, K.; Rembisz, D. Analysis of the sensitivity of microorganisms contaminating museums and archives to silver nanoparticles. Int. Biodeterior. Biodegrad. 2012, 68, 7-17, doi:10.1016/j.ibiod.2011.12.002.

5. Van De Perre, E.; Jacxsens, L.; Van Der Hauwaert, W.; Haesaert, I.; De Meulenaer, B. Screening for the presence of patulin in molded fresh produce and evaluation of its stability in the production of tomato products. J. Agric. Food Chem. 2014, 62, 304-309, doi:10.1021/jf404192n.

6. Pattono, D.; Grosso, A.; Stocco, P.P.; Pazzi, M.; Zeppa, G. Survey of the presence of patulin and ochratoxin $A$ in traditional semihard cheeses. Food Control 2013, 33, 54-57, doi:10.1016/j.foodcont.2013.02.019.

7. Vansteelandt, M.; Kerzaon, I.; Blanchet, E.; Fossi Tankoua, O.; Robiou Du Pont, T.; Joubert, Y.; Monteau, F.; Le Bizec, B.; Frisvad, J.C.; Pouchus, Y.F.; et al. Patulin and secondary metabolite production by marine-derived Penicillium strains. Fungal Biol. 2012, 116, 954-961, doi:10.1016/j.funbio.2012.06.005.

8. Geiger, M.; Guitton, Y.; Vansteelandt, M.; Kerzaon, l.; Blanchet, E.; Robiou du Pont, T.; Frisvad, J.C.; Hess, P.; Pouchus, Y.F.; Grovel, O. Cytotoxicity and mycotoxin production of shellfish- 
derived Penicillium spp., a risk for shellfish consumers. Lett. Appl. Microbiol. 2013, 57, 385-392, doi:10.1111/lam.12143.

9. Tournas, V.H.; Uppal Memon, S. Internal contamination and spoilage of harvested apples by patulin-producing and other toxigenic fungi. Int. J. Food Microbiol. 2009, 133, 206-209, doi:10.1016/j.jijfoodmicro.2009.05.025.

10. Reddy, K.R.N.; Spadaro, D.; Lore, A.; Gullino, M.L.; Garibaldi, A. Potential of patulin production by Penicillium expansum strains on various fruits. Mycotoxin Res. 2010, 26, 257-265, doi:10.1007/s12550-010-0064-5.

11. Tannous, J.; El Khoury, R.; Snini, S.P.; Lippi, Y.; El Khoury, A.; Atoui, A.; Lteif, R.; Oswald, I.P.; Puel, O. Sequencing, physical organization and kinetic expression of the patulin biosynthetic gene cluster from Penicillium expansum. Int. J. Food Microbiol. 2014, 189, 51-60, doi:10.1016/j.ijfoodmicro.2014.07.028.

12. European Commission Regulation EC 1881/2006, setting maximum levels for certain contaminants in foodstuffs. Off. J. Eur. Union 2006, No 1881, 26.

13. Dong, X.; Jiang, W.; Li, C.; Ma, N.; Xu, Y.; Meng, X. Patulin biodegradation by marine yeast Kodameae ohmeri. Food Addit. Contam. - Part A Chem. Anal. Control. Expo. Risk Assess. 2015, 32, 352-360, doi:10.1080/19440049.2015.1007090.

14. Mercier, J.; Smilanick, J.L. Control of green mold and sour rot of stored lemon by biofumigation with Muscodor albus. Biol. Control 2005, 32, 401-407, doi:10.1016/j.biocontrol.2004.12.002.

15. Dara, S.K. The New Integrated Pest Management Paradigm for the Modern Age. J. Integr. Pest Manag. 2019, 10, doi:10.1093/jipm/pmz010.

16. Chanchaichaovivat, A.; Ruenwongsa, P.; Panijpan, B. Screening and identification of yeast strains from fruits and vegetables: Potential for biological control of postharvest chilli anthracnose (Colletotrichum capsici). Biol. Control 2007, 42, 326-335, doi:10.1016/j.biocontrol.2007.05.016.

17. Spadaro, D.; Droby, S. Unraveling the mechanisms used by antagonistic yeast To control postharvest pathogens on fruit. In Proceedings of the Acta Horticulturae; International Society for Horticultural Science, 2016; Vol. 1144, pp. 63-70.

18. Irtwange, S. V Application of Biological Control Agents in Preand Postharvest Operations; 2006; 
19. Muccilli, S.; Restuccia, C. Bioprotective Role of Yeasts. Microorganisms 2015, 3, 588-611, doi:10.3390/microorganisms3040588.

20. Janisiewicz, W.J.; Korsten, L. Biological control of postharvest diseases of fruits. Annu. Rev. Phytopathol. 2002, 40 (1), 411441.

21. Manso, T.; Nunes, C. Metschnikowia andauensis as a new biocontrol agent of fruit postharvest diseases. Postharvest Biol. Technol. 2011, 61 , 64-71, doi:10.1016/j.postharvbio.2011.02.004.

22. Parafati, L.; Vitale, A.; Restuccia, C.; Cirvilleri, G. Biocontrol ability and action mechanism of food-isolated yeast strains against Botrytis cinerea causing post-harvest bunch rot of table grape. Food Microbiol. 2015, 47, 85-92, doi:10.1016/j.fm.2014.11.013.

23. Cunha, S.C.; Faria, M.A.; Pereira, V.L.; Oliveira, T.M.; Lima, A.C.; Pinto, E. Patulin assessment and fungi identification in organic and conventional fruits and derived products. Food Control 2014, 44, 185-190, doi:10.1016/j.foodcont.2014.03.043.

24. Cao, J.; Zhang, H.; Yang, Q.; Ren, R. Efficacy of Pichia caribbica in controlling blue mold rot and patulin degradation in apples. Int. J. Food Microbiol. 2013, 162, 167-173, doi:10.1016/j.ijfoodmicro.2013.01.007.

25. Castoria, R.; Mannina, L.; R., D.-P.; Maffei, F.; Sobolev, A.P.; De Felice, D. V.; ...; Wright, S.A. Conversion of the mycotoxin patulin to the less toxic desoxypatulinic acid by the biocontrol yeast Rhodosporidium kratochvilovae strain LS11. J. Agric. Food Chem. 2011, 59(21), 11571-11578.

26. Karlovsky, P. Biological detoxification of fungal toxins and its use in plant breeding, feed and food production. Nat. Toxins 1999, 7(1), 1-23.

27. Riachy, R. Al; Strub, C.; Durand, N.; Guibert, B.; Guichard, H.; Constancias, F.; Chochois, V.; Lopez-Lauri, F.; Fontana, A.; Schorr-Galindo, S. Microbiome status of cider-apples, from orchard to processing, with a special focus on Penicillium expansum occurrence and patulin contamination. J. Fungi 2021, 7, 244, doi:10.3390/jof7040244.

28. Querol, A.; Barrio, E.; Huerta, T.; Ramon, D. Molecular monitoring of wine fermentations conducted by active dry yeast strains. Appl. Environ. Microbiol. 1992, 58, 2948-2953, doi:10.1128/aem.58.9.2948-2953.1992. 
29. Kurtzman, C.P.; Robnett, C.J. Identification and phylogeny of ascomycetous yeasts from analysis of nuclear large subunit (26S) ribosomal DNA partial sequences. Antonie van Leeuwenhoek, Int. J. Gen. Mol. Microbiol. 1998, 73, 331-371, doi:10.1023/A:1001761008817.

30. Esteve-Zarzoso, B.; Belloch, C.; Uruburu, F.; Querol, A. Identification of yeasts by RFLP analysis of the 5.8S rRNA gene and the two ribosomal internal transcribed spacers. Int. J. Syst. Bacteriol. 1999, 49, 329-337, doi:10.1099/00207713-49-1-329.

31. Peŕez-Través, L.; Lopes, C.A.; Querol, A.; Barrio, E. On the complexity of the Saccharomyces bayanus taxon: Hybridization and potential hybrid speciation. PLoS One 2014, 9, e93729, doi:10.1371/journal.pone.0093729.

32. Reddy, K.R.N.; Spadaro, D.; Gullino, M.L.; Garibaldi, A. Potential of two Metschnikowia pulcherrima (yeast) strains for in vitro biodegradation of patulin. J. Food Prot. 2011, 74, 154-156, doi:10.4315/0362-028X.JFP-10-331.

33. Canelas, A.B.; ten Pierick, A.; Ras, C.; Seifar, R.M.; van Dam, J.C.; van Gulik, W.M.; Heijnen, J.J. Quantitative Evaluation of Intracellular Metabolite Extraction Techniques for Yeast Metabolomics. Anal. Chem. 2009, 81, 7379-7389, doi:10.1021/ac900999t.

34. Tannous, J.; Atoui, A.; El Khoury, A.; Kantar, S.; Chdid, N.; Oswald, I.P.; Puel, O.; Lteif, R. Development of a real-time PCR assay for Penicillium expansum quantification and patulin estimation in apples. Food Microbiol. 2015, 50, 28-37, doi:10.1016/J.FM.2015.03.001.

35. Muccilli, S.; Restuccia, C. Bioprotective Role of Yeasts. Microorganisms 2015, 3, 588-611, doi:10.3390/microorganisms3040588.

36. Janisiewicz, W.J.; Tworkoski, T.J.; Kurtzman, C.P. Biocontrol potential of Metchnikowia pulcherrima strains against blue mold of apple. Phytopathology 2001, 91, 1098-1108, doi:10.1094/PHYTO.2001.91.11.1098.

37. Molnár, O.; Prillinger, H. Analysis of yeast isolates related to Metschnikowia pulcherrima using the partial sequences of the large subunit rDNA and the actin gene; Description of Metschnikowia andauensis sp. nov. Syst. Appl. Microbiol. 2005, 28, 717-726, doi:10.1016/j.syapm.2005.05.009.

38. Davenport, R.R. Distribution of yeasts and yeast-like organisms 
from aerial surfaces of developing apples and grapes. Microbiol. Aer. plant surfaces 1976, 325-359.

39. Spadaro, D.; Sabetta, W.; Acquadro, A.; Portis, E.; Garibaldi, A.; Gullino, M.L. Use of AFLP for differentiation of Metschnikowia pulcherrima strains for postharvest disease biological control. Microbiol. Res. 2008, 163, 523-530, doi:10.1016/j.micres.2007.01.004.

40. Spadaro, D.; Lorè, A.; Garibaldi, A.; Gullino, M.L. A new strain of Metschnikowia fructicola for postharvest control of Penicillium expansum and patulin accumulation on four cultivars of apple. Postharvest Biol. Technol. 2013, 75, 1-8, doi:10.1016/j.postharvbio.2012.08.001.

41. Miller, M.W.; Phaff, H.J. Metschnikowia Kamienski. In The Yeasts; Elsevier, 1998; pp. 256-267.

42. Pawlikowska, E.; James, S.A.; Breierova, E.; Antolak, H.; Kregiel, D. Biocontrol capability of local Metschnikowia sp. isolates. Antonie van Leeuwenhoek, Int. J. Gen. Mol. Microbiol. 2019, 112, 1425-1445, doi:10.1007/s10482-019-01272-w.

43. Yang, H.; Wang, L.; Li, S.; Gao, X.; Wu, N.; Zhao, Y.; Sun, W. Control of postharvest grey spot rot of loquat fruit with Metschnikowia pulcherrima E1 and potential mechanisms of action. Biol. Control 2021, 152, 104406, doi:10.1016/j.biocontrol.2020.104406.

44. Pawlikowska, E dan Kręgiel, D. Enzymatic Profiles and Antimicrobial Activity of the Yeast Metschnikowia pulcherrima. Acta Innov. 2017, 6, 1-7.

45. Saravanakumar, D.; Ciavorella, A.; Spadaro, D.; Garibaldi, A.; Gullino, M.L. Metschnikowia pulcherrima strain MACH1 outcompetes Botrytis cinerea, Alternaria alternata and Penicillium expansum in apples through iron depletion. Postharvest Biol. Technol. 2008, 49, 121-128, doi:10.1016/j.postharvbio.2007.11.006.

46. Settier-Ramírez, L.; López-Carballo, G.; Gavara, R.; HernándezMuñoz, P. Antilisterial properties of PVOH-based films embedded with Lactococcus lactis subsp. lactis. Food Hydrocoll. 2019, 87, 214-220, doi:10.1016/j.foodhyd.2018.08.007.

47. Guimarães, A.; Abrunhosa, L.; Pastrana, L.M.; Cerqueira, M.A. Edible Films and Coatings as Carriers of Living Microorganisms: A New Strategy Towards Biopreservation and Healthier Foods. Compr. Rev. Food Sci. Food Saf. 2018, 17, 594-614. 
48. Barad, S.; Sionov, E.; Prusky, D. Role of patulin in post-harvest diseases. Fungal Biol. Rev. 2016, 30, 24-32.

49. Li, X.; Tang, H.; Yang, C.; Meng, X.; Liu, B. Detoxification of mycotoxin patulin by the yeast Rhodotorula mucilaginosa. Food Control 2019, 96, 47-52, doi:10.1016/j.foodcont.2018.08.029.

50. Zhu, R.; Feussner, K.; Wu, T.; Yan, F.; Karlovsky, P.; Zheng, X. Detoxification of mycotoxin patulin by the yeast Rhodosporidium paludigenum. Food Chem. 2015, 179, 1-5, doi:10.1016/j.foodchem.2015.01.066.

51. Sanzani, S.M.; Reverberi, M.; Punelli, M.; Ippolito, A.; Fanelli, C. Study on the role of patulin on pathogenicity and virulence of Penicillium expansum. Int. J. Food Microbiol. 2012, 153, 323331, doi:10.1016/j.jijoodmicro.2011.11.021.

52. Moss, M.O.; Long, M.T. Fate of patulin in the presence of the yeast Saccharomyces cerevisiae. Food Addit. Contam. 2002, 19, 387-399, doi:10.1080/02652030110091163.

53. Coelho, A.R.; Celli, M.G.; Ono, E.Y.S.; Wosiacki, G.; Hoffmann, F.L.; Pagnocca, F.C.; Hirooka, E.Y. Penicillium expansum versus antagonist yeasts and patulin degradation in vitro. Brazilian Arch. Biol. Technol. 2007, 50, 725-733, doi:10.1590/S151689132007000400019.

54. Diao, E.; Hou, H.; Hu, W.; Dong, H.; Li, X. Removing and detoxifying methods of patulin: A review. Trends Food Sci. Technol. 2018, 81, 139-145.

55. Morales, H.; Marín, S.; Ramos, A.J.; Sanchis, V. Influence of postharvest technologies applied during cold storage of apples in Penicillium expansum growth and patulin accumulation: A review. Food Control 2010, 21, 953-962.

56. Nguyen Van Long, N.; Vasseur, V.; Coroller, L.; Dantigny, P.; Le Panse, S.; Weill, A.; Mounier, J.; Rigalma, K. Temperature, water activity and $\mathrm{pH}$ during conidia production affect the physiological state and germination time of Penicillium species. Int. J. Food Microbiol. 2017, 241, 151-160, doi:10.1016/j.ijfoodmicro.2016.10.022.

57. Snini, S.P.; Tannous, J.; Heuillard, P.; Bailly, S.; Lippi, Y.; Zehraoui, E.; Barreau, C.; Oswald, I.P.; Puel, O. Patulin is a cultivardependent aggressiveness factor favouring the colonization of apples by Penicillium expansum. Mol. Plant Pathol. 2016, 17, 920-930, doi:10.1111/mpp.12338.

58. Tannous, J.; Keller, N.P.; Atoui, A.; El Khoury, A.; Lteif, R.; Oswald, 
I.P.; Puel, O. Secondary metabolism in Penicillium expansum: Emphasis on recent advances in patulin research. Crit. Rev. Food Sci. Nutr. 2018, 58, 2082-2098, doi:10.1080/10408398.2017.1305945. 



\section{Artículo 8}

\section{Apple-based coatings incorporated with wild apple isolated yeast to reduce Penicillium expansum postharvest decay of apples}

Laura Settier-Ramírez ${ }^{1,2}$, Gracia López-

Carballo ${ }^{1}$, Pilar Hernández-Muñoz ${ }^{1}$, Angélique Fontana-Tachon ${ }^{2}$, Caroline Strub², Sabine Schorr-Galindo ${ }^{2}$

\section{Postharvest Biology and Technology,} (Submitted 2021)

1 Packaging Lab, Instituto de Agroquímica y Tecnología de Alimentos, IATA-CSIC, Av. Agustín Escardino 7, 46980 Paterna, Spain.

${ }^{2}$ Qualisud, Univ Montpellier, Avignon Université, CIRAD, Institut Agro, IRD, Université de La Réunion, Montpellier, France. 



\section{ABSTRACT}

The aim of this work has been to prevent the growth of Penicillium expansum on the surface of apples by means of the use of biocontrol agents in combination with edible coatings. For that, Metschnikowia pulcherrima yeast isolated from wild apples was incorporated in edible film matrices based on pectins, cellulose ethers with and without the addition of liquid culture medium (yeast extract and glucose) and apple pomace residues.

The viability and biocontrol activity of the yeast incorporated in the films were evaluated after film drying process and after being stored for 21 days at $10{ }^{\circ} \mathrm{C}$. Furthermore, applied as a coating on apples artificially inoculated with $P$. expansum in order to evaluate its efficacy to prevent blue mold during storage and to prevent the production of its mycotoxin, the patulin. M. pulcherrima remained viable after film drying and after films stored 21 days, but viability depended on the matrix composition, being lower in pectin films and higher in apple pomace films. The highest antimicrobial activity in vitro was observed in methylcellulose films supplemented with yeast extract and glucose (YEG), and in apple pomace residues films, matrix which was therefore selected to be applied as coatings on apples inoculated with $P$. expansum. The results proved that bioactive coatings significantly reduce $P$. expansum growth and patulin production during storage. The results obtained in this work give added value to the apple industry residues which, in combination with apple isolated M. pulcherrima can be applied as coatings on apples to provide protection against blue mold and its mycotoxin as an alternative of postharvest disease management.

Keywords: Biocontrol, Metschnikowia pulcherrima, Penicillium expansum, Antimicrobial coating, Apple, Biopolymers, Food waste 


\section{Introduction}

Apple is one of the most produced fruits around the world. It is not only consumed as fresh fruit but also as a wide range of industrially processed products. During the postharvest storage, apples can be affected by several invasions and spoilages.

Blue mold caused by Penicillium expansum is considered one of the most severe postharvest fungal disease since it can cause great economical loses [1] and it is the postharvest fungi considered as the predominant producer of the mycotoxin patulin [2]. Several studies have shown the presence of patulin at levels exceeding the limits established by the European Union (European commission Regulation No 1881/2006) not only in fresh apples but also in apple products such as pasteurized apple juice and even uperized apple compotes [3]. Prolong intake of this mycotoxin has been reported to produce among others cytotoxicity, mutagenicity or neurotoxicity $[4,5]$. Consequently, to ensure consumers' health, the control of initial infection of apples by $P$. expansum remains essential.

Chemical fungicides are still used as the main method to prevent the spoilage of $P$. expansum in fresh fruit. However, the utilization of those substances leave residues in the fruits and in industrial wash-water which can be potentially toxic for human health and environment [6]. It can also produce the development of pesticide-resistant pathogen strains [7]. Hence, nowadays consumers demand new and natural strategies to protect fresh products. In this way, the use of living microorganisms as biocontrol tool has risen interest during last decades. Among all the microorganisms, antagonist yeasts are very good candidates because they present many characteristics that make them useful as biocontrol agents in fruits $[8,9]$. Many species are able to survive during long periods of time in dry surfaces, they have simple nutritional requirements, they are able to colonize wounds on fruits and have a low impact on environment. Also, most yeasts do not produce allergenic spores or toxins as many other microorganisms (Spadaro and Droby, 2016). Also, numerous studies have demonstrated that different yeasts used as biocontrol agents (BCA), alone or in combination with other 
preservation techniques, were effective on the control of $P$. expansum on apples [11]. Janisiewicz et al., 2001 demonstrated the biocontrol potential of eight strains of Metschnikowia pulcherrima applied on Golden delicious apples. Likewise, Usall et al., 2000 [13] studied a strain of Candida sake in combination with controlled atmosphere conditions to prevent blue mold decay on Golden delicious apples. The progress in the development of BCA during last 20 years has been so powerful that a lot of registration and commercialization of biocontrol products have been made Spadaro and Droby, 2016 [10].

In addition, the use of active autochthonous yeasts is even more interesting because they naturally compete with fungus pathogen in their environment of origin, so they are phenotypically more adapted to survive and to attack pathogens [6]. To maintain a high concentration of viable yeasts on the fruit surface, their incorporation into edible coating formulations could be an effective approach. At the same time, coatings can decrease diffusion processes as respiration rate, ethylene production or even avoid weight loss due to perspiration which can control postharvest decay [14,15]. Edible coatings made with natural biopolymer could be good candidates for this work as an alternative of conventional wax coatings usually used in apples which are normally composed of oxidized polyethylene, organic solvents and surfactants $[16,17]$.

Byproducts of apple juice, cider or wine industries represent between $25-30 \%$ of the original apple weight and are generated every year worldwide [18]. Its high composition in acids and sugars and its low composition in proteins does not allow its use for animal feedstock or landfilling so it is considered as a food waste. This byproduct is mainly composed of cellulose, pectin, starch and lignin $[19,20]$. Accordingly, it is a good source to extract biopolymers as well as a good blend of biopolymers which can act as a matrix itself [21,22]. The aim of this work was to study the viability and antifungal activity of M. pulcherrima when is incorporated in different edible biopolymer films and to evaluate the antifungal potential of the developed active films in the form of coatings on the surface of apples. 


\section{Materials and methods}

\subsection{Culture preparation}

Metschnikowia pulcherrima was previously isolated and identified from the skin surface of cider apples obtained directly from the orchard [23]. This yeast was chosen for its good antifungal properties previously tested against Penicillium expansum [24]. The strain was maintained in Yeast extract glucose (YEG) containing $20 \%(\mathrm{v} / \mathrm{v})$ glycerol (Sigma, Germany) at $-80{ }^{\circ} \mathrm{C}$. The microbial culture was maintained by regular subculture at $4{ }^{\circ} \mathrm{C}$ on Potato Dextrose Agar (PDA) and transferred monthly. Prior to the start of the experiments, a loopful of the strain was transferred to $10 \mathrm{~mL}$ of YEG and incubated overnight at $28^{\circ} \mathrm{C}$.

Patulin producing-Penicillium expansum (NRRL 35695) was grown on PDA in Petri dishes for 7 days at $28^{\circ} \mathrm{C}$. The inoculum was collected by flooding the surface of the plates with sterile peptone water with Tween $80(0.05 \% \mathrm{v} / \mathrm{v})$ and then scraping the surface with a spatula. A $5 \mathrm{~mL}$ sample of the mold was transferred with a sterile syringe with cotton in order to remove mycelium, to a sterile tube and shaken to obtain a homogeneous suspension. Several dilutions were made to obtain a concentration of $10^{5}$ spores $/ \mathrm{mL}$. The spore concentration was determined using Thoma cell chamber.

All microbiological products were provided by Biokar diagnostics (France).

\subsection{Antifungal edible film formation}

Ten different film-forming solutions (FFS) were prepared with biopolymers that are presented in apple byproducts. Films obtained are summarized in table 1 .

Pectin (P) and Pectin Crosslinked (PC) were made dissolving $2 \%$ of pectin (Pectin from apple, Sigma, China) in sterile distilled water. Hydroxylpropylmethylcellulose (HPMC) (HPMC Food grade F4M, Methocel, U.S.A.) and Methylcellulose (MC) (MC Food grade A4C, Methocel, U.S.A.) were made at a concentration of $2 \%$ in distilled water. A total amount of $30 \%(\mathrm{w} / \mathrm{w})$ of glycerol was added as 
plasticizer in all matrices. As nutritional supplement for yeasts, the same films were also prepared dissolving biopolymers at $2 \%$ in YEG broth instead of sterile distilled water obtaining (P-YEG), (PC-YEG), (HPMC-YEG) and (MC-YEG) and adding the same glycerol quantity.

Table 1. Films prepared

\begin{tabular}{lccc}
\hline Biopolymer & Film & Film & Film \\
& (Solvent: water) & (Solvent: YEG) & (Treatment $\mathrm{CaCl}_{2}$ ) \\
Pectin & P & P-YEG & PC \\
& MC & MC-YEG & PC-YEG \\
MC & HPMC & HPMC-YEG & - \\
\hline HPMC & A & - & AC \\
Apple pomace & & & \\
\hline
\end{tabular}

YEG: Yeast extract $(9 \mathrm{~g} / \mathrm{L})$ and glucose $(20 \mathrm{~g} / \mathrm{L})$ liquid culture medium

Furthermore, films using only apple juice industry residues were prepared. To make them on a lab scale, "Golden delicious" apples were purchased from a local supermarket and were let overnight at room temperature. Prior to work, apples were surface cleaned by immersion in a $2 \%$ sodium hypochlorite solution for $2 \mathrm{~min}$ and then rinsed in distilled water. A juice extractor (Kenwood, JMP $600 \mathrm{WH}$, United Kingdom) was used to extract apple pomace (pulp, skin, grains and lignified parts). The juice was discarded. Apple pomace was mixed with distilled water in mass ratio (1:1) and mashed in a stomacher (Stomacher 400, Seward, United Kingdom) at high speed for 2 minutes. Then, to remove the big parts of apple pomace, the obtained mix was again passed through the juice extractor and 
this time "the juice" was recuperated. This juice corresponded to the "apple pomace washing water" (hereinafter referred to as "apple residues") and was kept to prepare films (A). This FFS was cold sterilized using $1 \mathrm{~g} / \mathrm{L}$ of dymethyldicarbonate (Merk, Germany) [25] and maintained overnight at $5{ }^{\circ} \mathrm{C}$. The amount of added glycerol was the same as for the other films.

M. pulcherrima was harvested by centrifugation at $8000 \times \mathrm{g}$ for 10 min at $4{ }^{\circ} \mathrm{C}$ and washed twice with physiological water. Then, it was incorporated into the film-forming solutions in order to obtain the concentration previously determined of 8 log CFU/film (artículo toxins). $15 \mathrm{~g}$ of FFS were cast in Petri dishes and dried at room temperature $\left(25^{\circ} \mathrm{C}\right)$ for $24 \mathrm{~h}$ under laminar flow. Films without yeasts were used as control.

Finally, a part of $P$ films and A films were aseptically removed from Petri dishes after drying. These films were dipping during 1 minute in a solution containing $10 \%$ of calcium chloride (Calcium Chloride, Labosi, France) in order to crosslink them. They were dried at $25^{\circ} \mathrm{C}$ for $3 \mathrm{~h}$ obtaining (PC) films and (AC) films.

\subsection{Yeast survivalafter film processing}

Yeast viability was evaluated after the film was formed. Just made films were aseptically removed from Petri dishes and placed in $40 \mathrm{~mL}$ of physiological water (P, P-YEG, HPMC, HPMC-YEG MC, MC-YEG and A) or in $40 \mathrm{~mL}$ of sterile $0.1 \mathrm{M}$ sodium citrate (Trisodium citrate dehydrate, Prolabo, France) solution (PC, PC-YEG and AC) in order to dissolve films by calcium chelation (Smidsrød and Skjåk- Braek, 1990). Then, films were stirred until complete dissolution. Serial dilutions were made and plated onto Yeast extract glucose chloramphenicol Agar (YGC Agar) (Merk, Germany) and colonies were counted after 48 $\mathrm{h}$ at $30^{\circ} \mathrm{C}$. Test were carried out in triplicate.

\subsection{Effect of film storage time on yeast survival}

The viability of $M$. pulcherrima was studied in the selected films $(P$, P-YEG, MC, MC-YEG, A and AC) for 21 days. For that, films were stored at $21{ }^{\circ} \mathrm{C}$ and $43.3 \%$ relative humidity $(\mathrm{RH})$ simulating supermarket 
conditions. Once a week, films were placed in tubes with $40 \mathrm{~mL}$ of sterile physiological water, except for AC films that were placed in $\mathbf{4 0}$ $\mathrm{mL}$ of sterile $0.1 \mathrm{M}$ sodium citrate and vigorously stirred until complete dissolution. Then serial dilutions were made and plated onto Yeast extract and glucose agar with chloramphenicol (YEGC Agar). Colonies were counted after incubation at $30{ }^{\circ} \mathrm{C}$ during $48 \mathrm{~h}$. Tests were carried out in duplicate.

\subsection{In vitro antifungal activity of the films}

The antifungal activity of the films carrying the yeast was evaluated in PDA Petri dishes.

First, sterilized cellophane films (Cellophane sheets, Hutchinson, France) cut with the same diameter than Petri dishes $(9 \mathrm{~cm})$ were placed directly on PDA surface. Then, cellophane was covered by active films. Cellophane prevents the evaluated films are in contact with the PDA [26]. Films without antagonistic yeasts were used as controls. Finally, a spot of $20 \mu \mathrm{L}$ of spores concentration previously adjusted to $1 \times 10^{5}$ spores $/ \mathrm{mL}$, was inoculated in the center of the Petri dish directly on the film. Plates were closed with parafilm to avoid dehydration and were placed at $21^{\circ} \mathrm{C}$. Periodically and during the storage time, the percentage of infected Petri dish was qualitatively measured considering that a dish completely covered by $P$. expansum represent a $100 \%$ of infection. Tests were carried out in triplicate.

\subsection{Application of active coatings on apples}

\subsubsection{Coating preparation and antifungal activity}

The matrix "apple residues" (A) was chosen for application as coating on apples due to its effectiveness in vitro against $P$. expansum and viability of the BCA. "Golden delicious" apples were purchased from a local supermarket and used in $24 \mathrm{~h}$. Fruits with a similar size $(200 \pm 20 \mathrm{~g})$, similar maturity and without injuries were selected. Prior to coating, apples were surface disinfected by immersion in a $2 \%$ sodium hypochlorite solution for $2 \mathrm{~min}$, then rinsed in distilled water and finally dried at room temperature. Later, four wounds were 
artificially made with a sterile needle ( $3 \mathrm{~mm}$ diameter $\times 3 \mathrm{~mm}$ deep) along the equator of each apple.

Then, apples were submitted to four different treatments: I) Control apples dipped in water, II) Apples coated with (A) without BCA, III) Apples dipped in water containing a suspension of BCA and IV) Apples coated with (A) incorporating BCA. Fruits were dipped in the four different coating solutions for $2 \mathrm{~min}$ and dried at room temperature under laminar flow during $2 \mathrm{~h}$. Once dried, wounds were inoculated with $20 \mu \mathrm{L}$ of $P$. expansum conidial suspension $\left(10^{5}\right.$ spores $/ \mathrm{mL}$ ). Treatments I) and III) were also prepared without $P$. expansum in order to observe if potential changes occur on wounds due to oxidative reactions or yeasts colonization. Coated apples were placed in sealed plastic boxes (one box per treatment) and were stored at $21{ }^{\circ} \mathrm{C}$ for 17 days. The disease incidence was then expressed as the measure of $P$. expansum invasion diameter.

Tests were carried out in quadruplicated.

\subsubsection{Yeast survival on apple surface}

Yeast survival in apple surface after drying was measured for treatments containing yeasts, that are III) and IV). Wounds were removed from each apple with a sterile knife. Each apple and "its wounds" were placed in a sterile plastic bag with $100 \mathrm{~mL}$ of sterile distilled water. Apples were then rinsed inside the bag, rubbing them with the hands during $3 \mathrm{~min}$. Then, apples were aseptically removed, and bags were stomached during $2 \mathrm{~min}$ in order to extract yeasts from the wounds. Serial dilutions were made and plated in YEGC agar. Colonies were counted after incubation during $48 \mathrm{~h}$ at $30{ }^{\circ} \mathrm{C}$.

\subsubsection{Patulin quantification in apples}

After 17 days of storage, patulin was quantified in the apples employed in the in vivo test. Methodology was adapted from Tannous et al., 2015 [27]. Apples were placed individually in sterile plastic bag and were homogenized in a Stomacher. $5 \mathrm{~g}$ of apple puree were weighed and were mixed with $5 \mathrm{~mL}$ of distilled water, and $75 \mu \mathrm{L}$ of pectinase (Pectinase from Aspergillus aculeatus, Sigma, Danemark) on 
a falcon tube. The mixture was homogenized and let it overnight at room temperature. After that, samples were centrifuged at 4,500 $\mathrm{xg}$ during $5 \mathrm{~min}$ and $5 \mathrm{~mL}$ of the supernatant were recovered for make the extraction. The patulin was then extracted and prepared for highperformance liquid chromatography (HPLC) following the next steps.

\subsubsection{Patulin extraction}

About $5 \mathrm{~mL}$ of the previous supernatant were transferred separately into Falcon flask of $50 \mathrm{~mL}$ containing $2 \mathrm{~g}$ of sodium bicarbonate (Fluka, France) and $15 \mathrm{~g}$ sodium sulphate anhydrous (VWR Chemicals, France). $15 \mathrm{~mL}$ of a mixture of ethylacetate (VWR chemicals, France) and hexane (Fisher scientific, U.K.) in proportion (60/40) were added before shaking for 10 minutes. Then, samples were centrifuged at $3,000 \times \mathrm{g}$ for 10 minutes. The organic layer was recovered and completely evaporated under nitrogen stream. The dry extract was suspended in $9 \mathrm{~mL}$ of $50 \%$ acetic acid solution and sonicated during $30 \mathrm{~min}$. Finally, $1 \mathrm{~mL}$ of an internal standard was added, and samples were filtered through a $0.45 \mathrm{~mm}$ syringe filter into a clean $2 \mathrm{~mL}$ vial.

\subsubsection{HPLC MS/MS analysis}

HPLC/MS-MS (LCMS 8040 Shimadzu) was used to detect and quantify patulin in the samples. The data were analyzed using Labsolution software (Shimadzu).

The chromatographic separation was carried out on Kinetex $2.6 \mu \mathrm{m} \mathrm{C18} \mathrm{100A} 50 \times 2.1 \mathrm{~mm}$ ID column (Phenomenex). Column temperature was maintained at $50{ }^{\circ} \mathrm{C}$ and injection was made with a volume of $50 \mu \mathrm{L}$. The mobile phase A consisted of $90 \%$ water 10 $\%$ Mobile phase B consisted acetonitrile (HPLC MS grade, Sigma).

Electrospray ionization was the ionization source. The parameters were as follows: positive and negative ionization ES+ and ES-, MRM (Multiple Reaction Monitoring) mode, Desolvation line: $250^{\circ} \mathrm{C}$, Heater block: $400^{\circ} \mathrm{C}$, NEB gas: $3 \mathrm{~L} / \mathrm{min}$, Drying gas: $15 \mathrm{~L} / \mathrm{min}$.

\subsection{Statistical analysis}


One-way analyses of variance were carried out with the SPSS computer program (SPSS Inc., Chicago, IL). Tukey b test for a confidence interval of $95 \%$ was used to evaluate differences in pairs of mean values.

\section{Results and discussion}

3.1 Yeast survival after film processing

The viability of yeast incorporated in films was assessed after drying in order to compare the suitability of different edible biopolymers. Figure 1 shows the viability of M. pulcherrima (log CFU/film) in film after being dryed for $20 \mathrm{~h}$ at $25^{\circ} \mathrm{C}$.

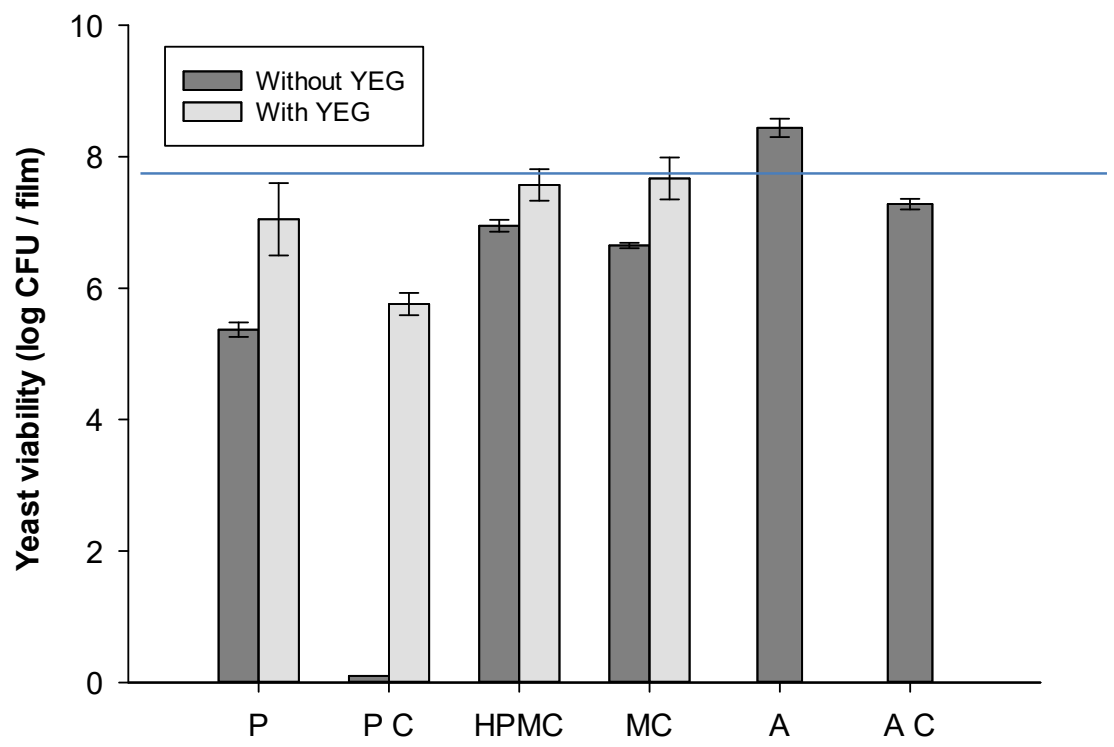

Films

Blue line represents the initial concentration of yeasts inoculated (log CFU/film)

Figure 1. Changes in the total viable counts of Metschnikowia pulcherrima during the film forming dehydration process. Mean values and 95\% LSD intervals.

Yeast stress resistance mechanisms, as it occurs in a dehydration process are related to several and complex physiological 
characteristics of the cell resulting from millions years of evolution under stress conditions [28]. This resistance is strain-dependent (intrinsic physiological characteristics of each strains) and it has been demonstrated that $M$. pulcherrima has a strong tolerance to environments with high osmotic pressure and is capable to growth in products with a low water activity [29]. As can be observed in figure 1, yeast survival depended on the matrix formulation.

Except for PC films, the viability of yeasts ranges from $66.5 \%$ to $104.46 \%$ survival. This shows that the methodology used to process these films by casting at $20^{\circ} \mathrm{C}$ for $20 \mathrm{~h}$ ) does not represent a big shock that implies a high mortality of yeasts. This is probably due to the low dehydration rate achieved drying the film at low temperature which has probably led to a slower water transfer from inside of the cell to outside. This may cause less damage to cell membranes and to structural components that are essential for maintaining cell viability as it has been showed by other authors $[29,30]$.

The best survival of yeast population occurred in "Apple residues films" (A). In fact, it was the only matrix where the population of M. pulcherrima was higher than the initial amount of inoculated cells, which means cell growth occurs during the drying step. This could be explained by the fact that this yeast has been isolated from apples so it is naturally habituated to grow in surfaces with similar composition [17,31]. In contrast, a yeast reduction of 2.71 log was observed in pectin films. This mortality can be explained because pectin has a low $\mathrm{pH}$ ( $\mathrm{pH}$ P FFS=2,7).

Regarding cellulose derivatives, yeast viability in HPMC and MC films was lower than in A films but was maintained between 6.65 and 6.95 log probably due to the lack of nutrients compared with films made of apple extract. Similar results were obtained by Marín et al., 2017 when incorporated Candida sake in HPMC coatings comparing with films made with proteins (sodium caseinate and pea protein) and a polysaccharide (starch). In all the cases, when YEG was added to the film forming solution, the viability after drying was higher than in films without YEG. This can be due to YEG provides with nutrients needed to sustain yeast survival like glucose and amidic acid mix [33,34]. The 
presence of a medium rich in nutrients has also related to the resistance of yeast to dehydratation.

Previous works have shown that the resistance of yeast to dehydration is also related to the composition of the growth media. When nutrient-rich media are used, greater resistance to dehydration is observed [29]. Besides, a precedent study has already demonstrated that supplementing medium with $\mathrm{Ca}^{2+}$ or $\mathrm{Mg}^{2+}$ allows cells to increase their resistance to dehydration [35]. In this context, yeast extract not only presents high amounts of essential amino acids, vitamins and glucose as a source of carbohydrates, minerals are also present in its. In this line, Brachkova et al., 2011 observed the same positive effect in the viability of Lactobacillus plantarum [36]. When MRS broth was added to alginate films

When films were crosslinked with $\mathrm{CaCl}_{2}$, in all the cases, the viability decreased. It may be due to the crooslinked step itself which consist of dipping newly dried films in a solution for $2 \mathrm{~min}$. During this time a partial dissolution of film before being crosslinked occurred. After film crosslinking, the remaining solution of was spread in YEGC agar and analyzed for yeast. The results revealed that about 2 log of viable yeast were lost in this process (results not shown).

The films P, P-YEG, MC, MC-YEG, A and AC were selected to continue the work.

\subsection{Effect of film storage time on yeast survival}

The viability of M. pulcherrima in selected films was also studied for 21 days at $20^{\circ} \mathrm{C}$ and $43.3 \% \mathrm{RH}$ in order to reproduce the usual conditions of apple storage at the supermarket. In the effect of storage time on the viability of M. pulcherrima immobilized cells is shown in figure 2 . 


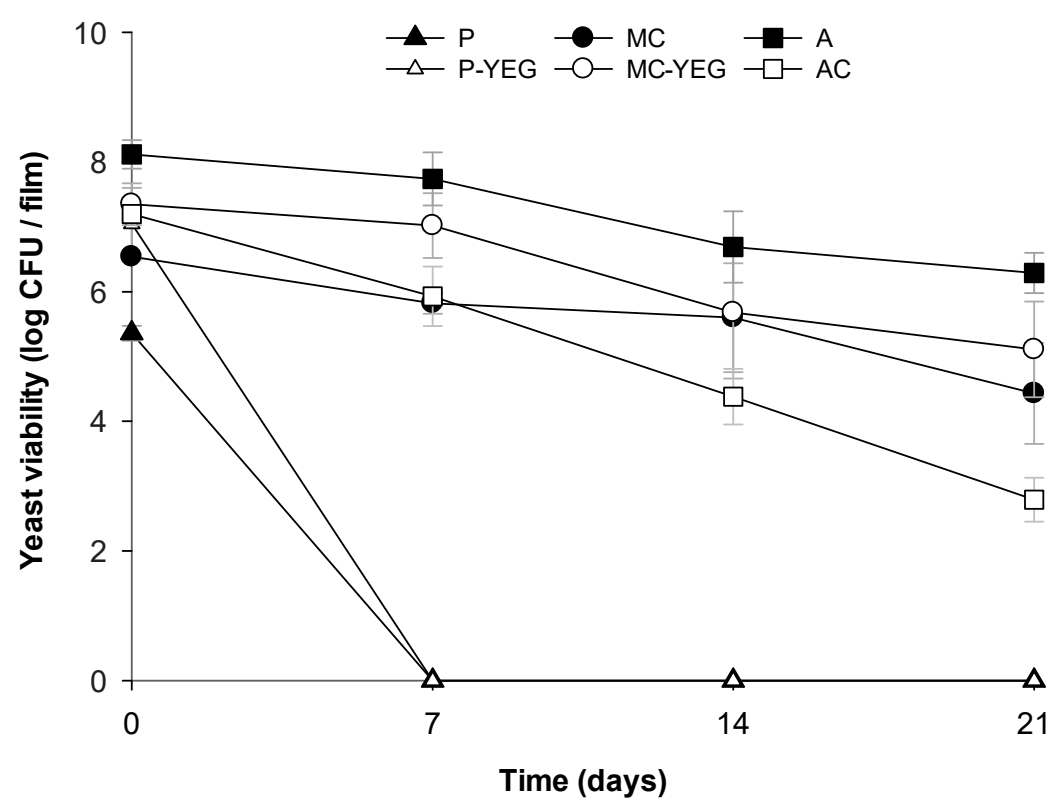

Figure 2. Viability of Metschnikowia pulcherrima in films throughout storage time at $21^{\circ} \mathrm{C}$ and $43 \% \mathrm{RH}$. Mean values and $95 \%$ LSD intervals.

In general, and regardless of the biopolymer film, a decrease in cell viability throughout storage time can be observed. However, this effect was more accused in pectin films since a $100 \%$ of mortality was observed after one week, independently of the addition of YEG. In this case, dehydrated yeasts did not resist in a low $\mathrm{pH}$. Thus, the survival ability of the microorganisms in films is closely related to the $\mathrm{pH}$ reached during the drying process [37]. M. pulcherrima viability observed in A, MC and MC-YEG films was higher showing reductions of $1.83,2.1$ and 2.2 log respectively, after 21 days of storge. The high rate of survival in almost all the matrices (except pectin based and AC films) is the result of several factors. Firstly, the storage conditions of low relative humidity ( $43 \%$ ) could favor the viability of the cells. Other authors have shown that the survival of $C$. sake in polysaccharide and protein matrices was higher at $53 \%$ humidity than at $68 \%$ [32]. These results suggest that, at a lower water activity the yeast could be in a latent state, due to the low water availability, prolonging its survival. 
While in a water stress medium without adequate nutrients, cells remain more vital and end up exhausting themselves fighting for survival [38]. In the same way, films carrying lactic acid bacteria experimented a higher survival rate when films were stored at low temperatures [39] pointing to a drop in their metabolism and a longer latency state.

On the other hand, the composition of the film can play a role in the protection of the yeast. In this regard, incorporation of glycerol in the film composition has been previously reported that enhance the viability of yeast and bacteria [40-42]. Moreover, glycerol can penetrate the cell wall and the cytoplasmatic membrane, protect the cell against the osmotic shock due to the dehydration in films [43,44]. The highest viability was found in A films. This was probably due to the complexity of the matrix which is composed by water soluble and insoluble fraction with sugars, polysaccharides and fibers [22]. On the one hand, it can serve as substrate during drying step and provide protection. It should be noted that this yeast has been isolated from the epiphytic microbial community of apples so they used to survive in this type of substrates since they are phenotypically adapted to this niche $[17,45]$.

In the case of MC and MC-YEG, the reductions were more accentuated that for $A$ films. Survival rate of the strain was lower in $M C$ films than in MC-YEG during the first 7 days of storage. At the end of the storage, the viability was similar in both films. This could indicate that cellulose derivatives allows yeast survival but with deaths throughout storage probably due to the poor nutrient content or protection properties of this medium as it has been also proved by other authors that studied the survival rate of both yeasts and $L A B$ in MC and HPMC films [46].

In the case of AC films, the highest mortality was observed. $M$. pulcherrima viability decreased from $7.2 \mathrm{log}$ CFU/film in newly dried films to $2.7 \mathrm{log} \mathrm{CFU} / \mathrm{film}$ at day 21. $\mathrm{CaCl}_{2}$ has no antimicrobial effect against yeast, in fact, $\mathrm{CaCl}_{2}$ has been used by other authors to enhance the antifungal capacity of other yeasts such as C. laurentii [47]. In this case, the decrease was due to the process of crosslinking itself. Yeasts 
were exposed to a greater stress than in the other films since they suffered a first dehydration to make the apple pomace film, a rehydration in the $\mathrm{CaCl}_{2}$ bath for 2 minutes and then a later dehydration. On the other hand, by immersing the film for two minutes in an $10 \% \mathrm{CaCl}_{2}$ bath, just as a part of yeasts migrated (see previous section) to the bath, a part of the film does too, especially the water-soluble fraction. In this way, small molecules were lost, including glycerol, which acted as protectors against dehydration during storage.

\subsection{In vitro antifungal activity of the films}

In vitro antifungal effect of the film formulations carrying $M$. pulcherrima against $P$. expansum is shown in figure 3 , and given as the percentage of PDA agar plate colonized by $P$. expansum over an incubation period of 19 days at $21^{\circ} \mathrm{C}$.

It should be noted that this test was carried out with newly dried films so the viability of the initial yeast was the same than these observed in section 3.1. P. expansum growth was influenced by the nature of the polymer as it can be appreciated in control films. This is surely due to the progressive adaptation of this fungus to a new environment since formulation, process and environmental factors influencing mold growth [48]. Although polymers used do not have any antifungal activity, differences in fungal growth on the film without yeasts were observed.

The fastest growth was observed in P, P-YEG and A films probably because pectin is one of the major components of apples and $A$ films are made with apple and this mold has been isolated from this medium (showing an adaptation to this substrate). Then, the mold grew a little slower in AC films, probably because $\mathrm{CaCl}_{2}$ may have a small inhibitory effect against $P$. expansum [49] and because the film is crosslinked, which can imply that nutrients needed by the fungus may not be as bioavailable as in the A film. 


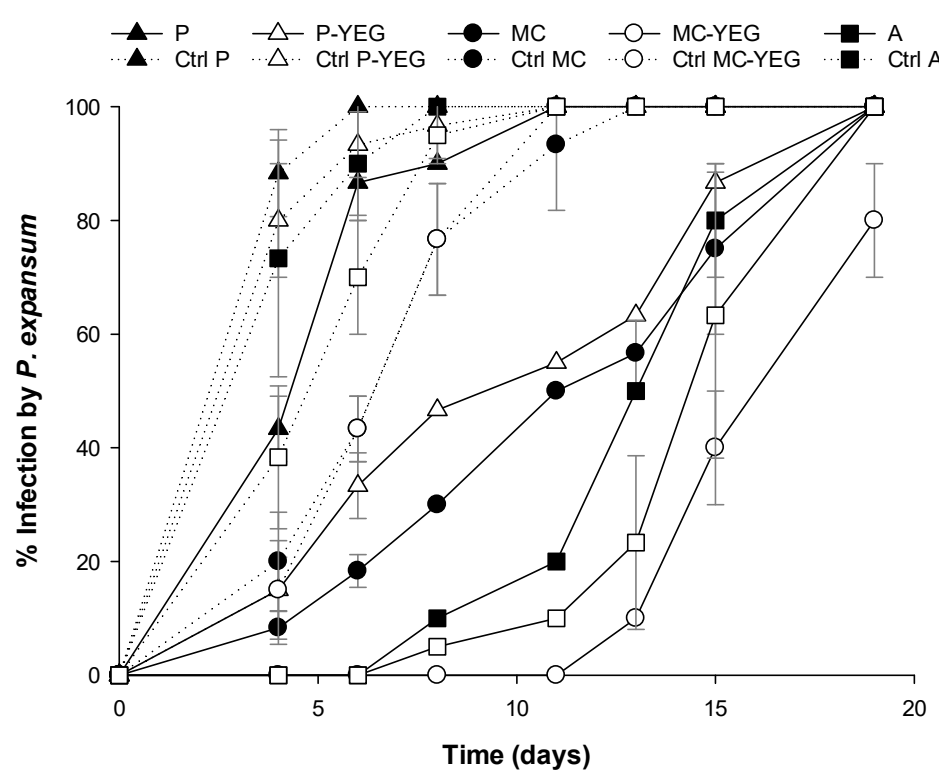

Figure 3. Biocontrol activity of active and control films placed on the surface of PDA agar plates artificially inoculated with Penicillium expansum stored at $21^{\circ} \mathrm{C}$ for 19 days. Mean values and 95\% LSD intervals

Finally, the less growth was observed in MC films. Cellulose is a natural polymer; it is insoluble in water because of the hydrogen bonds between its molecules. Through an etherification, this insoluble cellulose is converted into a water-soluble non-ionic cellulose ether like MC. Therefore, MC does not have the same structure as cellulose. This may mean that since the mold is not adapted to grow on this type of substrate, it has more difficulties to develop. When YEG was added, no major growth was observed either. Other authors observed the same behavior when they applied sodium alginate films and locust bean gum without adding an antimicrobial agent and observed a decrease in the growth of Penicillium digitatum compared with the uncoated PDA plates [50].

$P$ films showed the worst antifungal activity followed by P-YEG and $\mathrm{MC}$ films (although the latter two had significantly higher activity than P). These films corresponded to those that showed the least viability of yeast after drying. This result is consistent since in all the 
cases in which viable microorganisms have been entrapped into matrices, both yeasts and $L A B$, it has been demonstrated that the antifungal activity is a function of the initial concentration of the antagonist microorganism $[46,51]$. On the other hand, in a previous work, the minimum inoculum of this strain of M. pulcherrima active against $P$. expansum was studied and a very considerable reduction was observed when the concentration of this strain was 5 times higher than the inoculum of $P$. expansum [24]. Therefore, the antifungal assays performed on PDA plates showed that bioactive films enriched with M. pulcherrima significantly inhibited the growth of $P$. expansum or modified its morphological growth (inhibiting in certain cases both spore germination and mycelium proliferation).

Different strains of $M$. pulcherrima have been used as BCA against different fungal species such as $P$. expansum. The main biocontrol mechanisms exercised by $M$. pulcherrima are nutritional competition and parasitism. In fact, this yeast produces a secondary metabolite, pulcherrimin, that forms a chelate complex and immobilizes the iron ions in the growth medium preventing the growth of the mold. And in addition, it is also able to produce lytic enzymes such as chitinase that contribute to the overall antagonistic effect $[52,53]$. The progression of the infection in vitro after 8 and 15 days of incubation is depicted in figure 4 .

(A) films showed a delay of 8 days in the appearance of the mold that can be clearly seen in this figure. Although M. pulcherrima has lower viability in $A C$ film, the antifungal activity of this film was slightly better. It may be due to addition of $\mathrm{CaCl}_{2}$ affects fungal growth as can be seen in the previous section. It has been widely demonstrated that $\mathrm{CaCl}_{2}$ can improve de biocontrol activity of various antagonistic yeasts $[47,49]$. Finally, the film that had the best antifungal properties was MC-YEG due to several factors such as a high yeast viability, a good source of nutrients provided by YEG and because of the difficulty of $P$. expansum to grow in this polymer. 


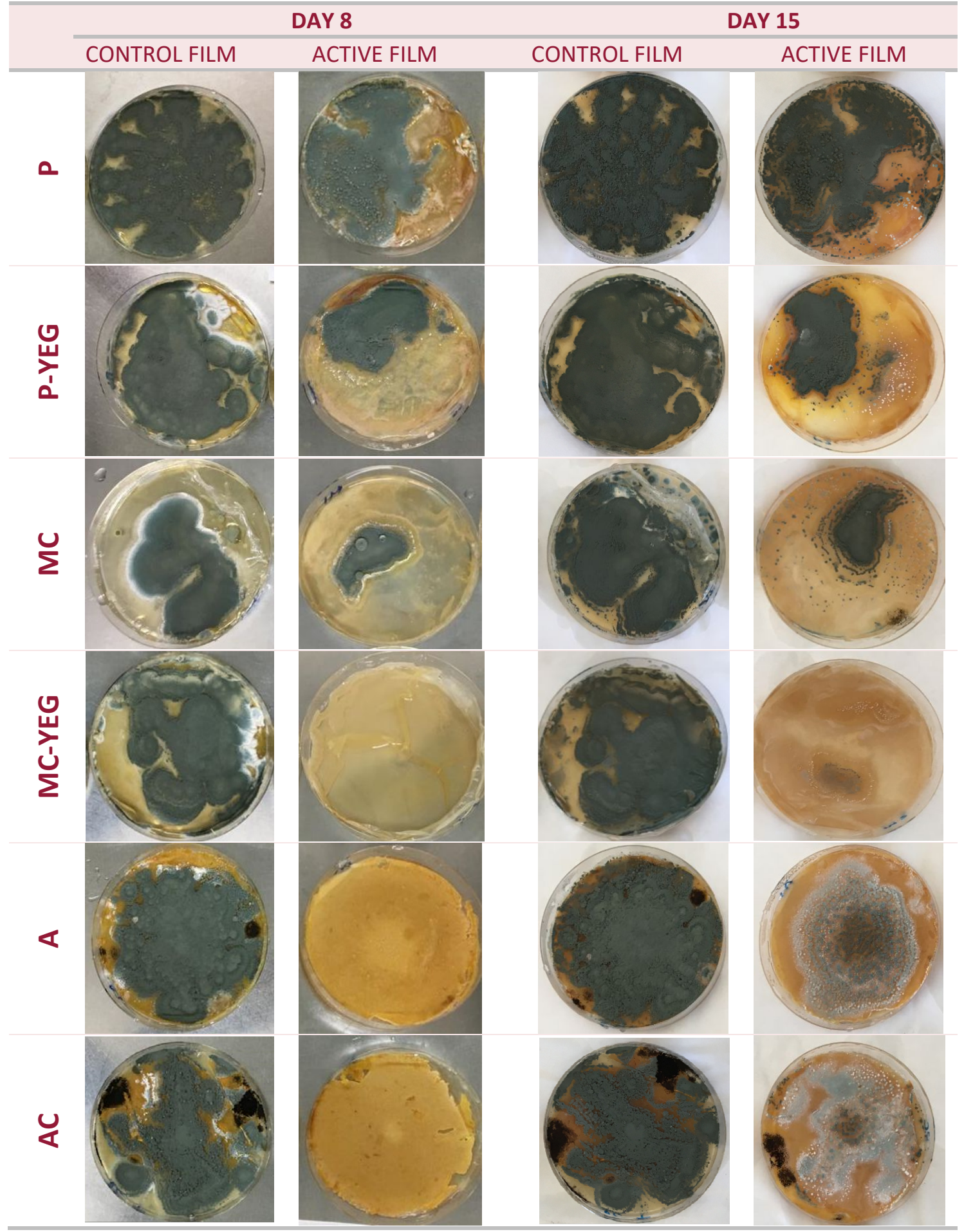


Figure 4. Visual effect of the biocontrol activity of active and control films placed on the surface of PDA agar plates artificially inoculated with Penicillium expansum after incubation at $21^{\circ} \mathrm{C}$ for 8 and 15 days.

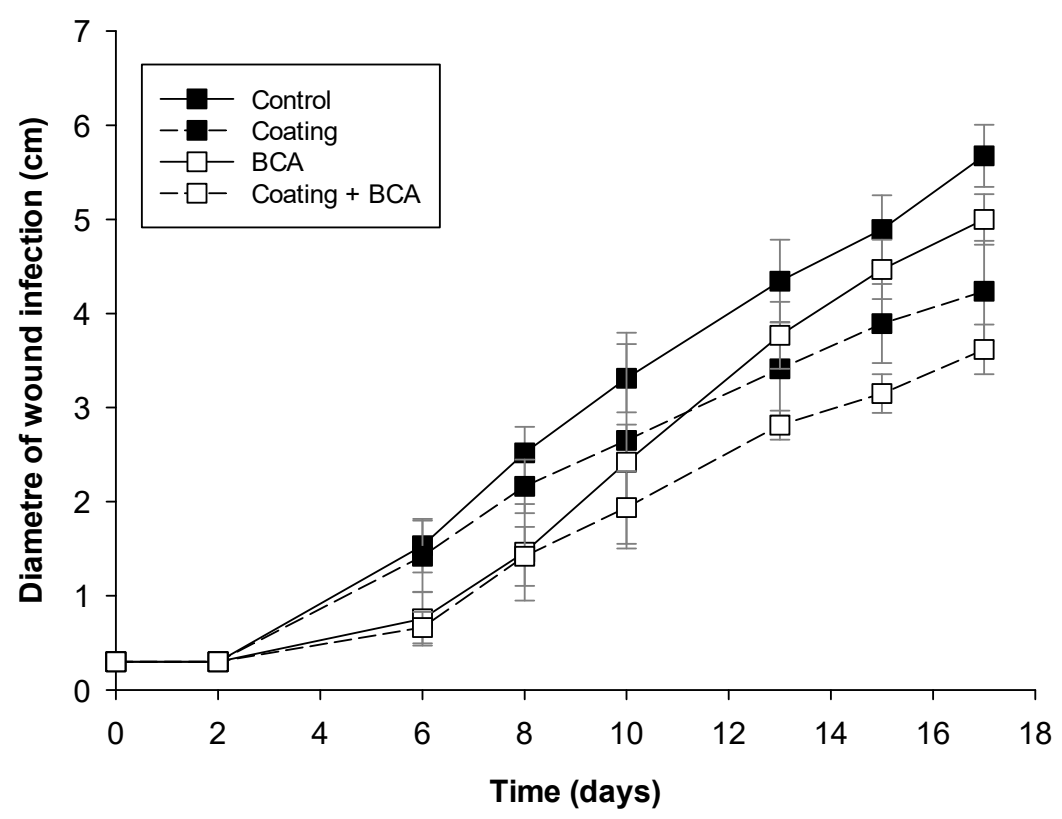

Figure 5. Biocontrol activity of treatments applied on apples artificially inoculated with Penicillium expansum stored at $21^{\circ} \mathrm{C}$ for 17 days.

It should be mentioned that the halo size of apples dipped in water and apples dipped in water containing a suspension of BCA without $P$. expansum, did not exceed $5 \mathrm{~mm}$ throughout storage time (data not shown). Thus, neither the oxidative reaction that naturally occur on apple wounds, nor M. pulcherrima colonization of the wounds had a significant impact on the development of the halo.

Samples treated with Coating $+B C A$ proved to be the most effective with very significant reductions in the growth of $P$. expansum with respect to the other treatments. No differences were observed in the progression of the infection between apples with BCA and with 
Coating +BCA until day 8 , so both were able to delay the disease. However, from day 10 the mold managed to develop more intensely in uncoated apples that were only treated with BCA. On the contrary, from day 10, a reduction in mold growth was observed in apples treated with the stand-alone coating, with the diameter of the infection being smaller than that of apples treated only with BCA from day 13.

On the one hand, the initial amount of yeast is lower in apples treated only with BCA and the adhesion and colonization capacity is lower than in those with Coating+BCA. This can cause the amount of viable yeast to be reduced over time and not to be sufficient to compete with $P$. expansum, thus diminishing its antifungal capacity. The appearance of the apples and the progression of the infection are depicted in figure 6.

(A) coatings applied in this experiment can act as barrier to gaseous exchanges in the fruit as has been seen with other edible biobased coatings [54], decreasing the oxygen permeability and increasing $\mathrm{CO}_{2}$ accumulation in the fruit. This could explain the inhibition of $P$. expansum observed in apples treated with the standalone coatings since molds are strictly aerobic and highly sensitive to $\mathrm{CO}_{2}$ [55]. It should be noted that from day 8, opportunistic molds (not only $P$. expansum) appeared on stand-alone coatings (not only on the wound but on the whole coating) that advanced rapidly colonizing the surface of the apple during storage. This reinforces the idea that the coating has no antimicrobial effect, as it can even act as a substrate for fungal growth.

Finally, the good effectiveness of the treatment Coating $+B C A$ was due to several factors, on the one hand, a greater viability and effectiveness of $M$. pulcherrima thanks to the adhesive properties and protection that the coating exerts on the yeast (seen in sections 3.1 and 3.2) and on the other hand, the effect of the coating on the fungal growth. It should be noted that M. pulcherrima is a facultative aerobic yeast and therefore able to grow under low oxygen conditions. 


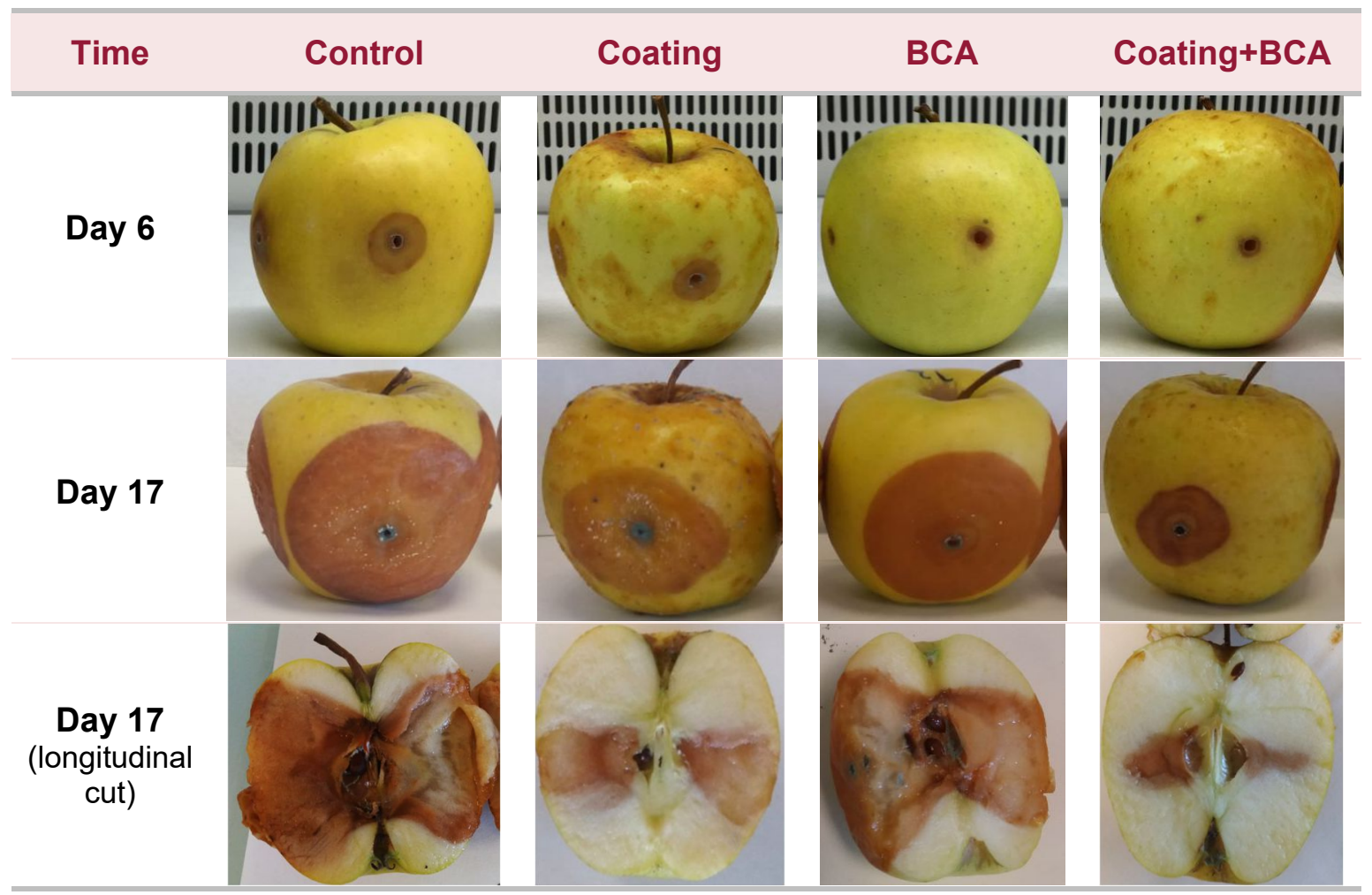

Figure 6. Visual effect of the application of treatments on apples artificially inoculated with Penicillium expansum after incubation at $21^{\circ} \mathrm{C}$ for 6 and 17 days. 


\subsection{Patulin quantification of treated apples}

Apples and apple products such as juice or compote are the commodities most infected by the pathogens that produce patulin. Among them, $P$. expansum is frequently cited as the most likely source of patulin production [56]. At the end of the storage (after 17 days at $21^{\circ} \mathrm{C}$ ), apples artificially inoculated with $P$. expansum and subjected to the different treatments were crushed and extracted to determine the production of patulin in vivo. Results are shown in figure 7 .

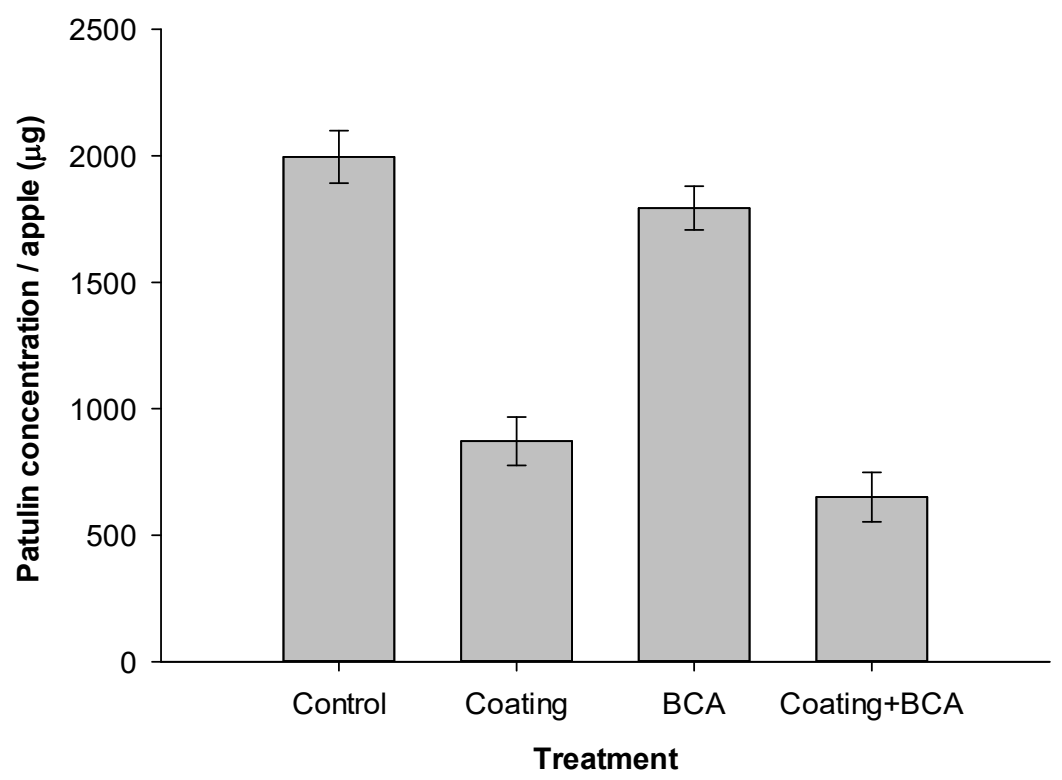

Figure 7. Patulin accumulation $(\mu \mathrm{g} / \mathrm{kg}$ ) in apples artificially inoculated with Penicillium expansum (in 4 wounds around the equator of the fruit) with different treatments after incubation at $21^{\circ} \mathrm{C}$ for 17 days.

Patulin was produced in all the samples ranging from 600 $\mu \mathrm{g} /$ fruit in apples with Coating+BCA to $2000 \mu \mathrm{g} /$ fruit in control apples. It must be pointed out that each apple was injured with four wounds and each wound was inoculated with a high concentration of $P$. expansum. Therefore, such high amounts of patulin per apple after 17 days of storage period at $21^{\circ} \mathrm{C}$ were expected. The amount of patulin 
is related with the diameter of wound infection in treated apples (seen in section 3.4) corresponding the higher infection with the higher concentration of patulin.

Other authors have studied the kinetic of the patulin production in Golden delicious apples artificially inoculated with $P$. expansum during storage [57]. Patulin was not detected for the first three days in apples and its content increased correlated with the developmental profiles of the blue mold observed on apples as occurs in the present work.

Indeed, differences in biochemical characteristics of apples, such as sugar concentration, composition, phenolic compounds and $\mathrm{pH}$ can affect the growth and production of secondary metabolites by this fungal specie [58]. Different studies in Golden delicious apples pointed out that patulin is a virulence factor that helps $P$. expansum to grow $[57,59]$.

Instead, the ability of this yeast strain to biodegrade patulin has been demonstrated in a previous work [24]. In this study, it is not possible to know which proportion of the lower amount of patulin observed in the BCA and Coating+BCA samples corresponds to a biodegradation or a non-production of this patulin by $P$. expansum. Further studies are needed to determine and quantify the biodegradation products of patulin in order to draw conclusive results on this reduction.

\section{Conclusions}

The development of naturally efficient control strategies that can reduce food loss remains a research preference since harvested fruits are perishable products of great value. The results of this study provide evidence of the high potential of the incorporation of $M$. pulcherrima isolated from apples into edible coatings as a safe, natural and sustainable postharvest control tool. Edible fims maintained $M$. pulcherrima cell viability for long-term, and also reduced the growth of $P$. expansum under in vitro conditions. The apple pomace matrix exhibited the bests results maintaining viability and producing antifungal activity in vitro. Therefore, it was chosen as a carrier of $M$. pulcherrima for coating apples, the active coating exerted a good level 
of inhibition of blue mold decay on artificially inoculated apples. These results are encouraging, remarkably considering that the conditions assessed in the study are far worse than those that normally occur during the postharvest, in terms of the degree of fruit damage and pathogen inoculum level. In addition, the results are pioneering showing the antifungal effectiveness of a biocontrol yeast isolated from apples and entrapped in a coating made entirely from apple residues. The developed active coating was able to control the most sever apple disease, the blue mold decay produced by $P$. expansum and also its harmful mycotoxin, the patulin.

\section{Acknowledgments}

The authors acknowledge the financial support of the European union (Erasmus grant) and the PATRISK project funded by Agence Nationale de la Recherche (ANR), grant number ANR-17-CE21-0008.

\section{References}

1. Tournas, V.; Katsoudas, E. Effect of $\mathrm{CaCl} 2$ and Various Wild Yeasts From Plant Origin on Controlling Penicillium expansum Postharvest Decays in Golden Delicious Apples. Microbiol. Insights 2019, 12, 117863611983764, doi:10.1177/1178636119837643.

2. Abouraïcha, E.; El Alaoui-Talibi, Z.; El Boutachfaiti, R.; Petit, E.; Courtois, B.; Courtois, J.; El Modafar, C. Induction of natural defense and protection against Penicillium expansum and Botrytis cinerea in apple fruit in response to bioelicitors isolated from green algae. Sci. Hortic. (Amsterdam). 2015, 181, 121-128, doi:10.1016/j.scienta.2014.11.002.

3. Vidal, A.; Ouhibi, S.; Ghali, R.; Hedhili, A.; De Saeger, S.; De Boevre, M. The mycotoxin patulin: An updated short review on occurrence, toxicity and analytical challenges. Food Chem. Toxicol. 2019, 129, 249-256.

4. Saleh, I.; Goktepe, I. The characteristics, occurrence, and toxicological effects of patulin. Food Chem. Toxicol. 2019, 129, 301-311, doi:10.1016/J.FCT.2019.04.036.

5. Mahunu, G.K.; Zhang, H.; Yang, Q.; Li, C.; Zheng, X. Biological Control of Patulin by Antagonistic Yeast: A case study and 
possible model. Crit. Rev. Microbiol. 2016, 42, 643-655.

6. da Rocha Neto, A.C.; Luiz, C.; Maraschin, M.; Di Piero, R.M. Efficacy of salicylic acid to reduce Penicillium expansum inoculum and preserve apple fruits. Int. J. Food Microbiol. 2016, 221, 54-60, doi:10.1016/j.ijfoodmicro.2016.01.007.

7. Lamichhane, J.R.; Dachbrodt-Saaydeh, S.; Kudsk, P.; Messéan, A. Toward a Reduced Reliance on Conventional Pesticides in European Agriculture. Plant Dis. 2016, 100, 10-24, doi:10.1094/PDIS-05-15-0574-FE.

8. Gava, C.A.T.; de Castro, A.P.C.; Pereira, C.A.; Fernandes-Júnior, P.I. Isolation of fruit colonizer yeasts and screening against mango decay caused by multiple pathogens. Biol. Control 2018, 117, 137-146, doi:10.1016/J.BIOCONTROL.2017.11.005.

9. Jijakli, M.H.; Lepoivre, P.; Grevesse, C. Yeast Species for Biocontrol of Apple Postharvest Diseases: An Encouraging Case of Study for Practical Use. In Biotechnological Approaches in Biocontrol of Plant Pathogens; Springer US: Boston, MA, 1999; pp. 31-49.

10. Spadaro, D.; Droby, S. Development of biocontrol products for postharvest diseases of fruit: The importance of elucidating the mechanisms of action of yeast antagonists. Trends Food Sci. Technol. 2016, 47, 39-49, doi:10.1016/j.tifs.2015.11.003.

11. Freimoser, F.M.; Rueda-Mejia, M.P.; Tilocca, B.; Migheli, Q. Biocontrol yeasts: mechanisms and applications. World J. Microbiol. Biotechnol. 2019, 35, 154.

12. Janisiewicz, W.J.; Tworkoski, T.J.; Kurtzman, C.P. Biocontrol potential of Metschnikowia pulcherrima strains against blue mold of apple. Phytopathology 2001, 91, 1098-1108, doi:10.1094/PHYTO.2001.91.11.1098.

13. Usall, J.; Teixidó, N.; Fons, E.; Viñas, I. Biological control of blue mould on apple by a strain of Candida sake under several controlled atmosphere conditions. Int. J. Food Microbiol. 2000, 58, 83-92, doi:10.1016/S0168-1605(00)00285-3.

14. Guilbert, S.; Gontard, N.; Gorris, L.G.M. Prolongation of the Shelf-life of Perishable Food Products using Biodegradable Films and Coatings. LWT - Food Sci. Technol. 1996, 29, 10-17, doi:10.1006/FSTL.1996.0002.

15. Cazón, P.; Velazquez, G.; Ramírez, J.A.; Vázquez, M. Polysaccharide-based films and coatings for food packaging: A review. Food Hydrocoll. 2017, 68, 136-148, 
doi:10.1016/j.foodhyd.2016.09.009.

16. Porat, R.; Weiss, B.; Cohen, L.; Daus, A.; Biton, A. Effects of polyethylene wax content and composition on taste, quality, and emission of off-flavor volatiles in 'Mor' mandarins. Postharvest Biol. Technol. 2005, 38, 262-268, doi:10.1016/J.POSTHARVBIO.2005.07.009.

17. Parafati, L.; Vitale, A.; Restuccia, C.; Cirvilleri, G. Biocontrol ability and action mechanism of food-isolated yeast strains against Botrytis cinerea causing post-harvest bunch rot of table grape. Food Microbiol. 2015, 47, 85-92, doi:10.1016/j.fm.2014.11.013.

18. Plaza, M.; Abrahamsson, V.; Turner, C. Extraction and Neoformation of Antioxidant Compounds by Pressurized Hot Water Extraction from Apple Byproducts. J. Agric. Food Chem. 2013, 61, 5500-5510, doi:10.1021/jf400584f.

19. Skinner, R.C.; Gigliotti, J.C.; Ku, K.-M.; Tou, J.C. A comprehensive analysis of the composition, health benefits, and safety of apple pomace. Nutr. Rev. 2018, doi:10.1093/nutrit/nuy033.

20. Bhushan, S.; Kalia, K.; Sharma, M.; Singh, B.; Ahuja, P.S. Processing of apple pomace for bioactive molecules. Crit. Rev. Biotechnol. 2008, 28, 285-296.

21. Min, B.; Lim, J.; Ko, S.; Lee, K.G.; Lee, S.H.; Lee, S. Environmentally friendly preparation of pectins from agricultural byproducts and their structural/rheological characterization. Bioresour. Technol. 2011, 102, 3855-3860, doi:10.1016/j.biortech.2010.12.019.

22. Gustafsson, J.; Landberg, M.; Bátori, V.; Åkesson, D.; Taherzadeh, M.J.; Zamani, A. Development of Bio-Based Films and 3D Objects from Apple Pomace. Polymers (Basel). 2019, 11, 289, doi:10.3390/polym11020289.

23. Riachy, R. Al; Strub, C.; Durand, N.; Guibert, B.; Guichard, H.; Constancias, F.; Chochois, V.; Lopez-Lauri, F.; Fontana, A.; Schorr-Galindo, S. Microbiome status of cider-apples, from orchard to processing, with a special focus on Penicillium expansum occurrence and patulin contamination. J. Fungi 2021, 7, 244, doi:10.3390/jof7040244.

24. Settier-Ramírez, L.; López-Carballo, G.; Hernández-Muñoz, P.; Fontana, A.; Strub, C.; Schorr-Galindo, S. New Isolated Metschnikowia pulcherrima Strains from Apples for Postharvest Biocontrol of Penicillium expansum and Patulin Accumulation. Toxins (Basel). 2021, 13, 397, doi:10.3390/toxins13060397. 
25. Kregiel, D. Health safety of soft drinks: Contents, containers, and microorganisms. Biomed Res. Int. 2015, 2015, doi:10.1155/2015/128697.

26. De Araújo, Á.A.; Roussos, S. A technique for mycelial development of ectomycorrhizal fungi on agar media. Appl. Biochem. Biotechnol. - Part A Enzym. Eng. Biotechnol. 2002, 98100, 311-318, doi:10.1385/ABAB:98-100:1-9:311.

27. Tannous, J.; Atoui, A.; El Khoury, A.; Kantar, S.; Chdid, N.; Oswald, I.P.; Puel, O.; Lteif, R. Development of a real-time PCR assay for Penicillium expansum quantification and patulin estimation in apples. Food Microbiol. 2015, 50, 28-37, doi:10.1016/J.FM.2015.03.001.

28. Marsit, S.; Dequin, S. Diversity and adaptive evolution of Saccharomyces wine yeast: a review. FEMS Yeast Res. 2015, 15, 67.

29. Câmara, A. de A.; Maréchal, P.A.; Tourdot-Maréchal, R.; Husson, F. Dehydration stress responses of yeasts Torulaspora delbrueckii, Metschnikowia pulcherrima and Lachancea thermotolerans: Effects of glutathione and trehalose biosynthesis. Food Microbiol. 2019, 79, 137-146, doi:10.1016/j.fm.2018.12.008.

30. Câmara, A. de A.; Maréchal, P.A.; Tourdot-Maréchal, R.; Husson, F. Oxidative stress resistance during dehydration of three nonSaccharomyces wine yeast strains. Food Res. Int. 2019, 123, 364-372, doi:10.1016/j.foodres.2019.04.059.

31. Muccilli, S.; Restuccia, C. Bioprotective Role of Yeasts. Microorganisms 2015, 3, 588-611, doi:10.3390/microorganisms3040588.

32. Marín, A.; Atarés, L.; Chiralt, A. Improving function of biocontrol agents incorporated in antifungal fruit coatings: a review. Biocontrol Sci. Technol. 2017, 27, 1220-1241, doi:10.1080/09583157.2017.1390068.

33. Kasprow, R.P.; Lange, A.J.; Kirwan, D.J. Correlation of Fermentation Yield with Yeast Extract Composition as Characterized by Near-Infrared Spectroscopy. Biotechnol. Prog. 1998, 14, 318-325, doi:10.1021/bp980001j.

34. Vieira, E.F.; Carvalho, J.; Pinto, E.; Cunha, S.; Almeida, A.A.; Ferreira, I.M.P.L.V.O. Nutritive value, antioxidant activity and phenolic compounds profile of brewer's spent yeast extract. J. Food Compos. Anal. 2016, 52, 44-51, 
doi:10.1016/j.jfca.2016.07.006.

35. Trofimova, Y.; Walker, G.; Rapoport, A. Anhydrobiosis in yeast: influence of calcium and magnesium ions on yeast resistance to dehydration-rehydration. FEMS Microbiol. Lett. 2010, 308, 55-61, doi:10.1111/j.1574-6968.2010.01989.x.

36. Brachkova, M.I; Marques, P.; Rocha, J.; Sepodes, B.; Duarte, M.A.; Pinto, J.F. Alginate films containing Lactobacillus plantarum as wound dressing for prevention of burn infection. J. Hosp. Infect. 2011, 79, 375-377, doi:10.1016/j.jhin.2011.09.003.

37. Settier-Ramírez, L.; López-Carballo, G.; Gavara, R.; HernándezMuñoz, P. Broadening the antimicrobial spectrum of nisinproducing Lactococcus lactis subsp. lactis to Gram-negative bacteria by means of active packaging. Int. J. Food Microbiol. 2021, 339, 109007, doi:10.1016/j.jifoodmicro.2020.109007.

38. Marín, A.; Atarés, L.; Cháfer, M.; Chiralt, A. Properties of biopolymer dispersions and films used as carriers of the biocontrol agent Candida sake CPA-1. LWT - Food Sci. Technol. 2017, 79, 60-69, doi:10.1016/j.lwt.2017.01.024.

39. Pavli, F.; Tassou, C.; Nychas, G.J.E.; Chorianopoulos, N. Probiotic incorporation in edible films and coatings: Bioactive solution for functional foods. Int. J. Mol. Sci. 2018, 19, 150.

40. González-Estrada, R.R.; Carvajal-Millán, E.; Ragazzo-Sánchez, J.A.; Bautista-Rosales, P.U.; Calderón-Santoyo, M. Control of blue mold decay on Persian lime: Application of covalently cross-linked arabinoxylans bioactive coatings with antagonistic yeast entrapped. LWT - Food Sci. Technol. 2017, 85, 187-196, doi:10.1016/J.LWT.2017.07.019.

41. Odila Pereira, J.; Soares, J.; Sousa, S.; Madureira, A.R.; Gomes, A.; Pintado, M. Edible films as carrier for lactic acid bacteria. LWT Food Sci. Technol. 2016, 73, 543-550, doi:10.1016/j.Iwt.2016.06.060.

42. Tripathi, M.K.; Giri, S.K. Probiotic functional foods: Survival of probiotics during processing and storage. J. Funct. Foods 2014, 9, 225-241.

43. Carvalho, A.S.; Silva, J.; Ho, P.; Teixeira, P.; Malcata, F.X.; Gibbs, P. Relevant factors for the preparation of freeze-dried lactic acid bacteria. Int. Dairy J. 2004, 14, 835-847.

44. Meng, X.C.; Stanton, C.; Fitzgerald, G.F.; Daly, C.; Ross, R.P. Anhydrobiotics: The challenges of drying probiotic cultures. 
Food Chem. 2008, 106, 1406-1416, doi:10.1016/j.foodchem.2007.04.076.

45. Manso, T.; Nunes, C. Metschnikowia andauensis as a new biocontrol agent of fruit postharvest diseases. Postharvest Biol. Technol. 2011, 61 , 64-71, doi:10.1016/j.postharvbio.2011.02.004.

46. Guimarães, A.; Abrunhosa, L.; Pastrana, L.M.; Cerqueira, M.A. Edible Films and Coatings as Carriers of Living Microorganisms: A New Strategy Towards Biopreservation and Healthier Foods. Compr. Rev. Food Sci. Food Saf. 2018, 17, 594-614.

47. Yu, T.; Yu, C.; Chen, F.; Sheng, K.; Zhou, T.; Zunun, M.; Abudu, O.; Yang, S.; Zheng, $X$. Integrated control of blue mold in pear fruit by combined application of chitosan, a biocontrol yeast and calcium chloride. Postharvest Biol. Technol. 2012, 69, 49-53, doi:10.1016/J.POSTHARVBIO.2012.02.007.

48. Phane Dagnas, S.; Membré, J.-M. Predicting and Preventing Mold Spoilage of Food Products. J. Food Prot. 2013, 76, 538551, doi:10.4315/0362-028X.JFP-12-349.

49. $Y u, T$.; $Y u, C$.; Lu, H.; Zunun, M.; Chen, F.; Zhou, T.; Sheng, K.; Zheng, $X$. Effect of Cryptococcus laurentii and calcium chloride on control of Penicillium expansum and Botrytis cinerea infections in pear fruit. Biol. Control 2012, 61, 169-175, doi:10.1016/j.biocontrol.2012.01.012.

50. Aloui, H.; Licciardello, F.; Khwaldia, K.; Hamdi, M.; Restuccia, C. Physical properties and antifungal activity of bioactive films containing Wickerhamomyces anomalus killer yeast and their application for preservation of oranges and control of postharvest green mold caused by Penicillium digitatum. Int. J. Food Microbiol. 2015, 200, 22-30, doi:10.1016/J.IJFOODMICRO.2015.01.015.

51. Settier-Ramírez, L.; López-Carballo, G.; Gavara, R.; HernándezMuñoz, P. Antilisterial properties of $\mathrm{PVOH}$-based films embedded with Lactococcus lactis subsp. lactis. Food Hydrocoll. 2019, 87, 214-220, doi:10.1016/j.foodhyd.2018.08.007.

52. Türkel, S.; Korukluoğlu, M.; Yavuz, M. Biocontrol Activity of the Local Strain of Metschnikowia pulcherrima on Different Postharvest Pathogens. Biotechnol. Res. Int. 2014, 2014, 1-6, doi:10.1155/2014/397167.

53. Gore-Lloyd, D.; Sumann, I.; Brachmann, A.O.; Schneeberger, K.; Ortiz-Merino, R.A.; Moreno-Beltrán, M.; Schläfli, M.; Kirner, P.; 
Santos Kron, A.; Rueda-Mejia, M.P.; et al. Snf2 controls pulcherriminic acid biosynthesis and antifungal activity of the biocontrol yeast Metschnikowia pulcherrima. Mol. Microbiol. 2019, 112, 317-332, doi:10.1111/mmi.14272.

54. Sharma, P.; Shehin, V.P.; Kaur, N.; Vyas, P. Application of edible coatings on fresh and minimally processed vegetables: a review. Int. J. Veg. Sci. 2019, 25, 295-314, doi:10.1080/19315260.2018.1510863.

55. Soliva-Fortuny, R.C.; Elez-Martínez, P.; Martín-Belloso, O. Microbiological and biochemical stability of fresh-cut apples preserved by modified atmosphere packaging. Innov. Food Sci. Emerg. Technol. 2004, 5, 215-224, doi:10.1016/J.IFSET.2003.11.004.

56. Reddy, K.R.N.; Spadaro, D.; Lore, A.; Gullino, M.L.; Garibaldi, A. Potential of patulin production by Penicillium expansum strains on various fruits. Mycotoxin Res. 2010, 26, 257-265, doi:10.1007/s12550-010-0064-5.

57. Snini, S.P.; Tannous, J.; Heuillard, P.; Bailly, S.; Lippi, Y.; Zehraoui, E.; Barreau, C.; Oswald, I.P.; Puel, O. Patulin is a cultivardependent aggressiveness factor favouring the colonization of apples by Penicillium expansum. Mol. Plant Pathol. 2016, 17, 920-930, doi:10.1111/mpp.12338.

58. Tannous, J.; Keller, N.P.; Atoui, A.; El Khoury, A.; Lteif, R.; Oswald, I.P.; Puel, O. Secondary metabolism in Penicillium expansum: Emphasis on recent advances in patulin research. Crit. Rev. Food Sci. Nutr. 2018, 58, 2082-2098, doi:10.1080/10408398.2017.1305945.

59. Sanzani, S.M.; Reverberi, M.; Punelli, M.; Ippolito, A.; Fanelli, C. Study on the role of patulin on pathogenicity and virulence of Penicillium expansum. Int. J. Food Microbiol. 2012, 153, 323331, doi:10.1016/j.jifoodmicro.2011.11.021. 


\section{DISCUSIÓN GENERAL}



Los resultados de esta Tesis Doctoral, que se presentan en los tres capítulos anteriores, responden a un objetivo común de desarrollo, caracterización y aplicación de películas y recubrimientos activos basados en la incorporación de agentes de biocontrol con el fin de inhibir la proliferación de microorganismos (como bacterias y hongos) para aumentar la seguridad y prolongar la vida útil de los alimentos.

La tabla 1 muestra un resumen de las matrices poliméricas empleadas, así como el coadyuvante añadido y su concentración nominal, el agente de biocontrol utilizado, los microorganismos patógenos y alterantes ensayados, la forma de aplicación y el alimento al que se aplicó. 
Tabla 1. Desarrollo y aplicación de películas activas portadoras de microorganismos para la bioconservación de alimentos

\begin{tabular}{|c|c|c|c|c|c|c|c|}
\hline & \multirow{2}{*}{ Matriz } & \multicolumn{2}{|c|}{ Coadyuvante } & \multirow{2}{*}{$\begin{array}{l}\text { Agente de } \\
\text { biocontrol }\end{array}$} & \multirow{2}{*}{$\begin{array}{c}\text { Microorganismos } \\
\text { diana }\end{array}$} & \multirow{2}{*}{ Aplicación } & \multirow{2}{*}{ Alimento } \\
\hline & & Tipo & Concentración & & & & \\
\hline \multirow{7}{*}{$\frac{\overline{0}}{\frac{2}{3}}$} & & - & - & & & & - \\
\hline & & Gel & & & & & - \\
\hline & PVOH & Cas & & lactic & 1 monocytorenes & Película & - \\
\hline & $(2 \%)$ & HGel & $(1: 0.125)$ & L. Iactis & L. monocytogenes & Pellcula & Leche \\
\hline & & HCas & & & & & - \\
\hline & & YE & & & & & - \\
\hline & $\begin{array}{l}\text { PVOH } \\
(2 \%)\end{array}$ & $\begin{array}{c}- \\
\text { HCas } \\
\text { HCas }\end{array}$ & $\begin{array}{c}- \\
(1: 0.125) \\
(1: 1)\end{array}$ & $\begin{array}{l}\text { L. lactis } \\
\text { L. sakei }\end{array}$ & L. monocytogenes & Película & - \\
\hline \multirow{3}{*}{$\begin{array}{l}\frac{=}{0} \\
\frac{0}{3} \\
\frac{\pi}{0} \\
\frac{0}{0}\end{array}$} & $\begin{array}{l}\text { PVOH } \\
(10 \%)\end{array}$ & HGel & $(1: 0.125)$ & L. lactis & L. monocytogenes & $\begin{array}{l}\text { Recubrimiento en PLA } \\
\text { Bolsas }(4 \times 8 \mathrm{~cm}) \\
\text { Recubrimiento en PLA } \\
\text { Separador lonchas }\end{array}$ & $\begin{array}{c}\text { Crema de } \\
\text { setas } \\
\text { Jamón cocido }\end{array}$ \\
\hline & $\begin{array}{l}\text { PVOH } \\
(2 \%)\end{array}$ & HCas & $(1: 1)$ & $\left.\begin{array}{c}- \\
\text { L. lactis } \\
\mathrm{AF} \\
\text { L. lactis y } \mathrm{AF}\end{array}\right\}$ & $\begin{array}{c}\text { E. coli } \\
\text { S. enterica } \\
\text { P. fluorescens } \\
\text { L. monocytogenes }\end{array}$ & Película & - \\
\hline & $\begin{array}{l}\text { PVOH } \\
(10 \%)\end{array}$ & HCas & $(1: 1)$ & L. lactis y AF & $\begin{array}{c}\text { Microorganismos } \\
\text { totales }\end{array}$ & $\begin{array}{c}\text { Recubrimiento en PE } \\
\text { Bolsas }(4 \times 8 \mathrm{~cm})\end{array}$ & $\begin{array}{c}\text { Crema } \\
\text { pastelera }\end{array}$ \\
\hline
\end{tabular}




\begin{tabular}{|c|c|c|c|c|c|c|c|}
\hline \multirow{10}{*}{ 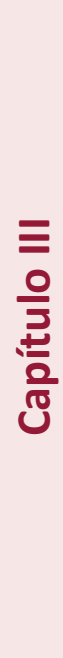 } & & - & - & \multirow{10}{*}{ M. pulcherrima } & \multirow{10}{*}{ P. expansum } & & \multirow[b]{10}{*}{$\begin{array}{c}\text { Manzanas } \\
\text { Golden } \\
\text { Delicious }\end{array}$} \\
\hline & & YEG & Medio cultivo & & & \multirow{8}{*}{ Película } & \\
\hline & Pectina & $\mathrm{CaCl}_{2}$ & $10 \%, 2 \mathrm{~min}$ & & & & \\
\hline & & $\mathrm{YEG}+\mathrm{CaCl}_{2}$ & $\begin{array}{c}\text { Medio cultivo+ } \\
10 \%, 2 \mathrm{~min}\end{array}$ & & & & \\
\hline & & - & - & & & & \\
\hline & $\mathrm{IVIC}$ & YEG & Medio cultivo & & & & \\
\hline & HPMC & $\overline{Y E G}$ & Medio cultivo & & & & \\
\hline & Orujo de & - & - & & & & \\
\hline & manzana & $\mathrm{CaCl}_{2}$ & $10 \%, 2 \mathrm{~min}$ & & & & \\
\hline & $\begin{array}{l}\text { Orujo de } \\
\text { manzana }\end{array}$ & - & - & & & $\begin{array}{l}\text { Recubrimiento } \\
\text { sobre alimento }\end{array}$ & \\
\hline
\end{tabular}


En el capítulo I se ha trabajado con el objetivo de desarrollar películas de $\mathrm{PVOH}$ que incorporen bacterias ácido lácticas con actividad antimicrobiana frente a $L$. monocytogenes. En la figura 1 , se muestran las diferentes partes en las que se divide este capítulo.

Parte I

\section{Optimización de películas}

- Polímero principal: $\underline{\mathrm{PVOH}}$

- Coadyuvantes, proporción (1:0.125)*

Gel, Cas, $\underline{\mathrm{HGel}}$ HCas, YE

- Agente de biocontrol: L. lactis
Caracterización películas

Viabilidad BCA en películas

Capacidad antilisteria películas

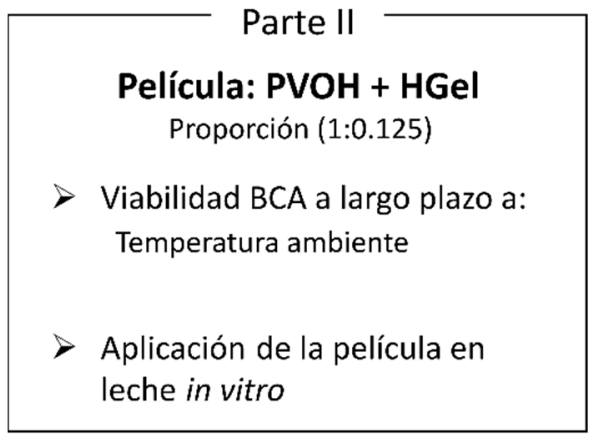

Parte III

Película: PVOH + HCas

Comparación cambiando las proporciones de $\mathrm{PVOH}$ y $\mathrm{HCas}$ Proporciones (1:0), (1:0.125) y (1:1)

$>$ Comparación L. lactis y L. sakei

Caracterización de las películas

*Todas las proporciones se refieren a (Polímero principal:Coadyuvante)

Figura 1. Esquema de las partes del capítulo 1

La bacteria ácido láctica Lactococcus lactis, ampliamente estudiada por su capacidad de generar nisina y tener actividad antimicrobiana frente a bacterias Gram-positivas, se escogió para el desarrollo de las películas activas. En un primer estudio realizado en medio de cultivo con diferentes concentraciones de $L$. lactis frente a $4 \mathrm{log} / \mathrm{mL}$ de $L$. monocytogenes, se estableció la concentración inicial mínima necesaria de L. lactis viable para observar un efecto antimicrobiano sobre la bacteria patógena. Esta concentración de $L$. lactis fue la seleccionada para trabajar durante toda la tesis. Independientemente de la concentración de L. lactis inicial, tras $24 \mathrm{~h}$ incubando frente a L. monocytogenes, fue capaz de alcanzar la misma concentración, aunque su actividad antimicrobiana fue menor cuanta menos concentración inicial de $L$. lactis se inoculó. Por lo tanto, la concentración elegida de $L$. lactis para incorporar en las películas fue de $10^{9} \mathrm{UFC} /$ película. EI 
PVOH se escogió como polímero principal por sus múltiples ventajas a nivel tecnológico y sus buenas propiedades para hacer películas. Sin embargo, al ser un polímero sintético que carece de $\mathrm{C}$ y $\mathrm{N}$ se decidió añadir una pequeña proporción de diferentes proteínas como coadyuvante para aumentar la viabilidad de las bacterias ácido lácticas cuando se incorporan en las películas y así, potenciar su actividad antimicrobiana.

En la primera parte del capítulo I se desarrollaron películas de PVOH a las que se le añadió como coadyuvante en proporción (1:0.125), gelatina, caseinato sódico, gelatina hidrolizada, caseína hidrolizada o extracto de levadura (cóctel de aminoácidos y vitaminas). Estas proteínas se caracterizan por tener un tamaño de cadena más o menos largo pudiendo modificar las propiedades de las películas desarrolladas y fomentar en mayor medida la viabilidad de las LAB. Para ello se llevaron a cabo estudios de caracterización en los que se demostró que la adición de esta proporción de proteínas no tuvo efecto sobre el espesor de las películas. Las imágenes de SEM revelaron una buena compatibilidad de las matrices entre sí. La adición de proteínas aumentó el contenido en humedad en un $25 \%$ en las películas almacenadas a $43 \%$ debido al carácter higroscópico de las proteínas y aumentó la opacidad de las películas en el espectro UV.

El secado de las películas es un factor crítico en la supervivencia de las LAB y se observó que efectivamente, dicha supervivencia dependió de la matriz a la que se incorporaron. La mayor viabilidad se obtuvo en las películas a las que se les añadió HGel y HCas. También se estudió la supervivencia de las LAB en películas almacenadas durante 1 mes a $43 \% \mathrm{HR}$ y $20{ }^{\circ} \mathrm{C}$ y su actividad antilisteria tras ese periodo de almacenamiento. Una vez más, las películas que incorporaron $\mathrm{HGel}$ y $\mathrm{HCas}$ fueron capaces de mantener la viabilidad de L. lactis. Esto es seguramente debido a que tanto el tamaño como la naturaleza de los hidrolizados proporcionó protección durante la deshidratación y el posterior almacenamiento.

La actividad antilisteria observada fue mayor cuanto mayor fue la viabilidad de las bacterias lácticas en las películas independientemente del crecimiento posterior de L. lactis en contacto con L. monocytogenes. Por lo tanto, los dos coadyuvantes que mostraron mantener la viabilidad de $L$. lactis y aumentar su capacidad antilisteria a la vez que no supusieron grandes cambios en las propiedades de las películas, se seleccionaron para seguir el capítulo.

En la segunda parte del capítulo I se trabajó con películas de $\mathrm{PVOH}+\mathrm{HGel}$ en proporción (1:0.125). Como se ha visto en el apartado anterior, al ser la viabilidad de $L$. lactis un requisito determinante en la posterior actividad antilisteria de las películas, se estudió su viabilidad en películas 
almacenadas a $22 \% \mathrm{HR}, 43 \% \mathrm{HR}$ y $75 \% \mathrm{HR}$ a $20{ }^{\circ} \mathrm{C}$ durante 1 año que se muestra en la figura 2.

\section{L. lactis viability}

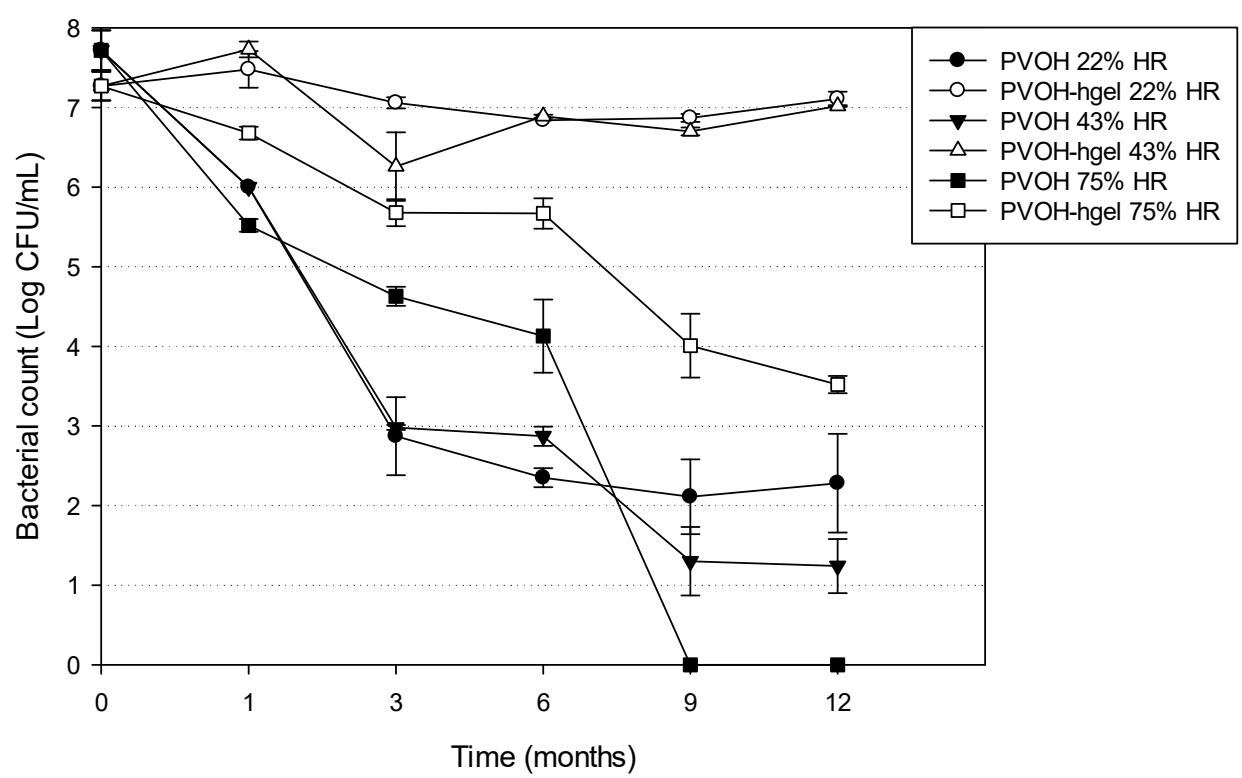

Figura 2. Viabilidad de $L$. lactis en películas de $\mathrm{PVOH}$ y $\mathrm{PVOH}+\mathrm{HGel}$ durante 1 año de almacenamiento a $20^{\circ} \mathrm{C}$ y a $22 \% \mathrm{HR}, 43 \% \mathrm{HR}$ y $75 \% \mathrm{HR}$.

La humedad y la composición de la matriz resultaron ser factores decisivos en el mantenimiento de la viabilidad de L. lactis. A mayor humedad relativa ambiente, menor viabilidad. Esto puede explicarse porque a mayor humedad, las células salen de la latencia, determinadas reacciones enzimáticas se ponen en marcha como han apuntado otros autores [1]. Además, cabe destacar que el PVOH y el HGel son alta barrera al oxígeno, molécula responsable del deterioro de la membrana lipídica y la consiguiente muerte celular. Cuanto mayor humedad presentan estas películas, mayor es su permeabilidad al oxígeno y, por lo tanto, menor es la protección que ejercen sobre L. lactis. Por otro lado, una pequeña cantidad de HGel añadida a la matriz de $\mathrm{PVOH}$ fue suficiente para mantener la viabilidad de las bacterias lácticas durante un año perdiéndose únicamente 1 log en la viabilidad. Además de este ensayo, las películas fueron almacenadas durante 2 años obteniéndose una viabilidad de $1.60 \pm 0.20 \mathrm{log}$ para el PVOH al $22 \%, 4 \pm 0.12$ log para el PVOH+HGel al $22 \%, 3.77 \pm 0.32$ log para el PVOH+HGel al $43 \%$ y no se mantuvieron viables en el $\mathrm{PVOH}$ al $43 \%$, el $\mathrm{PVOH}$ al $75 \%$ y el 
$\mathrm{PVOH}+\mathrm{HGel}$ al $75 \%$. Por último, películas de $\mathrm{PVOH}+\mathrm{HGel}$ almacenadas al 43 $\%$ demostraron mantener la viabilidad en $3.57 \pm 0.18$ log durante 4 años. Estos últimos resultados permiten afirmar que las películas preparadas con $\mathrm{PVOH}+\mathrm{HGel}$ y almacenadas en condiciones de baja humedad relativa tienen una vida útil de mínimo 4 años. Viendo estos resultados tan prometedores, esta forma de incorporar bacterias a películas podría ser usada para otros fines diferentes al del desarrollo de envases como por ejemplo al de la conservación de cepas microbiológicas en condiciones de temperatura ambiente o en el almacenamiento o transporte de cepas.

Por último, se realizó una primera aplicación en un alimento real inoculado con L. monocytogenes. Se eligió la leche por tener un pH neutro y por ser uno de los principales ingredientes de alimentos listos para su consumo como salsas, cremas, batidos o alimentos precocinados que pueden presentar L. monocytogenes. Los resultados en cuanto a viabilidad y actividad antilisteria fueron muy similares a los obtenidos en medio de cultivo líquido. Sin embargo, el pH fue disminuyendo a lo largo del almacenamiento debido a la generación de ácido láctico por parte de L. lactis. Para solucionar este inconveniente se estudió la utilización de un corrector de acidez y se demostró que, tras añadirlo en la leche, no solo se mantuvo el pH a lo largo del almacenamiento, sino que, además no se modificó la actividad antilisteria proporcionada por las películas por lo que todo apuntó a que el principal mecanismo antimicrobiano de L. lactis es la generación de la bacteriocina nisina.

En la tercera parte del capítulo I, se trabajó con películas de PVOH con el coadyuvante HCas. En esta parte, con el objetivo de estudiar la capacidad antimicrobiana de las películas, se añadieron diferentes concentraciones de HCas y se compararon entre sí. Para ello se desarrollaron películas sin y con HCas en proporción (1:0.125) y (1:1). Además, se comparó la viabilidad y la actividad antilisteria de L. lactis con otra bacteria láctica, Lactobacillus sakei conocida por ser capaz de generar sakacina, una bacteriocina que también tiene capacidad antimicrobiana contra las bacterias Gram-positivas como L. monocytogenes.

La viabilidad de las células tras el secado de la película dependió de la cepa, siendo más resistente L. lactis. Esta viabilidad fue mayor cuanto mayor fue el contenido de HCas en la matriz polimérica. Las películas suplementadas con HCas también mantuvieron la viabilidad de L. lactis y L. sakei durante un mes de almacenamiento. El estudio de la morfología de la superficie de las películas mediante microscopía óptica de fluorescencia reveló que la adición de HCas promovió la autoagregación de las células, que fue más acusada para 
la cepa $L$. lactis que para $L$. sakei. La autoagregación celular está relacionada con una mayor tasa de supervivencia frente a estreses tales como la deshidratación que sufren las bacterias durante el secado de la película o frente al oxígeno, molécula responsable de la oxidación de la capa lipídica de la membrana celular y su consiguiente muerte. La mayor actividad antilisteria se obtuvo con las películas de PVOH mezclado con HCas en una proporción de peso de (1:1) e incorporando L. lactis. HCas actuó como plastificante del $\mathrm{PVOH}$, cuando se añadió una gran cantidad de HCas a las películas, su resistencia mecánica disminuyó drásticamente mejorando la elongación de la película, aumentaron las propiedades de barrera frente a los rayos UV, disminuyó la cristalinidad de las películas y aumentó casi en un $100 \%$ la capacidad antioxidante de las mismas.

En este capítulo ha quedado demostrado que las matrices de $\mathrm{PVOH}+\mathrm{HGel}$ en proporción (1:0.125) y de $\mathrm{PVOH}+\mathrm{HCas}$ en proporción (1:1) que incorporan Lactococcus lactis son las mejores opciones para desarrollar envases activos con capacidad antimicrobiana para controlar el crecimiento de L. monocytogenes en alimentos.

La propuesta del capítulo II se centra en la aplicación tecnológica de las películas desarrolladas en el capítulo anterior seleccionadas por su actividad antimicrobiana, como envases activos antilisteria y como envases activos para aumentar la vida útil de los alimentos.

En la primera parte del capítulo II se desarrollaron recubrimientos de PVOH con una pequeña cantidad de hidrolizado de gelatina sobre PLA incorporando Lactococcus lactis para controlar el crecimiento de Listeria monocytogenes en alimentos y se estudió la viabilidad de L. lactis y su capacidad antilisteria in vitro, en medio de cultivo líquido y sólido en condiciones de refrigeración.

La principal diferencia entre las películas estudiadas en el capítulo anterior $\mathrm{y}$ los recubrimientos es que se tuvieron que aumentar las concentraciones de polímero y de bacterias por $\mathrm{cm}^{2}$ de película ya el espesor del recubrimiento fue menor $(15 \mu \mathrm{m})$ que el espesor de las películas $(45 \mu \mathrm{m})$. Además, esto conllevó a una reducción significativa del tiempo de secado pasando de $20 \mathrm{~h}$ para las películas a 30 min para los recubrimientos. A pesar de estos cambios la viabilidad de $L$. lactis y el efecto bacteriostático contra $L$. monocytogenes en medio líquido (TSB + YE) fue muy similar. Para predecir el crecimiento de las bacterias en alimentos sólidos, los estudios in vitro deben realizarse en condiciones que reflejen lo máximo posible las condiciones reales, por lo que se realizó el mismo estudio con los recubrimientos desarrollados, pero en medio de cultivo sólido (TSA+YE). 
Aunque la viabilidad de L. lactis observada fue la misma que en medio de cultivo líquido, los recubrimientos demostraron tener un efecto bacteriostático y un efecto bactericida tras los primeros 4 días de almacenamiento. En este caso, las bacterias no pudieron migrar hacia el interior del agar sólido y las colonias aparecieron inmovilizadas en la superficie por lo que, aunque la proporción entre L. lactis y L. monocytogenes fue la misma, la zona de contacto de ambas bacterias es mayor, por lo tanto, habrá más competencia por el alimento y el espacio para crecer. Además, los subproductos del metabolismo de L. lactis, como la nisina o los ácidos orgánicos, estarán más concentrados que en el medio líquido, lo que podría explicar los resultados de este estudio. Por otro lado, las cepas de $L$. monocytogenes son altamente flageladas y móviles a bajas temperaturas $(\leq 30$ ${ }^{\circ} \mathrm{C}$ ), mientras que $L$. lactis no es móvil. En varios casos en los que existe competencia entre varias especies bacterianas, se ha demostrado que la motilidad con flagelos puede proporcionar una ventaja específica para una bacteria en un medio de cultivo líquido [2].

Para aplicar los recubrimientos en alimentos reales se realizaron bolsas termoselladas de PLA bioactivas para envasar crema de champiñones y separadores de lonchas de PLA bioactivo para aplicar en lonchas de jamón cocido tal y como se describe en el esquema de la figura 3.

En ambos alimentos se estudió la viabilidad de L. lactis, así como su actividad antilisteria durante su almacenamiento en condiciones de refrigeración. La actividad antilisteria de L. lactis observada en la crema de champiñones fue muy similar a las obtenidas en el medio de cultivo líquido donde el envase ejerció un efecto bacteriostático sobre el patógeno inoculado en la crema de setas. Debido a la complejidad de la matriz alimentaria con respecto al medio de cultivo, varios estudios han demostrado que se requiere una mayor concentración de nisina en alimentos reales que en medios de cultivo. Por lo tanto, generalmente se requieren mayores concentraciones de agentes antimicrobianos cuando se aplican a los alimentos [3]. 


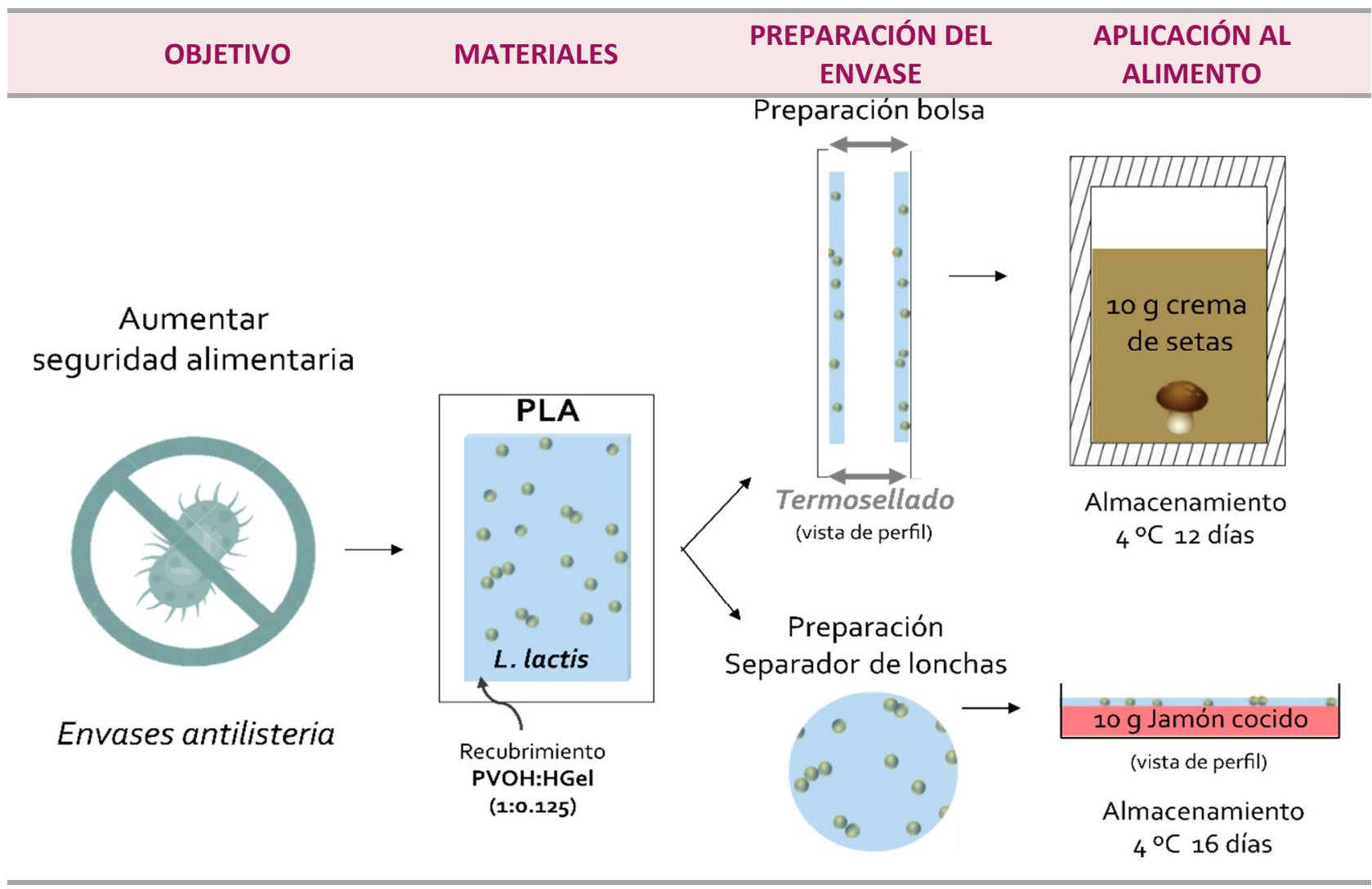

Figura 3. Esquema de la preparación de bolsas bioactivas antilisteria para el envasado de crema de setas y de separadores de lonchas bioactivo antilisteria para aplicar sobre jamón cocido 
Sin embargo, las bolsas activas que llevan bacterias en lugar de nisina pudieron inhibir el crecimiento de L. monocytogenes inoculado. Los resultados aquí pueden explicarse argumentando que L. lactis, además de producir nisina in situ, puede producir ácidos orgánicos y al no estar la crema de setas tamponada como el medio de cultivo líquido, los ácidos pueden disociarse y contribuir al efecto antimicrobiano sobre el patógeno. Además, hay varios estudios sobre la acción antimicrobiana de las bacteriocinas producidas por las $\mathrm{LAB}$ en combinación con un pH inferior a 5.5 [4]. En particular, el pH óptimo para el crecimiento de L. monocytogenes es neutro, y aunque este patógeno parece ser relativamente tolerante a las condiciones de acidez, especialmente a bajas temperaturas, el pH alcanzado durante el almacenamiento de la crema de setas también podría afectar a su crecimiento.

En el caso del jamón cocido, cuando se aplicaron los separadores de lonchas activos no se detectó ninguna actividad antimicrobiana durante los tres primeros días. Sin embargo, a partir del día 4, se observó una reducción del crecimiento de $L$. monocytogenes, aunque muy inferior a la que encontró cuando se aplicaron los recubrimientos in vitro en agar. Esto puede explicarse porque el jamón cocido es una matriz más compleja, mientras que el agar está diseñado exclusivamente para el crecimiento microbiano. El entorno de los productos alimentarios rara vez ofrece condiciones óptimas para el crecimiento de los microorganismos. Los principales factores que afectan al crecimiento bacteriano en los alimentos son el $\mathrm{pH}$, la temperatura, la concentración de nutrientes, la concentración de $\mathrm{NaCl}$ y la actividad del agua $\left(a_{w}\right)$. Los nutrientes y su biodisponibilidad no son los mismos en ambas matrices; el jamón cocido en lonchas contiene proteínas, grasa y azúcares complejos, como el almidón, mientras que el TSA + YE contiene hidrolizados de proteínas y componentes de glucosa libre que están más disponibles para las bacterias. Además, la estructura del jamón cocido en lonchas con tejido fibroso difiere de la del agar que tiene una superficie lisa pudiendo limitar el contacto entre la superficie del jamón y la superficie del recubrimiento y por tanto la adecuada exposición de L. lactis a la loncha. Además, la menor $a_{w}$ del jamón cocido en lonchas, en comparación con el agar, puede ralentizar la erosión de película hidrosoluble de $\mathrm{PVOH}$ y, por tanto, la migración de L. lactis, afectando su capacidad antilisteria. Por lo tanto, a pesar de las cantidades similares de $L A B$ en el jamón cocido en lonchas y en el medio de agar, su actividad metabólica puede ser diferente. Esta baja actividad metabólica repercutió en la pequeña bajada del pH observada en el jamón cocido con respecto a la de la crema de setas.

Por último, se realizó una prueba sensorial con consumidores para estudiar la aceptación de los productos alimentarios almacenados en 
refrigeración en los envases bioactivos. Estos estudios demostraron que la acidificación de los alimentos producida por las $L A B$, fueron percibidas por el panel de catadores en la crema de setas, pero no en el jamón cocido. En líneas generales la intención de compra del jamón cocido fue mayor que la de la crema de setas debidas al sabor ácido que describieron los catadores como toque de limón. En ambos alimentos la intención de compra mejoró tras dar la explicación sobre los envases activos a los catadores.

En la segunda parte del capítulo II se desarrollaron recubrimientos de una mezcla a partes iguales de $\mathrm{PVOH}$ e hidrolizado de caseína que incorporaron $L$. lactis con el objetivo de desarrollar un envase activo que aumentara la vida útil.

Para ampliar el espectro de acción de L. lactis frente a bacterias Gramnegativas, se incorporó ácido fítico (AF) en la formulación de las películas y se estudió la viabilidad de L. lactis y la actividad antimicrobiana frente a la bacteria Gram-positiva L. monocytogenes y frente a las bacterias Gramnegativas Salmonella enterica, Escherichia coli y Pseudomonas fluorescens en medio de cultivo a temperaturas de refrigeración y simulando roturas en la cadena del frío.

L. lactis mantuvo la viabilidad durante el almacenamiento, en todas las temperaturas ensayadas y frente a todos los patógenos independientemente de la adición de AF. En todos los casos las películas que incorporaron únicamente $A F$ no fueron efectivas frente a ningún patógeno. Las películas que incorporaron únicamente bacterias lácticas no fueron efectivas frente a las Gram-negativas ya que la nisina no es capaz de atravesar la membrana de estas bacterias, pero sí frente a Listeria monocytogenes. Por último, la combinación de películas de L. lactis y AF mostraron tener un efecto sinérgico ya que mostraron efectividad frente a todos los patógenos. Cabe destacar que no se observaron diferencias en el crecimiento de $E$. coli y $S$. enterica cuando se ensayaron a $4{ }^{\circ} \mathrm{C}$ ya que, al tratarse de bacterias mesófilas, las bajas temperaturas ejercieron un efecto bacteriostático cuando se aplicaron las propias películas control.

A continuación, las películas activas se aplicaron como recubrimiento sobre polietileno (PE) para envasar crema pastelera casera y así aumentar su vida útil. La figura 4 recoge el objetivo, la preparación del envase activo y la aplicación al alimento. 


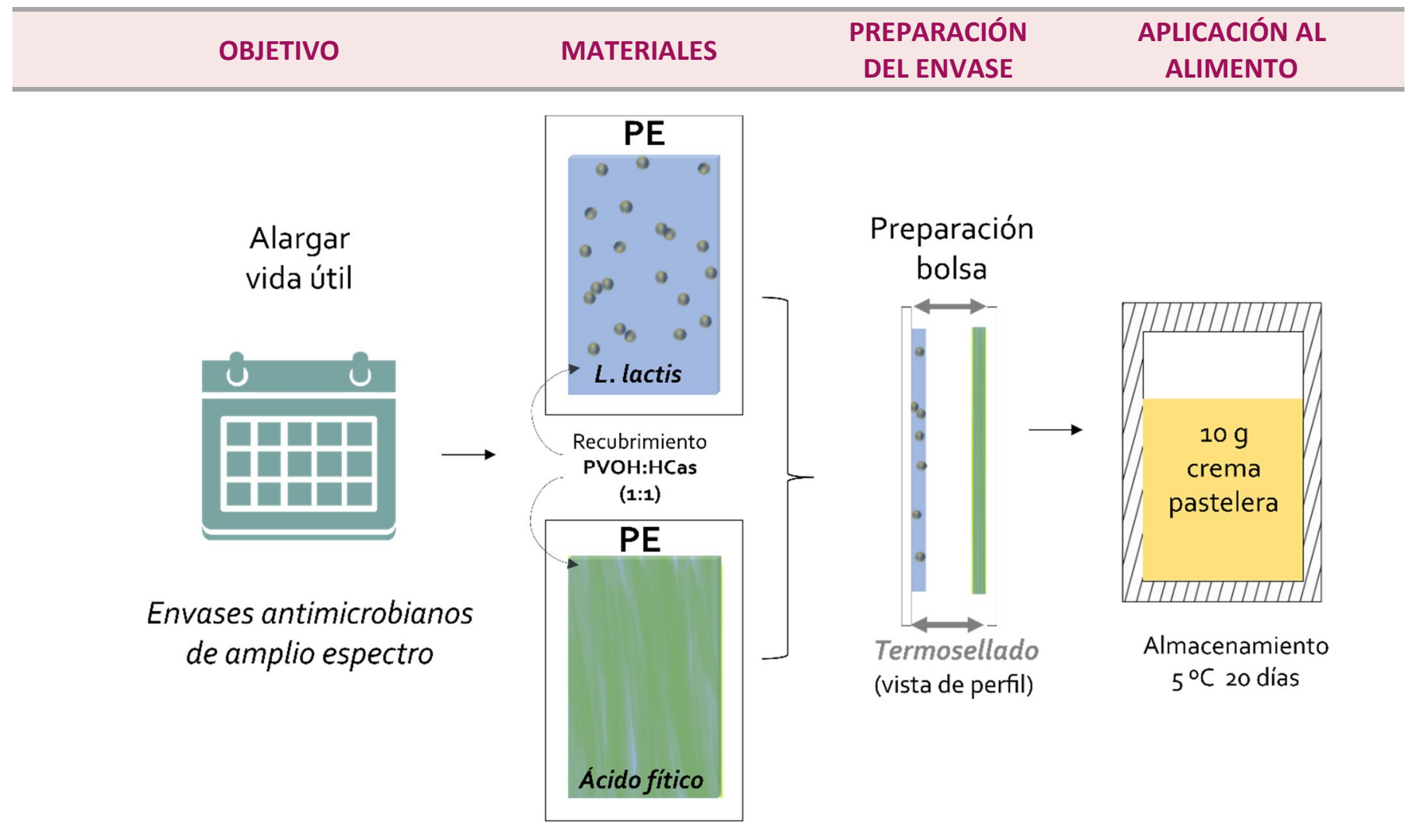

Figura 4. Esquema de la preparación de bolsas bioactivas antimicrobianas aplicadas en el envasado de crema pastelera casera 
El envase antimicrobiano desarrollado aumentó la vida útil de la crema pastelera de 3 días a 20 días desde un punto de vista microbiológico. En el análisis sensorial llevado a cabo, los catadores concluyeron que hasta el día 13, la crema pastelera fue apta para su consumo desde un punto de vista organoléptico. Por lo tanto, se pudo deducir que este envase fue capaz de aumentar la vida útil de la crema pastelera de 10 días, lo que supone un resultado prometedor desde un punto de vista de pérdidas económicas y de desperdicio alimentario.

Por último, se estudiaron los impactos ambientales del envase convencional y del envase activo para la crema pastelera fresca. En este estudio se evaluaron las implicaciones medioambientales de la selección del envase, considerando tanto los efectos directos como los indirectos, en términos de vida útil y de residuos alimentarios. Se evaluó el equilibrio entre el aumento del impacto debido a la adición del recubrimiento activo y los beneficios medioambientales relacionados con la reducción de la pérdida de alimentos. Además, la ampliación de la vida útil de los alimentos ha demostrado ser una cuestión clave a la hora de evaluar los impactos medioambientales de los nuevos envases. Estas reducciones no sólo afectaron al almacenamiento refrigerado en la venta al por menor, sino también en la fabricación, ya que se pudo disminuir el número de lotes producidos por semana, y en el consumo, porque una vez abierto el envase, el efecto antimicrobiano sigue activo. Por lo tanto, el cálculo de la tasa de equilibrio del desperdicio de alimentos puede ayudar a determinar un umbral de reducción del desperdicio de alimentos proporcionado por el envase activo que puede disminuir los impactos ambientales globales. En cualquier caso, a pesar de las limitaciones relativas a la estimación del producto desperdiciado, no cabe duda de que la prolongación de la vida útil mediante la innovación de los envases puede reducir significativamente los impactos ambientales de todo el sistema de envasado de alimentos.

En la presente tesis, también se exploró el potencial uso de levaduras autóctonas con capacidad antifúngica para el control de $P$. expansum y el control de su micotoxina, la patulina, en manzanas en postcosecha.

Para ello, el capítulo 3 se ha dividido en 3 partes que se encuentran resumidas en la figura 5

El objetivo de la primera parte del capítulo 3 se basó en la elección de una levadura con capacidad antifúngica para utilizarla como agente de biocontrol contra el hongo patógeno Penicillium expansum. 


\section{Parte I: Selección BCA Parte II: Selección Matriz}

\section{Parte III: Aplicación tecnológica}

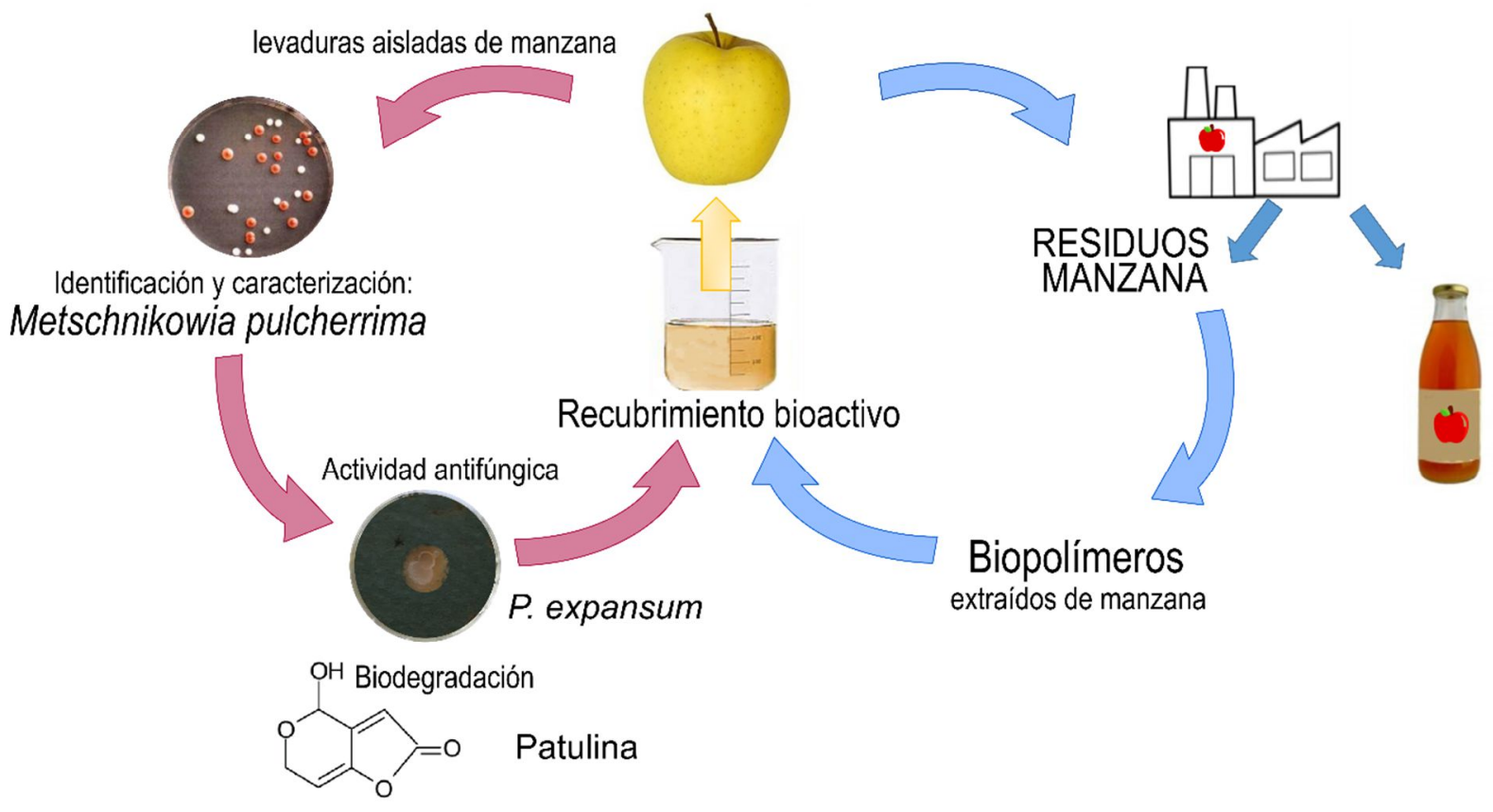

Figura 5. Esquema de las partes del capítulo 3 
En la presente investigación se seleccionaron nuevas cepas de levadura aisladas de la superficie de manzanas de sidra por su eficacia contra $P$. expansum que se denominaron Y33, Y29 e Y24. Las levaduras fueron identificadas como la especie Metschnikowia pulcherrima a través de la secuenciación de la región ITS. Los patrones de ADN-mt pudieron distinguir claramente que eran tres cepas diferentes de M. pulcherrima.

Los experimentos in vitro revelaron que las tres cepas fueron eficaces contra $P$. expansum siendo mayor la capacidad antifúngica cuanto mayor era la concentración de levadura inoculada. Al igual que se observó con L. lactis frente a $L$. monocytogenes, la concentración inicial del agente bioactivo sigue siendo esencial para obtener una alta inhibición del patógeno. A pesar de que las levaduras pertenecían a la misma especie, mostraron actividad antifúngica diferente siendo la más eficaz la cepa denominada Y29.

Al igual que es importante controlar el crecimiento de $P$. expansum, también es importante controlar la presencia de la micotoxina que genera, la patulina. Para ello se realizaron pruebas con las tres cepas seleccionadas en medio de cultivo líquido con una alta concentración de patulina $1000 \mu \mathrm{g} / \mathrm{mL}$ durante $120 \mathrm{~h}$ a $25^{\circ} \mathrm{C}$.

A pesar de que la presencia de patulina ralentizó la tasa de crecimiento de las levaduras y redujo la concentración final de levaduras viables entre 0.5 y $1 \mathrm{log}$, todas las levaduras seleccionadas fueron capaces de reducir el contenido de patulina del medio líquido contaminado artificialmente, siendo la más efectiva Y29. En $120 \mathrm{~h}$ de incubación, los niveles de patulina estuvieron por debajo de los límites establecidos por la EFSA para Y24 e Y29. Tampoco se detectó patulina en los metabolitos intracelulares ni en la pared celular de la levadura en ninguno de los días analizados. Esto indicó que la micotoxina no fue absorbida, sino que presumiblemente se trató de un proceso de degradación biológica en compuestos menos tóxicos como el ácido desoxipatulínico, E-ascladiol o Z-ascladiol como ya han apuntado otros estudios $[5,6]$.

Por último, la cepa que mostró mejores resultados en los estudios descritos anteriormente, fue aplicada como BCA sobre manzanas inoculadas con $P$. expansum y almacenadas durante 17 días a $20^{\circ} \mathrm{C}$. Y29 fue capaz de retrasar la enfermedad ocasionada por $P$. expansum en las manzanas. Sin embargo, durante los últimos días de almacenamiento, la reducción de $P$. expansum se ralentizó. Esto podría deberse a varios factores, aunque el principal sea una pérdida de viabilidad de M. pulcherrima y baja capacidad de adhesión de esta levadura sobre la superficie de las manzanas.

Con el objetivo aumentar la eficacia antifúngica de la cepa en manzanas contaminadas por $P$. expansum mediante el aumento de la viabilidad de las 
levaduras o de las propiedades adhesivas en la piel de la manzana, en la segunda parte del capítulo 3 se incorporó la cepa Y29 en diferentes matrices poliméricas.

Para ello, se escogieron biopolímeros comestibles derivados de manzana, pectina (P) y derivados de celulosa (hidroxipropilmetilcelulosa (HPMC) y metylcelulosa (MC)). Como suplemento nutricional para las levaduras, también se prepararon las mismas películas disolviendo los biopolímeros en medio de cultivo YEG (extracto de levadura y glucosa) en lugar de en agua destilada estéril. Por último, se prepararon películas utilizando únicamente residuos de la industria del zumo de manzana (orujo de manzana (A). Este orujo se obtuvo a escala de laboratorio utilizando la piel, pulpa y semillas de las manzanas. Además, las películas de pectina (PC) y de orujo de manzana (AC) se entrecruzaron en una disolución de $10 \%$ de $\mathrm{CaCl}_{2}$. M. pulcherrima se incorporó a las disoluciones formadoras de película y se realizaron películas por casting. Las películas preparadas sin BCA se utilizaron como control.

Para comparar la idoneidad de las diferentes matrices utilizadas, se estudiaron los 3 parámetros más relevantes, que son, la viabilidad de $M$. pulcherrima tras el secado de la película, la viabilidad de M. pulcherrima tras 21 días de almacenamiento de las películas a temperatura y humedad controladas y la actividad antifúngica de las películas desarrolladas contra $P$. expansum. El resumen de los resultados se muestra en la tabla 2.

Los mecanismos de resistencia al estrés de las levaduras, como ocurre en un proceso de deshidratación están relacionados con varias y complejas características fisiológicas de la célula. Esta resistencia es dependiente de la cepa (características fisiológicas intrínsecas de cada cepa) y se ha demostrado que $M$. pulcherrima tiene una fuerte tolerancia a ambientes con alta presión osmótica, como los productos con baja actividad de agua como ocurre en una película.

Sin embargo, su supervivencia dependió de la formulación de la matriz. De hecho, la magnitud de la cinética de deshidratación tiene un alto impacto en la viabilidad celular [7]. La mejor supervivencia de la población de levaduras se produjo en las películas realizadas con orujo de manzana. De hecho, fue la única matriz en la que la población de M. pulcherrima fue superior a la cantidad inicial de células inoculadas, lo que apunta a un crecimiento celular durante la etapa de secado. Esto podría explicarse por el hecho de que esta levadura ha sido aislada de manzanas, por lo que están naturalmente habituadas a crecer en superficies con una composición similar [8]. 
Tabla 2. Viabilidad de M. pulcherrima tras el secado y almacenamiento de las películas a $21^{\circ} \mathrm{C}$ y $43 \%$ de HR y actividad antifúngica in vitro durante 19 días a $21^{\circ} \mathrm{C}$

\begin{tabular}{|c|c|c|c|c|c|c|}
\hline \multirow{3}{*}{ Película } & \multicolumn{2}{|c|}{$\begin{array}{c}\text { Viabilidad M. pulcherrima } \\
\text { (log UFC / película) }\end{array}$} & \multicolumn{4}{|c|}{ Actividad antifúngica in vitro } \\
\hline & \multirow{2}{*}{ Tras secado } & \multirow{2}{*}{$\begin{array}{c}\text { Tras } 21 \text { días } \\
\text { almacenamiento }\end{array}$} & \multicolumn{2}{|c|}{ Primera aparición hongo } & \multicolumn{2}{|c|}{ Más de un 50 \% colonización } \\
\hline & & & Película Control & Película activa & Película Control & Película activa \\
\hline $\mathbf{P}$ & $5.37 \pm 0.11$ & $0 \pm 0$ & Día 4 & Día 4 & Día 4 & Día 6 \\
\hline P-YEG & $5.76 \pm 0.550$ & $0 \pm 0$ & Día 4 & Día 4 & Día 4 & Día 11 \\
\hline MC & $6.65 \pm 0.04$ & $4.43 \pm 0.78$ & Día 4 & Día 4 & Día 8 & Día 13 \\
\hline MC-YEG & $7.67 \pm 0.32$ & $5.11 \pm 0.74$ & Día 4 & Día 13 & Día 8 & Día 19 \\
\hline A & $8.44 \pm 0.14$ & $6.29 \pm 0.31$ & Día 4 & Día 8 & Día 4 & Día 15 \\
\hline AC & $7.28 \pm 0.08$ & $2.79 \pm 0.34$ & Día 4 & Día 8 & Día 6 & Día 15 \\
\hline
\end{tabular}


La mortalidad encontrada en las películas de pectina puede explicarse debido a un $\mathrm{pH}$ bajo $(\mathrm{pH}$ disolución formadora de película $=2.7)$ y las películas derivadas de la celulosa demostraron tener una menor viabilidad debido en parte a la falta de nutrientes.

En todos los casos, cuando se añadió YEG a la solución formadora de la película, la viabilidad tras el secado fue mayor que las películas sin YEG. Esto se debe en parte a su capacidad de proporcionar los nutrientes necesarios para mantener su supervivencia, como la mezcla de glucosa y los aminoácidos del extracto de levadura. Esta tendencia se ha observado en el primer capítulo con las LAB.

Finalmente, cuando las películas fueron entrecruzadas, en todos los casos, la viabilidad disminuyó. En el proceso de entrecruzamiento, que consistió en sumergir las películas recién secadas en una solución de $\mathrm{CaCl}_{2}$ durante 2 minutos se perdieron alrededor de 2 log de levadura viable.

Para continuar el trabajo, las películas seleccionadas fueron $\mathrm{P}, \mathrm{P}-\mathrm{YEG}$, MC, MC-YEG, A y AC.

Durante el almacenamiento de las películas se observó una disminución de la viabilidad de M. pulcherrima. Sin embargo, este efecto fue mucho más marcado para las películas de pectina. Así, la capacidad de supervivencia de los microorganismos en las películas está estrechamente relacionada con el $\mathrm{pH}$ alcanzado en el proceso de secado como ocurrió con las LAB y el AF en el capítulo 2. La viabilidad de M. pulcherrima observada en el resto de películas fue mayor como se puede observar en la tabla 2.

La composición de la película desempeñó un papel crucial en la protección de la levadura. Al igual que ocurrió con las LAB en el primer capítulo, hay que tener en cuenta que los compuestos con diferente tamaño tienen diferente permeabilidad a las células, lo que afecta al mecanismo de su efecto protector. La mayor viabilidad se encontró en las películas A cuya matriz, compuesta por una fracción hidrosoluble y otra insoluble con azúcares y polisacáridos sirvió de sustrato durante el secado y proporcionó protección durante el almacenamiento. Además, cabe destacar que, al tratarse de levaduras aisladas de manzana, esta matriz formulada a base de manzana es un sustrato en el que están evolutiva adaptadas.

El efecto antifúngico in vitro de las formulaciones de las películas que llevan M. pulcherrima contra $P$. expansum se estudió durante un período de incubación de 19 días a $21{ }^{\circ} \mathrm{C}$. Aunque los polímeros utilizados no tienen ninguna actividad antifúngica, como se observa en la tabla 2 , hubo diferencias 
en el crecimiento de los hongos en función de la película control. Debido a la naturaleza de cada uno de los polímeros utilizados, $P$. expansum puede tardar más tiempo en crecer o hacerlo de forma diferente, lo que sugiere la adaptación progresiva de este hongo a un nuevo entorno, ya que la formulación, el proceso y los factores ambientales influyen en el crecimiento del hongo [9].

Los datos de los ensayos antifúngicos realizados en placas con agar mostraron que las películas bioactivas enriquecidas con $M$. pulcherrima inhibieron significativamente el crecimiento de $P$. expansum o modificaron su crecimiento morfológico. Sin embargo, estos cambios dependieron de la película aplicada. Cabe señalar que esta prueba se realizó con películas recién obtenidas, por lo que la viabilidad de la levadura inicial fue la indicada en "Viabilidad tras el secado" de la tabla 2. La peor actividad antifúngica se observó en las películas en las que M. pulcherrima obtuvo la menor supervivencia tras el secado. Este resultado es similar al estudiado en los capítulos 1 y 2, en los que se demostró que la actividad antimicrobiana es función de la concentración inicial del agente de biocontrol. Finalmente, la película que tuvo las mejores propiedades antifúngicas fue la MC-YEG debido a varios factores como una alta viabilidad de la levadura, una buena fuente de nutrientes proporcionada por el YEG y por la dificultad de crecimiento de $P$. expansum en este polímero.

Además de que la película $A$ mostró un retraso de 8 días en la aparición del hongo, además de un retraso en su crecimiento morfológico durante el almacenamiento, cabe destacar que otra de las ventajas de esta materia prima es que procede de subproductos de la manzana y no requiere tratamientos de extracción, separación y purificación como ocurre con otros biopolímeros. Por lo tanto, en la tercera parte del capítulo III se escogió como matriz para aplicar como recubrimiento sobre manzanas inoculadas con $P$. expansum. Los diferentes tratamientos aplicados se ilustran en la tabla 3. 
Tabla 3. Aplicación de diferentes tratamientos sobre manzanas Golden Delicious y crecimiento de $P$. expansum y concentración de patulina tras 17 días a $10{ }^{\circ} \mathrm{C}$.

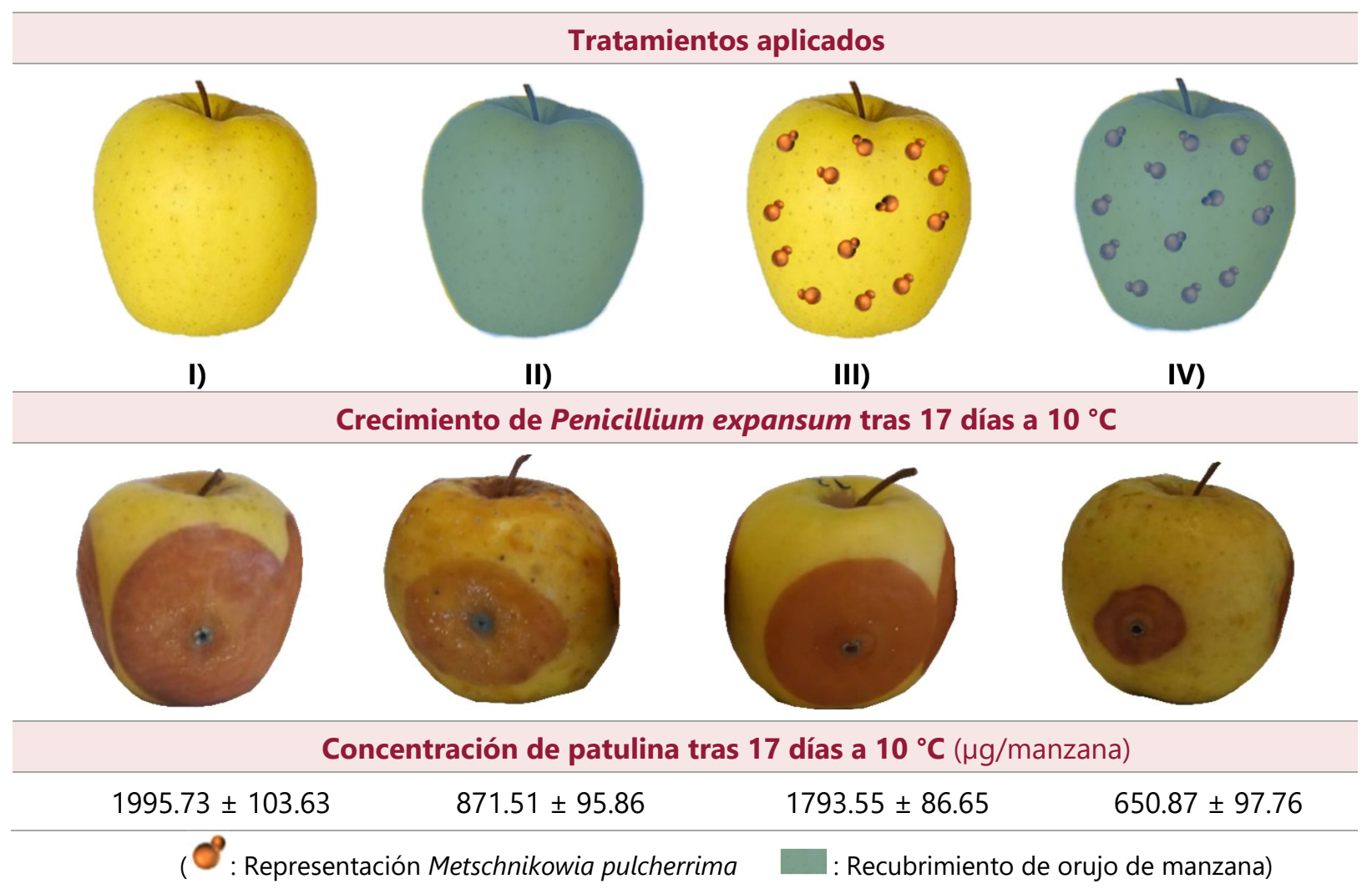


La cantidad inicial de levadura viable fue de 6.11 log UFC/manzana para la manzana tratada con la suspensión de levadura (III) y de 7.70 log UFC/manzana para la manzana tratada con recubrimiento y levadura (IV). El recubrimiento mantuvo un mayor número de levaduras viables ya que les proporcionó protección contra la desecación y buenas propiedades de adhesión a la fruta. El crecimiento de $P$. expansum se monitorizó midiendo el halo de infección alrededor de la herida de $3 \mathrm{~mm}$ realizada en las manzanas. Cabe mencionar que ni la reacción oxidativa que se produce de forma natural en las heridas de las manzanas, ni la colonización de las heridas por $M$. pulcherrima tuvieron un impacto significativo en el desarrollo del halo. Las manzanas tratadas con (IV) resultaron ser las más eficaces, con reducciones muy significativas en el crecimiento de $P$. expansum respecto a los otros tratamientos. Como han apuntado otros autores, los recubrimientos pueden actuar como barrera para los intercambios gaseosos en la fruta, disminuyendo la permeabilidad al oxígeno y aumentando la acumulación de $\mathrm{CO}_{2}$ en la fruta [10]. Esto podría explicar la inhibición de $P$. expansum observada en las manzanas tratadas con (II) ya que esto hongos son estrictamente aerobios y muy sensibles al $\mathrm{CO}_{2}$ [11]. Cabe destacar que a partir del día 8 aparecieron hongos oportunistas (no sólo P. expansum) sobre los recubrimientos (II) (no sólo en la herida sino en todo el recubrimiento) que avanzaron rápidamente colonizando la superficie de la manzana durante el almacenamiento.

El contenido de patulina se cuantificó al final del almacenamiento, como se observa en la tabla 3, obteniéndose una menor cantidad de esta micotoxina en las manzanas tratadas con (IV) probablemente debido a varios factores, como una mayor viabilidad y eficacia de M. pulcherrima $\mathrm{y}$, por otro lado, al efecto del recubrimiento sobre el crecimiento fúngico.

Estos resultados son alentadores, sobre todo si se tiene en cuenta que las condiciones evaluadas en el estudio son mucho peores que las que se dan normalmente durante la postcosecha, en cuanto al grado de daño de la fruta y al nivel de inóculo del patógeno. Además, los resultados son pioneros al demostrar la eficacia antifúngica de una levadura de control biológico aislada de la superficie de manzanas e incorporada en un recubrimiento hecho enteramente de residuos de manzana. El sistema fue capaz de controlar la enfermedad más grave de las manzanas, la podredumbre del moho azul producida por $P$. expansum y su micotoxina, la patulina.

\section{Referencias bibliográficas}

1. Guimarães, A.; Abrunhosa, L.; Pastrana, L.M.; Cerqueira, M.A. Edible Films and Coatings as Carriers of Living Microorganisms: A New 
Strategy Towards Biopreservation and Healthier Foods. Compr. Rev. Food Sci. Food Saf. 2018, 17, 594-614.

2. Moens, S.; Vanderleyden, J. Functions of bacterial flagella. Crit. Rev. Microbiol. 1996, 22, 67-100.

3. Gutierrez, J.; Barry-Ryan, C.; Bourke, P. The antimicrobial efficacy of plant essential oil combinations and interactions with food ingredients. Int. J. Food Microbiol. 2008, 124, 91-97, doi:10.1016/j.ijfoodmicro.2008.02.028.

4. Gao, Y.; Li, D.; Liu, X. Effects of Lactobacillus sakei C2 and sakacin C2 individually or in combination on the growth of Listeria monocytogenes, chemical and odor changes of vacuum-packed sliced cooked ham. Food Control 2015, 47, 27-31, doi:10.1016/j.foodcont.2014.06.031.

5. Janisiewicz, W.J.; Tworkoski, T.J.; Kurtzman, C.P. Biocontrol potential of Metchnikowia pulcherrima strains against blue mold of apple. Phytopathology 2001, 91, 1098-1108, doi:10.1094/PHYTO.2001.91.11.1098.

6. Coelho, A.R.; Celli, M.G.; Ono, E.Y.S.; Wosiacki, G.; Hoffmann, F.L.; Pagnocca, F.C.; Hirooka, E.Y. Penicillium expansum versus antagonist yeasts and patulin degradation in vitro. Brazilian Arch. Biol. Technol. 2007, 50, 725-733, doi:10.1590/S1516-89132007000400019.

7. Lemetais, G.; Dupont, S.; Beney, L.; Gervais, P. Industrial production of dried yeast: plasma membrane as a survival indicator of air drying process; 2011;

8. Parafati, L.; Vitale, A.; Restuccia, C.; Cirvilleri, G. Biocontrol ability and action mechanism of food-isolated yeast strains against Botrytis cinerea causing post-harvest bunch rot of table grape. Food Microbiol. 2015, 47, 85-92, doi:10.1016/j.fm.2014.11.013.

9. Phane Dagnas, S.; Membré, J.-M. Predicting and Preventing Mold Spoilage of Food Products. J. Food Prot. 2013, 76, 538-551, doi:10.4315/0362-028X.JFP-12-349.

10. Sharma, P.; Shehin, V.P.; Kaur, N.; Vyas, P. Application of edible coatings on fresh and minimally processed vegetables: a review. Int. J. Veg. Sci. 2019, 25, 295-314, doi:10.1080/19315260.2018.1510863.

11. Soliva-Fortuny, R.C.; Elez-Martínez, P.; Martín-Belloso, O. Microbiological and biochemical stability of fresh-cut apples preserved by modified atmosphere packaging. Innov. Food Sci. Emerg. Technol. 2004, 5, 215-224, doi:10.1016/j.ifset.2003.11.004. 

4. CONCLUSIONES 

From the results obtained in the development of the present Doctoral Thesis it is possible to highlight the following conclusions:

1. Lactococcus lactis and Lactobacillus sakei were effective as biocontrol agents against Listeria monocytogenes when an inoculum size of at least $4 \log (\mathrm{CFU} / \mathrm{mL})$ greater than the population of $L$. monocytogenes was employed.

2. Film formulation directly affected the viability of the lactic acid bacteria and their antimicrobial activity. Protein hydrolysates have proven to be efficient coadjuvants, increasing the viability of the bacteria in the film matrix.

3. The resistance of lactic acid bacteria to dehydration and storage in polyvinyl alcohol films is strain dependent, Lactococcus lactis being more resistant than Lactobacillus sakei, whereas the viability of lactic acid bacteria in the polyvinyl alcohol matrix increased with the content of protein hydrolysate.

4. A polyvinyl alcohol matrix blended with a commercial gelatin hydrolysate was successfully adapted as a coating onto polylactic acid films for technological application in food packaging. An active pouch for mushroom soup and an active slice separator liner for cooked ham were designed and each demonstrated antimicrobial activity against L. monocytogenes.

5. Mushroom soup and cooked ham packaged with active films received good acceptance from a consumer panel. However, the presence of lactic acid generated by the lactic acid bacteria during storage was detected in the mushroom soup by the panel.

6. The antimicrobial spectra of coatings based on polyvinyl alcohol blended with commercial casein hydrolysates incorporating L. lactis were broadened to Gram-negative bacteria by incorporating phytic acid in the design of an active bag for pastry cream. The active bag was able to extend the shelf life of home-made pastry cream by 10 days.

7. The life cycle analysis of the active packaging for home-made pastry cream showed that, despite the fact that the fabrication of the 
packaging had a greater environmental impact than that of a conventional package, the increased shelf life and consequent reduction in food waste obtained led to a much lower environmental impact of the whole product/active packaging chain.

8. To develop antifungal coatings, three different strains of the yeast Metschnikowia pulcherrima were isolated from apples, selected and characterized, and were shown not only to have antifungal activity against Penicillium expansum but also able to reduce the patulin content of liquid media.

9. Films based on the biopolymers naturally present in apples and incorporating M. pulcherrima were formulated. The best ratio of viability after drying, viability after storage and in vitro antifungal activity was obtained with films made with apple pomace.

10. The films developed have been applied as coatings on apples inoculated with $P$. expansum, achieving high antifungal effectiveness due to the synergy between the coating and the isolated yeast. A lower concentration of patulin was also observed compared to other treatments.

11. Biocontrol agents were successfully incorporated in the design of antimicrobial packages improving the shelf-lives of different foods and constituting an effective, healthier and more sustainable alternative to artificial preservatives. 
6. ANEXO 



\title{
Antilisterial properties of PVOH-based films embedded with Lactococcus lactis subsp. lactis
}

\author{
Laura Settier-Ramírez, Gracia López-Carballo, Rafael Gavara, Pilar Hernández-Muñoz* \\ Packaging Lab, Instituto de Agroquímica y Tecnología de Alimentos, IATA-CSIC, Av. Agustín Escardino 7, 46980, Paterna, Spain
}

\section{A R T I C L E I N F O}

\section{Keywords:}

Lactococcus lactis

PVOH films

Gelatin

Sodium caseinate

Protein hydrolysates

Listeria monocytogenes

\begin{abstract}
A B STR A C T
The incorporation of lactic acid bacteria (LAB) in edible films and coatings has recently emerged as an innovative strategy to provide packaging films with new functionalities in order to ensure food quality and safety. In this work, bioactive films were made by incorporating Lactococcus lactis subsp. lactis in cast polyvinyl alcohol (PVOH) matrices, alone or blended with a small percentage of proteins, protein hydrolysates, or yeast extract, and the effect of incorporating them on the morphology and optical properties of the PVOH films was studied. Moreover, the viability of L. lactis in the films developed stored at $20^{\circ} \mathrm{C}$ and $43.2 \%$ relative humidity for four weeks, and the antimicrobial activity against L. monocytogenes were determined.

The thickness, color properties, and morphology of the films incorporating $L A B$ and nutrients did not show significant differences compared with plain PVOH films, but moisture content increased slightly with nutrient incorporation. L. lactis remained viable for 4 weeks of storage, but viability depended on the matrix composition, being lower in plain PVOH films and higher in films supplemented with proteins, hydrolysates, or yeast extract. The highest antimicrobial activity was observed in PVOH matrices with hydrolyzed gelatin or casein, and the lowest in plain PVOH films. The growth of L. lactis was similar in all the films after incubation in contact with $\mathrm{L}$. monocytogenes at $37^{\circ} \mathrm{C}$ in liquid medium, regardless of the initial concentration. The films developed could be applied in the design of food packages with the purpose of inhibiting growth of L. monocytogenes.
\end{abstract}

\section{Introduction}

Nowadays, there is an increasing tendency for food consumption to be linked intrinsically with a healthy lifestyle. Consumers now demand less processed foods made with natural ingredients, which means a preference for products free of synthetic additives and preservatives. In order to satisfy the wishes of consumers while maintaining food safety, the use of naturally occurring antimicrobials has been presented as an alternative to synthetic ones, causing great interest in the food industry (Xu et al., 2007). Many studies have shown that incorporating antimicrobials in polymer films or coatings is more effective than adding them directly to the food product. In fact, films and coatings not only immobilize the antimicrobial compound and provide a protective environment for it, but also modulate its release to the packaged food (Aloui \& Khwaldia, 2016; Realini \& Marcos, 2014).

Bacteriocins are antimicrobial peptides and products of the metabolism of certain bacteria. The use of bacteriocins from lactic acid bacteria (LAB) in the food industry has been an advance for improving the shelf-life of foods while guaranteeing the safety and health of consumers (Reis, Paula, Casarotti, \& Penna, 2012). The incorporation of bacteriocins from LAB into packaging films and coatings has been studied, with results that only show good effectiveness of the antimicrobial at the beginning of the food storage period (Coma, Sebti, Pardon, Deschamps, \& Pichavant, 2001; Ercolini et al., 2009; Marcos, Aymerich, Monfort, \& Garriga, 2008). This is due to the gradual depletion of the bacteriocin from the matrix reservoir. In order to solve this problem, some studies propose the incorporation of LAB directly into the film as a natural tool to extend film antimicrobial activity over time by means of the ability of bacteria to produce bacteriocins (Espitia, Batista, Azeredo, \& Otoni, 2016). In this regard, other mechanisms such as competition between bacteria and pathogens for nutrients and the production of organic acids can help bioactivity. Lactococcus lactis subsp. lactisis used in food preservation because of its ability to produce nisin (Deegan, Cotter, \& Ross, 2006). This bacteriocin is a polycyclic peptide with antibacterial properties that has been well characterized and that is classified as GRAS (Generally Recognized as Safe) by the FDA (Food and Drug Administration). L. lactis inhibits the growth of certain Gram + bacteria, such as Listeria monocytogenes, a pathogen that causes listeriosis, a serious foodborne disease (Benkerroum \& Sandine, 1988).

\footnotetext{
* Corresponding author.

E-mail address: phernan@iata.csic.es (P. Hernández-Muñoz).
} 


\title{
PVOH/protein blend films embedded with lactic acid bacteria and their antilisterial activity in pasteurized milk
}

\author{
Laura Settier-Ramírez, Gracia López-Carballo, Rafael Gavara, Pilar Hernández-Muñoz* \\ Packaging Lab, Instituto de Agroquímica y Tecnología de Alimentos, IATA-CSIC, Av. Agustín Escardino 7, 46980 Paterna, Spain
}

\section{A RTICLE IN FO}

\section{Keywords:}

Lactococcus lactis

PVOH films

Protein

Protein hydrolysates

Listeria monocytogenes

Pasteurized milk

\begin{abstract}
A B STRACT
PVOH-based polymer matrices in the form of films were evaluated as carriers of living Lactococcus lactis subsp. Lactis. These lactic acid bacteria are capable of producing nisin, which is an effective antilisterial peptide. A low percentage $(1: 0.125 \mathrm{w} / \mathrm{w})$ of yeast extract, gelatin, sodium caseinate, gelatin, or casein hydrolysates was incorporated in $\mathrm{PVOH}$ matrices with the aim of increasing the viability of bacteria in the film. The films were obtained by casting after incorporating L. lactis. Then they were evaluated for antilisterial activity in liquid medium at $37{ }^{\circ} \mathrm{C}$ for $24 \mathrm{~h}$, and also at $4^{\circ} \mathrm{C}$ for 21 days in order to simulate the storage of liquid foods in refrigeration conditions. The survival of the lactic acid bacteria was al so evaluated at both temperatures during the experiment. L. lactis remained viable in all the films tested at 37 and $4^{\circ} \mathrm{C}$. The antimicrobial activity of the films was greater at $4{ }^{\circ} \mathrm{C}$ than at $37^{\circ} \mathrm{C}$. With regard to the effect of the film composition, the activity of the films was higher when protein hydrolysates and sodium caseinate were incorporated in the formulation. Films supplemented with protein hydrolysates or sodium caseinate inhibited growth of the pathogen during the 21 days of storage at $4{ }^{\circ} \mathrm{C}$. At $37^{\circ} \mathrm{C}$, after $24 \mathrm{~h}$ the films had slowed the growth of the inoculated pathogen by between 2 and $4 \log \mathrm{CFU} / \mathrm{mL}$.

Finally, as the films developed are intended to be used in the design of active packaging of foods, they were tested in pasteurized milk inoculated with $4 \mathrm{log}$ CFU/mL of Listeria monocytogenes and stored at $4^{\circ} \mathrm{C}$ for 21 days. The pathogen began to grow after the second day of storage with or without film, but when the films were added to the medium the growth of the pathogen was slowed down, without reaching $>6 \mathrm{log}$ CFU, whereas the control reached a maximum growth of $8.5 \mathrm{log} \mathrm{CFU}$. The $\mathrm{pH}$ of the milk was monitored throughout the experiment, and it decreased with time. This was due to the generation of organic acids by the lactic bacteria. Buffering the food stabilized the $\mathrm{pH}$ without modifying the activity of the films. Thus, the current study shows that PVOH films supplemented with nutrients can act as carriers of L. lactis, and they can help to increase the safety of refrigerated dairy beverages and sauces.
\end{abstract}

\section{Introduction}

Since ancient times, refrigeration has been a conservation method for perishable food that we continue to use daily in our home. Unfortunately, sometimes this method is not enough to ensure the safety of fresh foods. Various pathogenic bacteria can be sources of food toxin infections. Among them, Listeria monocytogenes continues to be a major concern for food safety (Batz et al., 2012).

This Gram-positive foodborne pathogenic bacterium is responsible for listeriosis. The manifestations of this disease produce septicemia, meningitis or meningoencephalitis, and encephalitis, usually producing symptoms similar to flu (Muriel-Galet et al., 2015). Listeriosis is a rare but severe disease, especially for pregnant women, newborns, children, the elderly, and immunosuppressed people. The morbidity of listeriosis is relatively low, although the rate of mortality from systemic disease can be very high (Muriel-Galet et al., 2015; Ramaswamy et al., 2007).

Food products can be contaminated with L. monocytogenes by cross contamination in the various steps of the production chain, such as cutting, peeling, or even packaging. Furthermore, L. monocytogenes is able to form biofilm and survive by adhering to the surfaces of processing equipment, becoming a potential route of contamination (Møretrø and Langsrud, 2004).

This pathogen has the capacity to grow at refrigeration temperatures, and even at temperatures below $-0.5^{\circ} \mathrm{C}$ (Walker et al., 1990), and to survive at low $\mathrm{pH}$ values that are normally inhibitory for other food pathogens (Cole et al., 1990). Furthermore, studies have shown

\footnotetext{
* Corresponding author.

E-mail address: phernan@iata.csic.es (P. Hernández-Muñoz).
} 


\title{
Effect of casein hydrolysates on the survival of protective cultures of Lactococcus lactis and Lactobacillus sakei in PVOH f Ims
}

\author{
Laura Settier-Ramírez, Gracia López-Carballo, Rafael Gavara, Pilar Hernández-Muñoz \\ Packaging Lab, Instituto de Agroquímica y Tecnología de Alimentos, IATA-CSIC, Av. Agustín Escardino 7, 46980, Paterna, Spain
}

\section{A R T I CLE IN F O}

\section{Keywords:}

Lactic acid bacteria

Biocontrol agents

anti-Listeria f Ims

Casein hydrolysates

Polymer matrices

Bacterial auto-aggregation

\begin{abstract}
A B ST R A C T
The aim of this work has been to explore the potential of blending polyvinyl alcohol (PVOH) with casein hydrolysates (HCas) to obtain self-standing $f$ Ims capable to act as carriers of lactic acid bacteria (LAB) as biocontrol agents against food pathogens. For this purpose, $\mathrm{PVOH}$ was blended with $\mathrm{HCas}$ at different weight ratios and the blends were incorporated with Lactococcus lactis and Lactobacillus sake. Blending HCas with PVOH resulted in the modif cation of some functional properties of the f Ims whereas bacteria did not change them. Moreover, incorporation of HCas resulted in an increase in cell viability after $\mathrm{f} \mathrm{Im}$ casting and in long-term $\mathrm{f}$ Im storage, and also in $\mathrm{f} \mathrm{Im}$ antilisterial properties. These results could be related to the capacity of bacterial autoaggregation in the $\mathrm{f} \mathrm{Ims} \mathrm{during} \mathrm{the} \mathrm{drying} \mathrm{process} \mathrm{when} \mathrm{HCas} \mathrm{was} \mathrm{added,} \mathrm{as} \mathrm{observed} \mathrm{by} \mathrm{f}$ uorescence light microscopy. Blends could be used in the active packaging of foods.
\end{abstract}

\section{Introduction}

The use of bacteriocins to design active packages to control the growth of foodborne patogens has been greatly explored in the last years. However, antimicrobial packaging based on the use of bacteriocin producing bacteria as biocontrol agents has not been deeply explored. The use of bacteria instead of their bacteriocins presents several advantages. In this regard, commercial bacteriocins preparations have a high price due to the low fermentation yields and high production costs (Musatti et al., 2020), and some bacteriocins are not classif ed as GRAS.

It is known that foodborne pathogens and spoilage organisms can lose viability during growth in associative cultures with lactic acid bacteria (LAB), which in most of the cases is attributed to the production of bacteriocins and also other antimicrobial compounds such as organic acids and hydrogen peroxide that help to increment the antimicrobial effect; in addition, bacteria also compete with other bacteria that can cause spoilage in foods or being pathogens (De Vuyst \& Leroy, 2007).

The incorporation of LAB as protective cultures into $\mathrm{fIms}$ and coatings is recent and a deeper understanding of the dependency between $\mathrm{LAB}$ viability and antimicrobial activity, and the $\mathrm{f} / \mathrm{m}$ composition, processing and storage is required (Guimarães et al., 2018). Until now, most of the studies are based on the use of water soluble biopolymers which are incorporated with low molecular compounds with the aim of acting as nutrients or protective agents for bacteria (Bekhit et al., 2018;
Gialamas et al., 2010; Guimarães et al., 2018; Ye et al., 2018a). However, the use of water soluble Polyvinyl alcohol (PVOH) has been little explored.

$\mathrm{PVOH}$ is a water soluble biodegradable and synthetic polymer with excellent $\mathrm{f} \mathrm{Im}$ forming properties. $\mathrm{PVOH}$ is widely used in the industry due to its emulsifying and adhesive properties, having an excellent mechanical strength and fexibility. Contrary to water soluble f Ims made from biopolymers, $\mathrm{PVOH} \mathrm{f}$ Ims are stable during storage without altering their physico-chemical properties; that can be a great advantage for its industrial application as carrier of protective cultures for active food packaging purposes. PVOH is approved by the FDA for use in food contact and as a food additive with INS $\mathrm{n}^{\circ} .1203$ (Codex alimentarius) (FAO, 2018, p. 5). In the EU, PVOH is approved by the EFSA as a food additive in food supplements in accordance with Annex II to Regulation (EC) No 1333/2008. The studiesfocused on the use of PVOH as carrier of protective cultures for active packaging are scarce. Only a couple of works related to the use of $\mathrm{PVOH}$ coatings as carriers of antilisterial producing bacteriocin are documented in the bibliography (Degli Esposti et al., 2018; Iseppi et al., 2011).

In previous studies, the authors of the current work have reported that PVOH is capable of maintaining the viability of $L$. lactis and its antilisterial properties. They also found that these properties are improved when a low percentage of proteins or protein hydrolysates are incorporated in the $\mathrm{f} \mathrm{Im}$ formulation (Settier-Ramírez et al., 2019).

\footnotetext{
* Corresponding author.

E-mail address: phernan@iata.csic.es (P. Hernández-Muñoz).
} 


\title{
Evaluation of Lactococcus lactis subsp. lactis as protective culture for active packaging of non-fermented foods: Creamy mushroom soup and sliced cooked ham
}

\author{
Laura Settier-Ramírez, Gracia López-Carballo, Rafael Gavara, Pilar Hernández-Muñoz* \\ Packaging Lab, Instituto de Agroquímica y Tecnología de Alimentos, IATA-CSIC, Av. Agustín Escardino 7, 46980, Paterna, Spain
}

\section{A R T I CLE IN F O}

\section{Keywords:}

Polyvinyl alcohol

Gelatin hydrolysates

Lactococcus lactis

Listeria monocytogenes

Protective culture. sliced cooked ham

Creamy mushroom soup

\begin{abstract}
A B STR A C T
An innovative edible coating, made from food grade polyvinyl alcohol (PVOH) and gelatin hydrolysates (HGel), was evaluated as a carrier of Lactococaus lactis acting as anti-listeria protective culture for refrigerated foods. The coating was applied on a compostable polylactic acid $\mathrm{f} I \mathrm{~m}$ surface and its anti-listeria activity was evaluated at $4{ }^{\circ} \mathrm{C}$ in a liquid culture medium and in solid agar, inoculated with Listeria monocytogenes. The best results were obtained in agar, exerting a bactericide effect, whereas in the liquid medium the coating had bacteriostatic behaviour. Furthermore, the active coating was applied to the surface of bags or separator liners made from polylactic acid. Its effectivity was evaluated with creamy mushroom soup (bags) and sliced cooked ham (separator liners) previously inoculated with $L$. monocytogenes and stored at $4{ }^{\circ} \mathrm{C}$. Results showed that the coating was effective at inhibiting pathogen growth; however, it did not display a bactericide effect in the foods. In addition, $L$. lactis remained viable in all experiments conducted in this study. The acidif cation produced by $L$. lactis, because of the generation of organic acids, did not compromise the sensory properties of the sliced cooked ham after 16 days of refrigerated storage. In contrast, consumers perceived a mushroom soup acidif cation because of a greater decrease in $\mathrm{pH}$ than the sliced cooked ham.

This study demonstrates that a food grade polyvinyl alcohol polymer blended with gelatin hydrolysates can be used as a carrier of protective cultures of $L$. lactis to increase the microbiological safety of refrigerated foods.
\end{abstract}

\section{Introduction}

Changes in consumer demands and lifestyles have increased the consumption of ready-to-eat (RTE) products. RTE food products require no further treatment before consumption, in such a way that may signif cantly reduce the microbial load (Cabedo et al., 2008), thus, it is essential to control pathogenic bacteria that can cause food-borne infectious diseases.

Among these diseases, listeriosis is a key for its profound consequences. Listeriosis is caused by a Gram + pathogenic bacterium, Listeria monocytogenes. This bacterium can affect the bloodstream, the central nervous system, and the placenta, with immunosuppressed people, newborns, elderly, and pregnant women the high-risk groups (Centers for Disease Control and Preservation, 2019; Donovan, 2015).

Authors have shown, for years, that although other modes of transmission exist, food is the main source (Schlech et al., 1983). L. monocytogenes is a psychrophilic bacterium capable of growing at low temperatures and adapting to different types of food (Walker et al., 1990). Its high prevalence in food, together with a high mortality rate from listeriosis, make this bacterium a health hazard. Therefore, L. monocytogenes in food and food environments must be controlled.

Key RTE food categories related with human listeriosis include meat, $\mathrm{f}$ sh, and milk products in Canada, the European Union, and United States (Rodrigues et al., 2017). Moreover, according to the EFSA (EFSA Panel on Biological Hazards (BIOHAZ), 2018), "Between 2008 and 2015 in the EU/EEU, the 'dairy' food category was responsible for four outbreaks causing 44 cases, while 'f sh and seafood' and 'meat and meat products' food categories were responsible for 7 and 11 outbreaks causing 40 and 126 cases, respectively. These three categories caused 22 (59\%) strong-evidence food-borne outbreaks, 210 (40\%) human cases, 125 (69\%) hospitalisations and 26 (70\%) deaths".

Unfortunately, despite having a very strict legislation on microbiological criteria for L. monocytogenes in RTE foods (Commission Regulation (EC) No 2073/2005) and routine controls, cases of listeriosis are

\footnotetext{
* Corresponding author.

E-mail address: phernan@iata.csic.es (P. Hernández-Muñoz).
} 


\title{
Broadening the antimicrobial spectrum of nisin-producing Lactococcus lactis subsp. Lactis to Gram-negative bacteria by means of active packaging
}

\author{
Laura Settier-Ramírez, Gracia López-Carballo, Rafael Gavara, Pilar Hernández-Muñoz* \\ Packaging Lab, Instituto de Agroquímica y Tecnología de Alimentos, IATA-CSIC, Av. Agustín Escardino 7, 46980 Paterna, Spain
}

\section{A R T I C L E I N F O}

\section{Keywords:}

Lactococcus lactis, $\mathrm{PVOH}$

Bioactive packaging

Phytic acid

Broad-spectrum

Pastry cream

\begin{abstract}
A B STR A C T
Cast $\mathrm{f}$ Ims obtained from polyvinyl alcohol (PVOH) blended with casein hydrolysates (HCas) in a weight ratio of 1:1 were employed to carry nisin-producing L. lactis and phytic acid in order to broaden the antimicrobial spectrum of $L$. lactis to Gram-positive and Gram-negative spoilage and pathogen bacteria. For this purpose, the effect of the antimicrobial activity of various $\mathrm{f} I \mathrm{~m}$ formulations and combinations of $\mathrm{f} I \mathrm{~ms}$ on the growth of $E$. coli at $37^{\circ} \mathrm{C}$ for $24 \mathrm{~h}$ was studied. The $\mathrm{f} \mathrm{Im}$ system that showed antimicrobial activity against Gram-negative bacteria consisted of phytic acid and $L$. lactis incorporated in separate $\mathrm{fIms}$. When the active agents were in the same $\mathrm{f} I \mathrm{~m}$ the viability of $L$. lactis decreased considerably and it did not exert antimicrobial activity against the bacterium. Therefore, the combination of $L$. lactis and phytic acid in separate $\mathrm{IIms}$ was chosen as the reliable system, and the effect of its activity on the growth of Gram-negative bacteria ( $E$. coli, Salmonella enterica, and Pseudomonas $f$ uorescens) and Gram-positive bacteria (Listeria monocytogenes) in liquid culture medium was tested at refrigeration temperature $\left(4^{\circ} \mathrm{C}\right)$, and with simulated breaks in the cold chain $\left(14{ }^{\circ} \mathrm{C}\right.$ and $\left.24^{\circ} \mathrm{C}\right)$. The survival of $\mathrm{L}$. lactis in coexistence with these bacteria was also studied. The $\mathrm{f} \mathrm{Im}$ system exerted an antimicrobial effect against the Gram-negative bacteria tested, and the activity depended on the bacteria and the temperature assayed. With regard to the antimicrobial activity against $L$. monocytogenes, phytic acid improved the antimicrobial capacity of $L$. lactis. The survival of $L$. lactis was maintained at $7-8 \log (C F U / m L)$ culture in liquid medium throughout the storage period.

The $\mathrm{f} \mathrm{Ims} \mathrm{developed} \mathrm{were} \mathrm{intended} \mathrm{to} \mathrm{be} \mathrm{used} \mathrm{as} \mathrm{coatings} \mathrm{in} \mathrm{the} \mathrm{design} \mathrm{of} \mathrm{a} \mathrm{double-sided} \mathrm{active} \mathrm{bag} \mathrm{for} \mathrm{a} \mathrm{non-}$ fermented dairy product. The bags were f Iled with homemade preservative-free pastry cream, and the microbiological shelf life and evolution of $\mathrm{pH}$ of the packaged ready-to-eat food stored at $4{ }^{\circ} \mathrm{C}$ was studied for 20 days. The results showed a reduction in the growth of spoilage bacteria and therefore an increase in the shelf life of the packaged product. The $\mathrm{f}$ Ims developed could be applied in the design of packages for perishable dairy foods in order to increase their microbiological shelf life.
\end{abstract}

\section{Introduction}

Currently, there is increasing demand for home-cooked meals without sacrif cing quality and safety. It is necessary to control the presence of pathogenic bacteria that can be a source of important food toxin infections. Recently, an outbreak of listeriosis related to the consumption of a meat product in Spain infected more than 200 people and caused three deaths and seven abortions, leading the authorities to issue an international health alert (WHO (World Health Organization), 2019).

The use of antimicrobial active packaging is a technology that can extend the shelf life of food products and maintain their safety. In this context, the use of matrixes with natural antimicrobials is a new way of obtaining safe products, reducing the quantities of artif cial additives and preservatives.

Choosing environmentally friendly polymers is just as important as selecting natural antimicrobial agents. The main disadvantage of synthetic polymers is that they are usually not biodegradable. However polyvinyl alcohol (PVOH) is a synthetic polymer that is completely biodegradable and biocompatible, and it has excellent $\mathrm{f} / \mathrm{m}$-forming properties (López-De-Dicastillo et al., 2011). PVOH has been approved by the FDA for use in food contact and as a food additive with INS No. 1203 (Codex Alimentarius) (FAO/WHO (Food and Agriculture Organization/World Health Organization), 2004). In the EU it is permitted by the EFSA as a food additive in food supplements in accordance with

\footnotetext{
* Corresponding author.

E-mail address: phernan@iata.csic.es (P. Hernández-Muñoz).
} 


\section{Journal of Cleaner Production}

\section{Assessing the environmental consequences of shelf life extension: conventional versus active packaging of pastry cream --Manuscript Draft--}

\begin{tabular}{|c|c|}
\hline Manuscript Number: & JCLEPRO-D-21-05657 \\
\hline Article Type: & Original article \\
\hline Keywords: & Antimicrobial active packaging; food waste; LCA; shelf life \\
\hline Corresponding Author: & $\begin{array}{l}\text { Neus Sanjuan, Dr. Agronomist Engineer } \\
\text { UPV: Universitat Politecnica de Valencia } \\
\text { València, VALENCIA SPAIN }\end{array}$ \\
\hline First Author: & Neus Sanjuan, Dr. Agronomist Engineer \\
\hline \multirow[t]{6}{*}{ Order of Authors: } & Neus Sanjuan, Dr. Agronomist Engineer \\
\hline & Laura Settier-Ramirez \\
\hline & Gracia López-Carballo \\
\hline & Pilar Hernandez-Muñoz \\
\hline & Raisa Tinitana \\
\hline & Rafael Gavara \\
\hline Abstract: & $\begin{array}{l}\text { Shelf life extension can reduce food losses throughout the entire food chain and } \\
\text { packaging can be an effective way to attain this goal. In this study, conventional and } \\
\text { bioactive bags carrying viable Lactococcus lactis subsp. lactis and phytic acid with } \\
\text { antimicrobial activity were used to pack pastry cream and the environmental } \\
\text { implications of the packaging choice have been assessed considering both the direct } \\
\text { and indirect effects in terms of shelf life and food waste. Specifically, life cycle focus } \\
\text { has been applied, including the impacts of the waste treatment according to EU } \\
\text { statistics. To assess the empty packages, a bag of } 200 \mathrm{~mL} \text { capacity was the functional } \\
\text { unit. In that case, the active packaging implies an increase in all the impact categories, } \\
\text { due to the application on the conventional bag film of the bacterial coating. When } \\
\text { assessing the food-packaging systems, considering } 218 \mathrm{~g} \text { of pastry cream packed as } \\
\text { functional unit, this effect is compensated by shelf life extension from } 3 \text { to } 13 \text { days, with } \\
\text { the subsequent reduction in the waste generated along the food chain. In this way, a } \\
\text { reduction in all the impact categories corresponding to the pastry cream in active } \\
\text { packaging has been observed, with ranging from } 45 \text { for ionizing radiation to } 75 \% \text { for } \\
\text { climate change. It can be concluded that, despite the limitations regarding waste } \\
\text { estimation, extending the shelf life of foods is a key issue when assessing the } \\
\text { environmental impacts of novel packages. Future research should focus on developing } \\
\text { better models, based on empirical data, which relate product shelf life and the potential } \\
\text { waste. In addition, a holistic sustainability assessment should also consider economic } \\
\text { issues under a life cycle approach. }\end{array}$ \\
\hline \multirow[t]{4}{*}{ Suggested Reviewers: } & $\begin{array}{l}\text { Jacopo Bacenetti } \\
\text { University of Milan: Universita degli Studi di Milano } \\
\text { jacopo.bacenetti@unimi.it } \\
\text { He has a wide experience in LCA applied to food systems }\end{array}$ \\
\hline & $\begin{array}{l}\text { Yokokawa Naoki } \\
\text { University of Tokyo Graduate School of Engineering School of Engineering: Tokyo } \\
\text { Daigaku Daigakuin Kogakukei Kenkyuka Kogakubu } \\
\text { n-yokokawa@pse.t.u-tokyo.ac.jp } \\
\text { Specialist in LCA applied to food packaging }\end{array}$ \\
\hline & $\begin{array}{l}\text { Ximena Schmidt-Rivera } \\
\text { Brunel University London } \\
\text { ximena.schmidt@brunel.ac.uk } \\
\text { Expert in sustainable food systems and LCA }\end{array}$ \\
\hline & Almudena Hospido \\
\hline
\end{tabular}


Article

\title{
New Isolated Metschnikowia pulcherrima Strains from Apples for Postharvest Biocontrol of Penicillium expansum and Patulin Accumulation
}

\author{
Laura Settier-Ramírez ${ }^{1,2, *}$, Gracia López-Carballo ${ }^{1}$, Pilar Hernández-Muñoz ${ }^{1} \mathbb{0}$, Angélique Fontana ${ }^{2}{ }^{\circledR}$, \\ Caroline Strub ${ }^{2, *(D)}$ and Sabine Schorr-Galindo ${ }^{2}$ (D) \\ 1 Packaging Lab., Instituto de Agroquímica y Tecnología de Alimentos, IATA-CSIC, Av. Agustín Escardino 7, \\ 46980 Paterna, Spain; glopez@iata.csic.es (G.L.-C.); phernan@iata.csic.es (P.H.-M.) \\ 2 Qualisud, University Montpellier, Avignon Université, CIRAD, Institut Agro, IRD, Université de La Réunion, \\ 34095 Montpellier, France; angelique.fontana@umontpellier.fr (A.F.); sabine.galindo@umontpellier.fr (S.S.-G.) \\ * Correspondence: laura.settier@iata.csic.es (L.S.-R.); caroline.strub@umontpellier.fr (C.S.); \\ Tel.: +34-963-900-022 (L.S.-R.); +33-467-143-201 (C.S.)
}

Citation: Settier-Ramírez, L.;

López-Carballo, G.;

Hernández-Muñoz, P.; Fontana, A.; Strub, C.; Schorr-Galindo, S. New Isolated Metschnikowia pulcherrima Strains from Apples for Postharvest Biocontrol of Penicillium expansum and Patulin Accumulation. Toxins 2021, 13, 397. https:/ / doi.org/ 10.3390 / toxins 13060397

Received: 26 April 2021

Accepted: 27 May 2021

Published: 2 June 2021

Publisher's Note: MDPI stays neutral with regard to jurisdictional claims in published maps and institutional aff 1iations.

Copyright: (c) 2021 by the authors. Licensee MDPI, Basel, Switzerland. This article is an open access article distributed under the terms and conditions of the Creative Commons Attribution (CC BY) license (https:/ / creativecommons.org/ licenses/ by/ 4.0/).

\begin{abstract}
Wild yeasts isolated from the surface of apples were screened for antagonistic activity against Penicillium expansum, the main producer of the mycotoxin patulin. Three antagonistic yeasts (Y33, Y29 and Y24) from a total of 90 were found to inhibit P. expansum growth. Identif cation by ITS region sequence and characterization showed that three selected isolates of yeast should be different strains of Metschnikowia pulcherrima. Several concentrations of the selected yeasts were used to study their in vitro antifungal effectivity against P. expansum on Petri dishes (plates with $63.6 \mathrm{~cm}^{2}$ surface) whereas their potential activity on patulin reduction was studied in liquid medium. Finally, the BCA that had the best in vitro antifungal capacity against $P$. and the best patulin degradation capacity was selected to be assessed directly on apples. All the selected strains demonstrated antifungal activity in vitro but the most eff cient was the strain Y29. Isolated strains were able to reduce patulin content in liquid medium, Y29 being the only strain that completely reduced patulin levels within $120 \mathrm{~h}$. The application of Y29 as biocontrol agent on the surface of apples inoculated with P. expansum, inhibited fungal growth and patulin production during storage. Therefore, the results shown that this yeast strain could be used for the reduction of P. expansum and its mycotoxin in apples or apple-based products by adapting the procedure application.
\end{abstract}

Keywords: biological control; Metschnikowia pulcherrima; Penicillium expansum; patulin; epiphytic isolated yeasts; apple

Key Contribution: Wild Metschnikowia pulcherrima isolated strains from apples demonstrated to be an effective biocontrol agent against Penicillium expansum growth and were able to reduce patulin content. Isolated M. pulcherrima can be applied as a natural alternative of postharvest disease management.

\section{Introduction}

Currently, more than $30 \%$ of fruit and vegetables produced worldwide is discarded every year [1]. These losses occur throughout all the supply chain from cultivation to household consumption although most of them happen during the postharvest stage, processing, transportation or storage. The decomposition of fruits by fungal spoilage represents the main cause of those economic losses [2].

Penicillium expansum is one of the best-known species of the genus Penicillium due to its high relevance as it is a widespread species found in the natural environment both in soil, air and even indoor air [3,4]. Furthermore, P. expansum infect a wide range of food products including pome and stone fruits (such as apples, pears, cherries, or peaches) 


\section{Postharvest Biology and Technology Apple-based coatings incorporated with wild apple isolated yeast to reduce Penicillium expansum postharvest decay of apples --Manuscript Draft--}

\begin{tabular}{|c|c|}
\hline \multicolumn{2}{|l|}{ Manuscript Number: } \\
\hline Article Type: & Research Paper \\
\hline Keywords: & $\begin{array}{l}\text { Biocontrol; Metschnikowia pulcherrima; Penicillium expansum; Antimicrobial coating; } \\
\text { Apple; Food waste }\end{array}$ \\
\hline Corresponding Author: & $\begin{array}{l}\text { Laura Laura Settier Ramírez } \\
\text { IATA: Instituto de Agroquimica y Tecnologia de Alimentos } \\
\text { SPAIN }\end{array}$ \\
\hline First Author: & Laura Laura Settier Ramírez \\
\hline \multirow[t]{6}{*}{ Order of Authors: } & Laura Laura Settier Ramírez \\
\hline & Gracia López-Carballo, Doctor \\
\hline & Pilar Hernández-Muñoz, Doctor \\
\hline & Angélique Fontana-Tachon \\
\hline & Caroline Strub \\
\hline & Sabine Schorr-Galindo \\
\hline Abstract: & $\begin{array}{l}\text { The aim of this work has been to prevent the growth of Penicillium expansum on the } \\
\text { surface of apples by means of the use of biocontrol agents in combination with edible } \\
\text { coatings. For that, Metschnikowia pulcherrima yeast isolated from wild apples was } \\
\text { incorporated in edible film matrices based on pectins, cellulose ethers with and without } \\
\text { the addition of liquid culture medium (yeast extract and glucose) and apple pomace } \\
\text { residues. } \\
\text { The viability and biocontrol activity of the yeast incorporated in the films were evaluated } \\
\text { after film drying process and after being stored for } 21 \text { days at } 10{ }^{\circ} \mathrm{C} \text {. Furthermore, } \\
\text { applied as a coating on apples artificially inoculated with P. expansum in order to } \\
\text { evaluate its efficacy to prevent blue mold during storage and to prevent the production } \\
\text { of its mycotoxin, the patulin. M. pulcherrima remained viable after film drying and after } \\
\text { films stored } 21 \text { days, but viability depended on the matrix composition, being lower in } \\
\text { pectin films and higher in apple pomace films. The highest antimicrobial activity in vitro } \\
\text { was observed in methylcellulose films supplemented with yeast extract and glucose } \\
\text { (YEG), and in apple pomace residues films, matrix which was therefore selected to be } \\
\text { applied as coatings on apples inoculated with P. expansum. The results proved that } \\
\text { bioactive coatings significantly reduce P. expansum growth and patulin production } \\
\text { during storage. The results obtained in this work give added value to the apple industry } \\
\text { residues which, in combination with apple isolated M. pulcherrima can be applied as } \\
\text { coatings on apples to provide protection against blue mold and its mycotoxin as an } \\
\text { alternative of postharvest disease management. }\end{array}$ \\
\hline \multirow[t]{3}{*}{ Suggested Reviewers: } & $\begin{array}{l}\text { Luís Abrunhosa } \\
\text { Universidade do Minho - Campus de Gualtar: Universidade do Minho } \\
\text { luisjap@deb.uminho.pt } \\
\text { Experience edible films and coatings carying biocontrol agents }\end{array}$ \\
\hline & $\begin{array}{l}\text { Davide Spadaro } \\
\text { Università degli Studi di Torino: Universita degli Studi di Torino } \\
\text { davide.spadaro@unito.it } \\
\text { Experience on postharvest diseases, moulds and mycotoxins }\end{array}$ \\
\hline & $\begin{array}{l}\text { Lorena Atarés-Huerta } \\
\text { Universitat Politecnica de Valencia } \\
\text { loathue@tal.upv.es } \\
\text { Experience on active packaging and development of antimicrobial } \\
\text { materials carying biocontrol agents }\end{array}$ \\
\hline
\end{tabular}


800 